\title{
CONTRIBUIÇÃO AO CONHECIMENTO GEOLÓGICO E PETROLÓGICO DAS ROCHAS ALCALINAS DA ILHA DOS BÚZIOS, SP
}

FRANCISCO RUBENS ALVES

Orientador: Prof. Dr. Celso de Barros Gomes

TESE DE DOUTORAMENTO

COMISSÃO JULGADORA

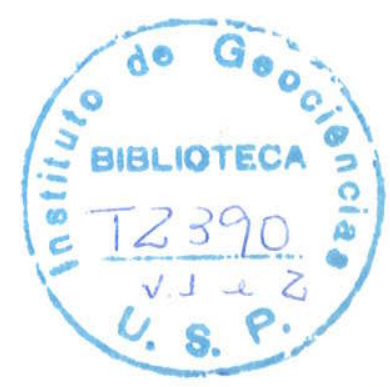

Nome

Assinatura

Presidente: Prof. Dr. Celso de Barros Gomes

Examinadores: Prof. Dr. Akihisa Motoki

Prof. Dr. Excelso Ruberti

Prof. Dr. Luiz Fernando Scheibe

Prof ${ }^{\mathrm{a}}$ Dr $^{\mathrm{a}}$. Mabel Norma Costas Ulbrich

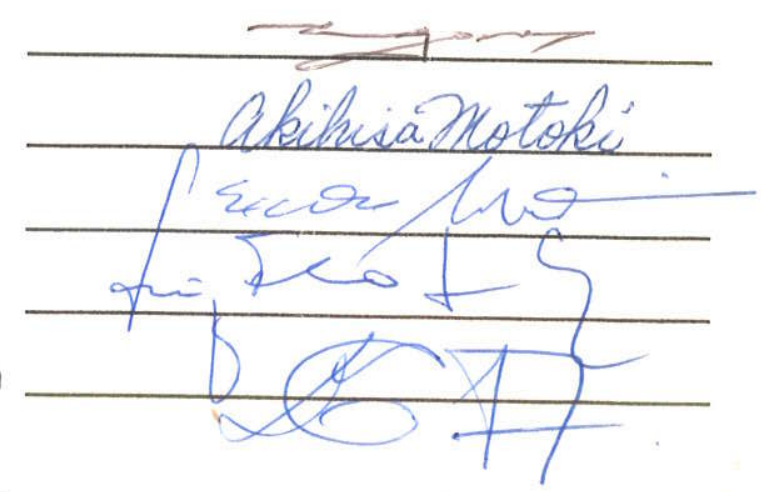

SÃO PAULO

1997 


\title{
UNIVERSIDADE DE SĀO PAULO INSTITUTO DE GEOCIENCIAS
}

DEDALUS - Acervo - IGC

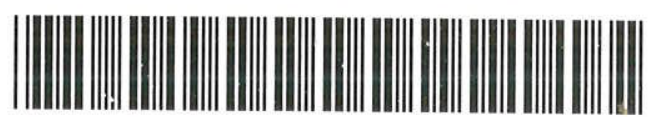

30900004466

\section{CONTRIBUIÇÃO AO CONHECIMENTO GEOLÓGICO E PETROLÓGICO DAS ROCHAS ALCALINAS DA ILHA DOS BÚZIOS, SP}

\author{
Francisco Rubens Alves
}

Orientador: Prof. Dr. Celso de Barros Gomes

TESE DE DOUTORAMENTO

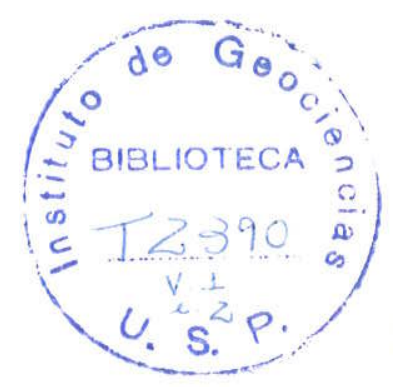

Programa de Pós-Graduação em Mineralogia e Petrologia 


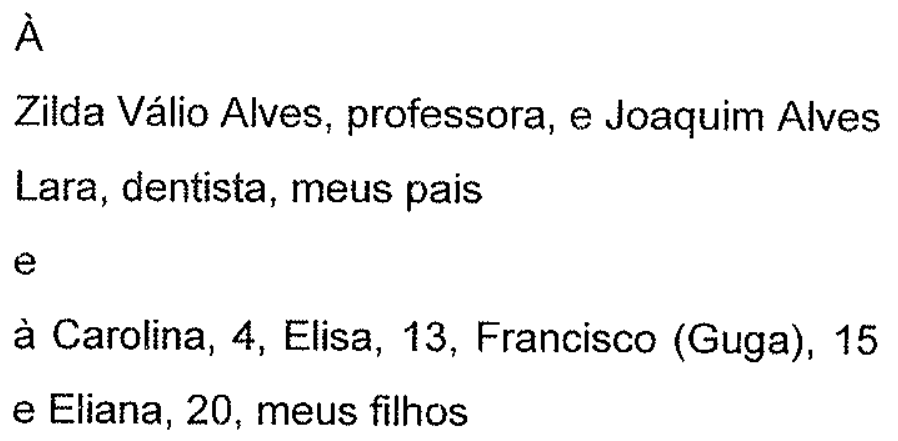


Homenagem

- ao meu amigo Gouveia

- ao Prof. Dr. Ruy Ozório de Freitas, geólogo pesquisador, pelo pioneirismo solitário 


\section{INDICE GERAL}

LEGENDAS DAS FOTOS $\mathrm{V}$

LEGENDAS DAS FOTOMICROGRAFIAS …..............................................................

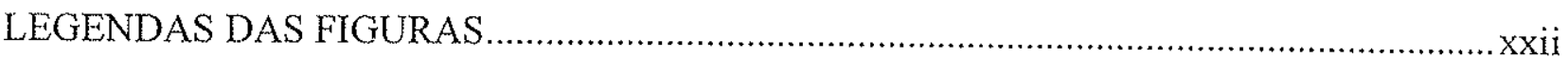

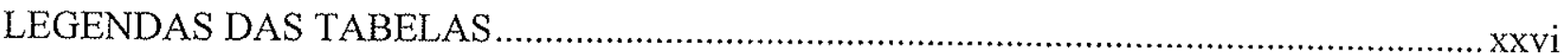

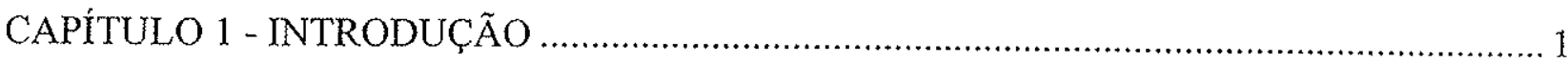

1.1. O projeto "Magmatismo básico-alcalino da Bacia do Paraná" .............................................. 1

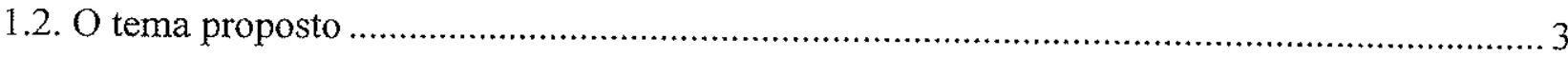

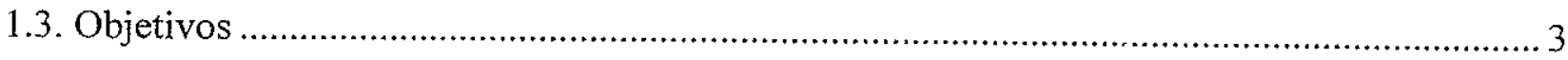

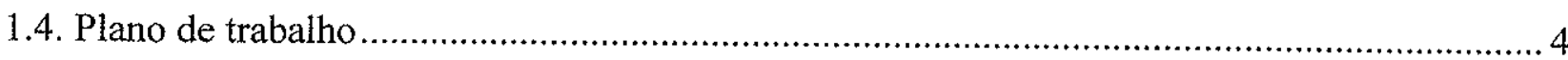

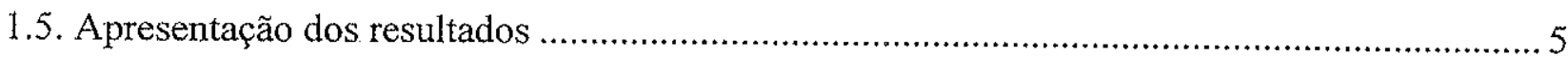

CAPÍTULO 2 - METODOLOGIA, TÉCNICAS E TRABALHOS EFETIVOS ........................ 6

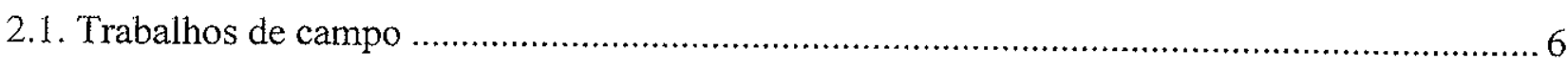

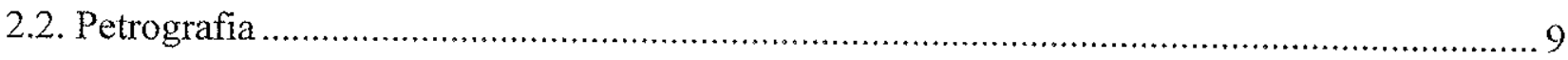

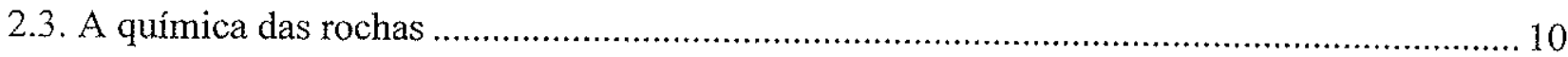

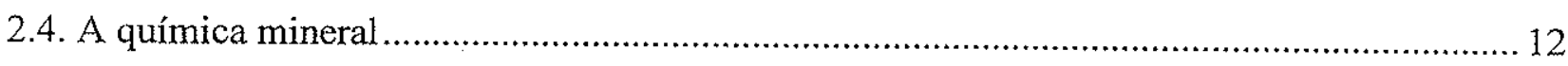

2.5. Estudos isotópicos $\mathrm{K} / \mathrm{Ar}$ e $\mathrm{Rb} / \mathrm{Sr}$ e Geocronologia ........................................................... 14

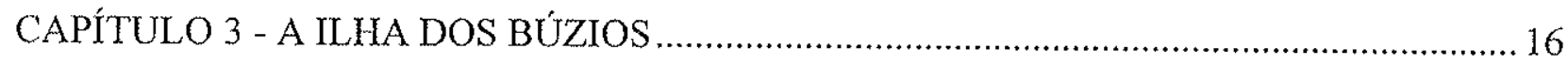

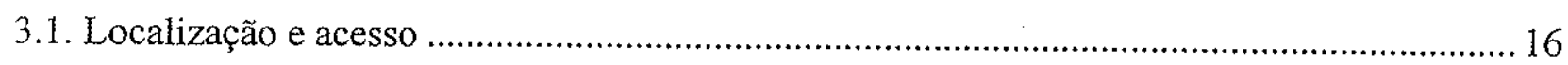

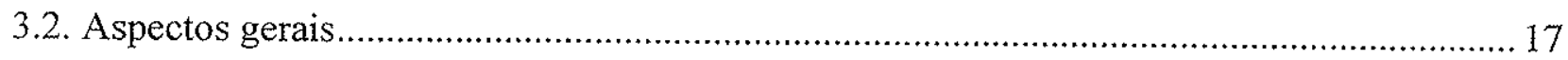

3.3. Aspectos fisiográficos, erosivos e intempéricos ........................................................... 22

3.4. Trabalhos anteriores sobre a morfologia litorânea e a llha dos Búzios................................ 28

CAPÍTULO 4 - TRABALHOS GEOLÓGICOS ANTERIORES …........................................ 31

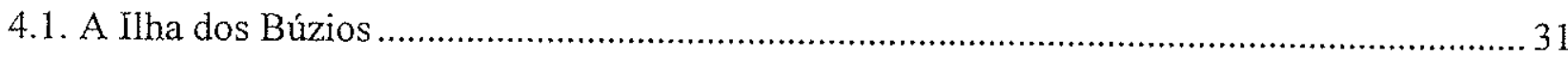

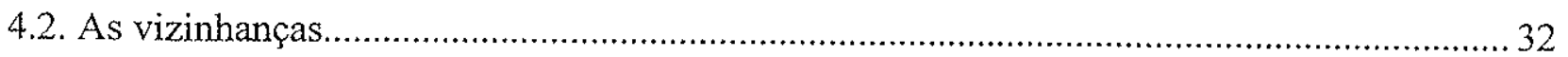

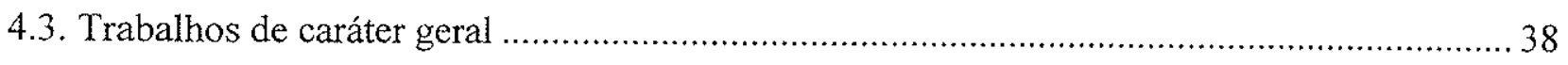

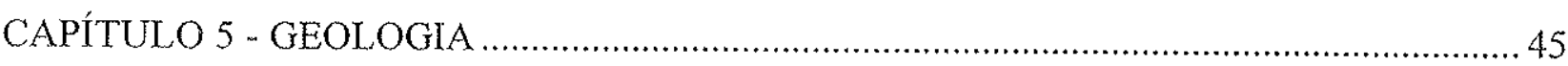




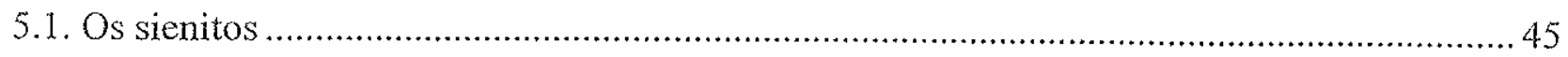

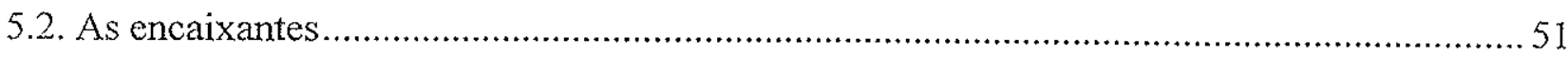

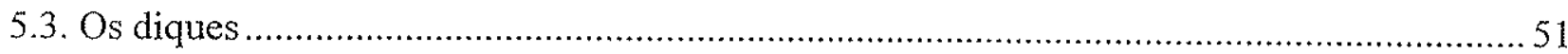

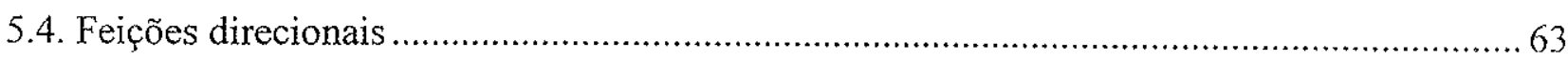

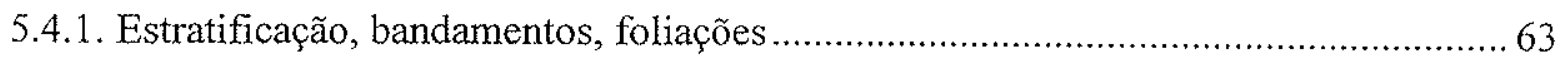

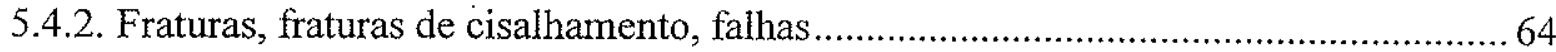

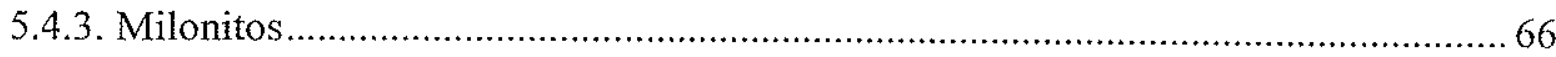

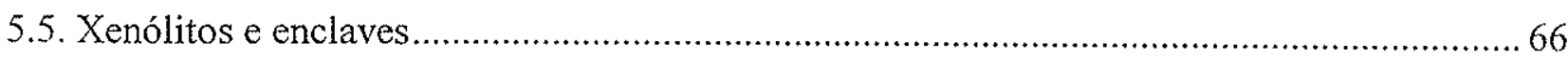

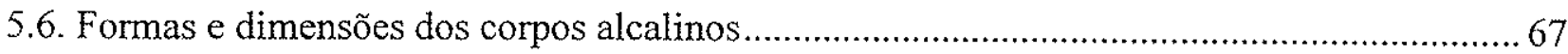

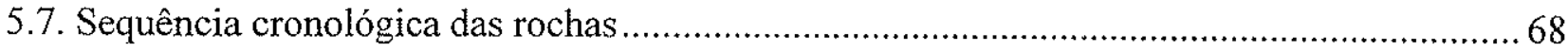

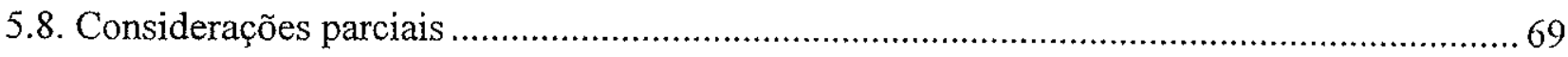

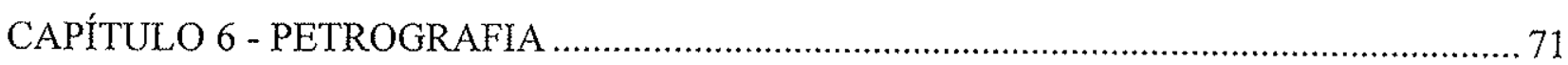

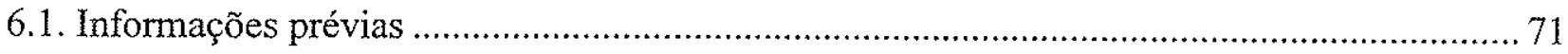

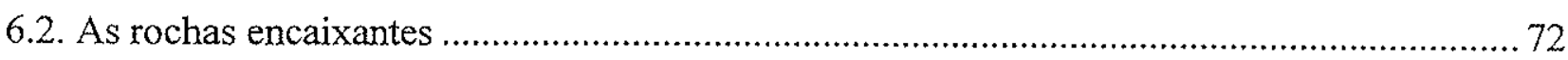

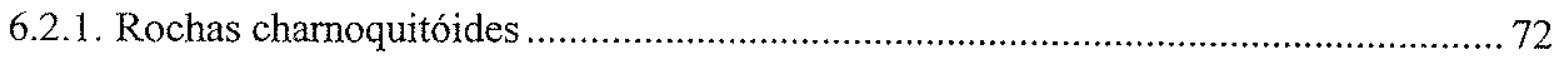

6.2.2. Hiperstênio dioritos gnáissicos e variedades .................................................... 74

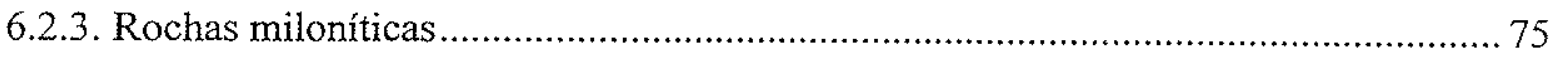

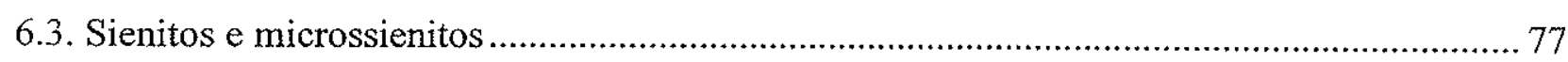

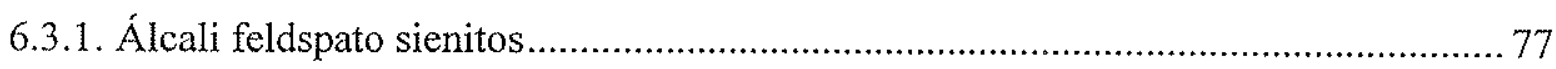

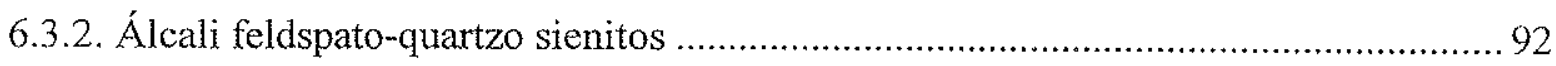

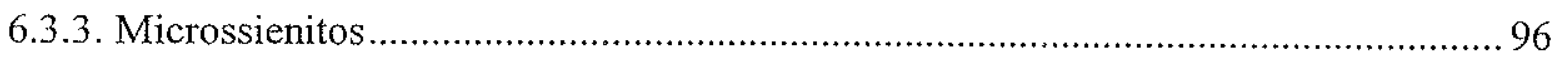

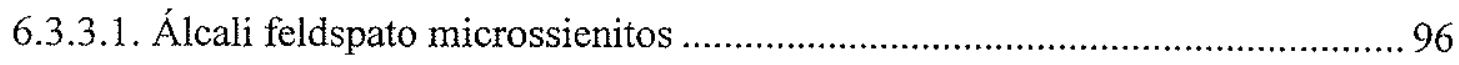

6.3.3.2. Álcali feldspato-quartzo microssienitos ............................................. 101

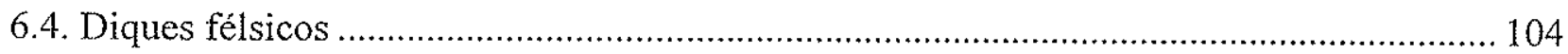

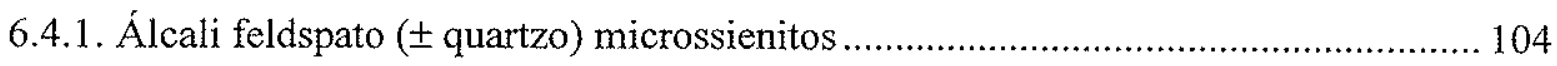

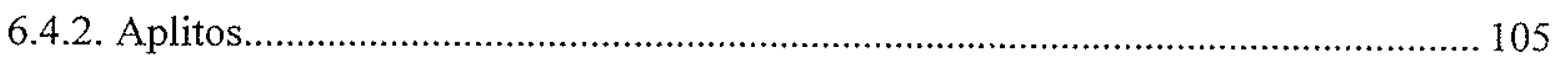

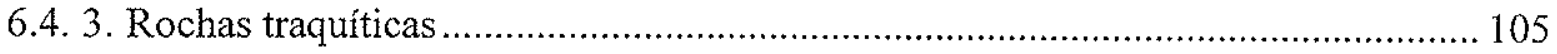

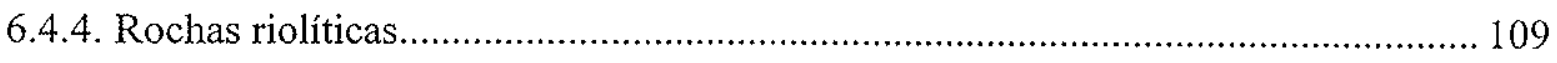

6.4.5. Sodalita fonólitos e nefelina (sodalita) microssienitos ...................................... 110

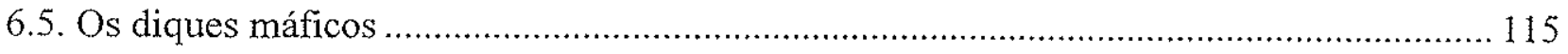

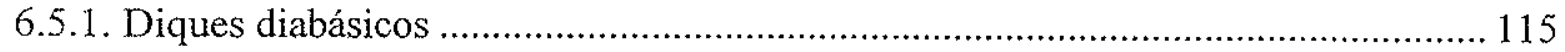

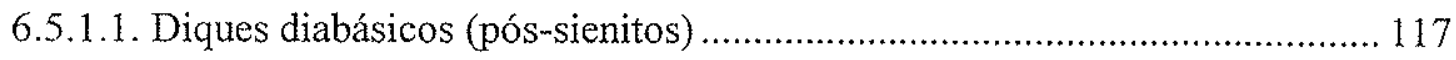


6.5.1.2. Diques diabásicos hornfélsicos (pré-sienitos)

6.5.2. Diques máficos microdioríticos ("andesíticos").

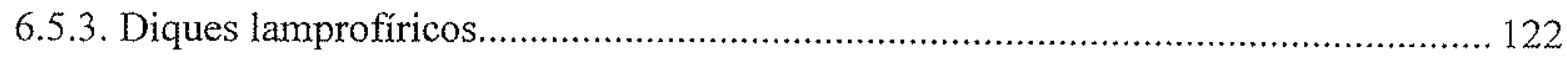

6.5.4. Diques máfico-ultramáficos deformados (pré-sienitos)...................................... 128

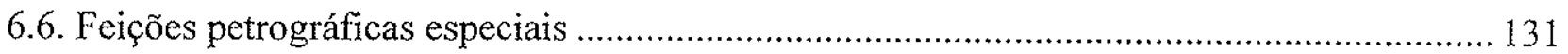

6.6.1. Variações mineralógicas e texturais internas dos diques máficos ......................... 131

6.6.2. Intercrescimentos granofíricos e micrográficos................................................ 135

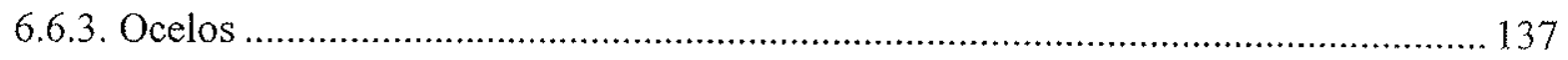

6.6.4. Xenocristais (glomerocristais) e xenólitos.............................................................. 141

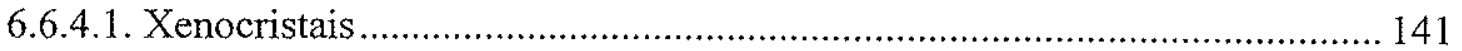

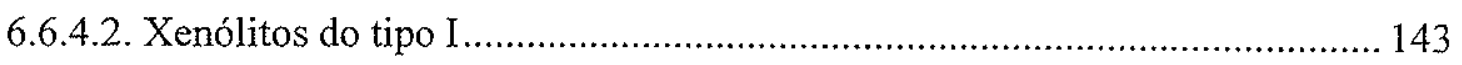

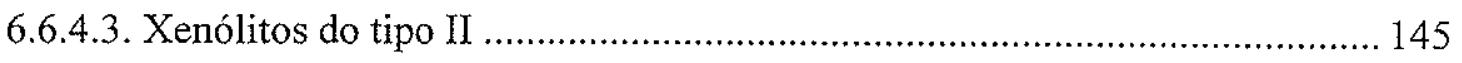

6.6.5. Contatos e feições de cisalhamento ...................................................................... 145

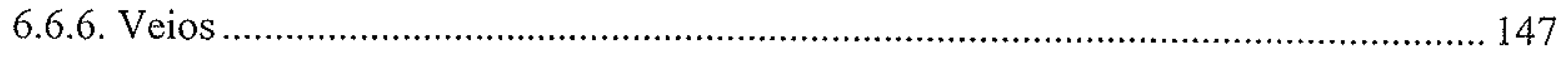

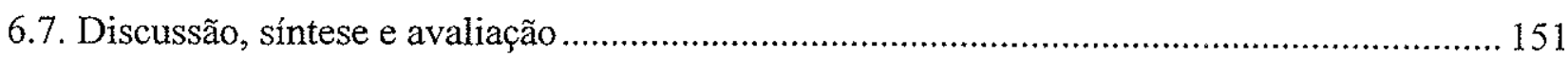

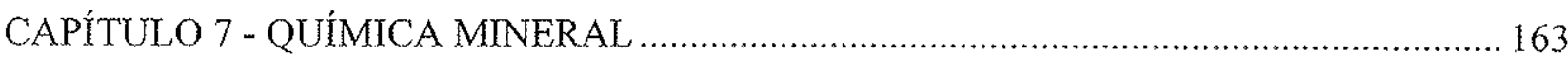

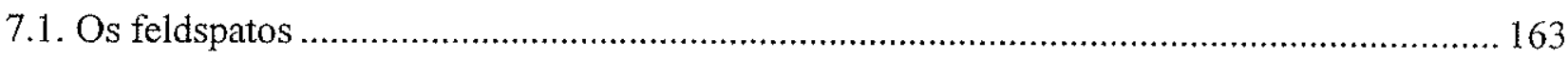

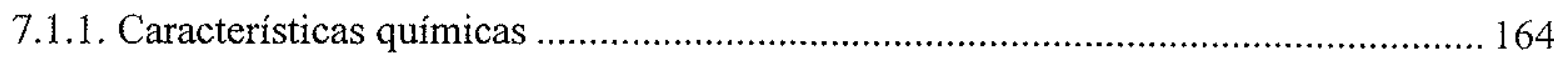

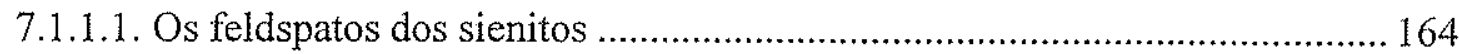

7.1.1.2. Os feldspatos dos diques félsicos ...................................................... 168

7.1.1.3. Os feldspatos dos diques máficos...................................................... 168

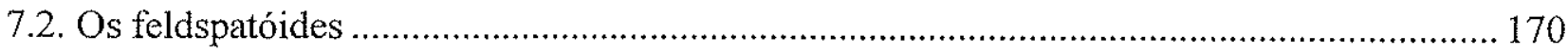

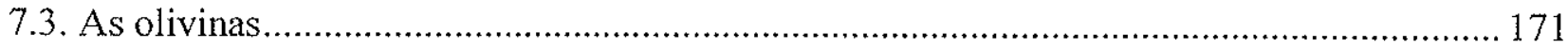

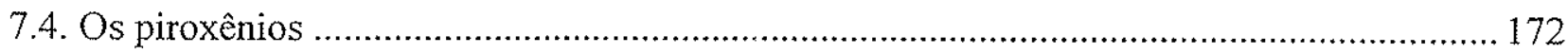

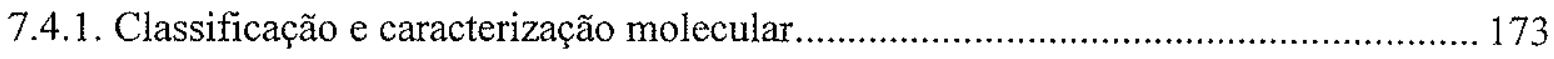

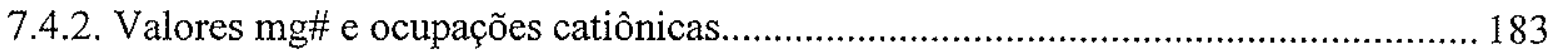

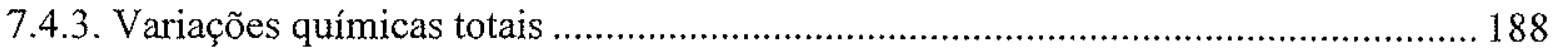

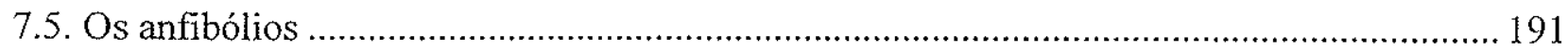

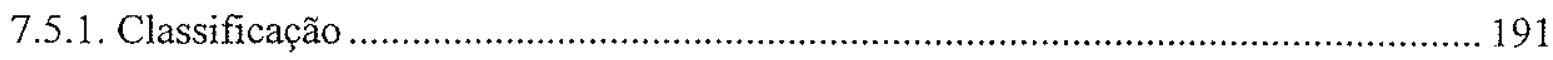

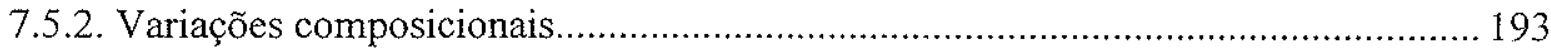

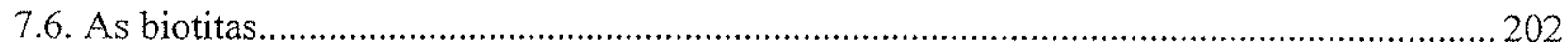

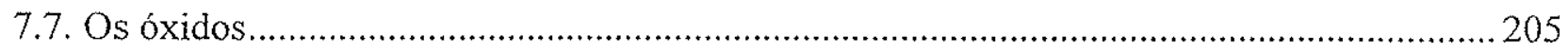


7.8. Síntese e observações preliminares

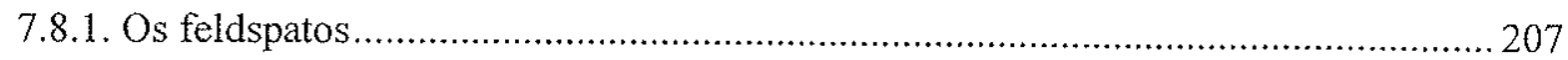

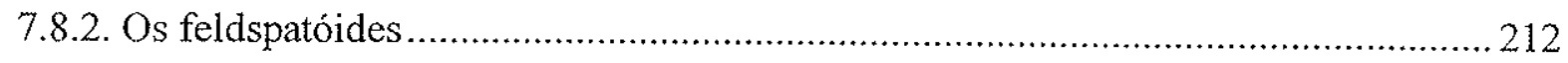

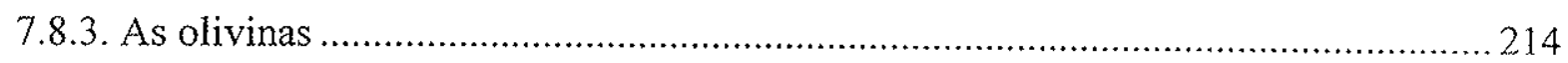

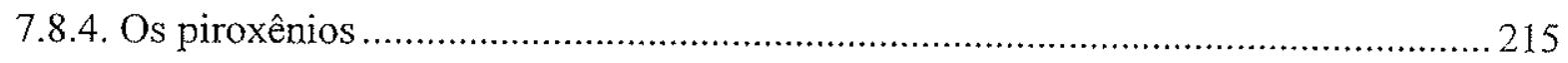

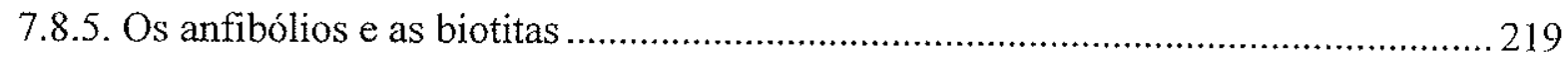

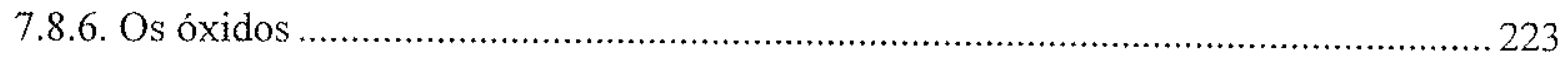

CAPÍTULO 8 - A COMPOSIÇÃO QUÍMICA DAS ROCHAS …...................................... 225

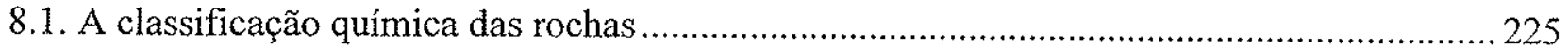

8.1.1. As rochas alcalinas de Búzios: a classificação da IUGS .......................................226

8.1.2. As rochas alcalinas de Búzios: a classificação no campo R1R2 …....................... 228

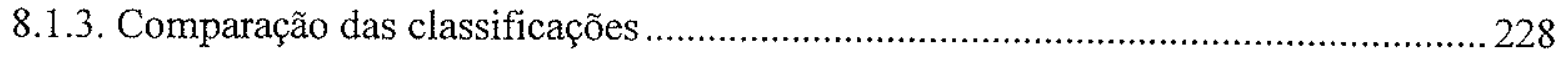

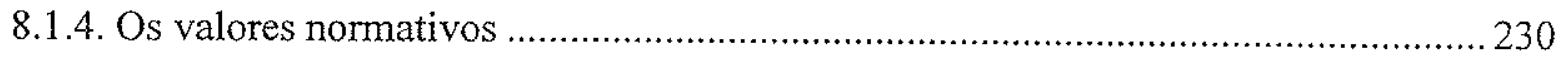

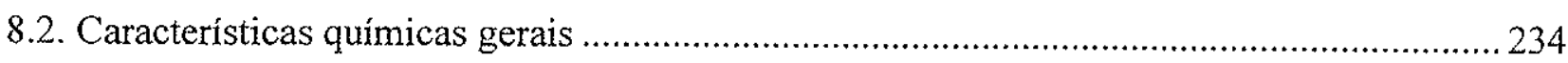

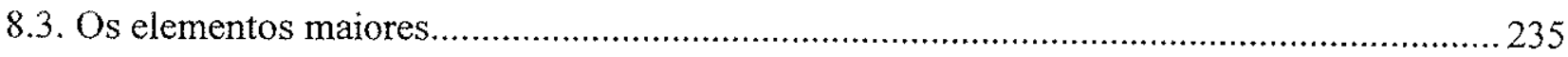

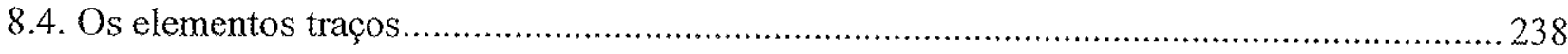

8.4.1. Diagramas multi-elementos ("spidergrams") ............................................... 243

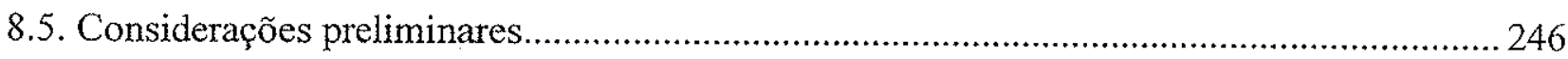

CAPÍTULO 9 - ISOTOPIA K/Ar e Rb/Sr e GEOCRONOLOGIA ….................................... 250

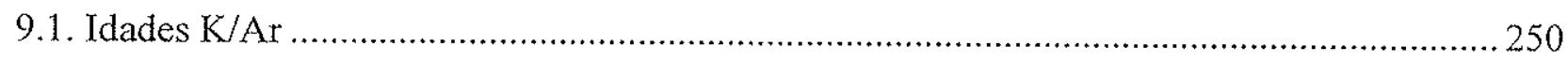

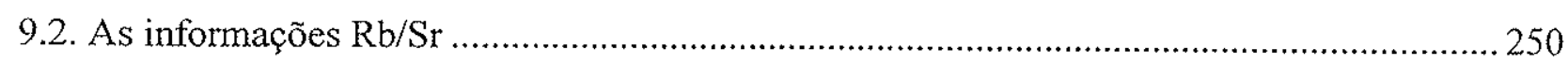

9.3. Avaliação e discussão dos resultados ......................................................................... 255

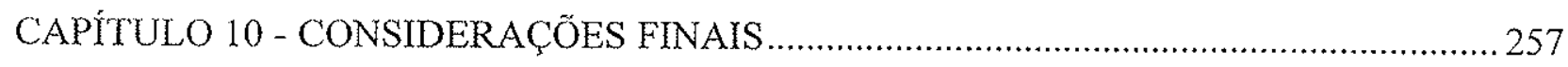

10.1. Esboço da evolução geológica da Região Sudeste........................................................... 258

10.2. O magmatismo mesozóico-cenozóico da Região Sudeste ............................................ 260

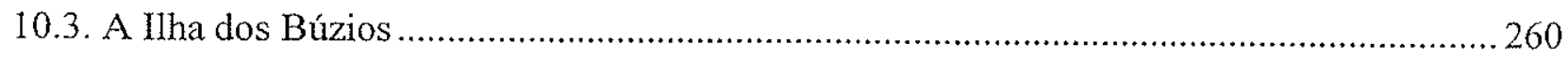

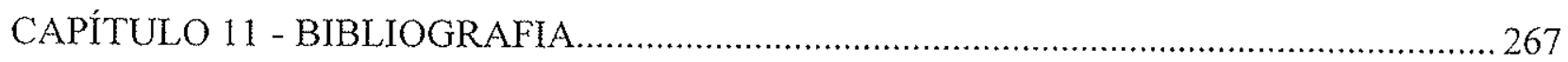




\section{LEGENDAS DAS FOTOS}

Foto 1 - A Ilha dos Búzios vista de oeste (face ocidental). À esquerda (N), a Ponta do Lenço; no centro esquerdo, meia encosta e baixa encosta, o Porto do Meio. Ao centro, o ponto culminante. À direita próxima, Pitangueiras; mais ao fundo, o espigão que desce até o Porto do Sul.

Foto 2 - Illhabela, a $8 \mathrm{~km}$, vista do Porto do Meio, para oeste-sudoeste. Pode-se distinguir, da esquerda para a direita, os picos dos maciços do Mirante, de São Sebastião e da Serraria.

Foto 3 - Embarcadouro da Mãe Joana - o trapiche. Ao fundo, a Ilha de Vitória a 11 $\mathrm{km}$ a NE.

Foto 4 - Ilhabela, vista do Porto do Meio, para oeste-sudoeste, reconhecendo-se, da esquerda para a direita, os picos dos maciços alcalinos do Mirante, de São Sebastião e da Serraria. Notar o denso nevoeiro, que surgia a qualquer hora durante o dia, em fevereiro de 1992

Foto 5 - Foto tirada do centro da Ilha, em altitude de mais ou menos $300 \mathrm{~m}$ para leste. Notar vegetação, matacões dos sienitos. Ao fundo, a porção do extremo leste após a Mãe Joana. O cume mais distante está a mais de 3 $\mathrm{km}$ de distância do fotógrafo. Notar os topos suaves

Foto 6 - A Ponta do Lenço e a Enseada da Guanxuma, vistas do centro e do alto da Ilha para norte. Notar vegetação, matacões dos sienitos. A trilha corta a crista a $120 \mathrm{~m}$ de altitude.

Foto 7 - Costão, no caso muito íngreme, quase vertical, a sul do Gentio e norte das Pintangueiras. No local, ocorrem sienitos, diques de quartzo microssienito e charnoquito.

Foto 8 - Costão de blocos, no Saco Grande. Mar excepcionalmente calmo para o local (face sul). Observar na porção central laje aflorante em meio aos blocos que desce até o mar. Notar cobertura florestal

Foto 9 - Lajes do parcel em frente à Pontinha, parte norte-noroeste da Ilha. As lajes são de sienito. Ao fundo, a costa continental 
Foto 10 - Afloramento "in situ", na forma de blocos descontínuos, de grandes dimensões. Há matacões maiores ainda à beira-mar. Poucos blocos deslocados e rolados na parte inferior. Local no Saco Grande, sul.

Foto 11 - Ponto 318, Costa Sul, Porto Sul - Saco do Maneco. Blocos "in situ" de sienito empilhados sobre charnoquito (parte inferior da foto). Observar xenólito máfico arredondado ao pé do bloco à direita. Ao fundo, à esquerda, a Ponta Sul a $1 \mathrm{~km}$. A referência, uma marreta, pouco visível abaixo e à direita do centro da foto.

Foto 12 - Bloco do sienito de granulação grossa dominante na llha. A cor cinzenta clara, presente em todos os blocos, já indica capa de alteração, embora a rocha ainda se mostre resistente. Notar faixas mais claras de fraturamento e miárolo junto ao ponto de referência.

Foto 13 - Ponto 310. Sienito fino envolvendo xenólito de rocha máfica. Observar fragmentos soltos do xenólito, angulosos e injetados por sienito e variação na interface sienito-xenólito, que se mostra regular, linear ou muito irregular.

Foto 14 - Ponto 310. Sienito fino envolvendo conjunto xenolítico de rocha máficacharnoquito, com contato regular entre ambas. Fraturamento e venulação típicos da porção máfica, interrompidos no charnoquito. Apenas pequeno dique decimétrico atravessa o charnoquito.

Foto 15 - Feição do "grande bandamento" pegmatóide do Saco Grande, notando-se simetria e alternância de porção feldspática pegmatóide e sienito comum, que é também a rocha encaixante. 50

Foto 16 - Feição do "grande bandamento" do Saco Grande. Nota-se alternância de bandas decimétricas pegmatóides e aplíticas. Na porção central da banda, à esquerda, cristais de magnetita. À direita da faixa mais fina, a rocha é um sienito comum.

Foto 17 - Charnoquito, da Ponta das Pintangueiras, já um pouco descorado. Na foto, pela posição, não mostra muita orientação. Observar dimensão dos feldspatos.

Foto 18 - Dique curvo (N25-70E) na Ponta das Pitangueiras, ponto 313. O local reúne cinco diques quase paralelos, de direção $\mathrm{NE}$, que cortam um sexto 
dique transversal. O dique da Foto (BZ 313/5) tem 40 a $50 \mathrm{~cm}$ de espessura e está encaixado em charnoquito.

Foto 19 - Dique máfico alcalino, com 0,60-0,80 m de espessura, cortando charnoquito na costa sudoeste. Mostra deslocamento em "off-set" sinistral com conexão oblíqua entre os segmentos. Fraturamento ortogonal e conexão oblíqua indicam direção de dilatação, ausentes outros indicadores direcionais de tensões. O prolongamento do segmento superior (na fotografia) na forma de um minúsculo dique indica o fluxo magmático no mesmo sentido ou vertical, ou combinação. Observar discordância com a foliação do charnoquito.

Foto 20 - Dique félsico, curvo e oblíquo à foliação do charnoquito, na laje do Porto do Meio. Mostra ponte de charnoquito e terminação normal.

Foto 21 - Dique máfico alcalino em charnoquito, costa sudoeste. Mostra "overlap" entre os dois segmentos do dique, o superior terminando em ponta e o inferior em conexão obliqua interrompida por ponte de charnoquito indicando deslocamento sinistral. Fraturas indicativas de dilatação. Ponta do segmento superior pode indicar o fluxo magmático.

Foto 22 -" Dique BZ 313/2, riolítico, cortando o dique BZ 313/1, máfico alcalino, ambos encaixados em charnoquito.

Foto 23 - Ponta Sul, ponto 191. Três diques máficos de dimensão métrica ressaltados "in situ" na topografia. Fraturamento transversal ortogonal, horizontal, e fraturamento axial, indicativos de dilatação simples, ausentes esforços e deformações cisalhantes. Em primeiro plano, encaixante sienítica, foliada e rica em xenólitos.

Foto 24 - Ponta Sul, ponto 191. Dique paralelo aos outros do local, agora com inversão na característica erosiva. Encaixante sienítica aparece intensamente foliada, paralelamente ao dique, junto ao contato, passando de pronto a rocha mais maciça. Padrão de fraturamento igual aos anteriores

Foto 25 - Ponta Sul, ponto 191. Detalhe da laje sienítica com os xenólitos de charnoquito e rocha máfica. Notar angulosidade, fraturamento e veios de sienito no fragmento máfico, além da presença de fraturas de cisa- 
lhamento com deslocamento. Não aparecem injeções e tampouco angulosidades no charnoquito

Foto 26 - Ponta Sul, ponto 191. Feições da laje ao pé dos diques anteriores em local onde estes não aparecem, dando lugar a grande quantidade de xenólitos angulosos e subangulosos de charnoquito e rocha máfica. Notar foliação/fraturamento cisalhante da encaixante sienítica. Observar falta de angulosidade no charnoquito.

Foto 27 - Saco do Coruja (sul). O maior dique da Itha, facilmente visível pela cor e fraturamento. Observar que, vindo do mar, o dique deflete bruscamente para a direita. O personagem "referência" da Foto está sobre um dique "riolítico", de mesma direção que o dique máfico. Ponto 326

Foto 28 - Dique riolítico encaixado em charnoquito (ponto 326, Saco do Coruja). No local da foto, o dique mergulha para $\mathrm{E}$ (direita). A sombra delimita a parede vertical de charnoquito; o chão plano, esquerda inferior, de cor clara, é charnoquito. Contato vertical entre as rochas é visto à esquerda, superior. A escala é a caderneta de campo.

Foto 29 - Sienito de granulação grossa do tipo dominante passando de forma brusca ("cortado") para microssienito ou aplito sienítico, comum por toda a Ilha, com contato "diluído" e forma curva.

Foto 30 - Ponto 181, costa norte, proximidades da Ponta Leste. Dique de basalto alcalino cortando sienito. Mostra homogeneidade transversal, fraturamento normal e paralelo aos contatos não deformados e ausência de outros sinais de movimentação cisalhante, no dique e na encaixante.

Foto 31 - Detalhe do dique do Saco Coruja, mostrando o faturamento curvo e, aparentemente, pequeno dique máfico que corta o maior, e prossegue pelo charnoquito (direita, superior). Ponto 326.

Foto 32 - Dique BZ $313 / 5$ em detalhe. Observar alternância e simetria das partes afaníticas e maciças com as zonas esburacadas, mais erodidas (portadoras de ocelos e/ou fenocristais).

Foto 33 - Restos muito deformados e rompidos de dique máfico decimétrico, maciço. A rocha tem aspecto ígneo preservado, inclusive em secção delgada, mas a deformação e a encaixante, uma mistura e alternância de sienito e charnoquito, deixam dúvidas. Local, Pontinha 
Foto 34 - Chamoquito porfiroclástico, superfície paralela à foliação. Reticulado: 5 $\times 5 \mathrm{~cm}$

Foto 35 - Sienito híbrido. Notar labradorescência e forma sub-retangular dos cristais de feldspato. Amostra inclinada para obtenção do efeito na parte inferior, o feldspato ficando quase preto na parte superior menos iluminada. Reticulado: $5 \times 5 \mathrm{~cm}$.

Foto 36 - Sienito comum, sem quartzo. Mesmo praticamente fresca, nota-se a variação na cor das mesopertitas. Superfície serrada. Efeito de cor obtido, em parte, por impregnação moderada com nujol (a seco, a rocha é mais clara). Reticulado: $5 \times 5 \mathrm{~cm}$

Foto 37 - Amostra de dique da costa oeste da llha (pontos 120 a 123). Rocha inequigranular a subporfirítica, com tendência panidiomórfica dos feldspatos maiores $(\leq 10 \mathrm{~mm}) /$ fêmicos dispersos, menores em torno dos 10\%. A cor pardacenta já revela alteração incipiente. Reticulado: 5 × 5 $\mathrm{cm}$

Foto 38 - Microssienito equigranular das proximidades dos contatos principais, na encosta oeste da llha. A rocha verde é fresca e passa a tipo quase branco, incipientemente alterado. Afora a cor e alguma limonita, não há diferença quanto à resistência, ou mesmo na textura e mineralogia principal, entre o núcleo e a envoltória. A granulação é média, os feldspatos subidiomórficos e os fêmicos representam em torno de $10 \%$. Notar a presença do quartzo (cinzento) na envoltória clara. Reticulado: $5 \times 5 \mathrm{~cm}$

Foto 39 - Microssienito com quartzo, porfirítico (xenocristais?). Resto charnoquítico, mostrando contatos, ao mesmo tempo, nítidos e difusos no microssienito. A feição não é fácil de ser encontrada, mas é comum junto aos contatos. Reticulado: $5 \times 5 \mathrm{~cm}$.

Foto 40 - Rocha riolítica, do ponto 326. A rocha, afanítica, tem cor castanha escura, mas sempre mostra alguma alteração. Notar xenocristais de feldspato, com envoltórias concêntricas, sucessivas. Reticulado: $5 \times 5 \mathrm{~cm}$.

Foto 41 - Nefelina microssienito. Identificáveis: feldspato, nefelina (marrom) e clinopiroxênio egirínico. Reticulado: $5 \times 5 \mathrm{~cm}$.

Foto 42 - Fonólito. Rocha afanítica, com alto teor de fêmicos (egirina), com venulação de mineralogia rara (eudialita, vermelha). Presença de zeólitas (?), de cor branca. Reticulado: $5 \times 5 \mathrm{~cm}$. 
Foto 43 - Lamprófiro. Observam-se dois tipos de ocelos. Junto aos de forma irregular, maiores, a rocha adquire cor mais clara, por diminuição ou ausência dos fêmicos. Reticulado: $5 \times 5 \mathrm{~cm}$.

Foto 44 - Contato "riólito" - charnoquito. O contato mostra cisalhamento, com formação de faixa microbrechada e estrutura fluxionar. Na extremidade direita, inferior, já se observa o riólito normal. Reticulado: $5 \times 5 \mathrm{~cm}$.

Foto 45 - Sienito em contato com porção nefelínica, também sienítica, pegmatóide. Notar alguma invasão, discreta, do nefelina sienito na encaixante. Reticulado: $5 \times 5 \mathrm{~cm}$ 


\section{LEGENDAS DAS FOTOMICROGRAFIAS}

Fotomicrografia 1-Milonito/blastomilonito quartzo-feldspático. Feições alongadas, paralelas, de quartzo e opacos, segmentam o agregado granoblástico (recristalizado) de pertitas, com algum plagioclásio. Não ocorrem fêmicos. Dimensão maior, 5,50 mm, filtros fosco e azul, polarizadores semicruzados.

Fotomicrografia 2 - Detalhe de sienito com textura foiaítica. Notar o arranjo dos indivíduos, paralelos e plano de composição da geminação paralelo às bordas. Contatos praticamente retilíneos. Padrão irregular das mesopertitas. Porções mais claras e limpas, mais albíticas; escuras ou mais sujas, mais potássicas. Dimensão maior, $1,39 \mathrm{~mm}$, filtro azul, polarizadores semicruzados

Fotomicrografia 3 - Detalhe de sienito. O arranjo não é mais foiaítico, havendo já bastante embainhamento mútuo entre grãos, ao mesmo tempo que se conservam partes retilíneas dos contatos. Mesopertita não típicamente lamelada ("tigrada"), em grande parte anastomosada. Porções mais escuras, mais potássicas. Notar que as lamelas sódicas se bifurcam e cruzam ou subdividem as porções potássicas. Observar possível exsolução de fratura no individuo escuro, em forma de semicírculo, convexo para a esquerda. Notar porção central mais sódica do indivíduo maior. Notar ainda quartzo intergranular à esquerda, inferior. Dimensão maior, 2,80 $\mathrm{mm}$, filtro azul, polarizadores semicruzados.

Fotomicrografia 4 - O grau de interação entre os indivíduos micromesopertíticos aumenta, e estes passam a se interpenetrar. Resultam formas xenomórficas e textura alotriomórfica. Observar predomínio da fase sódica, nos indivíduos (porções limpas) e padrão indefinido das exsoluções. Dimensão maior, $5,50 \mathrm{~mm}$, filtro 
azul, polarizadores semicruzados. Nota: a secção é para microssonda e, portanto, mais espessa.

Fotomicrografia 5 - Textura "subfoiaitica" de sienito, já com algum desarranjo no tamanho e nos contatos dos indivíduos. Micromesopertitas de padrão variado e algum rearranjo estrutural presentes (ondulações). Notar fímbrias claras, interpenetradas, albíticas. Placas de biotita inclusas. Dimensão maior, $5,50 \mathrm{~mm}$, filtro azul, polarizadores semicruzados.

Fotomicrografia 6 - Sienito. Notar o feldspato com aspecto homogêneo, característica rara nos sienitos da Ilha. Fêmicos enfileirados e intercrescidos: clinopiroxênio e biotita, mais apatita e opacos. Observar contato quase retilíneo dos feldspatos. Opacos orlados por titanita. Dimensão maior, $5,50 \mathrm{~mm}$, filtro azul, polarizadores semicruzados.

Fotomicrografia 7 - Sienito. Agregado de clinopiroxênio esverdeado e biotita, bastante típicos, aparentemente em "sineusis", pelo menos descritivamente. Agregado inclui apatita e opacos. Mesopertita com padrão muito irregular, fases potássicas muito "sujas". Dimensão maior, $2,80 \mathrm{~mm}$, filtros azul e fosco, polarizadores descruzados.

Fotomicrografia 8 - Sienito. Mesopertita de padrão irregular. Fase amarelada, sódica; cinzenta clara, intermediária, a cinzenta escura, potássica - no indivíduo da esquerda. Dimensão maior, 2,80 $\mathrm{mm}$, filtro azul, polarizadores semicruzados.

Fotomicrografia 9 - Sienito. Detalhe de mesopertita em manchas ("patch"), com geminação polissintética na fase albítica, fase potássica mais escura e suja. Dimensão maior, $1,39 \mathrm{~mm}$, filtro azul, polarizadores semicruzados. 84

Fotomicrografia 10 - Sienito. Detalhe da micromesopertita lamelada ("tigrada"). Notar bizelamento, bifurcações. Fase cinzenta mais clara, limpa, sódica. Observar pertitização transversal, provavelmente o tipo chamado de "pertita de fratura". Dimensão maior, 1,39 $\mathrm{mm}$, filtro azul, polarizadores semicruzados. 
Fotomicrografia 11 - Sienito. Padrões e distribuição das fases em um indivíduo. Centro, à esquerda, albítica, quase homogênea, passa a manchas, em que aumenta a fase potássica. Na borda, à direita, domina padrão anastomosado, com maior presença da fase potássica. A separação entre a borda, à direita, e a porção manchada mostra fases albíticas alongadas transversalmente, talvez, exsolução de fratura. Dimensão maior, $2,80 \mathrm{~mm}$, filtros azul, polarizadores semicruzados.

Fotomicrografia 12 - Sienito. Agregado fêmico, com clinopiroxênio, biotita, opacos e apatita. Clinopiroxênio do tipo incolor/esverdeado, pouco alterado. Notar relações de inclusão entre os minerais. Dimensão maior, $2,80 \mathrm{~mm}$, filtros azul e fosco, polarizadores descruzados

Fotomicrografia 13 - Sienito. Clinopiroxênio, de aspecto possivelmente corroído, constituído em sua maior parte por um núcleo incolor, passando a esverdeado e verde nas bordas. Manchas internas, cinzentas claras, de anfibólio; um segundo anfibólio, verde escuro, está presente nas bordas. Inclusos e periféricos: biotita, apatita e titanita. Dimensão maior, $2,80 \mathrm{~mm}$, filtros azul e fosco, polarizadores descruzados.

Fotomicrografia 14 - Sienito. Nas rochas com presença de quartzo, esse anfibólio, pouco mais escuro (verde oliva/pardo-amarelado escuro), é o mais comum. Inclui resto de clinopiroxênio limonitizado, apatita, opacos e zircão. Observar parte das bordas, à esquerda, com tendência ao intercrescimento com a mesopertita contígua. Dimensão maior, 2,80 $\mathrm{mm}$, filtro azul, polarizadores descruzados.

Fotomicrografia 15 - Sienito, da extremidade sudeste da Ilha. Associação biotitaclinopiroxênio. Notar cor da biotita e do piroxênio, este com verde acentuado. Observar inclusões de apatita e opacos e bordas digitadas da biotita. Dimensão maior, 5,50 mm, filtro azul, polarizadores descruzados. 
Fotomicrografia 16 - Sienito, tipo com quartzo, e microssienito. Variedade mais comum entre os anfibólios. Direção do polarizador paralela à clivagem, anfibólio com elongação positiva. Notar os tons de cores do anfibólio, seu manchamento/zoneamento (verdeamarelado/verde-acinzentado) e a cor azul intenso junto às periferias. Observar inclusões de zircão, apatita e halos pleocróicos em torno de mineral não identificado. Dimensão maior, 1,39 mm, filtro azul, polarizadores descruzados.

Fotomicrografia 17 - Sienito. Intercrescimento de biotita com anfibólio verde oliva. Notar a fina interdigitação. Inclusões de opacos e apatita. Dimensão maior $5,50 \mathrm{~mm}$, filtros azul e fosco, polarizadores descruzados

Fotomicrografia 18 - Quartzo sienito, com textura alotriomórfica. Mesopertitas lameladas ("tigradas") ou de padrão irregular. Dimensão maior, 2,80 $\mathrm{mm}$, filtro azul, polarizadores semicruzados.

Fotomicrografia 19 - Sienito. Textura inequigranular, seriada, alotriomórfica/hipidiomórfica. Contatos não muito irregulares, pouca interpenetração. Notar variação no padrão micromesopertítico do indivíduo à esquerda, com faixa de borda "tigrada". Presentes biotita, clinopiroxênio e opacos. Dimensão maior, $5,50 \mathrm{~mm}$, filtro azul, polarizadores semicruzados.

Fotomicrografia 20 - Quartzo sienito, com textura quase equigranular hipidiomórfica. Notar contatos moderadamente irregulares e presença de microgranulação intersticial, que inclui quartzo (branco), albita (branca) e opacos. Padrão micromesopertítico variado. Dimensão maior, 2,80 mm, filtros fosco e azul, polarizadores semicruzados.

Fotomicrografia 21 - Quartzo sienito. Anfibólio comum, com resto alterado de clinopiroxênio incolor. Inclusões de opacos e apatita. Biotita aparece, vizinha. Dimensão maior, $2,80 \mathrm{~mm}$, filtro azul, polarizadores descruzados. 
Fotomicrografia 22-Microssienito. Rocha fina, equigranular, alotriomórfica/hipidiomórfica. Micromesopertita "tigrada", xenomórfica, representa mais que $90 \%$. Quartzo, branco $(<5 \%)$, intergranular (não confundir com fases albíticas); opacos e fêmicos não mais que $5 \%$. Dimensão maior, $5,50 \mathrm{~mm}$, filtro azul, polarizadores semicruzados

Fotomicrografia 23 - Microssienito. Textura hipidiomórfica, inequigranular $(>3$ $\mathrm{mm} \leq 0,4 \mathrm{~mm})$, micromesopertita variada $(95 \%)$, quartzo $<$ $5 \%$, clinopiroxênio (grãos coloridos) $<5 \%$, opacos $1-2 \%$. Fêmicos: clinopiroxênio e biotita em plaquetas e opacos intragranulares. Comparar forma dos grãos e padrão micromesopertítico com Fotomicrografias 22, 24 e 26. Dimensão maior, $5,50 \mathrm{~mm}$, filtro azul, polarizadores semicruzados.

Fotomicrografia 24 - Microssienito (com quartzo, $\sim 5 \%$ ) equigranular, hipidiomórfico, micromesopertita retangular, quadrada ou xenomórfica, tipos não "tigrados". Anfibólio em torno dos 5\%, opacos 1 a $2 \%$, intergranulares. Dimensão maior, $2,80 \mathrm{~mm}$, filtro azul, polarizadores semicruzados.

Fotomicrografia 25 - Microgranito de zona de contato, com quartzo em torno dos 25-30\%, intercrescido ou incluso na micromesopertita. Mesopertita de padrão variado, rocha inequigranular alotriomórfica. Fêmicos: opacos e biotita, traços. Dimensão maior, $1,39 \mathrm{~mm}$, filtro azul, polarizadores semicruzados.

Fotomicrografia 26-Álcali feldspato-quartzo microssienito. Esse tipo caracteriza mais as rochas de dique, mas ocorre próximo às zonas de contato. Textura quase panidiomórfica, micromesopertita "tigrada" típica (reportar-se à descrição dos sienitos), geminada. Quartzo (branco) intersticial, tipo "moldura", anfibólio relativamente bem formado, intergranular.

Dimensão maior, $2,80 \mathrm{~mm}$, filtro azul, polarizadores cruzados. 102 
Fotomicrografia 27 - Traquito porfirítico, textura não traquítica. Mesopertita (95\%), opacos e traços de fêmicos. Dimensão maior, $5,50 \mathrm{~mm}$, filtros azul e fosco, polarizadores semicruzados.

Fotomicrografia 28 - Traquito porfirítico, com textura traquítica. Os minerais, mesopertita em traves longas, biotita e opacos orientam-se paralelamente ao fluxo, que envolve o fenocristal. Fenocristal com núcleo mais limpo, circundado por linhas de crescimento, marcadas pelos fêmicos. Dimensão maior, $5,50 \mathrm{~mm}$, filtro azul e fosco, polarizadores cruzados.

Fotomicrografia 29 - Nefelina microssienito, textura mais granular, fina a média. Mesopertita, nefelina com alguma cancrinita, biotita e opacos. Preto, isótropo, sodalita. Observar hábito e inclusões da nefelina, e formas da mesopertita. Dimensão maior, $5,50 \mathrm{~mm}$, filtros azul e fosco, polarizadores semi- cruzados.

Fotomicrografia 30 - Nefelina microssienito/fonólito, com mesopertita, nefelina, sodalita, egirina e biotita. Notar hábitos da pertita e da nefelina, e inclusões na nefelina e na sodalita. Fêmicos quase sempre intersticiais. Dimensão maior, $2,80 \mathrm{~mm}$, filtros azul e fosco, polarizadores semicruzados

Fotomicrografia 31 - Fonólito. Feldspato alcalino somente em traves longas. Nefelina xenomórfica, com inclusões de feldspato e fêmicos, pouca sodalita. Egirina e biotita dispersos. Alguns $\mathrm{Ti}-\mathrm{Zr}$ silicatos, parte concentrados à direita, inferior, sendo reconhecível a enigmatita, superpostos aos félsicos. Dimensão maior, 5,50 $\mathrm{mm}$, filtros azul e fosco, polarizadores semicruzados.

Fotomicrografia 32 - Fonólito, detalhe. Glomerocristais de biotita e egirina, com inclusão de ripas de albita. Fundo claro de feldspatos e nefelina, zonas mais cinzentas de nefelina ou feldspato mesopertítico, restante, albita mais egirina. Dimensão maior, $2,80 \mathrm{~mm}$, fítros azul e fosco, polarizadores descruzados.

Fotomicrografia 33 - Rocha diabásica/basáltica (pós-sienitos). Textura subofítica, traquitóide. Ripas de plagioclásio, placas de anfibólio e biotita, 
e opacos. Observar retilinidade e angulosidade das formas e contatos. Dimensão maior, $2,80 \mathrm{~mm}$, filtros azul e fosco, polarizadores descruzados.

Fotomicrografia 34 - Rocha diabásica/basáltica (pré-sienitos). Ripas alongadas de plagioclásio, com núcleos acinzentados e bordas limpas (mais sódicas). Arranjo blastossubofítico, traquitóide. Anfibólio marrom, biotita, clinopiroxênio incolor. Notar embainhamento e arredondamento das formas em geral. Dimensão maior, 2,80 $\mathrm{mm}$, filtros azul e fosco, polarizadores semicruzados

Fotomicrografia 35 - Mesmo tipo de rocha, textura mais granoblástica, plagioclásio com formas mais largas. Notar embainhamento e arredondamento generalizados das formas e contatos. Dimensão maior, 1,39 $\mathrm{mm}$, filtros azul e fosco, polarizadores semicruzados.

Fotomicrografia 36 - Microxenólito. Olivina, com alteração de borda (biotita+opacos) e apatita no centro, ao lado de plagioclásio zonado, com inclusões, clinopiroxênio pardo, zonado abaixo. Dimensão maior, $5,50 \mathrm{~mm}$, filtros azul e fosco, polarizadores descruzados

Fotomicrografia 37 - Camptonito. Plagioclásio cálcico predominante. Dois xenocristais de anfibólio amarelo-esverdeado à esquerda. Clinopiroxênio zonado (centro, direita), biotita vermelha, opacos granulares. Porções cinzentas intersticiais, muito limpas, material isótropo (analcita?). Dimensão maior, 2,80 $\mathrm{mm}$, filtro azul e fosco, polarizadores semicruzados.

Fotomicrografia 38 - Camptonito. Textura, à direita, muito comum e típica. Porções cinzentas: plagioclásio alterado e isótropos. Fenocristal de clinopiroxênio zonado (pardo/róseo/amarelado) com forma reentrante, mas que não deve ser corrosão (observar o zoneamento recorrente). Dimensão maior, $2,80 \mathrm{~mm}$, filtros azul e fosco, polarizadores semicruzados.

Fotomicrografia 39 - Camptonito típico, com plagioclásio pouco alterado e analcita (isótropo). Dois fenocristais de olivina, à esquerda. 
Cristais amarelos estão pseudomorfisados. Clinopiroxênio com cores claras. A rocha apresenta biotita vermelha e não contém kaersutita. Dimensão maior, 5,50 mm, filtros azul e fosco, polarizadores semicruzados.

Fotomicrografia 40 - Monchiquito. Destacam-se microfenocristais de olivina e clinopiroxênio. Matriz granular fêmica com os mesmos minerais e kaersutita. À esquerda, ocelo com vidro (marrom) e vidro (branco), que se expande para os interstícios. Notar três formas de opacos, em particular as grades. Dimensão maior, $2,80 \mathrm{~mm}$, filtros azul e fosco, polarizadores descruzados

Fotomicrografia 41 - Camptonito, com kaersutita (alaranjada) e biotita vermelha, mais piroxênio. Áreas cinzentas são de plagioclásio, parte microcristalino, e porções isótropas, mais limpas, de analcita. Notar microfenocristal de biotita, esquelético, no centro. Opacos, parcialmente esqueléticos. Dimensão maior, 2,80 mm, filtros azul e fosco, polarizadores semicruzados.

Fotomicrografia 42 - Sannaíto, com clinopiroxênio, kaersutita e biotita, de coloridos variados, e opacos. Ocelos, lado esquerdo, é à direita, parte superior. Ocelos com feldspato potássico, analcita (isótropa), alguma biotita e kaersutita. Também aparece plagioclásio alterado, minoritário. Dimensão maior, 2,80 mm, filtros azul e fosco, polarizadores semicruzados.

Fotomicrografia 43 - Monchiquito. Coloridos: microfenocristais de olivina (coloridos fortes) e clinopiroxênio com zoneamento setorial. Matriz granular com os mesmos mais opacos. Matriz quase isótropa: fêmicos finos, analcita, vidro, vidro pouco cristalizado. Sem feldspato. Dimensão maior, $5,50 \mathrm{~mm}$, filtros azul e fosco, polarizadores semicruzados

Fotomicrografia 44 - Provável monchiquito. Destaques maiores: ocelos com carbonato, zeólita, serpentina; apatita (centro) e clinopiroxênio (canto superior direito). Matriz granular: opacos (notar a quantidade), kaersutita e clinopiroxênio prismático. A textura 
não é tipicamente lamprofírica. Dimensão maior, $1,39 \mathrm{~mm}$,

filtros azul e fosco, polarizadores descruzados.

Fotomicrografia 45 - Lamprófiro não classificado (camptonito? sannaíto?). Matriz

clara com feldspato (?), material isótropo (?) e apatita.

Coloridos: kaersutita prismática, longa, e titanita (?). Dimensão

maior, 1,39 mm, filtros azul e fosco, descruzados.

Fotomicrografia 46 - Rocha máfica-ultramáfica (deformada). "Fenocristais" de

clinopiroxênio, idiomórficos, cantos arredondados e embainhados, com matriz de preenchimento. Matriz granular, aspecto granoblástico, muito fino, com biotita, clinopiroxênio, opacos e plagioclásio. Dimensão maior, $5,50 \mathrm{~mm}$, filtros azul e fosco, polarizadores semicruzados.

Fotomicrografia 47 - Dique lamprofírico, contato com charnoquito (canto inferior).

Vidro marrom alaranjado, com glóbulos de carbonato.

Fenocristais de olivina, clinopiroxênio e opacos. Até $1,5 \mathrm{~mm}$ do contato, o vidro é homogêneo. As esferas de carbonato aumentam de tamanho. Canto direito superior, rocha já quase holocristalina. Dimensão maior, $5,50 \mathrm{~mm}$, filtros azul e fosco, polarizadores descruzados.

Fotomicrografia 48 - Fenocristal de olivina junto ao contato anterior. Região bastante cristalizada e grande quantidade de carbonato em glóbulos e opacos. Minerais ainda criptocristalinos, não reconhecíveis. A olivina está alterada em serpentina + carbonato e algum opaco. Dimensão maior, $1,39 \mathrm{~mm}$, filtros azul e fosco, polarizadores semicruzados. 136

Fotomicrografia 49 - Quartzo microssienitos, com intercrescimento granofírico.

Notar no centro, à direita, um feldspato homogêneo, aparentemente não pertítico, orlado por quartzo granofírico. Dimensão maior, $5,50 \mathrm{~mm}$, filtros azul e fosco, polarizadores semicruzados.

Fotomicrografia 50 - Charnoquito, junto a contato com dique máfico do tipo diabásico hornfélsico. Faixa de cisalhamento em diagonal NESW corta uma porção granofírica, e não afeta a seguinte. 
Presentes opacos e ortopiroxênio. Dimensão maior, $2,80 \mathrm{~mm}$,

filtros azul e fosco, polarizadores semicruzados.

Fotomicrografia 51 - Lamprófiro (camptonito/sannaíto) com ocelos esféricos (4), portadores de feldspato potássico, analcita, carbonato, biotita e kaersutita. Plagioclásio (?) presente fora dos ocelos. Notar redes de opacos e sua ausência nos ocelos. Dimensão maior, 1,39 $\mathrm{mm}$, filtros azul e fosco, polarizadores semicruzados.

Fotomicrografia 52 - Ocelos de formas irregulares, em lamprófiro. Ocelo com analcita e zeólita, esta apenas orlando. Matriz: opacos, clinopiroxênio, biotita, kaersutita, feldspato, analcita, vidro (?). Dimensão maior, $2,80 \mathrm{~mm}$, filtros azul e fosco, polarizadores semicruzados

Fotomicrografia 53 - Ocelo esférico de analcita com carbonato e serpentina. Rocha: camptonito, com clinopiroxênio, biotita, kaersutita, opacos, plagioclásio, vidro (?) e analcita. Dimensão maior, 5,50 $\mathrm{mm}$, filtros azul e fosco, polarizadores cruzados 140

Fotomicrografia 54 - Ocelo de analcita e vidro. Vidro marrom, analcita incolor e fibras (biotita), além de feldspato potássico e kaersutita, mais desenvolvidos. Notar relações clinopiroxênio pardo rosa com a kaersutita. Observar opacos em grãos e grades. Dimensão maior, 1,39 mm, filtros azul e fosco, polarizadores descruzados

Fotomicrografia 55 - Microssienito mesopertítico, com restos de plagioclásio de charnoquito, típico, deformado (previamente). Notar contato e orla externa, mais fina, do plagioclásio. Dimensão maior, 5,50 $\mathrm{mm}$, filtros azul e fosco, polarizadores semicruzados.

Fotomicrografia 56 - Contato rocha diabásica hornfélsica com charnoquito. No charnoquito, à esquerda, alinhamento do ortopiroxênio e dos opacos, poucos intercrescimentos granofíricos. O dique inicia com faixa de plagioclásio (mais cálcico), piroxênios e opacos (2 $\mathrm{mm})$ e, só mais distante, passa à mineralogia original, com biotita. Faixa de transição de interpretação polêmica. Plagioclásio paralelo. Dimensão maior, $5,50 \mathrm{~mm}$, filtros azul e fosco, polarizadores semicruzados 
Fotomicrografia 57 - Contato entre microssienitos (quartzo, branco). Notar a interface de acomodação entre as partes, sem evidências de reação e cisalhamento. Dimensão maior, $5,50 \mathrm{~mm}$, filtros azul e fosco, polarizadores semicruzados.

Fotomicrografia 58 - Veio de microssienito (canto superior direito), com mesopertita e raro quartzo, em rocha diabásica hornfélsica. Alinhamento e subparalelismo mineral junto ao contato, pouca interação entre partes. Dimensão maior, $5,50 \mathrm{~mm}$, filtros azul e fosco, polarizadores semicruzados. 


\section{LEGENDAS DAS FIGURAS}

Pág.

Figura 1 - Mapa de localização da Ilha dos Búzios, SP

Anexo

Figura 2 - Mapa geográfico e toponímico da Ilha dos Búzios, SP Anexo

Figura 3 - Mapa geológico da Ilha dos Búzios, SP Anexo

Figura 4 - Mapa de localização dos pontos de observações e amostragem. Anexo

Figura 5 - Distribuição e dimensões dos corpos alcalinos em Carta Batimétrica do

Litoral Norte, SP Anexo

Figura 6-Composições pontuais de feldspatos, por amostra, para (a) sienitos e microssienitos (amostras BZ 123) e (b) diques félsicos da llha dos Búzios, no triângulo An-Ab-Or (\% em peso). Grão comum: núcleo †, borda $O$; microfenocristal: núcleo $\diamond$, borda $\diamond$; intergranular $\times$; incluso $\square$; grão da matriz: núcleo $\nabla$, borda $\nabla$ 165

Figura 7-Composições pontuais de feldspatos, por amostra, para os diques máficos da tiha dos Búzios, no triângulo An-Ab-Or (\% em peso). Xenocristal: núcleo , borda $\square$; ocelo . Demais símbolos como na Figura 6 166

Figura 8-Diagramas Quad $\left(\mathrm{Ca}+\mathrm{Mg}+\mathrm{Fe}^{2+}\right)$ - J (2Na), En (enstatita) - Fs (ferrossilita) - Wo (wollastonita) e Jd (jadeíta) - Ae (egirina) - WEF (Quad) de Morimoto (1988) para piroxênios de sienitos da llha dos Búzios. Grão comum: núcleo , borda $O$; inclusão 174

Figura 9 - Diagramas Quad $\left(\mathrm{Ca}+\mathrm{Mg}+\mathrm{Fe}^{2+}\right)$ - J $(2 \mathrm{Na})$ e Jd (jadeíta) - Ae (egirina) WEF (Quad) de Morimoto (1988) para piroxênios de diques félsicos da tha dos Búzios. Símbolos como na Figura 8

Figura 10-Diagramas Quad $\left(\mathrm{Ca}+\mathrm{Mg}+\mathrm{Fe}^{2+}\right)$ - J (2Na) e En (enstatita) - Fs (ferrossilita) - Wo (wollastonita) de Morimoto (1988) para piroxênios de diques máficos da tha dos Búzios. Matriz $\times$; microfenocristal: núcleo $\triangle$, borda $\triangle$; xenocristal: núcleo $\diamond$, borda $\diamond$; demais símbolos como na Figura 8

Figura 11a - Diagramas de variação mg\# vs. Si, $\mathrm{Al}^{\mathrm{IV}}, \mathrm{Al}^{\mathrm{vI}}$, Ti, $\mathrm{Na}$ e $\mathrm{Fe}^{3 .+}$ (auf) para piroxênios de sienitos da llha dos Búzios. Símbolos como na Figura 8 
Figura $11 \mathrm{~b}$ - Diagramas de variação mgł vs. Si, $\mathrm{Al}^{\mathrm{IV}}, \mathrm{Al}^{\mathrm{Vt}}$, Ti, $\mathrm{Na}$ e Fe $\mathrm{e}^{3+*}$ (auf) para piroxênios de diques félsicos da Ilha dos Búzios. Símbolos como na Figura 8 .

Figura 11c - Diagramas de variação mg\# vs. $\mathrm{Si}, \mathrm{Al}^{\mathrm{IV}}, \mathrm{Al}^{\mathrm{VI}}$, Ti, Na e Fe $\mathrm{F}^{3+}$ (auf) para piroxênios de diques máficos da llha dos Búzios. Símbolos como nas Figuras 8 e 10

Figura 12 - Diagrama $\mathrm{Mg}-\mathrm{Na}-\left[\mathrm{Fe}^{2+}+\mathrm{Mn}+\left(\mathrm{Fe}^{3+}-\mathrm{Na}\right)\right]$ para piroxênios de sienitos (grão comum: núcleo , borda $O$; inclusão $\square$ ), diques félsicos ( $\$$ ) e diques máficos $(+)$ da llha dos Búzios

Figura 13 - Diagrama $\left(\mathrm{Ti}+\mathrm{Al}^{\mathrm{lV}}\right)-\left(\mathrm{Fe}^{2+}+\mathrm{Mg}+\mathrm{Ca}\right)-\left(\mathrm{Na}+\mathrm{Fe}^{3+}\right)$ para piroxênios de sienitos (grão comum: núcleo - borda $O$; inclusão $\square$ ), diques félsicos ( ) e diques máficos (xenocristal: núcleo $\diamond$, borda $\diamond$;

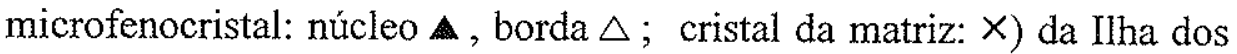
Búzios

Figura 14 - Diagrama Na-Ti-Al ${ }^{\mathrm{IV}}$ para piroxênios de sienitos (grão comum: núcleo , borda $O$; inclusão $\square$ ), diques félsicos ( $\Theta$ ) e diques máficos (xenocristal: núcleo , borda $\diamond$; microfenocristal: núcleo borda $\triangle$; cristal da matriz: $x$ ) da llha dos Búzios

Figura 15a-Diagramas Si vs. $\mathrm{Mg} /\left(\mathrm{Mg}+\mathrm{Fe}^{2++}\right)$ de Leake (1978) para anfibólios cálcicos $\left[(\mathrm{Ca}+\mathrm{Na})_{\mathrm{B}} \geq 1,34 ; \mathrm{Na}_{\mathrm{B}}<0,67\right.$ auf], acima, e sódico-cálcicos $\left[(\mathrm{Ca}+\mathrm{Na})_{\mathrm{B}} \geq 1,34 ; \mathrm{Na}_{\mathrm{B}}\right.$ entre 0,67 e 1,34 auf $]$, abaixo, de sienitos da Ilha dos Búzios. Grão comum: núcleo , borda $O$, inclusão 192

Figura $15 b$ - Diagramas Si vs. $\mathrm{Mg} /\left(\mathrm{Mg}+\mathrm{Fe}^{2+}\right)$ para anfibólios sódico-cálcicos $\left[(\mathrm{Ca}+\mathrm{Na})_{\mathrm{B}} \geq 1,34 ; \mathrm{Na}_{\mathrm{B}}\right.$ entre 0,67 e 1,34 auf $]$, acima, e Fe $\mathrm{e}^{3+} /\left(\mathrm{Fe}^{3+}+\mathrm{Al}^{\mathrm{Vk}}\right)$ vs. $\mathrm{Mg} /\left(\mathrm{Mg}+\mathrm{Fe}^{2++}\right)$ para anfibólios alcalinos $\left(\mathrm{Na}_{\mathrm{B}} \geq 1,34\right)$, abaixo, de Leake (1978) de diques félsicos da Ilha dos Búzios. Grão comum: núcleo $\nabla$, borda $\nabla$; grão da matriz $\times$

Figura 15c - Diagramas Si vs. $\mathrm{Mg} /\left(\mathrm{Mg}+\mathrm{Fe}^{2+}\right)$ de Leake (1978) para anfibólios cálcicos $\left[(\mathrm{Ca}+\mathrm{Na})_{\mathrm{B}} \geq 1,34 ; \mathrm{Na}_{\mathrm{B}}<0,67\right.$ auf $]$ de diques máficos da tha dos Búzios. Grão comum: núcleo $\mathbf{A}$, borda $\triangle$; ocelo ; inclusão 195

Figura 16 - Diagramas de variação mg\# vs. Si, Al, Ti, Ca, BNa e K (auf) para anfibólios de sienitos, diques félsicos e diques máficos da Ilha dos Búzios. Símbolos como na Figura 15 
Figura 17 - Diagrama Si vs. Al (auf) para anfibólios de sienitos, diques félsicos e diques máficos da Ilha dos Búzios. Símbolos como na Figura 15

Figura 18 - Diagrama $\mathrm{Mg}-\mathrm{Na}-\left[\mathrm{Fe}^{2+}+\mathrm{Mn}+\left(\mathrm{Fe}^{3+}-\mathrm{Na}\right)\right]$ para $(\mathrm{A})$ piroxênios $(+)$ de rochas sem anfibólios e $(B)$ de rochas com coexistência de piroxênios $(+)$ e anfibólios (O)

Figura 19 - Diagrama $\mathrm{Al}^{\mathrm{IV}}$ vs. Fe/(Fe+Mg) para biotitas de sienitos, diques félsicos e diques máficos da Ilha dos Búzios. Símbolos como na Figura 15

Figura 20 - Diagrama Total Álcalis Sílica "TAS" (Le Maitre, 1989). Sienitos $\square$;

Ne-sienitos Q Q-sienitos diques félsicos: insaturados supersaturados $O$; diques máficos ; mangerito de Búzios $X$; charnoquito de Ubatuba (média para 23 análises, Neumann, 1993) $*$

Figura 21 - Diagrama de classificação R1R2 de De La Roche (1986). Símbolos como na Figura 20. Em parênteses, equivalente intrusivo. 1, ankaratrito (melteigito); 2, basanito (teralito); 3, basalto alcalino (gabro alcalino); 4 , olivina basalto (olivina gabro); 5 , nefelinito (ijolito); 6 , tefrito (essexito); 7, traquibasalto (sienogabro); 8, latibasalto (monzogabro); 9 , fonotefrito (essexito); 10, traquiandesito (sienodiorito); 11, latito (monzonito); 12, fonólito (sienito nefelínico); 13, traquifonólito (nefelina sienito); 14, traquito (sienito); 15, quartzo traquito (quartzo sienito); 16, riólito alcalino (granito alcalino); 17, riólito (granito)

Figura 22 - Diagrama TAS com campos alcalino e subalcalino (MacDonald e Katsura, 1964). Símbolos como na Figura 20

Figura 23 - Diagrama AFM mostrando "trend" médio de toleitos havaianos (linha tracejada) e suíte alcalina (linha cheia) de MacDonald e Katsura (1964).

Símbolos como na Figura 20. .236

Figura 24 - Diagrama $\mathrm{K}_{2} \mathrm{O}$ vs. $\mathrm{Na}_{2} \mathrm{O}$ (Middlemost, 1975). Símbolos como na Figura 20. 236

Figura 25a - Diagramas bivariantes: mg\# [MgOx100/(MgO+FeO)] vs. elementos maiores. Símbolos como Figura 20.

Figura 25b - Diagramas bivariantes: $\mathrm{mg \#}[\mathrm{Mg}) \times 100 /(\mathrm{MgO}+\mathrm{FeO})]$ vs. elementos traços. Símbolos como Figura 20.

Figura $25 \mathrm{c}$ - Diagramas bivariantes mg\# $[\mathrm{Mg}) \times 100 /(\mathrm{MgO}+\mathrm{FeO})]$ vs. elementos

Terras Raras. Símbolos como Figura 20. 
Figura 26 - Diagramas multi-elementos (spidergram) normalizados a partir do manto primitivo (Wood et al., 1979). A, diques máficos; B, sienitos, Qsienitos e Ne-sienitos, sobre sombra de diques; $\mathrm{C}$, diques insaturados sobre sombra de diques máficos. Símbolos como Figura 20.

Figura 27 - Diagramas multi-elementos (spidergram) normalizados a partir do manto primitivo (Wood et al., 1979). A, Charnoquito de Ubatuba (média para 23 análises, Neumann, 1993) e mangerito sobre sombra de sienitos; $\mathrm{B}$, diques insaturados sobre sombra de sienitos; $\mathrm{C}$, diques supersaturados sobre sombra de sienitos. Símbolos como na Figura 20.

Figura 28 - Gráfico ${ }^{87} \mathrm{Sr} /{ }^{86} \mathrm{Sr} \mathrm{x}{ }^{87} \mathrm{Rb} /{ }^{86} \mathrm{Sr}$ para rochas alcalinas da tha dos Búzios. Valores analíticos obtidos de rochas totais. As barras indicam desvio padrão dos valores médios. Amostras: 1, BZ 313/6A e 2, BZ 326A7, diques máficos; 3, BZ 177, sienito; 4, BZ 165B, fonólito 254

Figura 29 - Superfície do "liquidus", no sistema $\mathrm{Q}-\mathrm{Ne}-\mathrm{Ks}$ a $\mathrm{pH}_{2} \mathrm{O}=1 \mathrm{~kb}$, com isotermas e linhas cotéticas (Hall, 1987). Plotadas composições normativas das rochas da llha dos Búzios. Símbolos como na Figura 20 


\section{LEGENDAS DAS TABELAS}

Tabela 1 - Composição química, em porcentagem de peso, de feldspatos de sienitos e microssienitos (amostra BZ 123) da Ilha dos Búzios. N, núcleo; B, borda; GC, grão comum; INTG, intergranular; INC, inclusão. $\mathrm{Fe}_{\text {total }}$ calculado como FeO. Fórmula estrutural calculada na base de 32 oxigênios

Tabela 2 - Composição química, em porcentagem de peso, de feldspatos de diques félsicos da llha dos Búzios. $\mathrm{N}$, núcleo; $\mathrm{B}$, borda; $\mathrm{GC}$, grão comum; INTG, intergranular; MTZ, matriz; MFN, microfenocristal; INC, inclusão. $\mathrm{Fe}_{\text {total }}$ calculado como FeO. Fórmula estrutural calculada na base de 32 oxigênios

Tabela 3 - Composição química, em porcentagem de peso, de feldspatos de diques máficos da Ilha dos Búzios. N, núcleo; $\mathrm{B}$, borda; $\mathrm{GC}$, grão comum; INTG, intergranular; MTZ, matriz; MF, microfenocristal; XF, xenofenocristal. Fe $\mathrm{Fetal}_{\text {tol }}$ calculado como FeO. Fórmula estrutural calculada na base de 32 oxigênios.

Tabela 4 a - Composição química, em porcentagem de peso, de nefelinas de diques félsicos da llha dos Búzios. $\mathrm{N}$, núcleo; $\mathrm{B}$, borda; $\mathrm{GC}$, grão comum; MTZ, matriz. $\mathrm{Fe}_{\text {totat }}$ calculado como FeO. Fórmula estrutural calculada na base de 32 oxigênios

Tabela 4b - Composição química, em porcentagem de peso, de sodalitas de diques félsicos da Ilha dos Búzios. N, núcleo; $\mathrm{B}$, borda; $\mathrm{GC}$, grão comum. $\mathrm{Fe}_{\mathrm{total}}$ calculado como FeO. Fórmula estrutural calculada na base de 21 oxigênios

Tabela 5 - Composição química, em porcentagem de peso, de analcimas de diques máficos da Ilha dos Búzios. MTZ, matriz; INC, inclusão. $\mathrm{Fe}_{\text {totat }}$ calculado como FeO. Fórmula estrutural calculada na base de 32 oxigênios

Tabela 6 - Composição química, em porcentagem de peso, de olivinas de diques máficos da tha dos Búzios. $\mathrm{N}$, núcleo; $\mathrm{B}$, borda; XF, xenofenocristal. $\mathrm{Fe}_{\text {total }}$ calculado como FeO. Fórmula estrutural calculada na base de 4 oxigênios 
Tabela 7 - Composição química, em porcentagem de peso, de piroxênios de sienitos da Iha dos Búzios. N, núcleo; B, borda; GC, grão comum; INC, inclusão. $\mathrm{Fe}_{\text {total }}$ calculado como FeO. Fórmula estrutural calculada na base de 6 átomos de oxigênio

Tabela 8 - Composição química, em porcentagem de peso, de piroxênios de diques félsicos da Ilha dos Búzios. $\mathrm{N}$, núcleo; $\mathrm{B}$, borda; $\mathrm{GC}$, grão comum. $\mathrm{Fe}_{\text {total }}$ calculado como FeO. Fórmula estrutural calculada na base de 6 átomos de oxigênio

Tabela 9 - Composição química, em porcentagem de peso, de piroxênios de diques máficos da llha dos Búzios. $N$, núcleo; $B$, borda; XF, xenofenocristal;

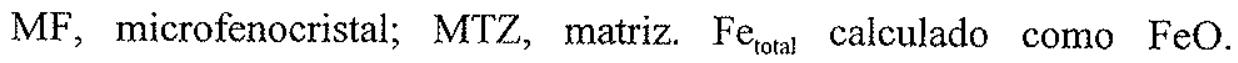
Fórmula estrutural calculada na base de 6 átomos de oxigênio A40

Tabela 10 - Composição química, em porcentagem de peso, de anfibólios de sienitos da Ilha dos Búzios. N, núcleo; B, borda; GC, grão comum; INC, inclusão. $\mathrm{Fe}_{\text {total }}$ calculado como FeO. Fórmula estrutural calculada na base de 23 átomos de oxigênio

Tabela 11 - Composição química, em porcentagem de peso, de anfibólios de diques félsicos da llha dos Búzios. $\mathrm{N}$, núcleo; $\mathrm{B}$, borda; $\mathrm{GC}$, grão comum; MTZ, matriz. Fe $\mathrm{e}_{\text {total }}$ calculado como FeO. Fórmula estrutural calculada na base de 23 átomos de oxigênio

Tabela 12 - Composição química, em porcentagem de peso, de anfibólios de diques máficos da llha dos Búzios. $\mathrm{N}$, núcleo; $\mathrm{B}$, borda; $\mathrm{GC}$, grão comum; MF, microfenocristal; $\mathrm{MTZ}$, matriz; $\mathrm{INC}$, inclusão. $\mathrm{Fe}_{\text {total }}$ calculado como FeO. Fórmula estrutural calculada na base de 23 átomos de oxigênio

Tabela 13 - Composição química, em porcentagem de peso, de biotitas de sienitos da Itha dos Búzios. $N$, núcleo; $B$, borda; $G C$, grão comum. $\mathrm{Fe}_{\text {total }}$ calculado como FeO. Fórmula estrutural calculada na base de 22 oxigênios

Tabela 14 - Composição química, em porcentagem de peso, de biotitas de diques félsicos da llha dos Búzios. N, núcleo; $\mathrm{B}$, borda; $\mathrm{GC}$, grão comum. $\mathrm{Fe}_{\text {total }}$ calculado como FeO. Fórmula estrutural calculada na base de 22 oxigênio 
Tabela 15 - Composição química, em porcentagem de peso, de biotitas de diques máficos da Ilha dos Búzios. N, núcleo; $\mathrm{B}$, borda; GC, grão comum; $\mathrm{MF}$, microfenocristal; MTZ, matriz; INC, inclusão. $\mathrm{Fe}_{\text {total }}$ calculado como FeO. Fórmula estrutural calculada na base de 22 oxigênios

Tabela 16a - Composição química, em porcentagem de peso, de ilmenitas de sienitos da llha dos Búzios. N, núcleo; B, borda; GC, grão comum. Fe $\mathrm{total}$ analisado como FeOl ( $\mathrm{FeO}$ inicial). $\mathrm{FeO}$ e $\mathrm{Fe}_{2} \mathrm{O}_{3}$ calculados a partir de FeOI.

Tabela 16b - Composição química, em porcentagem de peso, de ilmenitas de diques máficos da llha dos Búzios. $\mathrm{N}$, núcleo; $\mathrm{B}$, borda; $\mathrm{GC}$, grão comum; BOL, borda de olivina; BPX, borda de piroxênio. $\mathrm{Fe}_{\text {total }}$ analisado como FeOI (FeO inicial). $\mathrm{FeO}$ e $\mathrm{Fe}_{2} \mathrm{O}_{3}$ calculados a partir de FeOI

Tabela 17 a - Composição química, em porcentagem de peso, de magnetitas de sienitos da Itha dos Búzios. N, núcleo; B, borda; GC, grão comum. $\mathrm{Fe}_{\text {totai }}$ analisado como FeOI (FeO inicial). $\mathrm{FeO}$ e $\mathrm{Fe}_{2} \mathrm{O}_{3}$ calculados a partir de FeOI

Tabela $17 b$ - Composição química, em porcentagem de peso, de magnetitas e titano magnetitas de diques máficos da llha dos Búzios. MTZ, matriz; $\mathrm{N}$, núcleo; B, borda; XF, xenocristal; MF, microfenocristal; BOL, borda de olivina; INC, inclusão. Fe $\mathrm{t}_{\text {total }}$ analisado como FeOr (FeO inicial). FeO e $\mathrm{Fe}_{2} \mathrm{O}_{3}$ calculados a partir de $\mathrm{FeOl}$

Tabela 18 - Valores analíticos máximos (M) e mínimos (m) para os elementos maiores (\% em peso) e numeros mg\# das rochas de Búzios.

Tabela 19 - Composições médias (\% em peso) para algumas rochas extraídas de Cox et al. (1990; valores selecionados de Le Maitre, 1976, de Banco de Dados com 26373 análises)

Tabela 20 - Elementos traços (em ppm) das rochas de Búzios. A média é aritmética, não incluindo valores julgados anômalos

Tabela 21 - Valores médios (ppm) para elementos traços de rochas alcalinas, calculadas a partir das médias de províncias alcalinas brasileiras (cf. Morbidelli et al., 1995) 233

Tabela 22 - Valores analíticos, em base anidra e recalculados para 100\%, para elementos maiores (\%) e traços (ppm) de amostras de sienitos, do 
charnoquito e valor médio para 23 análises de charnoquitos de Ubatuba (Neumann, 1993). Inclui valores para norma CIPW, Mg\# (100xMgO/MgO+FeO, mol.), R1R2 (De La Roche et al., 1980; De La Roche, 1986), I.A. (Índice Agpaítico: $\mathrm{Na}_{2} \mathrm{O}+\mathrm{K}_{2} \mathrm{O} / \mathrm{Al}_{2} \mathrm{O}_{3}$, mol.), I.S. $\left(100 \times \mathrm{MgO} /\left(\mathrm{Fe}_{2} \mathrm{O}_{3}+\mathrm{FeO}+\mathrm{MgO}+\mathrm{Na}_{2} \mathrm{O}+\mathrm{K}_{2} \mathrm{O}\right)\right.$ (Kuno, 1965), I.D. (Q+Or+Ab+Ne+Ks+Kp (Thornton e Tuttle, 1960) e densidade (valores obtidos da ponderação dos minerais normativos)

Tabela 23 - Valores analíticos, em base anidra e recalculada para 100\%, para elementos maiores (\%) e traços (ppm), de amostras de rochas de diques félsicos. Inclui valores para norma $\mathrm{CIPW}, \mathrm{Mg \#}\left(100 \times \mathrm{MgO} / \mathrm{MgO}+\mathrm{FeO}_{t}\right.$, mol.), R1R2 (De La Roche et al., 1980; De La Roche, 1986), I.A. (Índice Agpaítico: $\quad \mathrm{Na}_{2} \mathrm{O}+\mathrm{K}_{2} \mathrm{O} / \mathrm{Al}_{2} \mathrm{O}_{3}, \quad$ mol.), I.S. $\left(100 \times \mathrm{MgO} /\left(\mathrm{Fe}_{2} \mathrm{O}_{3}+\mathrm{FeO}+\mathrm{MgO}+\mathrm{Na}_{2} \mathrm{O}+\mathrm{K}_{2} \mathrm{O}\right)\right.$ (Kuno, 1965), I.D. $(\mathrm{Q}+\mathrm{Or}+\mathrm{Ab}+\mathrm{Ne}+\mathrm{Ks}+\mathrm{Kp}$ (Thornton e Tuttle, 1960) e densidade (valores obtidos da ponderação dos minerais normativos) A75

Tabela 24 - Valores analíticos, em base anidra e recalculada para 100\%, para elementos maiores (\%) e traços (ppm), de amostras de rochas dos diques máficos. Inclui valores para norma CIPW, $\mathrm{Mg} \#$ (100xMgO/MgO+FeO, mol.), R1R2 (De La Roche et al., 1980; De La Roche, 1986), I.A. (Índice Agpaítico: $\mathrm{Na}_{2} \mathrm{O}+\mathrm{K}_{2} \mathrm{O} / \mathrm{Al}_{2} \mathrm{O}_{3}$, mol.), I.S. $\left(100 \times \mathrm{MgO} /\left(\mathrm{Fe}_{2} \mathrm{O}_{3}+\mathrm{FeO}+\mathrm{MgO}+\mathrm{Na}_{2} \mathrm{O}+\mathrm{K}_{2} \mathrm{O}\right)\right.$ (Kuno, 1965), I.D. $(\mathrm{Q}+\mathrm{Or}+\mathrm{Ab}+\mathrm{Ne}+\mathrm{Ks}+\mathrm{Kp}$ (Thornton e Tuttle, 1960) e densidade (valores obtidos da ponderação dos minerais normativos) 


\section{RESUMO}

Este trabalho se ocupa do estudo geológico e petrológico da liha dos Búzios, litoral norte do Estado de São Paulo.

Com menos do que $8 \mathrm{~km} 2$ de área, a tha tem forma irregular e dimensões de aproximadamente $2,5 \mathrm{~km}$ (NNE) e $5,0 \mathrm{~km}$ (EW), com topos achatados e cume a $400 \mathrm{~m}$ de altura, centralmente localizado. É formada por sienitos, que representam mais que $80 \%$ de sua área, e encaixantes charnoquíticas. Diques de litologia variada cortam tanto os sienitos como as encaixantes.

As rochas encaixantes mostram-se gnaissificadas, em parte por cisalhamentos antigos, e apresentam intercalações de caráter mais diorítico até "anortositico", todos os tipos portadores de ortopiroxênio, semelhantes a outras ocorrências continentais encontradas desde a Serra de Itatins (Peruibe), a sudoeste, até Ubatuba, a noroeste.

Os sienitos, variáveis entre tipos finos e de granulação grossa, estes últimos predominantes, têm relações complexas com as encaixantes. Sienitos finos, que englobam xenólitos em quantidade variável, passam a tipos mais grossos, também com xenólitos, formando faixa de centenas de metros. Os contatos podem ser gradativos, com os sienitos grossos passando a charnoquitos e dando lugar à formação de prováveis rochas híbridas. Os xenólitos, decimétricos a métricos, são angulosos e subangulosos, de natureza charnoquítica ou "diabásica". Com alguma freqüência, os microssienitos xenólíticos incluem parcialmente porções de charnoquito com dique diabásico, mostrando relações cronológicas claras.

Outros diques ocorrem. Na parte oeste, diques máficos variados, que rareiam nas porções leste e sul. Nas partes sudeste e leste, aparecem mais diques félsicos, principalmente fonólitos finos a afaníticos.

A maior parte dos diques apresenta direção em torno de N50-55E, subvertical. Diques com direção ortogonal, NW, radiais e merguthantes, são encontrados na porção sudeste.

Algumas feições especiais chamam a atenção. As cavidades miaroliticas presentes nas porções a oeste, próximas aos contatos, e a presença de bolsões pegmatóides por todo o corpo sienítico. O Saco Grande, enseada aberta na costa sul, tem forma semi-elíptica aberta para o mar. Além dos diques radiais, mostra dique estratificado espesso, paralelo à orla marinha por longa distância e com mergulho centripeto.

Os sienitos possuem mineralogia monótona, com a grande maioria sendo classificável como álcali feldspato sienitos. São as rochas predominantes, podendo conter quartzo. Com o aumento do quartzo, raramente acima dos $5 \%$, passam aos quartzo-álcali feldspato sienitos, que ocorrem mais na extremidade NW e SW. O feldspato presente é uma micromesopertita, com leve predomínio das fases albíticas, e com padrão variado. Os ferromagnesianos incluem 
clinopiroxênio, biotita, anfibólio e opacos. As associações mais comuns contêm sempre clinopiroxênio, opacos, além de biotita e/ou anfibólio. Os tipos com mais quartzo tendem a apresentar mais anfibólio, chegando a ausentar-se o clinopiroxênio. Não há registro de nefelina sienitos.

Esses sienitos variam para variedades de granulação mais fina, principalmente nas proximidades dos contatos. Os microssienitos formam tratos inteiros, bolsões ou diques, nos sienitos.

Os diques félsicos variam desde microgranitos - "riólitos", quartzo traquitos, traquitos, traquifonólitos e fonólitos. As variedades mais ricas em $\mathrm{SiO}_{2}$ ocorrem mais nas encaixantes e nas porções ocidentais da liha; já os tipos insaturados estão presentes no Saco Grande e na extremidade leste. As variedades com e sem quartzo são semelhantes, e nelas predominam as mesmas micromesopertitas, variando apenas o teor de quartzo. Os traquitos, típicos ou não, são encontrados por toda a liha, e se mostram constituídos por micromesopertita \pm clinopiroxênio \pm anfibóliotbiotita, com pequena fração de opacos. Os tipos insaturados são portadores de nefelinatsodalita em teores relevantes e compõem, ao lado das micro mesopertitas, 80 a $85 \%$ da rocha. Nestas rochas, que podem ser classificadas como fonólitos e nefelina microssienitos, o feldspato potássico pode ocorrer sozinho. Como representantes fêmicos aparecem clinopiroxênio, anfibólio e biotita. Boa parte dessas rochas tem caráter agpaítico e apresenta mineralogia acessória rara (Ti-Zr silicatos).

Os diques máficos são de difícil definição no campo. Ao lado das variedades alcalinas e de idade cretácica, reconhecem-se outros tipos, diabásicos e microdioríticos, parte cortando charnoquitos, parte deformados, de filiação duvidosa, ou mesmo brasilianos. Os tipos alcalinos e sincrônicos às associações sieníticas são de basaltos alcalinos, basanitos, tefritos e traquibasaltos e, à exceção dos primeiros, classificados como lamprófiros: camptonitos ou monchiquitos. Os basaltos alcalinos são semelhantes a diabásios comuns, contendo plagioclásio zonado, feldspato alcalino intersticial, piroxênio ou anfibólio, opacos, e com ou sem biotita. A grande maioria dos diques máficos é de filiação lamprofírica, e portadora de olivina, clinopiroxênio, kaersutita, biotita e opacos, envolvidos por mineralogia semelhante, mais fina, a menos da olivina. Nos interstícios e nos ocelos, que podem representar $40 \%$ da amostra, aparecem feldspato potássico, analcima, vidro, material criptocristalino, carbonatos, zeólitas e serpentina.

Os feldspatos das rochas félsicas mostram lamelas, que variam continuamente do ponto de vista composicional entre $\mathrm{Or}_{100}$ e $A b_{100}$, ou grupam-se nos dois extremos composicionais, sempre com teor de An muito baixo. Nas rochas máficas, esses minerais aparecem intersticialmente ou nos ocelos como fase potássica muito pura. Os plagioclásios são zonados e exibem variação dos individuos maiores para as matrizes, estas em geral mais sódicas. Sua composição é variável entre $A n_{75} \in A n_{15}$. 
As olivinas, analisadas em apenas duas amostras, têm composição entre $F_{O_{75}}$ e $F_{O_{85}}$.

Os piroxênios incluem tipos mais cálcio-ferromagnesianos, desde diopsídicos (rochas máficas) a hedembergíticos, até tipos mais cálcio-sódicos, nos sienitos.

O caráter sódico acentua-se nos diques félsicos chegando às egirinas nos fonólitos. Entre os diques máficos, os mesmos tipos dos sienitos passam a admitir teores elevados de $\mathrm{Ti}$ e Al, saindo do campo "Quad", com possivel molécula Ti-tschermakítica. Os anfibólios nos diques máficos são cálcicos, sendo a maioria, kaersutitas. Nos sienitos, são cálcicos, com composições mais primitivas de Mg-hornblendas, evoluindo para tipos mais cálcio-sódicos, winchitas, barroisitas e catoforitas. Tornam-se sódicos nos diques félsicos, ocorrendo então arfvedsonita e riebeckita. Tanto os clinopiroxênios como os anfibólios evoluem paralelamente das composições mais magnesianas para as mais ricas em ferro, derivando então em direção ao sódio. Essa evolução acompanha o tipo de rocha, mas, nos sienitos, ela pode se apresentar entre núcleos (mais $\mathrm{Mg}$ ) e bordas (mais $\mathrm{Fe}, \mathrm{Na}$ ) do mesmo grão.

As biotitas mostram continuidade composicional, variando desde flogopitas/Mg-biotitas (diques máficos) até Fe-biotitas (annita 90\%) nos diques máficos. Os opacos são da série MtUsp, ou II-Hem, esta mais rara nos diques máficos. As composições aproximam-se dos membros extremos Mt e IIm nos sienitos; nos diques máficos, elas estão próximas de $\mathrm{Ilm}$, variando a outra série de Usp a Mt.

A análise química das rochas mostra um "gap" composicional particularmente no teor de $\mathrm{SiO}_{2}$, entre 50 e $60 \%$, correspondendo ao intervalo entre diques máficos e sienitos. As rochas máficas são básicas e ultrabásicas e representam basaltos alcalinos, basanitos, tefritos e traquibasaltos. As rochas sieníticas correspondem aos sienitos (=traquitos), com composição evoluindo para os sienitos nefelina normativos, traquifonólitos e fonólitos, entre os diques félsicos. Os mesmos sienitos evoluem, também, para composições mais ricas em $\mathrm{SiO}_{2}$, culminando nos diques félsicos supersaturados, os quartzo traquitos e riólitos (e riólitos alcalinos). A bimodalidade das rochas de Búzios e a ausência composicional entre $\mathrm{SiO}_{2}=50$ $60 \%$, reflete-se em outros elementos químicos, particularmente $\mathrm{FeO}, \mathrm{MgO}, \mathrm{CaO}$ e $\mathrm{K}_{2} \mathrm{O} . \mathrm{O}$ indice mg\#, que varia entre 0 e 60 , mostra pequena interrupção em torno de 40 . Os outros elementos maiores apresentam distribuição mais contínua, ainda que pouco definida. Já os elementos traços, incluindo-se os TR, têm distribuição contínua e regular, bem definida. Todas as rochas são alcalinas, com exceção daquelas "riolíticas". O caráter potássico é manifesto, mostrando-se sódicos parte dos fonólitos, além de peralcalinos e agpaíticos típicos. Todas as rochas máficas são metaluminosas, e os sienitos dividem-se entre levemente metaluminosos a peraluminosos, com alguns poucos fracamente peralcalinos. Diagramas multielementos, normalizados para o manto primitivo, exibem padrão evoluido para as rochas máficas, com enriquecimento em praticamente todos os elementos. Essa característica é compativel com os teores moderados a baixos em $\mathrm{Cr}$ e $\mathrm{Ni}$ e $\mathrm{MgO}$. Nos sienitos, os padrões se alteram, passando a 
haver empobrecimento em $\mathrm{Ba}, \mathrm{Sr}$ e $\mathrm{Ti}$, e acentuando-se o enriquecimento nos outros elementos. As mesmas tendências observadas nos sienitos são ainda mais pronunciadas nos diques, mais nos fonólitos que nos "riólitos". Os padrões verificados nas abundâncias relativas dos elementos são compatíveis com processos de cristalização fracionada a partir dos sienitos, com concomitante enriquecimento em álcalis e elementos incompativeis nos fonólitos e, em menor escala, nos "riólitos", com queda nos teores de Ba, Sr e Ti.

Alguma química isotópica foi feita, obtendo-se nove idades $\mathrm{K} / \mathrm{Ar}$ em biotitas e anfibólios (e uma rocha total), com resultados razoáveis. Também foram efetuadas cinco análises $\mathrm{Rb} / \mathrm{Sr}$, com quatro delas aceitáveis. A idade preferencial K/Ar para os sienitos é de $81,4 \pm 2,6 \mathrm{Ma}$ e de $79,0 \pm 2,4$ Ma para os diques. "Errócrona" ou diagrama isocrônico ${ }^{87} \mathrm{Sr} /{ }^{86} \mathrm{Sr}$ vs. ${ }^{87} \mathrm{Rb} /{ }^{86} \mathrm{Sr}$ revela idade de $78,0 \pm 2,2 \mathrm{Ma}$ e $\mathrm{R}_{0}=0,70500$. A utilização do programa ISOJOB, a partir das razões atuais, chega a número semelhante, com $R_{0}=0,70497$, mas com alguma diferença para a idade, em torno de $75 \mathrm{Ma}$. As diferenças individuais para $R_{0}$ não parecem significativas, sendo o valor médio obtido coincidente com a freqüência máxima para as rochas alcalinas brasileiras.

A convivência de rochas supersaturadas e insaturadas em $\mathrm{SiO}_{2}$, entre as alcalinas, parece mais regra geral que exceção. Apesar disso, representa um problema, com várias soluções propostas. Os sienitos de Búzios, recalculados quimicamente, mostram composições sobre o alto termal Ab-Or, na superficie "liquidus", do sistema Q-Ne-Ks, a $1 \mathrm{~kb}$ de $\mathrm{PH}_{2} \mathrm{O}$ (Fig. 29). Os fonólitos, por um lado, concentram-se no sentido do eutético insaturado, enquanto que os "riólitos", por outro lado, acumulam-se no sentido do eutético granítico. Essa configuração é bastante coerente com a suposta evolução química dessas rochas. Atribui-se à insaturação a evolução normal do magma sienítico, sendo que a supersaturação pode ser resultante de pressões de água moderadas, suficientes para supersaturação nas zonas com temperaturas mais baixas (bordas do corpo), desestabilização do piroxênio e cristalização de anfibólio e/ou biotita, com sobra de $\mathrm{SiO}_{2}$. Parte da silica excessiva, característica das bordas, pode ter vindo da fusão parcial das encaixantes charnoquíticas.

Tal como em outras províncias alcalinas brasileiras, os magmas parentais primitivos mais prováveis estão representados pelas rochas máficas. Entre estas, as mais primitivas incluem basanitos, tefritos e basaltos alcalinos, cada qual podendo ser um derivado ou um representante evoluído de líquidos ainda mais primitivos, de origem em fusões mantélicas diferentes (fonte ou taxa), ou o conjunto de rochas máficas pode representar produtos resultantes de graus diferentes de fusão parcial da mesma fonte mantélica. Os tipos mais evoluidos são os traquibasaltos que, por fracionamento de fases fêmicas e do plagioclásio, poderiam dar origem a diferenciados mais félsicos (monzogabros/dioritos a sienitos). Estes magmas, por cristalização fracionada e acumulação, formariam líquidos mais enriquecidos em $\mathrm{Na}$ e $\mathrm{K}$ e empobrecidos em $\mathrm{Ca}$ (e em $\mathrm{Fe}$ e Mg), chegando-se ao ponto do desaparecimento do 
plagioclásio. Modas com 90\% de feldspato alcalino são caracteristicas, e até comuns, em rochas de outras províncias, incluindo-se a llha de Vitória. Em Búzios, não ocorrem essas rochas intermediárias, que aparecem na ltha de São Sebastião, ao lado de tipos tão evoluidos quanto os sienitos de Búzios e da liha de Vitória. 


\section{ABSTRACT}

This work concerns the geological ang petrological study of Búzios Island, on the northern coast of São Paulo State.

With a surface less then $8 \mathrm{~km}^{2}$, this island has an irregular shape and measures approximately $2,5 \mathrm{~km}$ (NNE) by $5,0 \mathrm{~km}$ (EW), with flat hilltops and a central peak at $400 \mathrm{~m}$ height. It is made up by syenites, which represent more than $80 \%$ of its area, and charnockitic country rocks. Dykes of varied lithology cut both sienites and country rocks.

The country rocks are gneissified, partly due to older shearings, and exhibit more dioritic to "anorthositic" intercalations in the charnockite, all orthopyroxene -bearing, similar to those which outcrop from Serra do Itatins (Peruibe), to the southwest, to Ubatuba, to the northeast.

The syenites vary between fine-grained, and largelly predominant (except at the contacts) coarse-grained types, and exhibit complex contact patterns with the enveloping country rocks. Fine-grained syenites, which envelope xenoliths in a variable quantity, grade to coarser-grained, also xenolith-bearing varieties, forming a hundreds of meters wide belt. The contact may be gradational, and the coarse-grained syenites are substituted imperceptibly by charnockites, with the formation of probable hybrid rock types. The decimetric to metric xenoliths are angulose to subangulose, mainly of charnockitic to "doleritic" charachter. Quite often, the xenolithic microsyenite zones partially enclose larger portions of doleritic dyke-bearing charnockites, exhibiting clear chronological relationships.

Other dykes also occur. In the western part, varied mafic dykes, which become rarer in the eastern and southern parts. In the southeastern and eastern parts mostly felsic dykes, mainly fine-grained to aphanitic phonolites.

Most dykes are subvertical, with directions around N50-55E. Ortogonally oriented (NW), radial and dipping dykes appear in the southeastern part.

Some special features draw the attention. The miarolitic cavities which occur in the portions to the west, close to the contacts, and the presence of pegmatoid domains through the whole syenitic body. The Saco Grande, a cove on the southern coast, has a semi-elliptical shape opened to the sea. Apart from the radial dykes, it shows a wide stratified dyke, parallel to the sea-shore through a long distance, and with centripetal dip.

The syenites have a monotonous mineralogy, and the large majority can be classified as alcali feldspar syenite. They are the predominant rocks, and may exhibit quartz. With the increase in quartz, rarely above $5 \%$, they grade into quartz alcali feldspar syenites, which occur mostly at the NW and SW extremities. Their feldspar is a micro-mesoperthite, with a slight predominance of the albitic phases, and with varied patterns. The ferromagnesians include 
clinopyroxene, biotite, amphibole and opaque oxides. The commonest associations always include the clinopyroxene, the opaques, with biotite and/or amphibole. The more quartz-rich types have a tendency to bear more amphibole, to the exclusion of clinopyroxene. There is no report of nepheline syenites.

These syenites vary to the microwarieties, mainly close to the contacts. The microsyenites make up whole tracts, domains, or dykes in the syenite.

The felsic dykes vary from micro-granites - "rhyolites", quartz trachytes, trachytes, trachyphonolites, and phonolites. The more $\mathrm{SiO}_{2}$-rich varieties occur mostly in the enveloping country rocks and in the parts to the west, and the undersaturated types in the Saco Grande cove and in the eastern extremity. The micro-varieties, with and without quartz, are similar, and the same micro-mesoperthites predominate in them, with a variable quartz content. The trachytes, either typical or not, occur all through the island, and are made up by micromesoperthite \pm clinopyroxene \pm amphibole \pm biotite, with a small fraction of opaques. The undersaturated rocks are nepheline \pm sodalite bearing, in considerable contents, which make up, together with the micro-mesoperthites, 80 to $85 \%$ of these rocks. In these rocks, which can be classified as phonolites and micro - nepheline syenites, the potassic feldspar can occur alone. As femic representatives, clinopyroxene, amphibole and biotite appear. A great part of these rocks has agpaitic character, and exhibits rare accessory mineralogy ( $\mathrm{Ti}-\mathrm{Zr}$ silicates).

The mafic dykes are difficult to be characterized in the field. Together with the alkaline varieties of cretaceous age, other types occur, doleritic and microdioritic, in part cutting across the charnockites, in part deformed, of doubtfull affiliation, or else of brasiliano age. The alkaline types, synchronous to the other alkalines, are of alkali basalts, basanites, tephrites and trachibasalts and, with the exception of the first ones, are classified as lamprophyres: camptonites and monchiquites. The alkali basalts are similar to the common dolerites, with zoned plagioclase, intersticial alkaline feldspar and pyroxene or amphibole, opaques, with or without biotite. The large majority of the mafic dykes is lamprophyric, olivine-, clinopyroxene-, kaersutitebiotite- and opaque-bearing, which are enveloped by a similar, finer-grained mineralogy, with the exception of olivine. In the intersticial spaces and in the ocelli, which might represent $40 \%$ of the samples, potassic feldspar, analcime, glass, cryptocrystalline material, carbonates, zeolites and serpentines occur.

The feldspar of the felsic rocks exhibits lamellae, which vary in composition between Or 100 and $A b_{100}$, either continuosly, or grouping in the two compositional extremes, always with very low An contents. In the mafic rocks these minerals appear interstitially or in the ocelli as a very pure potassic phase. The plagioclase is zoned, and shows variation from the larger individuals to the matrix ones, which are more sodic. Their composition varies between $A n_{75}$ and $A n_{15}$. 
The olivine, analized in only two samples, has compositions between Fo75 and Fo85.

The pyroxene varies between the more calcic ferromagnesian types, from those more diopsidic (in the mafic rocks) to hedenbergitic, and from those towards more calcic-sodic ones, in the syenites.

The sodic character becomes more pronounced in the felsic dykes, extending as far as aegirines in the phonolites. In the mafic dykes, the same types encountered in the syenites become richer in $\mathrm{Ti}$ and $\mathrm{Al}$, falling out from the "Quad" field, possibly with Ti-Tschermakitic substitutions. The amphiboles of the mafic dykes are calcic, and are, in their majority, kaersutites. In the syenites, they are calcic, with more primitive, Mg-hornblende compositions, evolving towards more calcic-sodic types, winchites, barroisites and catoforites. They become sodic in the felsic dykes, and than arfvedsonites and riebeckites occur. Both clinopyroxenes and amphiboles evolve in parallel, from more magnesian towards more iron-rich compositions, deviating towards more sodium-rich ones. This evolution follows the rock-types, but in the syenites it might appear in the same grain, between cores (more Mg-rich) and borders (more $\mathrm{Fe}, \mathrm{Na})$.

The biotites exhibit compositional continuity, varying from phlogopites / Mg-biotites (in the mafic dykes) to Fe-biotites ( $90 \%$ annite) in the felsic dykes. The opaque oxides are either from the Mt-Usp series, or from the IIm-Hem, this last one less common in the mafic dykes. The compositions are close to the Mt-IIm extreme compositions in the syenites, and in the mafic dykes have compositions close to $\mathrm{llm}$, with the other series varying between Usp and Mt.

The chemical analyses of the rocks show a compositional gap, mainly in $\mathrm{SiO}_{2}$ contents, between 50 and $60 \%$, which corresponds to the interval between mafic dykes and syenites. The mafic rocks, represented by the alkali basalts, basanites, tephrites and trachybasalts, are basic to ultrabasic. The syenitic rocks are, in general, represented by the syenites (=trachytes), with compositions evolving towards those of the normative nepheline syenites, trachyphonolites and phonolites, among the felsic dykes. The same syenites evolve also towards more $\mathrm{SiO}_{2}$-rich compositions, ending up in the oversaturated felsic dykes, the quartz trachytes and rhyolites (and alkali rhyolites). The bimodal distribution of the Búzios rocks and the absence of compositions between $\mathrm{SiO}_{2}=50-60$ is reflected also by other chemical constituents, in particular by $\mathrm{FeO}, \mathrm{MgO}, \mathrm{CaO}$ and $\mathrm{K}_{2} \mathrm{O}$. The $\mathrm{mg \#}$ index, which varies between 0,0 and 60,0 , exhibits a small interruption around 40,0. The other major elements show a more continuous, but less defined distribution. The trace elements, including the REE, have a continuous, regular and well defined distribution. All rocks are alkaline, with the exception of the "rhyolitic" ones. The potassic character is manifest, with part of the phonolites being sodic, apart from typically peralkaline and agpaitic. All mafic rocks are metaluminous, and the syenites are divided between slightly metaluminous to peraluminous, and a few weakly peralkaline. Multielemental 
diagramms, normalized to the primitive mantle, show evolved patterns for the mafic rocks, with enrichment in practically all elements. This characteristic is is compatible with the low to moderate contents in $\mathrm{Cr}, \mathrm{Ni}$ and $\mathrm{MgO}$. In the syenites, the patterns are modified, with depletion in $\mathrm{Ba}, \mathrm{Sr}$ and $\mathrm{Ti}$, and a more pronounced enrichment in the other elements. The trends found in the syenites are even more pronounced in the dykes, more in the phonolites then in the "rhyolites". The trends observed in the relative abundance of elements are compatible with fractional crystallization processes operative over the syenite compositions, with a concurrent enrichment in alkaline and incompatible elements in the phonolites, and, in lesser degree, in the "rhyolites", with a decrease in the $\mathrm{Ba}, \mathrm{Sr}$ and Ti contents.

Some isotopic chemical analyses where also made, with $9 \mathrm{~K} / \mathrm{Ar}$ determinations in biotites and amphiboles (and one in whole-rock), with acceptable results. Also $5 \mathrm{Rb} / \mathrm{Sr}$ analyses where undertaken, with 4 of them acceptable. The preferential $\mathrm{K} / \mathrm{Ar}$ age for the syenites is 81,4 $+2,6 \mathrm{Ma}$, and for the dykes, $79,0+2,4 \mathrm{Ma}$. An $87 \mathrm{Sr} / 86 \mathrm{Sr}-87 \mathrm{Rb} / 86 \mathrm{Sr}$ diagram, or "errochron" reveals an age of $78,0+2,2 \mathrm{Ma}$, with $\mathrm{R}_{0}=0,70500$. The ISOJOB program, based on presentm day ratios, obtains similar reasults, with $R_{0}=0,70497$, but with a somewhat different age, around $75 \mathrm{Ma}$. The individual differences for $R_{0}$ do not seem to be significative, and the average value coincides with the maximal frequency for brazilian alkaline rocks.

The coexistence of rocks oversaturated and understurated in $\mathrm{SiO}_{2}$, among the alkalines, seems to represent the rule, and not exceptions. Yet it represents a problem, with various possible solutions proposed. The Búzios syenites, chemically recalculated, exhibit compositions over the Ab-Or thermal height, on the liquidus surface, in the system Q-Ne-Ks, at $1 \mathrm{Kbar} \mathrm{PH}_{2} \mathrm{O}$ (figure 29). The phonolites, on one hand, fall towards the undersaturated eutectic, whilst the "rhyolites", on the other, concentrate towards the granitic eutectic. This pattern is coherent with the supposed chemical evolution of these rocks. The undersaturation is possibly due to the normal evolution of the syenitic magma, whilst the oversaturation might be the result of moderate water pressures, enough for oversaturation in the lower temperature zones (margins of the body), with unstabilization of pyroxene and crystallization of amphibole and/or biotite, with excess $\mathrm{SiO}_{2}$. Part of the excess $\mathrm{SiO}_{2}$, characteristical at the margins, might be accounted for through the partial melting of the charnockitic country rocks.

As in other brazilian alkaline provinces, the most probable primitive parental magmas are represented by the mafic rocks. Among these, the most primitive ones include basanites, tephrites, and alkali basalts, which could be each either a derivative, or an evolved representative of more primitive liquids, originated by different mantle meltings, or else the mafic rock set might represent derivatives at various evolutionary stages of the same partial mantle melting episode. The more evolved types are the trachybasalts, which could originate more felsic differentiates (monzogabros / diorites to syenites), through the fractionation of the femic 
phases and of plagioclase. These magmas, through fractional crystallization and mineral accumulation, would have originated the more $\mathrm{K}$ and $\mathrm{Na}$ enriched, and $\mathrm{Ca}$ (and $\mathrm{Fe}$ and $\mathrm{Mg}$ ) depleted liquids, to the point of plagioclase disappearence. Modal compositions with up to $90 \%$ alcali feldspars are a common characteristic in other provinces, including Vitória Island. In Búzios, these intermediate rocks, which in the São Sebastião Island appear following more evolved types, like the syenites from Búzios and Vitória Island, do not occur. 


\section{AGRADECIMENTOS}

Qualquer, e por menor que seja a empreitadam é muito dificil, e raro, que a enfrentemos a bom termo, sozinhos. Acabamos, de uma ou de outra forma, devedores.

Ao final deste trabalho, tornei-me um grande devedor, E, provavelmente, insolvente.

Devo

- aos meus fithos, pelas sistemáticas e prolongadas ausências

- ao Prof. Dr. Celso de Barros Gomes, meu permanente orientador, desde o mestrado. A tarefa não teria tido fim não fosse seu esforço e empenho, principalmente a partir do momento em que sentei-me para começar a juntar as informações e a escrever. Já por si imensa, a dívida não é só essa. Seu apoio acompanhou-me desde que me iniciei na atividade docente, após deixar a atividade privada

- ao Prof. Dr. Excelso Ruberti, pelo apoio incondicional em tudo que the foi possivel. Não fosse seu desprendimento em criar condições para a utilização da microssonda em horários e dias os mais inusitados, não haveria o capítulo 7 . Além disso, devo a ele a seleção dos resultados analíticos e o auxílio no tratamento dos dados

- ao Sr. Gaston Eduardo Einrich Rojas, quintoanista do curso de geologia, e bolsista da FAPESP, pelo tratamento "informático" de toda a "numerologia" química, manobrando o New Pet, o Min Pet, etc. e produzindo os gráficos: os que estão no trabalho, e número muito maior que não está

- ao Prof. Dr. Paulo Roberto dos Santos, pela melhor, mas pertinaz e mais eficaz forma de "cobrança" e incentivo que já conheci. Talvez eu tivesse "chutado o balde", se não fosse o Paulo

- ao Prof. Dr. Darcy Pedro Svisero, pelo empenho em tentar me auxiliar

- ao Prof. Dr. José Barbosa de Madureira Filho, e ao técnico, físico, Sr. Flávio Machado de Souza Carvalho, pelos difratogramas interpretados dos feldspatos, e às discussões que se seguiram

- aos colegas "de baixo", Profs. Drs. Silvio Roberto Farias Vlach e Gergely Andres Julio Szabó e à Profa. Dra. Mabel Norma Costas Ulbrich "de cima", pelas conversas e discussões variadas sobre assuntos pertinentes ao trabalho. Ao Gergely por encarar, sozinho, funçöes departamentais que também seriam minhas, e pela iniciação do Gaston no Min Pet

- ao Prof. Dr. Wilson Teixeira pela orientação inicial no equacionamento dos problemas geocronológicos

- ao colega geólogo do 1O-USP, Prof. Dr. Valdenir Veronese Furtado, pelo empréstimo e permissão na utilização de sua carta batimétrica, inédita e, no original, das vizinhanças da ilha 
- ao Alexandre Tomio, então quintoanista, bolsista do CNPq/Proantar pela execução dos mapas com a utilização do Auto Cad. Ao Reinaldo Penna Castellon, técnico, pelo acabamento da Figura 5

- à aluna do curso de geologia e ex-bolsista do PIBIC, Sra. Karen Costa Dias, grande parte do trabalho de separação de minerais e parte analítica para $\mathrm{K} / \mathrm{Ar}$ e $\mathrm{Rb} / \mathrm{Sr}$

- a todos da Seção de Serviços Especializados, principalmente ao Sr. Cláudio Hopp, e Srs. Paulo Roberto Molinaro, Giovani de Carvalho e Paulo Augusto de Carvalho, pela eficiência na preparação de cortes e seções delgadas de rochas em número elevado

- a todo o pessoal do CPGeo, que de uma ou de outra forma, foi co-responsável pelos números do capitulo 9: Srs. Décio Duarte Rosas, Artur Takashi Onoue, Key Sato, Liliane Aparecida Petronilho, Ivone Keiko Sonoki e Helen Maiumi Sonoki. Em especial ao Sr, José Elmano Gouveia pela prontidão, entre outras coisas

- ao Sr. Marcos de Souza Mansueto e Srta. Roseane Damião da Silva, pelo auxílio na microssonda e pela preparação das seções polidas

- à Sra. Thelma Maria Collaço Samara, pela gentileza e eficiência no desenho do mapa base, e incontáveis outros menores, retocados ou refeitos

- à Sra. Rita Parisé Conde e Srta. Márcia Cristina da Ponte, pela sempre gentil e simpática atenção a todos os problemas da sua área, e pela produção e correção de várias figuras, demoradas, em total de mais de uma centena de cópias

- às Sra. Marta José da Silva, Márcia Aparecida de Almeida Cruz Moreira e ao Sr. Tadeu Caggiano, pela digitação do texto; à Srta. Karina Roberta B. Vancini a diagramação final

- ao pessoal da gráfica, Srs. Edmir de Oliveira, Dalton Machado da Silva, Claudionor Barbosa e Henrique Martins, pela atenção a problemas variados e pela encadernação dos exemplares. Ao Sr. José Gonçalves Neto (o Zé), pela desmistificação das copiadoras xerox

- a todo pessoal do Instituto, que viabiliza a estrututra da instituição e torna o trabalho possivel

Fico em divida com os moradores da llha dos Búzios, mais a uns do que a outros, mas a todos. Pela acolhida, pelo convívio e pelo auxilio variado. Aos barqueiros Dito e Ivan, não só as travessias, mas a segurança. Pelo menos psicológica. Aos meus guias e "mateiros", Srs. Aristides (filho), Gini e Firmo (tio), aos "patriarcas" da itha, Sr. Antonio (falecido), Argemiro (pai) e Aristides (avô), e as senhoras anfitriãs locais, Sras. Dita (mãe) e Dita (nora).

Finalmente, quero agradecer ao Prof. Dr. Enzo Piccirillo e ao Prof Dr. Ângelo De Min, pelas análises químicas das rochas. Ao Prof. Piccirillo, também pelas conversas a respeito dos problemas geológicos da ilha.

O trabalho foi possivel graças a auxilio financeiro da FAPESP (Proc. 90/3692-7). 


\section{CAPÍTULO 1 \\ INTRODUÇÃO}

À Petrologia, aos petrólogos, interessa estudar rochas.

Ígneas, metamórficas, sedimentares, corpos pequenos ou extensas áreas, testemunhos de sondagem etc. podem ser o objeto de estudo. $O$ que mais caracteriza os objetivos da atividade é a natureza específica do objeto de estudo e, objeto de estudo e objetivos, definem a essência da metodologia e técnicas empregadas.

Não há como justificar, cientificamente, uma temática como sendo mais importante que outras. Ocorrem prioridades circunstanciais em qualquer atividade humana e, na pesquisa cientifica, alguns modismos temporais de objetos, objetivos, e mesmo metodológicos.

As propostas da ciência brasileira têm se pautado por eventuais relevâncias maiores ou menores, fruto de integração a nivel mundial, particularmente com os centros de pesquisa mais adiantados, e das disponibilidades orçamentárias das instituições de pesquisa e organismos financiadores. As propostas são amplas e, nesse sentido, as linhas de trabalho e objetivos imediatos têm sido, sobretudo, questão de eleição pessoal e condições operacionais.

Dentro desse universo e dessa dinâmica, a petrologia das rochas ígneas não foge à regra.

Desde há mais de duas décadas, existe uma linha de pesquisa bem definida no Departamento de Mineralogia do IG-USP, o estudo das rochas alcalinas.

Dinamizada por alguns pesquisadores do departamento, essa atividade recebeu impulso a partir de 1984, graças a convênio de cooperação cientifica, envolvendo a Universidade de São Paulo e instituições italianas (Universidades de Cagliari, Ferrara, Pádua, Roma, Trieste), e que vem contando com o apoio financeiro da FAPESP e do Ministério de Assuntos Universitários da ltália (MURST).

\subsection{O projeto "Magmatismo básico-alcalino da Bacia do Paraná"}

As sondagens para petróleo feitas pela Petrobrás nas Bacias de Pelotas, de Santos e de Campos, invariaveimente, quando programadas para atingir o embasamento, atravessam basaltos associados com freqüencia a sedimentos terrigenos, e assentados diretamente sobre rochas pré-cambrianas. São rochas semelhantes às da Bacia do Paraná (Formação Serra Geral), que se associam aos arenitos da Formaçäo Botucatu. Na costa da Namíbia, África, ocorrem basaltos, conhecidos como "Etendeka" ou derrames Kaoko, semelhantes e correlacionáveis aos basaltos brasileiros. Essas rochas representam o resultado de intenso e extenso magmatismo iniciado há $150 \mathrm{Ma}$, com a sua maior intensidade se dando ao redor de 
$130 \mathrm{Ma}$.

Tanto no Estado de São Paulo como em Santa Catarina, os derrames basálticos apresentam grande variação composional, sendo os topos das seqüências constituídos por pequena fração de rochas ácidas e supersaturadas. Como característica comum àquelas rochas cite-se o fato de serem todas representantes de suites cálcio-alcalinas ou subalcalinas ou toleíticas, e apresentarem grande significado geológico e econômico.

$\mathrm{Na}$ mesma porção do Brasil, mas com idades menores, até terciárias, e ocupando outros espaços crustais (faixas móveis Brasilianas e crátons do Sul-Sudeste) e menor volume, registra-se a reativação do magmatismo, agora de natureza alcalina, ultrabásica-básica a intermediária. A forma de ocorrência é outra e as rochas formam grandes complexos (Poços de Caldas, área superior a $800 \mathrm{~km}^{2}$ ), ou corpos menores litogicamente simples, como "stocks" de até $110 \mathrm{~km}^{2}$ de área (Passa Quatro), e até menores, com $20 \mathrm{~km}^{2}$ (Ponte Nova). Além desses tipos centrais, é bastante extensa e freqüente a presença de diques de litologia variada, mas sempre de caráter alcalino.

Também nas bacias de Santos e de Campos estão registradas atividades magmáticas básicas e alcalinas, descontinuas e acima dos basaltos basais, no intervalo aproximado de 100 a $50 \mathrm{Ma}$.

Desde o inicio da década de 80, o Instituto de Geociências e o Instituto Astronômico e Geofísico da USP vêm estudando esses registros magmáticos mesocenozóicos, tendo reunido respeitável acervo de conhecimento. Durante década e meia, vários projetos e programas, com participações e financiamentos variados, foram executados. No momento, acha-se em fase de conclusão o Projeto Temático da Fapesp "Magmatismo básico-alcalino da Bacia do Paraná", proposto para estudar, em colaboração com pesquisadores de diversas instituiçöes universitárias do pais e do exterior, notadamente da ttália, os dois temas acima. Pelo menos três dezenas de pesquisadores têm participado desses trabalhos, assim que hoje aquela situação de desconhecimento do início dos anos 80 acha-se em parte revertida.

Um pequeno número de ocorrências alcalinas já se encontra razoavelmente estudada, e contando com informações geológicas, petrográficas, mineralógicas, quimicas (rochas e minerais), isotópicas e geocronológicas; mais raramente existem dados estruturais e geofísicos. Grande número, porém, talvez mais da metade, ainda carece de conhecimentos, às vezes até básicos.

Assim, por exemplo, a Província Serra do Mar, proposta por Almeida (1983) para o conjunto de rochas alcalinas que se dispõe paralelamente à faixa litorânea São Paulo-Rio de Janeiro, ainda oferece muito para ser estudado. O corpo gabróide de Ponte Nova, na Serra da Mantiqueira, centenas de diques, variados, que povoam toda a faixa pré-cambriana, diversos outros corpos no Estado do Rio de Janeiro e, com certo destaque pela particularidade do seu posicionamento geográfico, as ocorrências das ilhas litorâneas do Estado de São Paulo. 


\subsection{O tema proposto}

Dentre desse panorama, amplo, elegeu-se a liha dos Búzios como objetivo de estudo (Foto 1).

A llha é conhecida, de forma pouco profunda geológica e petrograficamente, desde 1955 (Björnberg e Ellert, 1955), cabendo, assim, reavaliação da sua geologia, petrografia e estudo petrológico mais completo.

Ela faz parte de zona local de atividade magmática intrusiva, mais ou menos concentrada em área retangular ENE, de $80 \mathrm{~km}$ por $20 \mathrm{~km}$, com as llhas do Monte de Trigo (SW) e Vitória (ENE) ocupando os seus extremos, e tendo como centro geométrico aproximado o corpo alcalino de São Sebastião (Fig. 1). Note-se que o conjunto de ilhas representa a parte emersa dos corpos intrusivos, sendo mesmo possivel que $50 \%$ ou mais estejam submersos, sem se levar em conta eventuais corpos totalmente submersos.

Com os elementos conhecidos em mãos (Bjömberg e Ellert, 1955), e após a realização da primeira expedição, constatou-se de pronto que os contatos das alcalinas com as encaixantes, a extensa e complexa presença de xenólitos de natureza diversificada, a grande quantidade e variedade de diques, bem expostos nos costões, além do estudo petrológico global, eram razões mais que suficientes para justificar a execução de trabalho de mais fôlego. Além disso, o conjunto de ilhas se constitui na atividade alcalina mais próxima das ombreiras da Bacia de Santos e da Falha de Santos, e Búzios a mais afastada do continente, dentre as porções emersas.

Sem fugir à proposta geral da linha de pesquisa em andamento, este trabalho orientou-se para a solução de problemas já bem conhecidos daqueles que militam com rochas alcalinas: a dificil definição dos tipos existentes e sua interrelação, a interação com as encaixantes, a ocorrência freqüente de rochas supersaturadas e insaturadas no mesmo corpo, a presença, quantidade e natureza dos xenólitos, a estrutura dos corpos e, sempre que possivel, uma razoável definição petrológica.

Acresce ainda que o conjunto de ilhas representa, por um lado, o extremo SE de "trends" propostos ligados a plumas e, por outro, a atividade alcalina intrusiva mais oriental da borda da Bacia do Paraná.

\subsection{Objetivos}

Os objetivos propostos no início da pesquisa foram, evidentemente, modificados no decorrer dos trabalhos. Após a realização da programação de campo e alguma petrografia, tornou-se possivel, no entanto, defini-los com mais minúcias: 
- Reavaliação da geologia e estratigrafia da llha;

- cartograría interna do corpo alcalino, definição de litotipos e estruturas;

- exame detalhado das relações de contato entre as rochas alcalinas e encaixantes;

- exame dos diques quanto à ocorrência e características de campo;

definiçäo petrográfica mais aprofundada de todos os tipos presentes, com ênfase nas texturas e suas implicações genéticas, e nas assembléias minerais;

- identificação de atividades pós-magmáticas, tardias, presentes;

. caracterizaçäo química das rochas alcalinas e de seus minerais essenciais;

caracterização química dos diques e comportamento petroquímico das litologias alcalinas e diques;

estabelecimento de quadro modelístico genético magmático e evolutivo das intrusões;

. sintese dos resultados obtidos;

montagem de quadro petrológico global.

\subsection{Plano de trabalho}

Para o atendimento dos objetivos acima, foi elaborado plano de trabalho exeqüivel, prevendo-se:

- Mapeamento geológico de detalhe e amostragem, dando-se a atenção, merecida, aos diques e às feições supostamente tardias;

- petrografia de detalhe dos tipos litológicos, enfatizando-se os aspectos texturais e mineralógicos, sem detalhamento de caracteristicas ópticas trabalhosas (índices, $2 \mathrm{~V}$, dispersão etc.);

análise química de número representativo de amostras selecionadas, tanto do corpo alcalino como dos diques;

análise química mineral, dividida em duas etapas: minerais essenciais e mais importantes e, mais ocasionalmente, mineralogia rara (ambos sempre na espectativa de oportunidade, tempo e exeqüibilidade);

- análises isotópicas $\mathrm{KAr}$ e $\mathrm{Rb} / \mathrm{Sr}$, com vistas à obtenção de idades e, se possivel, razões iniciais ${ }^{87} \mathrm{Sr}{ }^{86} \mathrm{Sr}$.

Cumpridas essas etapas, têm-se como principais resultados:

a apresentação de mapa geológico da llha;

- a definição dos contatos ou tipos de interação intrusiva-encaixante, e registro dos indicadores da forma do corpo;

a definição das estruturas regionais e internas; 
a definição dos litotipos internos;

- a definição dos diques quanto a tipos, locais de ocorrência, dimensões, forma e posicionamento;

- a apresentação do quadro petrográfico de detalhe de todas as rochas alcalinas encontradas;

a caracterização química das rochas quanto a elementos maiores e alguns traços;

a caracterização química, por microssonda, dos minerais mais importantes das rochas sieníticas e dos diques;

. a obtenção de idades $\mathrm{K} / \mathrm{Ar}$ e razões isotópicas ${ }^{87} \mathrm{Sr} /{ }^{86} \mathrm{Sr}$;

\subsection{Apresentação dos resultados}

Para situar qualquer interessado neste trabalho, e obedecendo a seqüencia que parece mais lógica, sua apresentação não foge à tradicional, e inicia-se com a parte introdutória no Capítulo 1 , onde se define e se justifica o tema objeto de estudo, a sua forma de abordagem, como também o que foi efetivamente proposto e executado.

No Capítulo 2 são descritos com mais ou menos detalhes os métodos, as técnicas e toda a logística e dificuldades na obtenção dos resultados. No 3 é apresentada a liha dos Búzios, de forma minuciosa, incluindo-se aspectos não geológicos, mas de interesse geral; nesse capitulo são também dadas informações sobre a sua localização, acesso, fisiografia $e$ condiçōes dos afloramentos em geral.

Os conhecimentos prévios, tanto objetivos como modelísticos, acham-se reunidos no Capítulo 4, enquanto que o 5 discute a geologia nos seus mais diversos aspectos.

O Capítulo 6 reúne as informações petrográficas em geral e 07 os dados relacionados com o quimismo das principais fases minerais.

O Capitulo 8 trata da química das rochas. Segue-se a isotopia $\mathrm{K} / \mathrm{Ar}$ e $\mathrm{Rb} / \mathrm{Sr}$, para idades e razões iniciais ${ }^{87} \mathrm{Sr} /{ }^{86} \mathrm{Sr}$, no Capitulo 9 , e as considerações finais constituem o capítulo de número 10. A Bibliografia é o capítulo final, de número 11. 


\section{CAPÍTULO 2 \\ METODOLOGIA, TÉCNICAS E TRABALHOS EFETIVOS}

\subsection{Trabalhos de campo}

Foram marcados em mapa 170 pontos. O significado de cada ponto é variado. Alguns deles correspondem a paradas com observações diretas, simples e rápidas, mas a maioria representa secção à beira-mar, contínua, com extensões de até centenas de metros ou mais; outros, áreas de lajes expostas contínuas nos costões, ou então raros afloramentos grandes $e$ importantes de meia encosta. Em todos os casos, o ponto indica uma superfície exposta ou uma secção sempre de grandes dimensões, além de complexa, envolvendo as encaixantes, os sienitos, contatos com encaixantes, xenólitos ou diques. Quase nunca um ponto demandou menos de 1-2 horas de observação, com freqüência quase 4 horas, e em alguns casos mais raros, um dia inteiro.

Os pontos mostram distribuição irregular. Foram percorridas trilhas, costões, picadas onde possivel e, mais significativo, fez-se grande esforço para atingir todos aqueles julgados especiais. De certa forma eles estão distribuidos ao longo dos costões, das cristas e dos contatos favoráveis, como lajes grandes que se estendem por centenas de metros. As meias encostas também foram percorridas, ainda que menos amostradas, face à ocorrência mais rara de blocos frescos.

Toda a encosta sul da ltha é coberta por mata, sendo poucos, mesmo nas picadas e nas drenagens, os blocos expostos favoráveis, e daí o pequeno número de pontos. Alguns lugares nos costões também mostram ausência de pontos por se tratarem de locais inatingiveis e inviáveis. O percurso pelos costões levou por vezes a obstáculos intransponiveis.

O trabalho na liha teve sua $1^{\text {a }}$ etapa executada durante o mês de outubro de 1981, demorando 20 dias. A $2^{a}$ viagem ocorreu em fevereiro de 1982, tendo durado 15 dias, enquanto que a $3^{\text {a }}$ se deu em fevereiro de 1992, portanto, dez anos depois.

As duas primeiras viagens foram feitas em barco camaroneiro velho e precário, com canoa auxiliar ainda pior. Tão "pior"que afundou (com o autor) em uma das travessias.

Ao largo da llhabela, o mar pode ser encrespado, mas nos oito quilometros de canal separando as ilhas ele é sempre mais movimentado. Assim, as condições recomendáveis para a travessia são: vestimenta sumária, equipamentos e mantimentos vedados, além de embalados em sacos de plástico, com ar, pois a operação de carga e descarga exige que o canoeiro mantenha uma das mão com o remo, enquanto na outra passa a carga a quem está na laje ou trapiche. Durante a $1^{a}$ expedição, marinheiro de $1^{\text {a }}$ viagem, e logisticamente mal orientado, permitiu-se que a água do mar, que está por toda parte a toda hora, causasse estragos desanimadores. 
Na mesma viagem, por falta de informações, e pelas poucas conseguidas com Prof. $R$. Ellert, levoumse equipamento para verdadeira guerrilha: barraca, fogäo, panelas, lampiões etc. Mas a Ilha é habitada e logo conseguiu-se alugar casa e pensão, bem como mateiro e auxiliar. Durante o mês de outubro, choveu todos os dias: uma chuva contínua que, apesar de durar o dia todo, não impediu os trabalhos de campo.

Além do embarque e desembarque e certo desconforto nas acomodações (por exemplo: todo uso de água, por sinal boa, captada em fontes de água pluvial, é feito por cano de borracha único, e o banho é na bica ou com o auxilio de caneca), as maiores dificuldades para o trabalho residem na impossibilidade de uso de veículos e ausência de caminhos, trithas e picadas em boas condições.

Some-se a isso a existência de matas em metade da liha, além da sua topografia acidentada, com dois espigões na forma de $T$, com o cume a $400 \mathrm{~m}$ de altura e distante de 500 a $1000 \mathrm{~m}$ do mar. Não há terreno plano, tendo as encostas declive variável de $15^{\circ}$ a $45^{\circ}$. Além disso tudo, afora o caminho pelos cristas, relativamente fácil, $60 \%$ a $70 \%$ dos trabalhos foram feitos nos costões ou em locais próximos, onde a progressão não ultrapassa os $500 \mathrm{~m}$ por dia.

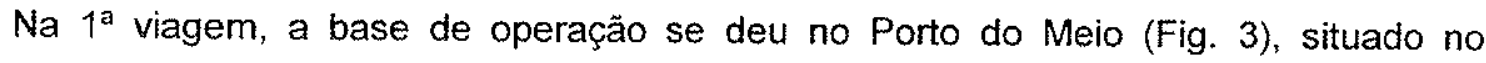
extremo oeste, na encosta voltada para a llhabela. A caminhada até a Ponta Sudeste, com tempo de parada para observações não levando mais que 2 horas, demandou perto de 13 horas.

Assim, o trabalho na liha tem baixo rendimento. Nas proximidades da base, aproveitam se o dia todo. Na medida em que os pontos vão ficando mais distantes, a melhor estratégia é a de caminhar o mais rápido possivel durante meio dia, entre $6 \mathrm{~h}$ até 11 ou $12 \mathrm{~h}$, de forma a atingir o local extremo visado, e voltar fazendo observações, até certo limite de tempo. Não é viável o trabalho até tarde do dia, uma vez que a locomoção se torna extremamente perigosa à noite, e mesmo porque os habitantes locais näo costumam sair à noite.

O deslocamento nos costões é penoso, perigoso e extremamente lento. Fora deles, as trilhas contornam a face oeste e norte da litha à baixa encosta, 20 a $50 \mathrm{~m}$ acima do mar, dentro de um emaranhado de grandes blocos de rocha e árvores. Raramente se pisa no "chão". Em algumas passagens, em razão da presença de fendas e grotöes que se abrem para o mar, o avanço somente se dá com o auxílio de corda, cipó ou mesmo pulando.

De qualquer forma, em termos de observações geológicas, o rendimento médio nunca ultrapassa de 2 a 3 horas por dia, o resto do tempo servindo para deslocamento. Como este é difícil (Ponta Sul, Ponta Sudeste, Saco do Chico Rosa) e longo, também não se consegue trabalhar todos os dias, havendo necessidade de variar a atividade ou pará-la por uns dias: um dia pela crista, outro pelo costão, outro nas proximidades da casa. Isso explica o espalhamento da seqüência numérica de pontos.

Some-se a esses problemas a densidade inusitada de cobras (duas variedades de 
jararaca - Bothrops brasiliensis) quando atravessando as matas.

Do Porto do Meio, acompanhado de guia e auxiliar, procurou-se trabalhar o mais próximo possível da base de operação, sendo então percorrida toda a face ocidental da llha, da Pontinha a Pitangueiras e até o espigão NE-SW, que marca a borda da mata. Para leste do espigão, na face norte, por onde corre a tritha principal, atingiu-se toda a porçäo norte dos costões e meias encostas, até o limiar da mata, que coincide com as cristas dos espigões quase alcançando a Mãe Joana. Na $2^{\text {a }}$ viagem, a base de operação foi na Mãe Joana, em casa de morador. Desse ponto, trabalhou-se toda a porção leste, separada por sela topográfica do resto da llha. Essa mesma sela é a única via de acesso ao Saco Grande, a sul, desde a Ponta Sudeste até a Ponta Sul. Algumas penetrações foram feitas na mata, com resultados infrutíferos, na tentativa de atingir-se o costão a oeste da Ponta Sul. Através da sela, em pouco tempo, chega-se ao Saco Grande: nos costöes de blocos dessa enseada foram gastos vários dias de trabalho, parte no sentido leste e parte ao contrário, até a Ponta Sul.

$\mathrm{Na} 3^{\mathrm{a}}$ e última viagem, a base de trabalho foi novamente no Porto do Meio. Nessa ocasião, reexaminaram-se alguns afloramentos chaves e não muito distantes. Além da tentativa de atravessar a mata pela crista até a costa sul, esta foi também percorrida desde a Ponta das Pitangueiras até o Porto Sul e Saco do Chico Rosa, próximos a Ponta Sul. O Porto Sul foi alcançado após 6 horas de caminhada, parte pela mata contornando o Saco do Coruja e parte pela meia encosta, até a altura do local, quando então se desce diretamente em direção ao mar.

Após a experiência vivida de quase 50 dias de campo, não se recomenda o trabalho nas ilhas litorâneas sem certos cuidados adicionais, além dos tomados nestas expedições: não sair com um único acompanhante, usar botas longas nas matas e calçado antiderrapante para as operações nos costões, além de carregar sempre cabo de pelo menos $10 \mathrm{~m}$ de comprimento. Duas recomendaçöes adicionais são ainda importantes: duvidar sempre da palavra do guia, quando este afirma que "não dá mais para ir em frente" ou que "não sabe qual a picada certa". A segunda: nunca marcar o dia e a hora do retorno, pois nunca se sabe como estará o humor do mar; o correto é marcar o retorno "a partir do dia x, se der".

Citam-se alguns números para se ter idéia do rendimento dos trabalhos de campo em locais do gênero, não oferecendo qualquer meio de transporte. As estadas em Búzios foram, respectivamente, de 18, 12 e 18 dias, totalizando assim 48 dias. Primeiramente, é seguro dizerse que nunca se consegue trabalhar mais que 4 a 5 dias seguidos, havendo então necessidade de se lançar mão de recursos como alternar locais de trabalho, parar metade do dia ou mesmo andar, na outra metade, por perto da base. Após esse periodo de tempo, dependendo dos percursos, como Porto do Meio-Ponta Sudeste, Mãe Joana-Saco Grande-Ponta Sudeste, Mãe Joana-Ponta Sul, a exaustäo era total, incluindo-se a do guia. Dessa forma, do total de permanência na liha, estima-se que não mais de 30 dias foram gastos em caminhadas e 
mapeamento. Nesses dias, a metade do tempo foi consumida simplesmente com o deslocamento, o que reduz o trabalho efetivo a cerca de 15 dias de 12 horas de atividade diária. Tendo a llha mais ou menos $8 \mathrm{~km}^{2}$ de área, com boa parte não percorrida (encostas sul, cobertas de mata), o rendimento não chega a $0,5 \mathrm{~km}^{2}$ por dia de efetiva geologia de campo. Se for levado em conta o tempo total, esse rendimento cairia no máximo para $0,2 \mathrm{~km}^{2}$ por dia.

Também o número de pontos marcados e a amostragem mostram números desencorajadores: no tempo efetivo de trabalho, 27 amostras e 10 pontos por dia (pouco mais que 2 amostras por ponto); se igualmente for considerado o tempo total de permanência na Itha, os números caem para 8 e 3 , respectivamente.

Tendo como suporte as observações de campo e o exame estereoscópico de fotografias aéreas, as quais, na verdade, pouco auxiliaram, decidiu-se pela definição de três formas de contato: observado, é aquele em que há bastante segurança na sua posição, com incerteza da ordem de metros; provável, correspondendo à maioria, é aquele em que a mistura de rochas em afloramentos ou a dispersão de blocos geram grande incerteza, cabendo nesse caso uma variação da ordem dos $50 \mathrm{~m}$. Por último, o inferido, com base nos pontos percorridos menos distantes, na topografia e no exame de fotografias aéreas; nesse caso, a incerteza pode ultrapassar a centena de metros ou ocorrer intercalação entre os tipos.

\subsection{Petrografia}

Além das observaçōes e registros obtidos diretamente em afloramentos, foram examinadas de forma convencional e rotineira, com lupa manual, aproximadamente 600 amostras de rochas, tanto frescas como alteradas.

Foram feitas 350 secçöes delgadas, parte delas visando o reconhecimento de feiçōes específicas presentes nas amostras, como contatos, variaçöes composicionais e granulométricas, veios e venulações, estratificações, bordas de xenólitos etc.

As secções delgadas foram examinadas à luz transmitida, primeiramente ao estereomicroscópio Zeiss, modelo STEMI-SV8, com grande campo visual $(30 \mathrm{~mm}$ ) e objetiva Zoom, além de ampliação variável. Esse procedimento tem a vantagem de permitir a visão da secção por inteiro, facilitando o reconhecimento textural e o relacionamento entre partes distintas da lâmina, ao mesmo tempo que faculta a observação de todas as fases minerais presentes, sem a necessidade rastreá-las em campos visuais microscópicos de maior detalhe. Adicionalmente, facilita a obtenção de uma primeira idéia da moda da amostra e das espécies e/ou grupos minerais existentes. A utilização do estereomicroscópio, tomada como medida preliminar da petrografia de detalhe, e com as vantagens enumeradas, torna fácil e rápido o 
agrupamento das amostras semelhantes, que, posteriormente, seräo examinadas ao microscópio. Em geral, o exame ao estereomicroscópio não consome menos de 30 minutos.

Após essa fase, empregou-se microscópio marca Zeiss, modelo AXIOPLAN, para o trabalho de microscopia petrográfica. O aparelho tem campo visual entre $10 \mathrm{~mm}$ e $0,49 \mathrm{~mm} e$ aumento máximo de $400 \mathrm{x}$.

Após o exame descritivo, foram selecionadas as secções delgadas representativas dos principais tipos petrográficos, bem como as feições texturais e microestruturais de interesse para a fotomicrografia, esta levada a efeito no mesmo microscópio, equipado com conjunto fotográfico marca Zeiss, modelo M35W, filme Kodak de 100 ASA, e exposição automática (fotocélula MC 63A). O mesmo procedimento foi adotado para fotografar os minerais. Foram feitas aproximadamente 100 fotomicrografias, com grande número ilustrando este trabalho, recorrendo-se a todos os recursos técnicos fotográficos rotineiros e outros improvisados: combinação de filtros, emprego de diafragma, lente condensadora inferior e compensador, variação no ângulo entre os polarizadores.

Foram feitas análises modais dos principais tipos litológicos, atribuindo-se contudo menor significado às dos sienitos de granulação mais grossa. $O$ trabalho de contagem de pontos teve como preocupação básica cobrir toda a seç̧ão e não tanto o espaçamento entre os pontos, variando-se mais a distância entre as linhas de contagem. Nas secçóes texturalmente mais homogêneas, a média da contagem foi de 1000 pontos, controlados por variações ou constâncias entre as linhas de contagem.

\subsection{A química das rochas}

Foram analisadas 60 amostras de rochas. As amostras de sienitos atingiram um total de 30 , as de rochas insaturadas de diques 6 , as de supersaturadas 7 e as de diques máficos 12. Também foi analisada uma amostra de charnoquito, sendo ainda que duas análises foram feitas em duplicata. Dessa forma, os resultados tabelados somam 58, mais a composição média de charnoquitos de Ubatuba (Neumann, 1993).

As amostras analisadas foram escolhidas dentre as que näo exibiam quaisquer evidências de alteração. Não houve preocupação em se trabalhar somente com tipos afíricos, e entre as amostras existiam algumas com evidências de saussuritização e presença de carbonato na forma de ocelos, ou estruturas esféricas, aparentemente primárias. O segundo critério foi o de ter-se a maior diversidade petrográfica possivel, com o cuidado de duplicar algumas variedades de diques semelhantes. Assim, o dique mais possante da liha teve duas amostras analisadas: uma do centro e outra da borda. Finalmente, considerou-se a distribuição geográfica, critério usado sobretudo para os sienitos. 
Após a seleção, as amostras foram serradas em placas de tamanho adequado à sua granulação, ou fragmentadas e quarteadas (rochas de granulação mais grossa), tomando-se aliquota suficiente.

As análises foram realizadas no Departamento de Ciências da Terra da Universidade de Trieste, Itália, com o auxílio de fluorescência de raios $X$ e empregando se os procedimentos descritos em Bellieni et al. (1983).

Os resultados análiticos foram tratados por meio do programa NewPet-94 (Deryl Clarke, 1994). A arte final dos gráficos, não muito simples, consistiu na combinação de recursos variados de informática. Ou seja, os gráficos obtidos com o NewPet foram salvos utilizando-se o arquivo PIC (Lotus 1-2-3), "exportando" os dados para o "Word for Windows 6.0 ", onde esses foram adequadamente trabalhados quanto a tamanho, escala, tipos gráficos etc.

O programa NewPet, não tão versátil, tem como suporte razoável bibliografia e adota algumas práticas e valores que se seguem:

. a base de cálculo para os elementos maiores é anidra, com os valores recalculados para $100 \%$;

. algumas casas decimais são fixadas de tal forma que não se pode alterá-las;

- para a razão de oxidação do ferro ( $\mathrm{FeO} / \mathrm{FeO}+\mathrm{Fe}_{2} \mathrm{O}_{3}$ ) adotou-se 0,85;

- para a normalização dos valores analíticos relativamente à composição do manto primitivo seguiumse Wood et al. (1979);

. o número $\mathrm{Mg \#}$ é dado pela relação $\mathrm{MgO} / \mathrm{MgO}+\mathrm{FeO}_{\text {. }}$.

Além dessas informações, é necessário esclarecer que foi adotado o valor teórico para a razão de oxidação do ferro porque os resultados analíticos para $\mathrm{Fe}^{2+}$ e o recálculo do $\mathrm{Fe}^{3+}$ forneceram dados muito variados, indicando, assim, a existência de alguma oxidação intempérica.

A adoção de valores teóricos, estes aceitos de forma geral, reflete melhor as condições finais da rocha cristalizada e não alterada. O ideal seria o emprego de valores teóricos distintos para rochas félsicas e máficas, além de vulcânicas e plutônicas (cf. Middlemost, 1989). Contudo, isso complicaria em muito o trabalho de processamento dos dados.

Na prática corrente, pode-se tratar os dados analiticos quimicos de rocha assumindo todo o ferro na forma de $\mathrm{FeO}_{4}$ (total), ou de $\mathrm{Fe}_{2} \mathrm{O}_{3}$ (total), e adotando-se um valor para a razão de oxidação que permita calcular um do outro; alternativamente, pode-se fazer a determinação analítica do ferro total como FeO, seguida da dosagem de FeO por via úmida, e calcular-se o $\mathrm{Fe}_{2} \mathrm{O}_{3}$.

Com as rochas de Búzios foi feito um ensaio experimental. Foram escolhidas amostras saturadas ou contendo na moda um mínimo de quartzo ou de nefelina. Os valores analíticos 
foram processados adotando-se $\mathrm{FeO}$ como total, $\mathrm{Fe}_{2} \mathrm{O}_{3}$ como total, os valores reais de $\mathrm{FeO}$ obtidos analiticamente e, finalmente, repartidos em $\mathrm{FeO}$ e $\mathrm{Fe}_{2} \mathrm{O}_{3}$ segundo razões de oxidação iguais a $0,90,0,85,0,80$ e 0,70 . Calculadas as normas CIPW, os resultados mais coerentes e sem aberrações foram aqueles obtidos a partir de FeO total ou o ferro repartido segundo a razão de oxidação 0,85 .

Os resultados finais, apresentados em tabelas e gráficos, seguem procedimentos mais ou menos rotineiros.

Primeiramente, as rochas foram classificadas segundo as recomendações do IUGS (Le Maitre et al., 1989) ou segundo De La Roche et al. (1980) e De La Roche (1986). Diagramas já clássicos foram empregados para fins de caracterização química genérica do grupamento total de amostras. Os dados foram também apresentados em diagramas multielementares e gráficos binários, tendo havido bastante trabalho na seleção do parâmetro de correlação mais adequado. A escotha envolveu diagramas de Harker (1909), clássicos, números mg\# e indices de S.I e D.I. Em algumas circunstâncias parece ser mais conveniente o uso de gráficos mono ou log-log. Todos foram tentados e estudados à exautão, terminando-se

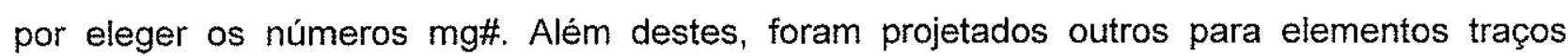
julgados interessantes.

$\mathrm{Na}$ ocasião, por falta de dados analíticos minerais e, portanto, na impossibilidade de se contar com os valores de $\mathrm{Kd}$ e $\mathrm{D}$, procurou-se extrair o máximo de informações dos diagramas químicos de rocha total, examinando-se com minúcia a mineralogia das rochas analisadas e tentando traçar um paralelo entre os minerais reais presentes, a seqüência de cristalização e o comportamento dos vários elementos.

\subsection{A química mineral}

A análise química mineral, além de contar com toda a aparelhagem, metodologia e técnicas conhecidas e seguras, foi antecedida pela petrografia (e a geologia, obviamente) e projeto de objetivos. Sem essas condições, ou teriamos resultados pouco confiáveis ou, embora confiáveis, não serviriam para muita coisa, e a um alto custo.

Tendo em vista os grupos de rochas petrograficamente definidos, o elenco dos minerais a serem analisados, em programa limitado, só deveria, e poderia mesmo, restringir-se aos essenciais. Além disso, limitou-se não só o número de amostras, como também o número de grãos por fase mineral e de análises ("pontos") por grão.

A localização dos pontos foi feita ao microscópio Zeiss, já referido, com o uso de luz transmitida e refletida. Contudo, nem isso evitou mudaças na programação. Quase todo o trabalho analítico foi conduzido de forma automática, boa parte de um dia para outro, após o 
registro das coordenadas $(X, Y, Z)$ dos pontos escolhidos. O rendimento dessa forma não é muito, mas oferece vantagens. Primeiro, despende-se 1 a 2 horas para registrar de maneira cuidadosa 30 a 60 pontos, mas ganha-se o tempo da análise, que no caso levaria entre 4 a 10 horas; segundo, consegue-se aumentar o tempo diário médio de utilização da microssonda.

As amostras foram selecionadas entre sienitos variados, diques félsicos (fonólitos e traquitos), microssienito, e diques máficos de caracteristicas diversas. Nos sienitos, foram analisadas as diferentes fases das mesopertitas, clinopiroxênio, anfibólio, biotita e opacos; nos diques, félsicos, as fases pertiticas, além de feldspatóides, clinopiroxênio e anfibólio. Nos diques máficos, foram analisados todos os minerais essenciais presentes, à exceção dos produtos de alteração e micro a criptocristalinos da matriz: olivina, clinopiroxênio, anfibólio e biotita entre os ferromagnesianos; plagioclásio, feldspatóides e feldspato alcalino.

As análises foram conduzidas no Laboratório de Microssonda e Microscopia Eletrônica do IG-USP. O aparelho em operação é um JEOL JXA-8600S, de cinco espectrômetros e completamente automático. Fatia da amostra, com até $30 \mathrm{~mm}$ de diâmetro, é reduzida até pouco mais que $30 \mu$ de espessura, polida, e metalizada com carbono, após o que servirá de objeto para as análises pontuais por WDS. A fase de metalização, contando com equipamento de fabricação Edwards, tem-se mostrado operação das mais delicadas, e capaz de influir bastante na qualidade dos resultados obtidos.

De modo geral, os félsicos foram analisados para $\mathrm{Si}, \mathrm{Al}, \mathrm{Fe}, \mathrm{Ca}, \mathrm{Sr}, \mathrm{Ba}, \mathrm{Na}$ e K , podendo-se optar pela inclusão de $\mathrm{S}$ e $\mathrm{Cl}$ (para análise de feldspatóides). No caso dos ferromagnesianos, foram determinados $\mathrm{Si}, \mathrm{Ti}, \mathrm{Al}, \mathrm{Fe}, \mathrm{Mg}, \mathrm{Mn}, \mathrm{Ni}, \mathrm{Cr}, \mathrm{Ca}, \mathrm{Na}$ e $\mathrm{K}$.

Os padrões, todos internacionais, são os usualmente empregados no laboratório: wollastonita (Si e Ca), periclásio $(\mathrm{Mg})$, corindon (Al), rutilo (Ti), ortoclásio (K), silicato de Sr e Ba sintéticos ( $\mathrm{Sr}$ e $\mathrm{Ba})$, hematita $(\mathrm{Fe})$ e rodonita $(\mathrm{Mn})$.

As condições operacionais usuais são, respectivamente, de $15 \mathrm{kV}$ e $20 \mathrm{nA}$ para potencial de aceleração e corrente do feixe. O diâmetro de feixe foi fixado em $10 \mu$ para análise dos feldspatos e $5 \mu$ para os ferromagnesianos, e os tempos de contagem variaram entre 5 " a 40", dependendo do elemento (maiores, traços). Como de rotina, as intensidades de pulso foram corrigidas para "background" e tempo morto. Efeitos de matriz foram também corrigidos automaticamente pelo ZAF.

Os resultados analíticos, que podem embutir erro variável entre 3 e $5 \%$ (maiores e menores), com reprodutibilidade ao redor de $1 \%$, foram tratados no programa MinPet de Richard (1995). 


\subsection{Estudos isotópicos K/Ar e Rb/Sr e Geocronologia}

Os estudos isotópicos $\mathrm{K} / \mathrm{Ar}$ e $\mathrm{Rb} / \mathrm{Sr}$ tiveram objetivos costumeiros, limitados porém no número de amostras a serem tratadas.

As amostras escolhidas para KJAr visaram a tentar resolver, ou pelo menos melhorar, o leque de idades disponiveis para as rochas alcalinas do litoral. Assim, foram selecionadas amostras exequíveis técnica e metodologicamente, evitando-se aquelas com alteraçōes indesejáveis, presença de vidro e carbonatos em excesso. Por último, levou-se em conta a granulação, visto que o limite para o método, no CPGeo, é da ordem de 0,1 $\mathrm{mm}$. Tendo em vista a situação de campo e o tipo de rocha, estudaram-se em secção delgada pelo menos 20 amostras, sendo eleitas 10 delas, representando litologias diversas. A essa altura, também já se havia escolhido o mineral a ser processado, descartando-se as amostras menos recomendáveis para a obtenção de dados seguros (por exemplo, rochas portadoras de anfibólio e piroxênio, procurando-se trabalhar amostras com biotita ou com anfibólio favoráveis à separação).

O procedimento seguido foi rotineiro: britagem, moagem e peneiramento nas malhas 30/35-60-100-150 mesh, seguido de lavagem em água corrente e secagem na caixa de lâmpadas (prática um tanto inadequada).

Após a obtenção das frações granulométricas em quantidade adequada (nem sempre o foi), passou-se à eliminação do material magnético ao imã manual e, só então, ao uso do separador eletromagnético isodinâmico "Frantz". Em alguns casos, à essa separação, seguiram-se técnicas com líquidos pesados, placa vibratória e "tapping" com papel de filtro, manualmente. Para as assembléias tratadas e os minerais pretendidos (biotita e anfibólio), a separação eletromagnética, seguida ou não do "tapping", revelou-se muito eficiente para as micas. Com os concentrados de biotita ou de anfibólio, dentro da faixa granulométrica tratada, e a um nivel mínimo estimado de $95 \%$ de pureza, eventualmente quase $100 \%$, foi seguida a metodologia descrita em Amaral et al. (1966). Foi feita uma dosagem em rocha total.

Com relação aos trabalhos com a química isotópica para $\mathrm{Rb}$ e $\mathrm{Sr}$, os critérios foram diferentes. Estabeleceu-se como meta principal a obtenção de razões iniciais ${ }^{87} \mathrm{Sr} /{ }^{86} \mathrm{Sr}$, partindo de idade conhecida K/Ar e, tentativamente, ajustando os valores disponiveis. Em segundo plano, a obtenção de linha isocrônica de referência, que por si só, poderia confirmar não apenas as idades KJAr obtidas, como também as razões conseguidas a partir das idades KJAr. O critério de seleção, uma vez que se trabalharia somente com rocha total, foi a escolha de tipos variados, desde os tidos menos evoluídos (basanitos, tefritos) até os mais evoluidos (sienitos e fonólitos). Ao mesmo tempo, cuidou-se dos valores totais de $\mathrm{Rb}$ e $\mathrm{Sr}$ tal que houvesse, primeiro, pelo menos um ponto próximo à origem (mínimo teor de $\mathrm{Rb}$, recomendando-se abaixo de $50 \mathrm{ppm}$, pelo menos, e alto teor de $\mathrm{Sr}$ ) e, em seguida, o maior 
espalhamento possivel de pontos. Cuidado adicional foi tomado com os aspectos de alteração da rocha, com a moagem de quantidade adequada à granulação de cada uma, e com o aproveitamento integral da amostra escolhida, seguida de quarteamento cuidadoso até o peso necessário.

Obtidos os pós, com granulometria abaixo de \# 250, foi feita análise por fluorescência de raios $X$ de $R b$ e $S r$ total nas amostras que seriam efetivamente aproveitadas, uma vez que já se dispunha dos valores de $\mathrm{Rb}$ e $\mathrm{Sr}$ para aquelas analisadas para química de rochas, o que, inclusive, permitiu comparação dos resultados.

A aparelhagem para XRF é de marca Philips, modelo PW-2184/00, utilizando-se os padröes PCC-1 e GSP-1. Foram seguidas as rotinas dos laboratórios do CPGeo, incluídas pequenas alterações, descritas por Kawashita (1972). As determinações isotópicas, após abertura com HF e HNO3 e a extração dos elementos nas resinas de trocas catiônicas, foram feitas em espectrômetro automatizado VGI, modelo VG-354, com erros admitidos, para as razões isotópicas, na quinta decimal. O laboratório do $\mathrm{CPGeo}$ adota a prática da DI nas amostras com teores de Rb e/ou Sr abaixo de 50 ppm ou acima de 700 ppm. 


\section{CAPITULO 3 \\ A ILHA DOS BÚZIOS}

\subsection{Localização e acesso}

A !lha dos Búzios (Foto 1) pertencente ao municipio de llhabela, situa-se dentro dos limites de um retângulo tendo por coordenadas geográficas $23^{\circ} 45^{\prime}-23^{\circ} 50^{\prime} \mathrm{S}$ e $45^{\circ} 05^{\prime}-45^{\circ} 10^{\prime} \mathrm{W}$, e que inclue também a ilhota chamada Somítica (Fig. 1).

Em indicação mais familiar, fica a leste da liha de São Sebastiāo (Ilhabela), litoral norte do Estado de São Paulo, distante poucos quilômetros mar afora. Habitualmente, não é vista da área do continente, estando sempre encoberta por aquela llha. Na descida da Rodovia dos Tamoios e no trecho entre Caraguatatuba e São Sebastião, é perfeitamente possivel distinguila. Do continente (São Sebastião) dista pouco mais de $30 \mathrm{~km}$ do ponto mais próximo. Essa cidade, a $200 \mathrm{~km}$ de São Paulo (Estação Rodoviária), pode ser atingida pela Via Dutra-Tamoios ou Imigrantes-Anchieta-Rio/Santos, com um tempo aproximado de percurso em torno de 3 horas.

O acesso a llha dos Búzios não é fácil, e tem como ponto de partida o Bairro de São Francisco (periferia da cidade de São Sebastião) ou o cais de llhabela. O percurso costeia a porção norte dessa llha por cerca de $20-25 \mathrm{~km}$ (a uma distância de 100 a $500 \mathrm{~m}$ do costão, dependendo das condiçōes do mar, que normalmente são melhores pela manhã), após a travessia do canal de São Sebastião. Atingida a Ponta Grossa, no extremo nordeste da Ilhabela, percorre-se $8 \mathrm{~km}$ de mar aberto, normalmente a pior parte da viagem, rumando se diretamente para a face ocidental da llha dos Búzios para o local denominado Porto do Meio, área de maior concentração de casas, e onde existe um trapiche inservivel de concreto.

A travessia, que dura de 2 a 3 horas, dependendo do barco e das condições do mar, pode ser feita em baleeiras de motor central, chatas de convés aberto, "canoas" centenárias com motor de popa (raras) ou ainda, embora mais caros e seguros, barcos camaroneiros de três tripulantes, com 8-10 $\mathrm{m}$ de comprimento e 3-4 $\mathrm{m}$ de boca, metro a metro e meio de calado, além de cabine do timoneiro razoavelmente ampla. Essa cabine fica à popa, de modo que se viaja de pé, sentado ou "agarrado a alguma coisa" (ao guincho, por exemplo) no convés fechado da proa, onde se abrem os compartimentos para gelo, camarões, bagagens etc. Esses barcos têm motores diesel potentes (mais que $120 \mathrm{HP}$ ) e rebocam pequena canoa ou bote ( 0 "caico"), porque normalmente não atracam: em São Sebastiăo, permanecem ancorados ou poitados a distância considerável da praia $(50$ a $200 \mathrm{~m}$ ), dependendo do mar, o mesmo sucedendo em Búzios, onde não existem praias, mas apenas trapiches toscos de madeira roliça ou lajes mais convenientes ao desembarque. Assim, o embarque e desembarque na liha obedece a um ritual que envolve o emprego de pequeno bote para operações em água rasa; a 
passagem do bote para o barco, ou vice-versa, requer também alguma agilidade. Em Búzios, o destino é uma pedra grande conveniente, se possivel chata, ou em condiçōes de mar mais calmo, o que é raro, o trapiche de paus roliços, a exigir sempre um pouco mais de destreza. Ao contrário da logística estabelecida na primeira viagem por ex-colega da pós-graduação, devese fazer a travessia em trajes sumários e mãos livres.

A propósito, existe um heliporto na llha. Havendo recursos, o helicóptero é o meio de transporte mais recomendável.

$\hat{E}$ interessante referir aqui, novamente, à proximidade de outras ilhas vizinhas, constituídas no todo ou em parte por rochas alcalinas. A llha de São Sebastião fica a $8 \mathrm{~km}$ a oeste (Foto 2), estendendo-se para o sul por mais de $25 \mathrm{~km}$; a llha de Vitoria dista $11 \mathrm{~km}$ a NE (Foto 3) e a liha do Monte de Trigo $80 \mathrm{~km}$ a WSW.

\subsection{Aspectos gerais}

Como ilha, Búzios é semelhante a todas as outras próximas à costa norte de São Paulo e sul do Rio de Janeiro. São todas principalmente remanescentes continentais de longo processo erosivo marinho. Há que se lembrar dos recuos marinhos nos últimos 10 até 120 mil anos, que expuseram o atual fundo até cotas ainda não conhecidas. Algumas ilhas pequenas aparecem como lajes, rochedos ou quase isso, como a Laje de Santos e Alcatrazes, enquanto outras conservam características das áreas altas do continente, como a llha de São Sebastião e a liha Grande. Algumas têm praias e outras, dada à dinâmica do processo erosivo, não. A maioria tem pelo menos parte coberta pela Mata Atlântica, em geral na face sul, e a ação do homem talvez seja responsável, parcial ou totalmente, pelas áreas de vegetação baixa. As ilhas de grande porte sustentam Mata Atlântica quase completa, incluindo a fauna continental original. Nas menores, como Búzios, a mata já está bastante alterada, inexistindo fauna de mamiferos; o reequilíbrio faunístico parece ter levado a reduzido número de espécies de vertebrados.

Búzios é uma ilha com menos de $8 \mathrm{~km}^{2}$, habitada hoje por cerca de 210 pessoas, de possivel ascendência portuguesa e francesa. A nivel de observação leiga, as pessoas são saudáveis, de porte mediano, delgadas, claras, estando praticamente ausentes negros, mulatos e outros mestiços. A alimentação de alguns anos atrás consistia essencialmente em mandioca, farinha de mandioca, banana, peixe e, ocasionalmente, outras frutas nativas não cultivadas. Mais recentemente, os habitantes foram presenteados com um barco camaroneiro e um gerador; além disso, passaram a adotar práticas associativas de pesca e acolheram um núcleo de Evangélicos, que tem se mostrado amigável e filantrópico, a troco da freqüência à lgreja.

Todos os homens com idade inferior a 50 anos praticam a pesca de peixes nobres, 

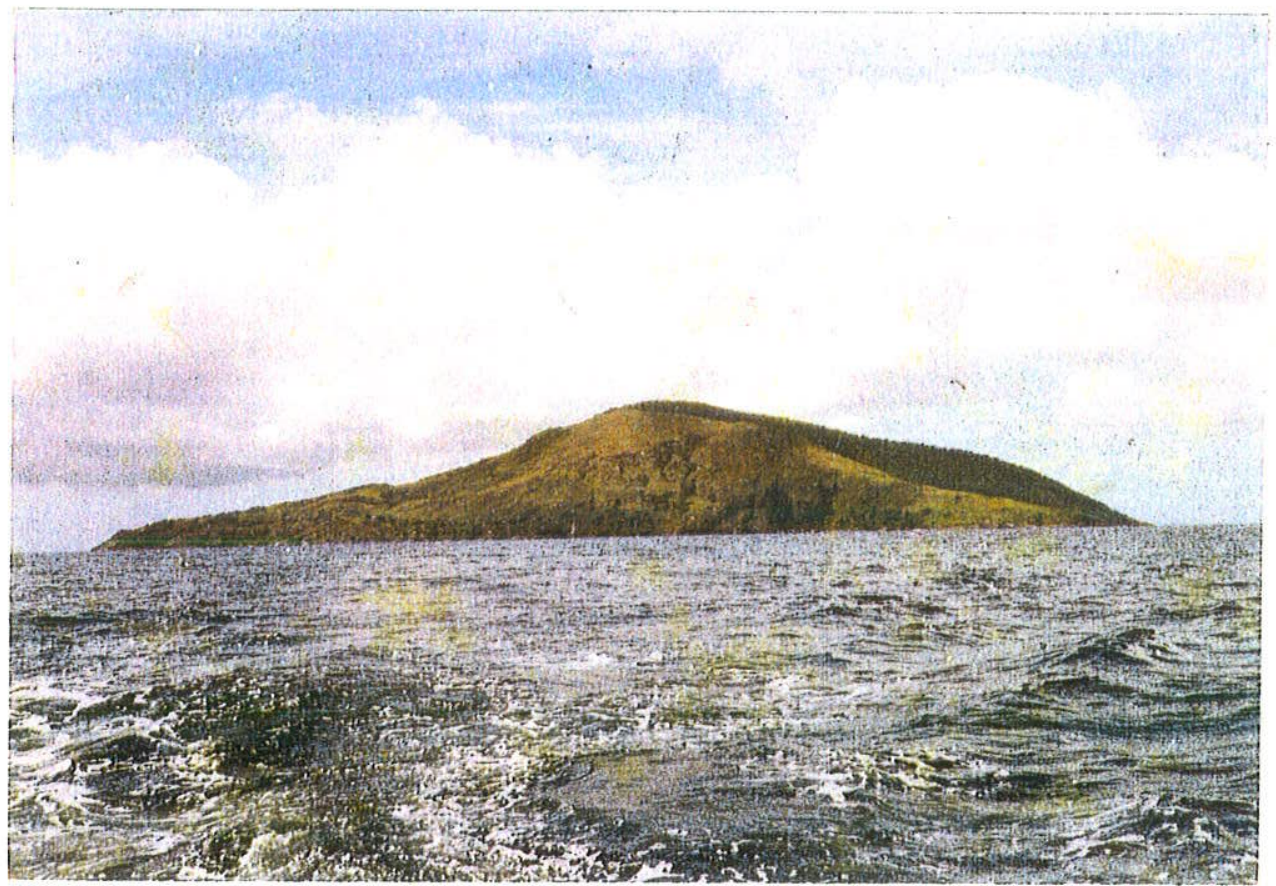

Foto 1 - A llha dos Búzios vista de oeste (face ocidental). A esquerda (N), a Ponta do Lenço; no centro esquerdo, meia encosta e baixa encosta, o Porto do Meio. Ao centro, o ponto culminante. À direita próxima, Pitangueiras; mais ao fundo, o espigão que desce até o Porto do Sul.

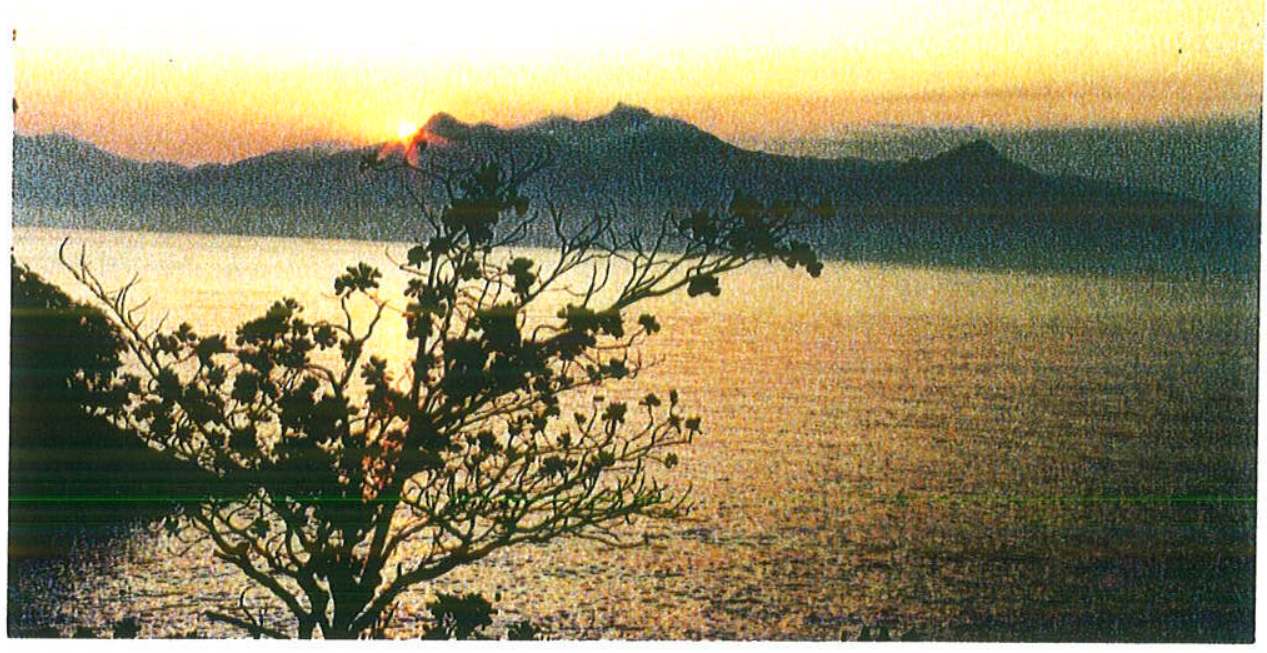

Foto 2 - Ilhabela, a 8 km, vista do Porto do Meio, para oeste-sudoeste. Pode-se distinguir, da esquerda para a direita, os picos dos maciços do Mirante, de São Sebastião e da Serraria. 
com linha ou rede. O produto é armazenado em caixas de isopor, misturados com gêlo picado, e levado periodicamente à llhabela por canoa motorizada. Há não muito tempo todos, inclusive os pescadores, eram também artesões, produzindo grande variedade de objetos de "fios" de taquarassú ou de um cipó singular, com grande engenho e habilidade. Aparentemente a prática perdeu-se. Hoje, os mais jovens, homens acima dos 12 ou 14 anos, só pescam; homens com mais de 50 anos, mulheres e crianças cuidam dos afazeres caseiros, cultivam a mandioca e produzem farinha de mandioca. A população se concentra em faixas etárias que vão até os 14 ou 15 anos e acima dos 40 anos, sendo mais raras as mulheres jovens. A evasão dos maiores de 15 anos se dá ou por casamento (mulheres) ou por emprego na atividade pesqueira mecanizada dos grandes barcos "sardinheiros"e "atuneiros".

Os habitantes têm hábitos sociais diferentes tanto do caiçara do litoral como do caipira, criando a impressão de certa promiscuidade nos relacionamentos, o que não é tão comum, realmente. Em todo caso, os exemplos de abandono e troca de marido ou mulher não são raros, assim como a "compra" de mulheres de fora, e a verdadeira "venda" de jovens que não se casaram até os 15 ou 16 anos.

Falam, entre si, de forma incomprensivel para qualquer outro brasileiro. Mas a diferença está muito mais na pronúncia e na velocidade do ato. $E$ falam muito alto, aos gritos. Essa conduta, contudo, muda quando se dirigem às pessoas do continente. De qualquer forma, na primeira meia hora na liha não foi possivel entender-se uma só palavra do que diziam.

Há dez anos não havia iluminação na llha e, tão logo escurecesse, todo mundo se recolhia. Ao alvorecer, ainda escuro, os homens já saiam à pesca. Hoje, com gerador que fornece energia para toda a encosta ocidental (o Porto do Meio), os hábitos mudaram um pouco, e a televisão invadiu parte das casas. A pesca continua a ser feita, de madrugada ou do meio da tarde até altas horas. O intercâmbio com São Sebastião e llhabela mudou radicalmente os hábitos alimentares: a população, em sua maioria, depende dos supermercados.

As pessoas são anormalmente longevas e, por volta de 1981, 1982 até 1990, haviam quatro ou cinco patriarcas com 80 anos ou mais. Em 1992, o "patriarca" era o Sr. Aristides, homem surpreendentemente educado, muito claro, com 92 anos, e sem lembranças de outros lugares onde tenha vivido a não ser Búzios.

A liha é propriedade da Marinha, que cede os terrenos para as casas e cultivos, sendo, no entanto, proibida a venda de terra e a vinda de moradores de fora (embora tenha sido construída uma Igreja Evangélica). Suas habitações são simples, com fogão à lenha (ou gás hoje), extremamente bem feitas, de "pau a pique" e sapé densamente amarrado. Hoje já existem casas de alvenaria e de madeira.

Somente em uma familia foram vistos os resultados negativos dos casamentos consangüineos. Entre 1982 e 1993 todos os membros dessa familia morreram. 
O maior número de casas, espalhadas entre as árvores da baixa encosta, entre 20 a $100 \mathrm{~m}$ cima do mar, encontra-se no Porto do Meio, na metade norte da face ocidental; na mesma face poucas casas são encontradas para o sul (Pitangueiras). Trilha antiga e batida sobe a encosta a norte, contornando a elevaçäo central mais alta, e desce até a Enseada da Guanxuma, onde aparece outro aglomerado de casas, desta vez em número bem menor. A trilha prossegue pela baixa encosta até o local chamado Mãe Joana, com duas familias, e outras dispersas ao longo da trilha.

Há registro local de ocupação e notícias de duas grandes fazendas existentes até a década de 50, pelo menos, pois não foram relatadas por Björnberg e Ellert (1955). As marcas ainda estão presentes: terreiro de café, restos de construção, grandes áreas desmatadas e laranjeiras. Nessa época, a llha exportava "de tudo", e pouco comprava. Era mais ou menos auto-suficiente, e todos os utensilios eram feitos de madeira, no que os habitantes locais se mantiveram hábeis até 1982 pelo menos.

Existem duas escolas funcionando regularmente na llha, e ambas com instalações adequadas. São conduzidas por dois ou três professores, alèm de frequentadas por mais ou menos cincoenta crianças. A merenda escolar é fornecida regularmente pela Prefeitura de Ilhabela.

A pluviosidade, temperatura e ventos se mostram um pouco distintos do litoral e planalto paulista, e provavelmente sejam tipicos para essa parte do litoral brasileiro. Durante um mês de outubro choveu todos os dias, e podia-se ver o continente sem chuvas; durante dois fevereiros, não caiu uma gota de água, enquanto que no planalto eram visiveis as nuvens de chuva. O vento ameniza muito a insolação e resfria a noite. Em uma das estadas em fevereiro a água do mar manteve-se anormalmente fria, havendo repentinas formações de denso nevoeiro a qualquer hora do dia, vindos de alto mar (Foto 4).

É provável que a liha tenha sido habitada por população mais antiga totalmente diferente da atual, talvez mesmo indigena. Essa ocupação pode datar de séculos ou mais, e sua presença está registrada nas "tocas", verdadeiras cavernas de porte variado, formadas pelo empilhamento de blocos. Rochas polidas, carvão no subsolo, restos de cerâmica e de rochas, além de ossos de crânio não deixam maiores dúvidas a respeito.

Levantamento feito nas primeiras viagens indicaram que $5 \%$ da população já havia sido picada por cobra, algumas pessoas até duas vezes. Nenhuma recebeu atendimento médico nas primeiras horas ou dias, e algumas nunca, não havendo contudo registro de óbito, mas somente de deformações e lesões. Quase todo mundo já teve um ou vários encontros com jararacas (não se fala aqui de outras cobras não-peçonhentas, de hábitos diurnos). A informação não deve surpreender: sendo menor, situada a maior distância do continente e, portanto, isolada há mais tempo, a llha suportou radical transformação faunística, com o desaparecimento dos mamiferos, sem suporte alimentar. Restaram as cobras, sapos e rãs e os 


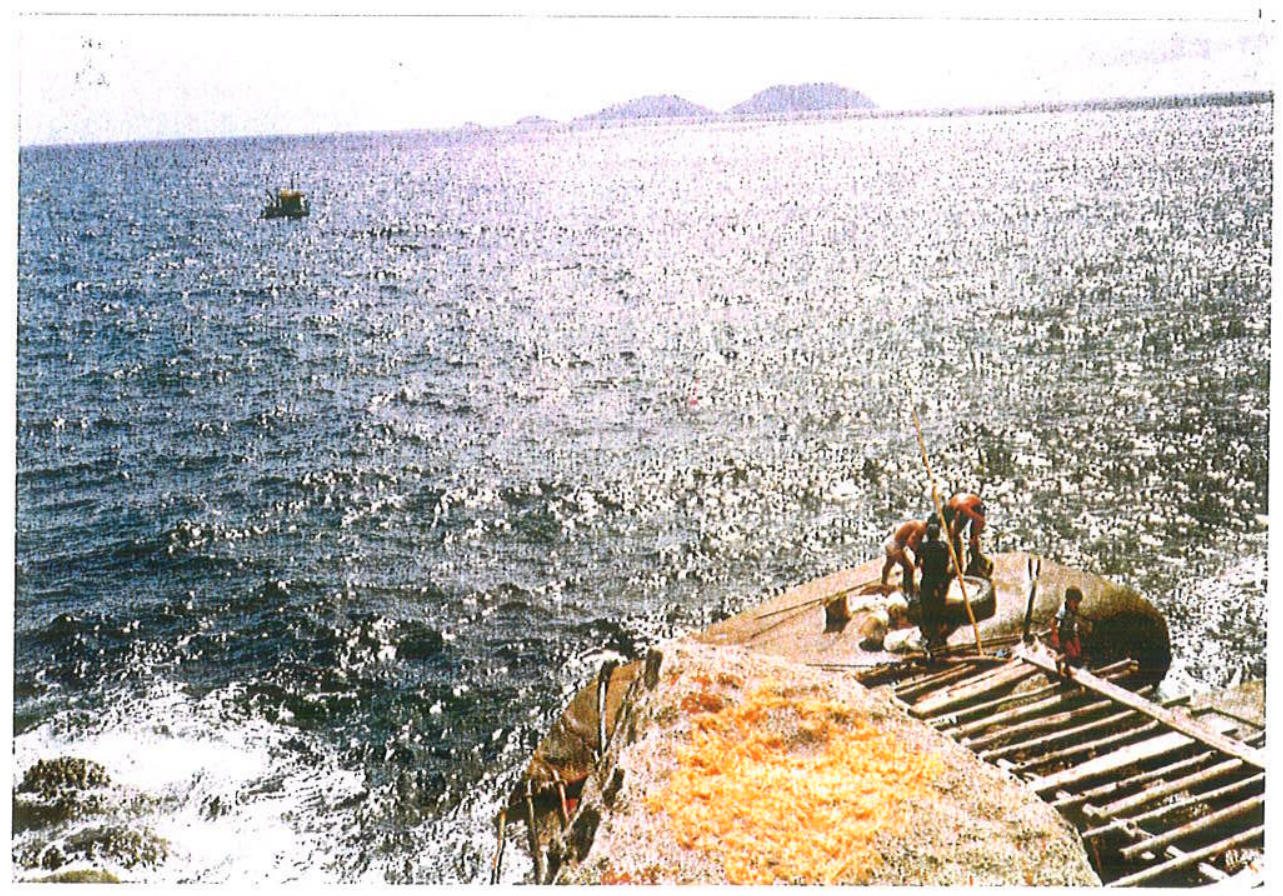

Foto 3 - Embarcadouro da Mãe Joana - o trapiche. Ao fundo, a llha de Vitória a 11 km a NE.

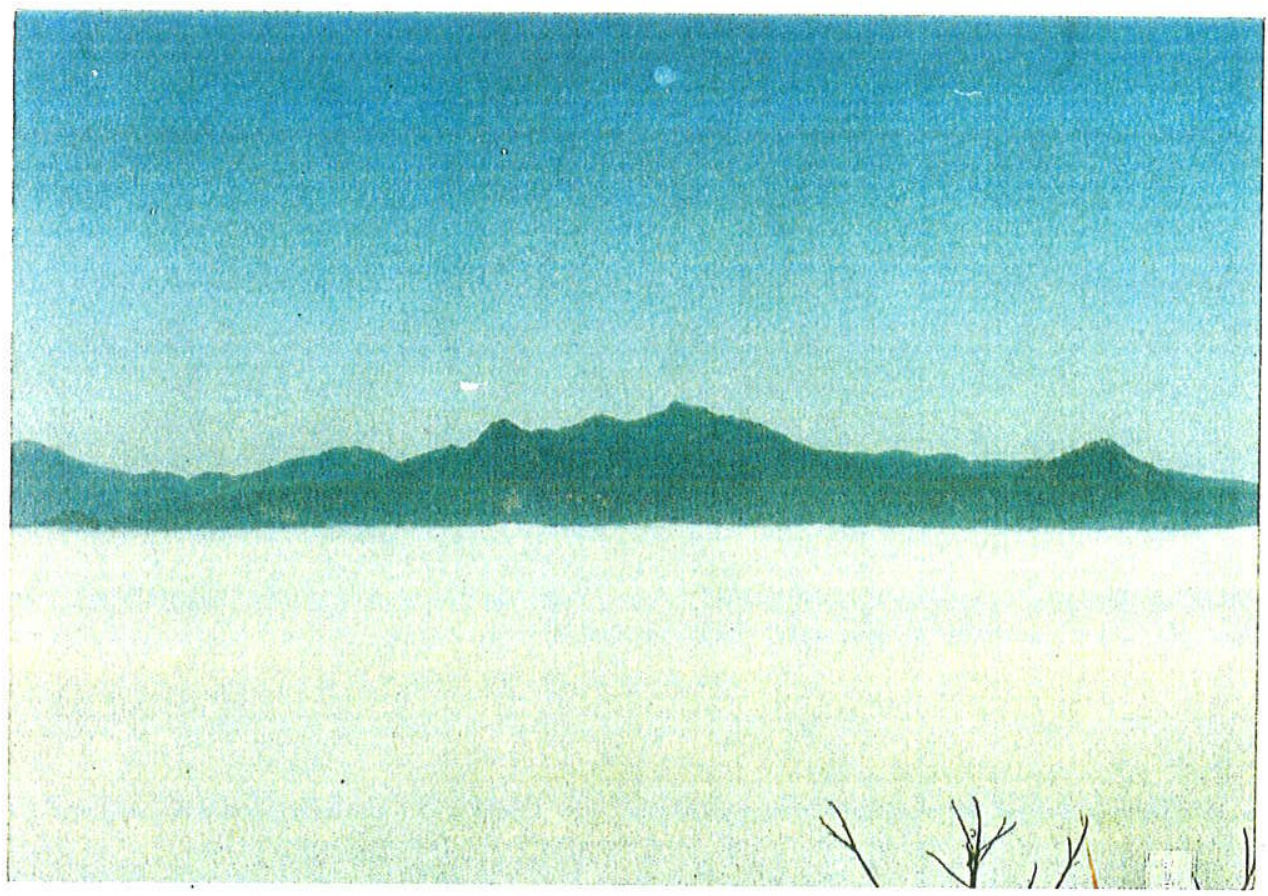

Foto 4 - Ilhabela, vista do Porto do Meio, para oeste-sudoeste, reconhecendo-se, da esquerda para a direita, os picos dos maciços alcalinos do Mirante, de São Sebastião e da Serraria. Notar o denso nevoeiro, que surgia a qualquer hora durante o dia, em fevereiro de 1992. 
lagartos, estes em incrivel quantidade e variedade. São o que resta dos vertebrados, além dos pássaros variados $€$ dos invertebrados. Pode-se dizer que houve um certo reequilibrio, mas a anormal freqüência de jararacas faz pensar que é um equilibrio desequilibrado: ela não tem predadores, além de uma outra espécie de cobra lá existente (mussurana?). Ao contrário das jararacas do interior, habitante de pastos, cerrados e clareiras, a jararaca de Búzios vive de preferência na mata, tal como a "jararacuçu". Em mais ou menos 50 dias pela llha, nenhuma foi vista fora desse ambiente e todas as vezes que se adentrou a mata encontrou-se pelo menos uma. São duas variedades: uma comum, padrão "chão com folhas secas", a outra cinzenta, com a cor dos blocos de rocha na mata, sombreados e com réstias de luz. A primeira é vista no chão com folhas secas, sendo inclusive mais freqüente; a outra, mais rara, sempre foi encontrada em cima ou entre os blocos de rocha.

\subsection{Aspectos fisiográficos, erosivos e intempéricos}

A liha tem forma irregular, algo alongada para EW, e se estende por cerca de $3100 \mathrm{~m}$ e $4800 \mathrm{~m}$, respectivamente, nas direções NS (Ponta Sul - Ponta do Arpoador) e EW (Ponta das Pitangueiras - Ponta Leste) (Fig. 2).

Sua parte oeste mais ampla pode inscrever-se em um quadrado, com lados a SW, NE e NW, com uma diagonal NS, e outra EW que se prolonga para leste em faixa mais estreita. Seu perfil suave, visto do continente (Foto 1), é um espigão de direção NE que se eleva até ponto culminante a $355 \mathrm{~m}$. Toda a face ocidental é observada. Ela é contínua e a encosta desce regularmente até o mar com gradiente de até 100\%. A SE do cume do espigão, ergue-se o ponto mais alto da ilha, a $400 \mathrm{~m}$, que ocupa o centro do quadrado, a partir do qual forma-se outro espigão para SW, que chega até o mar; entre os dois espigöes desenvolve-se vale profundo.

Para leste tem-se uma crista irregular e sinuosa, contínua, com altos e baixos, porém sempre descendente, até sela topográfica que secciona transversalmente a parte leste da liha, e que não ultrapassa os $150 \mathrm{~m}$ de altura (Foto 5). A oriente dessa sela, a liha apresenta a forma de morro achatado de contorno grosseiramente trapezoidal de $1000 \times 1300 \mathrm{~m}$, com cume central de $240 \mathrm{~m}$.

A encosta ocidental alonga-se pela Ponta do Lenço a NE, onde volta-se de $180^{\circ}$, curvando-se entäo gradativamente para leste, e vindo a formar a Enseada da Guanxuma (Foto 6). A costa prossegue por $2600 \mathrm{~m}$ com rumo ESE, desenvolvendo-se a face norte da llha, com encostas regulares até a Ponta Leste, na extremidade homônima, onde inflete de $90^{\circ}$ para sul, formando a face leste, de encostas quase verticais e com $1300 \mathrm{~m}$ de extensão, até a Ponta Sudeste. Esta representa nova inflexão de $90^{\circ}$, desta vez para oeste/noroeste, início da costa 


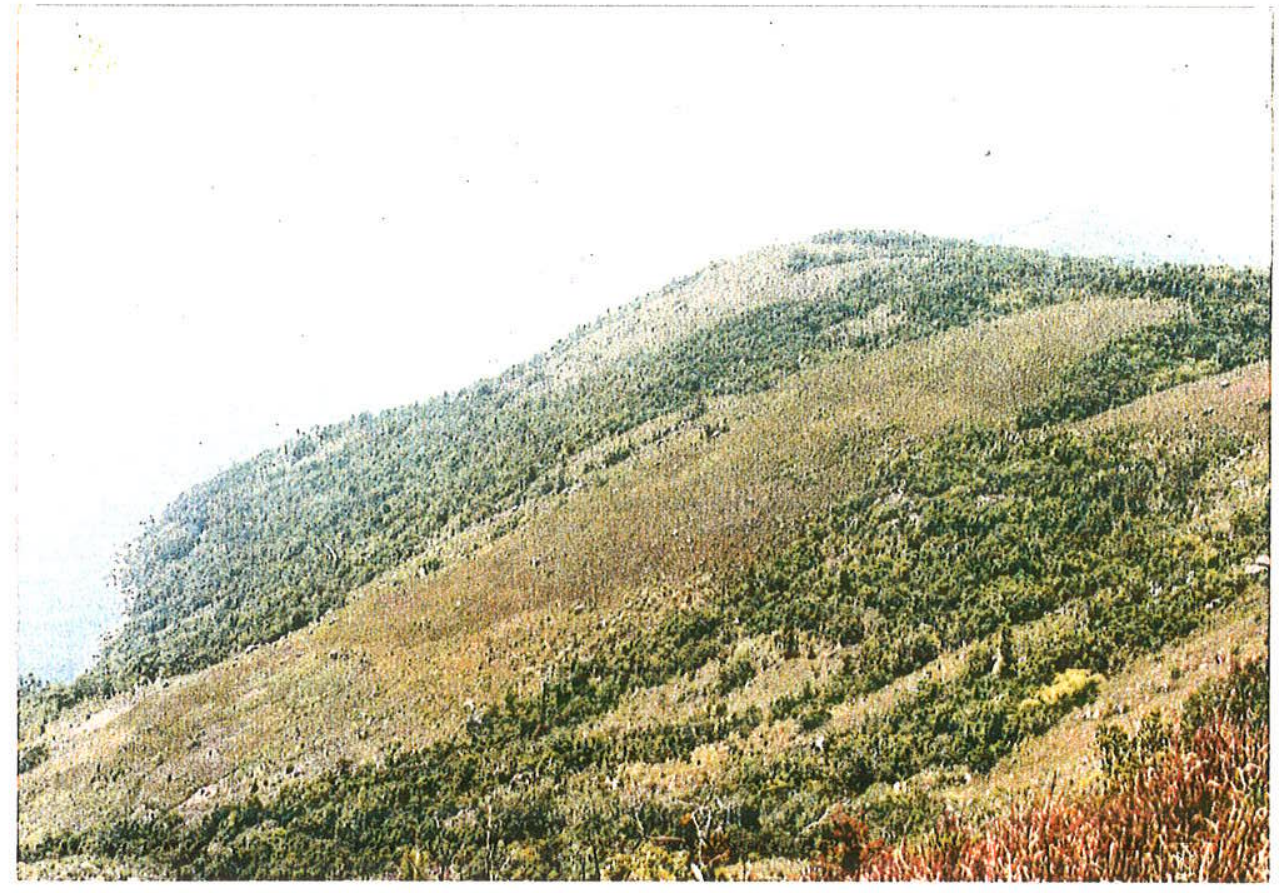

Foto 5 - Foto tirada do centro da llha, em altitude de mais ou menos $300 \mathrm{~m}$ para leste. Notar vegetação, matacões dos sienitos. Ao fundo, a porção do extremo leste após a Mãe Joana. O cume mais distante está a mais de $3 \mathrm{~km}$ de distância do fotógrafo. Notar os topos suaves.

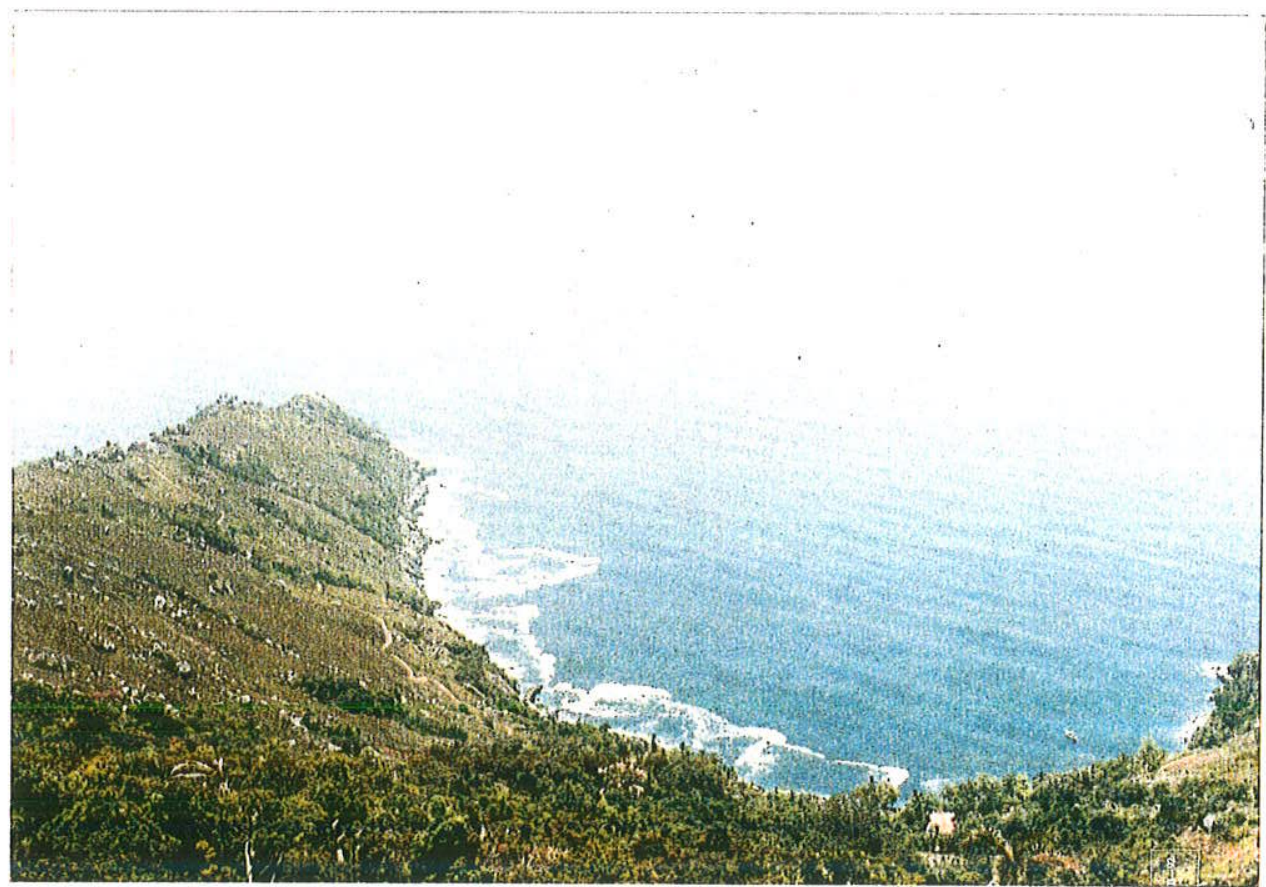

Foto 6 - A Ponta do Lenço e a Enseada da Guanxuma, vistas do centro e do alto da llha para norte. Notar vegetação, matacões dos sienitos. A trilha corta a crista a $120 \mathrm{~m}$ de altitude. 
sul. Em linha reta, rumo WSW, avista-se a Ponta Sul, a $2800 \mathrm{~m}$ e entre esses extremos, ampla concavidade aberta, o Saco Grande.

A partir da Ponta Sul, a costa toma o rumo NW por pouco mais de $2 \mathrm{~km}$ até a Ponta das Pitangueiras. Esta parte apresenta duas reentrâncias abertas e menores que o Saco Grande; são entradas sem nome e separadas pelo prolongamento do espigão já referido, que se inicia no cume da llha. Ambas as enseadas coincidem com os grotöes paralelos e limitantes desse espigão. A Ponta das Pitangueiras é o extremo SW do espigão ocidental. Em linhas gerais, pode-se imaginar o relevo como constituido por duas cristas: a ocidental, de posição NE, e a partir da sua porção mediana, a outra crista, sinuosa e descendente, no rumo ESE, formando o eixo da porção mais longa e mais estreita da llha (Foto 5).

Dos espigões descem encostas, em geral suavemente sulcadas, com declividade que varia de no mínimo $15^{\circ}$ até mais que $45^{\circ}$. A encosta ocidental, de direção $\mathrm{NE}$, é bastante regular e, junto com a face oeste da Enseada da Guanxuma, o promontório da Ponta do Lenço, e a borda da face leste, apresenta os maiores gradientes, sendo ocasionalmente quase vertical. A face norte é similar à ocidental. Todo o Saco Grande, face sul, se mostra sulcado por ravinamento mais fundo, que desce da crista principal ESE. A encosta da face sul termina em espigão de direção NS, que se inicia no terceiro cume mais alto, a SE do principal, e que se projeta no mar formando a Ponta Sul. A face SW é similar.

Cristas e espigões, ravinas e grotões e o traçado em detalhe do costão exibem forte $e$ constante tendência NE. Fazem exceção o espigão da Ponta Sul e os grotões a leste dessa feição.

Essa morfologia, com ravinas de no máximo $1000 \mathrm{~m}$ de extensão entre as cristas e o mar, não permite a existência de riachos e mesmo córregos, mas somente pequenos filetes de água. Existe também água permanente, de alimentação pluvial e freática. Acidentalmente, entre os dois pontos mais altos, tem-se uma área menos inclinada, onde a mistura de blocos e o solo represaram água formando pequena lagoa, sob a mata, referida em Björnberg e Ellert (1955).

De modo geral, as encostas terminam em costões rochosos, em que é possivel distinguir-se três tipos. Nos primeiros, a rocha é aflorante e desce diretamente para o mar, com gradientes de $30^{\circ}$, até verticais (Foto 7), havendo algum recobrimento de matacões variados. No segundo, ocorre rocha aflorante, mas quase totalmente recoberta por matacões e blocos, que se espalham, empilhados subaquaticamente, pelo mar por uma distância de até $50 \mathrm{~m}$ ou mais (Foto 8). Um terceiro tipo é intermediário ente os primeiros: as lajes aflorantes são menos largas e a quantidade de blocos menor, e ocupam menos o mar. As faces ocidental e norte são desse último tipo, enquanto que a face leste e o Saco Grande pertencem ao segundo; já a face SW é do primeiro tipo. Os costões rochosos são referidos como costões, mais altos, e costeiras, mais baixos (Freitas, 1947). 


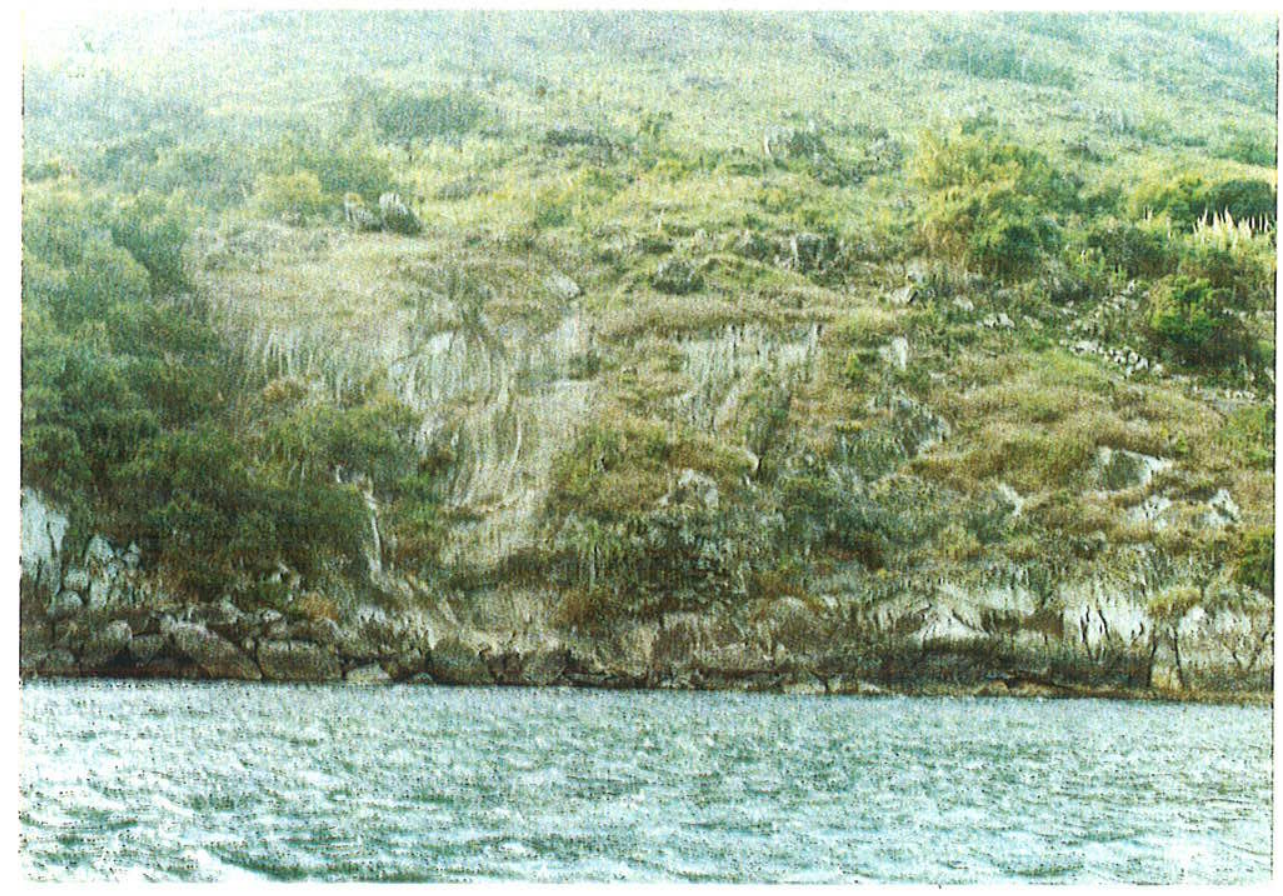

Foto 7 - Costão, no caso muito íngreme, quase vertical, a sul do Gentio e norte das Pintangueiras. No local, ocorrem sienitos, diques de quartzo microssienito e charnoquito.

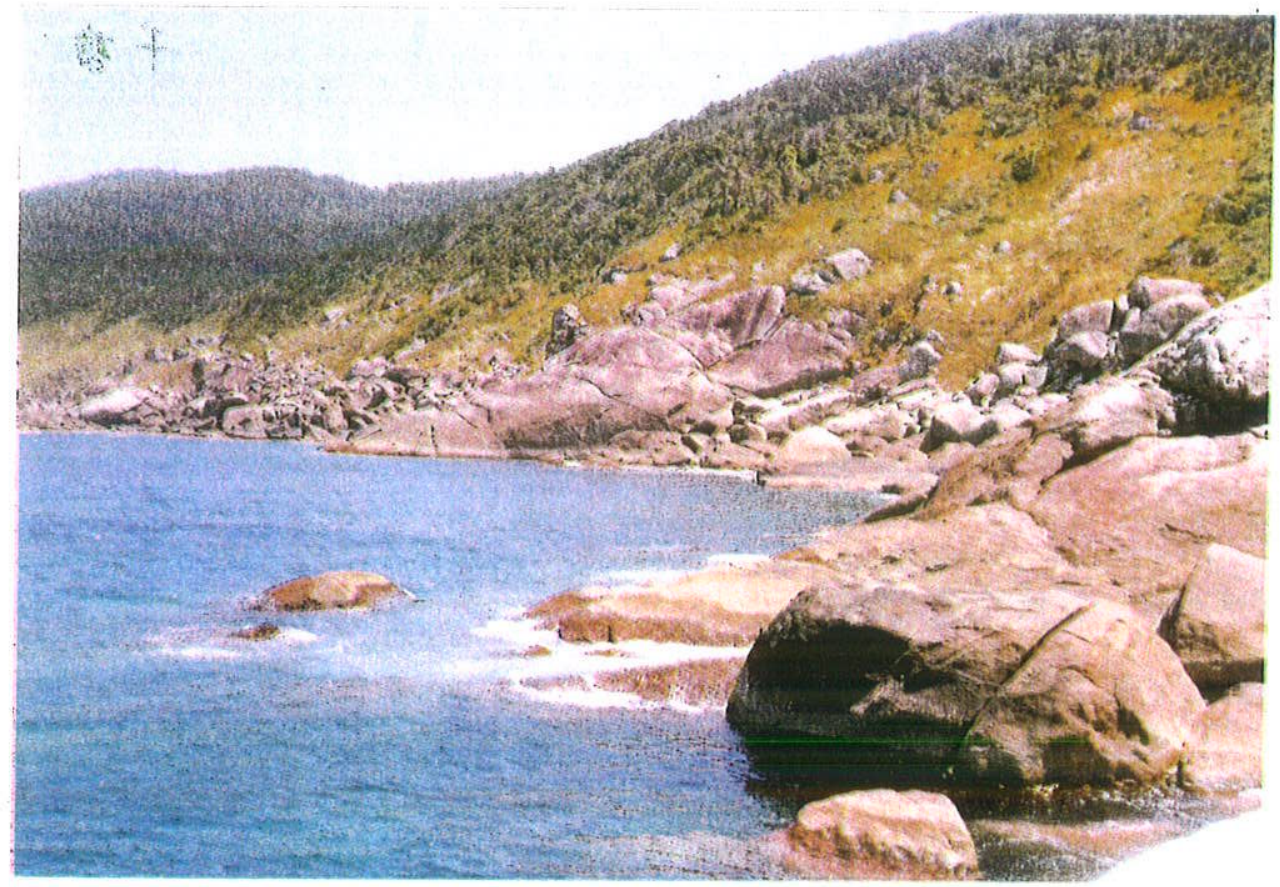

Foto 8 - Costão de blocos, no Saco Grande. Mar excepcionalmente calmo para o local (face sul). Observar na porção central laje aflorante em meio aos blocos que desce até o mar. Notar cobertura florestal. 
Toda a ampla Enseada de Ubatuba, balizada pelo continente, e pelas ihas de São Sebastião, Búzios e Vitória tem fundo arenoso e profundidades de até $50 \mathrm{~m}$. Junto a Búzios, como em outras ilhas, ocorrem os parcéis: fundos rochosos ligados ou não com a ilha e com profundidades bem menores, que se elevam a 10-30 $\mathrm{m}$ ou então aparecem emersos na forma de lajes e rochedos. São vários os parcéis próximos a Búzios, sendo o mais notável o que liga a Ilha Somitica, $1 \mathrm{~km}$ a SW, com a Ponta Sul: forma lajes emersas e mantém a linearidade da ithota com a Ponta Sul. Também a norte, afastados de $100 \mathrm{~m}$ da Pontinha, ocorrem rochedos que fazem parte de outro parcel (Foto 9). Outros mais estão presentes e podem ser reconhecidos em razão da mudança de cor da água.

Além dos costões em geral, inteiramente rochosos (Fotos 7 e 8 ), as encostas e cristas acham-se pontilhadas e mesmo atulhadas de blocos de tamanho variado até matacões com dimensão de dezenas de metros (Foto 10). Em muitos lugares não existe solo. É o caso da baixa encosta de modo geral e da Pontinha e proximidades, a norte. A freqüencia e tamanho dos blocos é maior na encosta ocidental. Na face norte, da Guanxuma para leste, os blocos diminuem o mesmo ocorrendo no morro além da Sela da Mão Joana. Na mata, em geral, aparentemente, tem-se uma menor quantidade dos blocos. Todas as ravinas, grotōes e depressões visitadas apresentam-se entulhadas de blocos.

As grandes lajes, alèm dos costōes, aparecem em algumas encostas onde há quebra do gradiente topográfico, como na meia encosta do Porto do Meio.

O solo é raso, seco e pedregoso, granuloso, com concreçōes e restos de minerais e rochas, na face norte. Espessa-se e se torna mais solto na encosta NW, acentuando-se essas características na mata. Em poucos lugares, aprisionado entre matacões e lajes, forma superficies menos inclinadas e se espessa muito, mantendo-se úmido e formando pequenas áreas de cultivo.

Parte das feições descritas, hoje, parece devida à ação antrópica em geral: embora não haja indicativos de desmatamento nas faces norte e noroeste, é bem provável que o processo tenha se dado, uma vez que não há motivo aparente para que a mata esteja concentrada a sul. Evidentemente, as áreas de vegetação baixa, em parte rala, são fácil e energicamente lavadas pelas águas pluviais, com alta energia devido aos gradientes. $\dot{E}$ possivel que materiais finos sofram certa influência dos ventos, o que näo deve ser muito significativo.

Aparentemente os processos erosivos, incluindo o escorregamento de blocos, parecem ter sido mais eficientes que os intempéricos, daí a grande quantidade de blocos, os acúmulos, as lajes freqüentes e os solos rasos. Superficialmente, os blocos nunca estão frescos, mostrando sempre vários envoltórios intempéricos. A enérgica lavagem dos materiais e seu escoamento em gradientes de $25^{\circ}$ a $45^{\circ}$ atuou no sentido de rebaixar igualmente toda a Ilha, expondo a rocha já reduzida a blocos. Todo o material carreado com muita energia não 


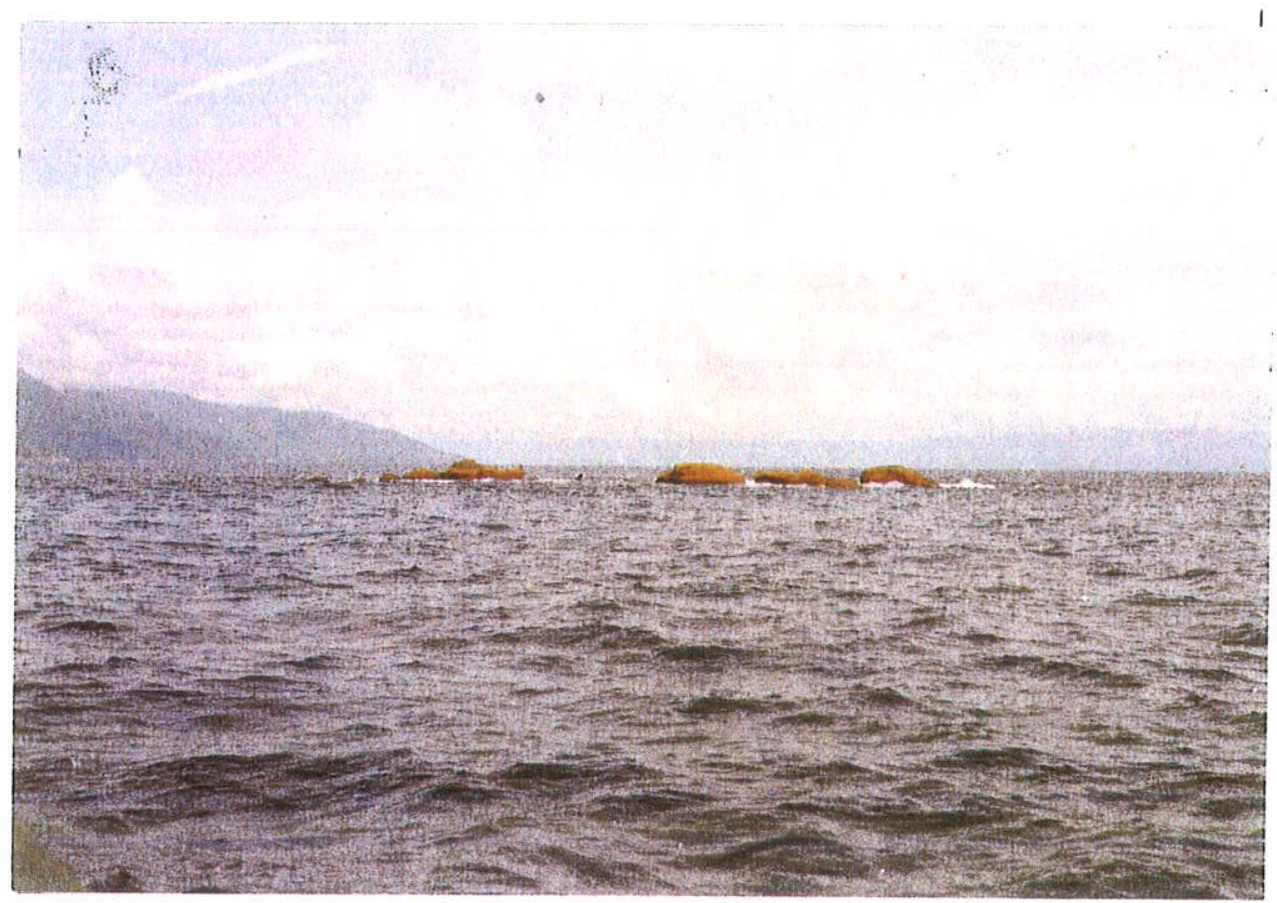

Foto 9-- Lajes do parcel em frente à Pontinha, parte norte-noroeste da llha. As lajes são de sienito. Ao fundo, a costa continental.

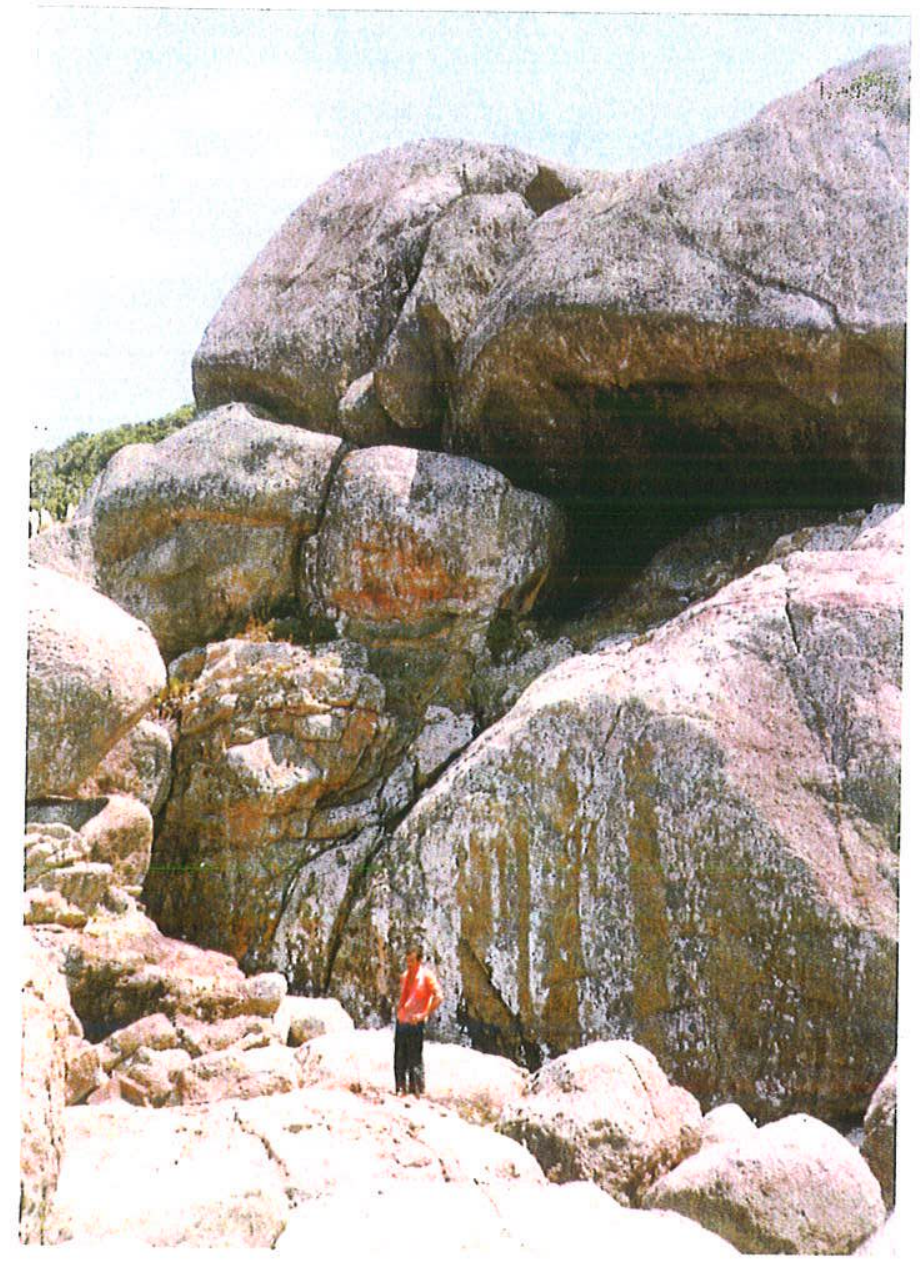

Foto 10 - Afloramento "in situ", na forma de blocos descontínuos, de grandes dimensões. Há matacões maiores ainda à beira-mar. Poucos blocos deslocados $\mathrm{e}$ rolados na parte inferior. Local no saco Grande, sul. 
tem oportunidade de parar ou acumular-se nas encostas, vindo a fazê-lo no mar (ou nos fundos de vales e ravinas). A ação do mar é mais efetiva nas costas leste e sul e no Saco Grande, disso resultando um grande acúmulo de blocos, dada a velocidade com que estes se destacam dos costões (ou descem pelas encostas). Em todas as irregularidades do contorno da liha, que têm direção perpendicular e se expõem ao vetor EW das ondas e correntes, nota-se maior acúmulo de blocos no mar. O mesmo ocorre no Saco Grande, voltado para sul (vetor SN).

Assim, não é de se estranhar que o contato maior das rochas se dê na porção oeste, onde são encontrados restos do embasamento pré-cambriano.

A forma e relevo atuais da llha dos Búzios e sua própria existência decorrem de uma combinação de três circunstâncias: primeiro, a presença de corpo ígneo intrusivo de grande dimensão; segundo, a ação combinada do intemperismo e da erosão por águas pluviais e pelo mar; por último, as estruturas de direção predominante NE, incluindo-se ai contatos, faixas de cisalhamento e a presença de diques. A existência de outras ilhas alcalinas, e em particular a forma da liha de São Sebastião, são indicadores seguros de que elas existem graças aos corpos alcalinos que oferecem maior resistência, provavelmente em razão do seu caráter mais isotrópico, ou seja, a inexistência de estruturação direcional.

Não obstante, é facilmente notável a forma semicircular a semielíptica das encostas do Saco Grande, com estremidades na Ponta Sul e Ponta Sudeste. Além disso, os fotolineamentos, que correspondem às ravinas dessas encostas, tem disposição radial, desde NW na porção oeste, NS no centro e a NE no lado leste, convergindo para um centro virtual no mar, a sul da liha.

\subsection{Trabalhos anteriores sobre a morfologia litorânea e allha dos Búzios}

Freitas (1947) trata com certo detalhamento a fisiografia do litoral paulista, incluindo a Serra do Mar, mas principalmente da llha de São Sebastião, até porque ela é um dos fundamentos das suas considerações tectônicas.

Os alinhamentos gerais NE da costa meridional brasileira seriam reflexo de tectonismo operante desde o Triássico, com auge no Eoceno, a partir do qual passariam a ter papel importante os movimentos epirogênicos, eustáticos e as flutuações do nível do mar relacionadas a glaciaçōes. O modelado do relevo do leste do Estado, considerado "jovem" (Cenozóico), teria como referencial, superfície senil de aplainamento cretácica, e subníveis mais baixos, locais. A superfície cretácica, nivelada nas altitudes de 1000-1300 m, estaria repartida em blocos de falhas normais, de direção geral NE, escalonados de forma descendente para SE, mas com topos adernados para NW. Os blocos de falhas seriam os principais responsáveis pela configuração do Planalto Paulista: Serra da Mantiqueira, Vale do 
Paraiba, Serra do Mar. Em todas as escarpas de falhas observa-se-ia modelado jovem, com drenagem enérgica, sem capturas e sem grandes depósitos de "piemonte". A superficie erosiva cretácica teria sido colocada em niveis diferentes, observados em topos senilizados, a $2000 \mathrm{~m}$ (Serra da Mantiqueira) ou até quase $3000 \mathrm{~m}$ (Itatiaia).

A llha de São Sebastião teria sua origem em bloco de falha (e erosão), com seu lado SE mais rejeitado, sofrendo erosão desde o final do Eoceno, conservando modelado juvenil nos cumes mais altos $(1300 \mathrm{~m})$ e senil nos topos planos a $400 \mathrm{~m}$. No Terciário, até o recente, todo - litoral teria experimentado movimentações e conseqüente variaçäo no nivel do mar. Como registro, ocorrem restos de terraços marinhos planos e horizontais, portanto pós- eocênicos, entre 20 a $30 \mathrm{~m}$ acima do nível atual do mar. Atualmente toda a costa paulista, principalmente a setentrional, seria do tipo afogado. A llha de São Sebastiāo estaria em ciclo erosivo marinho juvenil, com costa de submergência crenada por abrasão, praias ausentes ou restritas e protegidas, mostrando, quase somente, costões e costeiras rochosas.

Almeida (1964) divide o Estado de São Paulo em provincias fisiográficas, entre as quais as chamadas de Planalto Paulistano e de Província Costeira, esta subdividida em Serrania Costeira e Baixadas Litorâneas.

Empresta à litologia a sustentação do relevo, reduzindo o papel das estruturas e descreve superficie erosiva de aplainamento pré-Bauru (Cretáceo Superior), no mais expondo idéias semelhantes às de Freitas (1947). A Serra do Mar e a lliha de São Sebastião, bem como as outras ilhas, contudo, seriam resultantes da erosão de possivel escarpa de falha, localizada mais a leste. O Planalto Paulistano e sua superfície de aplainamento teriam se estendido bem mais para leste do atual alinhamento da Serra do Mar, pela Plataforma Continental. As ithas seriam remanescentes erosivos do Planalto e a Serra do Mar, uma escarpa erosiva remontante de falha. A llha de São Sebastião seria sustentada pelos "stocks" alcalinos.

Ao que parece, à luz dos conhecimentos atuais, ambos os autores estão ainda corretos em grande parte das observações, equivocando-se no entanto em algumas delas.

Os únicos geólogos a trabalharem em Búzios, até pelo menos 1975, foram Björnberg e Ellert, que publicaram seus resultados em 1955. Assim é que consideram o relevo da liha como juvenil, adiantado, dissecado radialmente, com dois picos proeminentes. Riachos de pequeno curso e forte gradiente atingiriam o mar em costa de submergência, crenulada, e formada por costões.

A descrição detalhada no item 3.3. deste capítulo mostra algumas diferenças com as sintéticas observações daqueles autores. Por exemplo, não é conveniente chamar de riachos filetes de água ou até mesmo simples drenagens. De resto, há flagrantes diferenças no estágio erosivo dos topos, quase aplainados ou suavemente curvos (Fotos 5 e 6), como descritos por Freitas (1947), que os considera senis, e as encostas sulcadas e ravinadas. Mesmo entre estas, as da face sul exibem ravinamento muito mais acentuado e profundo que as 
correspondentes das faces norte e oeste. De qualquer modo, os perfis NS (Foto 1) e EW da Ilha dos Búzios não podem ser encarados como juvenis, mas pelo menos como maduros.

Somente com observaçöes morfológicas é, talvez, impossível, demonstrar o exato posicionamento das falhas e, conseqüentemente, se a Serra do Mar está situada em um bloco, a liha de São Sebastiano noutro e a llha dos Búzios em um terceiro. Parece mais plausivel, entretanto, que os corpos atcalinos das ilhas estejam todos em um mesmo bloco de falha, de dimensões não conhecidas.

Resta observar que não foram registrados restos de terraços marinhos na liha dos Búzios. 


\section{CAPITULO 4 TRABALHOS GEOLÓGICOS ANTERIORES}

A abordagem dos conhecimentos prévios sobre um assunto qualquer pode ser feita de forma variada. Neste trabalho julgou-se conveniente relacionar e sintetizar os conhecimentos geológicos, em primeira aproximação, em capitulo à parte. A utilização e a discussão críticas das mesmas informações são tratadas nos capitulos pertinentes.

Nas vizinhanças de Búzios, existem outros seis corpos intrusivos alcalinos plutônicos: a llha do Monte de Trigo, a llha de Vitória e os "stocks" de São Sebastião, da Serraria e do Mirante, na llha de São Sebastião, mais o suposto corpo "das Canas". Nas mesmas ithas e no litoral próximo, principalmente entre as cidades de São Sebastião e Ubatuba, ocorre grande quantidade de diques de litologia e idade variadas.

Os corpos plutônicos, incluindo Búzios, distribuem-se por faixa de $20 \mathrm{~km}$ de largura e $80 \mathrm{~km}$ de extensão, na direção NE. Assim, o exame dos trabalhos geológicos anteriores não poderia deixar de incluir todos aqueles de interesse direto às manifestações magmáticas mesocenozóicas dessa área.

Resta lembrar, mais um vez, que magmatismo algo semelhante e, de certa forma, sincrônico, está presente na Bacia de Santos, cujas ombreiras distam 50 a $70 \mathrm{~km}$ da costa, sendo, entretanto, poucas e superficiais as referências a essas lavas testemunhadas por sondagens da Petrobrás e da Pecten.

\subsection{A liha dos Búzios}

Como objeto central de estudo geológico, a liha dos Búzios tem apenas uma referência: Björnberg e Ellert (1955). Conhecimentos geográficos anteriores são citados por esses autores, como o trabalho da Comissão Geográfica e Geológica do Estado de São Paulo, Exploração do Litoral, $1^{\circ}$ Seção, de 1915, e o de Euclides da Cunha, de 1902, e divulgado em 1944 no volume V do $9^{\circ}$ Congresso Brasileiro de Geografia.

O trabalho de Björnberg e Ellert (1955) trata sucintamente da geomorfologia, da tectônica e da idade geológica, e pouco mais extensamente da geologia. Segundo os autores, gnaisses e charnoquitos formam o embasamento cristalino encaixante do "stock" sienítico, representado por nordmarquitos e sienitos, e dos diques básicos e alcalinos. Os diques básicos estāo presentes em duas gerações, uma delas anterior e a outra posterior às rochas alcalinas. Descrições petrográficas detalhadas de amostras constituem cerca de dois terços do trabalho. Este representa contribuição importante, com cartografia geológica simplista e algo discutivel, mas sem dúvida relaciona e descreve com detalhe quase todos os tipos petrográficos 
existentes.

\subsection{As vizinhanças}

A vizinha llha de São Sebastião foi mais visitada que a de Búzios.

Freitas (1947) cita Derby (1887) como sendo o primeiro pesquisador a fazer referências às rochas alcalinas da liha de São Sebastião, ao qual seguir-se-iam Branner (1915) e Leonardos e Oliveira (1943). O próprio Freitas publicou artigo sobre a geomorfologia da llha, em 1944.

Sua monografia (Tese) de 1947 é um trabalho de grande fôlego. Estende-se por 244 páginas, é bastante e bem ilustrado, anexando ainda mapa geológico topográfico na escala de 1:100000. A abordagem do tema é completa para a época, utilizando-se o autor de muita informação de campo e da petrografia. São tratados temas como fisiografia e a tectônica da Iha e do litoral, além da estratigrafia das rochas, com surpreendente acerto à luz dos conhecimentos atuais. As fundamentações de modelos da literatura e os próprios são expostos de forma simples e direta, incluindo trabalhos de Bowen (1914, 1928, 1945), Kennedy (1933) etc. Dispondo de sete análises quimicas dos elementos maiores e tendo feito petrografia detalhada, até exaustiva (quase 100 páginas), trata de forma variada, simples e objetiva, chegando a elaborar seqüencia de diferenciação magmática dupla, a partir de magma primitivo olivina basáltico. Praticamente todos os tipos petrográficos hoje reconhecidos na llha são descritos por Freitas, à exceção de poucos (riólitos, lamprófiros), e o seu correto relacionamento cronológico é revelado. A cartografia geológica de Freitas tem sido criticada por alguns motivos: não aparece o hoje, supostamente, reconhecido "stock" (?) das Canas, mapeia pequenos corpos sieniticos tidos como inexistentes, periféricos aos três maiores "stocks", e descreve e mapeia rochas quartzo-dioriticas pós-alcalinas, não descritas por outros autores.

Hennies (1964) aborda as mesmas rochas, de forma superficial e sem mostrar fatos novos e relevantes.

Damasceno (1966) mapeia e descreve 128 afloramentos de diques básicos e ultrabásicos (diabásios e lamprófiros) entre as cidades de Ubatuba e Caraguatatuba, SP. OS resultados mais importantes incorporados à literatura geológica são as idades radiométricas de cinco deles, variáveis entre 124,5 Ma e 138,1 Ma, o esclarecimento das litologias encontradas (90\% de diabásios, $10 \%$ de lamprófiros), a extensão observada de $13 \mathrm{~km}$, provável de $42 \mathrm{~km}$ e possivel de $60 \mathrm{~km}$ de um deles, as espessuras de até $40 \mathrm{~m}$ de outros, e o alojamento desses corpos em fraturas tensionais orientadas preferencialmente segundo $\mathrm{N} 45-55^{\circ} \mathrm{E}$ e com mergulho vertical, inexistindo sinais de movimentação nos diques e nas fraturas. Apresenta mapa de localização dos diques na escala de 1:155000, e estende para a área litorânea algumas 
informações de Freitas (1947) relativas à llha de São Sebastião: a ocupação de fraturas tensionais pelos diques básicos (e alcalinos, posteriores) e sua orientação marcadamente NE. O trabalho, de cunho geológico, petrográfico e geocronológico é meticuloso no rastreamento das ocorrências litorâneas, despretencioso e representa contribuição pioneira.

Gomes et al. (1967) divulgam estudo preliminar sobre a llha de Vitória, onde são descritas as litologias encontradas: encaixantes charnoquíticas, intrusivas plutônicas nefelina sieníticas e diques de traquitos, nefelina microssienitos e sodalita microssienitos.

Hennies e Hasui (1968) publicam pequena contribuição, com cartografia geológica preliminar da llha de São Sebastião e cinco novas idades radiométricas KJAr para as rochas alcalinas. No mapa geológico consta um novo "stock", de pequenas dimensões, chamado de "das Canas", não aparecem os corpos sieniticos periféricos e tampouco o quartzo diorito. As idades variam entre $85,9 \pm 5,8 \mathrm{Ma}$ e $75,7 \pm 3,8 \mathrm{Ma}$, adotando, os autores, o valor preferencial de Amaral et al. (1967) de $81 \mathrm{Ma}$.

Coutinho e Melcher (1973) estudam a liha do Monte de Trigo. O trabalho restringe-se a levantamento de dois terços da linha de costa, posteriormente complementado por estudantes de geologia, que fazem levantamento dos contatos internos. O artigo traz mapa geológico na escala de 1:12000, grande número de análises modais e três análises químicas. A llha do Monte de Trigo apresenta forma alongada com eixo maior NE de $1,5 \mathrm{~km}$, área de $1,3 \mathrm{~km}^{2}$ e altitude central maior de $290 \mathrm{~m}$. Teralitos representam os $12 \%$ nordeste da llha, separados por contato NW quase retilineo dos foiaítos, que cobrem os restantes $88 \%$. Bandamento vertical $\left(\mathrm{N} 20-45^{\circ} \mathrm{W}\right)$ nos teralitos, próximos ao contato, e direções de fraturas de resfriamento $\left(\mathrm{N} 30^{\circ} \mathrm{E}\right.$, $\mathrm{N} 80^{\circ} \mathrm{E}$ e $\mathrm{N} 60^{\circ} \mathrm{W}$ ) levam a crer serem essas rochas intrusivas. Contudo, os teralitos, junto ao contato, têm granulação muito grossa (lembra-se aqui que as idades $\mathrm{K} / \mathrm{Ar}$ para ambas as rochas forneceram valores de $79 \mathrm{Ma}$ ). São descritos ou referidos os seguintes tipos petrográficos plutônicos: teralitos, melateralitos, olivina melagabros, piroxenitos ou jacupiranguitos, que poderiam variar para teschenitos, essexitos e glenmuiritos e foiaítos. São identificadas as seguintes rochas hipobissais: microfoiaitos, fonólitos, "rhomb prophyries", lamprófiros, sienobasaltos e microshonkinitos.

Gomes e Berenholc (1973) dão início à seqüência de estudos sobre o possante dique de diabásio, com $90 \mathrm{~m}$ de espessura, localizado na Praia das Toninhas a sul de Ubatuba. Nesse primeiro trabalho, säo abordadas as feições quimicas das rochas do dique, enquanto que logo depois Gomes (1974) se ocuparia da sua mineralogia, em particular dos feldspatos, inaugurando assim os trabalhos de química mineral com a utilização da microssonda eletrônica.

Freitas (1976) publica extensa monografia sobre o litoral norte, incluindo ai as rochas alcalinas. O trabalho mostra novo trabalho petrográfico, sem novidades no entanto com relação ao anterior. Como contribuição nova traz um modelo sobre as rochas magmáticas, organizadas em cinco ciclos magmáticos, sendo os dois primeiros pré-Ordoviciano e os demais, 
mesozóicos. A compartimentação é feita a partir de idades absolutas. Seu terceiro ciclo magmático marca o início da reativaçāo tectônica geral da Plataforma, sendo representado por rochas plutônicas básicas, gabros e dioritos, com idade de $221 \mathrm{Ma}$, manifestações precursoras dos ciclos seguintes no Sudeste brasileiro. Com base em idades radiométricas $\mathrm{K} / \mathrm{Ar}$ (cf. Amaral et al., 1966; Vandoros, 1966; Melfi, 1967; Minioli, 1971), propöe para o vulcanismo basáltico da Bacia do Paraná a duração de $26 \mathrm{Ma}$, entre 104 e $130 \mathrm{Ma}$. Coincidência ou não, sua afirmativa de que "o ciclo durou mais na Bacia do Paraná porque houve várias erupções vulcânicas, de modo que a idade das rochas diminui de baixo para cima na coluna das lavas basálticas", coincide com os resultados de trabalhos recentes de detalhe (Mantovani et al., 1994). As rochas que interessam mais diretamente são as alcalinas, às quais Freitas incluiu no $5^{\circ}$ ciclo, entre 68 a $96 \mathrm{Ma}$. De forma conflitante, afirma, também, que o ciclo iria de 58 a $96 \mathrm{Ma}$ "da llha de São Sebastião para o norte". Conclui essas idéias, sugerindo a "impressão" de que teria ocorrido grande ciclo magmático, pulsante, desde o fim do Permiano até o Cenozóico. Oferece, nesse mesmo trabalho, grande quantidade de medidas da atitude de fraturas, da xistosidade e/ou bandamento e dos diques.

Hennies e Hasui (1977) oferecem nova contribuição sobre as rochas alcalinas da liha de São Sebastião, desta vez abordando a geologia. Mapa geológico, mais detalhado que o anterior dos mesmo autores (1968), na escala de 1:150000, mostra os três "stocks" sieniticos, com contornos mais regularizados e um tanto menores que os de Freitas (1947), com estruturação interna, mas sem faciologias litológicas, além do corpo "das Canas", no canto noroeste; dele não constam os sienitos periféricos e tampouco os corpos de quartzo diorito de Freitas (1947). Diques básicos maiores e contínuos são cartografados. Afora a nova cartografia, mais detalhada, o trabalho, curto e sem ilustrações, discute aspectos fotogeológicos e de campo, sem nada acrescentar de novo às informações de Freitas (1947).

Gomes e Ruberti (1978) continuam os estudos de química mineral para completar as informações dos trabalhos anteriores sobre a ocorrência de Toninhas. Analisam com a microssonda augitas e pigeonitas coexistentes, aparentemente, em desequilibrio. A variação composicional dos piroxênios no sentido borda-centro do corpo, o desaparecimento da pigeonita, o agrupamento das augitas leva os autores a sugerirem, para o dique, intrusão múltipla ou diferenciação por mobilidade dos álcalis.

Motoki e Gomes (1984) publicam trabalho sobre a geologia e a petrografia das rochas da Ilha de Vitória. O assunto é retomado por Motoki (1986, inédito) com muito maior profundidade. A liha, na verdade um conjunto de três ilhas denominadas de Vitória, dos Pescadores e das Cabras, ocupa área pouco menor que $3 \mathrm{~km}^{2}$ e é constituída por maciços de forma irregular dispostos na direção NW. O autor descreve rochas plutônicas sieníticas sienitos azuis e sienitos brancos - e diques de duas gerações, uma primeira radial, seccionada pela segunda, de direção geral NE. Os sienitos azuis, que exibiriam curiosa mudança de cor 
nas fraturas praticadas, correspondem a álcali sienitos, saturados ou com algum quartzo; os brancos consistem em pulaskitos e nefelina sienitos com até $10 \%$ de nefelina modal. Curvas isonormativas apresentam forma concêntrica, a partir de $1 \%$ de quartzo, mas não se fecham, indicando centro de curvatura do lado oeste, submerso, da itha principal. As curvas, do lado leste, acompanham o contorno convexo da llha. A mineralogia descrita é monótona, sempre com largo predominio de feldspato alcalino pertítico/antipertítico $(\sim 90 \%)$, seguido de outros félsicos: quartzo ou nefelinatsodalita. Entre os máficos aparecem clinopiroxênios, anfibólios, biotitas e opacos. Os piroxênios, sempre corroídos, variam de rocha para rocha, de sodaaugitas/augitas hedembergíticas até egirina-augitas. Os anfibólios são genericamente edenitas, enquanto que as biotitas plotam próximo da annita. O plagioclásio está sempre ausente. As rochas de diques incluem traquitos, fonólitos, bostonitos e álcali diabásios (no original) na primeira geração; eles se dispõem radialmente a partir do presumido centro do "stock" e estão cortados por diques de orientação $\mathrm{N} 40-60^{\circ} \mathrm{E}$, paralelos, representados por traquitos e fonólitos. Não ocorrem diabásios comuns. Milonitos também não foram observados e são poucos os lugares em que deslocamentos por falhas, no caso sinistrais, estão presentes. Aparentemente, os diques radiais mostram fluxo magmático horizontal de oeste para leste, isto é, do centro para as bordas do corpo. A mineralogia dos diques félsicos, que passam de traquitos, com até $3 \%$ de nefelina, a fonólitos, com mais de $10 \%$ de nefelina, é também pouco variada. Os feldspatos alcalinos constituem entre $65 \%$ e $75 \%$, modalmente, seguidos pelos feldspatóides (nefelina e sodalita, com alterações diversas), e máficos (egirina-augita, barkevikita, biotita, clorita), além de opacos e apatita como acessórios. Não ocorrem quartzo e plagioclásio, e tampouco foi registrada a presença de silicatos raros de rochas agpaiticas. Além dos bostonitos, comuns, são descritos "álcali diabásios", com titano augitas e kaersutitas e cavidades com zeólitas, e matriz félsica com feldspato alcalino, plagioclásio, nefelina e sodalita. São apresentadas análises químicas de rochas para os elementos maiores, $\mathrm{CO}_{2}, \mathrm{Cl}, \mathrm{F}, \mathrm{S}$ e 35 elementos traços, tratadas adequadamente. Apenas três das amostras têm caráter peralcalino, embora o teor de $\mathrm{Na}$ e $\mathrm{K}$ mantenha-se em torno dos $6 \%$. A química mineral dos minerais majoritários confirma as informações ópticas e difratométricas, estas exclusivamente para os feldspatos. Também foram

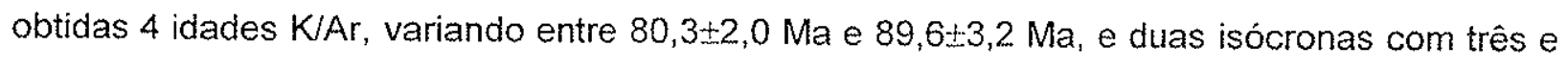

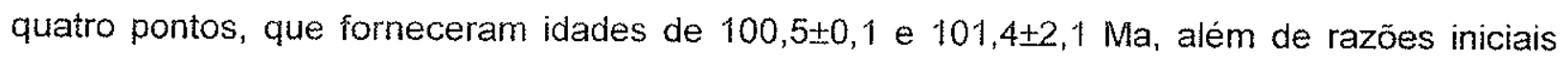
${ }^{87} \mathrm{Sr}{ }^{86} \mathrm{Sr}$ de 0,7053 e 0,7049 , respectivamente. O autor considera as rochas diabásicas como cumulaticas e possiveis representantes de magmas parentais, presentes, também, em outras ithas. A evolução magmática final proposta é antecedida de extensas considerações sobre os problemas da transposição do "vale termal", no sistema Q-Ne-Ks a $1 \mathrm{~kb}\left(\mathrm{H}_{2} \mathrm{O}\right)$, e a assimilação da rocha encaixante por superaquecimento ou super reaquecimento do magma nefelínico, provocada por intrusões básicas ultrabásicas. $O$ autor faz referência a xenólitos, de pequenas dimensöes e bastante deformados, de rochas quartzosas. Encaixantes charnoquíticas, 
anteriormente referidas (Gomes et al., 1967), são identificadas como variedades dos álcali sienitos das bordas do "stock". Embora muito preciso e simples nos aspectos cartográficos e petrográficos, o trabalho se constitui na contribuição mais volumosa e importante sobre as rochas igneas litorâneas, nivel superior à de Freitas (1947) è̀ de Damasceno (1966).

Motoki et al. (1987) fazem abordagem geoquímica das rochas alcalinas da liha de Vitória, tendo como alvo o estabelecimento de seu modelo petrogenético. As análises químicas, em número de 26, feitas em álcali sienitos, pulasquitos, álcali traquitos, nefelina fonólitos, sodalita-nefelina fonólitos, bostonitos e microessexitos incluem $\mathrm{CO}_{2}, \mathrm{Cl}, \mathrm{F}, \mathrm{S}$ e 8 elementos traços. O tratamento dos valores obtidos permite discussão das características físico-químicas conflitantes das rochas dessa liha, embora esse conflito seja comum em outras ocorrências alcalinas: a associação no mesmo corpo de rochas de caráter insaturado e supersaturado. zoneamento em porcentagem de $\mathrm{SiO}_{2}$, a presença ou ausência em menor ou maior quantidade de quartzo ou de nefelina, a ocorrência de xenólitos gnáissicos semi-digeridos, as seqüências superpostas de variações químicas, a impossibilidade termodimâmica de ultrapassar a barreira termal no diagrama Q-Ne-Ks e outras evidências são interpretadas como resultantes de dois processos evolutivos. Inicialmente, a rocha encaixante gnáissica, quartzosa, teria sido objeto de assimilação, total ou parcial, por magma nefelina sienítico a partir dos contatos e, daí, o zoneamento; a seguir teria ocorrido fracionamento magmático. Mesmo para os pulasquitos do núcleo, os autores admitem taxa de $30 \%$ de assimilação. Para explicar a assimilação, com base em trabalho de Motoki (1986), propõem o super aquecimento do magma nefelina sienitico inicial por injeções de magma básico-ultrabásico. O trabalho aproveita bem as informações disponiveis e trata de forma adequada os caminhos evolutivos das rochas, dando destaque correto ao fator assimilação.

Bellieni et al. (1990) estudam a geoquimica e a petrologia do magmatismo da liha de São Sebastião. Este trabalho contém mapa geológico na escala de 1:200000, modificado de Hennies e Hasui (1977), com detalhamento e novas ocorrências de diques, incluindo-se diques ácidos e alcalinos, até então não cartografados. As idades recalculadas (conforme Steiger e Jaegger, 1977, para os dados de Amaral et al., 1966, 1967, e Hennies e Hasui, 1977) seriam: dique ácido, "cortado por stock alcalino", $122 \pm 3 \mathrm{Ma}$; corpos plutônicos alcalinos, entre $81 \pm 6 \mathrm{Ma}$ e $87 \pm 5 \mathrm{Ma}$, e "valor médio" de $84 \pm 3 \mathrm{Ma}$; diques alcalinos, variáveis entre $78 \pm 8 \mathrm{Ma}$ e $83 \pm 6 \mathrm{Ma}$, porém, intrusivos nos "stocks". Nesse trabalho são descritos os diques básicos como andesibasaltos, latibasaltos e latiandesitos, e os ácidos como dacitos a riodacitos, todos do Cretáceo Inferior (EC basic dykes); e as rochas alcalinas, do Cretáceo Superior (LC), tanto os "stocks" de composição sienítica, como os diques de basanitos, tefritos, álcali basaltos, fonólitos e quartzo traquitos. São analisados quimicamente piroxênios, feldspatos, óxidos de ferro e titânio e anfibólios, além de 35 amostras de rochas para elementos maiores, $\mathrm{Fe}^{2+}$, L.O.I e elementos traços; elementos Terras Raras são dosados em 14 amostras. Após tratamento 
adequado das análises, alguns aspectos são enfatizados. Por exemplo, o caráter bimodal ácido básico dos diques da llha, similar ao encontrado para as vulcânicas da Bacia do Paraná, sendo os ácidos correlacionáveis aos da suite Chapecó (Bellieni et al., 1986), enriquecidos em elementos incompativeis, e diferentes dos chamados tipo Palmas do Sul do Paraná. A geoquimica possibilita correlacionar a atividade magmática ácida-básica bacinal aos diques do litoral Santos-Rio e à tha. Os resultados geoquímicos e as razões iniciais ${ }^{87} \mathrm{Sr}{ }^{86} \mathrm{Sr}$ são sugestivos de magmas derivados de manto litosférico subcontinental.

Garda et al. (1992) fornecem novas informaçōes sobre os diques do litoral. São descritos produtos de erupções fissurais, com posicionamento vertical e orientação NE. Os diques estudados situam-se nas costeiras junto à Praia Vermelha, Ubatuba, e enquadram-se em dois grupos, diabásios e monchiquitos/camptonitos, sendo os primeiros mais comuns. As rochas lamprofíricas são típicamente porfiríticas, xenolíticas a brechóides. O trabalho trata de ocorrência única nessa praia e aborda estruturas do tipo "bud" (Rickwood, 1990), descritas como condutos vulcânicos de secção elíptica e formando estruturas concêntricas que cortam as estruturas de fluxo planar. Magmas fissurais tornar-se-iam progressivamente ricos em voláteis, adquirindo caráter explosivo. Além de rica em xenólitos, a rocha nesses locais é formada em grande parte por estruturas globulares, que culminariam nas porçöes mais centrais em brechas soldadas. Com matriz criptocristalina, ela apresenta titano-augita e olivina como fenocristais, as vêzes barkevikita (?), e minerais granulares mais finos, augita, plagioclásio e opacos; analcima está presente em amigdalas. Xenocristais de olivina mostram "kink banding" e composição forsteritica, mais típicas de manto superior.

Garda et al. (1994a,b) abordam outros aspectos dos mesmos diques, agora estendendo o estudo para a área de Ubatuba a São Sebastião. Garda et al. (1995) reúne os dados disponiveis em trabalho de maior fôlego, dividindo, desta feita, os diques em basálticos e alcalinos. Os primeiros, mais abundantes, contêm em alguns casos intercrescimentos granofiricos, enquanto que os outros, igualmente máficos, mostram como fenocristais mais comuns clinopiroxênio e olivina, dispostos em matriz granular e criptocristalina consistindo em titano-augita, kaersutita, biotita magnesiana, opacos, feldspatos, analcima, vidro e carbonatos. São classificados como camptonitos-monchiquitos, biotita lamprófiros, picrito lamprófiros e alnoítos. Além disso, são feitas comparações químicas entre os diques de grupos diversos, e exibindo idades diferentes. Ao lado das idades KJAr da iteratura (Amaral et al., 1966, 1967), que apontam algumas dispersões muito grandes de valores (Sutuva, 128-144 Ma; Toninhas, 133-148 Ma), foram também obtidas idades isocrônicas $\mathrm{Rb} / \mathrm{Sr}$. Os basaltos possuem idade de $130 \mathrm{Ma}$ e $\mathrm{Ri}=0,7066$, enquanto que os lamprófiros de $116 \mathrm{Ma}$ e $\mathrm{Ri}=0,7055$. Entre as amostras analisadas, algumas alcalinas, em especial as de São Sebastião, apresentam idade de $80 \mathrm{Ma}$ e $\mathrm{Ri}=0,7042$. Embora os intervalos de idades entre as rochas sejam de $14 \mathrm{Ma}$ e 36 $\mathrm{Ma}$, foram feitas tentativas de análise dos resultados em conjunto. É chamada atenção para 
fato conhecido há muito tempo, qual seja, o posicionamento $N 55^{\circ} \mathrm{E}$ dos diques. O trabalho subdivide as rochas "não basálticas" em lamprófiros alcalinos - camptonitos e monchiquitos - $e$ ultramáficos - alnoitos e lamprófiros (?). De modo geral, as rochas são porfiriticas, com fenocristais ou pseudo fenocristais de olivina e clinopiroxenio, além de portadoras de "ocelli" com analcima, carbonatos e outros silicatos. A matriz, desde gräos até vidro marrom, inclue titano-augita, kaersutita, biotita, plagioclásio, opacos e minerais secundários-clorita e carbonatos (estes últimos tidos, em parte, como primários). Rochas em que o biotita supera a kaersutita foram chamadas de biotita lamprófiros ou ouachititos (lamprófiros de Rock, 1991). Além desses tipos, ocorrem alnoitos portadores de fragmentos carbonatíticos e contendo melilita e possivel melanita. Por último, são descritos os lamprófiros picríticos, com megacristais e textura cumulática. A quimica mineral para as rochas lamprofiricas revela: plagioclásio andesínico, clinopiroxênio diopsidico $\left(\mathrm{WO}_{50-60}\right)$, biotita magnesiana, flogopita, kaersutita ou TiFe-pargasita e Fe-hornblenda e olivina forsteritica $\left(\mathrm{FO}_{85}\right)$; os opacos mostram ilmenitas com exsolução de Ti magnetita. A química das rochas é discutida, onde são apontadas anomalias nos "spidergrams", em geral pouco convincentes. Além dos dados $\mathrm{Rb} / \mathrm{Sr}$, são apresentados também valores para $\mathrm{Nd}$ e $\mathrm{Pb}$, indicando fontes mantélicas diversas para basaltos e lamprófiros, estes últimos originados a partir de fração maior de fusões astenosféricas. Admitida como válida a idade de $116 \mathrm{Ma}$, teriam ocorrido dois eventos alcalinos: o primeiro produzindo lamprófiros, possivelmente associados a carbonatitos de pequena expressão, derivados de picritos, monchiquitos e camptonitos, e um segundo a $80 \mathrm{Ma}$, que teria gerado o restante das alcalinas. A idade de $116 \mathrm{Ma}$ intercala-se entre os cronogruposde 133 e $108 \mathrm{Ma}$ (cf. Ulbrich et al. 1991). Concluem os autores que a geração e a colocação dos diques lamprofíricos foram controladas pela tectônica em tempos distintos, mas que mantos diferentes poderiam estar associados a eventos distintos. Boa parte do trabalho apresentado mistura e compara informações, com base na idade de $116 \mathrm{Ma}$, obtida em linha isocrônica de referência pouco consistente.

\subsection{Trabalhos de caráter geral}

Amaral et al. (1966) divulgam os resultados do primeiro programa de dataçōes radiométricas pelo método KJAr do recém-criado Centro de Pesquisas Geocronológicas (da extinta FFCL-USP). Esse trabaho tem sido um referencial metodológico até hoje e representa importante marco para a geologia brasileira e sul-americana. Ele descreve, em detalhe, a metodologia e as técnicas analíticas empregadas, estabelecidas como rotina de trabalho em cooperação com a Universidade da Califórnia, Berkeley. Entre os aspectos metodológicos apresentados e discutidos, talvez o mais importante tenha sido o da validade do método. Além 
de esclarecer a idade do magmatismo básico da Bacia do Paraná (no trabalho, 119 a $147 \mathrm{Ma}$ ), o trabalho contribuiu para o melhor conhecimento do quimismo dessas rochas, particularmente quanto ao potássio. Concluem que há um real espalhamento das idades absolutas (onde se incluem aquelas referidas por Damasceno, 1966, para diques distantes da atual bacia), que não ocorrem diferenças significativas entre os tipos de ocorrências (derrames, diques) e tampouco correlação geográfica (NS ou EW etc.). Também são apontadas diferenças nas idades das atividades básicas datadas e as da África Sudoeste, Antártica e Tasmânia. Resta observar que as datações envolveram na sua quase totalidade rocha total. Entre as amostras há uma de dique da llha de São Sebastião, com idade de 119,4 Ma.

Ainda nesse ano, McDougall e Rüegg (1966) publicam resultados de datações radiométricas $\mathrm{KJAr}$ de concentrados minerais das mesmas rochas, contudo, em número muito menor de amostras.

Amaral et al. (1967) fornecem os resultados do segundo programa de pesquisa geocronológica efetuado no $\mathrm{CPGeo}$, agora sobre as rochas alcalinas do sul do Brasil, e usando a mesma metodologia (K/Ar). Foram datadas 66 amostras (minerais e rocha total) de 21 ocorrências. Dentre elas, sete referem-se às alcalinas da llha de São Sebastião e duas às da Ilha do Monte de Trigo. Em São Sebastião, foram datadas biotitas e feldspatos alcalinos de tinguaitos, sienitos e essexitos, com resultados entre 78,6 e 96,7 Ma, e idade preferencial de 81 $\mathrm{Ma}$. Na liha do Monte de Trigo, foi datado feldspato alcalino de nefelina sienito e biotita de "rhomb porphyry" (no original), com idades de 79,9 e 79,8 Ma. As conclusões do trabalho apontam para dois agrupamentos de idades para essas rochas, um a 122-133 Ma e outro a 51 82 Ma. Concluem, também, que: a maioria das rochas alcalinas do sul tem idades compreendidas nesses dois intervalos; a duração da atividade magmática alcalina é diferente daquela dos basaltos; há certo agrupamento geográfico das idades similares; em algumas das ocorrências existe espalhamento real da idade do magmatismo (Poços de Caldas, Jacupiranga); finalmente, não há correlação efetiva com as idades das rochas alcalinas africanas.

Minioli et al. (1974) fazem estudo geocronológico sobre a extensão do vulcanismo basáltico, empregando amostragem largamente espalhada pelo sul do Brasil, e particularmente de diques. Concluem por área muito maior do que a atualmente ocupada pelos basaltos.

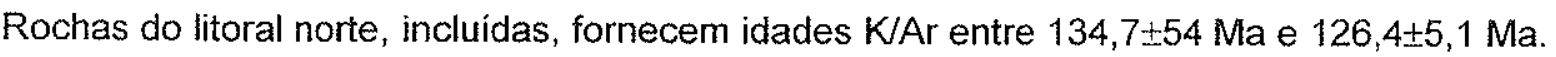

Uibrich e Gomes (1981) foram os primeiros autores a publicar trabalho de síntese geral dos conhecimentos sobre as rochas alcalinas do Brasil continental. Emprestam maior relevância aos aspectos geológicos e petrográficos, mas não deixam esquecidas a geocronologia e a tectônica. As ocorrências são mostradas em dois mapas geológicos de pequena escala, um da região sul e outro da região norte. Estabelecem oito tipos de associações petrográficas distintas: 1. associações sieniticas saturadas e insaturadas, 
tipicamente miasquiticas, entre as quais incluem a liha de Vitória; 2. associação sienítica insaturada, peralcalina, do tipo agpaítico; 3 . associação máfica-ultramáfica, alcalina saturada a peralcalina, podendo incluir tipos félsicos. Este grupo é subdividido em um a) com dunitos a piroxenitos, e presença de carbonatitos, outro b) principalmente com glimmeritos e carbonatitos e um terceiro c) semelhante ao primeiro, mas sem carbonatitos; 4. associação máficaultramáfica do tipo álcali gabros. Incluem pulaskitos, nefelina sienitos, essexitos e teralitos. A Ilha do Monte de Trigo e a llha de São Sebastiāo pertenceriam a este grupo; 5 . basalto alcalinotraquito-fonólito. Ocorreria como diques, "sills" etc., podendo representar as manifestações vulcânicas dos tipos 1 e $4 ; 6$. associação álcali granito-álcali sienito. Seriam ocorrências com rochas saturadas e supersaturadas, com núcleo insaturado; 7. associação vulcânica peralcalina, fortemente insaturada. Leucititos, uganditos, analcititos, com ou sem basaltos e fonólitos, seriam típicos; 8 . associação insaturada persódica, reunindo álcali sienitos, sodalita sienitos e litchfielditos.

Definem, para a regiāo sul, quatro grupos acumulativos de idades $\mathrm{K} / \mathrm{Ar}$. O maciço do Pão de Açúcar teria $240 \mathrm{Ma}$; um segundo grupo apresentaria idade em torno de $130 \mathrm{Ma}$. Entre - Barremiano (<124 Ma), Aptiano, Albiano até o Cenomaniano (>91 Ma), a atividade alcalina se mostraria mais reduzida, com novo incremento ocorrendo no Cretáceo Superior, e configurando o quarto grupamento de idades, dentro do qual se encontra a maioria das rochas alcalinas do sul. Não há correlação geológica e petrográfica entre as ocorrências de cada grupamento de idades, e espalhamentos de valores são tomados como reais (Poços de Caldas, $20 \mathrm{Ma}$ ). Ocorrências litorâneas e em ilhas oceânicas são indicativas que as atividades alcalinas continuaram após os 54 Ma de Cabo Frio: Abrolhos, 42-52 Ma, Fernando de Noronha, 22-2 Ma, Trindade e Martins Vaz, 0,8-2,5 Ma.

Reunindo as informações geológicas disponiveis, os autores delineam modelamento magmático tectônico para as rochas alcalinas. Primeiro, parece claro que há relações definidas entre as unidades estruturais e a colocação dos maciços. O magmatismo, desde o Jurássico Superior, guarda relação com rearranjos crustais, correlacionáveis com a ruptura do Gondwana, e posterior deslocamento das placas. Tendo cessado a estabilidade da Plataforma no Jurássico, subsidência e falhamentos deram lugar a sinéclises amplas e bacias continentais menores, ocorrendo movimentações até o Terciário. À atividade tectônica acham-se associadas manifestações basálticas, inicialmente como diques e, mais tarde, como lavas a $147 \mathrm{Ma}$, em Santa Catarina, com a sua maior intensidade oscilando entre 120-130 Ma. Essas atividades iniciais estão identificadas com a flexura do Arco de Ponta Grossa, que também teria controlado a atividade alcalina mais antiga (Jacupiranga, Juquiá) da área. As ocorrências alcalinas mais a NE e litorâneas estariam ligadas a falhamentos e riftes de direção NE. Por sua vez, as ocorrências de Minas Gerais e Goiás, ao longo do Cinturão Brasilia, exibindo caráter máfico-ultramáfico, parte potássico, e freqüentemente com carbonatitos, têm disposiçāo NW e 
são controladas por estruturas antigas do embasamento. Outras ocorrências da região (Iporá) estariam associadas a um sistema de lineamentos NNW. Considerações são ainda feitas sobre as alcalinas do Paraguai e da Bahia. Finalmente, as ocorrências são arranjadas em dez provincias, em função das associações petrográficas presentes, e, de certa forma, a idade.

Sonoki e Garda (1988), usando as novas constantes de Steiger e Jaeger (1977) para a metodologia KJAr, recalculam 295 idades de 52 ocorrências de rochas alcalinas do sul do Brasil e do Paraguai. Com o emprego dessas constantes verifica-se aumento nos valores das idades, em torno de 2,1 a $2,4 \%$ até mais que $10 \%$ (Garda et al., 1995).

É da maior conveniência a avaliação de Ulbrich et al. (1991) sobre o grande número de idades K/Ar disponiveis para as ocorrências do sul do Brasil e do Paraguai. São 200 valores, espalhados quase continuamente entre $270 \mathrm{Ma}$ e $25 \mathrm{Ma}$. Além dessa preocupação, os autores apontam o problema de algumas ocorrências (p.e. Jacupiranga, SP; Poços de Caldas, MG) revelarem intervalos muito dilatados entre idades mínimas e máximas. Tendo em vista refinar esses valores, fazem avaliação crítica das condições de trabalho, excluindo os valores que não obedeciam a certos critérios, e colocam sob suspeição algumas idades de maciços que ampliavam sobremodo os intervalos de atividade para aquela ocorrência. Com isso, metade dos valores foi invalidada. A partir de médias aritméticas das idades disponiveis e aceitáveis para cada ocorrência, obtêm idades acumuladas em quatro valores principais. Os quatro cronogrupos resultantes são os de $133 \mathrm{Ma}, 108 \mathrm{Ma}, 84 \mathrm{Ma}$ e 70-62 Ma, e acham-se relacionados a feições geológicas de grande expressão. As idades de $133 \mathrm{Ma}, 108 \mathrm{Ma}$ e $84 \mathrm{Ma}$ estariam associadas ao Arco de Ponta Grossa; o magmatismo do litoral São Paulo-Rio de Janeiro estaria concentrado em dois máximos: 133 e $84 \mathrm{Ma}$; a faixa das alcalinas Rio de Janeiro-Minas Gerais, que incluiria Poços de Caldas, teria idades no intervalo 70-62 Ma. As ocorrências de Minas Gerais-Goiás se concentrariam no grupo de $84 \mathrm{Ma}$; e as do Paraguai Oriental, no grupo de $133 \mathrm{Ma}$. Os resultados alcançados e suas distribuições geográficas levam os autores a descartarem os modelos que invocam anomalias termais móveis e regulares, tipo "hot spots", às quais deveriam refletir-se em padrão constante de distribuição de idades. $O$ quadro final obtido mostra que os cronogrupos repetem-se por toda a Bacia do Paraná e arredores, controlados por fatores tectônicos, reativados a cada 20 a $25 \mathrm{Ma}$.

Morbidelli et al. (1993) apresentam breve resumo da petrologia e da geoquímica das alcalinas brasileiras, enquanto que síntese mais abrangente é oferecida por Morbidelli et al. (1995). Este último trabalho divide as ocorrências em dois grupamentos: com carbonatitos e sem carbonatitos, e reúne informações mineralógicas, petrológicas e geoquímicas, com base em 2000 análises de minerais e 800 de rochas, além de dados sobre idades $\mathrm{K} / \mathrm{Ar}$ e $\mathrm{Rb} / \mathrm{Sr}$ e isótopos de $\mathrm{Sr}$ e Nd. Como ponto de partida geológico, leva em conta os trabalhos de Ulbrich e Gomes (1981) e Almeida (1983). 
Quanto às idades, excluídas as mais antigas (250-240 Ma) associadas à Província Alto Paraguai, Morbidelli et al. (1995) distinguem vários agrupamentos, sendo o primeiro deles de 130 Ma (Anitápolis, SC; Jacupiranga, Juquiá e Ipanema, SP) e contemporâneo às atividades basálticas (133 Ma, ${ }^{40} \mathrm{Ar} /{ }^{39} \mathrm{Ar}$, Renne et al., 1992). Como segundo agrupamento, citam os valores de 110-100 Ma e, por último, o de 50-90 Ma. Este seria o mais numeroso, incluindo ocorrências de diversas províncias, entre as quais a da Serra do Mar. Chamam a atenção para a pequena quantidade de dados $\mathrm{Rb} / \mathrm{Sr}$ disponiveis. Abordam, na mineralogia, todos os constituintes principais, a começar pelos feldspatos. Entre estes, os alcalinos predominam largamente, sendo os plagioclásios restritos ou mesmo ausentes. Nefelinas são os representantes maiores dos feldspatóides, aparecendo também sodalita, noseana e analcima; haüyna e leucita ocorrem mais raramente. Entre os máficos, os clinopiroxênios são os mais importantes, freqüentemente exibindo zoneamento e enriquecimento em $\mathrm{Fe}$ e $\mathrm{Na}$; gradam de diopsídios, nas rochas menos evoluídas, até egirinas, nas mais evoluídas peralcalinas. Os dados químicos mostram valores baixos para $\mathrm{Al}^{\mathrm{Vl}}$, indicando cristalização a baixas pressões. Os anfibólios, dominantemente cálcicos, variam de pargasitas a kaersutitas, a termos mais sódicos, katophoritas e richteritas. Comumente orlam e substituem os clinopiroxênios. Entre as micas predominam as biotitas, que gradam até flogopitas. Como minerais adicionais, aparecem magnetita, ilmenita, apatita, titanita, melanita e perovskita; os raros silicatos de $\mathrm{Ti}$ e $\mathrm{Zr}$ ocorrem em Poços de Caldas e Lages. Com relação à petrografia, separam as rochas alcalinas em cumuláticas e não-cumuláticas. Entre as primeiras, os clinopiroxenitos são os tipos mais comuns, ainda que a textura possa estar também presente nos gabros alcalinos e sienitos. Como fases cumuláticas são reconhecidas olivina, piroxênio, magnetita, plagioclásio, feldspato alcalino e nefelina. As rochas não-cumuláticas são tratadas em grupos diferentes. Entre elas, distinguem-se as representativas de magmas menos evoluídos, além de presentes como diques, incluindo basanitos porfiríticos, basaltos alcalinos, ankaratritos, olivina melilititos e olivina nefelinitos. Ainda como representantes mais primitivos, e sob a forma de "stocks", são citados gabros alcalinos, teralitos, essexitos, sienogabros e gabros essexíticos. Entre as rochas mais evoluidas reconhecem-se os sienitos em geral, tanto supersaturados como insaturados. Outros tipos não-cumuláticos e de granulação fina são citados: fonólitos, como o tipo evoluído mais comum e principalmente de ocorrência em diques, seguidos, com menor freqüência, por tefritos e fonotefritos, traquifonólitos, traquitos e quartzo traquitos. $\dot{E}$ dada pouca relevância aos lamprófiros, mencionando-se unicamente os de Poços de Caldas. As análises químicas de rochas são trabalhadas em gráficos binários, tendo o indice de diferenciação como parâmetro, e "spidergrams". Mostram relação positiva com esse indice os elementos incompativeis, $\mathrm{SiO}_{2}$, $\mathrm{Na}_{2} \mathrm{O}, \mathrm{K}_{2} \mathrm{O}$ e $\mathrm{Al}_{2} \mathrm{O}_{3}$, e negativa $\mathrm{CaO}, \mathrm{FeO}_{1}, \mathrm{MgO}, \mathrm{P}_{2} \mathrm{O}_{5}, \mathrm{TiO}_{2}, \mathrm{Cr}, \mathrm{Ni}$, Co e $\mathrm{V}$. Mn é constante e $\mathrm{Ba}$ e $\mathrm{Sr}$ dispersam-se. As variações são indicativas da importância da cristalização fracionada 
em cada ocorrência. As fases máficas se constituem em ponto de fixação dos elementos até os estágios evolutivos intermediários; já nas fases finais, feldspatos alcalinos e feldspatóides tiveram papel relevante. $O$ tratamento de multielementos, normalizados para o manto primitivo, permite resumir que as rochas menos evoluidas, tanto dos distritos com ou sem carbonatitos, possuem comportamento semelhante para os traços e menores, altamente enriquecidos com relação ao manto, sugerindo derivação a partir de fontes metassomatizadas ligeiramente diferentes.

Anomalias positivas de $\mathrm{Ba}, \mathrm{Nb}, \mathrm{Sr}, \mathrm{P}$ e $\mathrm{Zr}$ estão presentes nas associações sem carbonatito, e de Th, La e Ti naquelas com carbonatito, registrando-se, ainda, forte pico também positivo em Th e Ti nos cumulatos ultramáficos. Os tipos mais evoluidos revelam, igualmente, similaridades, com anomalias positivas para $\mathrm{Rb}, \mathrm{Nb}, \mathrm{Zr}$ e $\mathrm{Y}$ e negativas para $\mathrm{Ba}$, $\mathrm{Sr}, \mathrm{P}$ e Ti. Ocorre, de forma geral, enriquecimento em ETRL, típico das rochas alcalinas. Os tipos petrográficos mais primitivos mostram valores mais altos em ETRL e ETRI e mais baixos em ETRP junto às ocorrências com carbonatito; rochas mais evoluidas têm padrões semelhantes para os ETR. É sugerida cristalização fracionada para a evolução dos dois grupos, atribuida ao pequeno volume de magma carbonatitico formado.

Magmas parentais basálticos, variáveis, a partir de "gabros alcalinos" (Tunas, Pr) ou basanitos (Ilha de São Sebastião, Juquiá, SP; Lages, SC; Itatiaia, RJ), conduziriam a produtos finais de composição peralcalina, fonolitica (I.A. 1,16). As fases fracionadas no inicio do processo teriam sido clinopiroxênio, olivina, plagioclásio e óxidos $e$, num estágio mais avançado, adicionalmente, anfibólio, feldspato alcalino e nefelina. Os produtos finais representariam não mais do que $5 \%$ dos parentais basaniticos. A presença de carbonatos primários isolados ou em ocelos, acompanhados de micas e/ou anfibólios, seriam indicadores da presença de fases ricas em $\mathrm{CO}_{2}$ e $\mathrm{H}_{2} \mathrm{O}$, responsáveis pelos carbonatitos que não ultrapassariam $5 \%$ dos líquidos já mais evoluidos e, estes, $5 \%$ dos basanitos. Olivina melilititos seriam representantes de outros magmas primitivos, independentes dos basaníticos (Lages).

As razões iniciais ${ }^{87} \mathrm{Sr}{ }^{86} \mathrm{Sr}$ oscilam entre 0,7043 a 0,7058 para as rochas primitivas, com a variação indicando diferentes fontes mantélicas, enriquecidas, ainda que no mesmo distrito. Isto é também é sugerido por razões do tipo $\mathrm{La} / \mathrm{Nb}$ e $\mathrm{Zr} / \mathrm{Nb}$, enquanto que dados isotópicos de $\mathrm{Nd}$ indicam manto metassomatizado por $\mathrm{CO}_{2}$. As razões iniciais de $\mathrm{Sr}$ para as rochas evoluidas variam de 0,7045 a 0,7065 , com maior freqüência em torno de 0,7055. Encaixantes fortemente radiogênicas $(\mathrm{Ri} \cong 0,783)$ poderiam ser fonte de contaminação crustal, como em Lages, onde os fonólitos apresentam valor de $\mathrm{Sr}_{\mathrm{i}}=0,73108$ e de $\mathrm{Nd}_{\mathrm{i}}=0,51188$. Os valores mais baixos encontrados são de 0,702-0,703 e referem-se às rochas de Fortaleza, coerentes com o modelo da Anomalia Dupal. Elementos traços, $\mathrm{Sr}_{\mathrm{i}}$ e $\mathrm{Nd}_{\mathrm{i}}$ de rochas mais primitivas indicam gênese a partir de fonte mantélica metassomatizada variavelmente, com 
pequena porcentagem de fusão parcial ( $4 \%$ a $7 \%$ ). Tanto em Lages como em Juquiá, ou ainda em nódulos therzoliticos de kimberlitos do Alto Paranaiba, os dados indicam fonte granada peridotítica, com ou sem flogopita, da litosfera subcontinental. O mesmo tipo de fonte é sugerida por outros autores para as rochas basálticas da Bacia do Paraná (Piccirillo et al., 1988), alcalinas da região centro-oriental do Paraguai (Comin-Chiaramonti et al., 1992) e de Juquiá, SP (Beccaluva et al., 1992). Extensas conclusões fecham esse trabalho de síntese, oportuno, objetivo e abrangente, e de boa qualidade. 


\section{CAPITULO 5}

\section{GEOLOGIA}

Os traços geológicos da liha dos Búzios, como definidos por Björnberg e Ellert (1955), mostram-se simples, tanto em mapa quanto descritivamente. Por outro lado, a geologia apresentada neste trabalho (Figs. 3 e 4), embora mais detalhada e algo mais complexa no tocante aos contatos e à cronologia relativa das rochas, não difere, essencialmente, do trabalho daqueles autores.

Rochas sieniticas formam $80 \%$ a $90 \%$ da llha, estendendo-se da meia/alta encosta da face ocidental para leste, ocupando também pequena porção noroeste, na Pontinha. Remanescentes de terrenos charnoquíticos, encaixantes das alcalinas, aparecem somente nessa mesma encosta, em faixa NE, que desce até o mar; uma cunha isolada de charnoquitos, de dimensão mapeável, ocorre na costa sul, da Ponta Sul para oeste, estreitando-se para o interior da liha. Tanto os sienitos quanto o pacote de rochas metamórficas é cortado por grande quantidade de diques de espessura centimétrica a métrica, com predomínio daqueles variando de 0,40 a $0,80 \mathrm{~m}$, e extensões não verificáveis.

\subsection{Os sienitos}

Em geral, não foram observados contatos bruscos entre os sienitos e as encaixantes. Em raros locais onde isso ocorre, eles se dão através de falhas pequenas que não chegam a afetar lateralmente as rochas. É possivel que a faixa metamórfica faça contatos bruscos com os sienitos da Pontinha, marcados por ravina pouco profunda, linear, acompanhada por blocos de sienitos de um lado e charnoquitos do outro. Do interior da liha, com sienitos típicos, e aproximando-se de qualquer das zonas de contato nota-se mudança nos tipos sieníticos, além do aparecimento de xenólitos, que gradativamente aumentam de freqüência. Em todas as zonas de contato, o que realmente se vê é a passagem gradativa de um tipo de rocha para outro, sendo que em alguns casos isso se dá a uma distância métrica ou até no mesmo bloco. Essas observações são comuns nos costões por onde deveria passar o contato. Nessas passagens não há posição geográfica preferencial de uma ou outra rocha, mas sim uma certa recorrência de tipos petrográficos, provavelmente como resultado de falhamentos.

Blocos aparentemente "in situ", pela mútua justaposição, presentes em locais diferentes, e observações até no mesmo bloco, mostram relação até certo ponto inesperada: os sienitos aparecendo sempre por cima dos charnoquitos. Há indicações de contatos verticalizados, fato também notável no traçado da suposta zona de contato. Esta, como referido, pode ser métrica a decamétrica, acompanhada por faixa rica em xenólitos, com ambas 
as zonas perfazendo entre 100 a $300 \mathrm{~m}$ de largura aproximadamente. Em três diferentes locais, pelo menos, o terreno mostra charnoquitos por baixo dos sienitos, aparentemente com interfaces subhorizontais: a leste da Pontinha, na Laje da Escola e no Porto Sul (Foto 11).

Todas essas características são um pouco diferentes para os sienitos que envolvem a cunha sul de charnoquitos, onde as passagens são mais rápidas. Comum a todas as zonas de contato é a presença de rochas blastomiloníticas quartzo-feldspáticas, intercaladas aos charnoquitos; estes, por sua vez, quase sempre exibem alguma feição de cisalhamento, de intensidade variável, evoluindo para rochas miloníticas.

A partir dessa faixas, sienitos francos ocupam toda a llha para leste. As rochas são monótonas: em geral, de granulação grossa, variando localmente para média, e coloração clara (Foto 12). Variedades de granulação fina aparecem sempre, quer de forma gradativa quer como "diques" ou reticulado de diques e veios. Nas proximidades dos contatos, os sienitos exibem cor verde escuro a esverdeada, ou passam a rochas de cor cinzenta a esverdeada, aqui chamada de "hibridas", por apresentarem características de mistura entre intrusiva e encaixante. Além disso, há predomínio dos tipos com granulação fina.

Xenólitos são comuns por toda a faixa próxima dos contatos. Podem aparecer em grande concentração, $20 \%$ a $30 \%$ da área exposta, ou mais dispersos, não ultrapassando os $5 \%$ da superficie observada. São de dois tipos litológicos: charnoquitos e (meta) máficas.

Os xenólitos charnoquíticos podem ocorrer na forma de um único cristal de feldspato, ou ainda como pequenos agregados, e exibir dimensões métricas ou maiores. Não mostram arredondamento acentuado e tampouco são tipicamente angulosos. Conservam formas subretangulares, paralelas à orientação dos minerais, e apresentam contatos irregulares, em geral mal definidos, além de vértices arredondados.

Os xenólitos máficos, pretos, são também freqüentes, ocorrendo isoladamente ou em seqüências, às vezes curiosamente empilhados "in situ" como restos de um muro. Em outros locais, estão associados aos xenólitos de charnoquito, sendo claramente intrusivos nestes últimos. Geralmente, possuem dimensões inferiores àqueles, sendo mais angulosos e até bastante angulosos. Uma terceira variante dos xenólitos corresponde aos pequenos enclaves centimétricos arredondados, que estão presentes em pequena quantidade.

Algumas observações gerais merecem ser destacadas. Primeira, nas zonas sabidamente próximas aos contatos, os xenólitos são sempre dos dois tipos, e invariavelmente os fragmentos máficos têm pelo menos parte do seu contato com a encaixante charnoquítica. Nesses casos, os xenólitos máficos, que às vêzes possuem grandes dimensões, são minoritários e raramente se isolam. As feiçōes de campo indicam que a rocha máfica, fina, intrudiu o charnoquito $e$, adicionalmente, que o conjunto foi arrancado, fragmentado, envoivido e remobilizado parcialmente pelo sienito (Fotos 13 e 14). Segunda, quanto maior a distância do contato, menor o número de xenólitos, sendo que os máficos não só rareiam como diminuem 


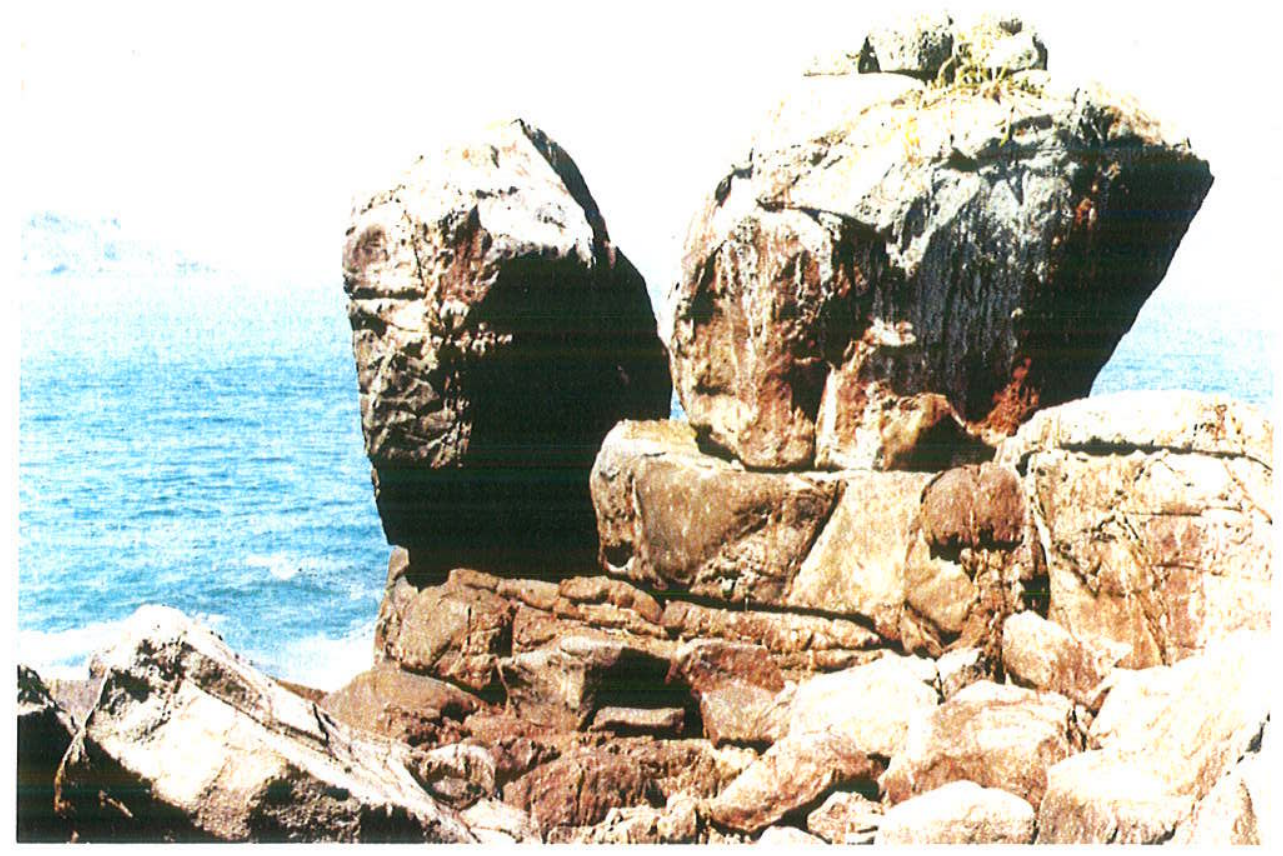

Foto 11 - Ponto 318, Costa Sul, Porto Sul - Saco do Maneco. Blocos "in situ" de sienito empilhados sobre charnoquito (parte inferior da foto). Observar xenólito máfico arredondado ao pé do bloco à direita. Ao fundo, à esquerda, a Ponta Sul a $1 \mathrm{~km}$. A referência, uma marreta, pouco visível abaixo e à direita do centro da foto.

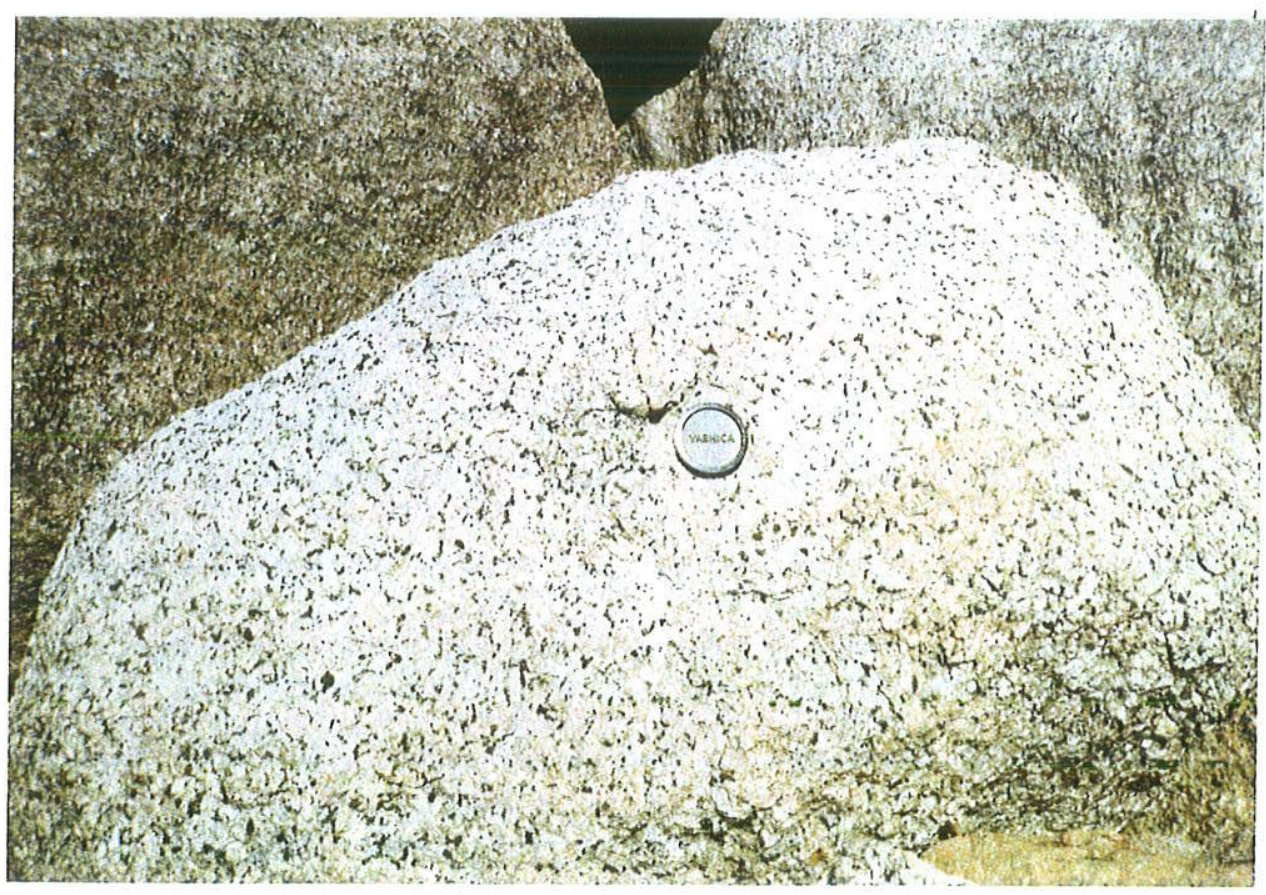

Foto 12 - Bloco do sienito de granulação grossa dominante na llha. A cor cinzenta clara, presente em todos os blocos, já indica capa de alteração, embora a rocha ainda se mostre resistente. Notar faixas mais claras de fraturamento e miárolo junto ao ponto de referência. 


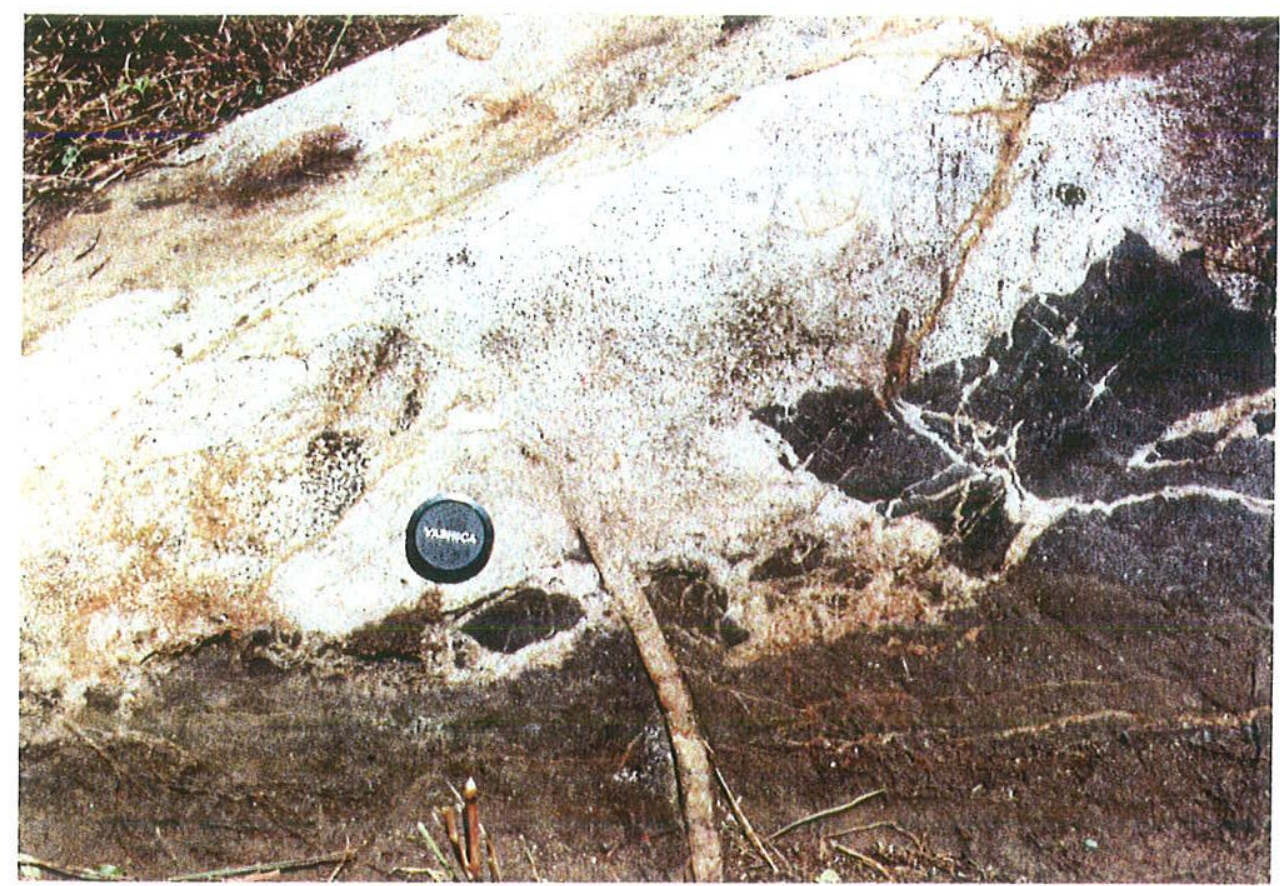

Foto 13 - Ponto 310. Sienito fino envolvendo xenólito de rocha máfica. Observar fragmentos soltos do xenólito, angulosos e injetados por sienito e variação na interface sienito-xenólito, que se mostra regular, linear ou muito irregular.

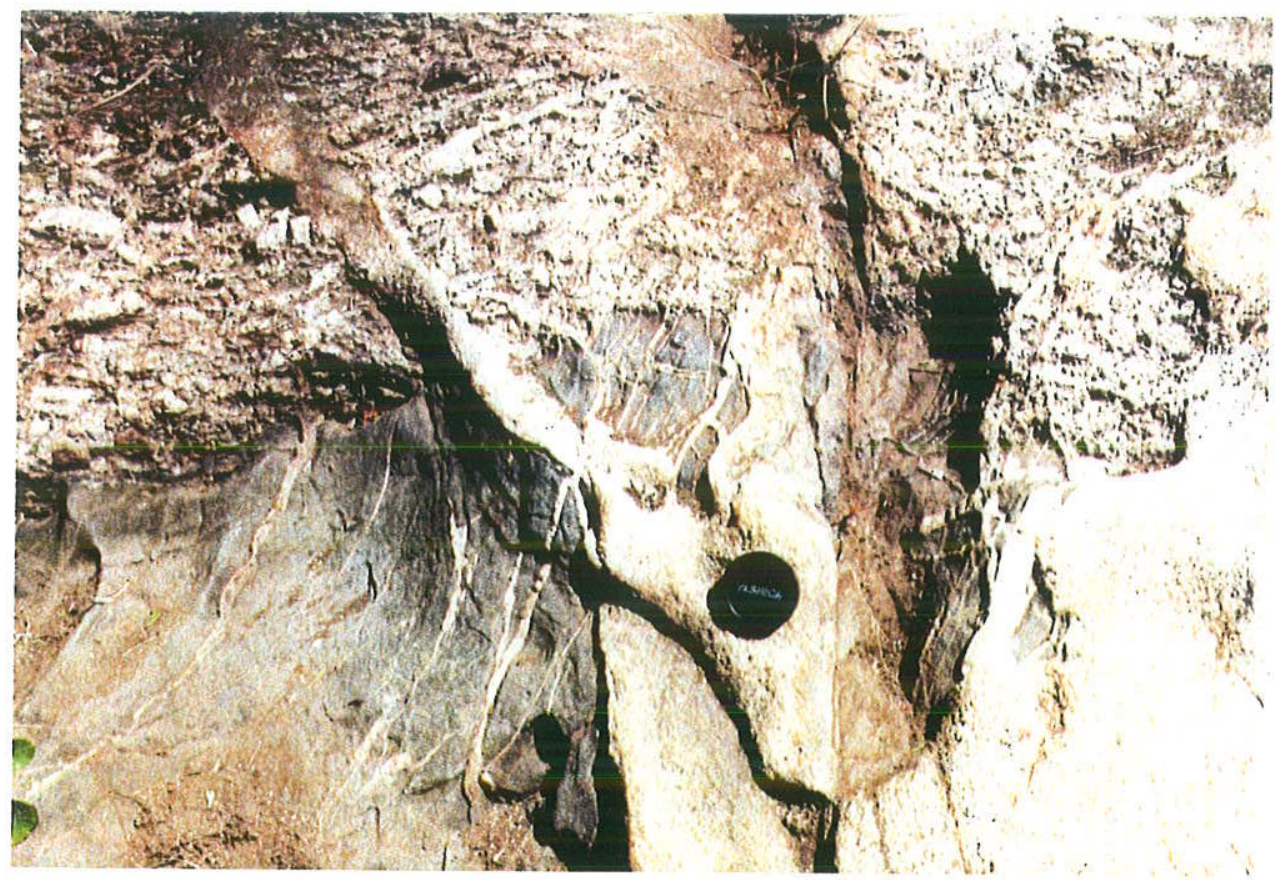

Foto 14 - Ponto 310. Sienito fino envolvendo conjunto xenolítico de rocha máfica-charnoquito, com contato regular entre ambas. Fraturamento e venulação típicos da porção máfica, interrompidos no charnoquito. Apenas pequeno dique decimétrico atravessa o charnoquito. 
de tamanho; já os de charnoquito, agora mais esparsos, tendem a arredondar-se. Terceira, na Laje da Escola e no Arpoador, nota-se zoneamento e concentração dos xenólitos com a variação de cota. Na Laje da Escola, por exemplo, os xenólitos, que se acham distribuídos em superfície sienítica regular de mais de $2000 \mathrm{~m}^{2}$, não aparecem lateralmente, quer dizer, em profundidade. Por último, existem os "xenólitos" isolados de rochas básicas, como amontoado regular de blocos, que podem bem representar restos de diques máficos, estes intrusivos nos sienitos de forma simplutônica (cf. Pitcher, 1995, p. 123) e mantidos mais ou menos "in situ".

Outros tipos de descontinuidade e heterogeneidade são igualmente visiveis nos sienitos

Cavidades miarolíticas até decimétricas, com ou sem preenchimento de quartzo, são comuns no corpo da Pontinha e nas proximidades dos contatos, até uma distância fora da zona xenolitica, onde diminuem de freqüencia; mais para o interior dos sienitos a sua ocorrência é rara. Veios associados de quartzo são também assinalados.

Rochas pegmatóides estão também presentes com alguma constância. Configuram em geral bolsöes decimétricos a métricos, de formas irregulares, com cristais de feldspato atingindo tamanho de até $5 \mathrm{~cm}$ ou mais. Comumente, são desprovidos de máficos, mas associam-se a zonas vizinhas enriquecidas em biotita e/ou anfibólio. Em alguns lugares, fazemse acompanhar por rocha de aparência aplítica, provável microssienito hololeucocrático. Em poucos lugares tanto o pegmatito como o aplito mostram alguma regularidade quanto à forma, mesmo assim pouco elucidativa. Na costa sul, contudo, ocorrem bandamentos em faixas métricas, persistentes, em que uma das litologias é pegmatóide (Fotos 15 e 16).

Estruturas bandadas são visiveis nas rochas da porção oriental do Saco Grande. Mergulhante para norte, o bandamento é regular, contínuo e de espessura em torno de 3 a $4 \mathrm{~m}$. A faixa é caracterizada por apresentar alternância regular de sienito comum encaixante, pegmatito e aplito. Tanto para o topo como para a base, ele näo se repete e tampouco aparece outro tipo de estratificação (Fotos 15 e 16).

Concentrações de minerais máficos (biotita e/ou anfibólio) não são incomuns e adotam forma linear, regular e persistente; a espessura é centimétrica. Nelas, nota-se em alguns lugares crescimento cristalino perpendicular à suposta parede, não obstante possam haver outras explicações para essa feição que não seja a de preenchimento de fratura. Concentrações máficas diferentes, reconhecidas em três lugares distintos e distantes entre si, configuram estrutura de $3-4 \mathrm{~m}$ por $2 \mathrm{~m}$, onde se distinguem camadas finas de máficos, com forma curva, que se repetem concentricamente, e que se acham separadas por sienito, além de truncadas por faixa máfica retilinea.

Tanto os bandamentos como as camadas máficas ocorrem na porção leste e mais a sul da llha.

Por último, mencione-se a presença, em alguns lugares, de zonas com grande 


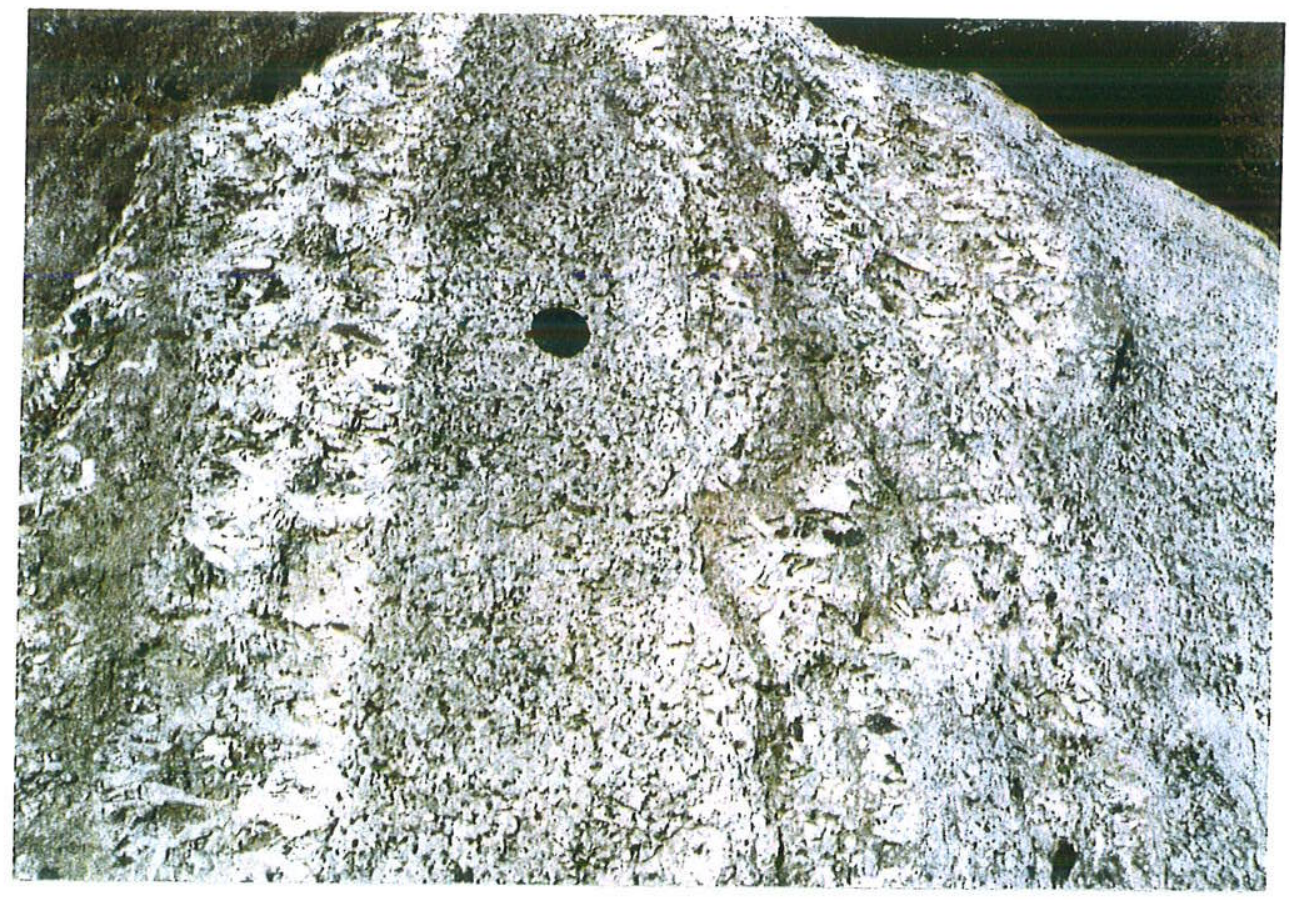

Foto 15 - Feição do "grande bandamento" pegmatóide do Saco Grande, notando-se simetria e alternância de porção feldspática pegmatóide e sienito comum, que é também a rocha encaixante.

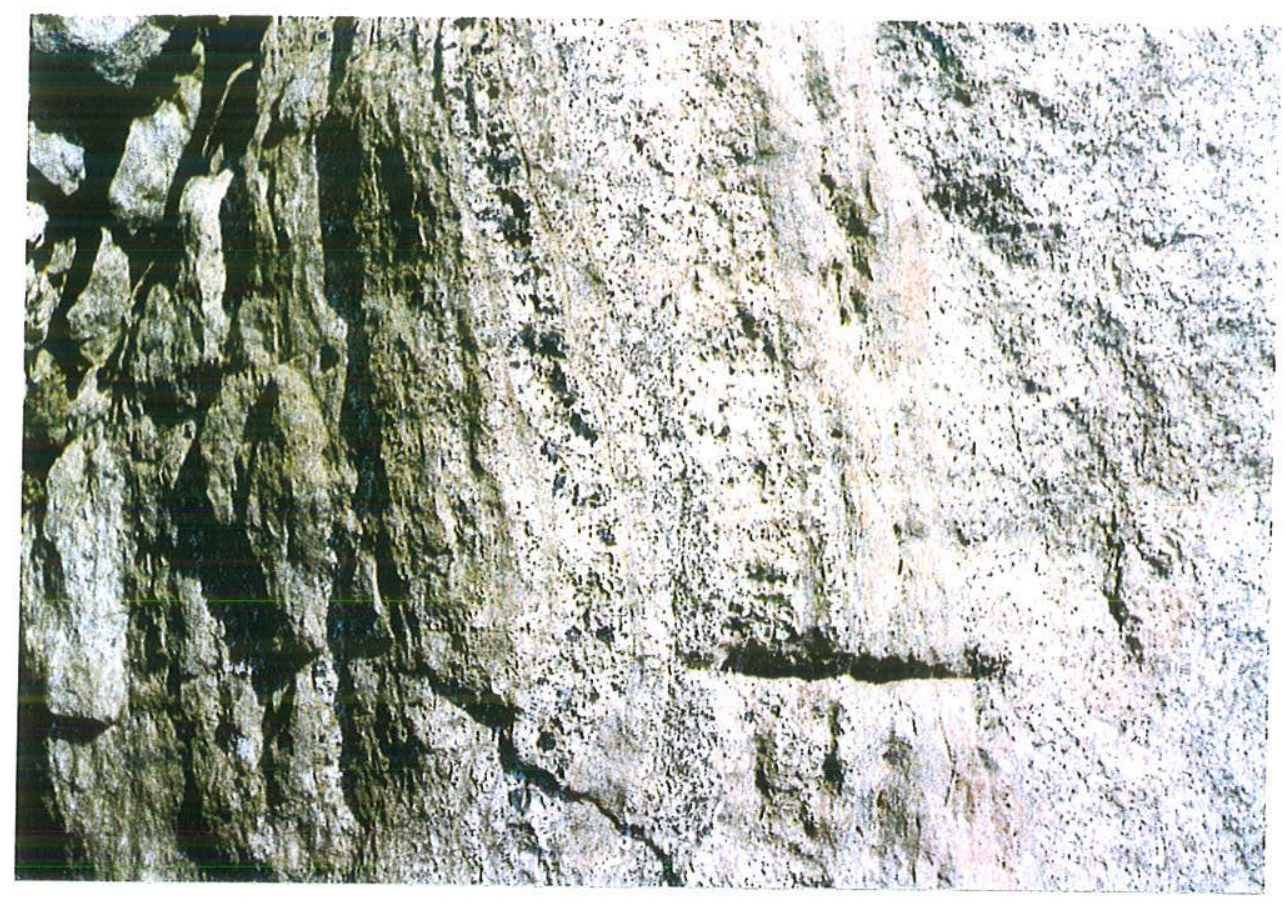

Foto 16 - Feição do"grande bandamento" do Saco Grande. Nota-se alternância de bandas decimétricas pegmatóides e aplíticas. Na porção central da banda, à esquerda, cristais de magnetita. A direita da faixa mais fina, a rocha é um sienito comum. 
concentração de veios feldspáticos centimétricos, paralelos, com pequeno afastamento, aparentemente associados a processos de cisalhamento. Tanto neste caso, como quando de ocorrência isolada, esses veios aparentam ser bastante tardios, uma vez que invarialvelmente cortam qualquer outra estrutura presente.

\subsection{As encaixantes}

Os terrenos encaixantes são representados por charnoquitos. Em geral, são rochas de coloração verde escuro, de granulação muito grossa, com marcada orientação dos feldspatos, não configurando exatamente uma gnaissificação ou foliação (Foto 17). Intercalados a eles ocorrem gnaisses mais claros, que podem representar uma variação de cor dos charnoquitos, gnaisses alasquiticos finos e possivelmente cisalhados, além de quartzo gnaisses, semelhantes aos anteriores. São comuns as camadas anfibolíticas ou metabásicas, concordantes estruturalmente, embora em algumas ocorrências elas se mostrem muito deformadas, rompidas e maciças, em situação duvidosa.

Toda a faixa de encaixantes, que começa a sudoeste na Ponta das Pitangueiras e prossegue para nordeste até a Laje da Escola a norte, separa o "corpo" sienítico da Pontinha do resto da llha e dos sienitos. Na realidade, a disposição e distribuição dos blocos de charnoquitos e sienitos leva a crer que existe uma zona de contato mais importante, mas, após ela, os charnoquitos em lugar de formar uma faixa homogênea e contínua, são cortados por um reticulado de diques/veios de microssienitos e microgranitos. Em geral, os afloramentos de charnoquitos são raros, pequenos e descontínuos. Na Ponta das Pitangueiras, ocorrem charnoquitos contínuos, que prosseguem pelos costões para nordeste e para leste, mas por curtas distâncias, não mais que uma a duas centenas de metros. Também a meia/alta encosta, junto à face ocidental da liha, contém grandes afloramentos de charnoquitos, embora descontínuos.

\subsection{Os diques}

Intrusivos tanto nos sienitos quanto nas encaixantes charnoquíticas, os diques estão presentes por toda a llha. Podem ser examinados com bastante acuidade nos costões. No campo, pode-se distingui-los e reuni-los em dois grupos: máficos/ultramáficos e félsicos. Os primeiros são de cor cinza escuro a preta, enquanto que os segundos exibem tonalidade clara a verde escuro.

A maior parte desses corpos exibe traçado retilineo e espessura constante, sendo 
contudo grande o número de variações desse padrão. Alguns podem mostrar mudanças bruscas de direção, chegando até a ser curvilíneos (Foto 18, Ponta das Pintangueiras). Outros apresentam padrão em "off set" (Foto 19) ou com pontes (Foto 20) e pescoços, deslocando-se paralela ou ortogonalmente a sua direção. Em alguns lugares, bifurcam-se em braços desiguais, a ângulos agudos, sugerindo o sentido de fluxo, interpretação, no entanto, sujeita a restrições (Foto 21).

As relações cronológicas entre os diques, entre eles próprios, e os sienitos, claras às vêzes, são freqüentemente dúbias, como já relatado por Björnberg e Ellert (1955), e ainda por Coutinho e Melcher (1973) para as ocorrências da liha do Monte de Trigo. Em mais de um lugar observaram-se conjuntos de diques em que os do tipo $A$ cortavam B e vice-versa. O que fica de objetivo dessas relações, além dessa dubiedade, è que diques máficos $\mathrm{A}$ cortam diques máficos $B$; as poucas observaçöes esclarecedoras indicam diques máficos cortando diques claros - mas estes podem ser simplesmente microssienitos, variantes do sienito e, portanto, mais precoces. Na Ponta das Pintangueiras, diques de composição riolítica cortam diques máficos B (Foto 22); tanto os diques máficos $A$ como os riolíticos são concordantes com a estruturação do charnoquito (NE-ENE) onde ocorrem.

De forma geral, nos sienitos, os diques são intrusivos. Em nenhum lugar foram encontrados diques claramente anteriores e seccionados e interrompidos totalmente pelo sienito. Na Ponta Sul, ocorre situação mais difícil de explicar: um conjunto de cinco diques paralelos formando muros ou escavados no início da encosta com solo (Fotos 23 e 24). Esses diques não têm continuidade na laje do costão: na sua direção o que se observa na laje são xenólitos angulosos, às vezes quase justapostos, de rochas máficas semelhantes às dos diques. No mesmo local, os sienitos são de coloração verde a verde acinzentado, de granulação fina principalmente, e incluem também xenólitos subangulosos de charnoquito (Fotos 25 e 26). Essa situação pode ser a mesma dos xenólitos encontrados amontoados como muros no sienito em outros locais (altos da Guanxuma), e já relatada.

Em alguns lugares, os diques apresentam relações complexas com as encaixantes. Eles cortam e se colocam na encaixante visivelmente, sendo contudo cortados por extensões da própria encaixante, o que, na verdade, representa uma segmentação normal dos diques ("ponte", Rickwood, 1990; Foto 20).

Em poucos locais, foram reconhecidos efeitos de borda, distinguindo-se neste caso contatos foliados (cisalhados) interna e externamente.

Não se encontraram internamente xenólitos de grande interesse, e os poucos notados são do próprio sienito ou do charnoquito.

Os diques félsicos, particularmente microssieniticos com quartzo e micrograníticos, afloram na faixa oeste com as encaixantes e, em menor quantidade, nas porçōes ocidentais da Iha. Na medida em que se vai para leste, começam a aparecer e a aumentar os traquitos e 


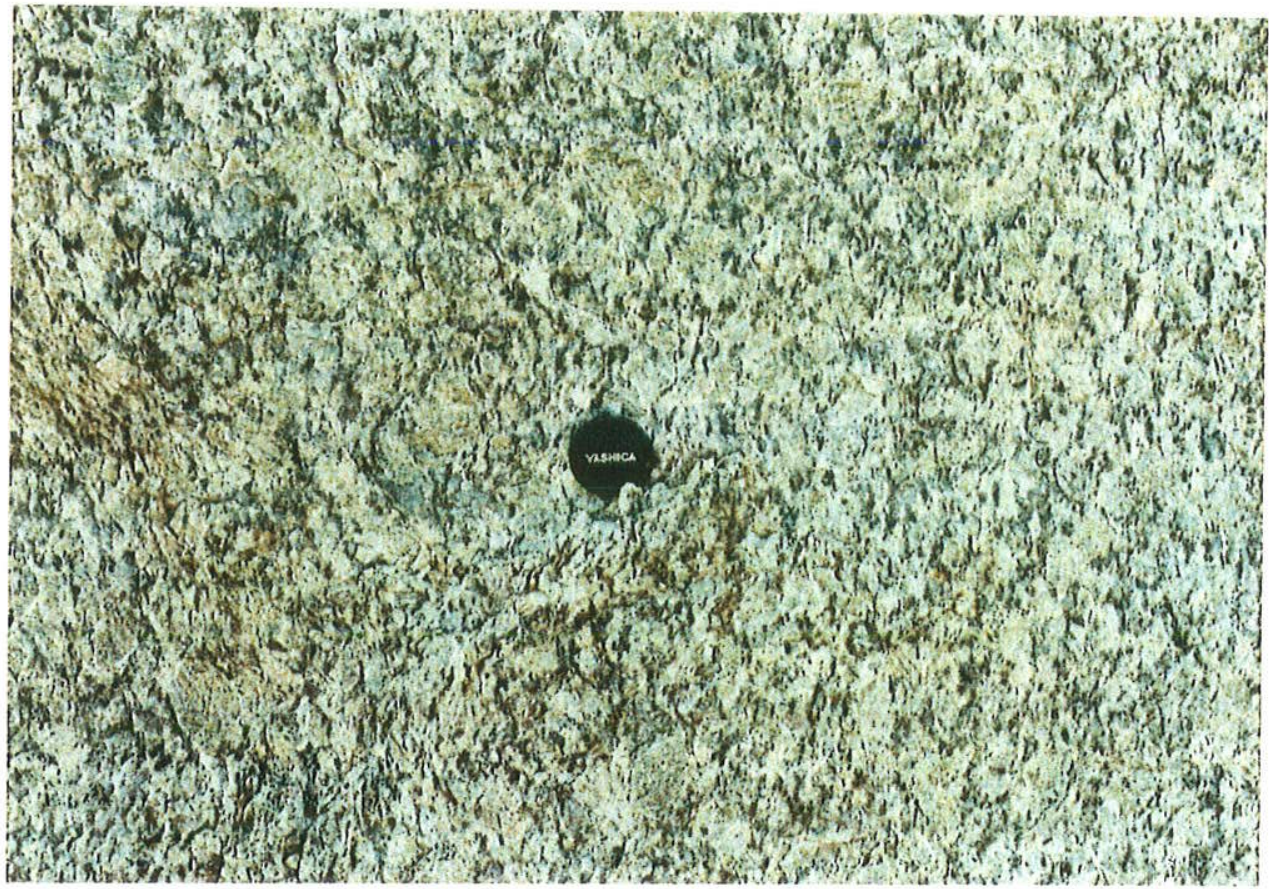

Foto 17 - Charnoquito, da Ponta das Pintangueiras, já um pouco descorado. Na foto, pela posição, não mostra muita orientação. Observar dimensão dos feldspatos.

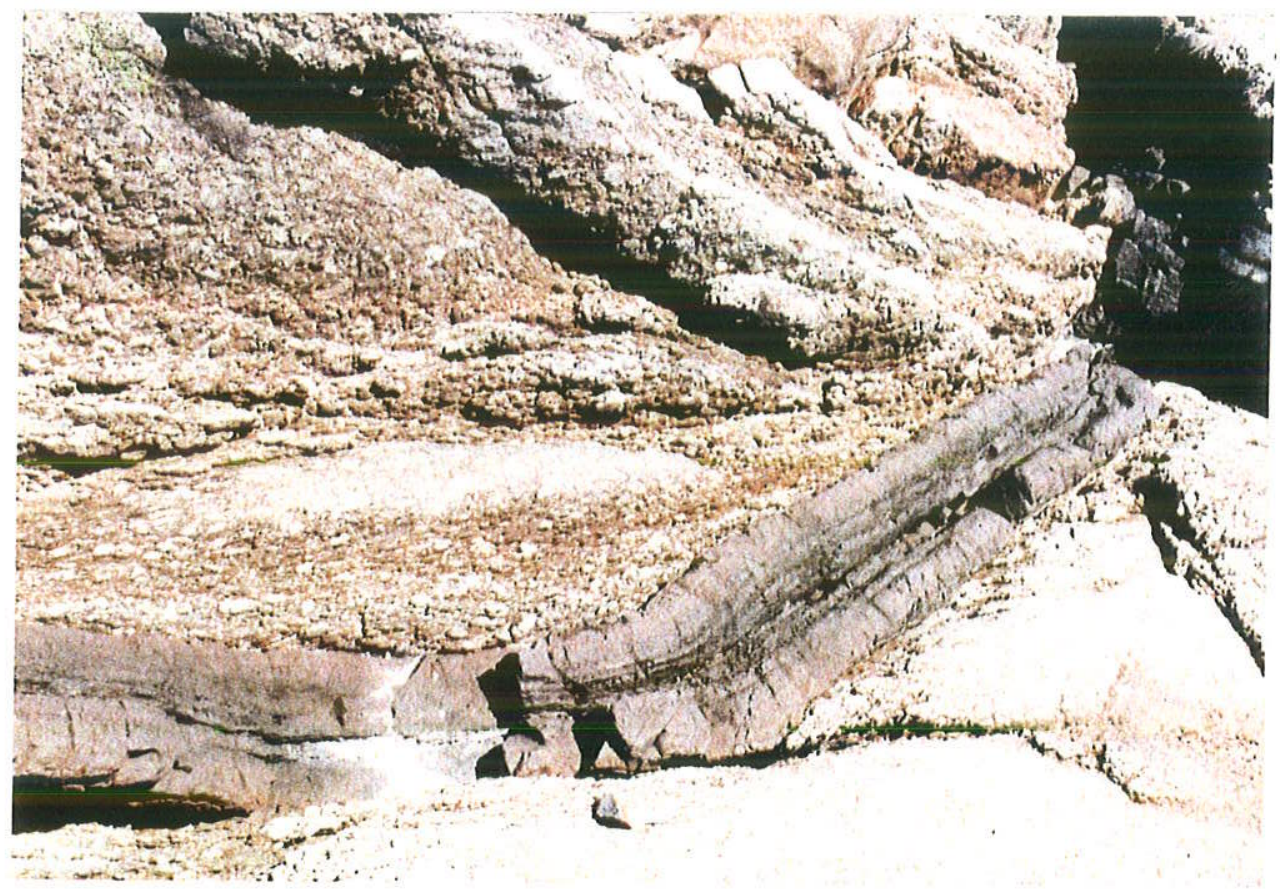

Foto 18 - Dique curvo (N25-70E) na Ponta das Pitangueiras, ponto 313. O local reúne cinco diques quase paralelos, de direção NE, que cortam um sexto dique transversal. O dique da Foto (BZ 313/5) tem 40 a $50 \mathrm{~cm}$ de espessura e está encaixado em charnoquito. 


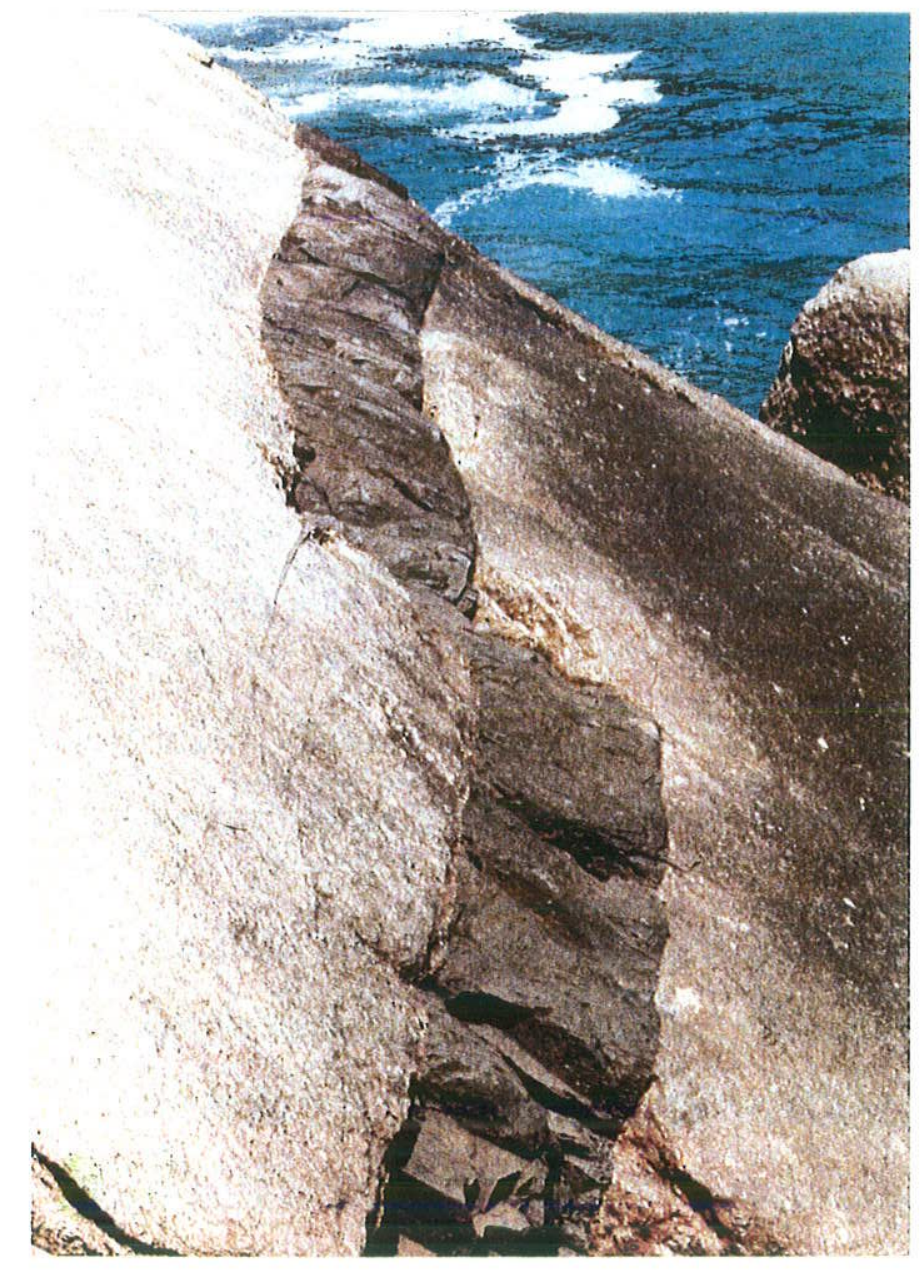

Foto 19 -Dique máfico alcalino, com 0,60-0,80 $\mathrm{m}$ de espessura, cortando charnoquito na costa sudoeste. Mostra deslocamento em "off-set" sinistral com conexão oblíqua entre os segmentos. Fraturamento ortogonal e conexão oblíqua indicam direção de dilatação, ausentes outros indicadores direcionais de tensões. O prolongamento do segmento superior (na fotografia) na forma de um minúsculo dique indica o fluxo magmático no mesmo sentido ou vertical, ou combinação. Observar discordância com a foliação do charnoquito.

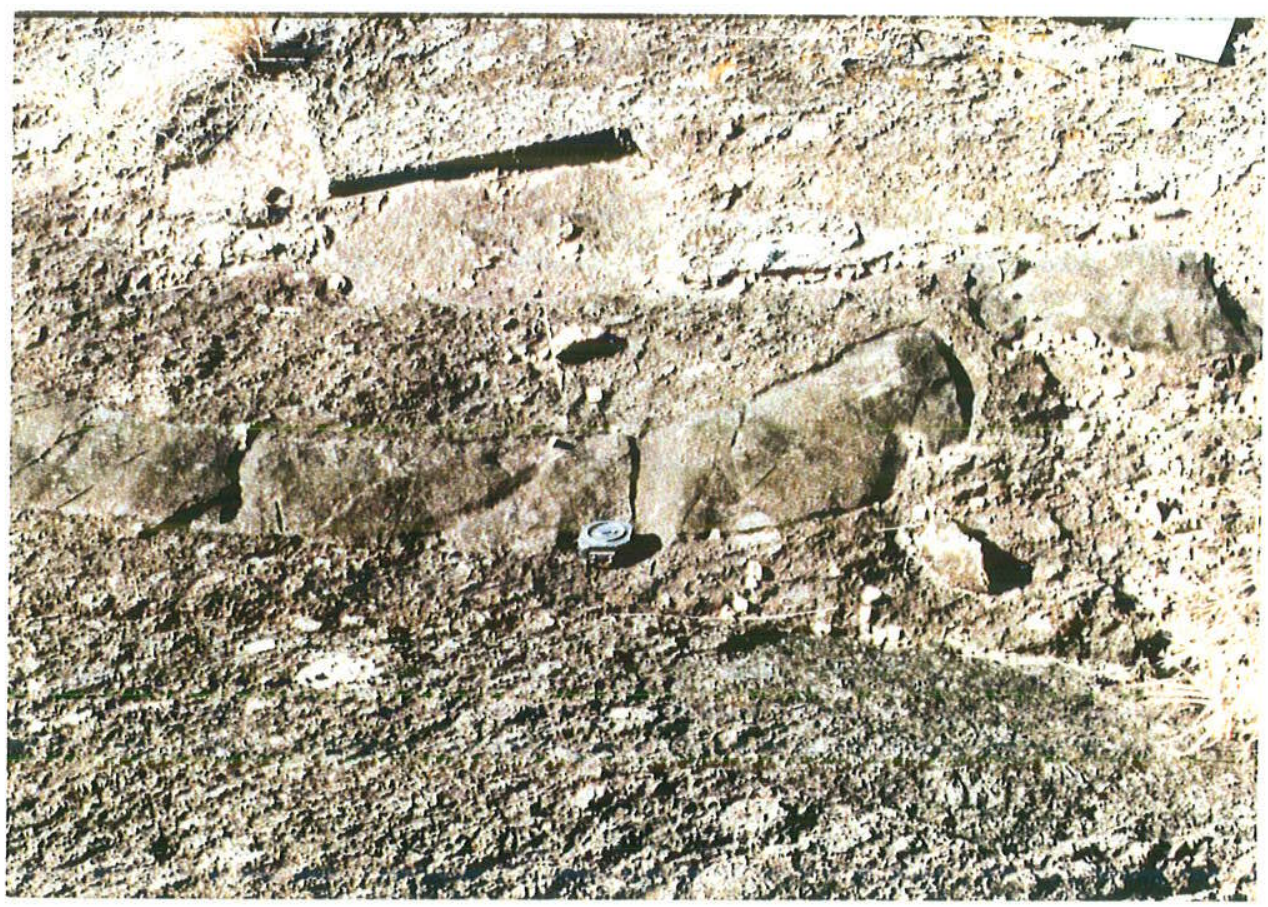

Foto 20 - Dique félsico, curvo e obliquo à foliação do charnoquito, na laje do Porto do Meio. Mostra ponte de charnoquito e terminação normal. 


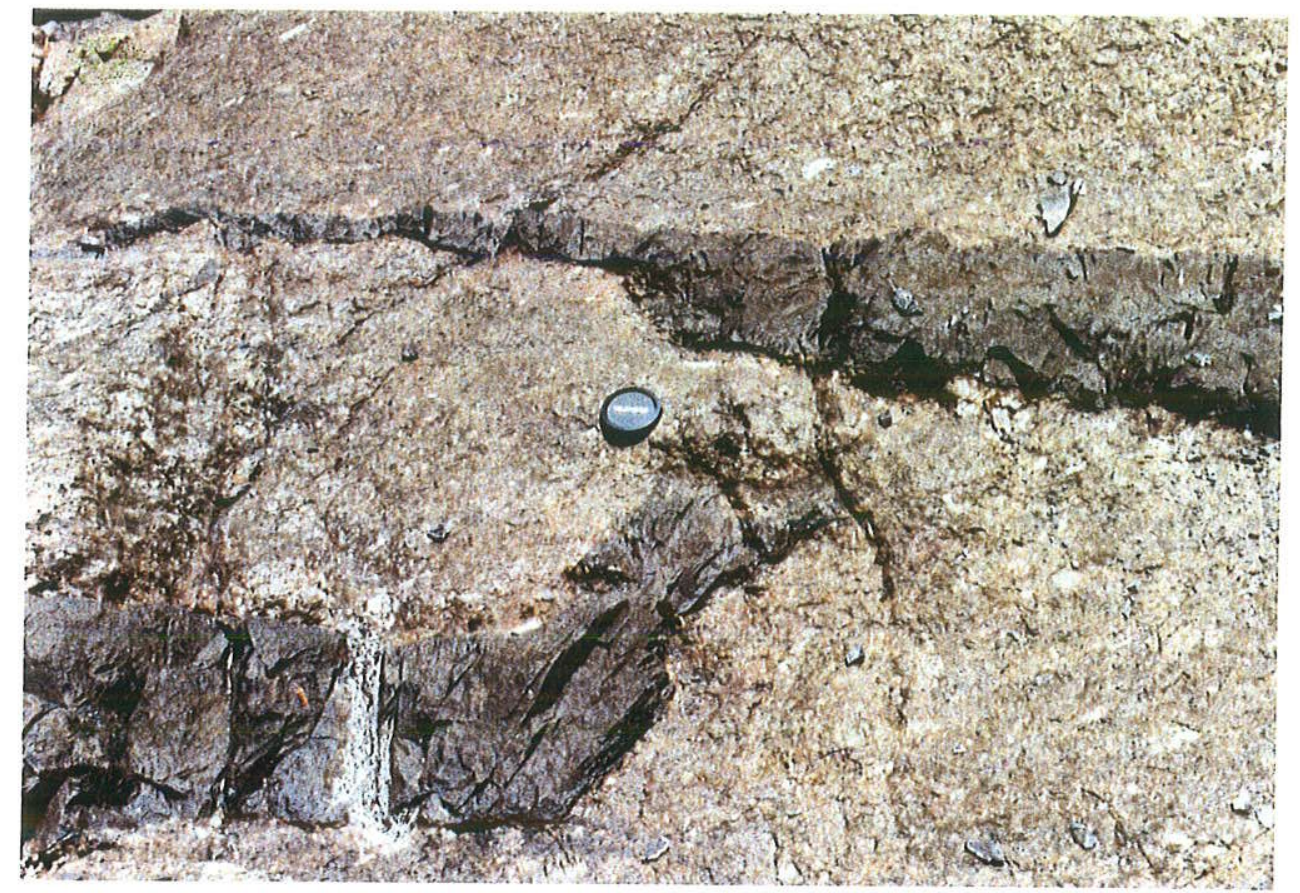

Foto 21 - Dique máfico alcalino em charnoquito, costa sudoeste. Mostra "overlap" entre os dois segmentos do dique, o superior terminando em ponta e o inferior em conexão oblíqua interrompida por ponte de charnoquito indicando deslocamento sinistral. Fraturas indicativas de dilatação. Ponta do segmento superior pode indicar o fluxo magmático.

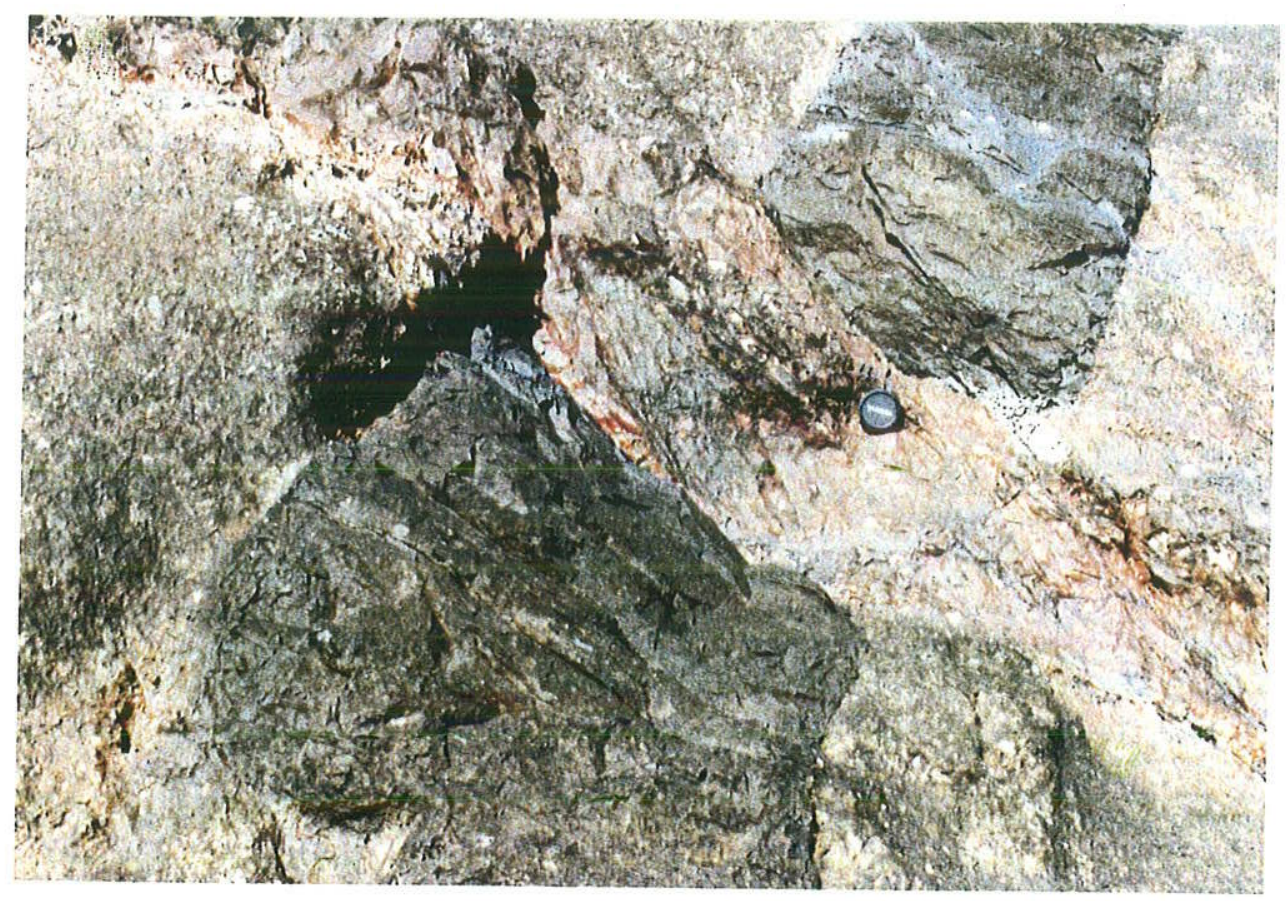

Foto 22 - Dique Bz 313/2, riolítico, cortando o dique Bz 313/1, máfico alcalino, ambos encaixados em charnoquito. 


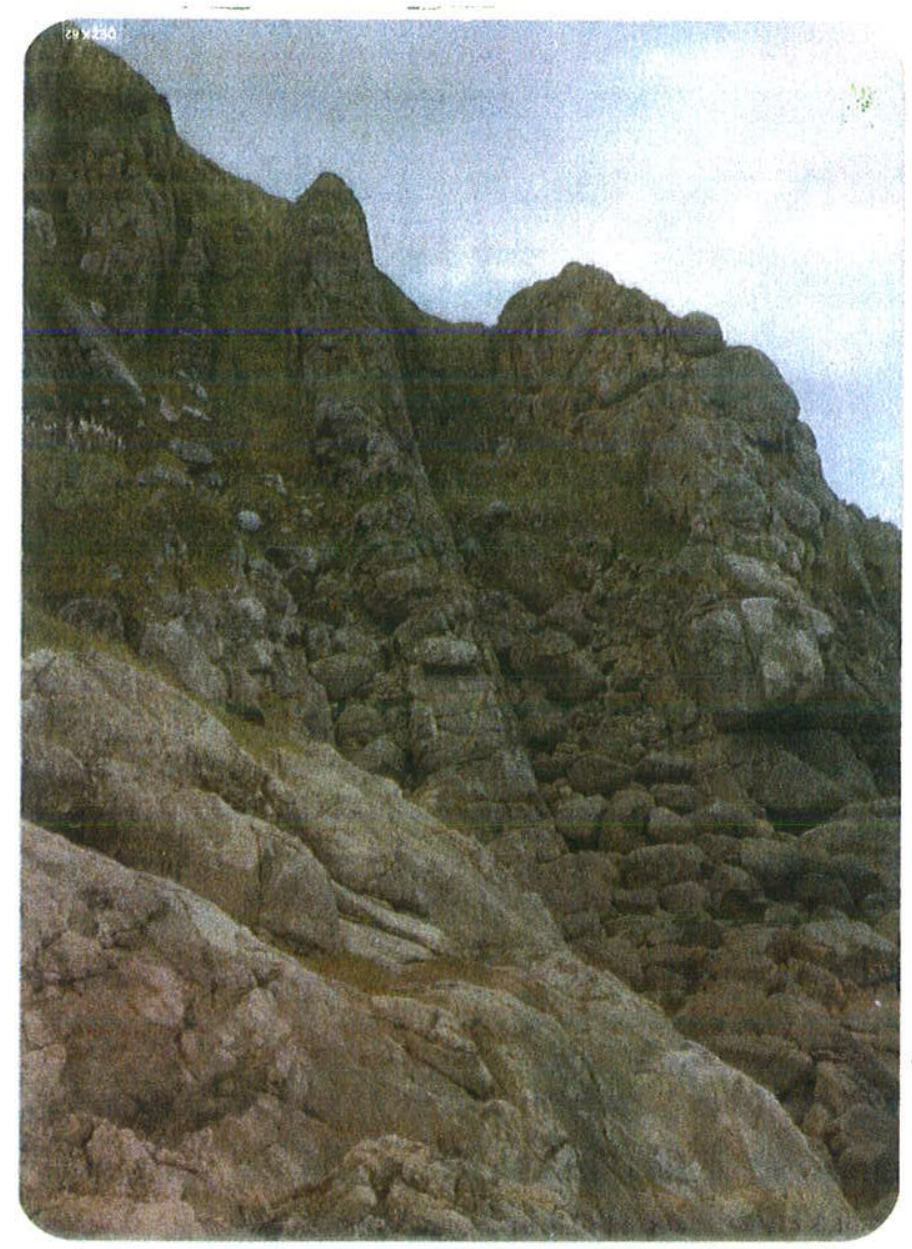

Foto 23 - Ponta Sul, ponto 191. Três diques máficos de dimensão métrica ressaltados "in situ" na topografia. Fraturamento transversal ortogonal, horizontal, e fraturamento axial, indicativos de dilatação simples, ausentes esforços e deformações cisalhantes. Em primeiro plano, encaixante sienítica, foliada e rica em xenólitos.

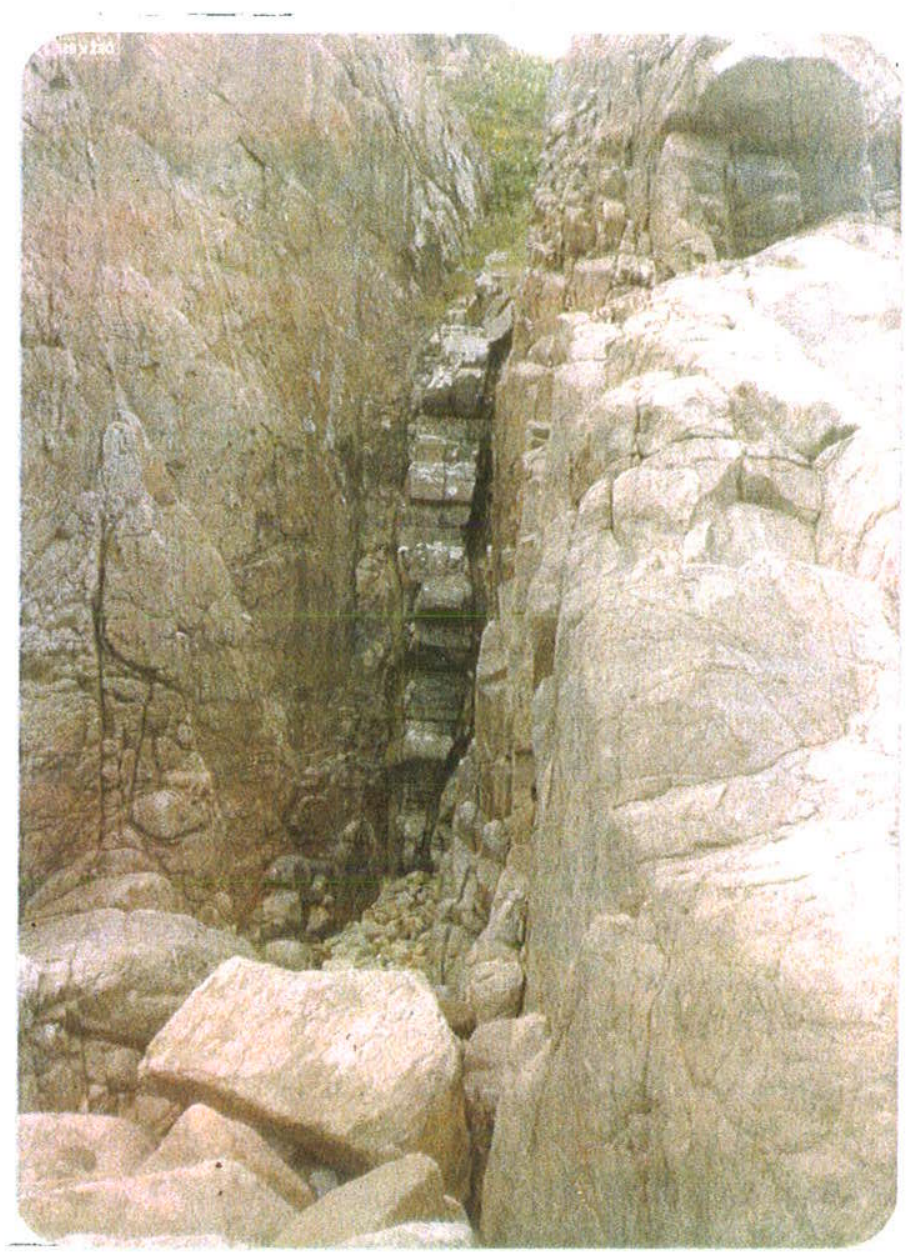

Foto 24 - Ponta Sul, ponto 191. Dique paralelo aos outros do local, agora com inversão na carac-terística erosiva. Encaixante sienítica aparece intensamente foliada, paralelamente ao dique, junto ao contato, passando de pronto a rocha mais maciça. Padrão de fraturamento igual aos anteriores. 


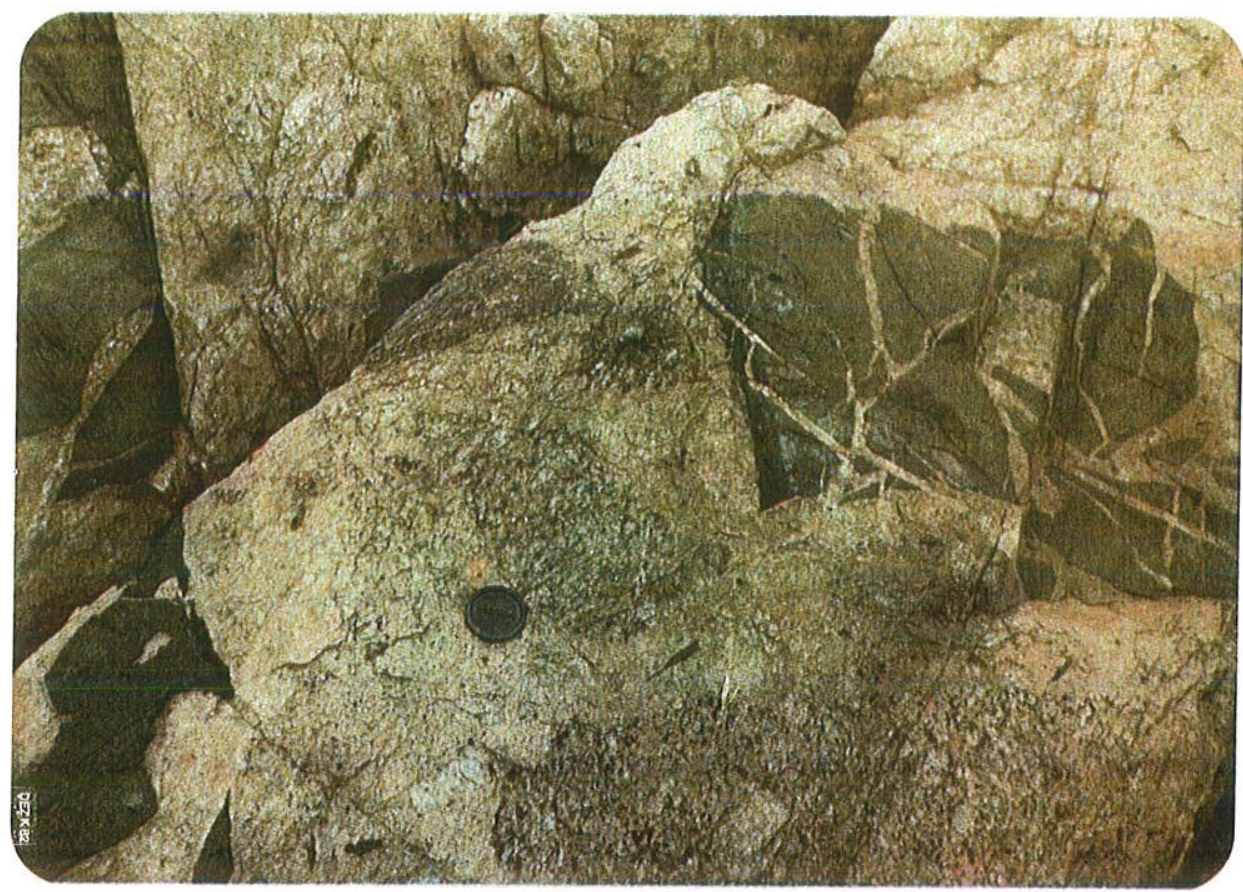

Foto 25 - Ponta Sul, ponto 191. Detalhe da laje sienítica com os xenólitos de charnoquito e rocha máfica. Notar angulosidade, fraturamento e veios de sienito no fragmento máfico, além da presença de fraturas de cisa Ihamento com deslocamento. Não aparecem injeções e tampouco angulosidades no charnoquito.

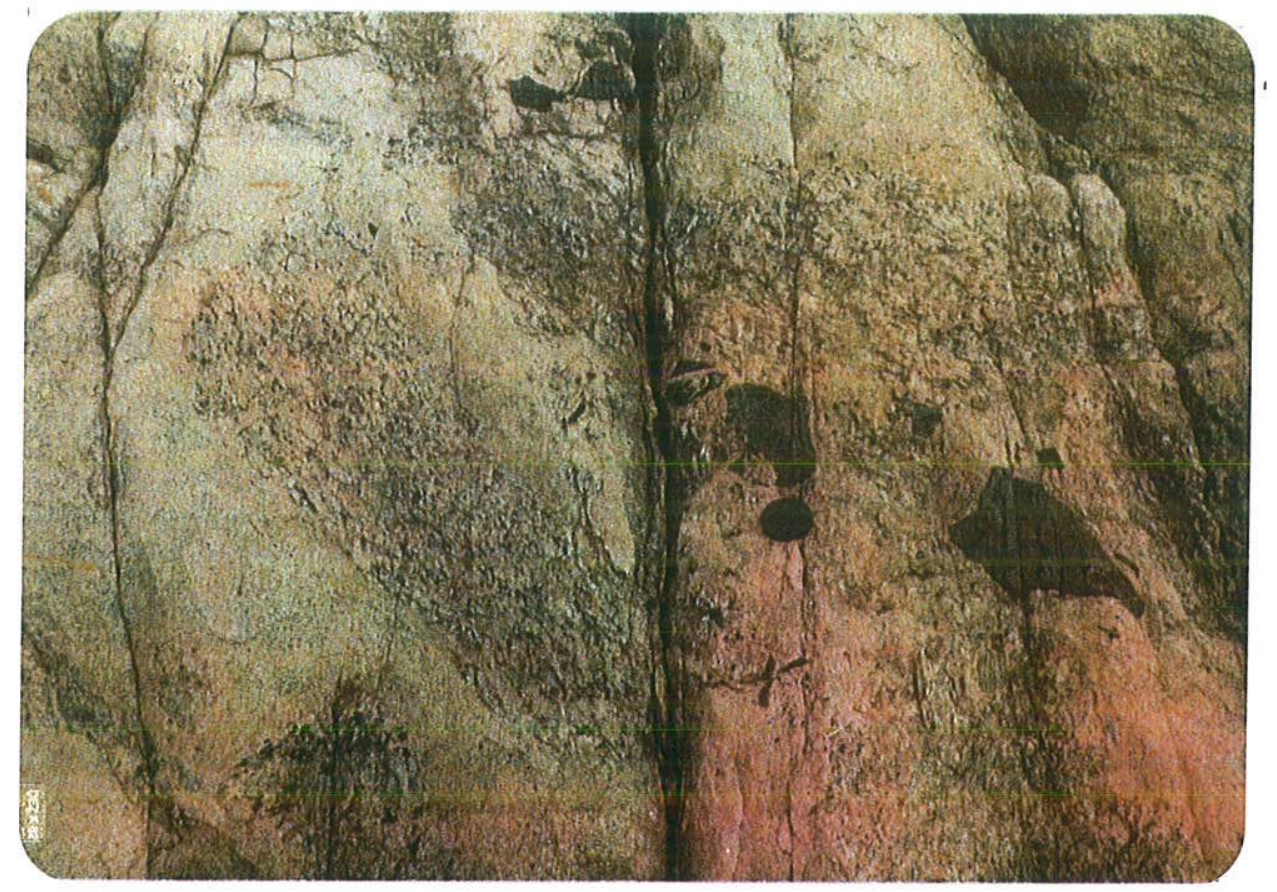

Foto 26 - Ponta Sul, ponto 191. Feições da laje ao pé dos diques anteriores em local onde estes não aparecem, dando lugar a grande quantidade de xenólitos angulosos e subangulosos de charnoquito e rocha máfica. Notar foliação/fraturamento cisalhante da encaixante sienítica. Observar falta de angulosidade no charnoquito. 
fonólitos, ocorrendo rochas fonolíticas, sieníticas e microssieníticas insaturadas somente na porção leste, próximo e além da sela topográfica da Mãe Joana. Dois diques pelo menos, de cor clara, afaníticos e composição riolítica estão presentes na porção SW, Pitangueiras e Saco do Coruja, com o último distante $10 \mathrm{~m}$ do dique máfico mais possante da llha (Fotos 27 e 28).

Os diques félsicos são menos possantes e mais comuns, embora menos notados. Os microssienitos, por exemplo, ocorrem por toda parte, ainda em maior quantidade nas porções ocidentais. É bastante grande a quantidade de verdadeiros veios de microssienito.

Entre os félsicos são observados dois padrōes: diques ou parte deles nitidamente distintos dos sienitos, intrusivos; outros diques ou mesmo extremidades daqueles do primeiro tipo, parecem diluir-se gradativamente no sienito, tanto lateral como longitudinalmente, e nesses casos não são retilineos e tampouco têm direção única (Foto 29).

A maior concentração dos diques máficos se dá na Ponta das Pintangueiras, onde são intrusivos nos charnoquitos, e costa sul até o Porto do Sul ou Ponta Sul; aqui se mostram intrusivos nos sienitos. Sempre aparecem em conjuntos paralelos de dois ou três até oito corpos em curta distância $e$, não raro, ałguns deles se posicionam transversalmente ao conjunto. Também estão presentes mais dispersos na costa norte, nos sienitos, até o extremo leste (Foto 30). Não foram reconhecidos no Saco Grande, com exceção de uma ocorrência.

Os diques máficos possuem espessura variável de centimétrica a métrica (máxima de $5 \mathrm{~m}$ ), sendo os mais possantes encontrados no Saco do Coruja (Fotos 27 e 31), na costa norte entre a Laje da Escola e a Ponta do Arpoador, na Enseada da Guanxuma e no lado norte da Ponta Leste. A maior parte apresenta espessura em torno de $0,5 \mathrm{~m}$ a menos de $1,0 \mathrm{~m}$. Suas extensões não puderam ser verificadas diretamente, mas é possivel que alguns sejam quilométricos e que cortem o corpo sienítico de um a outro lado, a julgar pelas posiçōes alinhadas e paralelas de alguns afloramentos e blocos.

É comum apresentarem estruturação interna, transversalmente simétrica. Bordas vitreas a afaniticas passam a rocha faneritica, acompanhada da presença de fenocristais de mineral ferromagnesiano e/ou plagioclásio ou de estruturas esféricas com minerais claros, brancos (ocelos), em seqüência repetida (Foto 32).

Diques máficos, possivelmente pré-cambrianos, foliados, de espessura decimétrica, aparecem intercalados aos charnoquitos não oferecendo dúvidas quanto à sua filiação. Sua aparência é típica de anfibolitos xistosos.

No ponto 3 ocorre dique decimétrico, amarrotado e rompido, porém, maciço e com estruturação interna (Foto 33). No campo, é impossivel decidir se ele é mais antigo ou pertence à seqüência de alcalinas cretácicas. 


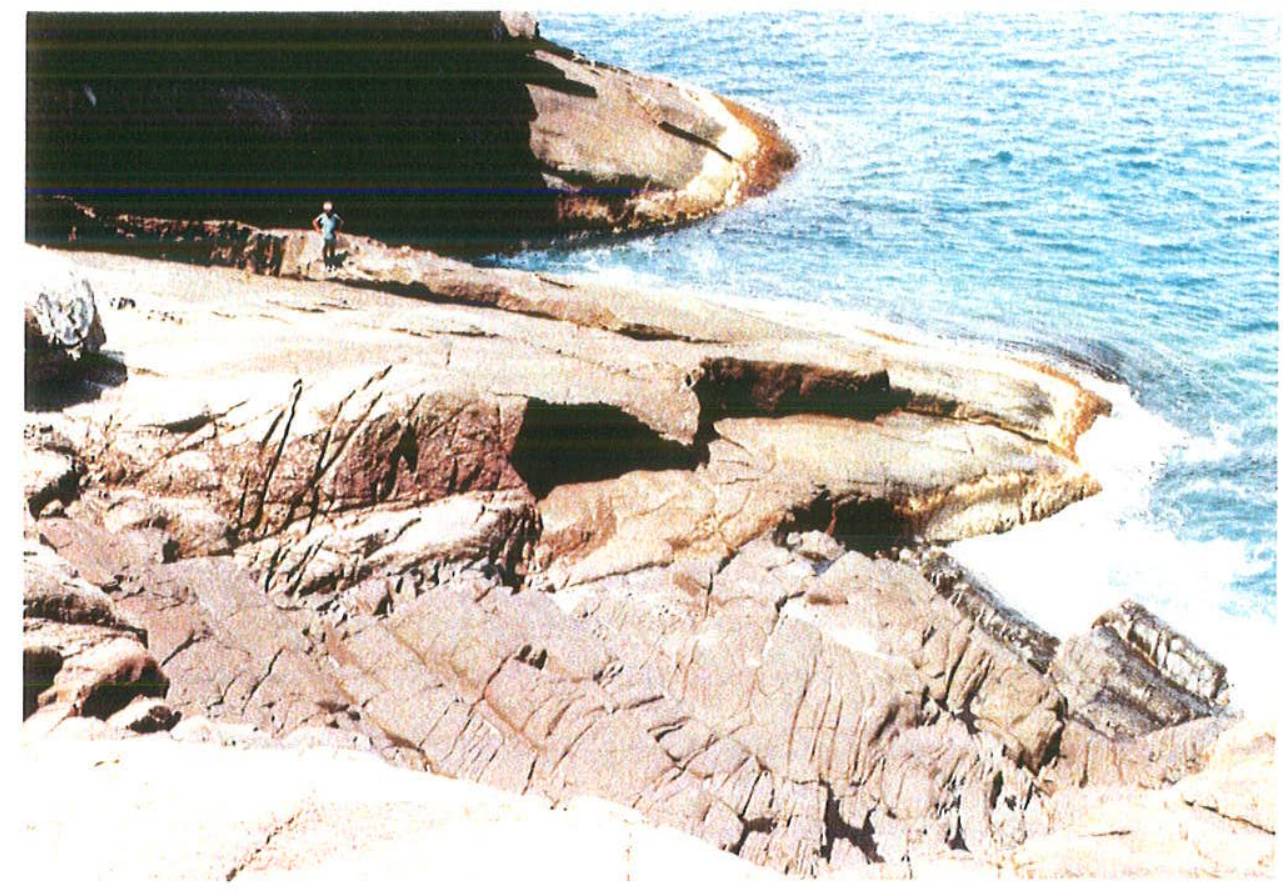

Foto 27 - Saco do Coruja (sul). O maior dique da Ilha, facilmente visivel pela cor e fraturamento. Observar que, vindo do mar, o dique deflete bruscamente para a direita. O personagem "referência" da foto está sobre um dique "riolítico", de mesma direção que o dique máfico. Ponto 326.

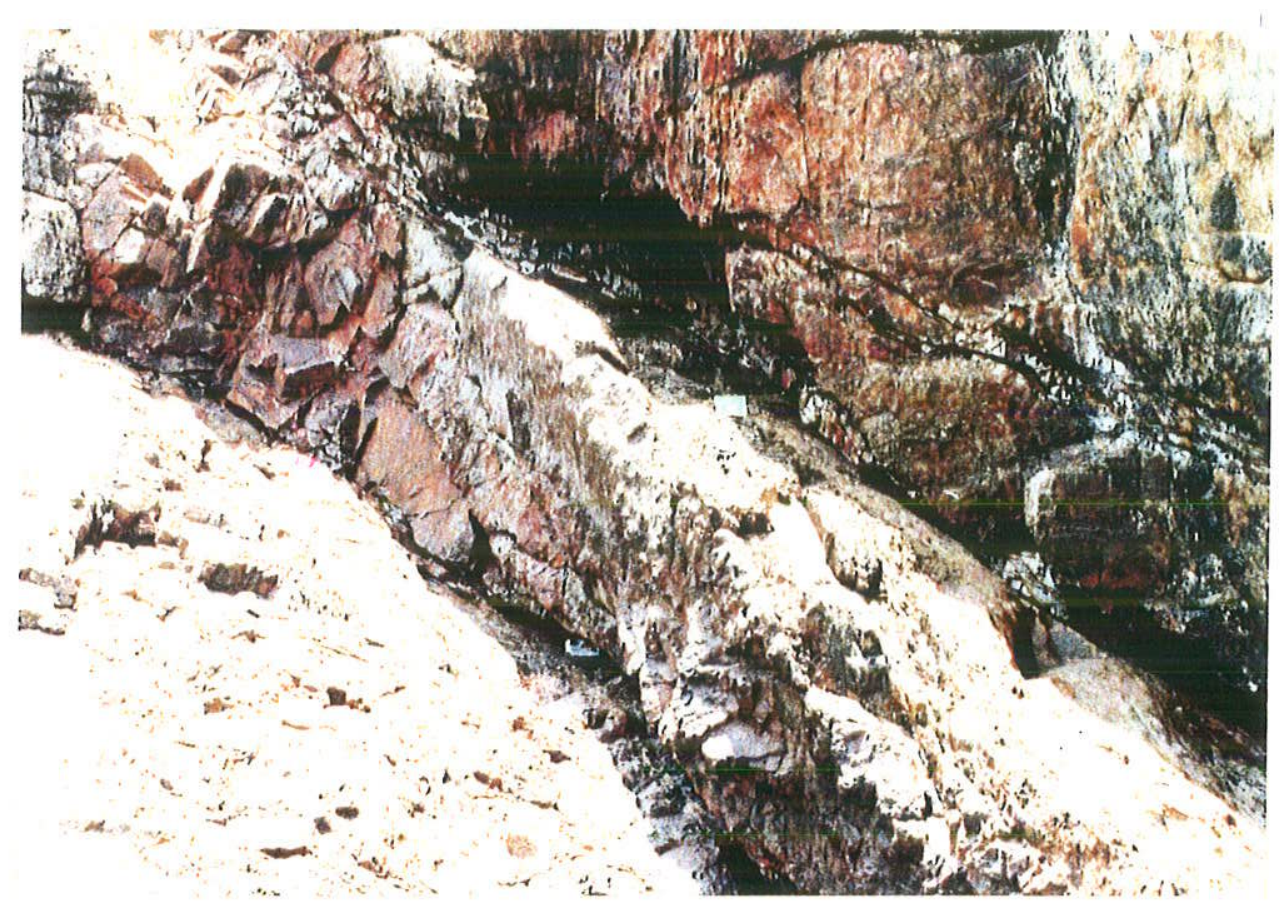

Foto 28 - Dique riolítico encaixado em charnoquito (ponto 326, Saco do Coruja). No local da foto o dique mergulha para $E$ (direita). A sombra delimita a parede vertical de charnoquito; o chão plano, esquerda inferior, de cor clara, é charnoquito. Contato vertical entre as rochas é visto à esquerda, superior. A escala é a caderneta de campo. 


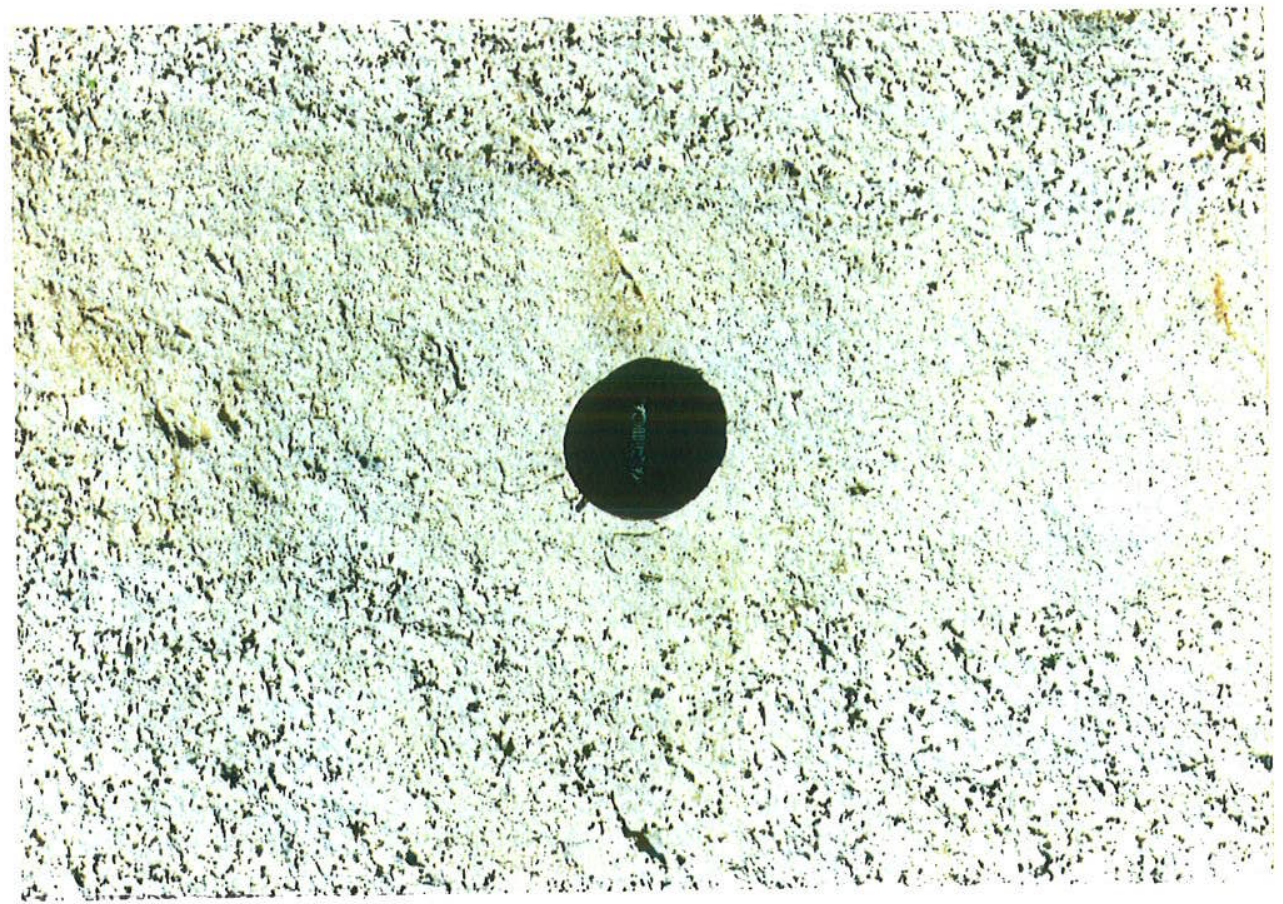

Foto 29 - Sienito de granulação grossa do tipo dominante passando de forma brusca ("cortado") para microssienito ou aplito sienítico, comum por toda a llha, com contato "diluído" e forma curva.

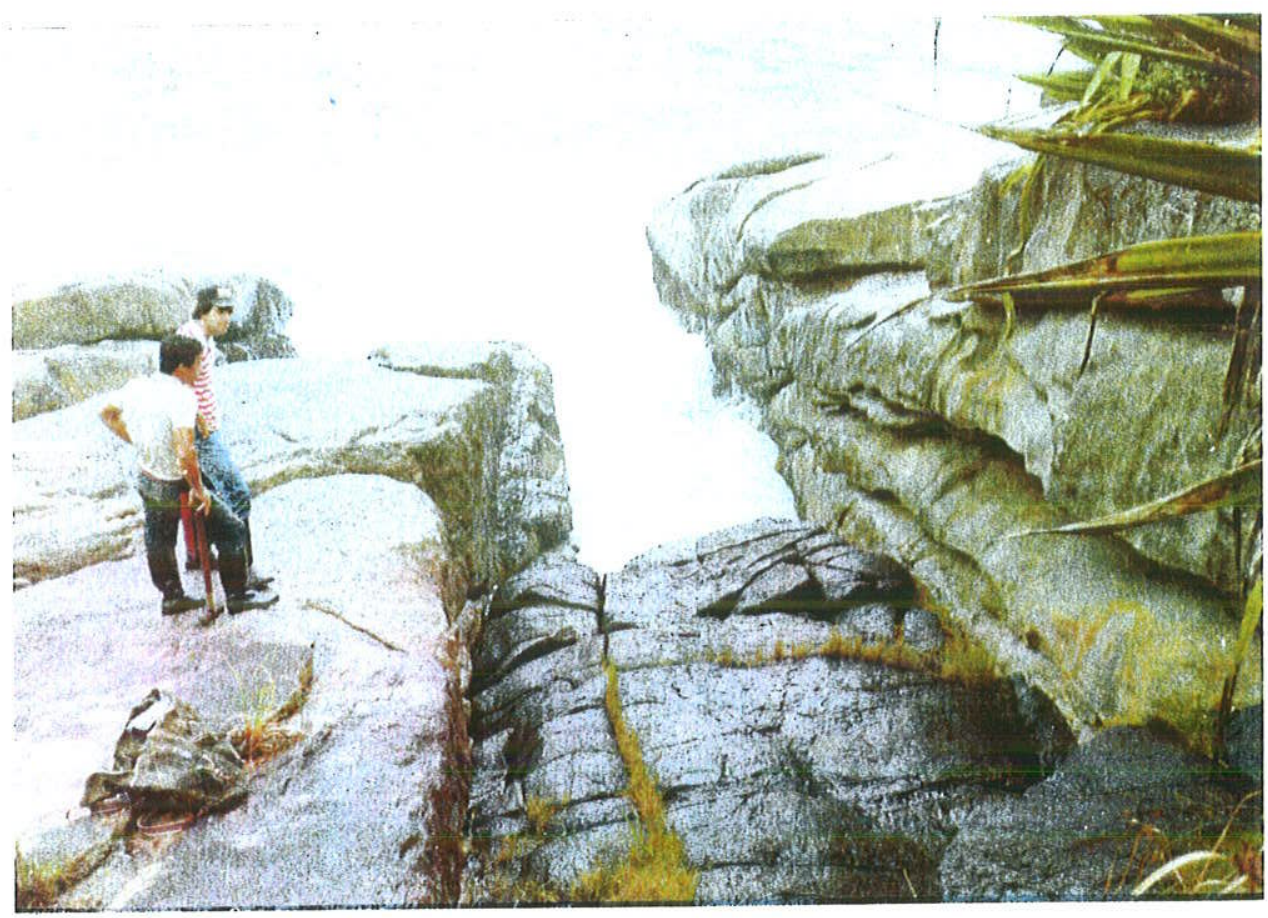

Foto 30 - Ponto 181, costa norte, proximidades da Ponta Leste. Dique de basalto alcalino cortando sienito. Mostra homogeneidade transversal, fraturamento normal e paralelo aos contatos não deformados e ausência de outros sinais de movimentação cisalhante, no dique e na encaixante. 


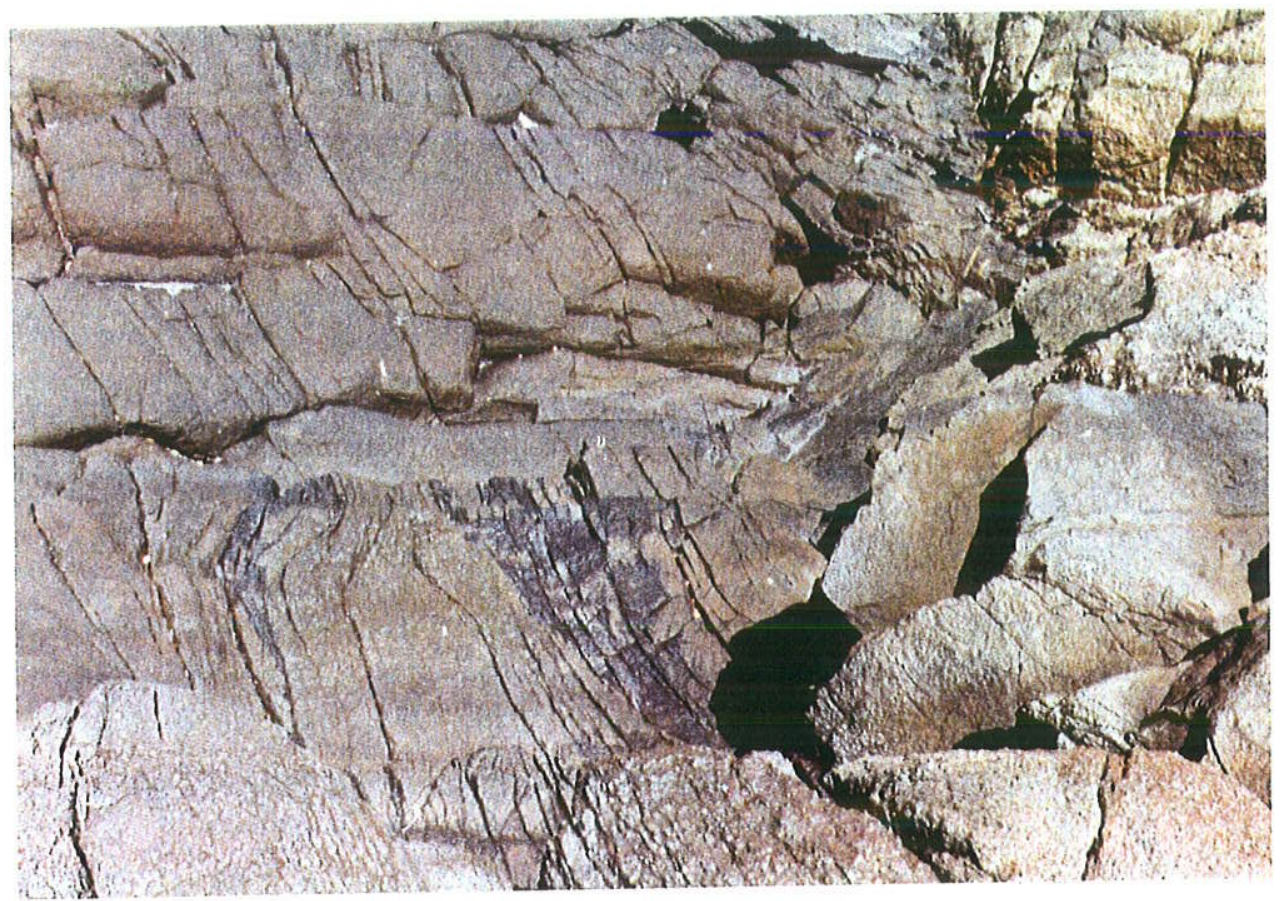

Foto 31 - Detalhe do dique do Saco Coruja, mostrando o faturamento curvo e, aparentemente, pequeno dique máfico que corta o maior, e prossegue pelo charnoquito (direita, superior). Ponto 326.

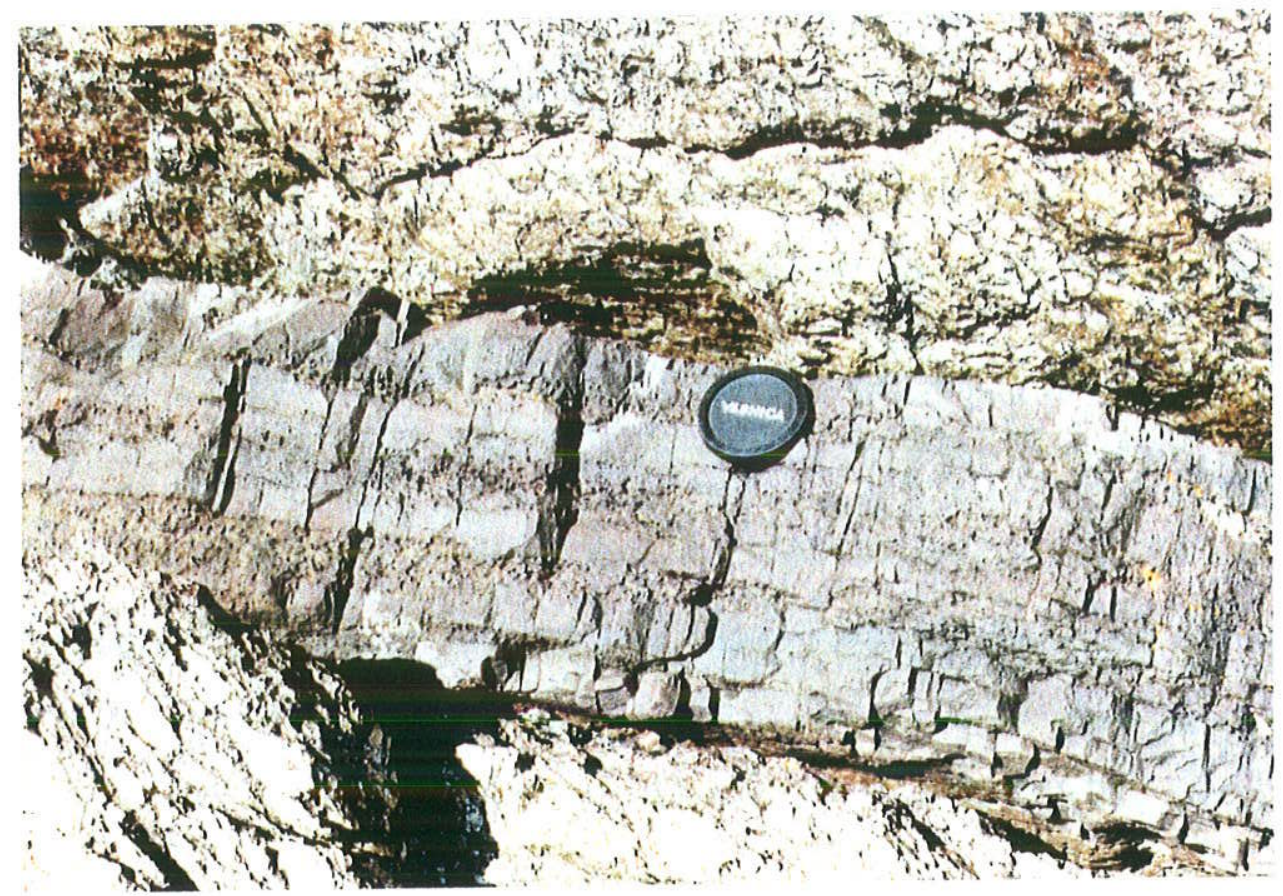

Foto 32 - Dique Bz 313/5 em detalhe. Observar alternância e simetria das partes afaníticas e maciças com as zonas esburacadas, mais erodidas (portadoras de ocelos e/ou fenocristais). 


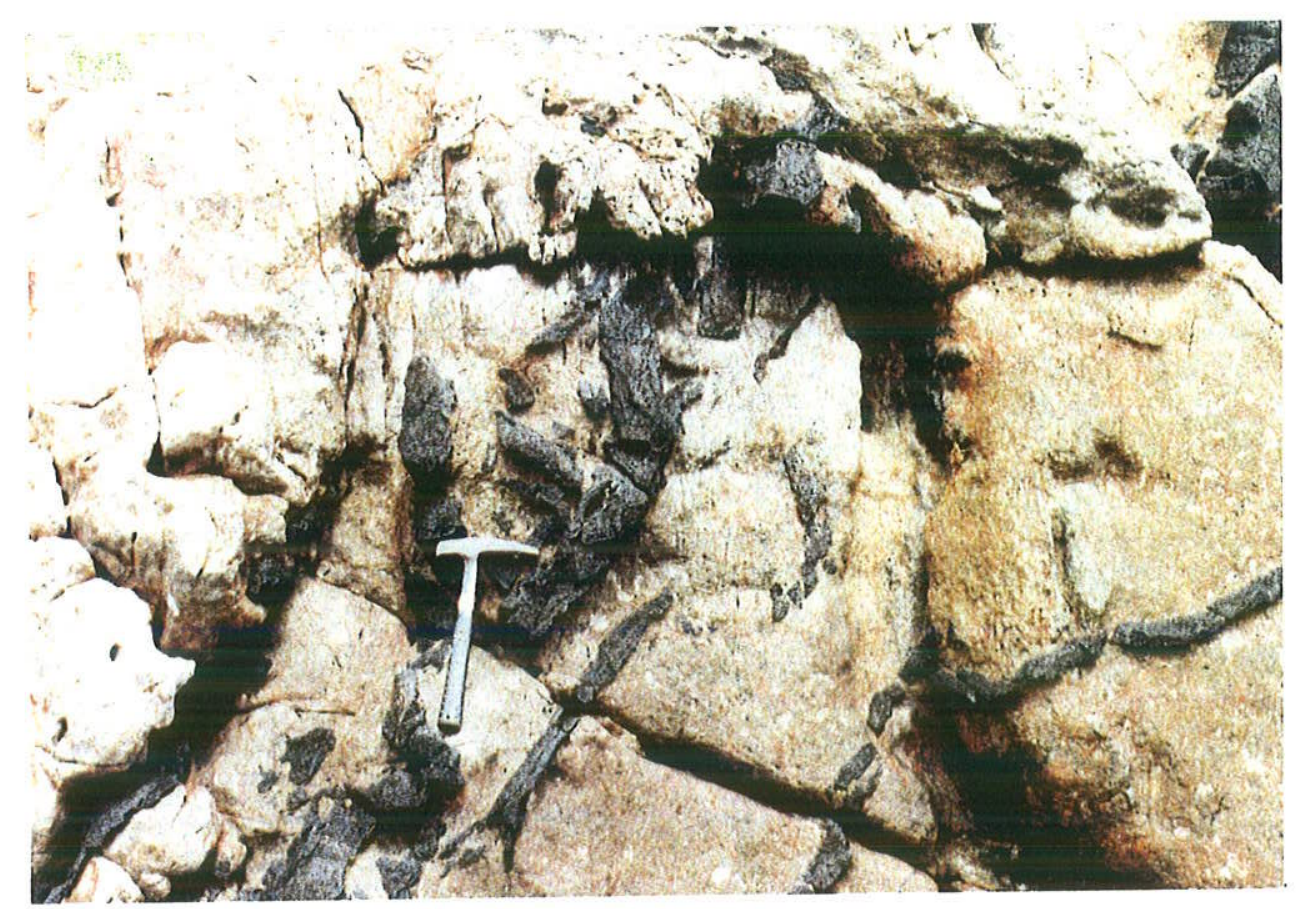

Foto 33 - Restos muito deformados e rompidos de dique máfico decimétrico, maciço. A rocha tem aspecto ígneo preservado, inclusive em secção delgada, mas a deformação e a encaixante, uma mistura e alternância de sienito e charnoquito, deixam dúvidas. Local, Pontinha. 


\subsection{Feiçöes direcionais}

Em geral, descontinuidades e anisotropias das unidades crustais, além de caracterizarem a cronologia relativa, são indicadoras de movimento e da ação de campos de força não hidrostáticos. As unidades ígneas meso-cenozóicas ou estão condicionadas a feições direcionais antigas ou foram submetidas a novos regimes de esforços simultâneos ou imediatamente posteriores ao seu alojamento e solidificação. Daí haver certa conveniência na caracterizaçāo conjunta dessas feições.

\subsubsection{Estratificação, bandamentos, foliações}

Bandamentos, embora não pronunciados, ocorrem principalmente nos charnoquitos.

Essas rochas, normalmente de granulação grossa, mostram alternância com tipos finos, até muito finos, mais foliados e laminados milimetricamente. Entre eles, também são comuns tipos porfiroclásticos. São feições de cisalhamento, concordantes com a estruturação geral NE, tal que é possivel encontrar-se variações decimétricas a métricas, desde charnoquitos íntegros até blastomilonitos de granulação muito fina. Não raro estão presentes bandas de milonitos esbranquiçados, quartzo-feldspáticos, alasquiticos. É freqüente a ocorrência desses milonitos junto à regiäo de contato com os sienitos.

Lentes de anfibolito, decimétricas, às vezes em leitos recorrentes, contínuas ou boudinadas, são também comuns nas encaixantes $e$, da mesma forma, se mostram concordantes com a estruturação geral NE.

A foliação nessas rochas é paralela ao bandamento, além de pouco evidente. $O$ aspecto gnaissóide dos charnoquitos é dado pelo paralelismo e alongamento dos feldspatos, circundados por granulometria contínua mais fina, principalmente dos máficos e do quartzo. Essa foliação, como feição de caráter milonítico, não é pronunciada devido à pequena quantidade de minerais placóides e prismáticos, com a rocha adquirindo aspecto maciço em pequena escala. Quando observada de longe, ou em grandes tratos, bem como nas rochas alteradas, ela se mostra mais visivel.

Ambas as feiçōes têm direções predominantes entre $N 50^{\circ} \mathrm{E}$ e $\mathrm{N} 70^{\circ} \mathrm{E}$, variando até $\mathrm{EW}$.

Nos sienitos, a não ser em algumas amostras de mão, não se reconheceu estratificação ou bandamento. Ele é notável somente no grande dique do Saco Grande, regular e persistente pelo menos por $1000 \mathrm{~m}$ entre os pontos 167 e 171 , com direção N65-90 $\mathrm{E}$ e mergulho $35-50^{\circ} \mathrm{N}$. Como já descrito, apresenta alternância simétrica, bilateral, de pegmatito, sienito, aplito e pegmatito com magnetita. Em algumas amostras de mão, de sienitos atípicos, distingue-se estratificação subcentimétrica de pouca continuidade, visivel como resultado da variação no teor de máficos. 
Camadas centimétricas de biotita e/ou anfibólio, verticais, persistentes e quase retilineas, ocorrem no Saco Grande, paralelas ao "grande pegmatito"; também são vistas em outros lugares e com outras atitudes. Em três lugares, dois no Saco Grande e um na Costa Nordeste, aparece estrutura na forma de um chapéu, de perfil redondo, de dimensões métricas, em que as camadas de biotita, centimétricas, são concêntricas e separadas por sienito, convergindo, em ambas as extremidades, para camada plana biotítica, que trunca as outras pelo seus lados côncavos. A estrutura lembra canais de escavação sucessivos e encaixados, superpostos por camada plana. As estruturas não guardam relações direcionais geográficas entre si.

A orientação mineral é praticamente ausente nos sienitos. Foliações foram registradas em alguns lugares e situações, como também locais com fraturamento finamente espaçado.

O fraturamento fino, denso, visivel por descoloração do fedspato e por cortar qualquer outra feição presente, não apresenta evidências de movimentação e tampouco é preenchido.

A foliação por fraturamento de cisalhamento é assinalada em alguns lugares, afetando pequenos tratos da rocha sienítica e de diques presentes.

Trata-se de foliação pouco expressiva, de cisalhamento, observável por planos de descontinuidade mecânica, fraturamento e estiramento mineral, com caráter mais rúptil que a foliação dos charnoquitos e milonitos. Às vezes nota-se deslocamento de partes das rochas, particularmente nos diques (ponto 169). Noutros lugares, foliação cisalhante está presente nas paredes encaixantes de diques, quer nos charnoquitos (ponto 312), quer nos sienitos (proximidades do Saco do Coruja); pode afetar o próprio dique e tem pequena expressão lateral. No ponto 191 ocorrem sienitos finos, em situação complicada pela presença de charnoquito e sienito de granulação grossa, encaixantes de vários diques máficos paralelos (Fotos 23 a 26). Nesse lugar, o intemperismo e a erosão fizeram realçar ressaltos e caneluras estreitos e paralelos a fraturas, simulando possivel foliação da rocha; não se observa, contudo, paralelismo e sequer ruptura dos minerais.

Os diques máficos, em geral, obedecem a dois padröes de campo. Num primeiro, mostram-se maciços e homogêneos, ocorrendo apenas variação granulométrica. No outro, os diques exibem zoneamento transversal simétrico, do centro para as bordas: aparecem bordas vítreas, rocha fanerítica, rocha porfiritica e rocha com ocelos ou amígdalas (?), dispostas em faixas regulares contínuas e paralelas às bordas. Esse padrão pode repetirmse indicando intrusäo múltipla (Fotos 18, 30-32).

\subsubsection{Fraturas, fraturas de cisalhamento, falhas}

As fraturas são a feição mais prontamente visivel nas rochas, presentes e homogeneamente distribuidas por toda a ltha. Durante o trabalho de campo foram feitas 
medidas, em pequeno número, mas sem as preocupações de análise estrutural mais profunda.

O fraturamento, a nivel de afloramentos e de forma integrada, obedece ao mesmo padräo direcional, com pequena variação para toda a liha e com o mesmo comportamento reconhecido nas fotos aéreas e no mapa topográfico. Dentro de certo intervalo de variação direcional e de freqüencia, o padräo parece ser o mesmo para todo o litoral e para as ithas adjacentes. Em Búzios não se notou diferença entre o fraturamento dos charnoquitos e dos sienitos, a menos das encostras ocidentais do Saco Grande.

O fraturamento comum, diaclasamento, apresenta maior freqüência direcional para NE e mergulho vertical ou quase. Medido com maior precisão, oscila em torno de $N 50^{\circ} E, \pm 5^{\circ}$, e tem caimento vertical. Existe outro grupamento de fraturas em torno de $N 70^{\circ} \mathrm{E}$ e um terceiro para $\mathrm{N} 40^{\circ} \mathrm{W}$, todos com caimento vertical. Pequenos desvios dessas direções são comuns. Fraturamento horizontal a subhorizontal é também muito freqüente.

A linha de costa da llha, tal como na vizinha de São Sebastião (Freitas, 1947), é fortemente condicionada pelo fraturamento $N E$, dando a essa interface aparência crenulada $e$ escalonada NE/NW. As fraturas NE formam comumente fendas abertas nos costões e costeiras, às vezes criando obstáculos quase intransponiveis, noutras vezes avançando llha adentro, com parcial soterramento, tal que o solo as cobre.

A grande totalidade dos diques ocupa fraturas NE, com pequena variação para ENE. Poucos têm direção no quadrante NW.

Freitas (1947) observou que essa direção é a mesma dos planos axiais, com caimento de 55 a $70^{\circ}$ para NW, das dobras isoclinais com as quais o pacote metamórfico se arranja. As fraturas teriam servido de conduto magmático por dilatação tensional.

É importante enfatizar que não ocorrem desvios significativos ao padrão, quando se passa do dominio charnoquítico ao sienitico.

Nos diques em geral, e de forma mais pronunciada nos máficos, é possivel observar padrões de fraturamento próprios para cada ocorrência, embora parte das fraturas afete igualmente encaixante e diques. Os padrões próprios têm grande simetria e não apresentam deformação ou assimetria com relação aos contatos, a nāo ser em raros caso. O maior ou menor desenvolvimento das fraturas varia um pouco de dique para dique. As fraturas são horizontais (vistas em cortes verticais) e ortogonais aos contatos, e verticais, estas paralelas, normais e obliquas de 30 a $45^{\circ}$ com os contatos (Fotos 19, 23, 24, 27, 30-32).

A regularidade e simetria do padrão de fraturamento dos diques e a ausência de feições de cisalhamento e deformação indicam colocação do magma em fraturas abertas e por dilatação ortogonal durante o processo, com pouca ou nenthuma movimentação longitudinal das partes.

Afora raro e pobre preenchimento carbonático visto em algumas fraturas, em um único dique, nas Pintangueiras, ocorre preenchimento por sulfetos variados, não identificados. 
São raros os falhamentos observáveis nos afloramentos. Um dos poucos reconhecidos ocorre no lado leste da Laje da Escola, colocando o charnoquito, a SW, em contato imediato com sienitos normais, a NE; essa falha possui caráter normal, com alto ângulo, e não apresenta evidências do sentido de movimento.

Embora conserve o padrão NE de fraturamento, a distribuição direcional dos fraturamentos nas encostas do Saco Grande, de forma geral semi-eliptica, é notável por sua distribuição radial, desde WNW a NW e NNW (Ponta Sul até a altura dos pontos 170, 171, 172), passando a NNE a partir da Sela da Mãe Joana, progressivamente para NE até a Ponta Sudeste.

\subsubsection{Milonitos}

Rochas miloníticas, praticamente todas cisalhadas e recristalizadas, portanto blastomilonitos, têm orientação NE.

Enquadram-se aí todos os tipos de bandas charnoquíticas ou pouco cisalhadas, ou porfiroclásticas, até blastomilonitos onde não mais se reconhece macroscopicamente o charnoquito. Não ocorrem grandes tratos de charnoquito integro, e são bastante comuns os diques encaixados no charnoquito blastomilonítico. Também ocorre blastomilonito claro, esbranquiçado, hololeucocrático, com muito quartzo, intercalado aos charnoquitos, além de comum junto aos contatos com os sienitos. Em alguns lugares, como na costa sul, a oeste da Ponta Sul, ocorrem milonitos entre os sienitos e rochas aparentemente híbridas.

Em alguns contatos de diques parece ocorrer, além de foliação por cisalhamento, alguma microbrechação por cataclase.

\subsection{Xenólitos e enclaves}

Tendo em vista as condiçōes de exposição parcial do corpo alcalino de Búzios e dada à ocorrência em grande quantidade e diversidade de lugares, os xenólitos assumem importância até certo ponto desproporcional a um estudo petrológico de corpo alcalino.

Eles estão presentes na costa sul, desde a Ponta Sul até quase o Saco do Coruja; aparecem em sienitos a Sul do Porto do Meio, isolados entre afloramentos de charnoquito; ocorrem esparsamente na Pontinha; são a feição mais relevante na Laje da Escola, excepcionalmente exposta; se mostram visiveis por toda a meia encosta NW da crista que une os cumes centrais à ponta do Lenço, diminuindo no lado reverso, restringindo-se a ocorrências máficas nos altos da Guaxuma (Fotos 13,14, 25 e 26).

Os xenólitos são de charnoquito, de rochas máficas, ou ainda, de charnoquito com 
rocha máfica. Variam em dimensão desde pequeno grupamento de feldspatos de charnoquito até blocos métricos ou decamétricos, e mesmo porções de afloramentos inteiros, junto ao que poderia ser o contato sienito e microssienito com charnoquito mais rocha máfica. É interessante notar que na Laje da Escola, no ponto 310 e na Pontinha, na passagem dos sienitos aos charnoquitos sempre aparecem os restos de diques de (meta) máficas (Fotos 13 e 14).

Outra variedade de inclusão nos sienitos poderia corresponder aos chamados enclaves microgranulares. Em geral são de tamanho centimétrico, não-angulosos a arredondados, e aparecem mais dispersos e em menor freqüência.

As aparências de campo e de amostra de mão são sugestivas que diques (meta) máficos penetraram o charnoquito, ramificando-se pelo bandamento/foliaçäo deste. É possivel que nesse momento, em condições dúcteis/rupteis, a porção proximal do charnoquito tenha sofrido fusão com formação generalizada de "back veining" (Foto 14). Posteriormente, a intrusão sienítica encontrou nesses lugares via preferencial e barreira ao mesmo tempo, tendo suas partes marginais em contato com esses conjuntos charnoquito (meta) máfica. $O$ aspecto de campo é que o sienito englobou o conjunto, dando the certa plasticidade e venulando as (meta) máficas e os charnoquitos.

Mais distantes dos contatos imediatos ocorrem xenólitos de charnoquito, que gradativamente diminuem de tamanho e se tomam mais arredondados, sem mostrar contudo associação com as máficas. As (meta) máficas, por sua vez, podem aparecer isoladamente, como já descrito, em conjuntos de blocos empilhados, com a forma de muros, como se fossem restos "in situ", culminando na situação do ponto 191, em que a ocorrência não poderia ser tomada como restos xenolíticos, mas de verdadeiros diques. Nos casos de máficas isoladas, o modelo deve ser outro e as rochas envolvidas possivelmente diferentes.

\subsection{Formas e dimensöes dos corpos alcalinos}

Os corpos alcalinos da lha de São Sebastião possuem forma elíptica, com eixos oscilando entre 10 e 7-8 km e relação entre eles variável entre 1,2-1,4:1. Os corpos menos erodidos, como os da Serraria e de São Sebastião, têm áreas em torno dos $65 \mathrm{~km}^{2}$ e eixos

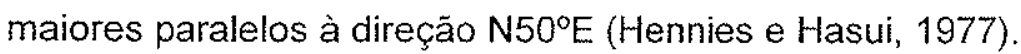

A llha do Monte de Trigo também apresenta forma elíptica, com eixo maior na direção N 50-60 E alcançando $1,5 \mathrm{~km}$ e eixo menor com $1,1 \mathrm{~km}$, além de razão em torno de 1,36:1. Sem dúvida, ela representa a porção emersa mínima de intrusão maior, a julgar pelas dimensões dos corpos alcalinos vizinhos e da total ausência de evidências de proximidade de contatos com as encaixantes do embasamento (Coutinho e Melcher, 1973).

A llha de Vitória seria um corpo alcalino de forma circular, com centro virtual submerso, 
a oeste, indicado pela intersecção dos diques radiais, curvos nas porções distais e efetivamente visitados e medidos, e pelas curvas isonormativas, concêntricas de $Q$ e Ne. A mais supersaturada $(Q=2)$ situa-se a $3,8 \mathrm{~km}$ do centro, enquanto que a curva de $Q$ e $N e=O$, que envolve praticamente todo o conjunto de ithas, está localizada a $2 \mathrm{~km}$ na direção $N 50^{\circ} \mathrm{E}$. Se se admitir proporção média entre os eixos entre 1,2 e 1,4 (média de 1,3), o raio da curva $\mathrm{Q}=\mathrm{Ne}=\mathrm{O}$, na direção do semi-eixo menor, seria de aproximadamente $1,55 \mathrm{~km}$. A forma elíptica dessa llha pode ser verificada pela sua convexidade para leste e explicada pelo curvamento das extensōes dos diques radiais, assim como a compartimentação em duas envoltórias isonormativas a partir de $\mathrm{Ne}=6$.

As curvas batimétricas das proximidades das llhas de Búzios e Vitória não são altamente elucidativas, mas indicam irregularidades e quebras no padrão batimétrico, compativeis com extensões submersas desses corpos (Fig. 5).

É possivel que Búzios represente a parte periférica de corpo alcalino muito maior, de forma também eliptica, com eixo maior para $N 50^{\circ} \mathrm{E}$, alinhado e paralelo às outras ocorrências. Assim como Vitória foi erodida externamente, tomando forma convexa voltada para leste, com um núcleo predominantemente saturado a insaturado, em Búzios ocorreu o inverso: o Saco Grande representaria a configuração atual, semi-elíptica, do corpo que se estenderia para SW, erodido pelo Sul e Leste, isto é, da borda meridional ao centro e deste para norte e nordeste. As curvas isonormativas caracterizando as rochas mais insaturadas correspondem, mais ou menos, aos valores quase iniciais de Vitória.

São factíveis valores de 7 e $9 \mathrm{~km}$ para os possiveis eixos do corpo de Búzios, levandose em conta os elementos apontados, mais a presença da liha Somítica $1 \mathrm{~km}$ a Sul. Assim, na realidade, as rochas sieniticas estender-se-iam para N, NE, E, SE, S e SW. O centro virtual, presumido, estaria a pelo menos $2 \mathrm{~km}$ a Sul do centro do Saco Grande.

$E$ É interessante notar o quase perfeito alinhamento dos corpos alcalinos do Mirante, de Búzios e de Vitória.

\subsection{Sequência cronológica das rochas}

As rochas encaixantes são charnoquitos, notoriamente atribuídos ao Pré-cambriano, e contando com datações radiométricas variadas.

As grandes massas de associaçōes charnoquito-(meta)máfica, em contato e envolvidas por sienitos finos, ricos em xenólitos, indicam que as (meta) máficas penetraram os charnoquitos, sendo o conjunto envolvido pelo material sienítico. Este último processo aqueceu suficientemente as rochas e, ao mesmo tempo, mobilizou-as mecanicamente a ponto de levar à formação de "back veining" do charnoquito nas máficas e dar plasticidade ao conjunto, inclusive 
com o desenvolvimento de vênulas. Não se pode descartar, contudo, que "back veining" já houvesse ocorrido previamente.

Sienitos finos, geralmente quartzosos, e sienitos de granulação grossa mostram relações duplas: junto aos contatos, os finos representam faciologia de contato e serviram de "lubrificante" termal para o alojamento dos segundos. Em outros locais, formam bolsões e diques aparentemente mais tardios.

Longe dos sienitos, os charnoquitos são cortados por máficas não diabásicas, quase sempre orientadas para NE. Ocasionalmente, ocorrem no quadrante NW, sendo então anteriores e cortadas por diques NE. Os diques de microssienitos com quartzo ou quartzo micro sienitos dispõem-se sempre para NE, concordantemente com a gnaissificação.

Dentro dos sienitos ocorrem diques máficos e félsicos. Alguns diques máficos podem ser simplutônicos, uma vez que aparentemente não têm continuidade. Os diques felsicos, afora os microssienitos mencionados, reúnem rochas feldspáticas claras a escuras, com atitudes diversas, ocupando posições NE ou espalhando-se (com poucas medidas) pelos quadrantes NE e NW. São claramente posteriores aos sienitos.

Outras características tardias são a formação de miárolos, bolsões pegmatóides, diques aplíticos, veios nefelínicos, veios de quartzo e de feldspato, raros preenchimentos de fraturas, além das alteraçōes minerais visíveis microscopicamente.

\subsection{Consideraçôes parciais}

Preliminarmente, é possivel somente com os trabalhos de campo extrair-se alguns fatos objetivos relativos à geologia de Búzios, e tecer alguns comentários sobre as informações disponiveis.

Parece claro que o exame das rochas da llha acaba se revestindo de caráter particular: na realidade trabalhou-se com pequena fatia periférica do corpo, e daí contatos e xenólitos assumirem relevância.

Ao colocar de lado os blocos e matacöes de meia encosta, Björnberg e Ellert (1955) deixaram de registrar grande número de observações. Há toda uma distribuição complexa desses blocos que complicam o mapeamento, mas não impede que se tirem informações. Dessa forma, o grande número de diques de micro quartzo sienitos e os complexos afloramentos xenolíticos de contato foram omitidos por aqueles autores. As dimensões e freqüencia dos diques fizeram com que fossem tomado por um terceiro corpo de nordmarkito, inexistente. $E$ os xenólitos são apenas referidos, quando seu exame revela a anterioridade das (meta) máficas com relação às alcalinas.

A llha Somítica não é citada e sequer amostrada, inexistindo qualquer referência à 
forma e tamanho do "stock" da llha.

O mais importante: é dificil definir contatos entre faciologias de rochas, denominadas de forma precisa nordmarkitos e sienitos, tal como no mapa dos autores citados.

Também não existe referência ao bandamento/dique bandado do Saco Grande, feição de grande importância litológica e estrutural.

A seqüencia de rochas corresponde à encontrada, exceção feita aos diabásios típicos, não reconhecidos neste trabalho.

Foi possivel, no campo, estabelecer as litologias aproximadas e a sua sequência cronológica:

1. Embasamento Precambriano charnoquítico, milonítico.

2. Diques máficos, básicos [(meta) máficas xenolíticas].

3. Rochas sieníticas finas e de granulação grossa, com e sem quartzo, este de distribuiçăo e teor variável, forma recorrente e pouco regular. As rochas com menos quartzo, chegando até as com nefelina normativa, aparecem no Saco Grande e no extremo leste da lilha, a partir da Sela da Mãe Joana.

4. Sincronica e posteriormente às alcalinas, diques máficos alcalinos e microssienitos.

5. Diques alcalinos em geral, em particular, félsicos.

Atividades tardias, ligadas a esses diques e restritas à porção leste, vieram a formar veios pequenos e raros, com nefelina. Atividades também tardias, talvez ligadas aos processos tectônicos cisalhantes, deram origem a veios de quartzo.

Nas proximidades e nos contatos, fica claro que os sienitos com xenólitos têm granulação fina e cor verde. Pelo menos no campo e nesses locais, as variedades mais finas parecem anteceder às de granulação mais grossa. Também é clara a natureza dos xenólitos e o seu comportamento térmico, levando-se em conta suas dimensões, angulosidade e arredondamento.

O exame bibliográfico mais o trabalho de campo permitem estabelecer a grande similaridade entre os corpos sieníticos de Búzios, Vitória e os da llha de São Sebastião, bem como o seu relacionamento, espacialmente muito próximo, com as grandes estruturas vizinhas comuns.

No entanto, parecem ocorrer algumas discrepâncias com relação aos diques, no que tange aos tipos litológicos e suas freqüências e idades radiométricas. 


\section{CAPÍTULO 6}

PETROGRAFIA

Presentemente, é tal a disponibilidade e a exigência de informações sofisticadas que a "numeralogia" química e isotópica parecem ter reduzido as outras etapas da petrologia a um conjunto de informações de pouca a nenhuma importância. Tal situação não é a desejável, uma vez que não conduz a melhores resultados. Talvez, unicamente, a resultados mais rápidos e mais matemáticos, ou paramétricos.

Neste trabalho, é dada bastante importância à parte petrográfica. Se os resultados não são completos, e nem totalmente satisfatórios, é porque a situação geológica, em si, é complicada e, talvez, nunca tenha sido abordada da forma adequada em outros trabalhos, havendo certa lacuna de elementos informativos de situaçóes semelhantes, e mesmo de pontos de vista mais teóricos e genéricos.

Compartimentou-se a petrografia da forma que parece a melhor. Em primeiro lugar, são tratadas as rochas encaixantes, com algum detalhamento, seguidas das sieníticas "lato sensu", plutônicas. Os tipos hipoabissais, os diques, foram grupados em félsicos e máficos. Algumas feiçōes litológicas merecem destaque à parte, o que torna os itens anteriores um pouco menos pesados. Assim como no capítulo anterior, este também é encerrado com alguma discussão sobre as informações reunidas.

\subsection{Informações prévias}

Em 1989, e após 20 anos de consultas a petrólogos de "reconhecido saber" do mundo inteiro, a subcomissão da Sistemática de Rochas Ígneas da IUGS concluiu sua proposta de classificação para essa tipologia (Le Maitre, 1989). Nela, o fundamento mais importante é a composição mineralógica presente na rocha, descartadas as alterações evidentes. O papel classificatório da composição quimica e normativa ficou restrito àquelas rochas de granulação muito fina a vítrea, de impossivel identificação mineral.

Tanto quanto permitido, procura-se aqui levar em conta essas recomendações.

Ao mesmo tempo, utilizou-se o seguinte apoio bibliográfico, particularmente, quanto aos aspectos e vocabulários descritivos: Tröger (1979) e Deer ế al. (1993) para a caracterização mineral; Smith e Brown (1988) para as informações de detalhe sobre os feldspatos; Williams et al. (1970), Rock (1991), Mackenzie et al. (1993), Bard (1980) e Wager (1968), tanto para a caracterização textural, quanto para interpretação. A nomenclatura das rochas miloniticas é, em linhas gerais, baseada em Higgins (1971) e Sibson (1977).

$\mathrm{Na}$ medida do possivel, as descrições sāo feitas de forma objetiva, alheias as idéias 
interpretativas que se seguem.

\subsection{As rochas encaixantes}

Os tipos encaixantes, largamente dominantes, são os charnoquitos, na verdade variáveis para charno-enderbitos (hiperstênio granodioritos), enderbitos (hiperstênio tonalitos) e mangeritos (hiperstênio monzonitos), todos de acentuado caráter gnáissico cataclástico, e predominantemente de granulação grossa a muito grossa. Leitos contínuos ou não, com largura decimétrica a métrica, mostram rochas escuras, tomadas no campo como anfibolitos, e rochas claras, finas de aspecto sacaróide, respectivamente, hiperstênio dioritos gnáissicos e hiperstênio plagioclasitos gnáissicos. Finalmente, em meio às encaixantes, ocorrem as rochas cataclásticas, desde proto blastomilonitos a blastomilonitos, porfiroclásticos ou não.

\subsubsection{Rochas charnoquitóides}

São rochas invariavelmente escuras, verdes a pardacentas, às vezes equigranulares, de granulação grossa a muito grossa, com feldspatos tabulares/retangulares de até $15 \mathrm{~cm}$ ou mais, que exibem subparalelismo. Os grandes cristais de feldspato, sempre deformados e com superficie de clivagem ondulada, são emoldurados por agregados de granulação mais fina, que incluem os máficos, nunca ultrapassando os 20 a $30 \%$. As porções de granulação mais fina desenvolvem-se de forma contínua ou lenticular, mantendo certo subparalelismo, o que dá ao conjunto com os grandes cristais feldspáticos uma aparência gnaissóide. Em Búzios, năo foram observados charnoquitos "lato sensu", com aspecto plutônico (Le Maitre, 1989). Na liha, essas rochas, afetadas com maior ou menor intensidade por esforços de cisalhamento, vão, no geral, diminuindo gradativamente de granulação, enquanto aumentam as faixas intergranulares de granulação mais fina. Com o crescimento da intensidade do cisalhamento, mantendo ainda a rocha mineralogia dos charnoquitos e variantes, como também algumas feições texturais, passam elas a charnoquitos porfiroclásticos (Foto 34). E, a partir daí, evoluem para as rochas blastomiloniticas. Essas variações podem ser observadas, por vezes de forma recorrente, em distâncias métricas.

A mineralogia dos charnoquitos e assemelhados consiste em feldspato alcalino, plagioclásio, quartzo, ortopiroxênio, clinopiroxênio, biotita, anfibólio, opacos, apatita e zircão.

Esses minerais distribuem-se, em secção delgada, em associações distintas, com granulação variada continua, desde milimétrica a centimétrica. Com mais que $1,5 \mathrm{~cm}$ reconhecemmse o feldspato alcalino e o plagioclásio. Ainda formando mosaico granoblástico, e com menos que $1,5 \mathrm{~cm}$, continuam a aparecer os feldspatos e, agora, o quartzo. Em geral, com menos que $0,5 \mathrm{~cm}$, ocorrem os ferromagnesianos enfileirados, com algum quartzo $\mathrm{e}$ 
plagioclásio. Faixas félsicas, sobretudo com quartzo e plagioclásio, apresentam também essa granulação. Cortando as outras partes da rocha, estão ainda presentes estreitas lâminas onduladas, de agregado submilimétrico, principalmente com plagioclásio e quartzo. De forma genérica, a textura pode ser descrita como granoblástica e lepidoblástica, com granulação seriada, desde fina a grossa, cataclástica.

O feldspato alcalino, em geral bastante homogêneo, é pertítico, com o hóspede na forma de gotas ou de filmes. Estima-se que o hóspede não ultrapasse os $10 \%$ dos individuos potássicos, com caracteristicas de ortoclásio. O feldspato alcalino pode ser sub-retangular ou xenoblástico, apresentar geminação simples e associar-se ao quartzo, em intercrescimentos granofíricos. Inclui também os outros minerais. Quando xenoblástico, ou levemente arredondado, mostra comumente orla de mirmequitas. Característica dos charnoquitos é o fraturamento subparalelo dos feldspatos, com preenchimento por filossilicatos amarelados a alaranjados, ou esverdeados, com alta birrefringência. Essas fraturas podem estar também preenchidas por carbonato.

O plagioclásio, um oligoclásio, também fraturado, exibe geminaçäo polissintética. Os indivíduos são deformados, com lamelas curvas, e essa é uma característica constante. Não raramente, o cristal se fragmenta e os pedaços mantêm-se justapostos. Nas faixas de granulação mais fina, a deformação não aparece devido às dimensões dos grãos. O plagioclásio pode ocorrer ainda em agrupamentos de individuos quase circulares, em contato, ou isolados e inclusos no feldspato alcalino ou no quartzo.

As mirmequitas são bastante freqüentes. Intercrescimentos granofíricos, micrográficos etc, são raros nos charnoquitos distantes dos sienitos. Esses intercrescimentos näo são afetados pelas feições de cisalhamento, desenvolvendo se sobre elas.

O quartzo, normalmente presente em grandes quantidades, varia em volume desde os 25 a $30 \%$ até menos que 10\%. Forma individuos maiores, centimétricos, alongados e deformados. Mostra invariavelmente evidências de recristalização quase integral, envolvendo porções dos outros minerais. Essas inclusões têm características de restos de cisalhamento, como, por exemplo, o plagioclásio redondo. Além dos indivíduos maiores, o quartzo aparece nas faixas de granulaçāo mais fina, subcentimétricas a submilimétricas.

O fêmico mais comum é o ortopiroxênio, com características ópticas de hiperstênio. Os individuos são xenoblásticos, não deformados, sem microlamelação. Eles integram os enfileiramentos minerais de fêmicos. Apresentam-se pouco alterados, em agregados não identificáveis, mas com a aparência de filossilicatos variavelmente coloridos. Este mineral está presente em quase todas as rochas encaixantes e amostras, à exceção dos milonitos. Modalmente, varia entre os $5-10 \%$ aos $15-20 \%$.

Junto ao piroxênio, aparece a biotita de cor alaranjada-avermelhada $\left(Z^{\prime}, Y\right)$, participando das fileiras dos fêmicos e em subparalelismo. Forma placas não muito alongadas, com formas irregulares. Engloba alguns acessórios e, não raro, apresenta bordas simplectíticas 
e intercrescimento com quartzo e/ou feldspato alcalino.

Mais raramente, está presente um clinopiroxênio incolor a pardacento e um anfibólio verde, verde-pardacento a amarelado. O piroxênio parece corresponder a uma variedade diopsídica/augítica e o anfibólio a um tipo hornblêndico.

Como acessórios ocorrem opacos granulares, uma magnetita. Também a apatita, em grãos equidimensionais, arredondados, é bastante comum, ao lado do zircão quadrado, retangular ou arredondado.

Como minerais secundários, além daqueles que preenchem as fraturas, reconhece-se biotita verde.

\subsubsection{Hiperstênio dioritos gnáissicos e variedades}

As rochas referidas no campo como anfibolitos revelaram-se, na verdade, variedades dioríticas a plagioclasíticas com ortopiroxênio. As variedades claras são totalmente confundiveis com rochas aplíticas ou variedades microssieníticas, praticamente ausente o subparalelismo mineral e a foliação.

As rochas mais escuras exibem foliação e algum lineamento mineral, além de se apresentarem na forma de leitos, quer regulares, quer boudinados, com feições totalmente distintas dos diques máficos. Os plagioclasitos, que também ocorrem como leitos, foram casualmente amostrados por evidenciarem certa peculariaridade de aspecto de campo.

Essas rochas mostram toda a variação mineralógica entre os termos extremos. Podem ser chamadas de ortopiroxênio gnaisses, adjetivados pelo nome ígneo, seguido da modificação gnáissico. Cobrem o espectro entre ortopiroxênio dioritos, ortopiroxênio leucodioritos a ortopiroxênio plagioclasitos, todos gnáissicos. Em geral, têm pouco quartzo, mas existem amostras quartzo dioriticas e quartzo plagioclasiticas.

Todas as variedades são equigranulares, com granulação fina a média, e possuem texturas dominantemente granoblásticas e, embora xenoblásticas, com contornos mais ou menos regulares dos minerais, equidimensionais a pouco alongadas. Desenvolve-se, paralelamente, textura lepidoblástica com o aumento da biotita. Mesmo o plagioclásio, que forma mosaico regular, demonstra certa suborientação segundo direções a aproximadamente $30^{\circ}$ para um lado e para outro da direção mediana principal, paralela ao alongamento do leito ou da lente de rocha.

O plagioclásio, andesinico $\left(\geq A n_{40}\right.$ ), está sempre presente, e varia modalmente de 50 $60 \%$ a mais que $90 \%$ (a maior parte das amostras apresenta composição modal próxima aos extremos). O plagioclásio, limpo e năo zonado, é sempre geminado polissinteticamente.

Os fêmicos presentes começam com baixos teores de ortopiroxênio e opacos, granulares, isolados e dispersos no mosaico de plagioclásio. Esses três minerais caracterizam 
os leucodioritos e plagioclasitos, com mais ou menos quartzo.

O aparecimento do quartzo, como grãos isolados e xenoblásticos, raramente em grande quantidade, leva essas rochas para as "quartzo variedades"

Enquanto o plagioclásio se mantém em torno dos $50 \%$, no mínimo, até os $90 \%$, no máximo, o quartzo oscila entre $1 \%$ e $5 \%$ a $30 \%$, ou mais, variando, simultaneamente, a quantidade dos fêmicos, onde o ortopiroxênio pode chegar aos $20 \%$. Outros ferromagnesianos incluem a biotita, o anfibólio (mais raro) e o clinopiroxênio, que somados chegam aos $40 \%$ ou pouco mais, além dos opacos.

Todos os minerais são bem formados, embora xenoblásticos, e formam fileiras descontínuas e sinuosas, mantendo certo paralelismo entre si e com o alongamento dos minerais.

A biotita é marrom-alaranjada a alaranjada (Z', Y) e amarelada clara (X'). O anfibólio, um tipo "hornblêndico", é verde oliva a amarelado ou mais ou menos escuro $(Z$ ', $Y)$ a amarelado $\left(X^{\prime}\right)$. O ortopiroxênio é semelhante ao dos charnoquitos, com cor esverdeada (Z') e rósea clara $\left(X^{\prime}\right)$ e birrefrigência baixa a média, provavelmente um hiperstênio; o clinopiroxênio é incolor a pardacento, um tipo augitico/diopsídico, de presença restrita.

Lembra-se, ainda, que os hiperstênio dioritos podem ser chamados de noritos (Le Maitre, 1989).

\subsubsection{Rochas miloniticas}

Desaparecendo as caracteristicas dos tipos petrográficos descritos e mesmo de outros por efeito do cisalhamento, pode-se aceitar essas novas rochas como protomiloníticas a ultramiloníticas, todas completamente recristalizadas, daí a utilização do prefixo blasto. Não há a menor intenção de classificá-las detalhadamente $e$, portanto, não existe inconveniente para o emprego do termo milonito, "lato sensu", seguido ou não de adjetivação.

Na mesma secção delgada, é possivel às vezes reconhecer uma porção milonítica que passa à rocha de origem. A partir dos charnoquitos e assemelhados, pouco a bastante cisaihados, formam-se lentes estreitas e bizeladas de agregado com quartzo, alternadas e anastomosadas às lentes dos restos da rocha original, em geral, agregado feldspático, sem quartzo (Fotomicrografia 1). O espaçamento é milimétrico, e chega-se a um ponto que as lentes se fundem, conservando restos das faixas feldspáticas inclusas. Essas porções feldspáticas podem incluir ambos os feldspatos ou somente um deles. Simultaneamente, vão desaparecendo os máficos, que dão lugar a porções estiradas de filossilicados não identificáveis. De início, o processo preserva alguns porfiroclastos que, contudo, diminuem gradativamente de tamanho e desaparecem.

A evolução das rochas que sofreram cisalhamento indica recristalização total, incluindo 


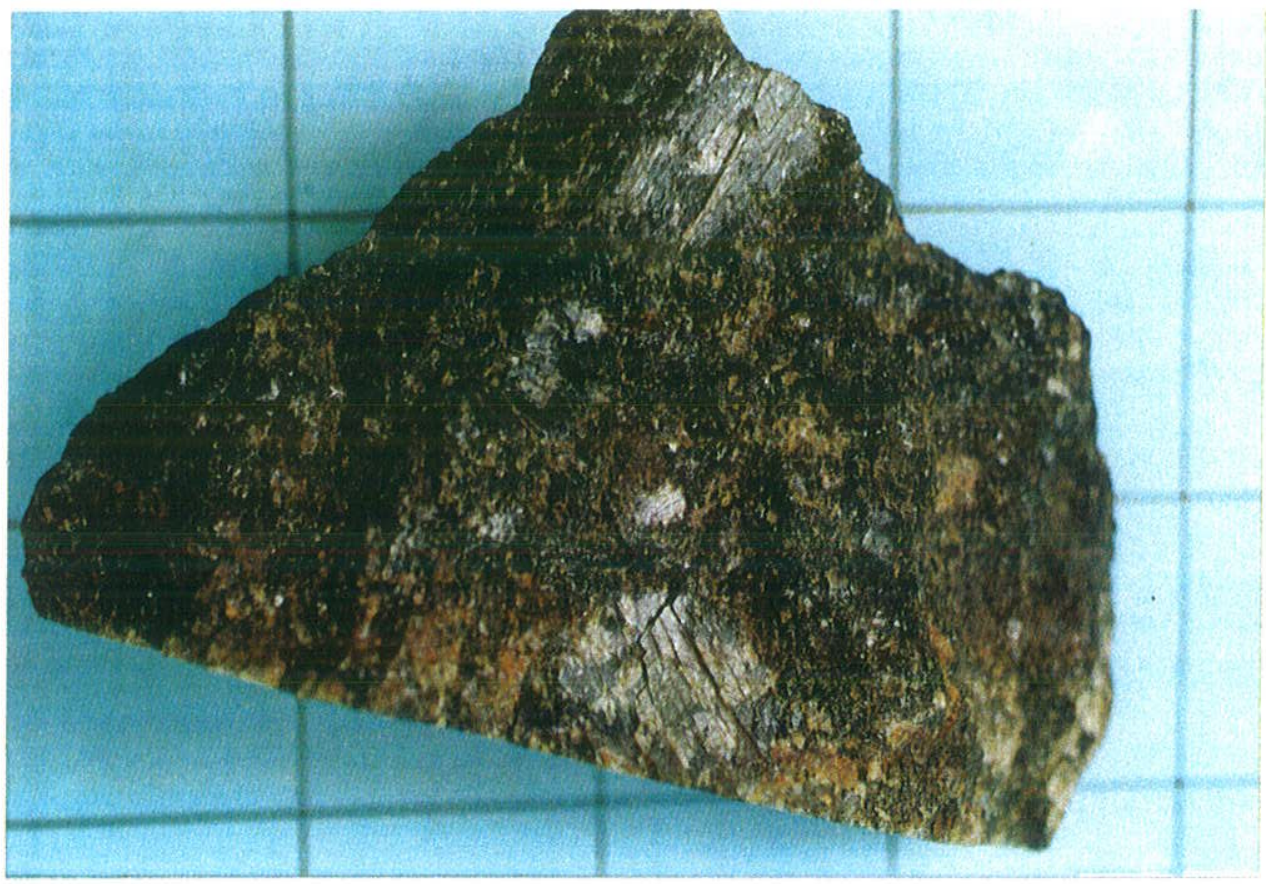

Foto 34 - Charnoquito porfiroclástico, superfície paralela à foliação. Reticulado: $5 \times 5 \mathrm{~cm}$.

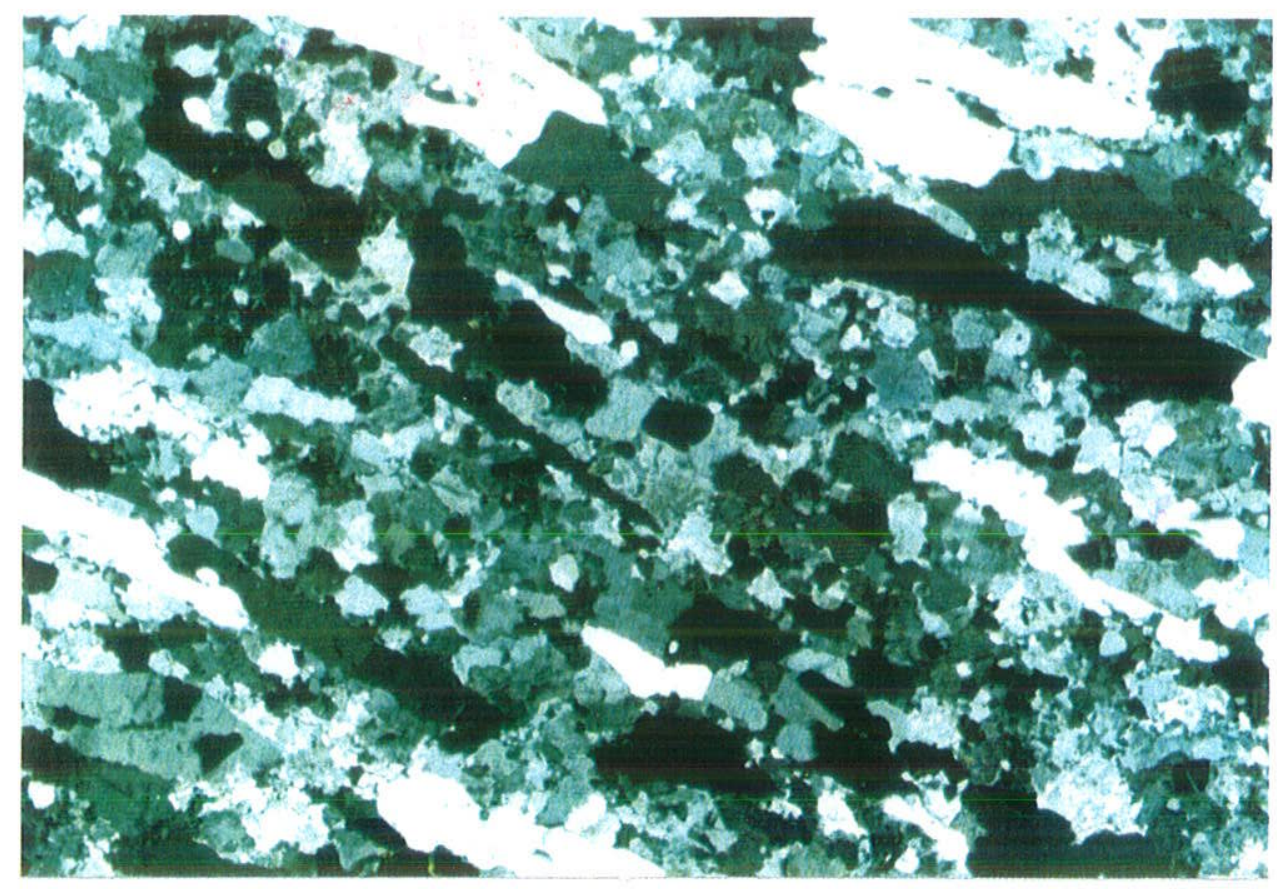

Fotomicrografia 1 - Milonito/blastomilonito quartzo-feldspático. Feições alongadas, paralelas, de quartzo e opacos, segmentam o agregado granoblástico (recristalizado) de pertitas, com algum plagioclásio. Não ocorrem fêmicos. Dimensão maior, 5,50 mm, filtros fosco e azul, polarizadores semicruzados. 
o quartzo, alongado e, agora, pouco deformado.

Embora em alguns tipos de milonitos, na verdade blastomilonitos, ocorram lentes de mesopertitas algo semelhantes àquelas dos sienitos e distintos dos feldspatos alcalinos das encaixantes, não há como afirmar, com segurança, que alguns dos milonitos são de rocha originalmente sienítica.

\subsection{Sienitos e microssienitos}

Incluem-se aqui os sienitos comuns da liha, que podem ser agrupados naqueles praticamente sem quartzo ou com traços do mineral $(<1 \%)$, que se mostram semelhantes, mas distintos nas minúcias, dos com mais de $1 \%$ até $5 \%$. Adicionalmente, os quartzo sienitos, com mais que $5 \%$ de quartzo, estes já apresentando uma série de diferenças texturais e mineralógicas; estas rochas dificilmente chegam ou ultrapassam os $10 \%$ de quartzo. Neste grupo estão também enquadrados os tipos chamados informalmente de "hibridos" (Foto 35). Alguns desses tipos, de difícil diagnóstico, são granofíricos a micrográficos e, podem conter teores altos de quartzo e exibir granulação variada na mesma amostra. Os microssienitos plutônicos, também incluídos os tipos granofíricos, variam desde aqueles sem quartzo até verdadeiros microgranitos. São em tudo semelhantes aos microssienitos de diques.

Todas essas rochas distribuem-se nos campos 6 e $6^{*}$ dos triângulos Q-A-P.F (Le Maitre, 1989), ou seja, os álcali feldspatos sienitos e os álcali feldspatos-quartzo sienitos. Como recomendado, o prefixo micro é utilizado para as rochas de granulação média a fina e, entre estas, ocorrem rochas do campo 2 , os álcali feldspatos (micro) granitos.

Tipo minoritário, raro até, mas merecedor de alguma atenção é o sienito-microssienito porfiritico.

\subsection{1. Álcali feldspato sienitos}

São os sienitos mais comuns na llha, evidenciando grande homogeneidade textural e mineralógica. Perfazem pelo menos $80 \%$ do corpo plutônico e, ausente a nefelina, possuem baixos teores de quarizo, principaimente entre 0 a $1 \%$, distinguindo-se assim daqueles com mais que $1 \%$ até $5 \%$.

Os sienitos com até $1 \%$ de quartzo representam $60 \%$ das amostras examinadas e ocupam todo o corpo sienítico, a partir de certa distância do contato principal; já os sienitos portadores de maior concentração em quartzo correspondem a $20 \%$ das amostras. Poucas delas aparecem a major distância dos contatos, e a maioria ou ocorre junto aos contatos, ou no corpo da Pontinha ou na costa Sul, entre o Saco do Coruja e a Ponta Sul.

São rochas claras, equigranulares, com largo predominio daquelas com granulação 
grossa, aparecendo, no entanto, tratos de rochas de granulação média. São sempre tipos homófanos e maciços, raramente com algum arranjo paralelo contínuo dos feldspatos, estes em boa parte tabulares a colunares. Os minerais fêmicos presentes dispersam-se, aleatoriamente, em grãos, prismas e agregados de dimensões inferiores às dos feldspatos, e representam 5-10\% da rocha (Foto 36 ).

A textura mais típica poderia ser chamada de foiaitica, sem conotação mineralógica, uma vez que não ocorre a nefelina (Fotomicrografia 2). A mesopertita tabular, centimétrica, se dispõe em grupos de individuos paralelos, justapostos, e os grupos distribuem-se ao acaso, com certa tendência a ortogonalidade reciproca. Individuos isolados completam as lacunas dos arranjos. Cortes, em direçōes diferentes da mesma amostra, podem mostrar indivíduos largos, com contornos irregulares, mas retilíneos. Os minerais fêmicos aparecem isolados e em grãos pequenos, inclusos nos feldspatos, ou formando agregados ou fileiras entre ou sobre os feldspatos.

Essas rochas säo equigranulares, passando para espécimens inequigranulares e de granulação média. Com certa freqüência, observa-se na mesma secção delgada granulação variável de grossa até fina, havendo seriação entre os diversos representantes.

Esse tipo textural, básico, além das mudanças na granularidade, varia ainda no sentido de maior interação entre os indivíduos de feldspato. Contornos e contatos retilíneos e angulosos passam a contatos com certo embainhamento (Fotomicrografia 3), aberto, que se acentua, até a interpenetração e interdigitação entre vizinhos, ao mesmo tempo que as formas geométricas transformam-se de retangulares, a sub-retangulares até xenomórficas. Essas variações também ocorrem na granulometria, culminando com rochas inequigranulares, grossas a médias. Em síntese, do arranjo "foiaítico" passa-se ao hipidiomórfico e, finalmente, ao alotriomórfico inequigranular (Fotomicrografia 4).

Como elemento adicional em termos texturais, em muitas dessas rochas, a mesopertita desenvolve fímbria albítica externa, contínua, engrenada à fímbria do indivíduo vizinho (Fotomicrografia 5).

Com o aparecimento e o aumento do quartzo, a textura "foiaitica" se altera. Praticamente, não ocorrem sienitos com textura "foiaitica" com mais de 3 a $5 \%$ de quartzo. 0 caráter textural alotriomórfico e a elevação do teor de quartzo parecem manter certa relação reciproca e simpatética.

Ao lado desses tipos texturais, aparece uma variante, quase panidionórfica, com individuos de contornos geométricos, sub-retangulares curtos a quadrados. Também nele a quantidade de quartzo é pequena. Ainda de ocorrência restriła são as variedades com verdadeira textura, localmente, traquitóide.

De modo geral, os fêmicos aparecem agrupados, com grãos subcentimétricos. Os agrupamentos podem ser compactos ou em fileiras (Fotomicrografia 6). Onde compactos, podem sugerir a presença de "sineusis" (Fotomicrografia 7), de ocorrência rara (Smith e Brown, 


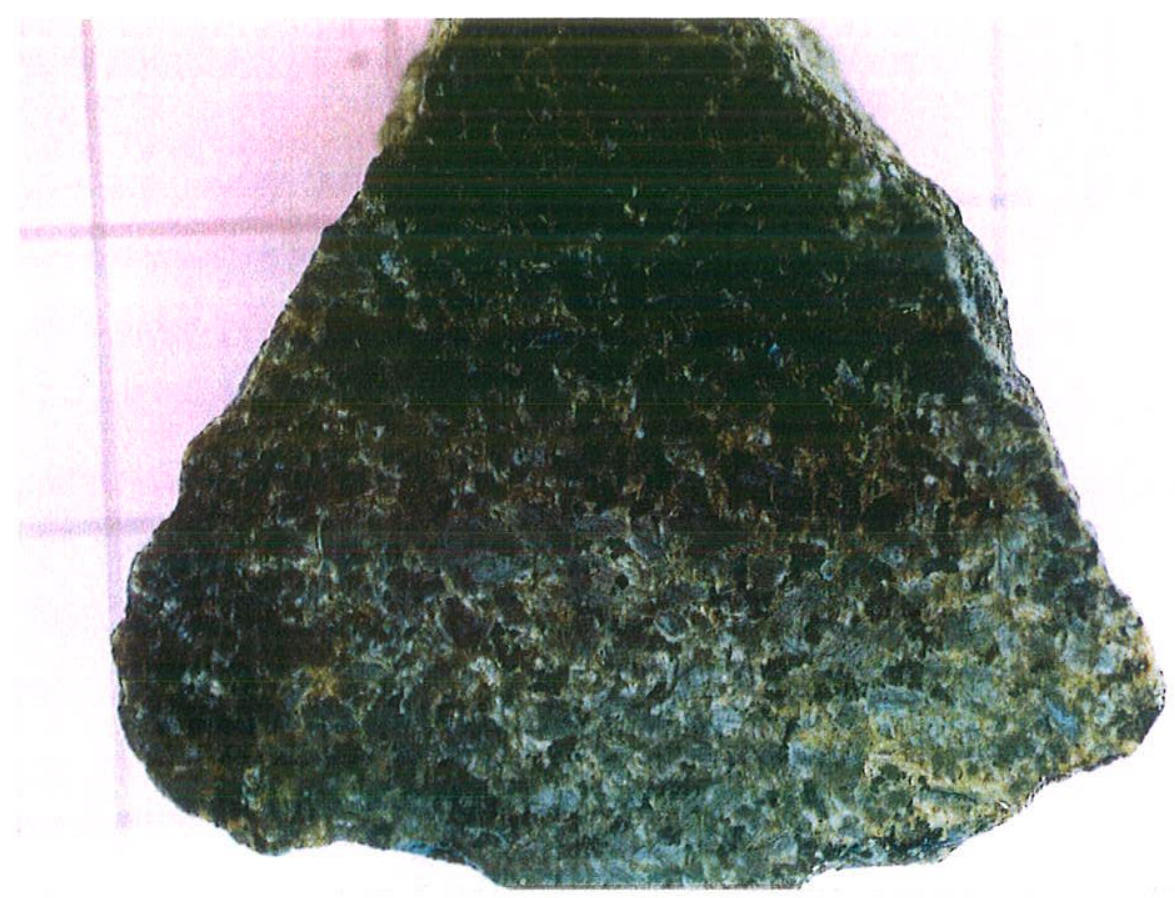

Foto 35 - Sienito hibrido. Notar labradorescência e forma sub-retangular dos cristais de feldspato. Amostra inclinada para obtenção do efeito na parte inferior, o feldspato ficando quase preto na parte superior menos iluminada. Reticulado: $5 \times 5 \mathrm{~cm}$.

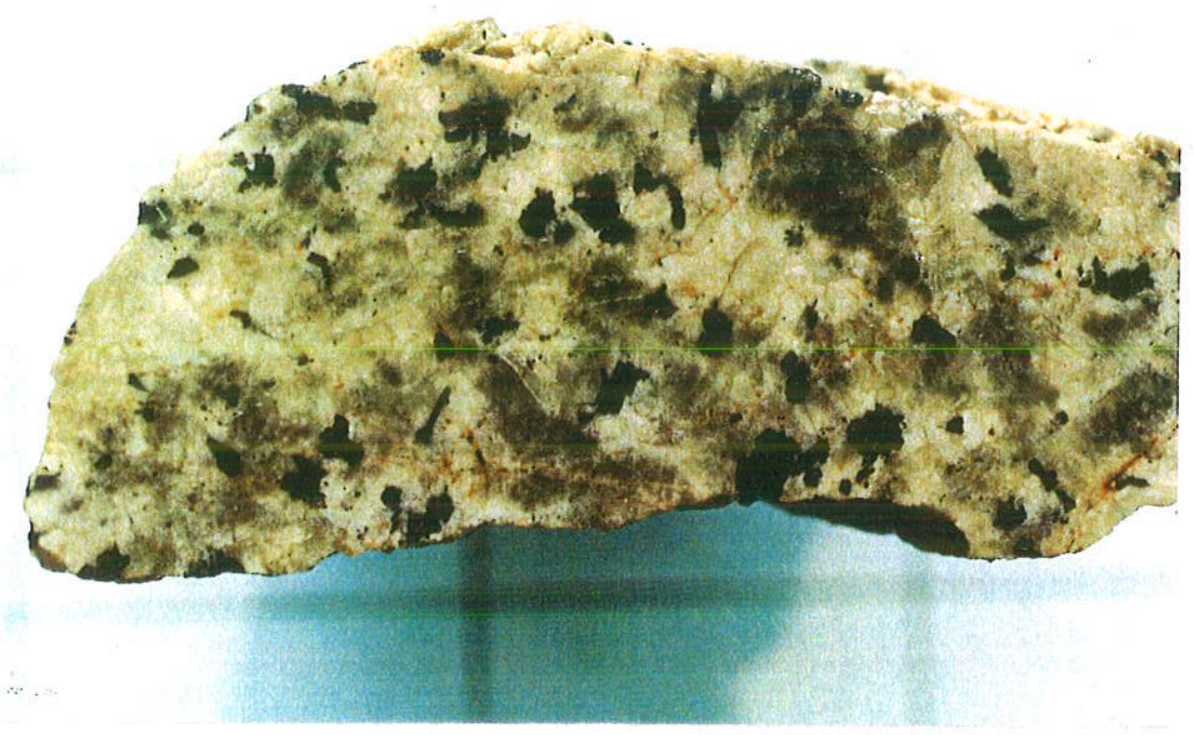

Foto 36 - Sienito comum, sem quartzo. Mesmo praticamente fresca, nota-se a variação na cor das mesopertitas. Superficie serrada. Efeito de cor obtido, em parte, por impregnação moderada com nujol (a seco, a rocha é mais clara). Reticulado: $5 \times 5 \mathrm{~cm}$. 


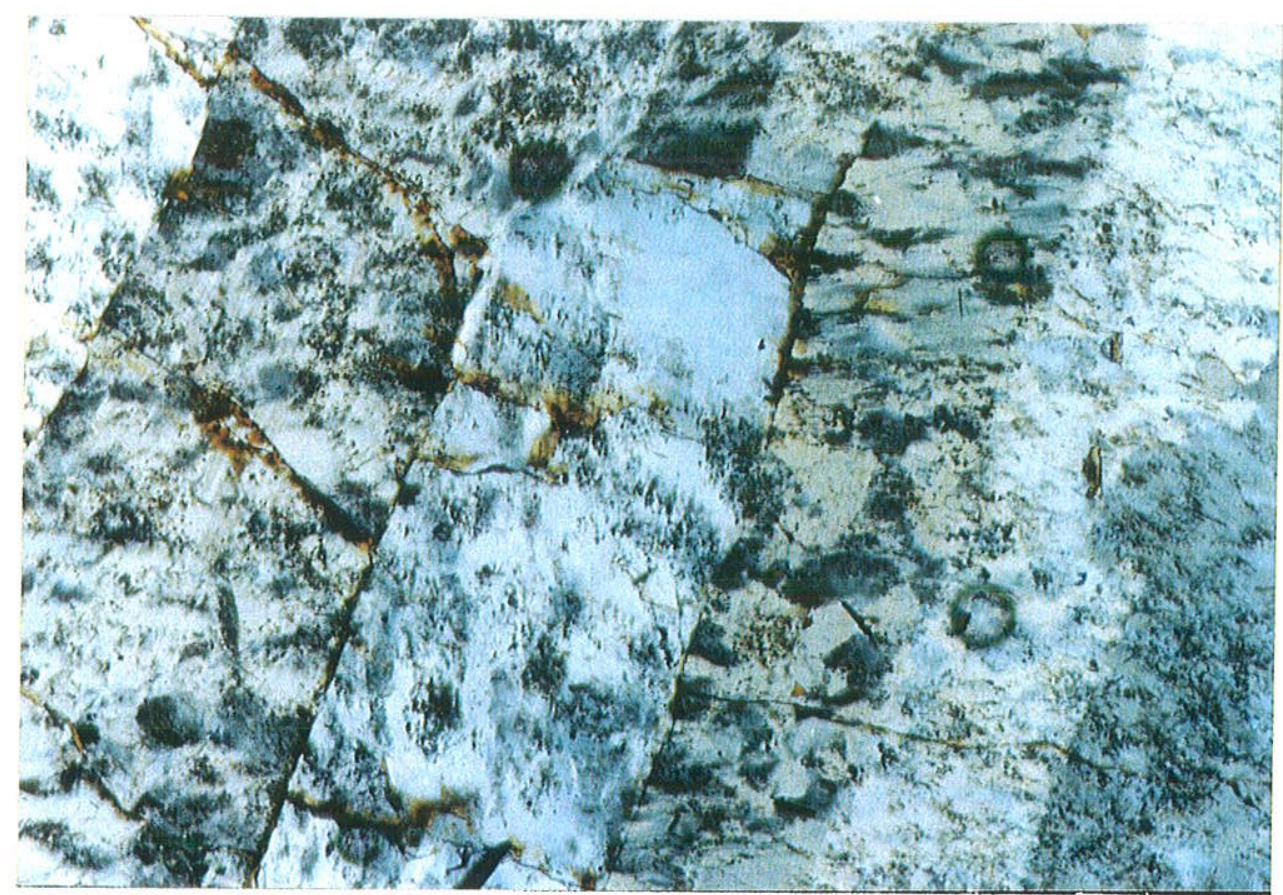

Fotomicrografia 2 - Detalhe de sienito com textura foiaítica. Notar o arranjo dos indivíduos, paralelos e plano de composição da geminação paralelo às bordas. Contatos praticamente retilíneos. Padrão irregular das mesopertitas. Porções mais claras e limpas, mais albíticas; escuras ou mais sujas, mais potássicas. Dimensão maior, $1,39 \mathrm{~mm}$, filtro azul, polarizadores semicruzados.

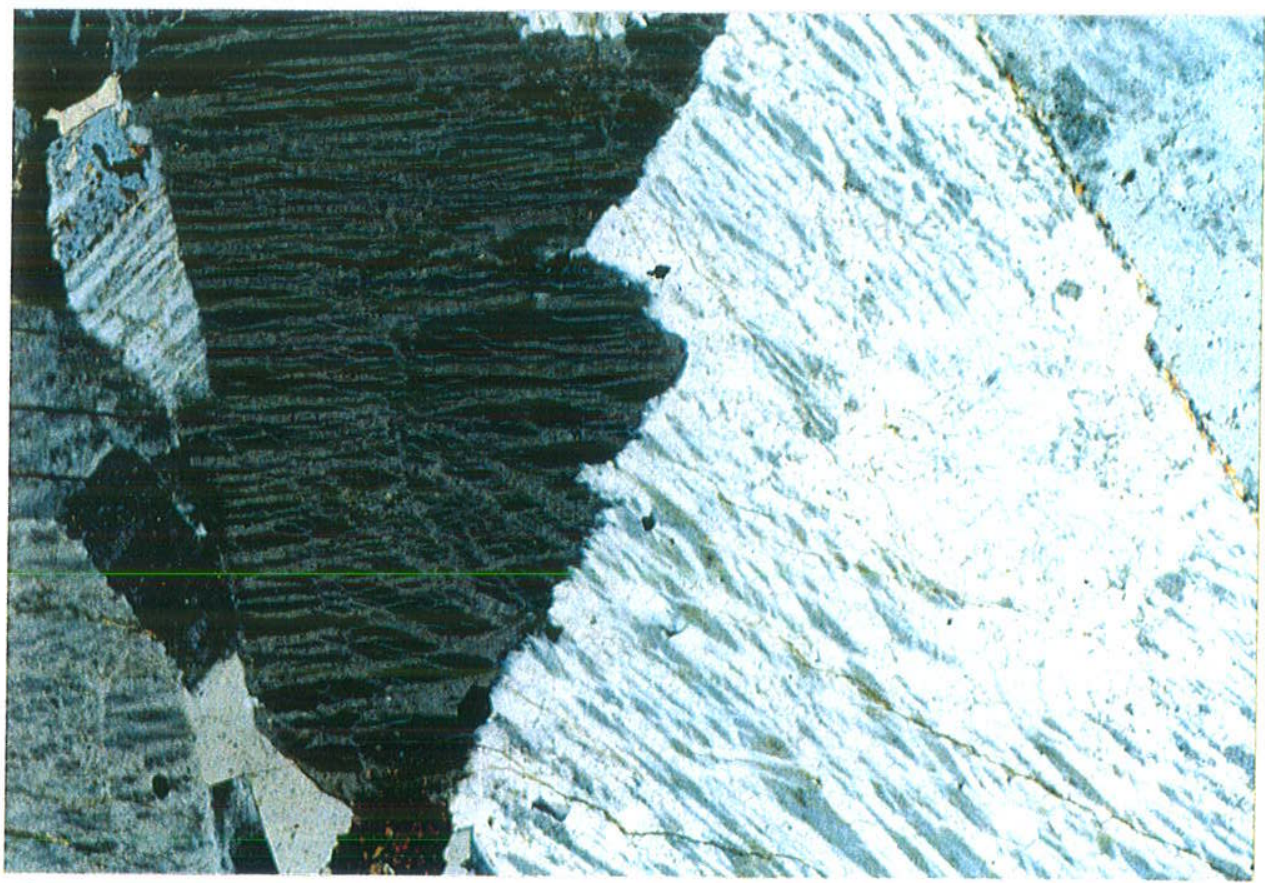

Fotomicrografia 3 - Detalhe de sienito. $\mathrm{O}$ arranjo não é mais foiaítico, havendo já bastante embainhamento mútuo entre grãos, ao mesmo tempo que se conservam partes retilíneas dos contatos. Mesopertita não típicamente lamelada ("tigrada"), em grande parte anastomosada. Porções mais escuras, mais potássicas. Notar que as lamelas sódicas se bifurcam e cruzam ou subdividem as porções potássicas. Observar possível exsolução de fratura no indivíduo escuro, em forma de semicírculo, convexo para a esquerda. Notar porção central mais sódica do indivíduo maior. Notar ainda quartzo intergranular à esquerda, inferior. Dimensão maior, $2,80 \mathrm{~mm}$, filtro azul, polarizadores semicruzados. 


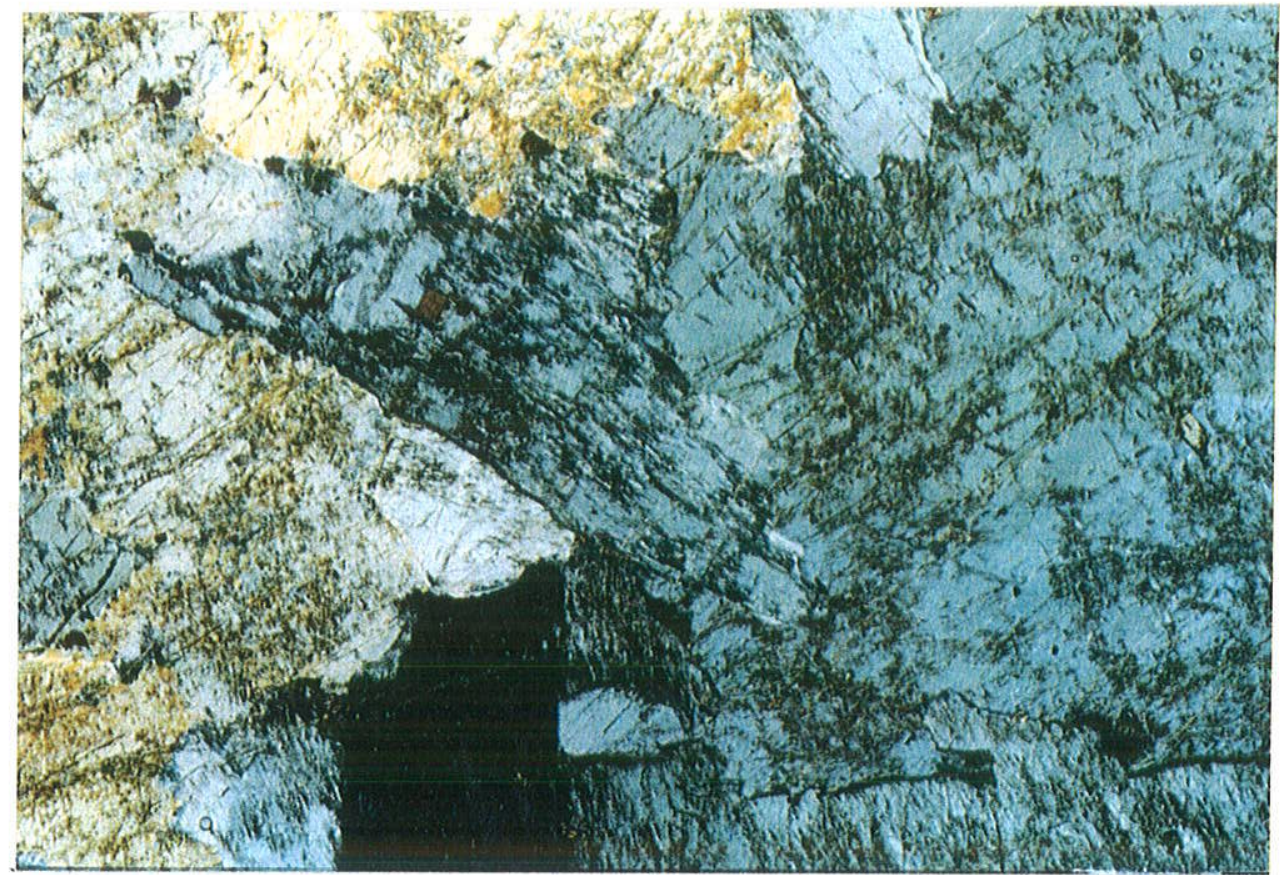

Fotomicrografia 4 - O grau de interação entre os indivíduos micromesopertíticos aumenta, e estes passam a se interpenetrar. Resultam formas xenomórficas e textura alotriomórfica. Observar predomínio da fase sódica, nos indivíduos (porções limpas) e padrão indefinido das exsoluções. Dimensão maior, 5,50 mm, filtro azul, polarizadores semicruzados. Nota: a secção é para microssonda e, portanto, mais espessa.

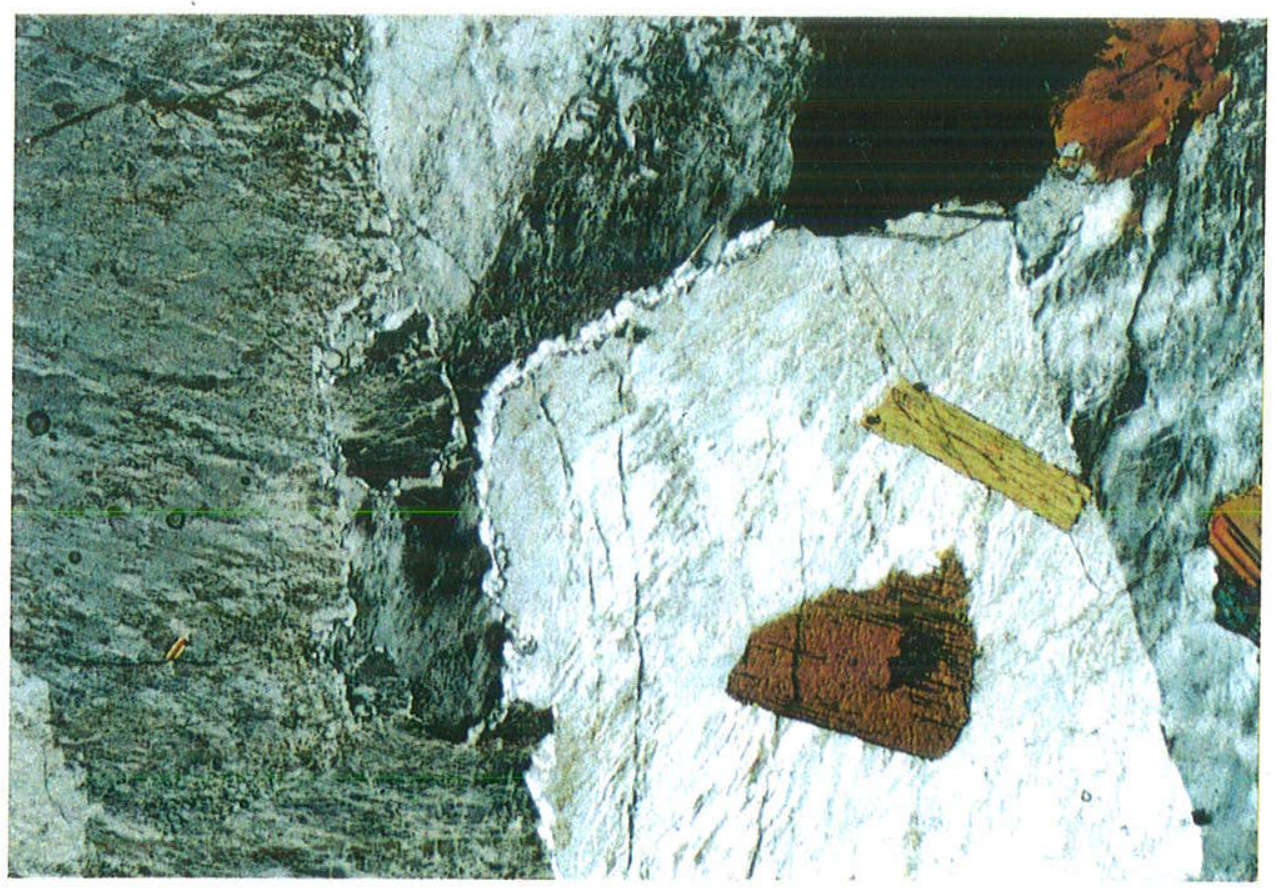

Fotomicrografia 5 - Textura "subfoiaítica" de sienito, já com algum desarranjo no tamanho e nos contatos dos indivíduos. Micromesopertitas de padrão variado e algum rearranjo estrutural presentes (ondulações). Notar fímbrias claras, interpenetradas, albíticas. Placas de biotita inclusas. Dimensão maior, 5,50 mm, filtro azul, polarizadores semicruzados. 


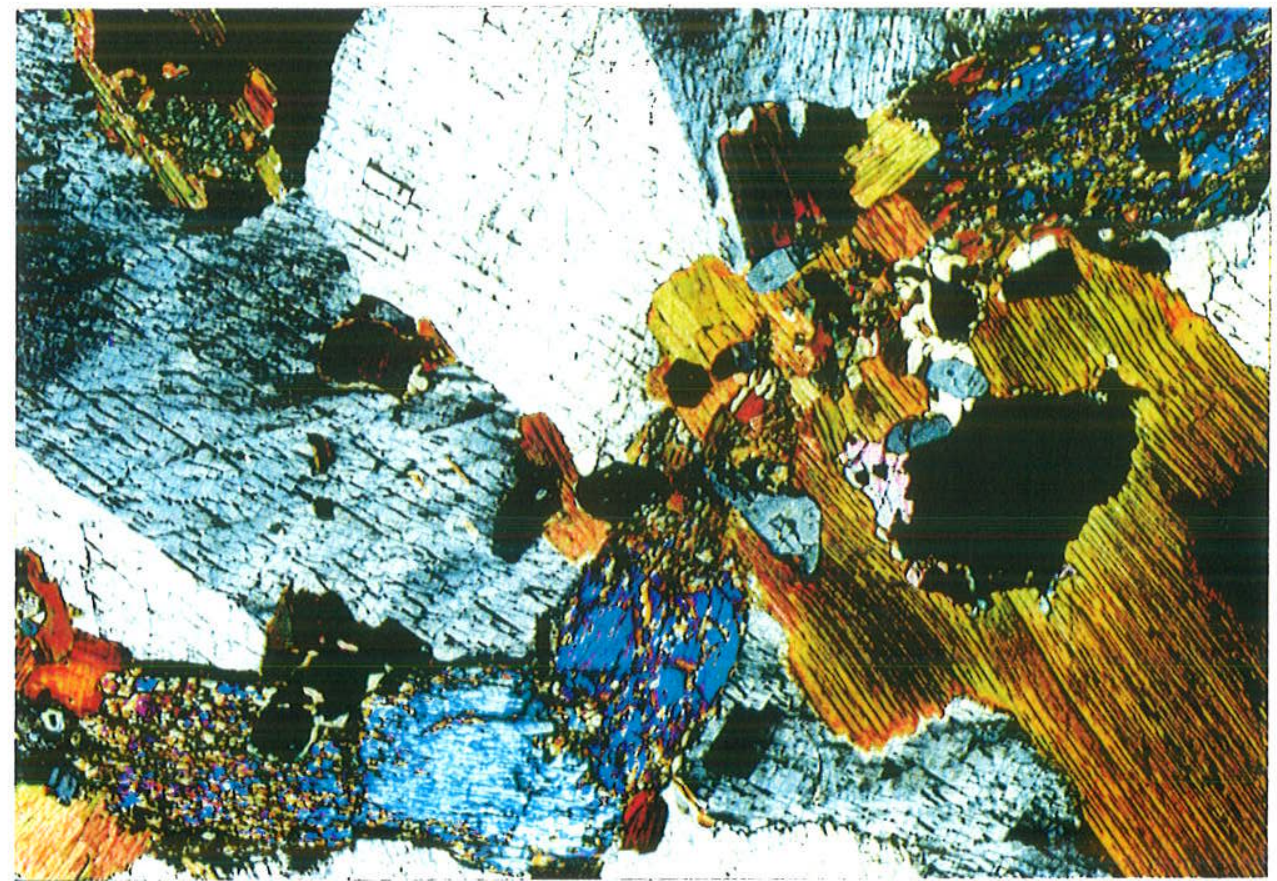

Fotomicrografia 6 - Sienito. Notar o feldspato com aspecto homogêneo, característica rara nos sienitos da Ilha. Fêmicos enfileirados e intercrescidos: clinopiroxênio e biotita, mais apatita e opacos. Observar contato quase retilíneo dos feldspatos. Opacos orlados por titanita. Dimensão maior, 5,50 mm, filtro azul, polarizadores semicruzados.

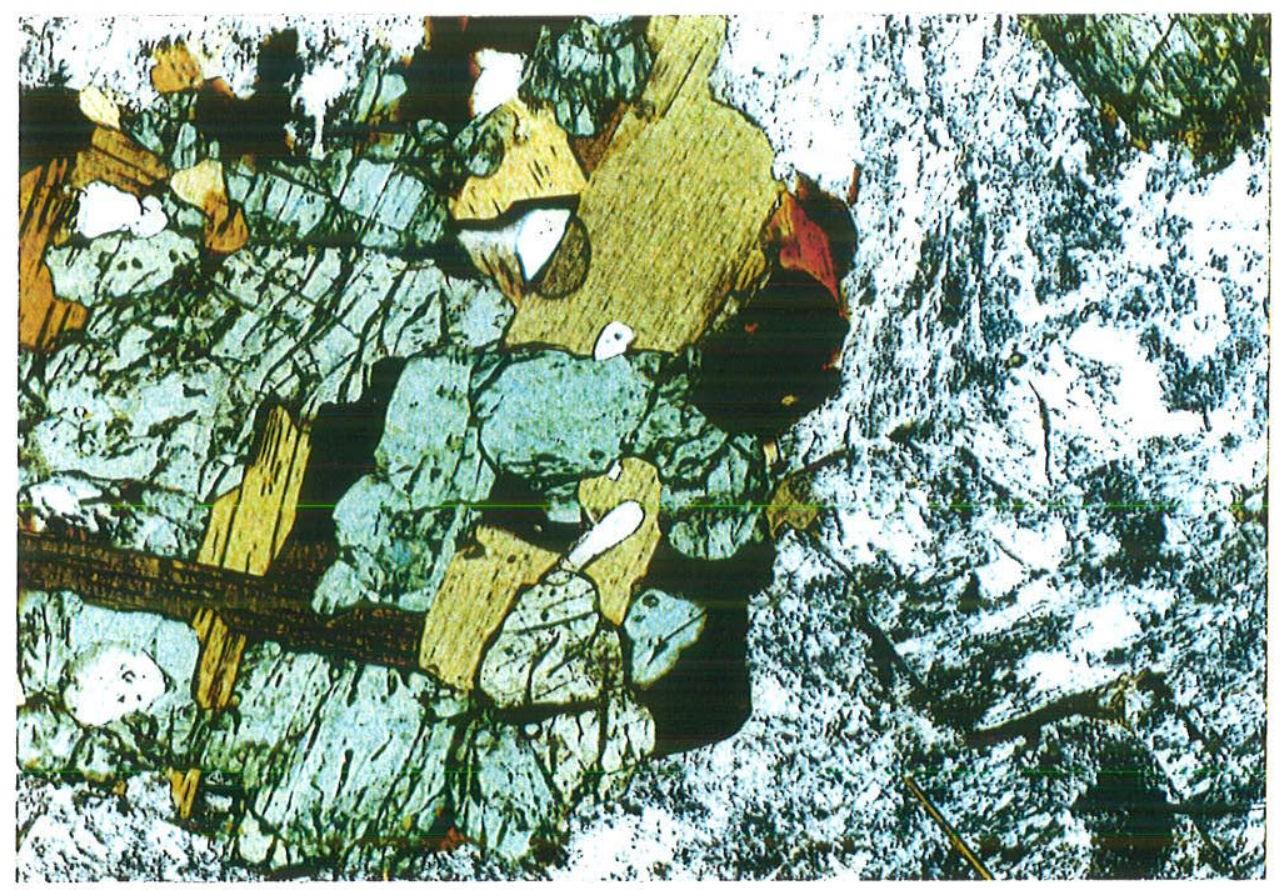

Fotomicrografia 7 -Sienito. Agregado de clinopiroxênio esverdeado e biotita, bastante típicos, aparentemente em "sineusis", pelo menos descritivamente. Agregado inclui apatita e opacos. Mesopertita com padrão muito irregular, fases potássicas muito "sujas". Dimensão maior, $2,80 \mathrm{~mm}$, filtros azul e fosco, polarizadores descruzados. 
1988). Os mesmos fêmicos, de dimensões milimétricas, povoam interna e aleatoriamente a mesopertita.

Ocasionalmente, ocorre alinhamento dos fêmicos de pequenas dimensões $e$ intragranulares, tal que uma fina camada atravessa os limites das micromesopertitas. Também se nota em algumas lâminas que o material intragranular povoa um ou dois individuos de micromesopertita, vizinhos, permanecendo limpos os outros em volta. Alinhamento semelhante ao referido foi também notado com apatitas dentro da biotita.

Análises modais e modas estimadas de sienitos de Búzios não fazem muito sentido quando examinadas isoladamente. A mesma amostra, laminada várias vezes, pode conter de 0 a $5 \%$ de quartzo e 5 a $10 \%$ ou 10 a $15 \%$ de fêmicos. Diferentes amostras do mesmo afloramento apresentam variação semelhante. A quantidade de amostras examinadas permite afirmar que os fêmicos representam na maioria das vezes $10 \%$ da mineralogia presente, passando em curta distância para mais ou para menos $5 \%$ e não ultrapassam os $15 \%$, e, conseqüentemente, a mesopertita perfaz $90 \% \pm 5 \%$. Com o aparecimento do quartzo, varia a quantidade de mesopertita, mas não a dos fêmicos.

A grande maioria das rochas deste grupo mostra o quartzo ausente ou até $1 \%$, sendo minoria aquelas com 3 a $5 \%$ do mineral.

Ao lado da mesopertita e do quartzo, aparecem em ordem de freqüência e quantidade, a biotita e o clinopiroxênio, os opacos e o anfibólio. Acessoriamente, a apatita, de forma equidimensional a hexagonal, é o mineral mais presente, seguido da titanita e do zircão, além de outros mais raros, como a allanita e alguns não caracterizados. Como minerais tardios de alteração ocorrem filossilicatos coloridos (amarelados, alaranjados) não identificados e, mais raramente, biotita verde.

$E$ interessante observar que, em nenhuma secção delgada, constatou-se a presença de plagioclásio.

A mesopertita, largamente dominante, mostra contornos idiomórficos, retangulares a sub-retangulares, mais ou menos alongados ( $>3: 1$ até $5: 1$ ), quase sempre com individuos com geminação simples, provavelmente do tipo Carlsbad (Fotomicrografia 2). Os individuos podem chegar comumente a 1 ou $2 \mathrm{~cm}$, sendo que nas rochas de granulação média eles tendem a formas retangulares mais alongadas ou a formas granulares equidimensionais, regulares ou xenomórficas.

A grosso modo, parece ocorrer leve predomínio da fase sódica, talvez em torno dos 55 a $60 \%$. Na realidade, estão presentes micromesopertitas com fases sódicas e com fases potássicas, além de possiveis fases intermediárias, homogêneas (Fotomicrografia 8). Poucas amostras têm feldspato alcalino opticamente homogêneo, de composição intermediária. As fases potássicas não são geminadas; já as sódicas, com bastante freqüência, exibem geminação polissintética, quando no padrão de manchas ("patch") (Fotomicrografia 9). Em geral, a fase sódica se apresenta muito limpa, enquanto que a potássica tem, invariavelmente, 


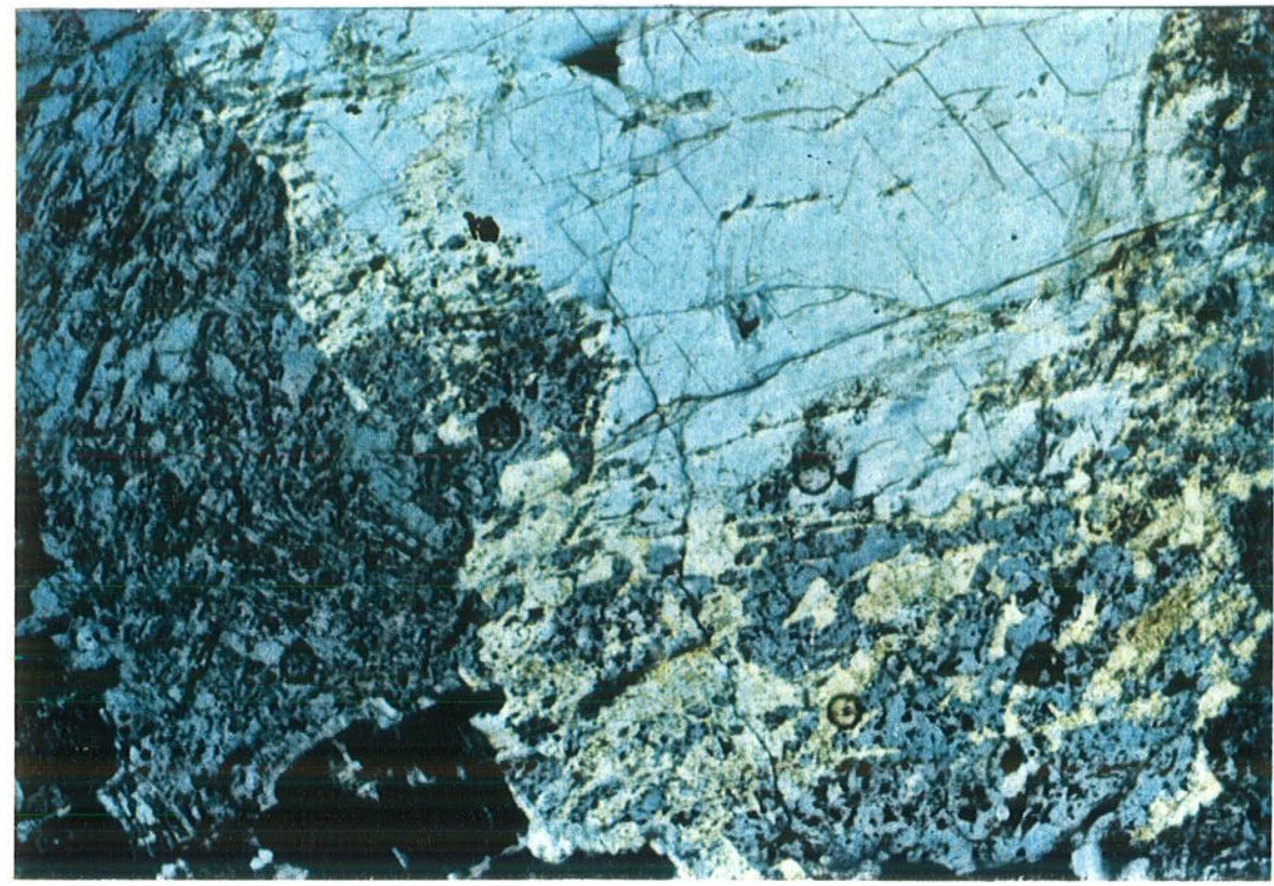

Fotomicrografia 8 - Sienito. Mesopertita de padrão irregular. Fase amarelada, sódica; cinzenta clara, intermediária, a cinzenta escura, potássica - no indivíduo da esquerda. Dimensão maior, 2,80 mm, filtro azul, polarizadores semicruzados.

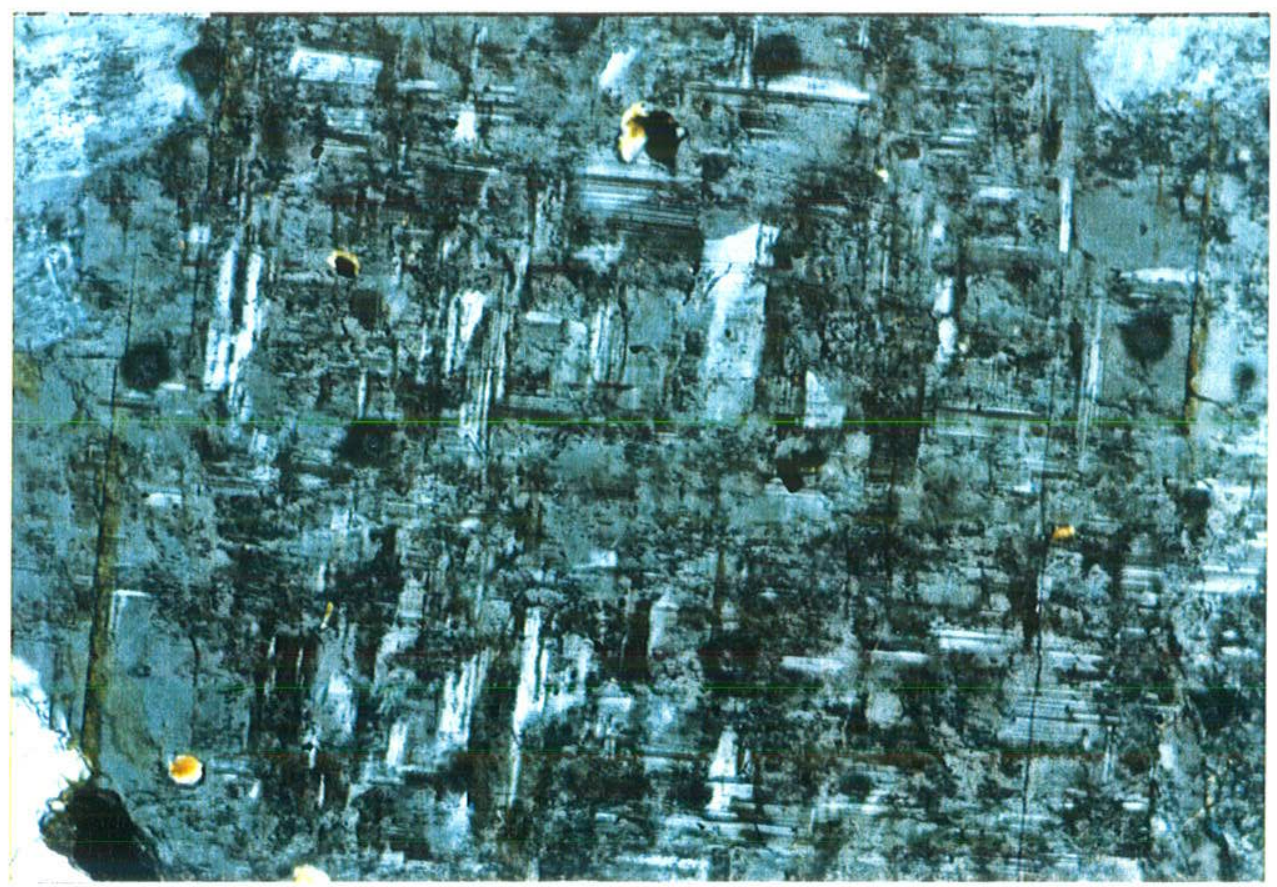

Fotomicrografia 9 - Sienito. Detalhe de mesopertita em manchas ("patch"), com geminação polissintética na fase albítica, fase potássica mais escura e suja. Dimensão maior, $1,39 \mathrm{~mm}$, filtro azul, polarizadores semicruzados. 
aspecto sujo, e se mostra crivada de "inclusôes" minúsculas e poeira (Fotomicrografias 2, 4, 79).

As micromesopertitas são descritas como representando os tipos "string" (lameladas, "tigradas", segundo informações verbais de J.M.V. Coutinho), "film" (raras), "braided", "patch" ou manchas ou de fraturas (Fotomicrografias $2-5$ e 7-11). O mesmo individuo ou conjunto geminado pode mostrar padrões variados, mas que obedecem em geral à distribuiçäo regular. É comum a porção central conter grande mancha albitica, que se espalha de forma irregular ou "braided", arranjando-se em lamelas bizeladas, alternadas, nas partes periféricas (Fotomicrografias 8 e 11). Invariavelmente, o tipo em lamelas, o mais típico e regular, possui lamelas perpendiculares às bordas dos cristais e aos planos composicionais (010) dos geminados Carlsbad. As lamelas, mais largas nas bordas, estreitam-se para dentro do cristal, ou terminam na forma de bisel. Ocorre, também, certo anastomosamento entre sub-lamelas e as lamelas, principalmente as sódicas nas potássicas. As lamelas sódicas são homogêneas; já as potássicas possuem lamelas quase submicroscópicas sódicas - o que significa que as fases potássicas são pertíticas, e que existem duas gerações de lamelas: as maiores $(0,01-0,1 \mathrm{~mm}) \mathrm{e}$ as mais finas $(>0,005 \mathrm{~mm})$.

É bastante comum que fases albiticas apareçam nas bordas, do lado interno dos indivíduos, assim como formando agregado intersticial, ou mesmo se interdigitem ou entrelacem com o cristal vizinho. Parte dessas distribuições pode ser chamada de "chess board" albita (Fotomicrografia 5).

Em um único individuo de feldspato alcalino observou-se zoneamento óptico.

O quartzo pode aparecer como gräo único em uma secção delgada, fato comum, até formando áreas maiores, intersticiais, onde é raramente granular. $\mathrm{Na}$ medida em que aumenta a sua quantidade, o mineral passa a envolver parcialmente os feldspatos. Indivíduos, cristalograficamente contínuos, assumem formas intersticiais angulosas e irregulares, com distribuiçäo homogênea ou estão concentrados. Ocorre ainda sob uma terceira forma, qual seja, em alinhamento contínuo de individuos com formas irregulares, apresentando vinculação com fratura, que atravessa os feldspatos, que, por sua vez, mantêm sua integridade.

A assembléia de fêmicos mais comum reúne clinopiroxênio, biotita, anfibólio e opacos (55\% das amostras), seguida daquela sem anfibólio (45\%). São raras as amostras contendo os pares clinopiroxêniomanfibólio e biotita-anfibólio, e não se observou amostra sem os opacos. Junto aos agregados dos fêmicos, a presença do quartzo é comum.

Os opacos, além de onipresentes, mantêm teor constante em torno dos $1-2 \%$ aos $5 \%$. Os outros ferromagnesianos são de ocorrência variável, com certo predomínio da biotita, mas que oscila de amostra para amostra, seguida do clinopiroxênio, sendo o anfibólio a espécie de menor participação.

Sem dúvida, o clinopiroxênio é o fêmico mais importante, mas não pela quantidade, que dificilmente ultrapassa os $5 \%$. O mineral pode assumir formas e posturas diversas: ocorrer 


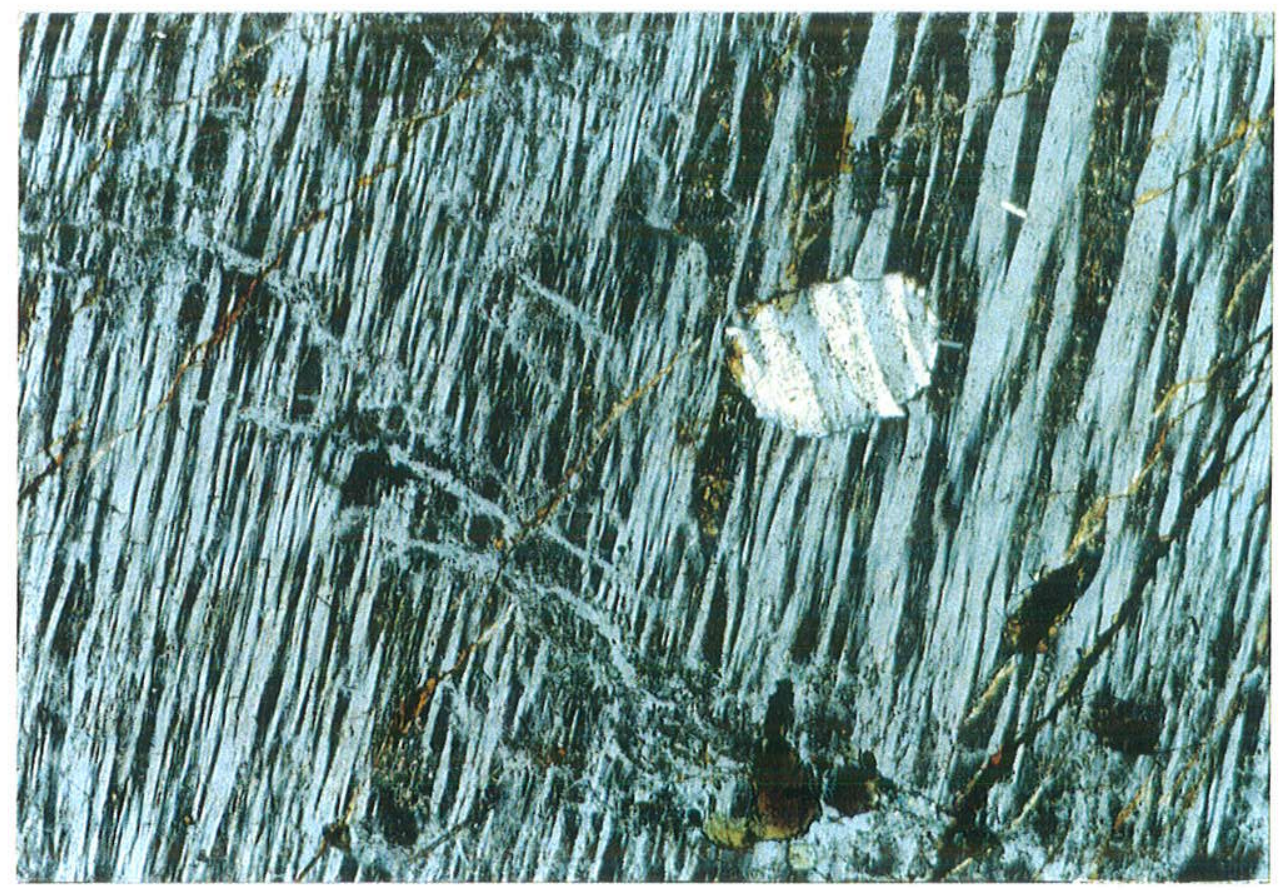

Fotomicrografia 10 - Sienito. Detalhe da micromesopertita lamelada ("tigrada"). Notar bizelamento, bifurcações. Fase cinzenta mais clara, limpa, sódica. Observar pertitização transversal, provavelmente o tipo chamado de "pertita de fratura". Dimensão maior, 1,39 mm, filtro azul, polarizadores semicruzados.

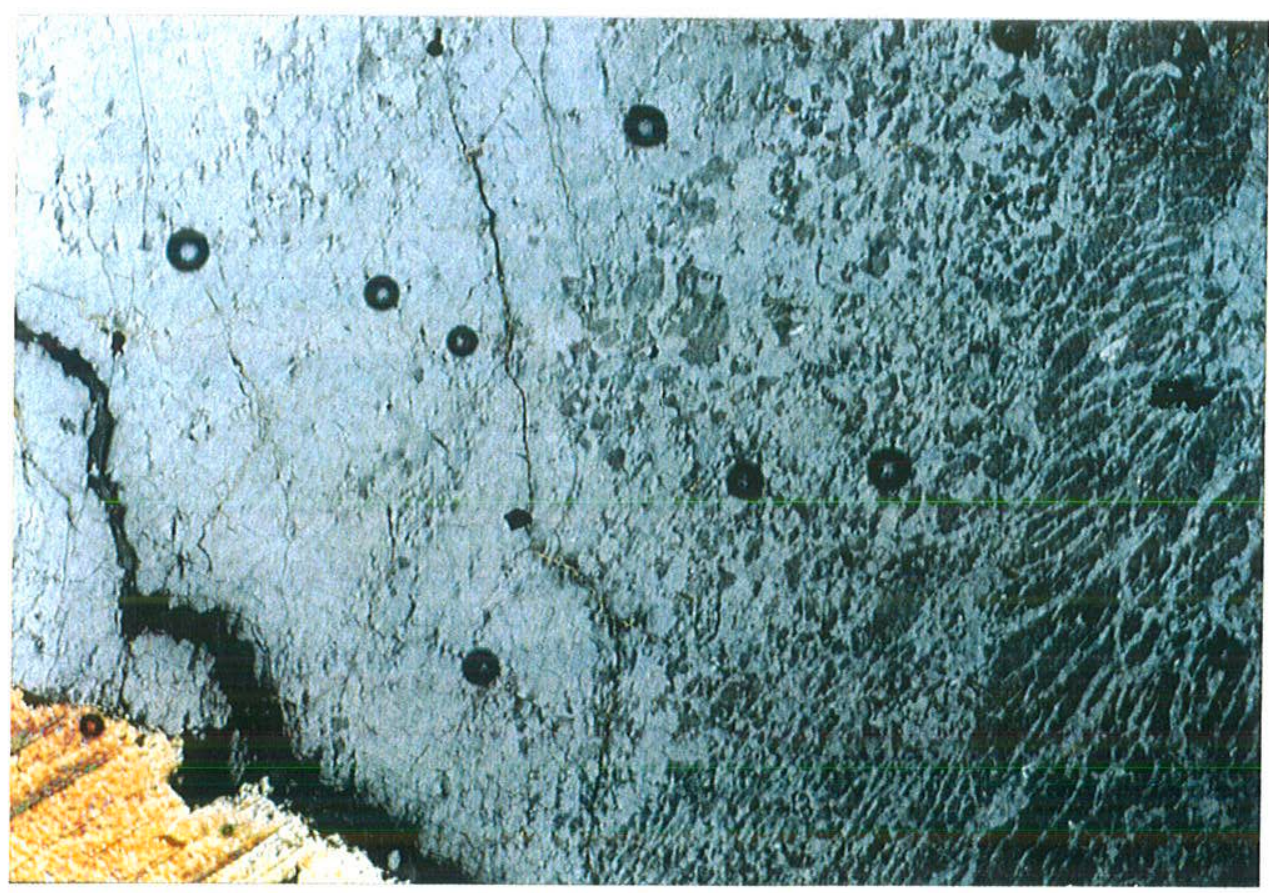

Fotomicrografia 11 - Sienito. Padrões e distribuição das fases em um indivíduo. Centro, à esquerda, albítica, quase homogênea, passa a manchas, em que aumenta a fase potássica. Na borda, à direita, domina padrão anastomosado, com maior presença da fase potássica. A separação entre a borda, à direita, e a porção manchada mostra fases albíticas alongadas transversalmente, talvez, exsolução de fratura. Dimensão maior, $2,80 \mathrm{~mm}$, filtros azul, polarizadores semicruzados. 
isolado, raramente, agrupado ou enfileirado, em contato, penetrado ou parcialmente incluso na biotita, principalmente. Apresenta contornos, em parte regulares, ou retilineos e angulosos, e sinuosos e descontínuos no mesmo individuo. É comum que o mesmo individuo seja descontínuo e segmentado por outros minerais. Mostra variações ópticas, ou seja, dos tipos, entre amostras, principalmente se levado em conta as diferenças observadas desde as zonas de contato, a oeste, até a extremidade leste da liha. Suas características variam entre as augitas, ou augitas diopsidicas, pardacentas incolores sem zoneamento (Fotomicrografia 12), nas porções de contato ou mais a oeste, para individuos incolores a esverdeados por inteiro ou nos núcleos (Fotomicrografia 13), com bordas em que a cor verde se acentua, até borda de cor verde intenso, quando aumenta a birrefringência e diminui o ângulo de extinção, só que agora $\mathrm{X} \Lambda \mathrm{c}$ de não mais que $3-5^{\circ}$. De modo geral, as caracteristicas ópticas ajustam-se à seqüência augitas-diopsídios-hedembergitas, até egirina-augitas.

Os cristais quase nunca são inteiros, íntegros e inalterados. Mostram-se segmentados em partes, quer por clivagem ou por fratura, ao longo das quais desenvolve-se zona de alteração colorida, às vezes de biotita. Além de orlado por biotita, mais raramente por anfibólio, pode ainda ocorrer incluso nesse último mineral (Fotomicrografia 14). Já este mesmo mineral pode aparecer como manchas internas no piroxênio. A forma externa dos cristais de piroxênio exibe comumente o aspecto descrito como "corroido".

Além dos minerais associados citados acima, tem-se que nos agregados fêmicos ainda ocorrem apatita, abundante, opacos e titanita, e que todas essas fases estäo presentes como inclusōes no clinopiroxênio.

O clinopiroxênio aparece incluso nos feldspatos. Tem dimensões menores, milimétricas a submilimétricas, contornos não geométricos, mas regulares, com formas equidimensionais a pouco alongadas, está pouco alterado e se mantém isolado. Não mostra lamelaçäo, sendo raramente geminado.

Os tipos descritos devem corresponder a augitas, augitas diopsidicas, diopsídios ou até ferroaugitas, com as variações se dando tanto na distribuição espacial (oeste para leste, norte para sul), quanto do centro para a borda no mesmo indivíduo. Essas mudanças são sempre no sentido da formaçāo de composições mais sódicas, talvez egirina augitas a egirinas (Fotomicrografia 15).

A biotita é o ferromagnesiano mais presente, e mostra pequena variação, concomitante àquela dos piroxênios. Biotita marrom $\left(Y, Z^{\prime}\right)$ a amarelada clara $\left(X^{\prime}\right)$ ocorre mais junto aos piroxênios incolores, passando gradativamente às de cor marrom escuro $\left(Y, Z^{\prime}\right)$ a alaranjadas $\left(X^{\prime}\right)$ quando em associação com piroxênios zonados e esverdeados a verdes (Fotomicrografia 15). É inalterada, orla e inclui outros minerais, como apatita, zircão, opacos e piroxênio, e forma placas maiores, milimétricas, e menores, submilimétricas. Tal como o piroxênio, aparece em palhetas e placas menores inclusas e dispersas nos feldspatos. Com bastante freqüência, mostra interdigitação, quase uma simplectita, com o feldspato contíguo 


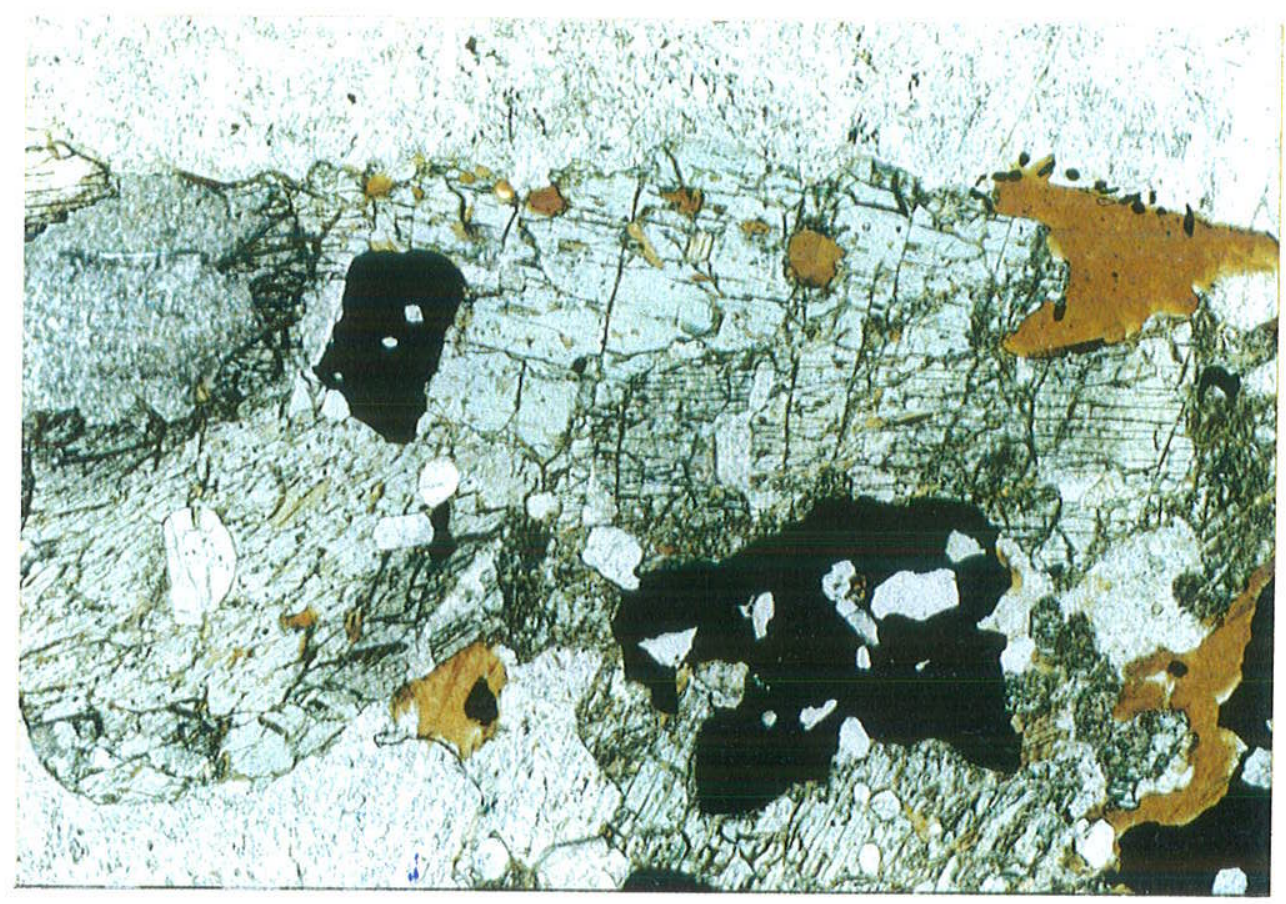

Fotomicrografia 12 - Sienito. Agregado fêmico, com clinopiroxênio, biotita, opacos e apatita. Clinopiroxênio do tipo incolor/esverdeado, pouco alterado. Notar relações de inclusão entre os minerais. Dimensão maior, $2,80 \mathrm{~mm}$, filtros azul e fosco, polarizadores descruzados.

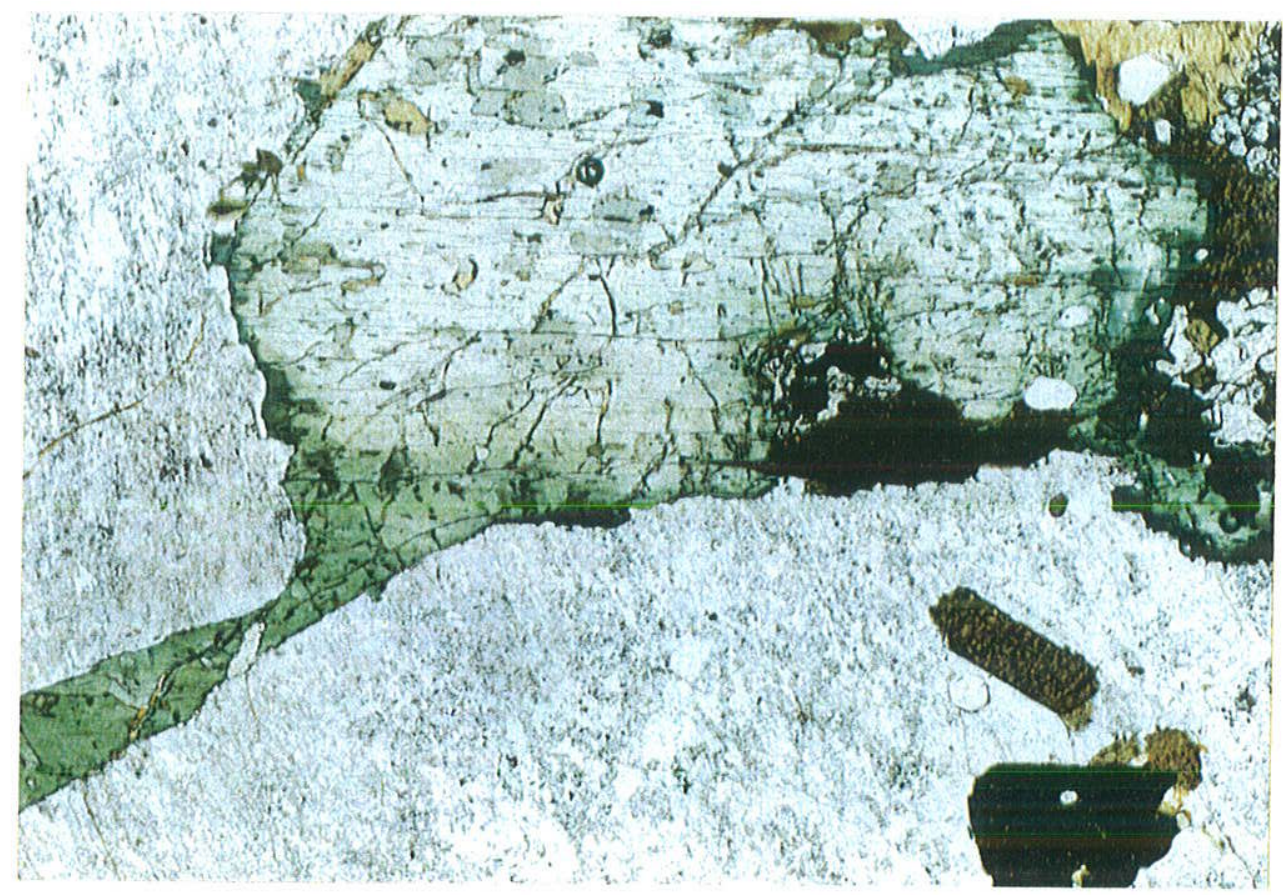

Fotomicrografia 13 - Sienito. Clinopiroxênio, de aspecto possivelmente corroído, constituído em sua maior parte por um núcleo incolor, passando a esverdeado e verde nas bordas. Manchas internas, cinzentas claras, de anfibólio; um segundo anfibólio, verde escuro, está presente nas bordas. Inclusos e periféricos: biotita, apatita e titanita. Dimensão maior, 2,80 mm, filtros azul e fosco, polarizadores descruzados. 


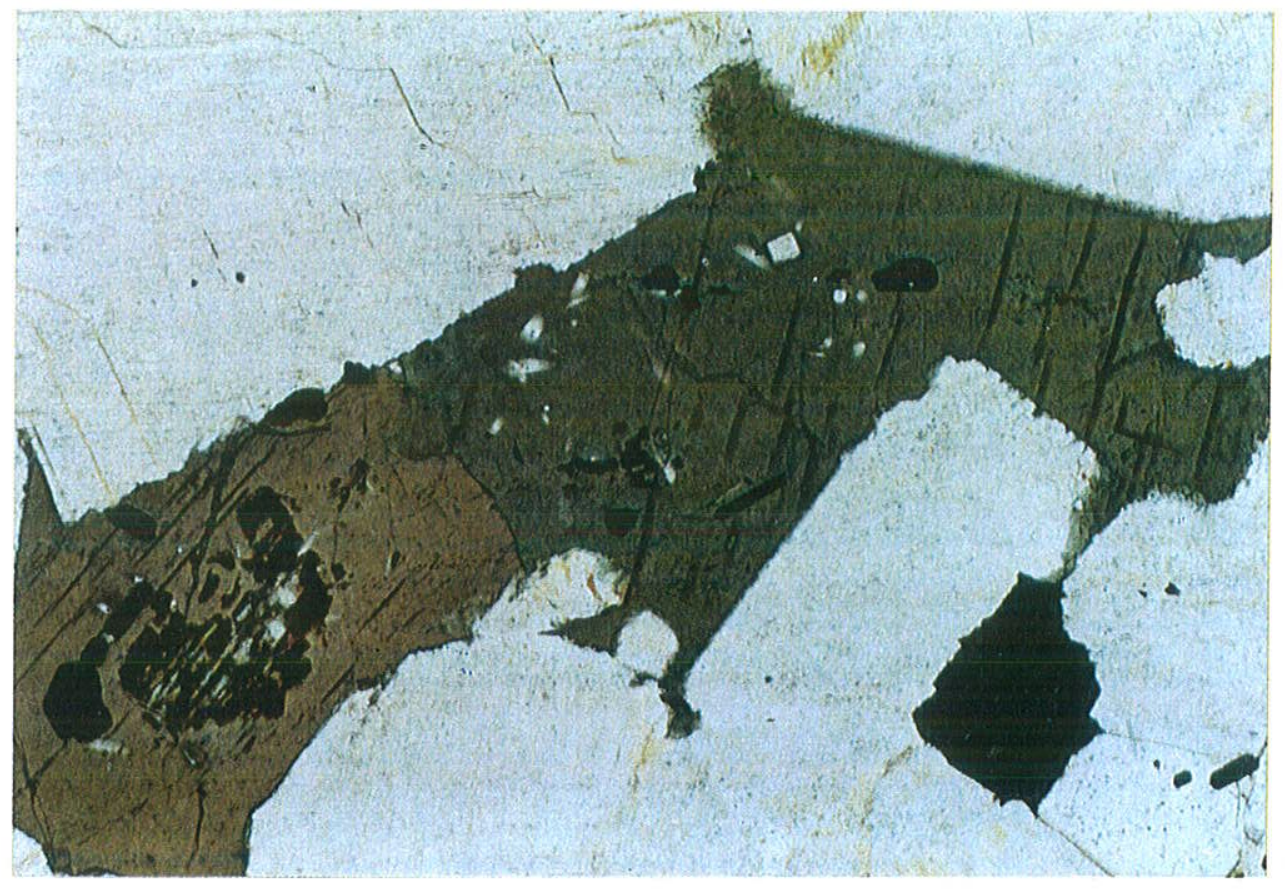

Fotomicrografia 14 - Sienito. Nas rochas com presença de quartzo, esse anfibólio, pouco mais escuro (verde oliva/pardo-amarelado escuro), é o mais comum. Inclui resto de clinopiroxênio limonitizado, apatita, opacos e zircão. Observar parte das bordas, à esquerda, com tendência ao intercrescimento com a mesopertita contígua. Dimensão maior, $2,80 \mathrm{~mm}$, filtro azul, polarizadores descruzados.

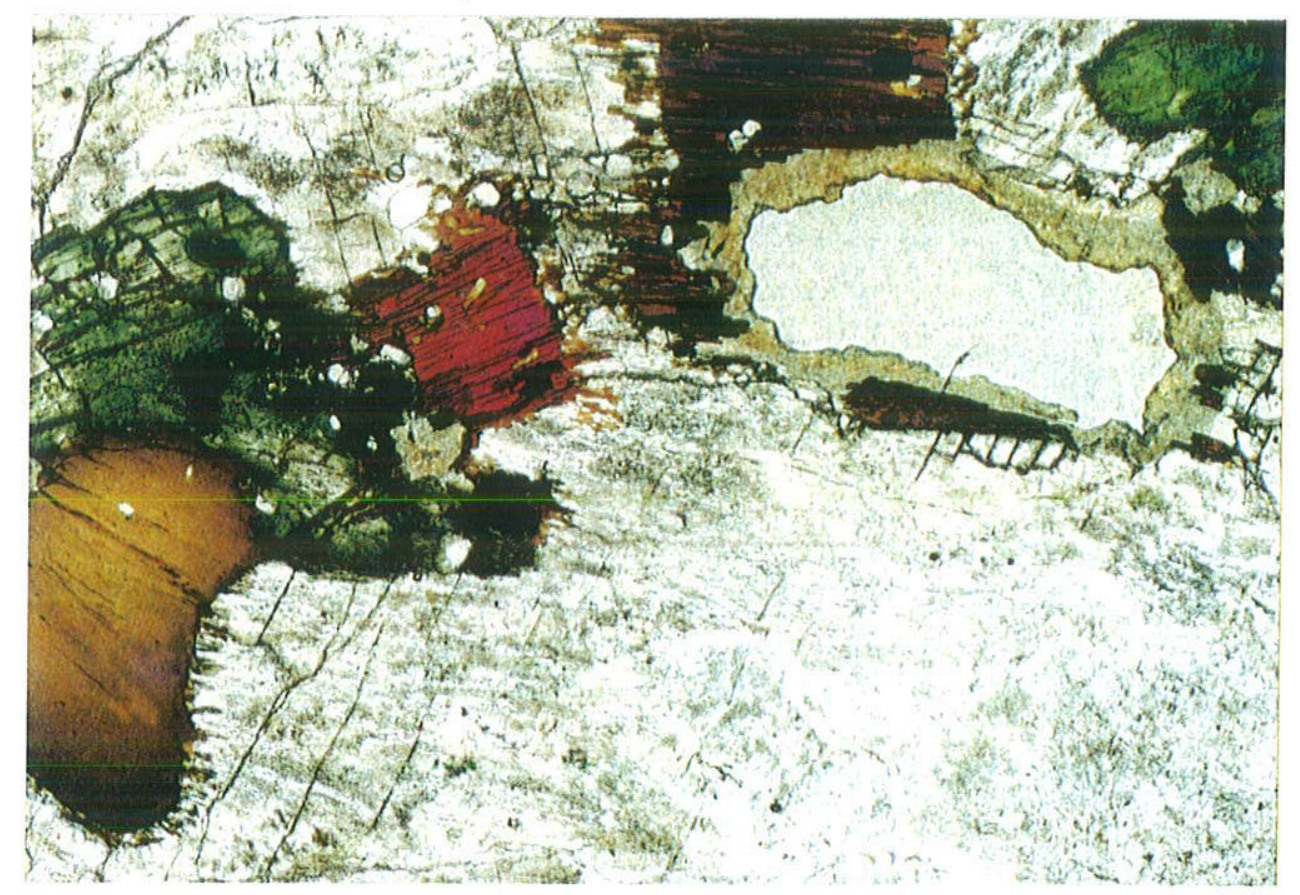

Fotomicrografia 15 - Sienito, da extremidade sudeste da llha. Associação biotita-clino-piroxênio. Notar cor da biotita e do piroxênio, este com verde acentuado. Observar inclusões de apatita e opacos e bordas digitadas da biotita. Dimensão maior, $5,50 \mathrm{~mm}$, filtro azul, polarizadores descruzados. 
(Fotomicrografia 15).

O anfibólio tem sempre cores esverdeadas a amareladas. Varia em tons de verde mais escuros a mais claros, mais ou menos amarelados, mais ou menos pardacentos ou, mais raramente, azulados ou acinzentados $(Z, Y)$; com intensidade semelhante ou menor, $Y$ varia também em tons de verde-amarelado, ou é mais acinzentado ou chega a ser pardo, enquanto que $X^{\prime}$, bem mais claro, é amarelado a amarelo-esverdeado, principalmente (Fotomicrografia 16). Freqüentemente é manchado, sendo que em alguns casos percebe-se, opticamente, zoneamento regular. Aparece orlando o clinopiroxênio ou incluindo-o, ou com a biotita em relação variada, mas principalmente e texturalmente igualitária (Fotomicrografia 17). Também ocorre em grãos isolados. Tal como a biotita, mostra fina interdigitação periférica com os feldspatos vizinhos. Inclui apatita e opacos.

Outras caracteristicas ópticas, mas particularmente $Z \Lambda c$ e a birrefringência, indicam variações composionais mas dentro dos anfibólios cáicicos, hornblêndicos e, mais raramente, cálcio-sódicos.

Em geral, o anfibólio não assume formas inteiras, acabadas, mas ocupa espaços de formas irregulares. Com relação aos outros ferromagnesianos, é constituinte minoritário, estando ausente na metade das amostras.

Em quase todas as amostras, as fases opacas são de dois tipos, magnetitas e ilmenitas, predominando as primeiras. Podem aparecer em grãos isolados, não obstante o intercrescimento entre as espécies seja comum. Em geral, ilmenitas, são lamelas retilineas, ou hóspedes de formas variadas, ou periféricas. É freqüente que apresentem borda de titanita. Têm, em geral, forma granular e equidimensional, e ocorrem como inclusões em ferromagnesianos.

Nas relações entre os cristais de piroxênio, biotita, anfibólio e opacos, parece bastante sistemático que os opacos não incluam os demais minerais (a não ser ocasional apatita) e se mostrem inclusos a semi-inclusos. O piroxênio, por sua vez, só engloba os opacos; eventuais manchas de biotita ou de anfibólio, internas, associam-se às fraturas e clivagem e, de modo geral, ocorre isolado, sem alteração de borda, incluso como restos ou semi-inciuso na biotita e anfibólio. Quer dizer, tanto a biotita como o anfibólio envolvem parcial a totalmente o piroxênio. Estes dois últimos minerais, por sua vez, mantêm relação de contato, em geral, de igual para igual.

A apatita, de dimensōes variadas, mas submilimétrica, reúne-se aos agregados de máficos, às vezes concentrando-se em teores locais apreciáveis. Nesses lugares, pode estar inclusa em qualquer deles, mas principalmente na biotita. Tem formas subhexagonais a arredondadas.

A titanita, além de orlar com muita freqüência os opacos, ocorre em grãos até milimétricos, com formas irregulares, isolada. É incolor a pardacenta. Zircão, quadrado, 


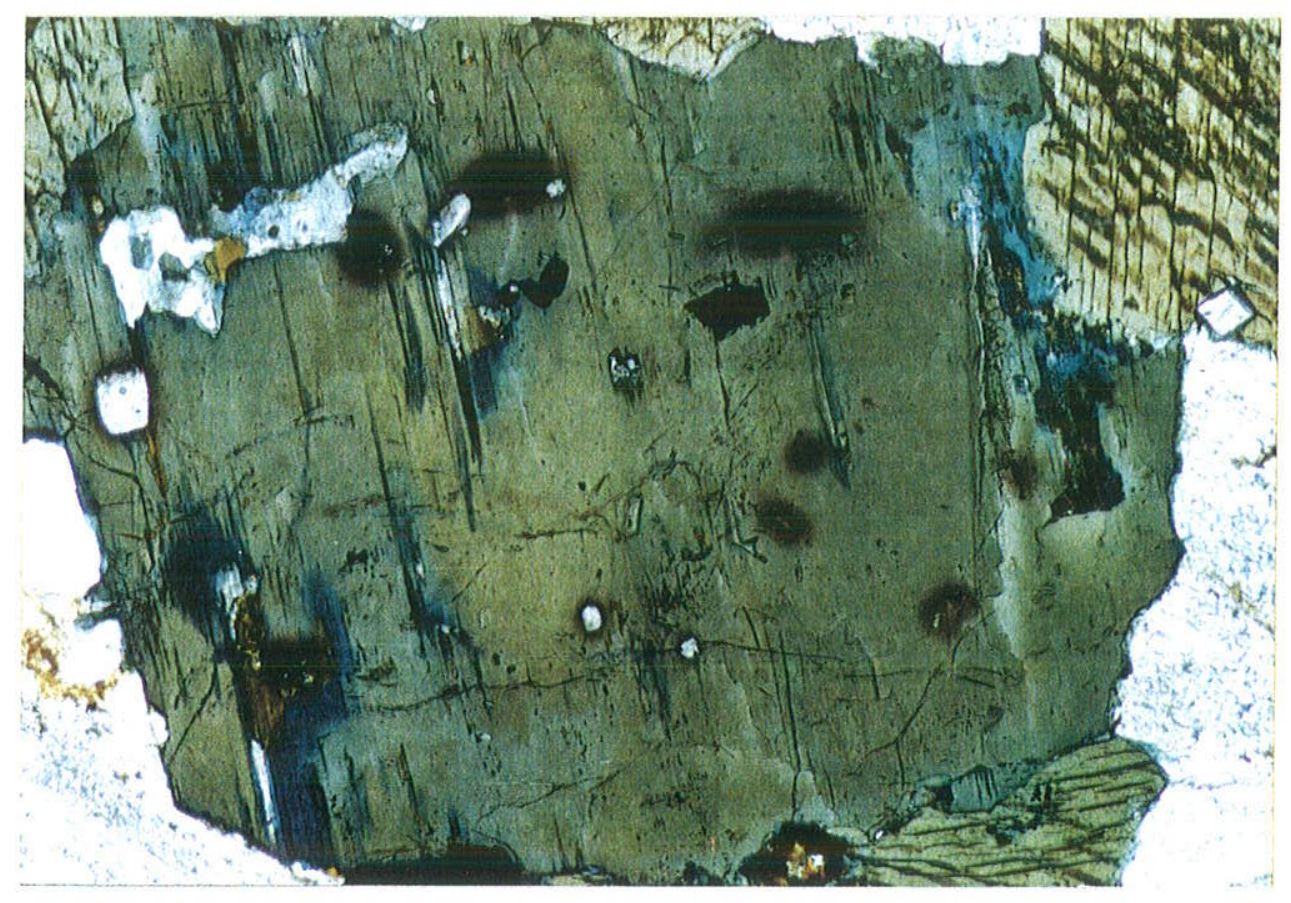

Fotomicrografia 16 - Sienito, tipo com quartzo, e microssienito. Variedade mais comum entre os anfibólios. Direção do polarizador paralela à clivagem, anfibólio com elongação positiva. Notar os tons de cores do anfibólio, seu manchamento/zoneamento (verde-amarelado/verde-acinzentado) e a cor azul intenso junto às periferias. Observar inclusões de zircão, apatita e halos pleocróicos em torno de mineral não identificado. Dimensão maior, 1,39 mm, filtro azul, polarizadores descruzados.

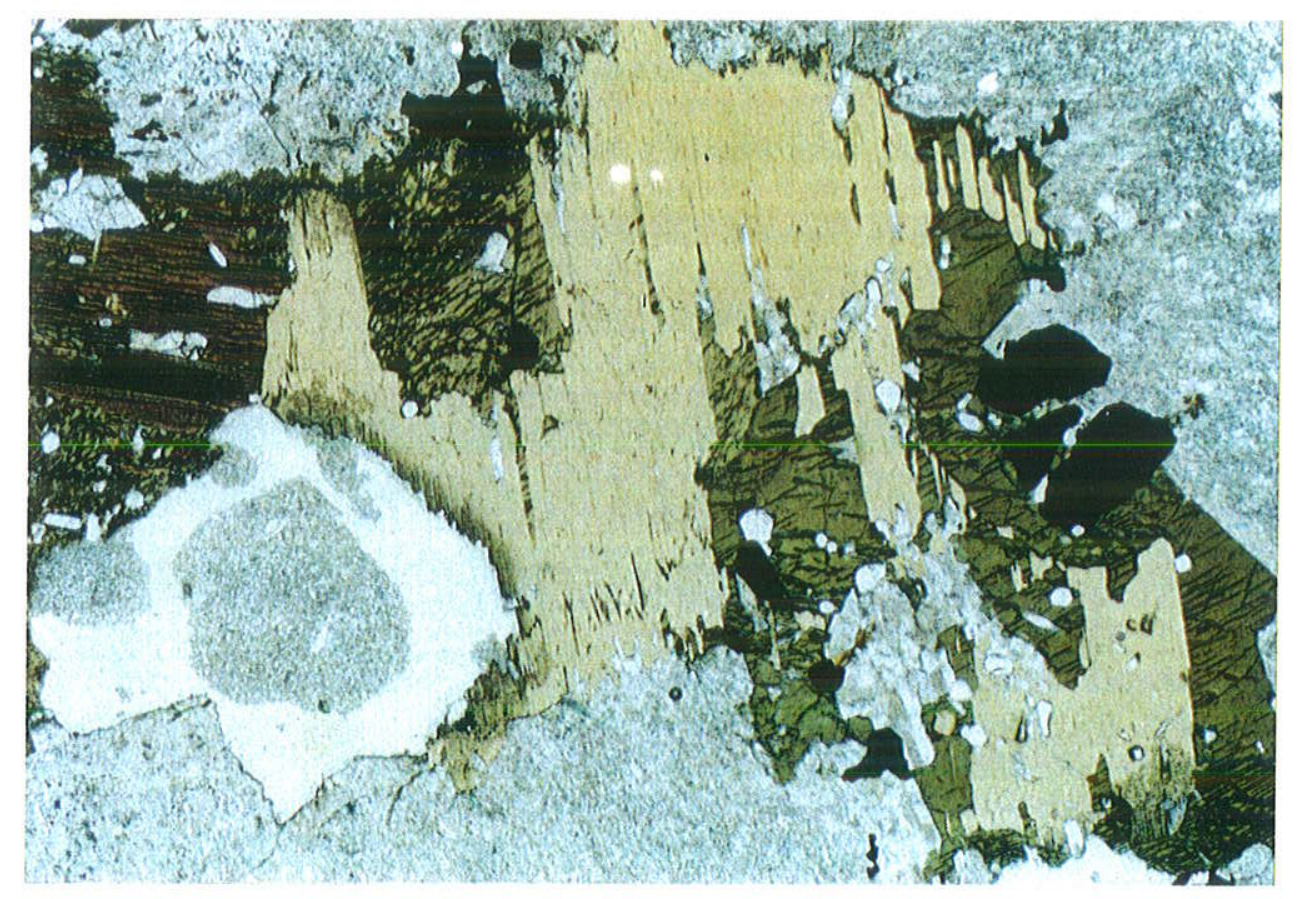

Fotomicrografia 17 - Sienito. Intercrescimento de biotita com anfibólio verde oliva. Notar a fina interdigitação. Inclusões de opacos e apatita. Dimensão maior $5,50 \mathrm{~mm}$, filtros azul e fosco, polarizadores descruzados. 
retangular ou arredondado, ocorre esparsa e raramente. É incolor. Allanita, metamítica, é rara. Afora a do piroxênio, outras alterações de caráter tardio a hidrotermal nessas rochas são raras e de pequena expressão.

\subsection{2. Álcali feldspato-quartzo sienitos}

Entre as amostras de sienitos estudadas, 20\% caem nessa classificação. Elas têm distribuição geográfica até certo ponto regular, em geral nos contatos e não longe deles, e não ocorrem nas porções mais internas do maciço. São a maioria da Pontinha e na costa sul e imediaçöes da cunha charnoquitica de sul. Da costa sul, entre o Saco do Coruja e a Ponta Sul, parecem adentrar o maciço, para norte, pelas encostas até antes dos cumes mais altos.

Como descrito, são rochas de granulação grossa, com o feldspato diferente dos sienitos. Este mineral apresenta formas macroscópicas mais irregulares, e é escuro, verde, pardacento e cinzento (Foto 35). Como um todo, essas rochas podem ser manchadas em claro-escuro, por alteração incipiente.

Esses sienitos incluem aqueles chamados de híbridos, outros tipos de difícil definição macroscópica, heterogêneos e/ou semelhantes aos charnoquitos mais finos. Não raro contêm restos de charnoquito, reduzidos a pequeno agregado, com um cristal de feldspato e alguns fêmicos. Outras heterogeneidades são visiveis, com rápidas alternâncias de granulação e finos bandamentos descontínuos. Neles ocorrem também cavidades miarolíticas típicas.

Texturalmente, essas rochas variam entre os tipos quase equigranulares, grossos, e aqueles inequigranulares, com seriação granulométrica entre grossa e fina. Em geral, são hipidiomórficas, raramente lembrando a disposiçäo subparalela de feixes de feldspatos da textura foiaitica. Ficam melhor definidas se vistas como variações texturais hipidiomórficas a alotriomórficas, com o feldspato se mostrando granular, tabular e xenomórfico ou até mesmo sub-retangular (Fotomicrografias 18-20). Os minerais fêmicos espalham-se, ou se concentram, nas faixas de granulação mais fina, mas parte ainda intergranular entre os feldspatos mais bem formados ou inteiros. Como nas rochas anteriores, os fêmicos estão ou mais ou menos reunidos, notando-se sempre a presença do quartzo junto a eles. Tal como nos tipos já descritos, os de menores dimensões ocorrem dentro dos feldspatos, ou enfileirados, ou podem aparecer em um ou dois individuos feldspáticos e se ausentar dos vizinhos.

Outras caracteristicas que diferenciam estes sienitos dos demais são a maior presença de produtos de alteraçäo, agora incluindo carbonatos, comuns, e a existência de fraturamento mineral, preenchido a exemplo dos charnoquitos. Além disso, nessas rochas não é incomum a presença de faixas estreitas de cisalhamento, embora a deformação, aparente, das rochas não seja acentuada. As fraturas de cisalhamento mostram desenvolvimento de anfibólio, clinopiroxênio e feldspatos, em parte deformados. 


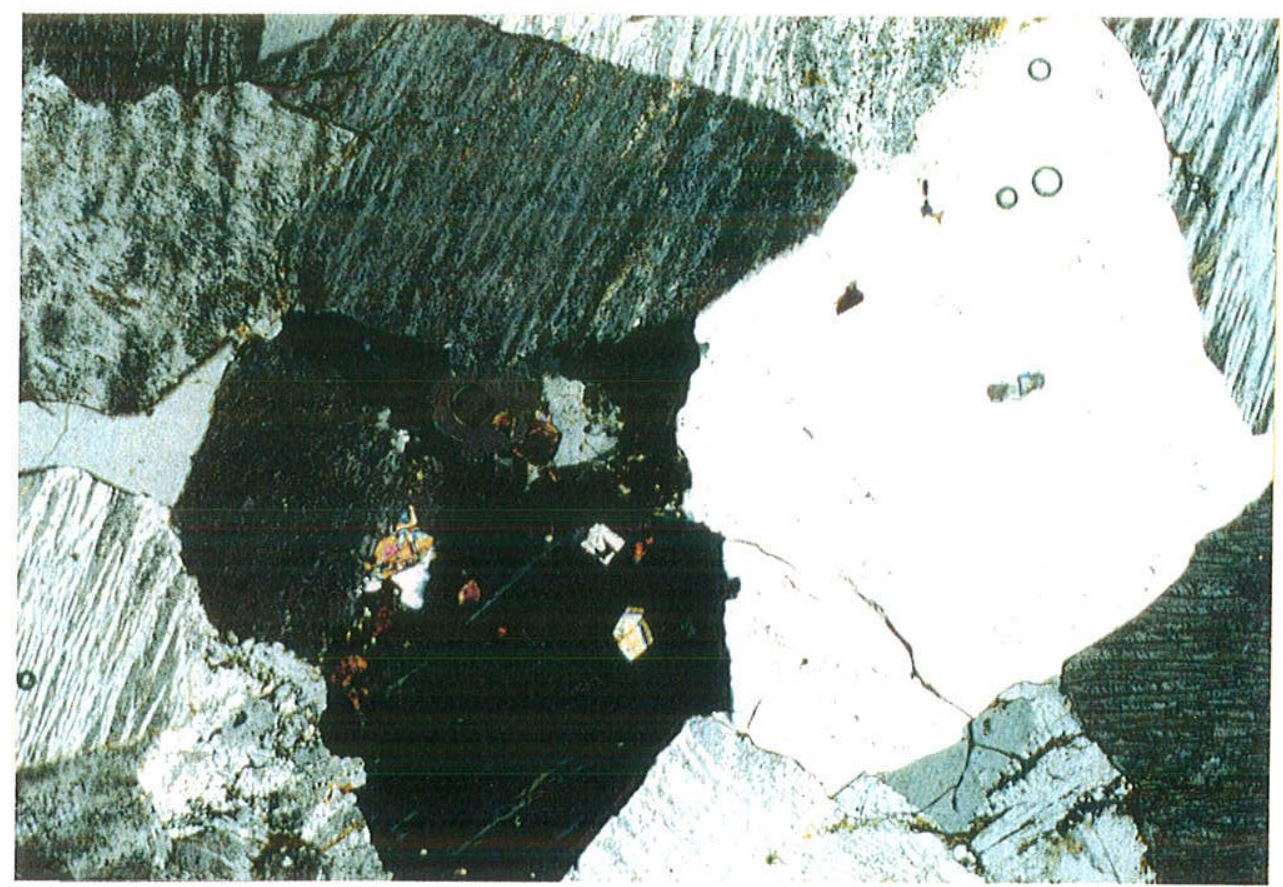

Fotomicrografia 18 - Quartzo sienito, com textura alotriomórfica. Mesopertitas lameladas ("tigradas") ou de padrão irregular. Dimensão maior, $2,80 \mathrm{~mm}$, filtro azul, polarizadores semicruzados.

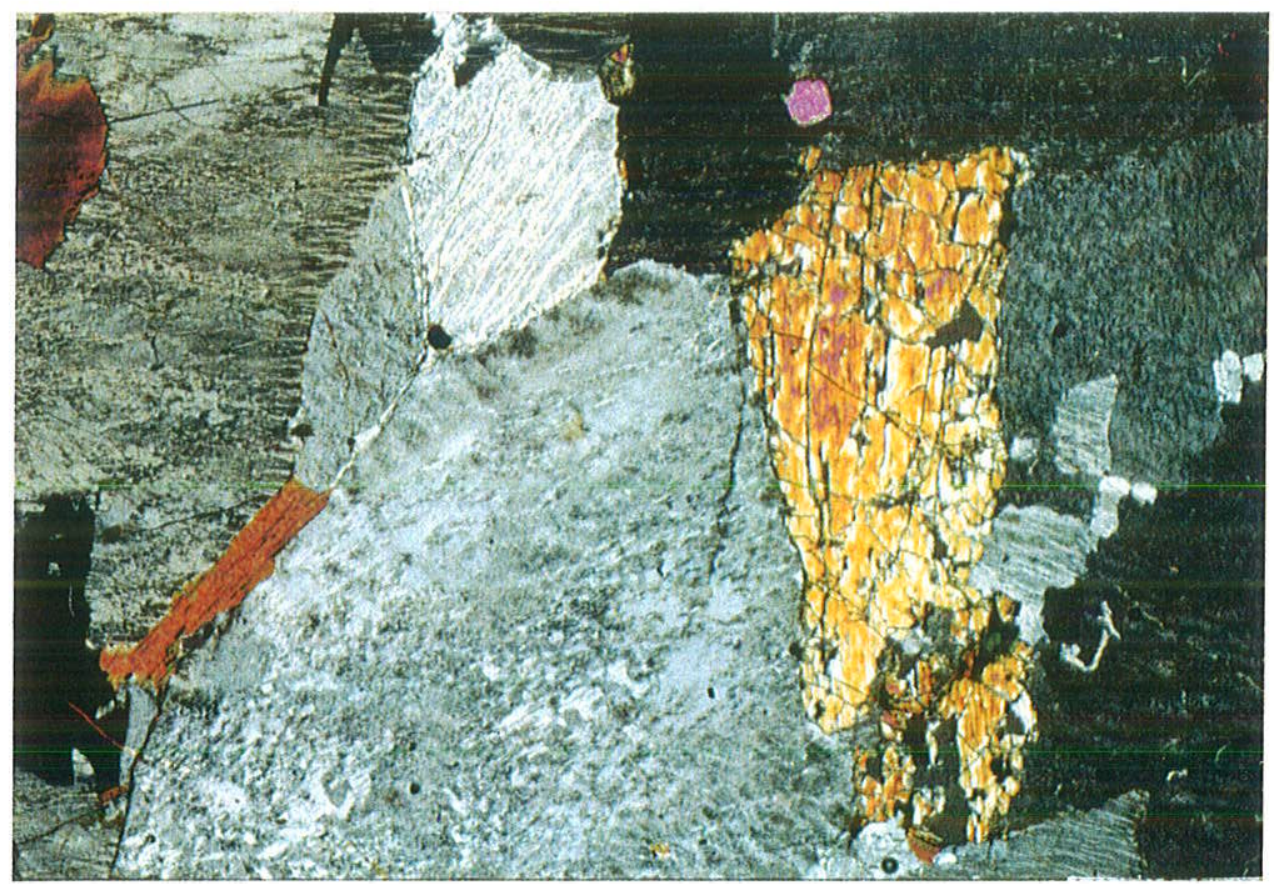

Fotomicrografia 19 - Sienito. Textura inequigranular, seriada, alotriomórfica/hipidiomórfica. Contatos não muito irregulares, pouca interpenetração. Notar variação no padrão micromesopertítico do indivíduo à esquerda, com faixa de borda "tigrada". Presentes biotita, clinopiroxênio e opacos. Dimensão maior, 5,50 $\mathrm{mm}$, filtro azul, polarizadores semicruzados. 
As diferenças não são apenas texturais, mas também mineralógicas. Em todas as amostras examinadas mantém-se a proporção mesopertitas-fêmicos, ainda que a participação do anfibólio seja muito maior: ele aparece em todas elas e predomina entre os fêmicos. Os opacos estão também presentes em todas as amostras, mas o piroxênio ocorre em não mais do que $40 \%$ delas, e da mesma maneira a biotita. Apenas $25 \%$ do total conservam a assembléia anfibólio-biotita-piroxênio, e parte igual contém somente o anfibólio.

A participação das mesopertitas é a mesma, porém nota-se mudança no padrão, mais indefinido, ainda que os tipos mais freqüentes sejam aparentemente homogêneos, embora mostrem domínios distintos, talvez devido à presença de geminação.

A maior riqueza em quartzo se constitui também em diferença marcante. Aqui, ele forma grãos xenomórficos equidimensionais isolados, ou se dispöe finamente entre os cristais vizinhos de feldspato (Fotomicrografia 18). Nessas rochas começam a aparecer os intercrescimentos granofíricos, micrográficos e os "finger print" (Smith e Brown, 1988) (esses intercrescimentos serão tratados em item à parte). O quartzo comparece com mais que $5 \% \mathrm{e}$, em geral, não ultrapassa os $10 \%$.

O clinopiroxênio é semelhante ao dos tipos augítico-diopsídicos já referidos, mas aparece mais como restos, quase sempre regularmente alterados em filossilicatos coloridos (biotita, clorita, óxidos hidratados etc.). Quando inclusos no anfibólio, somente se vê seu molde alterado (Fotomicrografia 21). Algumas amostras têm, ao lado do clinopiroxênio, restos reconheciveis de ortopiroxênio, em grande parte alterado. É interessante registrar a presença de microlamelação, semi-opaca, nos cristais de clinopiroxênio; essa microlamelação começa nas bordas dos grânulos, perpendicularmente a possivel direção (001), e atravessa o grão todo ou se interrompe, deixando o núcleo do piroxênio, limpo.

A biotita aparece na periferia de outros minerais ou como palhetas isoladas pequenas. Além do tamanho, também sua quantidade diminui. Mantém as características mais evidentes (Y, Z' - marrom, X', amarelado).

Não se notaram variações nos opacos.

O anfibólio é semelhante ao dos sienitos anteriores, mas muito melhor desenvolvido, em individuos largos, equidimensionais, alongados ou irregulares. Apresenta alteração para carbonatos e sempre se faz acompanhar de algum quartzo. É facilmente notado em todas as amostras o aumento da sua quantidade e a concomitante diminuição da participação do clinopiroxênio e da biotita. Além disso, os agrupamentos registram, muito mais, a associação anfibólio-opacos-apatita, diferente dos agregados de minerais ferromagnesianos dos álcali feldspatos sienitos

Outras diferenças foram registradas. Embora rara, registrou-se a ocorrência de plagioclásio intermediário (oligoclásio), quebrado e deformado. A essas variações, adicione-se a menor presença da apatita e maior do zircão. 


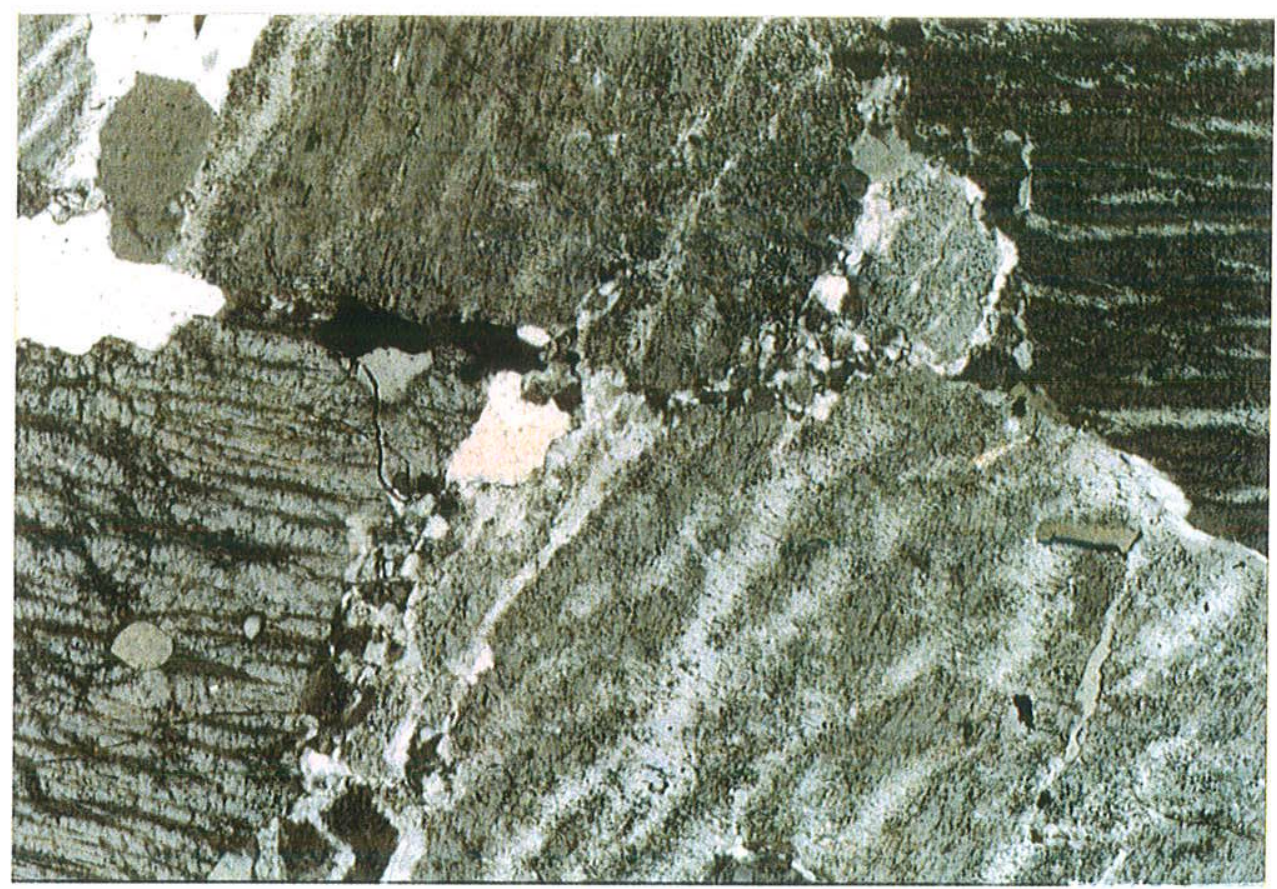

Fotomicrografia 20 - Quartzo sienito, com textura quase equigranular hipidiomórfica. Notar contatos moderadamente irregulares e presença de microgranulação intersticial, que inclui quartzo (branco), albita (branca) e opacos. Padrão micromesopertítico variado. Dimensão maior, 2,80 mm, filtros fosco e azul, polarizadores semicruzados.

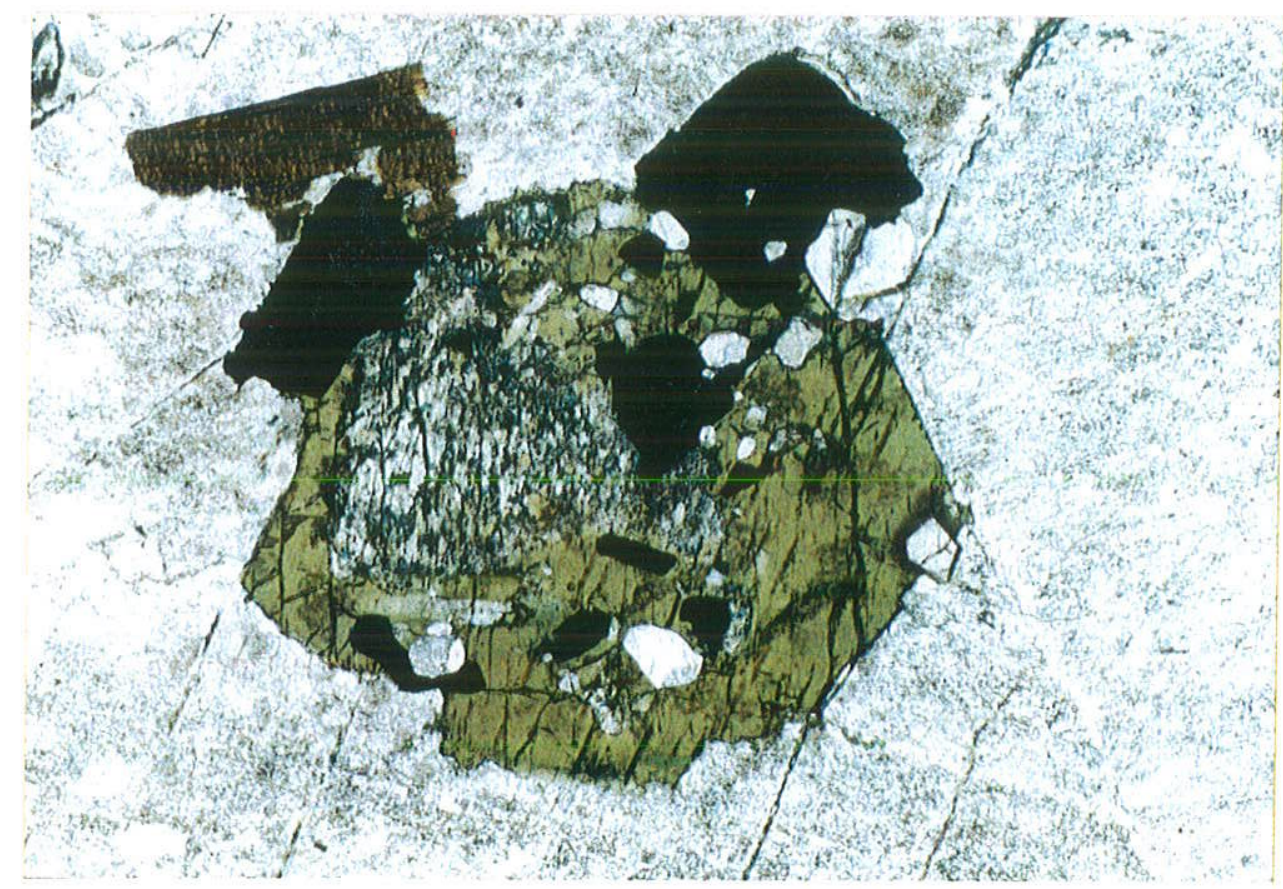

Fotomicrografia 21 - Quartzo sienito. Anfibólio comum, com resto alterado de clinopiroxênio incolor. Inclusões de opacos e apatita. Biotita aparece, vizinha. Dimensão maior, 2,80 mm, filtro azul, polarizadores descruzados. 


\subsubsection{Microssienitos}

Como mencionado, essas rochas ocorrem quer como fácies plutônicas, quer como diques. Os diques variam gradativamente para as rochas, mais apropriadamente, descritas como traquitos, separadamente.

Os microssienitos mostram pouca variação entre os vários tipos de ocorrências amostrados. Apresentam muita semelhança entre si e pequenas diferenças, boa parte sem grande relevância.

São rochas que variam desde aquelas equigranulares (Fotomicrografia 22), com granulação média a fina, até as com granulação seriada, desde grossa a fina (Fotomicrografia 23). Menor número de vezes, a rocha é porfirítica, e com essa estrutura, a maioria ocorre como dique. Macroscopicamente, sâo rochas de cores claras, esbranquiçadas, acinzentadas a pardacentas (Foto 37), com as variedades plutônicas das zonas de contato exibindo cores escuras, esverdeadas (Foto 38). Mesmo os tipos escuros são leụcocráticos a hololeucocráticos, e dificilmente o teor dos fêmicos ultrapassa os $10 \%$. As variações de cores, particularmente a cor verde, verde-pardacento, está ligada ao feldspato.

Essas rochas de cores escuras, tal como os sienitos, mostram mudança de cor com o tempo, às vezes em dias, ou por imersão no $\mathrm{HCl}$ diluído. Parte delas, contudo, conserva a cor verde original por longo tempo.

Além das variações texturais, a modificação mais notável é no teor de quartzo. Existem os tipos sem quartzo algum, os com pouco quartzo, em torno de 1 a $2 \%$ até $5 \%$ (Fotomicrografias 22-24), e, mais raros, os tipos com maior quantidade de quartzo, chegando até os $20 \%$ ou mais (Fotomicrografia 25). Essas variaçöes na presença do quartzo ocorrem de forma mais limitada entre as rochas descritas como traquitos, que nunca atingem os $10 \%$ de quartzo.

Pequenas variações mineralógicas e texturais, além do teor de quartzo, ligam-se à forma de ocorrência e ao posicionamento geográfico dos microssienitos. De modo geral, os microssienitos das zonas de contatos quase sempre têm quartzo e, com freqüência, acima dos $5 \%$ (Fotomicrografia 25). Os tipos que aparecem como bolsões, ou tratos de limites indefinidos nos sienitos, tanto podem conter quartzo, até acima dos $5 \%$, como esse mineral pode estar ausente. Os diques intrusivos nos charnoquitos são sempre portadores de quartzo, e junto a alguns tipos de contatos, são os que possuem maiores teores do mineral. Intrusivos nos sienitos, parecem variar para leste no sentido de diminuição no quartzo, até as rochas sem essa fase na extremidade leste.

\subsubsection{1. Álcali feldspato microssienitos}

Essas rochas variam, texturalmente, desde holocristalinas, panidiomórficas, com textura "foiaitica" a hipidiomórficas granulares ou não (Fotomicrografias 22-24) de um lado, ou 


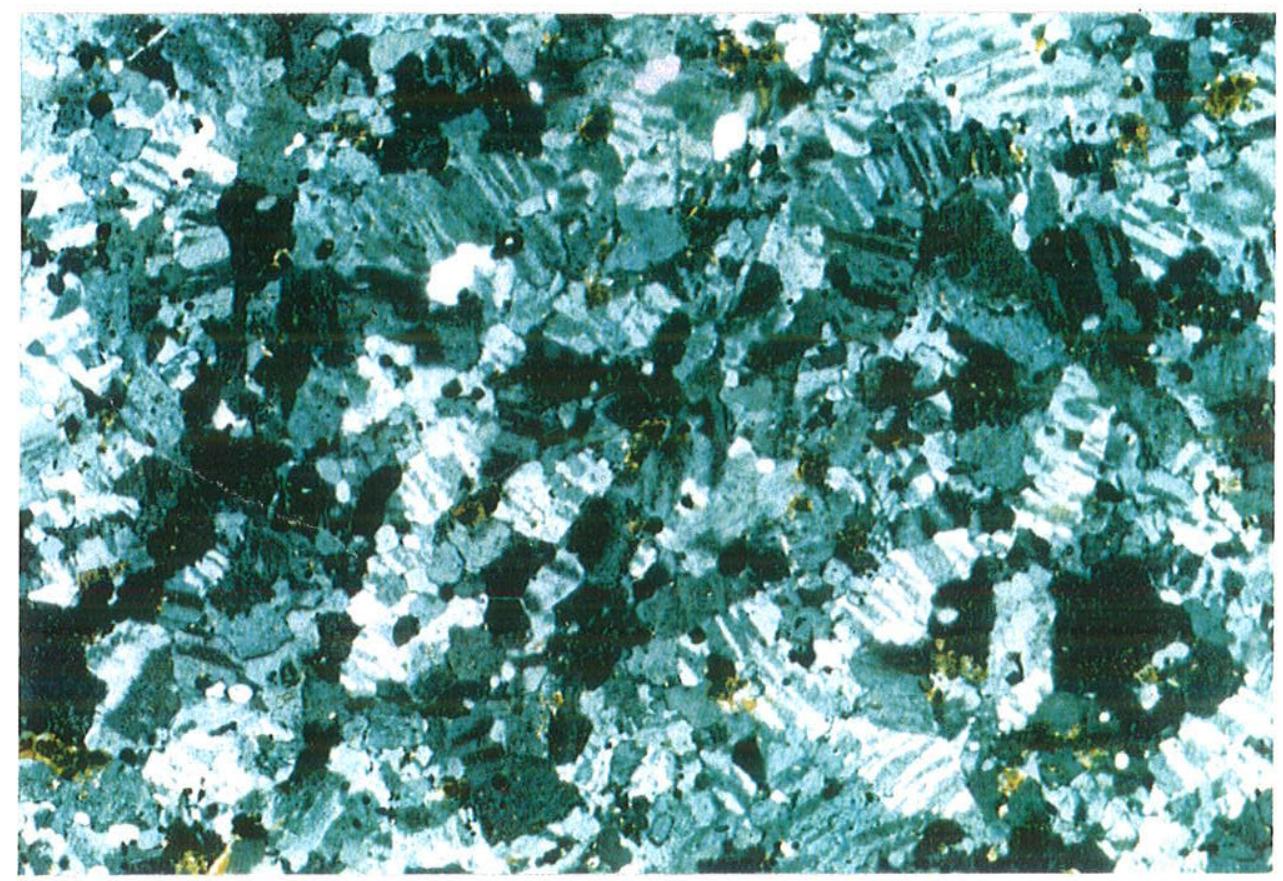

Fotomicrografia 22 - Microssienito. Rocha fina, equigranular, alotriomórfica/hipidiomórfica. Micromesopertita "tigrada", xenomórfica, representa mais que $90 \%$. Quartzo, branco $(<5 \%)$, intergranular (não confundir com fases albíticas); opacos e fêmicos não mais que $5 \%$. Dimensão maior, $5,50 \mathrm{~mm}$, filtro azul, polarizadores semicruzados.

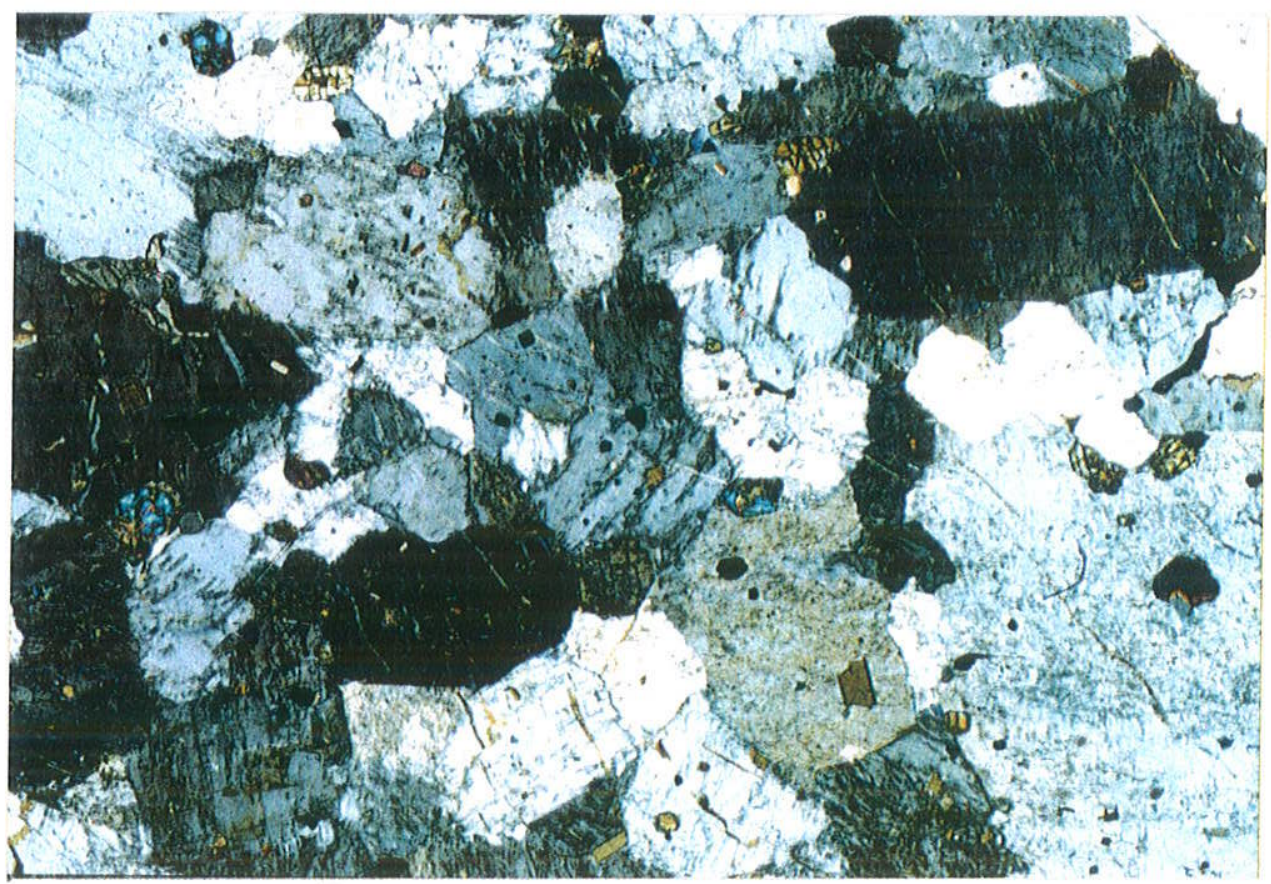

Fotomicrografia 23 -Microssienito. Textura hipidiomórfica, inequigranular (> $3 \mathrm{~mm}-<0,4 \mathrm{~mm}$ ), micromesopertita variada (95 \%), quartzo $<5 \%$, clinopiroxênio (grãos coloridos) $<5 \%$, opacos 1-2\%. Fêmicos: clinopiroxênio e biotita em plaquetas e opacos intragranulares. Comparar forma dos grãos e padrão micromesopertítico com Fotomicrografias 22, 24 e 26. Dimensão maior, 5,50 mm, filtro azul, polarizadores semicruzados. 


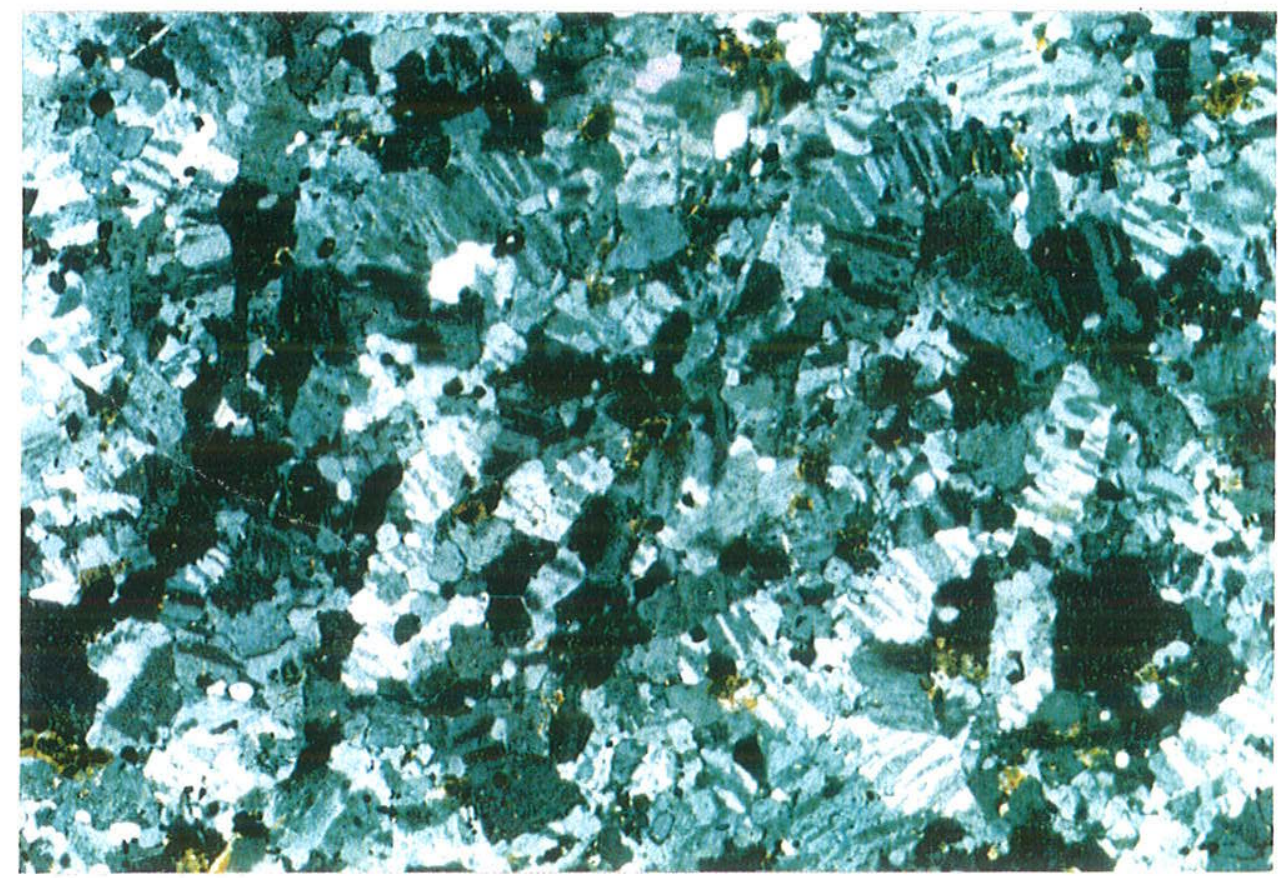

Fotomicrografia 22 - Microssienito. Rocha fina, equigranular, alotriomórfica/hipidiomórfica. Micromesopertita "tigrada", xenomórfica, representa mais que $90 \%$. Quartzo, branco $(<5 \%)$, intergranular (não confundir com fases albíticas); opacos e fêmicos não mais que $5 \%$. Dimensão maior, $5,50 \mathrm{~mm}$, filtro azul, polarizadores semicruzados.

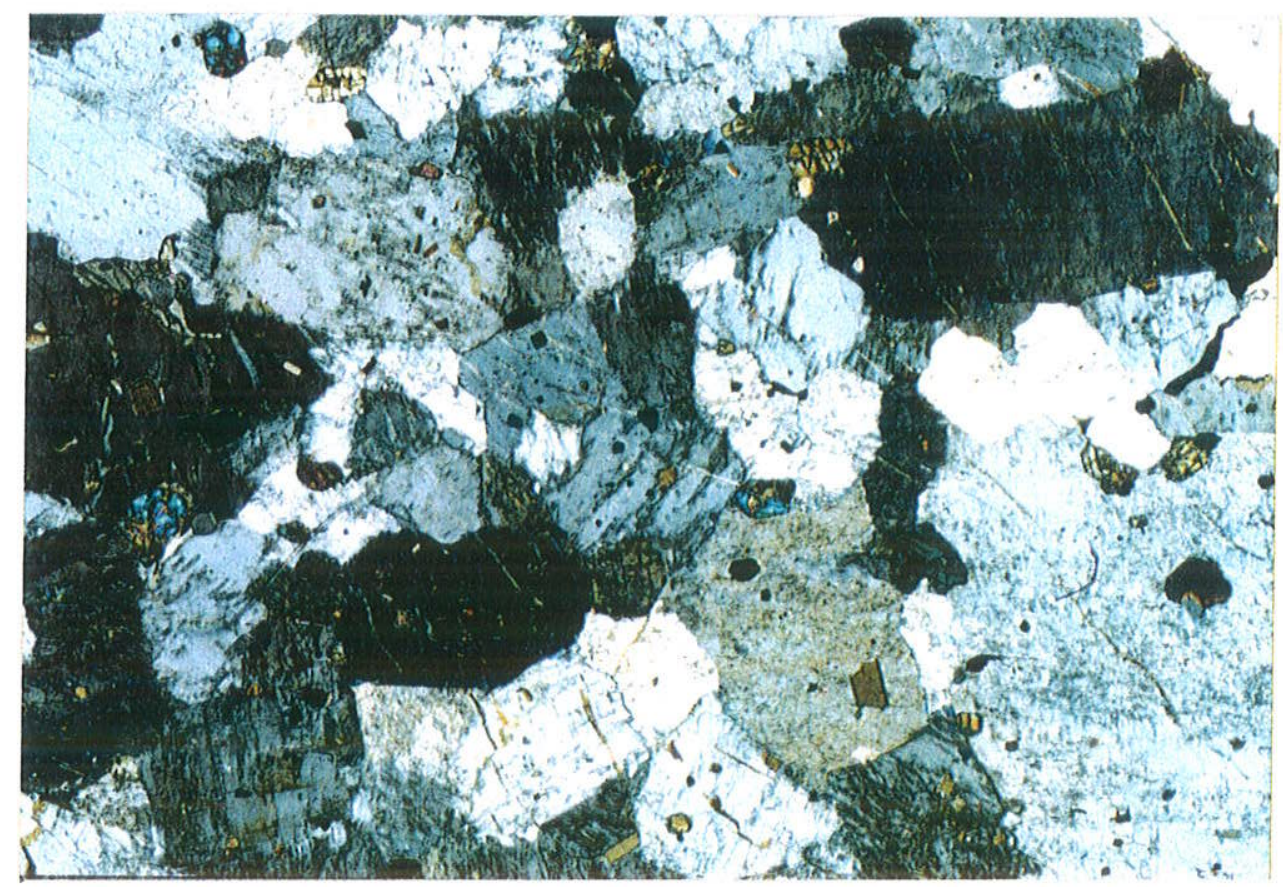

Fotomicrografia 23 -Microssienito. Textura hipidiomórfica, inequigranular ( $>3 \mathrm{~mm}-<0,4 \mathrm{~mm}$ ), micromesopertita variada (95\%), quartzo $<5 \%$, clinopiroxênio (grãos coloridos) $<5 \%$, opacos $1-2 \%$. Fêmicos: clinopiroxênio e biotita em plaquetas e opacos intragranulares. Comparar forma dos grãos e padrão micromesopertítico com Fotomicrografias 22, 24 e 26. Dimensão maior, 5,50 mm, filtro azul, polarizadores semicruzados. 


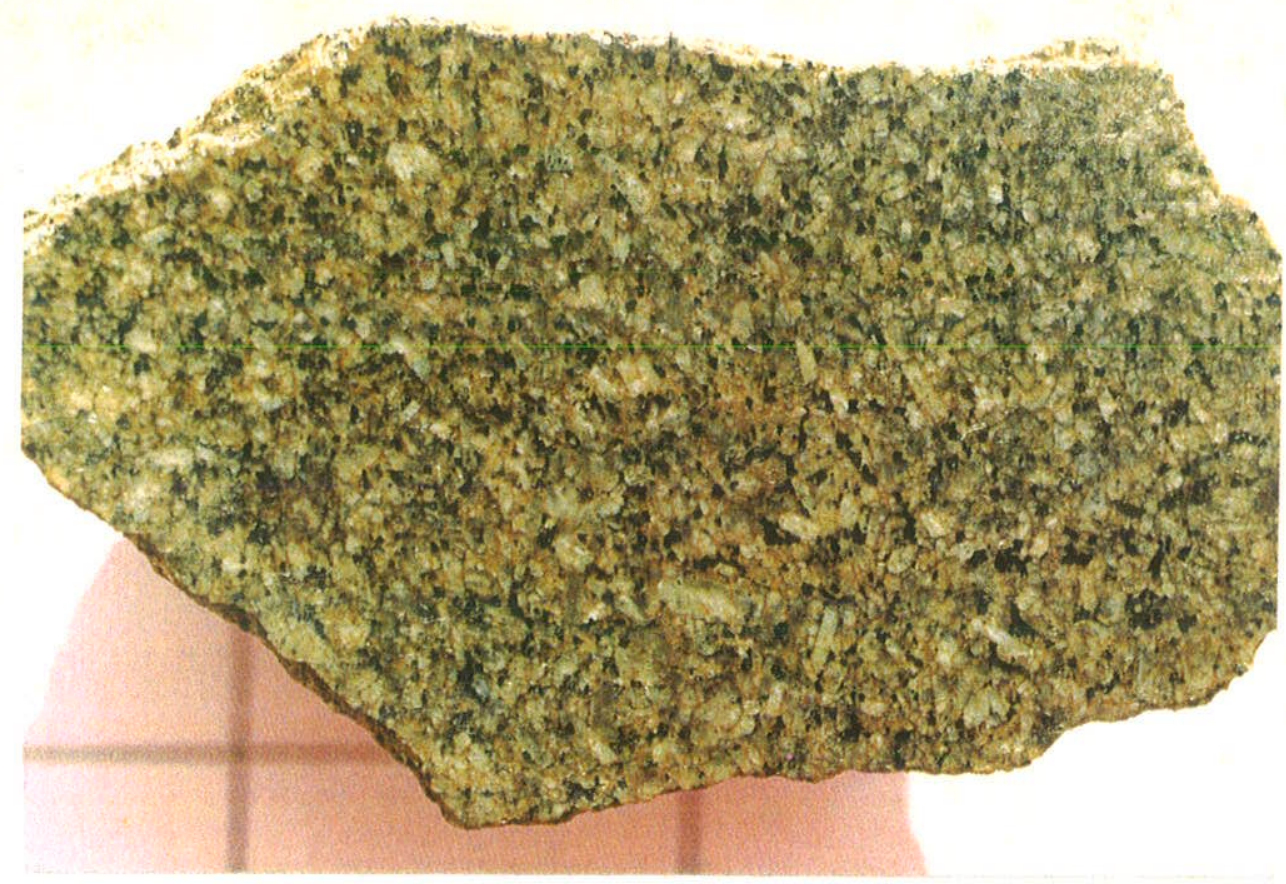

Foto 37 - Amostra de dique da costa oeste da llha (pontos 120 a 123). Rocha inequigranular a subporfirítica, com tendência panidiomórfica dos feldspatos maiores $(\leq 10 \mathrm{~mm}) /$ fêmicos dispersos, menores em torno dos $10 \%$. A cor pardacenta já revela alteração incipiente. Reticulado: $5 \times 5 \mathrm{~cm}$.

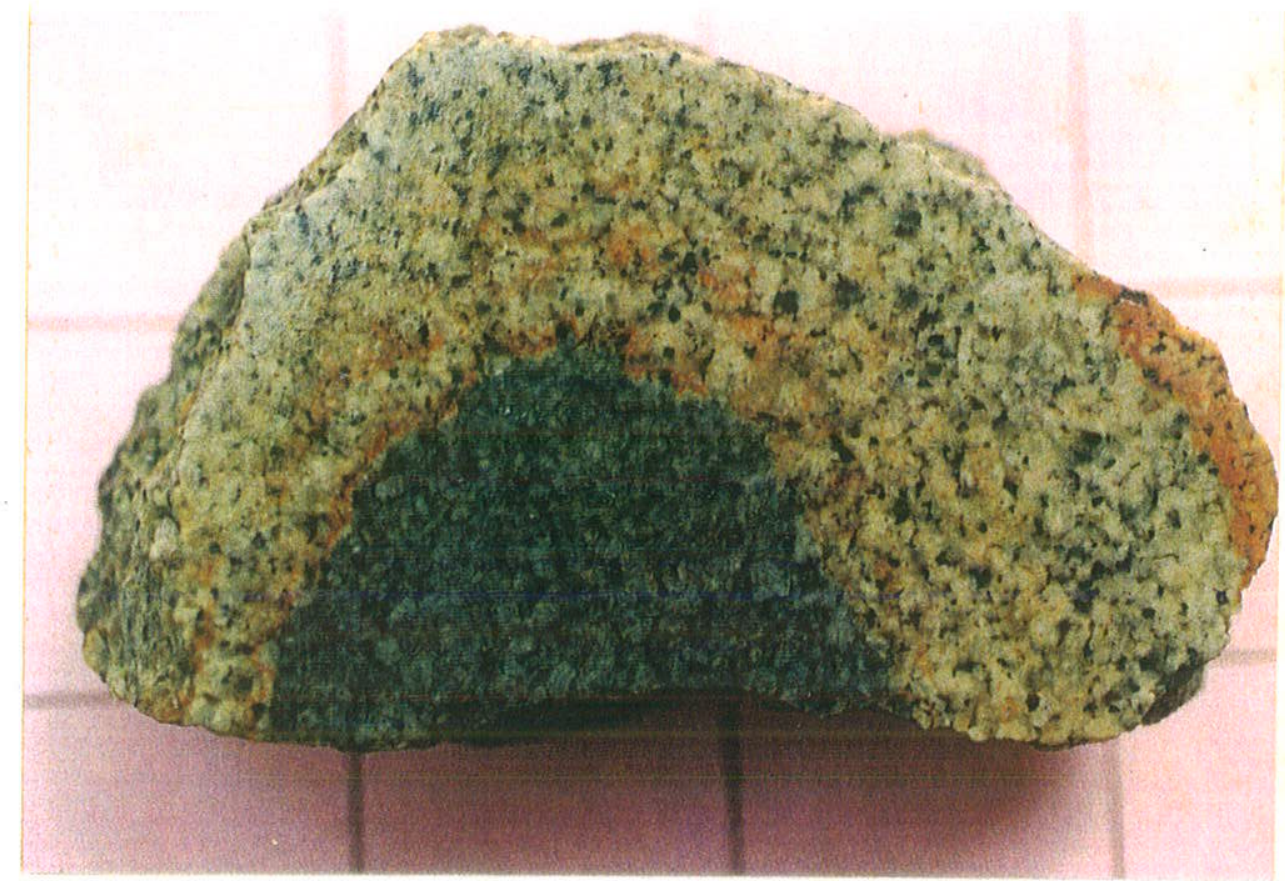

Foto 38 - Microssienito equigranular das proximidades dos contatos principais, na encosta oeste da llha. A rocha verde é fresca e passa a tipo quase branco, incipientemente alterado. Afora a cor e alguma limonita, não há diferença quanto à resistência, ou mesmo na textura e mineralogia principal, entre o núcleo e a envoltória. A granulação é média, os feldspatos subidiomórficos e os fêmicos representam em torno de $10 \%$. Notar a presença do quartzo (cinzento) na envoltória clara. Reticulado: $5 \times 5 \mathrm{~cm}$. 


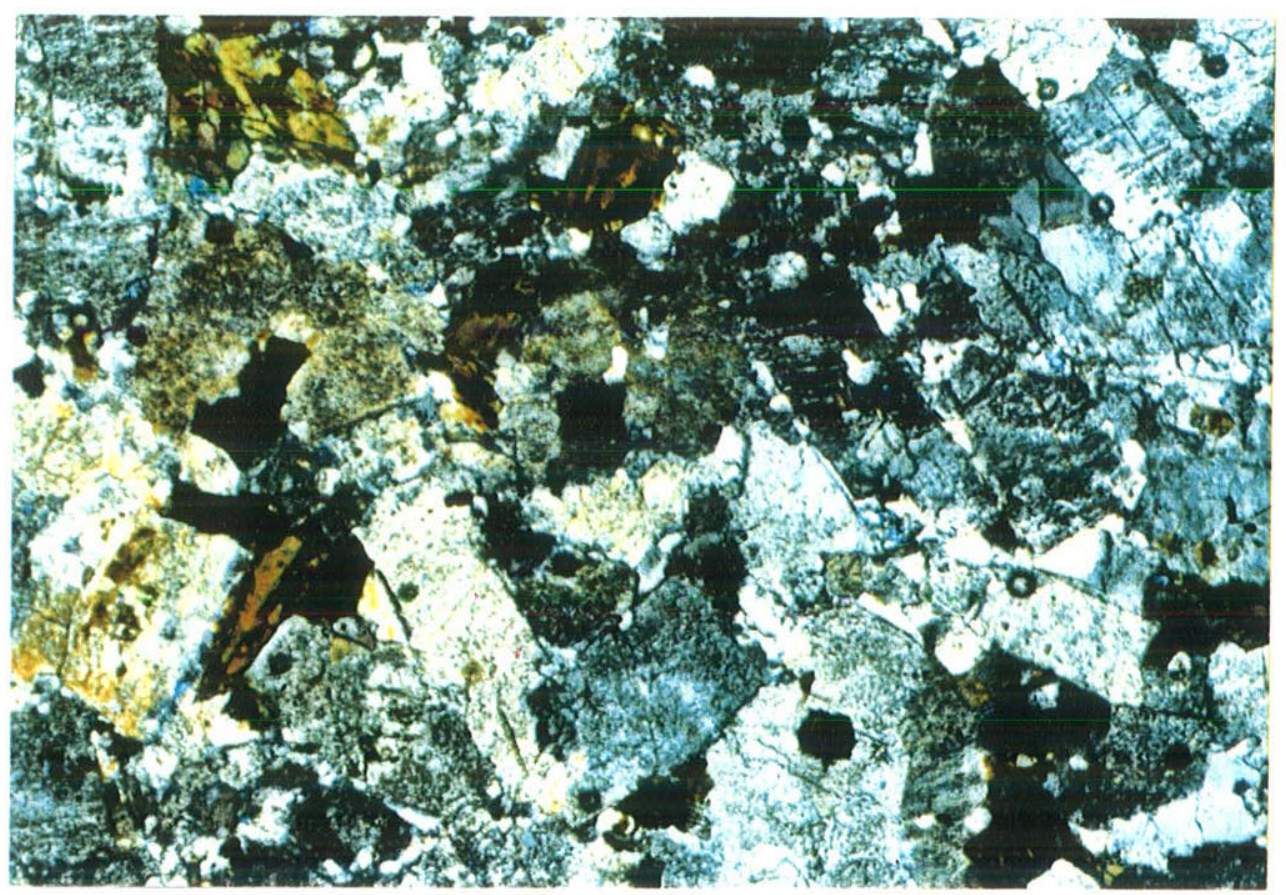

Fotomicrografia 24 - Microssienito (com quartzo, 5\%) equigranular, hipidiomórfico, mi-cromesopertita retangular, quadrada ou xenomórfica, tipos não "ti-grados". Anfibólio em torno dos $5 \%$, opacos 1 a $2 \%$, intergranulares. Dimensão maior, 2,80 mm, filtro azul, polarizadores semicruzados.

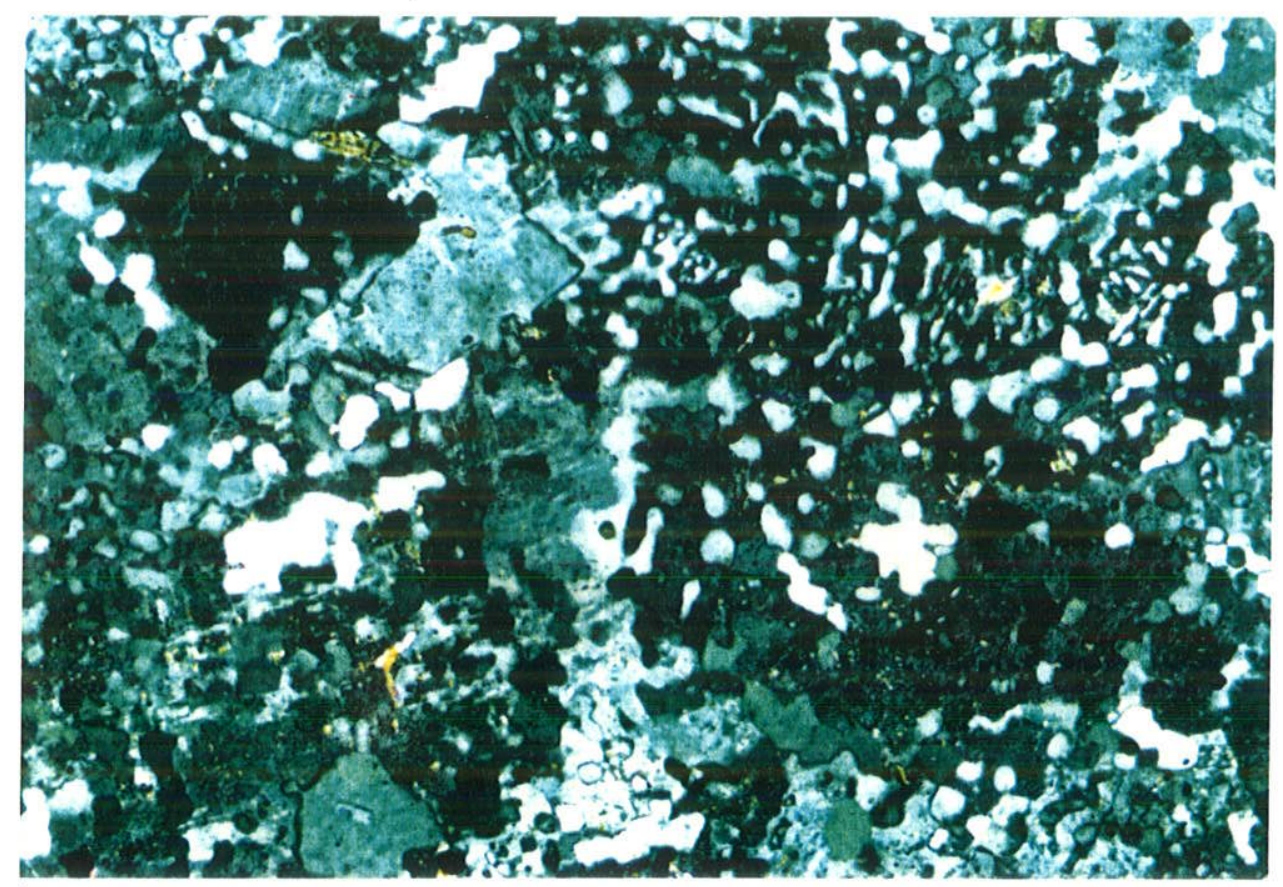

Fotomicrografia 25 - Microgranito de zona de contato, com quartzo em torno dos $25-30 \%$, intercrescido ou incluso na micromesopertita. Mesopertita de padrão variado, rocha inequigranular alotriomórfica. Fêmicos: opacos e biotita, traços. Dimensão maior, 1,39 mm, filtro azul, polarizadores semicruzados. 
para tipos com mesopertita tabular/retangular, com formas mais curtas $(2: 1,3: 1)$ ou mais longas (até 20:1), em arranjo aleatório ou com leve tendência ao subparalelismo ("traquitóide"), por outro lado. Os tipos alotriomórficos, com ausência de feldspato retangular/tabular, são minoria.

Entre diferentes ocorrências, e mesmo amostras distintas da mesma ocorrência, a granulação varia bastante. Existem os tipos equigranulares, raramente finos, quase sempre com granulação média. Essa equigranularidade passa a seriação granulométrica, com predominio de dimensão abaixo dos $3 \mathrm{~mm}$, até $0,5 \mathrm{~mm}$, mas que varia para grãos grossos e grãos finos (Fotomicrografia 23).

Nos tipos básicos, dominantes, a mineralogia é simples.

A mesopertita, do tipo lamelar ("tigrada") (Fotomicrografia 22), predomina sempre e representa invariavelmente 90 a $95 \%$ da rocha, e poucas amostras têm teores inferiores. 0 plagioclásio está sempre ausente. Entre os fêmicos domina o anfibólio, seguido do clinopiroxênio, que se faz acompanhar dos opacos. A biotita inexiste ou pouco representa. Como acessório, diversamente dos sienitos, o mais presente é o zircão quadrado a retangular, menos alongado. A apatita é ausente ou pouco presente, a titanita idem. Ocasionalmente aparece a allanita, e outros acessórios comuns, mas de dificil identificação segura (xenotima, rutilo, monazita), dada as dimensões dos grãos.

Com o aparecimento do quartzo, desde um único grão na seç̧ão delgada, e com a maioria das amostras com 2 a $3 \%$, e poucas em torno dos $5 \%$, ocorrem algumas modificaçöes, tanto texturais quanto mineralógicas (comparar Fotomicrografias 22 a 25).

Aparentemente, aumenta a quantidade de anfibólio, na medida em que cresce a do quartzo, e o clinopiroxênio começa a ocorrer mais como restos inclusos no anfibólio ou a ausentar-se. Além disso, aparece carbonato intersticial ou granular, isolado, e o anfibólio se altera para produtos variados, que incluem opacos e filossilicatos. Outras alterações ou produtos secundários fazem-se presentes, localizadamente. São agrupamentos de carbonato, titanita, zircão e uma mica zonada, de birrefringência muito alta, e cor variável entre tons alaranjados/avermelhados a verdes e cinzentos esverdeados.

Texturalmente, o caráter panidiomórfico e as formas geométricas dos feldspatos também se alteram no sentido de textura mais hipidiomórica (Fotomicrografia 24) a alotriomórfica, embora nem tanto como nos sienitos.

A mesopertita dos microssienitos é a mais típica e universal na llha. É do tipo lamelado ("tigrado"), bastante regular e, às vezes, não há um só cristal que não obedeça a esse padrão (Fotomicrografia 22). Para esse tipo de mesopertita, valem as considerações feitas anteriormente para os sienitos. Cumpre ainda ressaltar que nos tipos sem quartzo ou com pouco quartzo (2-3\%), a mesopertita tende a assumir formas retangulares bem definidas, dentro dos padrôes dimensionais citados, e com bordas e contatos quase que absolutamente retilineos. Por vezes, alguma amostra apresenta aspecto rendilhado de borda, dado pelo 
intercrescimento entre bordas/contatos vizinhos.

Os minerais fêmicos são raramente bem formados e, embora com formas geométricas e bordas retilineas, poucos exibem contornos regulares. Esses minerais podem ser intersticiais (Fotomicrografia 24) ou, com dimensões menores, estar inclusos nas mesopertitas (Fotomicrografia 23).

$O$ anfibólio, o mais presente dos fêmicos, é também o que apresenta formas mais regulares. Ou ocorre com formas retangulares alongadas ou como placas inteiras, de desenho anguloso e retilineo, mas pouco regular. Embora varie em suas caracteristicas, sempre exibe cores esverdeadas, mais claras ou mais escuras, às vezes verde oliva mais escuro (Z'), que passa para pardacento ou pardacento-amarelado claro $\left(X^{\prime}\right)$. Comumente é manchado ou zonado em tons de verde, assim como grada nas bordas, localmente, a um anfibólio azul intenso ( $\left.Z^{\prime}\right)$ a pardo-acinzentado $\left(X^{\prime}\right)$. Por vezes, mostra extinção fortemente anômala, indicativa (como verificado) de forte dispersão do $2 \mathrm{~V}$. Alguns ângulos de extinção medidos fornecem valores de $\mathrm{Z} \Lambda \mathrm{c} \sim 16-23^{\circ}$. A grande maioria dos cristais de anfibólio apresenta birrefringência alta, moderada $(\sim 0,020)$. Em algumas amostras, o mineral acha-se alterado e contém inclusões: passa a anfibólio incolor ou fase não identificada incolor, de baixa birrefringência, e inclui opacos, zircão, mesopertita e quartzo.

São raros os anfibólios verde-azulados, do tipo hastingsitico (cf. Tröger, 1979).

O clinopiroxênio é semelhante àquele dos sienitos. É sempre, desde levemente esverdeado a esverdeado, e em algumas amostras pode variar, na borda, para verde forte, lembrando os tipos egirínicos. Apresenta-se em prismas näo muito alongados, e sempre com alguma alteração. Pode aparecer totalmente isolado (Fotomicrografia 23), ou orlado por anfibólio ou por material verde escuro isótropo (?), ou ainda como resto dentro do anfibólio. Não chega a $5 \%$ nas rochas examinadas.

A biotita, quase ausente, forma placas pequenas de cor marrom/marrom-alaranjada a alaranjada (Fotomicrografia 23).

Os opacos granulares, xenomórficos ou prismáticos, isolam-se e dispersam-se, ou associam-se ao anfibólio. O zircão, idiomórfico, tem presença constante; é abundante e sempre incolor. O hábito é, quase sempre, quadrado a retangular. A apatita é bastante mais rara e forma prismas e formas equidimensionais. Os outros acessórios aparecem dispersos ou associados a produtos tardios.

\subsubsection{2. Álcali feldspato-quartzo microssienitos}

Essas rochas, como informado, não diferem em muito dos microssienitos já descritos, com destaque para o aumento do quartzo, na maior parte das vezes não uitrapassando os 10 a $15 \%$, e mais raramente chegando aos 20 ou mesmo $30 \%$, quando tem-se então os micro álcali feldspato granitos ou as variedades granofíricas (Fotomicrografias 25 e 26). 


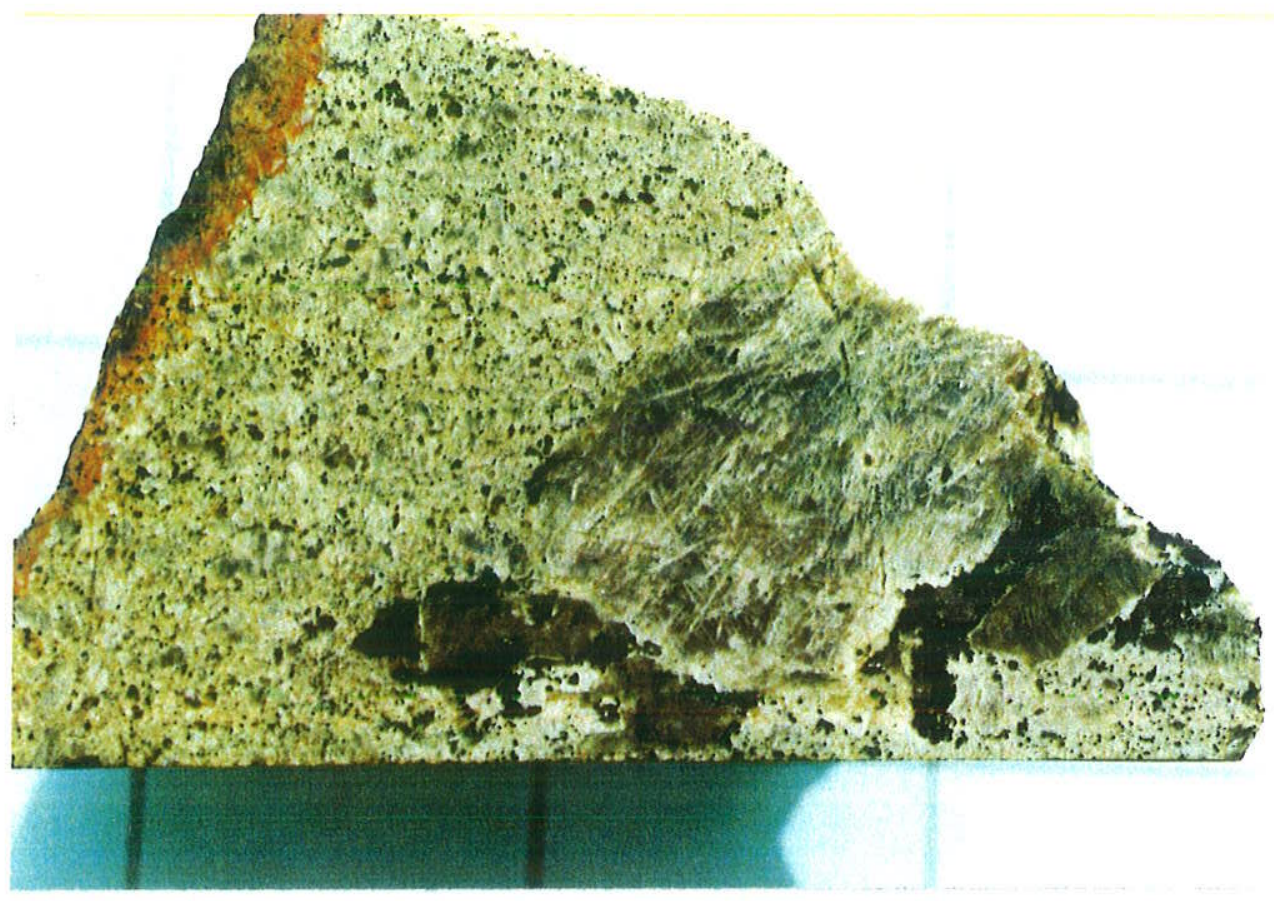

Foto 39 - Microssienito com quartzo, porfiritico (xenocristais?). Resto charnoquítico, mostrando contatos, ao mesmo tempo, nítidos e difusos no microssienito. A feição não é fácil de ser encontrada, mas é comum junto aos contatos. Reticulado: $5 \times 5 \mathrm{~cm}$.

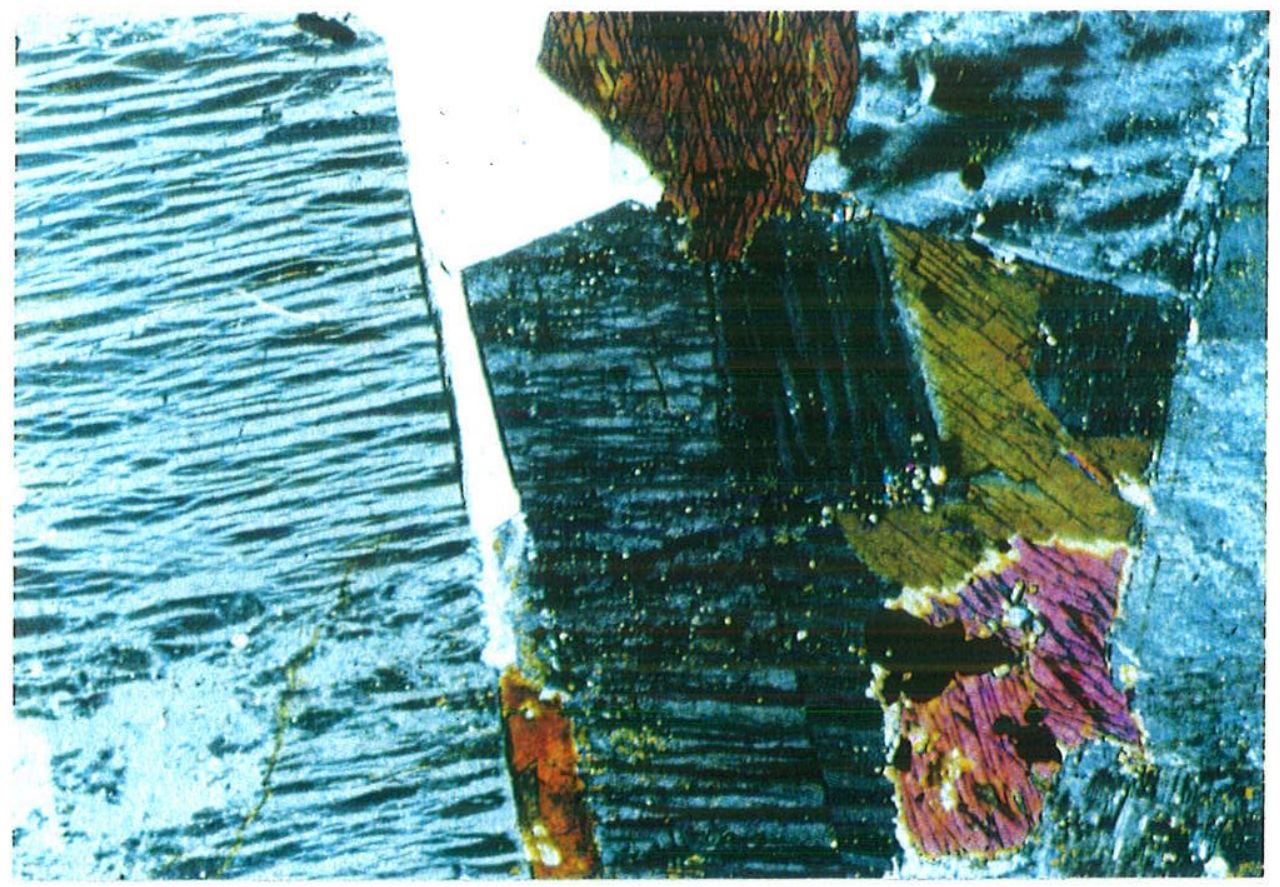

Fotomicrografia 26 - Álcali feldspato-quartzo microssienito. Esse tipo caracteriza mais as rochas de dique, mas ocorre próximo às zonas de contato. Textura quase panidiomórfica, micromesopertita "tigrada" típica (reportar-se à descrição dos sienitos), geminada. Quartzo (branco) intersticial, tipo "moldura", anfibólio relativamente bem formado, intergranular. Dimensão maior, $2,80 \mathrm{~mm}$, filtro azul, polarizadores cruzados. 
Texturalmente, as variaçöes mais importantes säo na granularidade e na forma dos grãos. Os padrões francamente inequigranulares são predominantes, e a forma e arranjo dos grãos caracteriza as texturas alotriomórficas granulares, às vezes pouco hipidiomórficas, com as formas retangulares mais ausentes (Fotomicrografias 24 e 25).

Fazem exceção algumas rochas de diques, que conservam tendência panidiomórfica.

Além disso, são vistas mudanças na mineralogia. Primeiro, tornam-se mais comuns rochas de diagnóstico um tanto duvidoso, pela presença de zonas xenolíticas coalescidas à trama do restante da rocha, ou de xenocristais (Foto 39). O quartzo, cujo padrão em baixos teores é o de moldura de forma irregular, cristalograficamente contínua em torno dos feldspatos, começa a adquirir postura isolada ou ocorrer em pequenos agregados intersticiais. As mesopertitas, que mantinham certa regularidade nos padröes, destacando-se as lameladas (Fotomicrografia 26), exibem agora padräo variado, com as "tigradas", além de atípicas, passando a rarear (Fotomicrografia 25).

Quanto aos fêmicos, dominados pelos anfibólios, ou pela biotita em menor número de amostras, também surgem diferenças. O clinopiroxênio isolado rareia, e aparece alterado, dentro ou fora do anfibólio. A presença de produtos tardios de alteração, bastante variados, aumenta muito, sendo que em algumas amostras praticamente inexistem fêmicos, afora os opacos.

Excepcionalmente, algumas amostras conservam porções de mesopertitas retangulares, em arranjo subfoiaitico. No mais, as mesopertitas obedecem aos padröes referidos.

Quanto ao quartzo nada há aduzir, a não ser o fato de que, quando em teores altos, principalmente nas rochas de contato portadoras de xenólitos, tomam dimensões e formas e distribuições muito regulares assemelhando-se a "quase-esferas" aleatoriamente distribuidas (Fotomicrografia 25). Separadamente são descritas aquelas rochas normalmente de granulação média, com intercrescimentos granofíricos e micrográficos, em que o quartzo assume hábito cuneiforme e distribuição regular, além de se associar ao quartzo tipo moldura, que pode envolver porções da rocha microscopicamente importantes.

Sem carater muito rigoroso, pode-se dizer que o "quartzo moldura" é mais típico nas rochas de diques, enquanto que o granular e granofírico nas rochas das zonas de contato.

Algumas amostras são objeto de alguma dúvida. São as portadoras de micro xenólitos e/ou micro xenocristais. Embora essas feições sejam tratadas em item à parte, é interessante fornecer algumas informações neste ponto.

Essas feiçōes são ou minerais isolados, nitidamente distintos do resto da rocha, em geral com dimensões superiores, e podem ser tanto de plagioclásio, como de feldspato alcalino típicos de charnoquitos. Ou săo porções de rocha, com plagioclásio, feldspato alcalino e quartzo, facilmente distintos do sienito envolvente. Essa distinção é feita com base na forma sub-retangular e no padrão típico das mesopertitas sieníticas. Além dessas inclusões, que se 
apresentam perfeitamente integradas à rocha envolvente, com leves mudanças nas bordas, e às vezes acúmulo de quartzo e de grãos menores no sienito, o plagioclásio também ocorre, como pequenos individuos intersticiais isolados ou aglomerados; mais raramente, o orto e 0 clinopiroxênio, em boa parte bastante alterados ou envolvidos por anfibólio, também estäo presentes. É possivel que biotiłas também sejam em parte xenocristais, mas não há como fazer a distinçäo opticamente. O mesmo pode-se pensar do clinopiroxênio e dos opacos.

$O$ anfibólio, fêmico dominante, é do ponto de vista óptico o mesmo. Varia para tipo mais escuro e com birrefringência superior nas amostras mais ricas em xenólitos, fato que levanta a questão de serem ou não xenocristais.

O clinopiroxênio, de presença comum em pequena quantidade, em nada difere dos tipos já descritos. Incolor a esverdeado, mostra-se mais alterado e com freqüencia incluso no anfibólio.

A biotita restringe-se a traços em algumas amostras, e outras, de contatos, ricas em quartzo, com cor marrom ( $\left.Z^{\prime}\right)$ a amarelada $\left(X^{\prime}\right)$, onde os outros fêmicos estão ausentes, à exceçäo dos opacos.

A apatita tem presença restrita, como nos outros microssienitos. $O$ zircão aparece em praticamente todas as amostras, e é em geral abundante, chegando a 1 ou $2 \%$. Mantém forma regular, quadrada a retangular, e é incolor. Titanita é rara. Ao lado da allanita, rara, comparecem outros acessórios não identificados, de cores variadas (rutilo, monazita, xenotima? etc.).

As alterações estão sempre presentes e, aparentemente, afetam os fêmicos. Quanto maior a sua presença, maior a quantidade de opacos e zircão associados, e menor o conteúdo de fêmicos, até amostras onde eles se ausentam.

\subsection{Diques félsicos}

Estão incluidos aqui microssienitos semelhantes aos já descritos, além de outros tipos variáveis desde "riólitos" até fonólitos peralcalinos. Os tipos supersaturados ocorrem junto aos charnoquitos e nas zonas sieníticas de contato, enquanto que os insaturados unicamente na extremidade leste da ltha e no Saco Grande. Tipos saturados, quer traquiticos, quer microssieniticos, aparecem por toda a llha.

\subsection{1. Álcali feldspato ( \pm quartzo) microssienitos}

São rochas similares às já descritas como fácies plutônica. Há que se destacar que tipos panidiomórficos (ou quase), com ou sem quartzo, estão presentes mais como diques, 
sendo tipicos aqueles com quartzo intersticial, tipo "moldura", e mesopertita tigrada.

\subsubsection{Aplitos}

As rochas aplíticas, encontradas por toda a llha, têm composição mineralógica variada, como seria de se esperar, com relação à presença, ausência e teor de quartzo. Também os fêmicos variam.

$\mathrm{Na}$ grande maioria das vezes, essas rochas ocorrem sob a forma de veios antes que diques. Mostram textura, obviamente, aplítica, em geral equigranular fina, por vezes com fenocristais de feldspato. A granulação não ultrapassa as dimensões de $0,5 \mathrm{~mm}$.

Mesmo quando encaixada nos charnoquitos, a variedade mais típica e comum, que não deixa dúvida quanto à sua correlação com os sienitos, apresenta mesopertita lamelada ("tigrada"), que, com ou sem quartzo, perfaz 90 a $95 \%$ da moda. O quartzo, que pode estar ausente, chega até aos $20 \%$, com as rochas variando nesse caso entre álcali feldspato sieníticas a álcali feldspato-quartzo sieníticas.

A mineralogia adicional, 5 a 10\%, pode conter as associações: a) opacos, biotita, grânulos esverdeados isótropos, fluorita, carbonato, titanita; b) opacos, anfibólio, biotita; c) opacos, biotita, ortopiroxênio, filossilicatos esverdeados.

A primeira associação, onde o mineral isótropo representa um produto de alteração do piroxênio, é comum a toda rocha aplítica típica. Com a segunda, o padrão pertítico é menos típico, bem como com a terceira. Em todas, algum feldspato mais homogêneo pode estar presente, às vezes com início aparente de geminação.

Quanto à cor, a biotita varia de marrom a avermelhada $\left(Z^{\prime}, Y\right)$ e amarelada $\left(X^{\prime}\right)$, e anfibólio de verde oliva a pardo-amarelado.

Registre-se, por último, que localmente o quartzo forma finas molduras angulosas de monocristais em torno dos grânulos de feldspato (informalmente, quartzo "moldura").

\subsubsection{Rochas traquíticas}

Entre os diques félsicos, ocorrem traquitos típicos, textural e mineralogicamente. Ainda classificáveis como traquitos são os tipos com mais quartzo e que passam aos álcali feldspato-quartzo traquitos; näo foram verificadas variedades com nefelina. Texturalmente, os traquitos típicos podem variar para tipos mais granulares ou para aqueles com pouco a nenhum paralelismo dos feldspatos (Fotomicrografia 27). E transformam-se em microssienitos com o aumento da granulação.

O traquito típico da llha contém fenocristais de feldspato alcalino (potássico, às vezes), pelo menos micropertítico, imerso em matriz fina a muito fina de ripas, traves ou palhetas, às 
vezes muito alongadas, quase fibrosas, de feldspato alcalino, em arranjo subparalelo a paralelo. Esse paralelismo é retilíneo, em parte, mas o conjunto mostra-se sinuoso.

Cabe observar que, em algumas amostras, aparecem também fenocristais de anfibólio, menores e em quantidade inferior à dos feldspatos.

Os fenocristais, idiomórficos, retangulares, mais ou menos alongados (relações dimensionais de $2: 1$ a $10: 1$ ), são micropertíticos e geminados. A micropertita toma padrões variados, sendo comum a do tipo filme (lamelas longas e finas), e a geminação é do tipo Carisbad e múltipla, aparentemente complexa, além de observável em zonas dos individuos. De modo geral, as dimensões dos fenocristais são subcentimétricas, desde 0,5 a 2,0 mm, nos tipos mais finos, chegando a mais que $10 \mathrm{~mm}$ nas variedades de granulação mais grossa. Representam, em média, 5 a $10 \%$ da rocha, e sempre se fazem presentes. Minerais inclusos são raros.

A matriz, que perfaz 85 a $95 \%$ da rocha, apresenta denso arranjo paralelo/sub paralelo do feldspato alongado. Os individuos podem ser micropertíticos e micromesopertíticos, com bordas albiticas, formas e contornos bem definidos, retilíneos ou curvos, ou ainda difusos nos tipos aparentemente mais "curvos" ou à semelhança de degraus sucessivos. Apertada e paralelamente aos indivíduos maiores, ocorre albita limpa, em interstícios finos. Os individuos maiores, majoritários, mostram padrão variado de micro (meso) pertitas, predominando o de zonas regulares e ortogonais ao eixo maior do feldspato. Geminação do tipo Carlsbald está sempre presente, às vezes associada a feição transversal, aparentemente de deformação, visivel pela alternância na extinção. Geminação múltipla, complexa ocorre em domínios dos individuos.

Os fêmicos consistem principalmente em anfibólios, acompanhados ou não de biotita, opacos e clinopiroxênio. Têm dimensöes inferiores às dos feldspatos $(0,2 / 0,3$ a $0,5 \mathrm{~mm})$ e representam entre menos que $10 \%$ até $20 \%$ da matriz. São, em geral, subidiomórficos

Em várias amostras, o anfibólio é o único mineral ferromagnesiano. Trata-se de tipo verde escuro, azulado (Z'), e amarelado/amarelado-pardacento $\left(X^{\prime}\right)$ e pardo esverdeado/acinzentado $(Y)$, com extinçäo $(Z \Lambda c)$ quase reta e fortemente anômala. Aparece em formas muito longas e paralelas à textura da rocha, mas alguns indivíduos cortam a orientação geral, sendo que pequena parte pode apresentar-se de forma granular em secçōes basais. Embora raro, forma também pequenos agregados uniminerálicos.

A rocha descrita pode ter quantidade variável de quartzo, desde nenhum até pouco mais que os $5 \%$. Esse mineral é granular, xenomórfico, com os gräos isolados dispersos pela matriz.

Também foram registradas rochas diferentes do padrão acima.

Assim, um segundo tipo mostra o feldspato, tanto matricial como os fenocristais, com a micromesopertita no padrão lamelado ("tigrado"). Os individuos são um tanto mais largos. 
Também o anfibólio pode variar para formas mais granulares.

Como minerais adicionais, ou mesmo dominantes, ocorrem ainda clinopiroxênio, biotita, opacos, poucos acessórios e algumas alterações.

Tanto o clinopiroxênio como a biotita aparecem preferencialmente em rochas de granulação pouco mais grossa, já tendendo aos microssienitos, mas mantendo marcada estrutura de fluxo.

Esse novo tipo, também comum na llha, possui granulação matricial quase milimétrica e fenocristais maiores, variáveis de $1 \mathrm{~mm}$ a mais que $10 \mathrm{~mm}$. Também inclui agregados máficos microgranulares de clinopiroxênio e biotita.

Os fenocristais de feldspato mostram indivíduos crivados de inclusões de biotita, opacos e clinopiroxênio, delimitando formas sucessivas, em geral com pelo menos um núcleo limpo, isento de inclusōes (Fotomicrografia 28). Exibem padrão de geminação e deformação (?) complexo, com o aspecto de enrugamento. Em algumas rochas, esses fenocristais interrompem o arranjo traquítico, mas esses tipos com biotita e clinopiroxênio tendem a acomodar-se paralelamente às traves da matriz. Essas fases podem representar de 10 a $25 \%$ da rocha.

A matriz é formada por traves longas de feldspato, encostadas umas as outras. Até onde possivel distinguir-se opticamente, parece haver predominio da albita, com traves praticamente sem a fase potássica.

Muito apertados entre si, seus contatos são pouco visiveis a polarizadores cruzados, mesmo com o auxillio de compensadores. Mostram aparência curva, tal que, ao longo da direção de fluxo, aparece sinuosidade. Além disso, feixes de indivíduos são atravessados obliquamente por alternância de faixas com orientação óptica diferente e recorrente, que, à primeira vista, tornam o conjunto semelhante a uma mesopertita lamelada, sugerindo alguma deformação do conjunto.

A biotita é marrom ( $\left.Z^{\prime}, Y\right)$ a alaranjada $\left(X^{\prime}\right)$ e aparece como palhetas idiomórficas pequenas, intersticiais, e arranjadas paralelamente aos feldspatos.

O clinopiroxênio, esverdeado, talvez um tipo diopsídico/salítico, forma grãos e prismas curtos, dispersos intersticialmente. Nos agregados microgranulares, centimétricos, tem maior desenvolvimento, ao lado da biotita.

Essas rochas contêm abundante opacos, estes ausentes no primeiro tipo.

Além dos minerais essenciais, podem estar presentes apatita, em grânulos muito pequenos, titanita xenomórfica e zircão arredondado.

Tipo distinto dos anteriores, é em tudo semelhante aos microssienitos, somente com granulação mais fina, menor do que $1,0 \mathrm{~mm}$. Isto é, uma rocha traquitica, hipidiomórfica granular, mais ou menos equigranular. A assembléia de fêmicos presentes é mais semelhante à dos microssienitos que aquela dos traquitos mais típicos. O quartzo, por sua vez, está geralmente presente, em pequena quantidade, de não mais que os $5 \%$. 


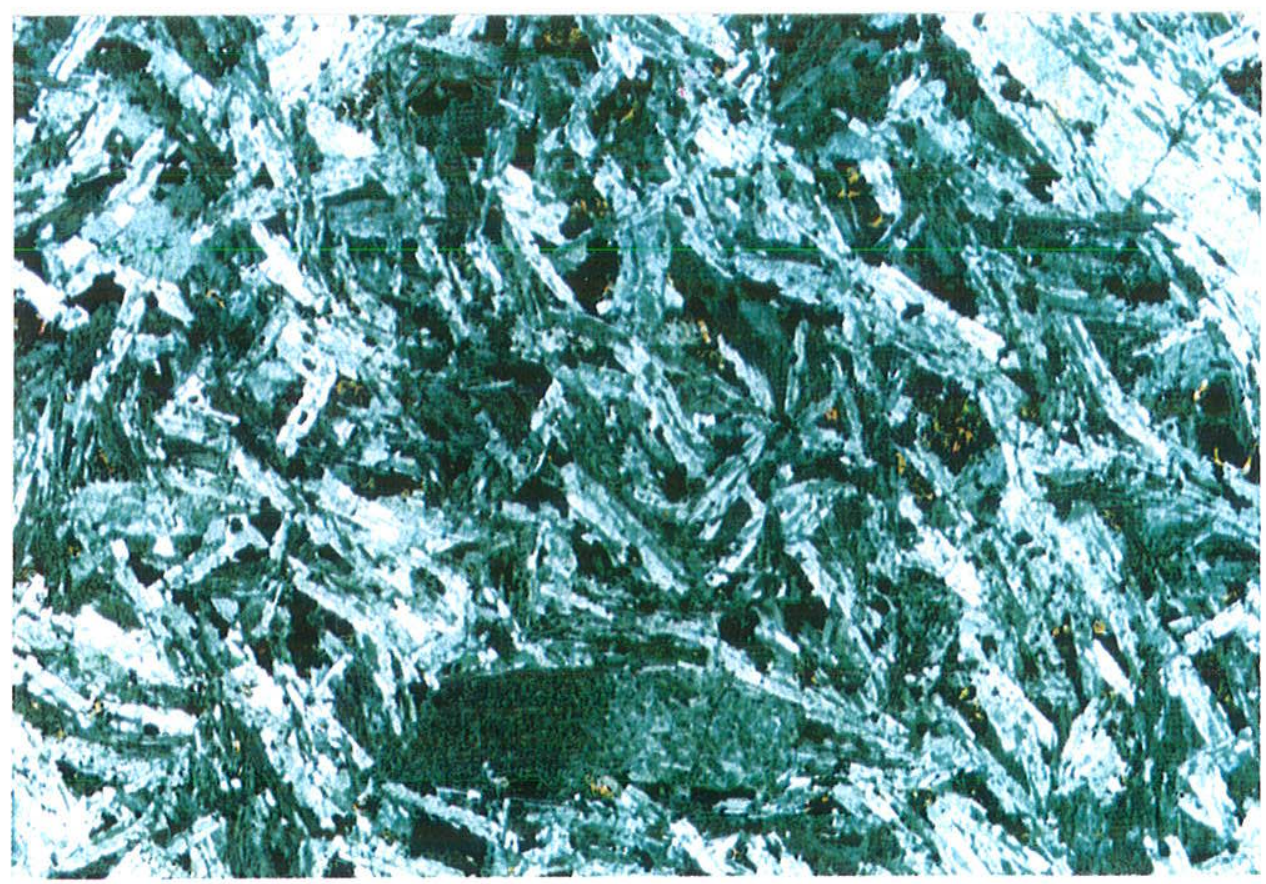

Fotomicrografia 27 - Traquito porfirítico, textura não traquítica. Mesopertita (95\%), opacos e traços de fêmicos. Dimensão maior, 5,50 mm, filtros azul e fosco, polarizadores semicruzados.

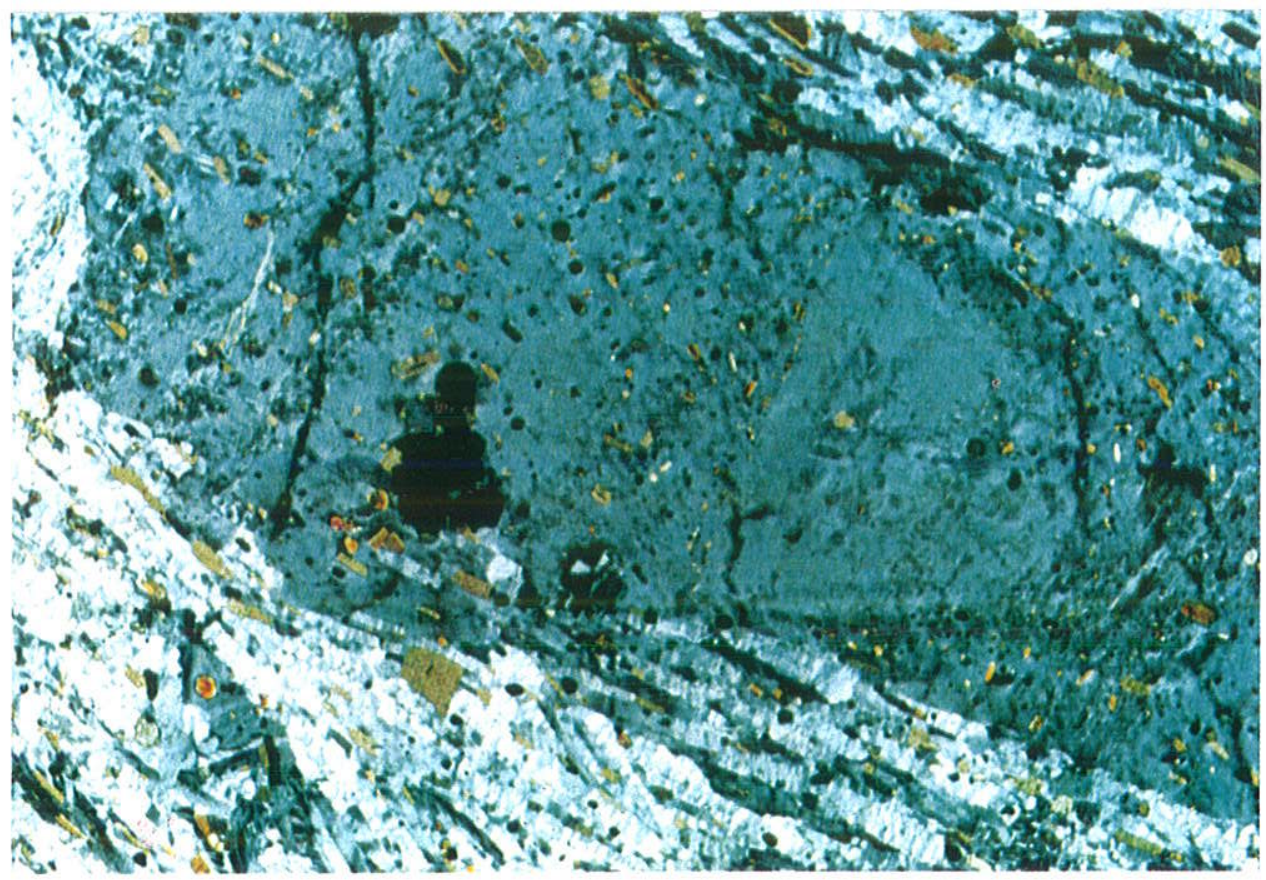

Fotomicrografia 28 - Traquito porfirítico, com textura traquítica. Os minerais, mesopertita em traves longas, biotita e opacos orientam-se paralelamente ao fluxo, que envolve o fenocristal. Fenocristal com núcleo mais limpo, circundado por linhas de crescimento, marcadas pelos fêmicos. Dimensão maior, 5,50 $\mathrm{mm}$, filtro azul e fosco, polarizadores cruzados. 


\subsubsection{Rochas rioliticas}

São rochas que contam com pequeno número de ocorrências, todas na face oeste da Itha, além de intrusivas nos charnoquitos.

Na realidade, composicionalmente, variam de ocorrência para ocorrência, e mesmo entre amostras da mesma ocorrência. Poderiam ser descritos como quartzo traquitos a riólitos, e enquadrados entre os traquitos. Mas apresentam algumas peculiaridades, além do fato de que parte das secçóes delgadas exibe elevados teores de quartzo.

A rocha tipo tem textura hipidiomórfica granular, e é inequigranular fina. O feldspato, uma mesopertita "tigrada", tem entre 0,5 a $0,3 \mathrm{~mm}$, e o quartzo menos que $0,5 \mathrm{~mm}$.

A mesopertita, bastante "pigmentada", apresenta forma sub-retangular a quadrada, e mostra individuos isolados ou agregados pequenos, isolados por faixas de quartzo equidimensional a arredondado, e com disposição ao acaso.

A assembléia mesopertita mais quartzo representa entre 90 a $95 \%$, participando o quartzo com teores variáveis de 20 a $30 \%$.

Entre 5 a $10 \%$ da rocha são constituidos por opacos e biotita marrom, além de restos de minerais coloridos não identificados. Variavelmente, estão presentes carbonato, fluorita, zircão, em grãos, palhetas e restos de dimensões muito reduzidas.

As amostras portadoras de xenocristais aureolados (Foto 40) possuem outras peculiaridades. Seu aspecto geral lembra o de vidro devitrificado, sobressaindo a presença de rosários interrompidos de opacos e outros minerais minúsculos de relevo forte e disposição aleatória (axiólitos ? fraturas ?). Pelo menos 80 a $85 \%$ da rocha mostram mosaico xenomórfico granular, muito fino $(<0,03 \mathrm{~mm}$ ) de quartzo e feldspato, sendo possivel o reconhecimento das fases, mas não a sua estimativa modal com precisão aceitável. O feldspato é homogêneo, além de alcalino. Em pequena quantidade, reconhecemse carbonato micrítico, regularmente disperso.

Nessa variedade é que ocorrem os xenocristais de feldspato alcalino, na maior parte das vezes uma micro (meso) pertita do tipo filme, semelhante àquelas observadas em granulitos. Eles podem ser "xenomórficos" ou idiomórficos, mas sempre com cantos arredondados. Às vezes, no centro de auréolas não mais aparecem individuos cristalinos, mas agregados de feldspato ou mesmo de rocha semelhante à matriz, com rosários de máficos esverdeados.

As auréolas, sucessivas, podem apresentar somente feldspato fibrorradiado ou associações com carbonato, fluorita ou mesmo opacos.

Quando o teor de quartzo diminui, chegando a rocha ao nivel dos quartzo traquitos, a própria textura torna-se em parte traquitóide. Poucos fenocristais de feldspato alcalino, idiomórficos, atingem até $0,5 \mathrm{~mm}$. Na matriz, identifica-se quartzo, xenomórfico, isolado, carbonato muito fino e opacos, em meio a uma trama de "palhetas" de feldspato alcalino. Este último, até onde discernivel, exibe albita orlando feldspato potássico ou (meso) pertita. 
Por mais de uma vez, as amostras laminadas junto aos contatos mostraram evidencias de microbrechação, com matriz vitrea a criptocristalina e clastos angulosos de natureza variada, quer de minerais, quer de rochas. Esses clastos têm semelhança com os minerais e rochas formadores da encaixante. Registre-se o aumento da quantidade de fluorita nessas microbrechas, alcançando mesmo a alguns porcentos.

\subsubsection{Sodalita fonólitos e nefelina (sodalita) microssienitos}

São rochas de aspecto diversificado, raramente com alguma foliação. Com granulação média a fina, até afaníticas, existem os tipos afiricos e os porfiriticos, em alguns casos com a mineralogia discernivel a olho nu (Foto 41). Sua cor varia desde os tipos cinzento-esverdeados até pretos, ou cinzentos a róseos. Não raro, os diques são vizinhos e apresentam bandamento regular e variado, por flutuação no teor dos máficos e mudança na granulometria. Macroscópica e texturalmente, esses bandamentos e venulações podem ser pegmatóides ou ter aspecto aplítico, com minerais visiveis.

Os tipos mais finos, submilimétricos, mostram mosaico de nefelina idiomórfica a subidiomórfica, sobre o qual aparecem fenocristais de feldspato potássico, traves pequenas e palhetas de albita e de feldspato potássico, com disposiçăo ao acaso ou subparalela, formando feixes de individuos, e minerais fêmicos e acessórios dispersos. A nefelina inclui ou molda todos os outros minerais.

Os fenocristais de feldspato potássico são micropertiticos até micromesopertíticos, com comprimento variável desde 1 até $10 \mathrm{~mm}$, além de exibirem formas sempre retangulares mais curtas (2:1) ou mais longas (>10:1). Em geral, näo mostram alteração e estão dispostos ao acaso, independente da matriz, ou paralelamente aos feixes de individuos ripiformes dos feldspatos matriciais. Näo representam mais que $10 \%$ da rocha. Raramente contêm inclusões e são orlados, de forma variada, pela matriz. Como descrito, podem penetrar ou delimitar a nefelina. Geminação pode estar presente.

A matriz de individuos ripiformes apresenta alternância e equivalência de albita e feldspato potássico, que não exibem exsolução. Em um dos tipos, os indivíduos formam feixes e têm disposição paralela. Nesses feixes, o feldspato está densamente arranjado. A distribuição geral mostra, então, feixes de feldspato sem nefelina, além de bandas de nefelina, em indivíduos enfileirados, com outros minerais inclusive o feldspato. Esse arranjo varia para menos denso, havendo homogeneidade na distribuição do feldspato e da nefelina, bem como dos outros minerais.

Nos tipos afíricos ou porfiríticos, o arranjo da rocha ou da sua matriz é semelhante ao da textura intergranular ou intersertal: o feldspato tem disposição casual, os indivíduos tocamse ou se atravessam, deixando entre eles espaços angulosos, triangulares ou poligonais, onde 


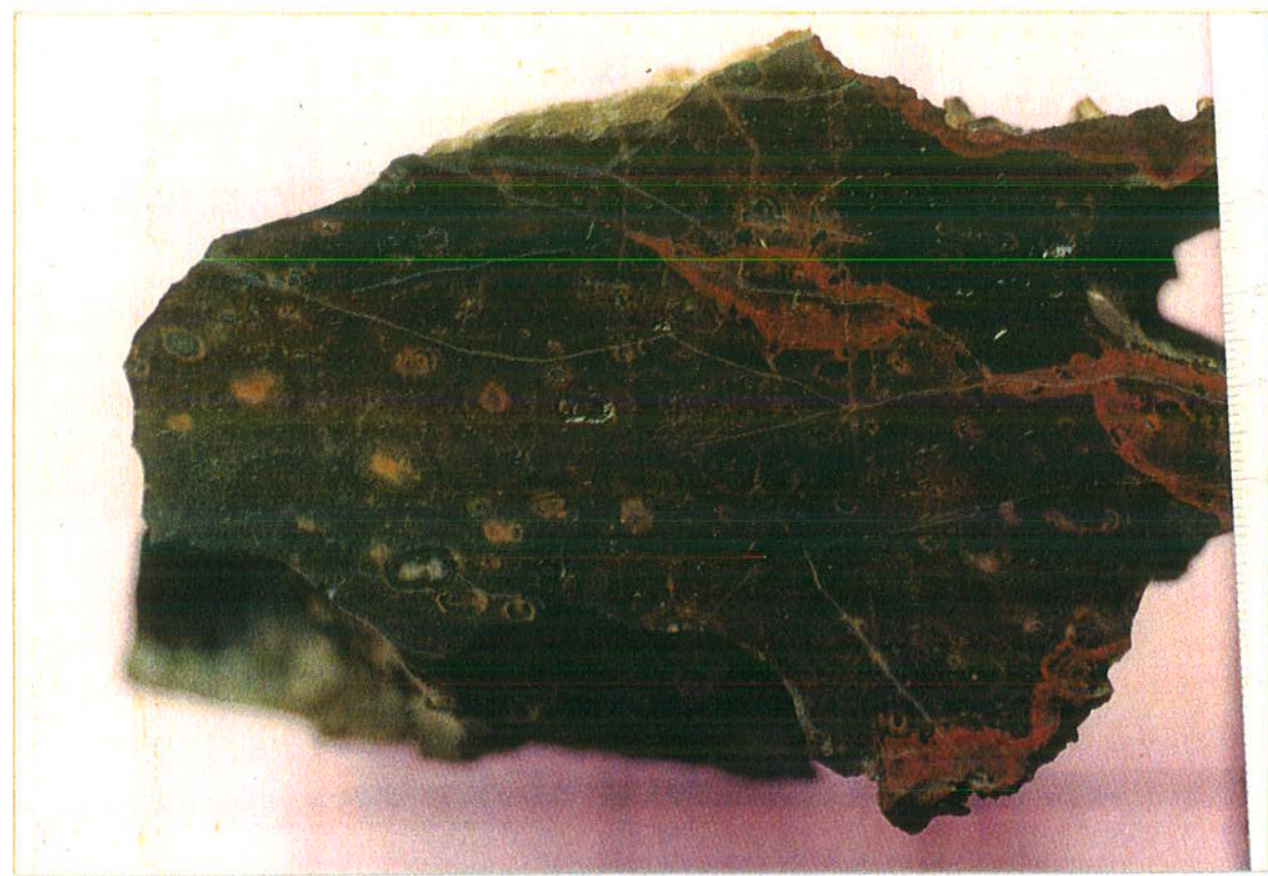

Foto 40 - Rocha riolítica, do ponto 326 . A rocha, afanítica, tem cor castanha escura, mas sempre mostra alguma alteração. Notar xenocristais de feldspato, com envoltórias concêntricas, sucessivas. Reticulado: $5 \times 5 \mathrm{~cm}$.

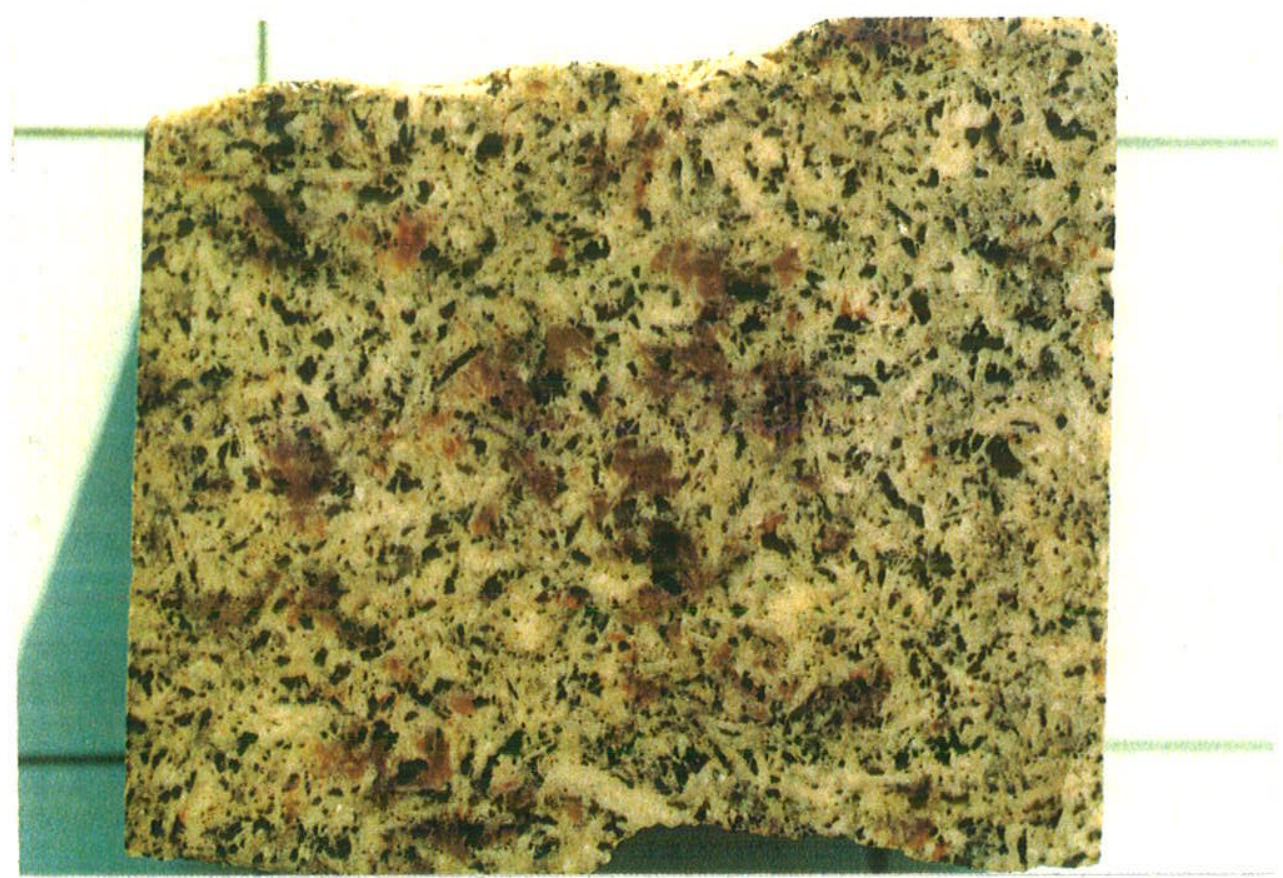

Foto 41 - Nefelina microssienito. Identificáveis: feldspato, nefelina (marrom) e clinopiroxênio egirínico. Reticulado: $5 \times 5 \mathrm{~cm}$. 
ocorrem os outros minerais.

A mineralogia essencial dessas rochas inclui fenocristais de feldspato potássico, de pertita ou de mesopertita, em indivíduos isolados ou agrupados, concordantes ou discordantes da matriz.

A porção mais fina, a matriz ou a própria rocha, apresenta ripas pequenas de feldspato potássico e de albita, com distribuição casual ou paralela, em feixes densos ou frouxos. Outras amostras contêm apenas ripas de albita, pouco antipertitica, e poucos individuos potássicos idiomórficos, ou acompanhando a nefelina. Ainda outros tipos, exibem ripas pertíticas a mesopertiticas, em geral com albita nas bordas (Fotomicrografia 29). Em alguns tipos, os individuos ripiformes pouco se tocam, aparecendo inclusos nos minerais que antes eram intersticiais (como na textura ofitica), nefelina e fêmicos. Pode-se fazer analogia descritiva com as rochas básicas, uma vez que os termos texturais disponiveis ("texturas agpaiticas" cr. Bard, 1980) possuem conotação genética discutivel. Nesse caso, as texturas dos fonólitos teriam aspecto variável entre a ofítica e a intergranular, passando a intersertal com o surgimento da sodalita junto à nefelina.

A sodalita aparece com a mesma disposição textural da nefelina. Em casos raros, está presente substituindo fenocristais de feldspato.

Os minerais fêmicos, mais os acessórios, não constituem menos que $10 \% \mathrm{em}$ quaisquer das amostras estudadas, podendo chegar a pouco mais que $25 \%$ do total. Os acessórios, de natureza rara, tornam-se ocasionalmente parte representativa dessas rochas, atingindo até 5 a $10 \%$. Entre os félsicos, existem os tipos com predomínio dos feldspatos, que podem representar $70 \%$ da rocha, e aqueles em que feldspatos e fóides se igualam, havendo mesmo casos em que estes últimos suplantam de pouco os primeiros. Pode-se dizer que os fóides variam no mínimo de 15 a 20\% até o máximo de 40-45\% das rochas examinadas.

Entre os fêmicos estão presentes clinopiroxênio (egirina ?), biotita e anfibólio. As associações podem reunir os três minerais, ou egirina com anfibólio ou com biotita.

A egirina comparece como grãos e pequenas formas prismáticas, subidiomórficas. Não raro, mostra núcleo de anfibólio e, na mesma rocha, cresce sobre ele. Também está inclusa na nefelina e na sodalita, e ocupa os interstícios entre os feldspatos ou intercresce com eles. Pode aparecer zonada para tipo mais claro.

$O$ anfibólio, verde intenso a verde escuro, azulado (Z') e pardo-esverdeado ou cinzento-esverdeado a amarelado $\left(X^{\prime}\right)$ é um tipo sódico. Além de ocorrer de forma semelhante à egirina, forma individuos maiores, poiquiliticos, que podem incluir feldspato e egirina, algum silicato raro, ou biotita.

A biotita, marrom escuro/preto $\left(Z^{\prime}, Y\right)$ e alaranjado intenso $\left(X^{\prime}\right)$, pode apresentar leve zoneamento. Forma pequenas placas, raras as de dimensões maiores, idiomórficas ou não, dispersas, com distribuição e disposição semelhante à do clinopiroxênio. Em algumas amostras, aparece dentro do anfibólio, formando conjunto mais avantajado. 
Além desses minerais, é constante a ocorrência de silicatos raros, presentes como espécie única ou até, pelo menos, quatro espécies diferentes. Foram identificados, com alguma segurança, enigmatita, lamprofilita, astrofilita e eudialita. São, em geral, idiomórficos a subidiomórficos e aparecem em pequenos grupos de cristais, ou ainda dispersos. Raramente estäo inclusos em feldspatos, mas com freqüencia são observados instersticialmente ou associados ao anfibólio, nefelina e sodalita, ou mesmo clinopiroxênio e biotita.

Não foram reconhecidos minerais opacos na maioria dessas rochas. Uma única amostra contém fluorita de cor lilás.

Como produtos secundários, ocorrem zeólitas (?) criptocristalinas, alterando o feldspato, cancrinita e silicato fibroso junto à nefelina. De modo geral, essas fases secundárias pouco representam, a não ser localmente.

As variedades classificáveis como microssienitos (Fotomicrografia 30) possuem mineralogia semelhante. Contudo, notam-se as seguintes particularidades: a) o feldspato é sempre pertítico a mesopertítico, idiomórfico a subidiomórfico, com formas retangulares curtas e longas, de contornos retilíneos ou escalonados; pode arranjar-se paralelamente ou não e apresenta dimensões bastante variadas na mesma amostra; b) a nefelina, idiomórfica, não contém tantas inclusões e tampouco é intersticial, mantendo relação textural mais igualitária com o feldspato; pode ser equigranular ou variar muito seu tamanho, o mesmo ocorrendo quanto à sua participação, que se aproxima localmente dos $40 \%$; c) a sodalita pode aumentar sua presença, suplantando a da nefelina; d) minerais opacos, poiquilííicos, são comuns; e) o fêmico dominante, às vezes único, é o anfibólio, acompanhado pela egirina minoritária; f) silicatos raros não foram identificados; g) amostra única (Fotomicrografia 31), muito semelhante texturalmente aos fonólitos, apenas com granulação mais grossa e com disposição aleatória dos minerais, precisamente aquela que apresenta predominio da sodalita sobre a nefelina, contém egirina e biotita, sem anfibólio; nela, o clinopiroxênio aparece com freqüência incluso na biotita.

Alguns reparos são ainda necessários.

O dique 163B é, na realidade, um sienito, com granulação subcentimétrica a centimétrica. Sua textura é hipidiomórfica, mas não exatamente granular, uma vez que há largo predomínio dos feldspatos, exibindo forma retangular alongada e disposição ao acaso. Tanto a sodalita como a nefelina se ajustam entre os feldspatos. Além desses minerais, ocorrem egirina, biotita, algum anfibólio esverdeado, distinto dos anteriores, raros opacos, pelo menos um silicato não identificado, provável titanita, e alguns secundários (cancrinita, zeólita). Relações texturais entre os minerais indicam que pequenas ripas de feldspato podem aparecer inclusas no piroxênio. Os fêmicos, em geral, são intergranulares.

O feldspato é mesopertítico, do tipo em manchas ou "braided".

Essas rochas podem contar em uma mesma seção delgada microbandamentos granulométricos e mineralógicos e venulações altamente diferenciadas, mas cuja mineralogia, 


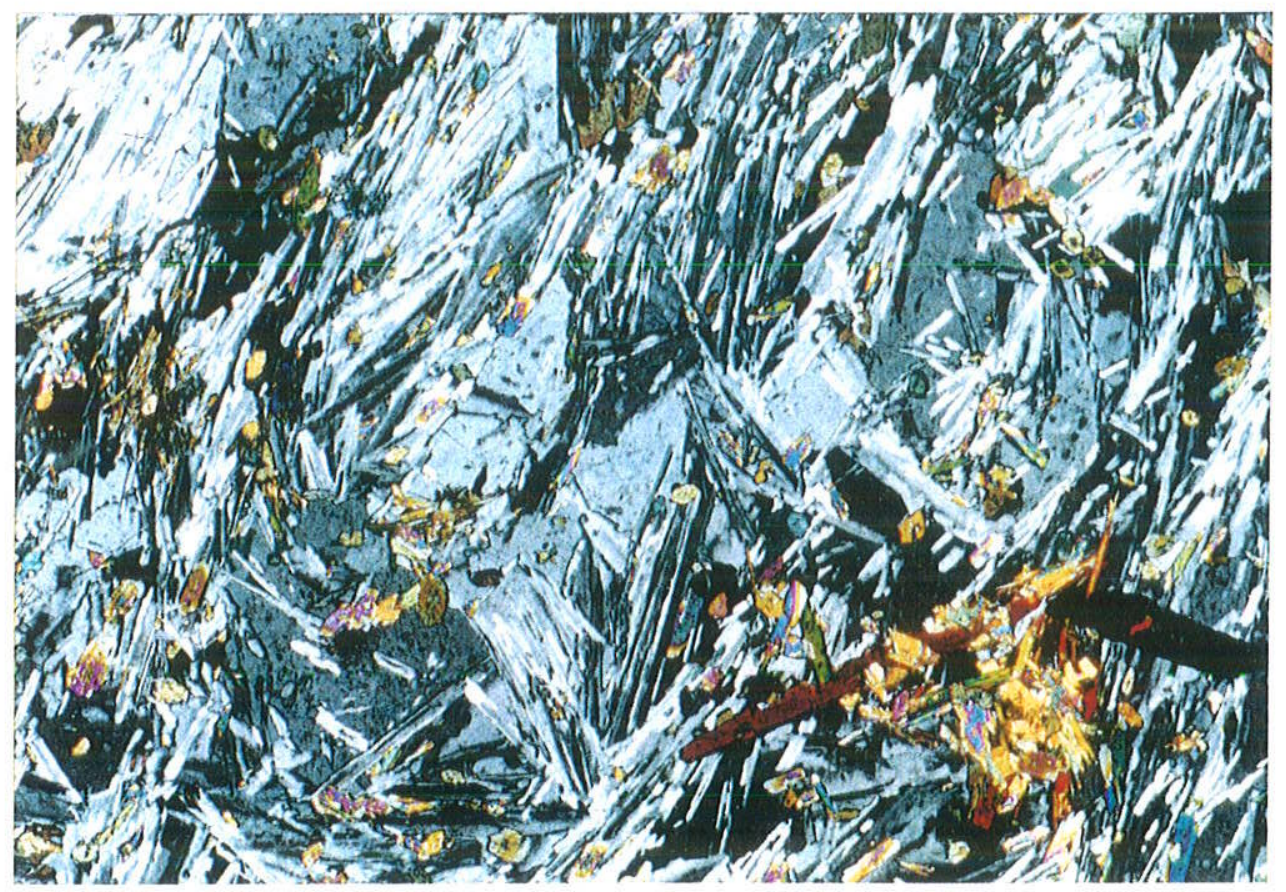

Fotomicrografia 29 - Nefelina microssienito, textura mais granular, fina a média. Mesopertita, nefelina com alguma cancrinita, biotita e opacos. Preto, isótropo, sodalita. Observar hábito e inclusões da nefelina, e formas da mesopertita. Dimensão maior, $5,50 \mathrm{~mm}$, filtros azul e fosco, polarizadores semi- cruzados.

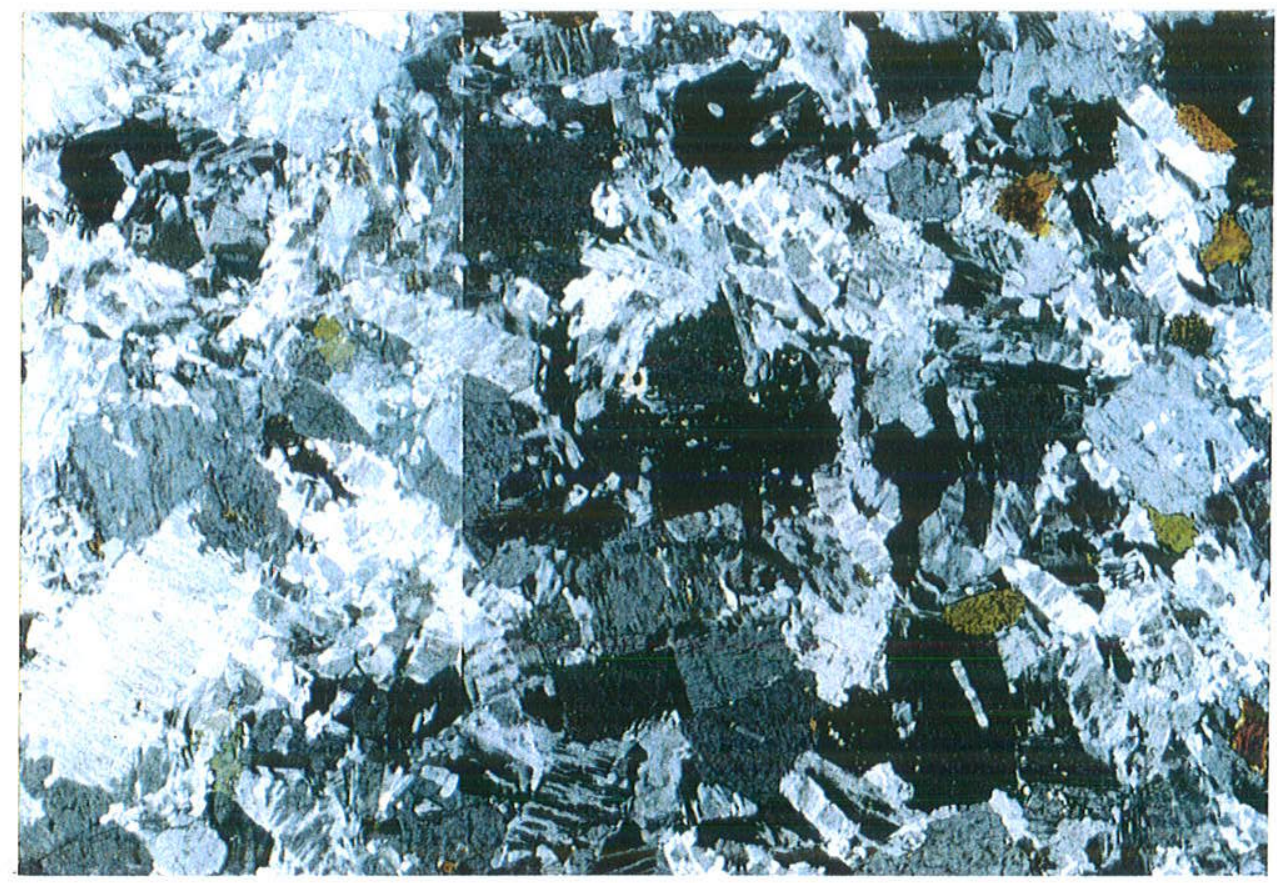

Fotomicrografia 30 - Nefelina microssienito/fonólito, com mesopertita, nefelina, sodalita, egirina e biotita. Notar hábitos da pertita e da nefelina, e inclusões na nefelina e na sodalita. Fêmicos quase sempre intersticiais. Dimensão maior, 2,80 mm, filtros azul e fosco, polarizadores semicruzados. 
em parte, está presente no restante da rocha.

A amostra 166C (Saco Grande) é um microssienito/fonólito, de textura granular hipidiomórfica, com mesopertita e pelo menos 50 a $55 \%$ de nefelina, com anfibólio verde preto/marrom claro, que passa a porções pegmatóides sieníticas ricas em nefelina.

A amostra $161 \mathrm{~B}$ mostra palhetas ripiformes de albita espalhadas sobre todos os outros minerais. Primeiro, sobre um mosaico de fundo de feldspato alcalino, potássico, homogêneo, majoritário, e nefelina; e também sobre glomerocristais de biotita, anfibólio e egirina (Fotomicrografia 32). Esses fêmicos também ocorrem isolados. O único fenocristal de feldspato observado inclui toda a assembléia de fêmicos, somente que de menores dimensões. Comparecem dois silicatos não identificados.

A amostra BZ180 (Foto 42) apresenta venulação com eudialita, feldspato, nefelina e egirina. A rocha, um fonólito do tipo descrito, porfirítico, contém albita, feldspato potássico, pertita, mineral isótropo ou vidro intersticial, nefelina, clinopiroxênio e anfibólio sódico, além de silicatos raros como eudialita, enigmatita, lamprofilita e pelo menos dois outros não identificados.

\subsection{Os diques máficos}

Embora, macroscopicamente, a maioria dessas rochas possa ser chamada de ultramáfica, isso não se verifica do ponto de vista microscopico, tratando-se mais de efeito da granulação, fina, muito fina ou mesmo afanítica.

Seu agrupamento e classificação, petrográficos, são, certamente, discutiveis. De modo geral, enquadram-se em dois tipos genéricos, textural e mineralogicamente: diabásicos e lamprofíricos. Além da ocorrência de tipos que não se ajustam muito bem em um ou outro grupo, eles podem ser subdivididos.

\subsubsection{Diques diabásicos}

Näo foi reconhecida amostra alguma de diabásio típico. Ou ocorrem variações mineralógicas importantes, ou elas são texturais. Além disso, parte dessas rochas corresponde na verdade a microdioritos. Essas diferenças e a subdivisão dessas rochas estão ligadas diretamente à sua posição geográfica e/ou estratigráfica: diques intrusivos nos sienitos, tipos iguais nos charnoquitos e diques que ocorrem somente nos charnoquitos e nas zonas de contatos. 


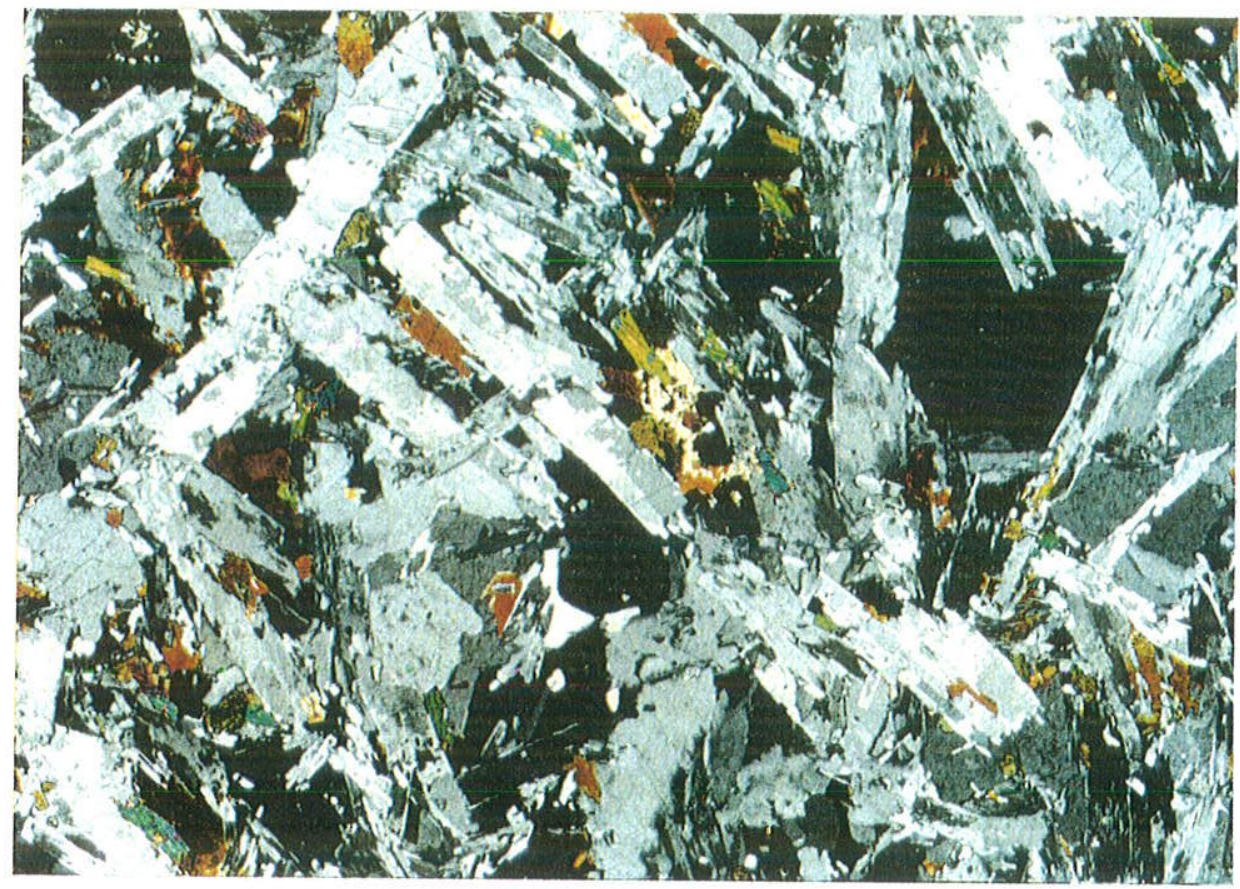

Fotomicrografia 31 - Fonólito. Feldspato alcalino somente em traves longas. Nefelina xenomórfica, com inclusões de feldspato e fêmicos, pouca sodalita. Egirina e biotita dispersos. Alguns Ti-Zr silicatos, parte concentrados à direita, inferior, sendo reconhecível a enigmatita, superpostos aos félsicos. Dimensão maior, 5,50 mm, filtros azul e fosco, polarizadores semicruzados.

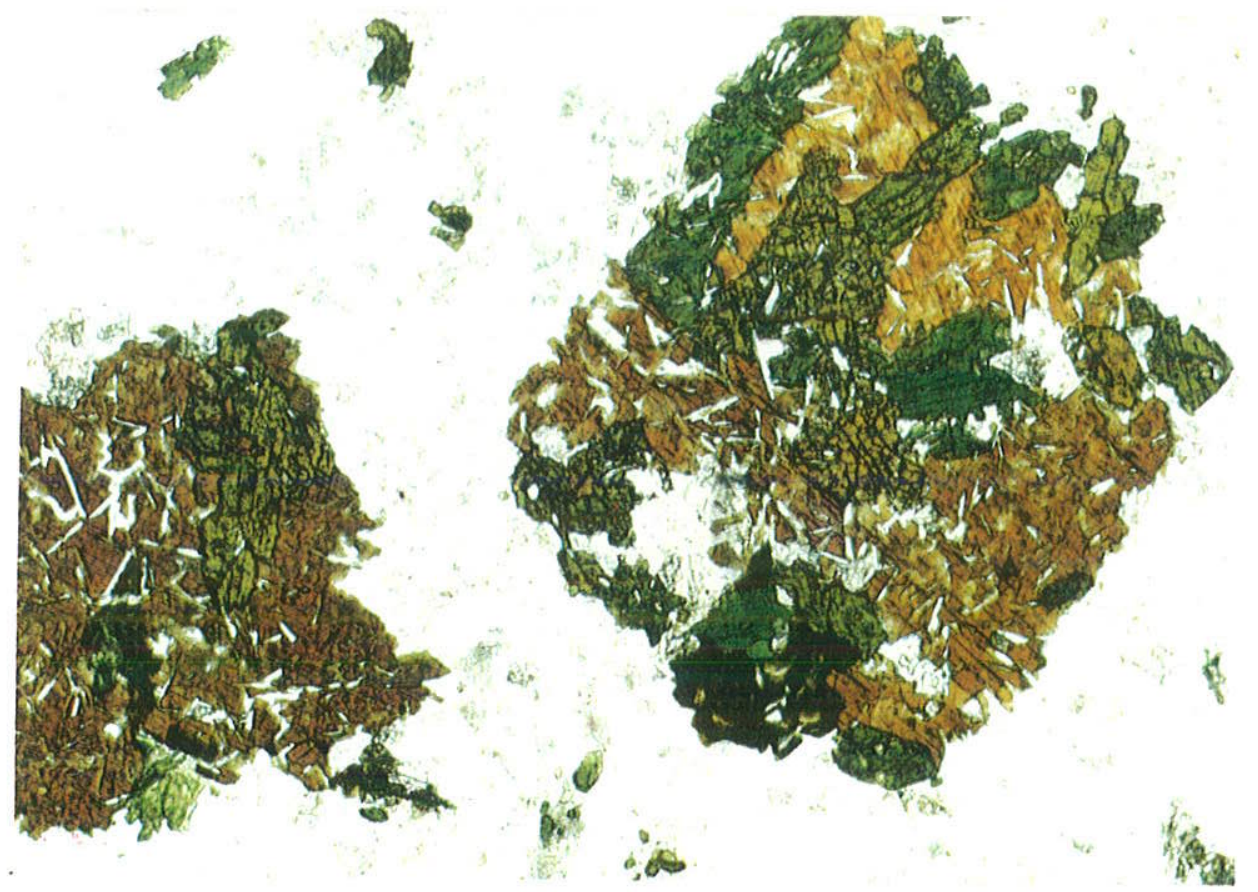

Fotomicrografia 32 - Fonólito, detalhe. Glomerocristais de biotita e egirina, com inclusão de ripas de albita. Fundo claro de feldspatos e nefelina, zonas mais cinzentas de nefelina ou feldspato mesopertítico, restante, albita mais egirina. Dimensão maior, $2,80 \mathrm{~mm}$, fitros azul e fosco, polarizadores descruzados. 


\subsubsection{Diques diabásicos (pós-sienitos)}

Sāo rochas cinzentas escuras a pretas, maciças, homófanas, com granulação fina a afaníticas. É incomum a presença de quaisquer estruturas macroscópicas, com essas rochas se mostrando normalmente afíricas. A textura é invariavelmente subofítica a intergranular, equigranular fina a média e holocristalina (Fotomicrografia 33). Traves e ripas de plagioclásio, menores que $2,0 \mathrm{~mm}$, em arranjo aleatório, por vezes subparalelo, envolvem ou moldam-se parcialmente aos fêmicos. Nas amostras examinadas, esse tipo textural é muito regular. Os minerais félsicos representam 55 a $60 \%$ da rocha.

O plagioclásio é geminado polissinteticamente e zonado, regular e normalmente. Apresenta-se com pouca alteração sericitica, sem indicios de saussuritização. Composições verificadas ao microscópio oscilam entre $A n_{35-40}$ a $A n_{55-60}$, pelo menos.

Os minerais ferromagnesianos, individualizados e desenvolvidos ou em agregados, ocupam os interstícios angulosos ou moidam as extremidades dos cristais de feldspato. São eles anfibólio, biotita, clinopiroxênio e opacos. Além desses, ocorrem em pequena quantidade titanita, apatita, carbonato e clorita esverdeada. Parte intersticial, restrita, é ocupada ainda por feldspato alcalino. Não foi visto quartzo nessas rochas e, tampouco, olivina.

$O$ anfibólio pode variar entre 15 e $40 \%$ da rocha e, da mesma forma, a biotita, 30 a menos que $10 \%$. Os opacos não chegam aos $5 \%$, enquanto que os minerais restantes estão presentes abaixo de $1 \%$. O feldspato alcalino, de impossivel estimativa modal, deve representar não mais que $5 \%$ dos félsicos.

$O$ anfibólio, em formas largas regulares, ou às vezes fibroso, é verde a verdeamarelado ou mesmo cor de oliva $\left(Z^{\prime}, Y\right)$ a pardo/amarelado claro a incolor $\left(X^{\prime}\right)$, com birrefringência média e $Z \Lambda c \sim 15-20^{\circ}$. Inclui opacos granulares.

O clinopiroxênio aparece em raros restos, sujos, incluso no anfibólio. É praticamente incolor/pardacento.

A biotita é marrom, pouco avermelhada $\left(Z^{\prime}, Y\right)$ a amarela-alaranjada $\left(X^{\prime}\right)$, e forma placas e palhetas com o anfibólio. Pode ocorrer com zoneamento, em Z', $Y$, passando de marrom no núcleo a mais alaranjada na borda.

Os opacos, dispersos ou associados aos outros fêmicos, são, em geral, granulares, quadrados ou xenomórficos. Podem formar grãos maiores, mas esqueléticos, principalmente nas bordas dos diques. Também aparecem como formas alongadas ou como grades ortogonais de individuos muito finos.

A apatita está presente em pequena quantidade, e possui forma prismática, alongada. A titanita, escura, está dispersa e é xenomórfica. O carbonato ocorre alterando o anfibólio, em pequena quantidade. Outros produtos de alteração incluem clorita, intersticial, ou associada ao anfibólio. 
Foto 42 - Fonólito. Rocha afanítica, com alto teor de fêmicos (egirina), com venulação de mineralogia rara (eudialita, vermelha). Presença de zeólitas (?), de cor branca. Reticulado: $5 \times 5 \mathrm{~cm}$.

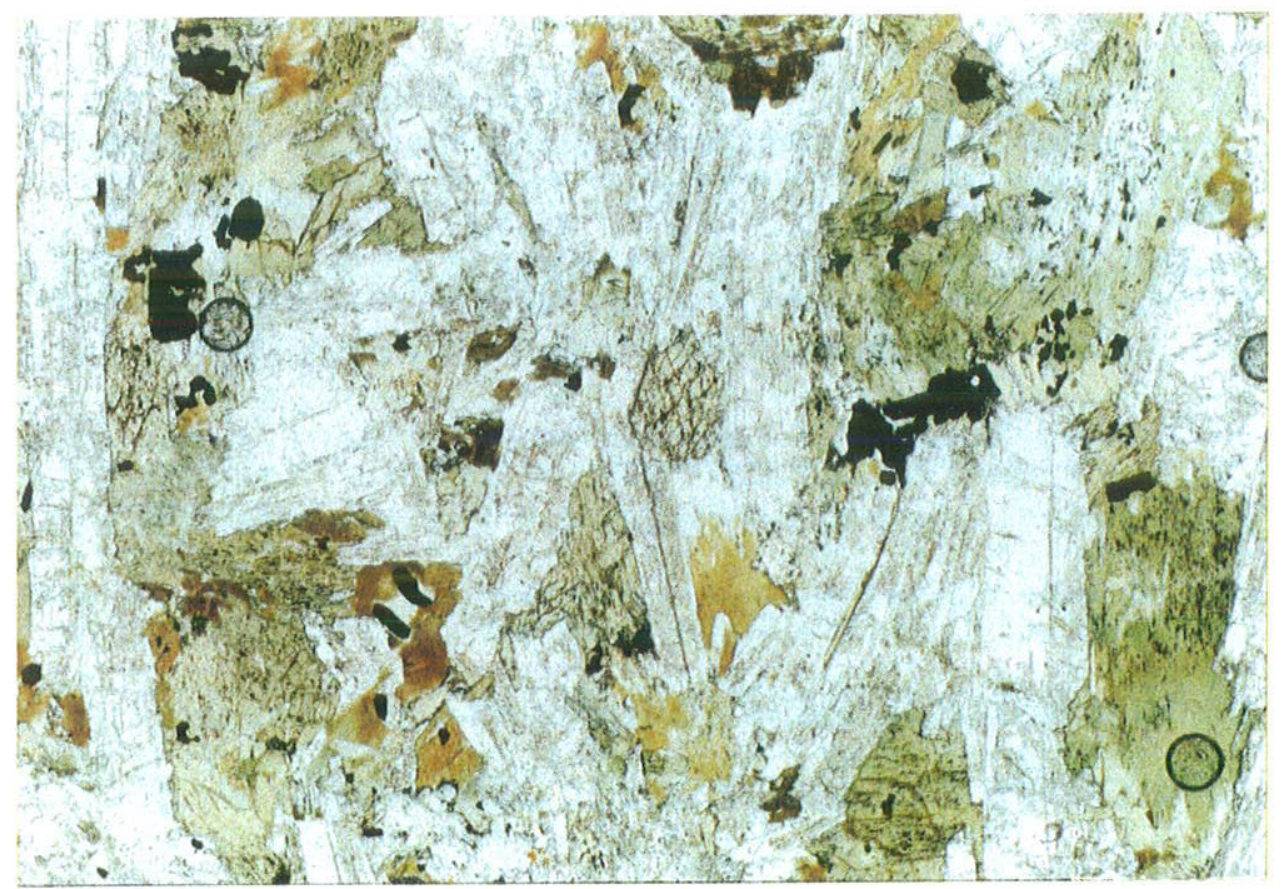

Fotomicrografia 33 - Rocha diabásica/basáltica (pós-sienitos). Textura subofítica, traquitóide. Ripas de plagioclásio, placas de anfibólio e biotita, e opacos. Observar retilinidade e angulosidade das formas e contatos. Dimensão maior, $2,80 \mathrm{~mm}$, filtros azul e fosco, polarizadores descruzados. 


\subsubsection{Diques diabásicos hornfélsicos (pré-sienitos)}

Esse tipo de rochas tem características muito próprias. Primeiro, a ocorrência. Alguns são intrusivos em quartzo sienitos, próximos aos contatos e zonas de rochas híbridas, e outros associam-se com charnoquito em um lado e sienito no outro; sempre estão ligados a zonas xenoliticas. Segundo, todos exibem textura granoblástica, hornfélsica. E, terceiro, grande parte é portadora de ortopiroxênio e/ou clinopiroxênio. Por último, não mostram deformação metamórfica seja no campo, seja em seç̧ão delgada. Nos lugares em que foram observados por inteiro, são nitidamente intrusivos, com contatos bruscos, além de muito diferentes das bandas, camadas e boudins das encaixantes.

São rochas cinzentas escuras a quase pretas, com granulaçăo média a fina, a afaníticas, homófanas e maciças, raramente porfiríticas. Quase sempre apresentam-se cortadas por veios claros centimétricos, sendo a maioria milimétricos.

Variam, texturalmente, desde rochas blastossubofiticas e blastointergranulares a granoblásticas (Fotomicrografias 34 e 35). Podem apresentar minerais poiquiloblásticos e, com freqüência, o plagioclásio tem marcada disposição subparalela (Fotomicrografia 34).

O plagioclásio tem forma retangular ou mais ou menos alongada (ripas, traves), sendo às vezes tabular. Sua forma geral é típica das rochas básicas hipoabissais. Sua linha de contato é desde levemente ondulada e embainhada até bastante irregular e imbricada. Em geral, possui um núcleo retangular bem definido, turvo, acinzentado e impregnado de inclusões opacas, contornado por borda limpa, mais sódica (Fotomicrografia 34). Composições medidas opticamente $X^{\prime} \Lambda(010)$ forneceram valores desde $A n_{35}$ até $A n_{50}$. Em rochas de caráter mais diorítico, até monzodioritico, ocorrrem mesopertitas/antipertitas junto às bordas limpas. Em algumas amostras, o plagioclásio é poiquiloblástico/blastopoiquilitico, incluindo grãos arredondados a prismáticos curtos de ortopiroxênio, às vezes em grande quantidade (50\% da superficie de corte). É comum o plagioclásio constituir agregado granoblástico regular, por vezes isento de feemicos, na forma de estrutura circular. Esse mesmo tipo de estrutura pode incluir ortopiroxênio poiquiloblástico ou ter orla de ortopiroxênio.

Esta mesma rocha é, novamente, abordada, entre os xenólitos do tipo I.

\subsubsection{Diques máficos microdioríticos ("andesíticos")}

Colocados nos charnoquitos, e com direçăo para NW, ocorrem pelo menos três diques, na Ponta das Pitangueiras e no Saco do Coruja. Reúnem mais outra característica em comum: todos são cortados pelos diques de direção NE, tanto lamprofíricos como riolíticos. São, também, petrograficamente semelhantes e, nesse aspecto, um quarto dique de direção NE os acompanha. Nenhum deles intrude os sienitos. 


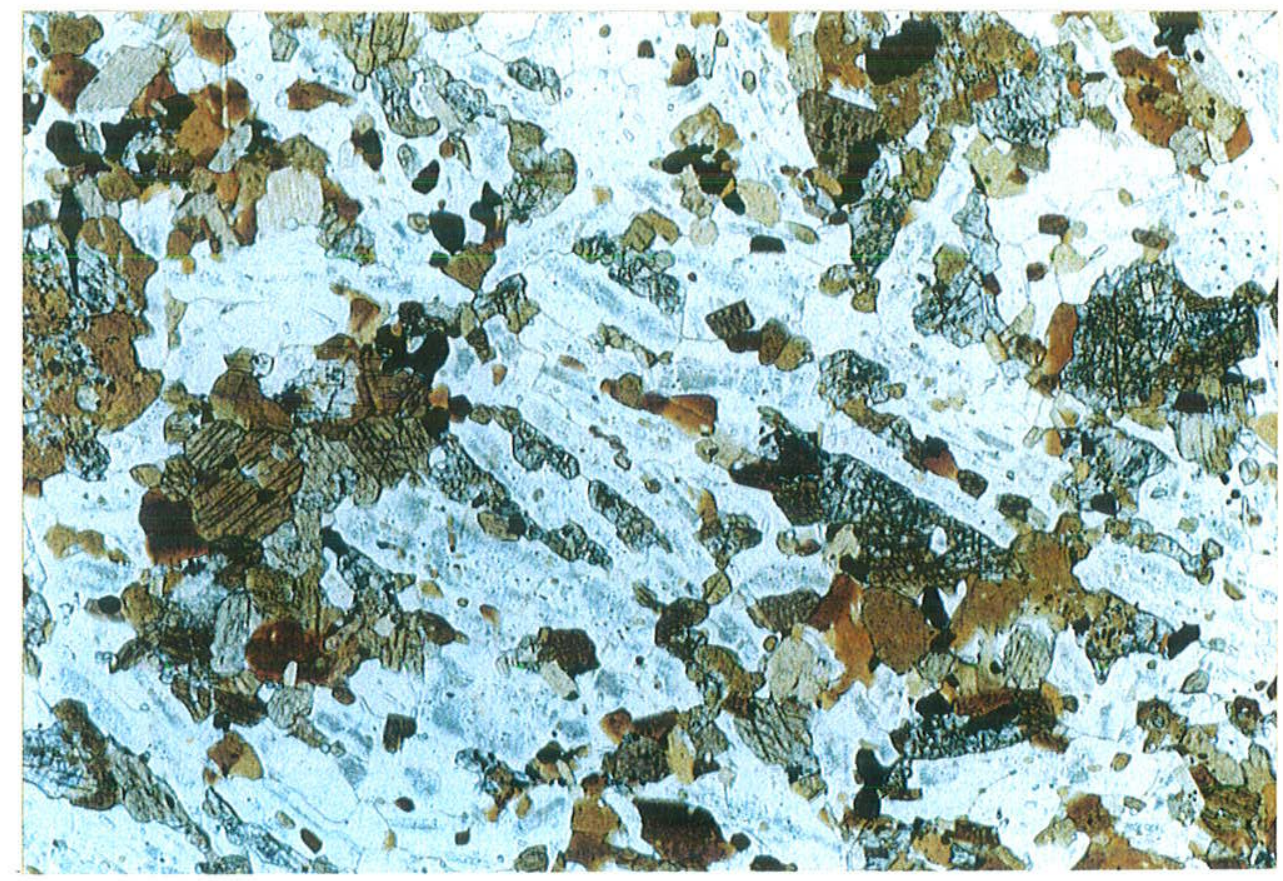

Fotomicrografia 34 - Rocha diabásica/basáltica (pré-sienitos). Ripas alongadas de plagioclásio, com núcleos acinzentados e bordas limpas (mais sódicas). Arranjo blastossubofítico, traquitóide. Anfibólio marrom, biotita, clinopiroxênio incolor. Notar embainhamento e arredondamento das formas em geral. Dimensão maior, $2,80 \mathrm{~mm}$, filtros azul e fosco, polarizadores semicruzados.

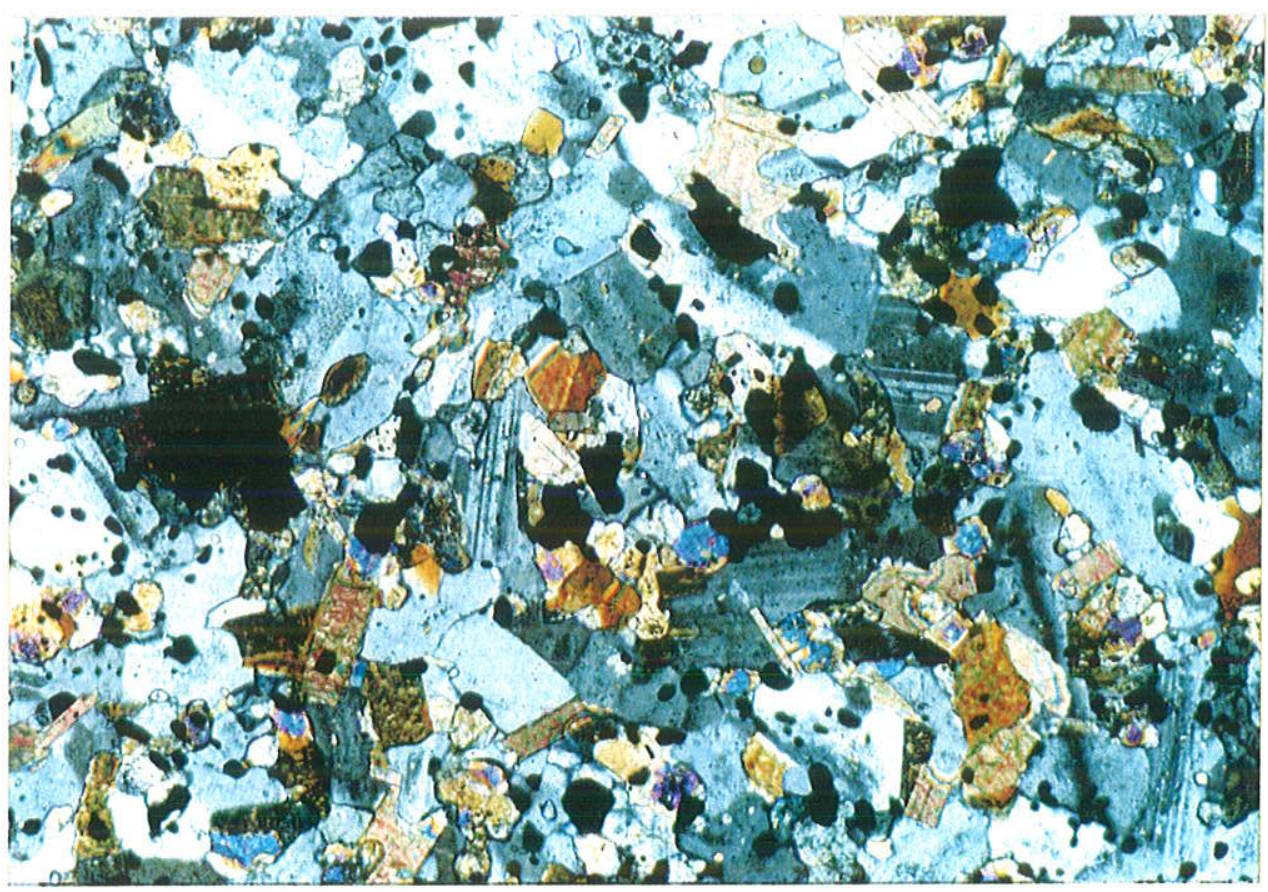

Fotomicrografia 35 - Mesmo tipo de rocha, textura mais granoblástica, plagioclásio com formas mais largas. Notar embainhamento e arredondamento generalizados das formas e contatos. Dimensão maior, $1,39 \mathrm{~mm}$, filtros azul e fosco, polarizadores semicruzados. 
São rochas cinzentas escuras a pretas, finas a afaniticas, densas, homófanas e maciças. Mostram textura porfiritica, com poucos e pequenos fenocristais e microfenocristais.

Quase todas apresentam arranjo textural pouco definido, entre intergranular a subofitico, mas não típico de qualquer deles, porque parte do feldspato não é ripiforme ou alongado. Sobre essa trama dos feldspatos, ou entre os feldspatos, ocorrem os fêmicos, com dimensões semethantes, ou menores, não ultrapassando os $0,3 \mathrm{~mm}$.

Os fenocristais de plagioclásio, com até $5 \mathrm{~mm}$, e chegando, no máximo, a $10 \%$ da rocha, aparecem sempre alterados em sericita, zeólita e carbonatos. Têm formas geométricas complexas, sendo retangulares, muitas vezes com cantos arredondados, ou totalmente arredondados. Com os fenocristais de plagioclásio, ou isoladamente, e com dimensões menores, ocorrem fenocristais de clinopiroxênio, idiomórfico, pouco zonado, pardacento a levemente róseo. Os mesmos clinopiroxênios formam, também, aglomerados de gräos justapostos.

Destacam-se da matriz, glóbulos de até $0,5 \mathrm{~mm}$ de carbonato, carbonato mais zeólita e de carbonato, zeólita e opacos, não ultrapassando os $10 \%$ da rocha.

O plagioclásio representa entre 40 e $70 \%$ da rocha. Entre os fêmicos, o mais comum e abundante é o clinopiroxênio, seguido por anfibólio, biotita e opacos. Entre os félsicos, parte do feldspato parece corresponder a feldspato alcalino, mas sem identificação segura. A apatita é comum, e como possiveis alterações estão presentes sericita, zeólita, alguma serpentina e clorita.

Algumas finas fraturas cortam essas rochas, e estão preenchidas por feldspato, zeólita, clinopiroxênio esverdeado e anfibólio, também esverdeado.

O mineral predominante, o plagioclásio, apresenta-se, na mesma amostra, geminado polissinteticamente e não geminado, ripiforme ou tabular ou xenomórico. Está, em geral, pouco alterado, e com certa imprecisão é possivel afirmar que se trata de uma andesina.

O clinopiroxênio, de hábito variado, granular ou prismático curto, é de cor parda a levemente rósea, além de pouco zonado. Pode aparecer quase que totalmente substituido por anfibólio verde escuro ou por kaersutita.

O anfibólio verde cinzento/verde-pardacento, e com impregnação de opacos, ocorre em uma amostra, substituindo total ou parciaimente o piroxênio. $\mathrm{Na}$ mesma amostra, reconhece-se kaersutita independente, de bordas esverdeadas. No primeiro caso, o anfibólio assume o hábito do clinopiroxênio e, quanto à kaersutita, esta pode ser granular ou mais ou menos idiomórfica, nunca muito alongada. Em parte das rochas aparece mal formada, como prismas largos, diminutos, de difícil reconhecimento.

Em algumas amostras, a biotita vermelha/marrom-avermelhado a alaranjada aparece também em formas e palhetas pouco definidas, mais raramente longas e idiomórficas.

Os opacos poucas vezes se mostram com formas maiores $(0,5-0,3 \mathrm{~mm})$. Em geral, são grânulos, menores que $0,1 \mathrm{~mm}$, e acompanham os fêmicos. Algumas amostras 
apresentam opacos em grades finas, com disposição obliqua das traves, e sempre ocupando pequenas porções isoladas. Nessas rochas, essas grades de opacos somente se superpöem aos feldspatos, respeitando o limite de todos os outros minerais.

É importante notar que não foram observadas regiões isótropas, nem ocelos típicos, afora os glóbulos carbonáticos.

Estimativas modais, médias da matriz, variam entre os valores: plagioclásio (feldspatos), em torno dos $50 \%$, podendo chegar aos $70 \%$ ou mesmo localmente restringir-se a $40 \%$; clinopiroxênio, nunca menos que 10-15\%, não ultrapassando os $30 \%$; anfibólio, sempre presente, desde $10 \%$ a mais que $25 \%$; biotita avermelhada, às vezes ausente, entre 5 e $10 \%$; opacos, desde menos que 5 a mais do que $10 \%$.

Essas rochas são petrograficamente referidas como microdioritos ou andesitos, a despeito da presença de kaersutita \pm biotita vermelha e dos corpos globulares carbonáticos. Como motivos para exclui-las do grupo dos lamprófiros, citam-se a presença de fenocristais de feldspato e a ausência da textura panidiomórfica típica, preferencialmente com fenocristais de fêmicos (cf. Le Maitre, 1989; Rock, 1991).

\subsubsection{Diques lamprofíricos}

Pelas características de campo e petrográficas, a maioria das rochas dos diques máficos, quer intrusivos nos charnoquitos, quer nos sienitos, pode ser classificada como lamprófiro (cf. Le Maitre, 1989; Rock, 1991).

Entre essas, a maior parte das amostras contém feldspato, piroxênio e opacos. Apresenta fenocristais, em granulação quase seriada, com porção matricial granular, e material muito fino, a isótropo, intersticiais. Estruturas ocelares (cf. Rock, 1991), de caracteristicas variadas, também se fazem presentes na quase totalidades das rochas. As variações mais importantes e notáveis são: presença e quantidade de feldspato alcalino, de olivina, de material intersticial isótropo (fóide ou vidro) e de carbonato em agregados esféricos; ausência de plagioclásio e de clinopiroxênio.

O conjunto de amostras, incluindo variação borda-centro nos mesmos diques, indica ser irrelevante quanto à classificação a presença e quantidade do antibólio ou da biotita. Aparentemente, um desses minerais, ou os dois simultaneamente, estão sempre presentes, tomando um o lugar do outro, além de representando fração percentual mais ou menos constante.

Não é demais lembrar que nessas rochas tanto os fenocristais maiores, como os grãos matriciais, são invariavelmente idiomórficos ou subidiomórficos.

As rochas sem características diabásicas, e com fenocristais de plagioclásio, foram excluídas deste grupo (cf. Le Maitre, 1989; Rock, 1991), sendo tratadas à parte (item 6.5.2.). 
Entre os fenocristais, ocorrem por vezes individuos, ou grupos deles, de plagioclásio ou de plagioclásio \pm olivina \pm clinopiroxênio, que devem ser tomados como xenocristais ou microxenólitos (Fotomicrografia 36). Em geral, contêm grande número de inciusões, não têm formas geométricas bem definidas, mostrando arredondamento dos cantos e embainhamento pouco pronunciado. Também reconhecem-se xenocristais de anfibólio amarelado (Fotomicrografia 37).

Fenocristais, principalmente de clinopiroxênio róseo/pardo/amarelado, idiomórficos, quase sempre zonados de forma oscilatória (Fotomicrografia 38), além de centimétricos, representam entre pouco menos que $5 \%$ a pouco mais que $10 \%$. Em algumas amostras, o clinopiroxênio é acompanhado por fenocristais de olivina (Fotomicrografia 39), desde pouco a totalmente atterada, idiomórfica, com $2 \mathrm{~V}$ de valor alto $\left(>80^{\circ}\right)$ e sinal óptico indeterminado, o que a limita às composições mais magnesianas que $\mathrm{Fo}_{65}$. Em uma única amostra ocorrem fenocristais quase centimétricos de kaersutita, ao lado daqueles de olivina e clinopiroxênio. Em conjunto, os fenocristais não ultrapassam os $20-25 \%$, perfazendo no geral cerca de $10 \%$ das rochas.

Suas formas são geométricas e angulosas. Em alguns contatos de rochas, entre os fenocristais observados, a olivina aparece embainhada, com preenchimento vítreo ou hipocristalino muito fino.

Nas rochas mais finas ou nas bordas das mais grossas (no máximo, médias), as dimensöes dos fenocristais tornam-se milimétricas, sendo apropriadamente designados de microfenocristais. A relação entre as dimensöes dos fenocristais ou dos microfenocristais com a parte matricial, quer granular e individualizada ou micro granular, mantém, contudo, certa constância. Essa relação é de, no mínimo, 2 a 3:1, chegando até os 10:1. Relações dimensionais muito diferentes são aquelas encontradas nos contatos com material vítreo a micro/criptocristalino: cristais milimétricos de olivina, plagioclásio e clinopiroxênio podem ser até 100 vezes maiores (linearmente) que os grãos matriciais.

Porção granular, ou matriz granular, representa 50 a $80 \%$ dessas rochas. Pode ser equigranular ou apresentar microfenocristais, cuja presença faz com que a textura mostre seriação granulométrica.

Os microfenocristais, sobretudo de clinopiroxênio, mais raramente de olivina, mantêm as características dos grãos menores.

A matriz granular, em geral submilimétrica $(<1,0 \mathrm{~mm}-0,1 \mathrm{~mm})$, é mais ou menos equigranular. O plagioclásio retangular alongado a ripiforme predomina amplamente (Fotomicrografia 39). Tem composição variada, com algum zoneamento normal, estando sempre geminado polissinteticamente. Mostra disposição aleatória, o que torna a textura, por vezes, semeihante à intergranular. Em algumas amostras, contudo, apresenta disposição fortemente paralela, emprestando ao conjunto aspecto traquitóide. De amostra para amostra, 


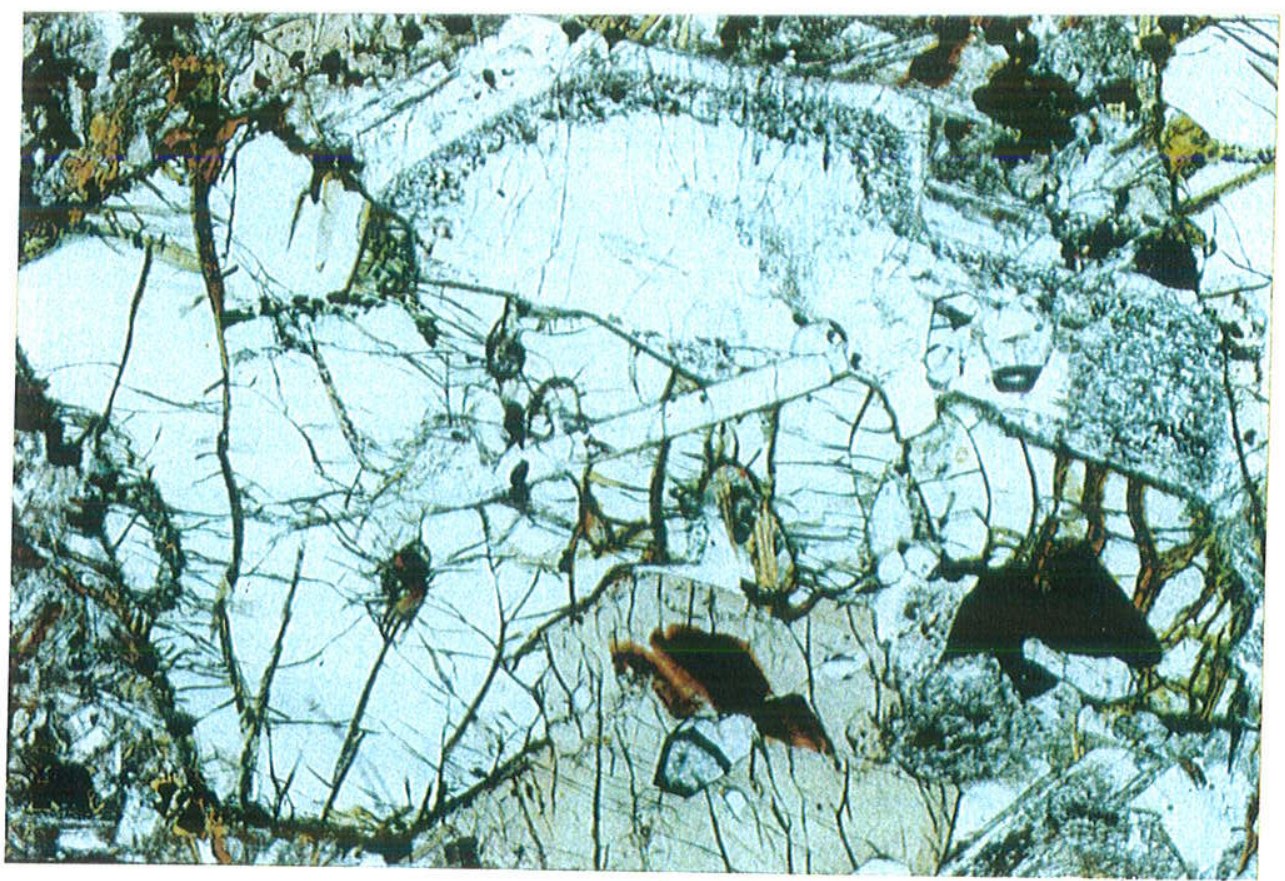

Fotomicrografia 36 - Microxenólito. Olivina, com alteração de borda (biotita+opacos) e apatita no centro, ao lado de plagioclásio zonado, com inclusões, clinopiroxênio pardo, zonado abaixo. Dimensão maior, $5,50 \mathrm{~mm}$, filtros azul e fosco, polarizadores descruzados.

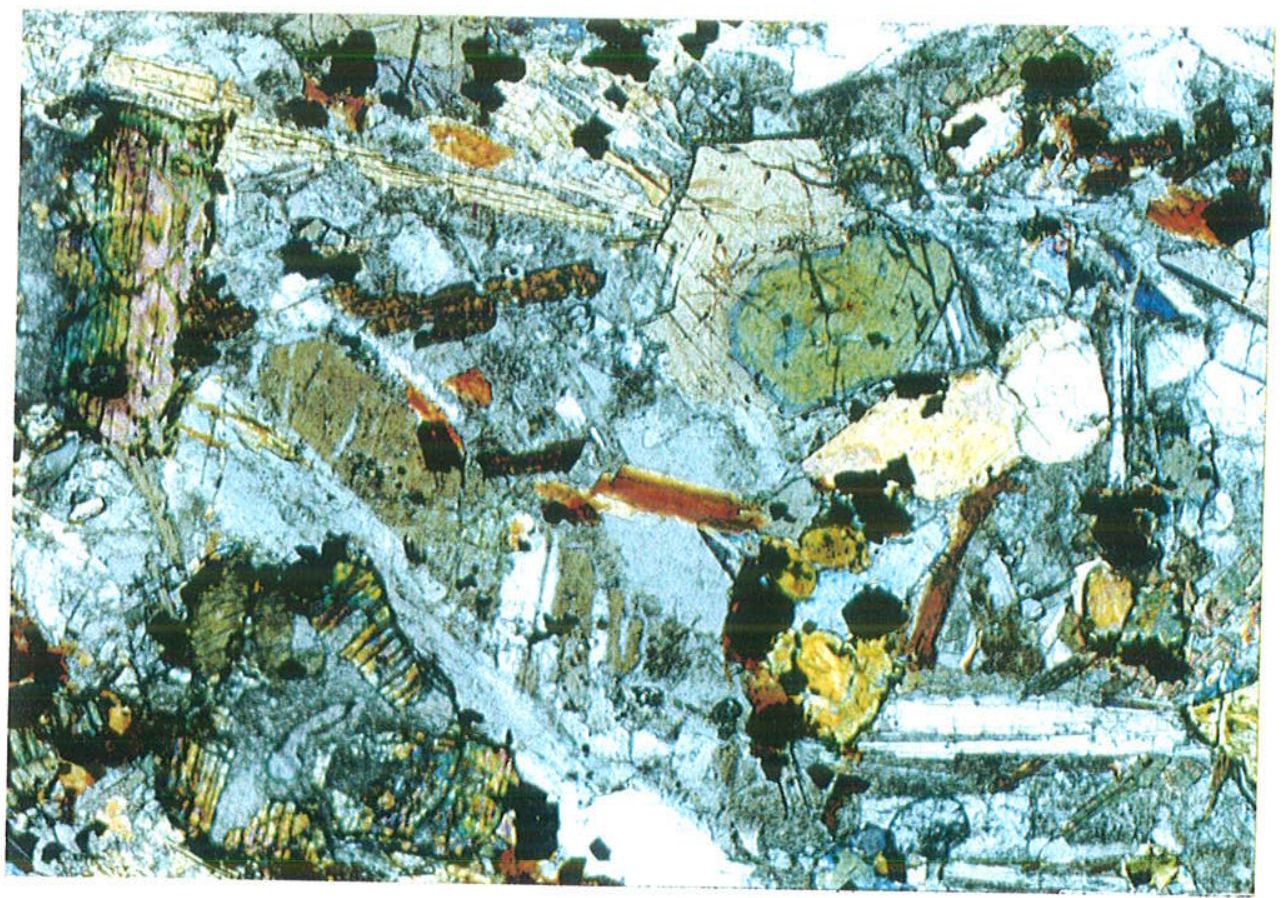

Fotomicrografia 37 - Camptonito. Plagioclásio cálcico predominante. Dois xenocristais de anfibólio amarelo-esverdeado à esquerda. Clinopiroxênio zonado (centro, direita), biotita vermelha, opacos granulares. Porções cinzentas intersticiais, muito limpas, material isótropo (analcita?). Dimensão maior, $2,80 \mathrm{~mm}$, filtro azul e fosco, polarizadores semicruzados. 


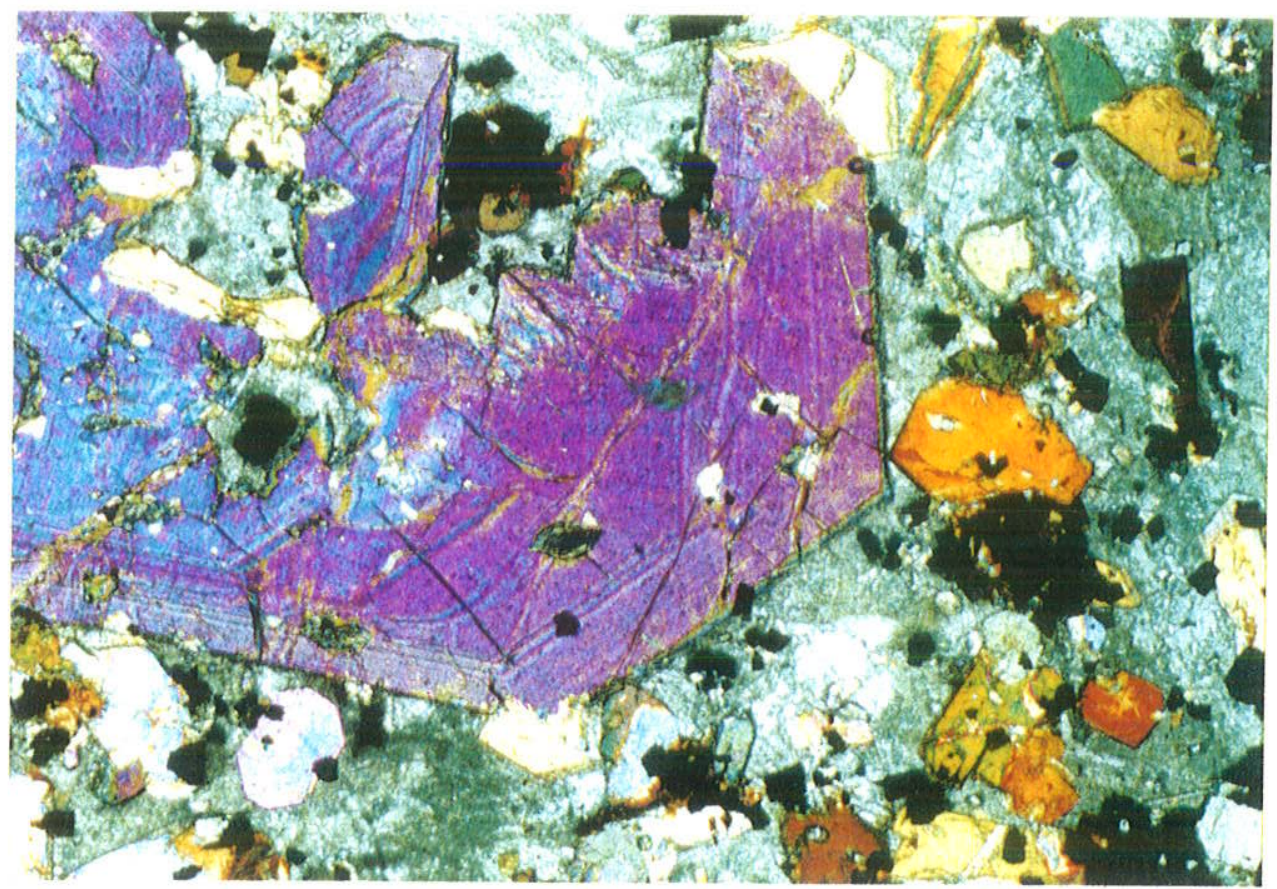

Fotomicrografia 38 - Camptonito. Textura, à direita, muito comum e típica. Porções cinzentas: plagioclásio alterado e isótropos. Fenocristal de clinopiroxênio zonado (pardo/róseo/amarelado) com forma reentrante, mas que não deve ser corrosão (observar o zoneamento recorrente). Dimensão maior, 2,80 mm, filtros azul e fosco, polarizadores semicruzados.

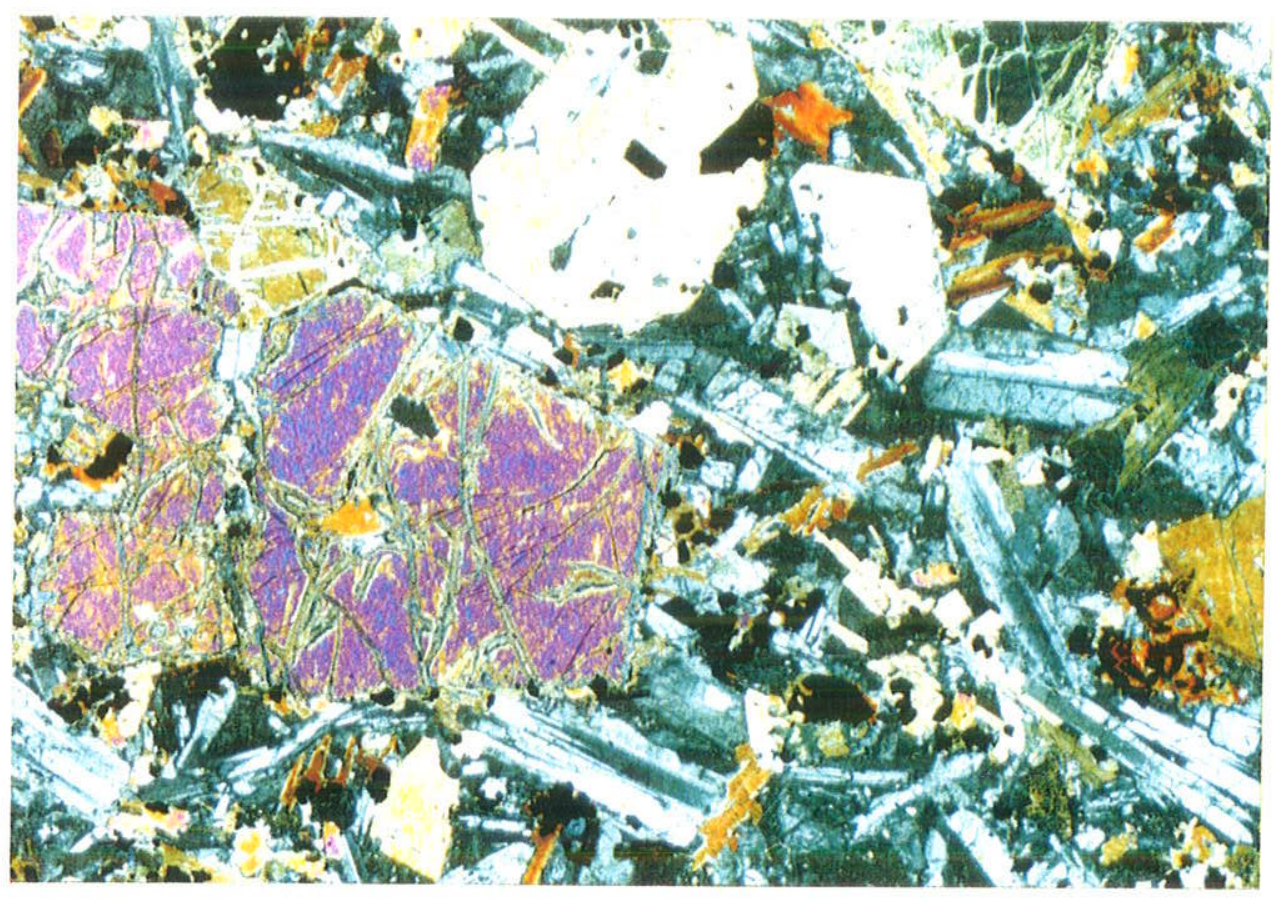

Fotomicrografia 39 - Camptonito típico, com plagioclásio pouco alterado e analcita (isótropo). Dois fenocristais de olivina, à esquerda. Cristais amarelos estão pseudomorfisados. Clinopiroxênio com cores claras. A rocha apresenta biotita vermelha e não contém kaersutita. Dimensão maior, $5,50 \mathrm{~mm}$, filtros e fosco, polarizadores semicruzados. 
os individuos variam entre totalmente frescos a totalmente alterados, com presença de zeólitas ou de provável argilo-mineral.

Entre os feldspatos, e nos intertícios angulosos, aparece em igualdade dimensional, ou em tamanho menor, clinopiroxênio, anfibólio, biotita, opacos e olivina.

O clinopiroxênio, raramente, deixa de ser róseo e zonado de forma oscilatória, não geminado. Opticamente parece titanoaugita, mas pode corresponder a uma variedade titanífera de augita/diopsídio. Essas características são do individuo como um todo ou de suas bordas. $O$ núcleo pode ser incolor a pardacento claro ou esverdeado. Sua forma varia. Nas rochas de granulação média, ou nas amostras mais distantes dos contatos, é menos alongado, formando prismas curtos a grãos quase quadrados a equidimensionais. Diques menos espessos e amostras de borda exibem clinopiroxênio mais alongado, até ao ponto de extremo alongamento, em conjuntos de prismas paralelos, com relação de 1:20 entre as dimensões. Sua transformação mais notável é para kaersutita, nas mais diversas situações e proporções.

A kaersutita, idiomórfica, comparece em cortes prismáticos, mais curtos ou mais longos, e basais hexagonais (Fotomicrografias 40 e 41). É fortemente colorida, e mesmo se ausente da rocha, pode aparecer nos ocelos ou envolvendo-os. Poucas vezes a biotita, marrom-avermelhada a avermelhada $(Z, Y)$ a alaranjada/amarelada, é homogênea. Aparece em longas placas esqueléticas (microfenocristais) em quantidade restrita ou em palhetas e placas menores, idiomórficas ou não (Fotomicrografias 40 e 41), quase sempre orlando os opacos e, com freqüência, também nas bordas da olivina e do clinopiroxênio. Como dito, em algumas amostras ocorre só a biotita, em outras apenas kaersutita, e noutras ambos os minerais, em proporções variáveis entre si (Fotomicrografias 39-41).

A biotita vermelha, além de participar da assembléia granular/matricial, associa-se aos ocelos. Pode estar presente em placas longas, envolvendo os ocelos, ou atravessando-os de um lado a outro, ou ocorre dentro do material ocelar isótropo na forma de finas e minúsculas palhetas.

A olivina, além de destacar wse como fenocristal, aparece como microfenocristal, inalterado e alterado. Idiomórfica, pode estar totalmente pseudomorfisada por serpentina \pm clorita \pm talco \pm carbonato \pm opacos (Fotomicrografia 40).

Os opacos apresentam-se comumente com diferentes hábitos e tamanhos, parecendo tratar-se de magnetita e ilmenita. Junto aos ocelos, é comum a pirita. As variações de formas e tamanhos relacionam-se à espessura dos diques e à distância dos contatos. Pode ocorrer como grãos majores, milimétricos, equidimensionais; como grânulos submilimétricos, agrupados ou isolados, orlados por biotita; em formas esqueléticas angulosas; ou, bastante freqüente, em conjuntos de grades ortogonais de individuos muito finos, às vezes ocupando toda a secção delgada (Fotomicrografias 40 e 41 ). 


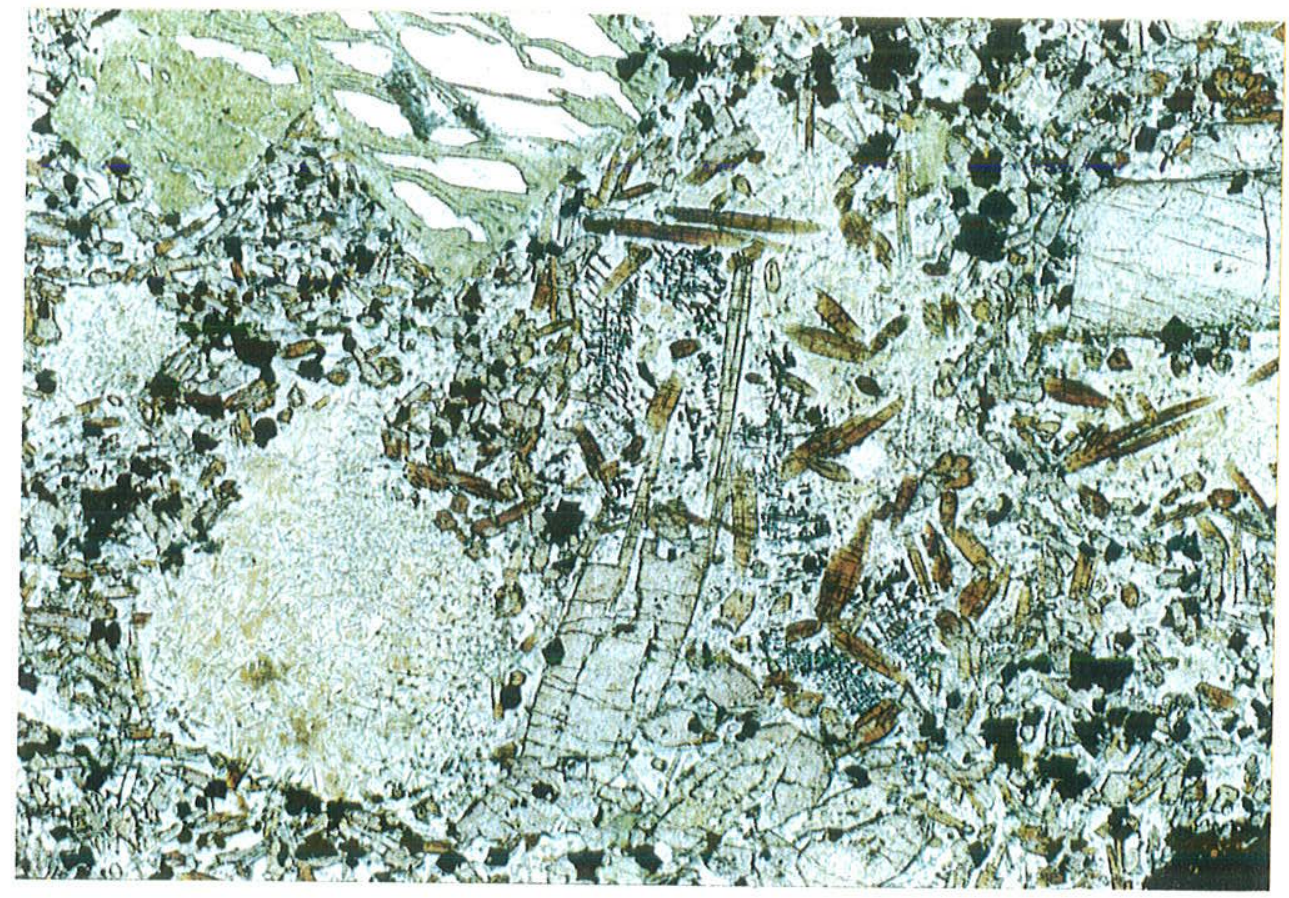

Fotomicrografia 40 - Monchiquito. Destacam-se microfenocristais de olivina e clinopiroxênio. Matriz granular fêmica com os mesmos minerais e kaersutita. À esquerda, ocelo com vidro (marrom) e vidro (branco), que se expande para os interstícios. Notar três formas de opacos, em particular as grades. Dimensão maior, $2,80 \mathrm{~mm}$, filtros azul e fosco, polarizadores descruzados.

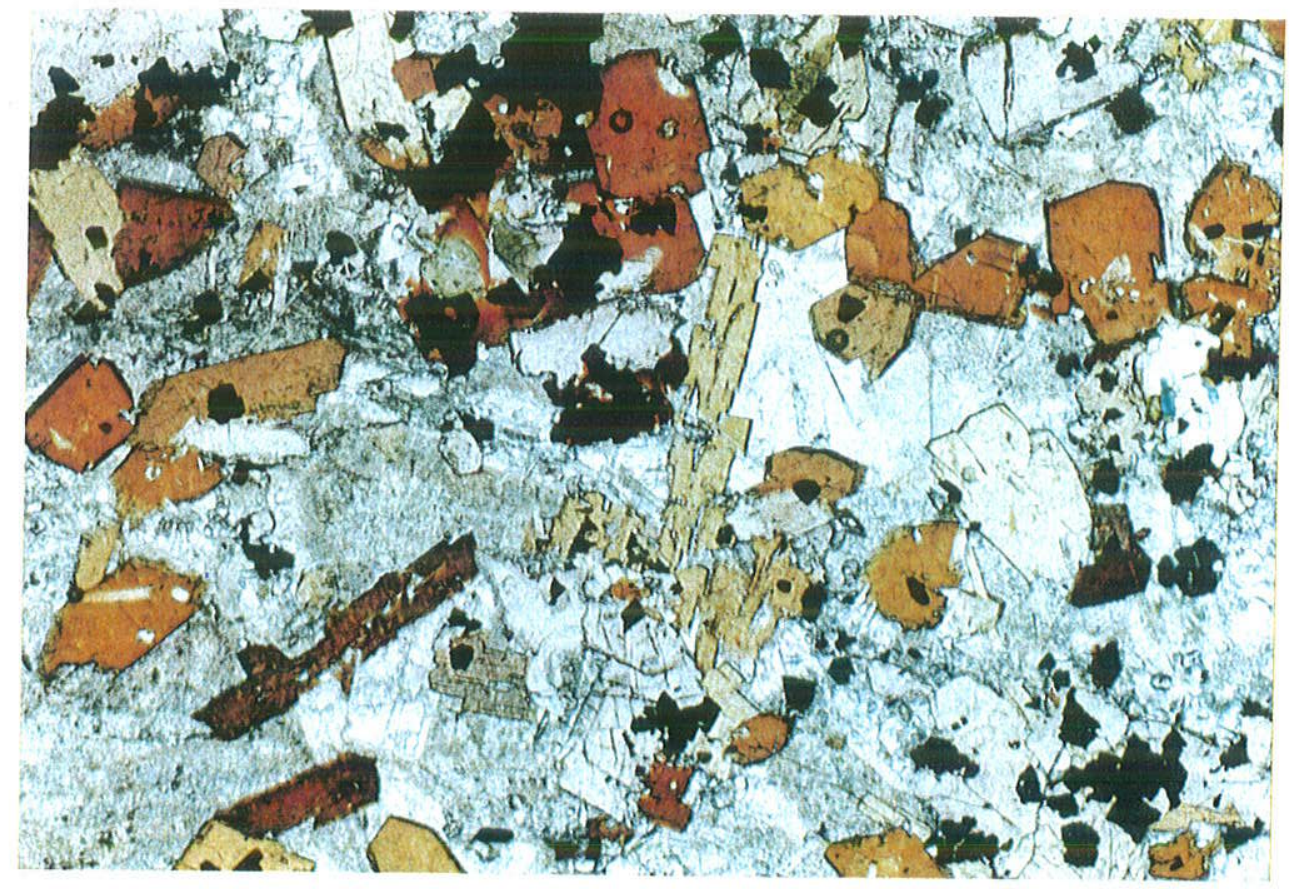

Fotomicrografia 41 - Camptonito, com kaersutita (alaranjada) e biotita vermelha, mais piroxênio. Áreas cinzentas são de plagioclásio, parte microcristalino, e porções isótropas, mais limpas, de analcita. Notar microfenocristal de biotita, esquelético, no centro. Opacos, parcialmente esqueléticos. Dimensão maior, $2,80 \mathrm{~mm}$, filtros azul e fosco, polarizadores semicruzados. 
O feldspato alcalino, possivelmente potássico, e de difícil reconhecimento, é identificado com segurança nos ocelos, junto a material isótropo (Fotomicrografia 42). Tem formas retangulares pouco alongadas e é geminado (Carlsbad). Em algumas variedades ricas em ocelos desse tipo, o feldspato potássico parece invadir também a rocha, não havendo um limite claro entre o ocelo e a trama da rocha. Nesses casos, sua quantidade aumenta muito, chegando a igualar ou mesmo suplantar à do plagioclásio. Em outro tipo de ocelo, mais raro, o feldspato alcalino é duvidosamente identificado, constituindo conjuntos subparalelos, radiados e convergentes de formas alongadas e sinuosos. Neste caso, a não ser pela birrefringência, não é possivel distingui-lo das zeólitas. Além dessas formas, em meio ao plagioclásio, ou ainda intersticialmente, ocorrem individuos com limites indefinidos, não geminados, que poderiam ser de feldspato alcalino (potássico ?).

Outro mineral comum, e até abundante, é a apatita prismática longa, passando a acicular. Forma emaranhado atravessando os outros minerais e, eventualmente, prismas maiores, quase milimétricos. principalmente.

A titanita, acinzentada, em grânulos pequenos, foi observada nos ocelos,

O material isótropo aparece como analcita ou ainda vidro. Pode ser incolor e timpo (vidro e analcita) ou sujo, marrom/avermelhado (vidro). Forma os ocelos ou preenche os intersticios entre os demais minerais.

Os lamprófiros aqui descritos correspondem àqueles portadores de plagioclásio, acompanhados de pequena quantidade de feldspato alcalino, até relaçōes igualitárias, vidro e feldspatóide (analcita). Portanto, a designação de camptonitos é a mais apropriada (cf. Le Maitre, 1989). Nos poucos casos em que se caracterizou a presença de feldspato alcalino, os camptonitos poderiam passar a sannaitos (cf. Le Maitre, 1989) (Fotomicrografia 42).

Algumas amostras, poucas, que näo se conformam estreitamente às características dos lamprófiros, não contêm feldspato, mas são portadoras de fases hidratadas (kaersutita) idiomórficas, podendo, assim, ser tratadas de monchiquitos (Fotomicrografias 40, 43e 44).

Este item agrupa rochas em que vidro e/ou fóides nunca se ausentam e, embora algumas exibam características de ultramáficas, não foi, conclusivamente, reconhecida a melilita. Todas as amostras são classificáveis petrograficamente como lamprófiros alcalinos (cf. Le Maitre, 1989), embora algumas näo se conformem exatamente aos padrões descritivos e classificatórios adotados na literatura (Fotomicrografia 45).

\subsubsection{Diques máfico-ultramáficos deformados (pré-sienitos)}

Alguns diques das zonas de contato, intrusivos em sienitos hibridos ou em rochas supostamente com caracteristicas sieniticas, foram amostrados. Esses diques apresentam 


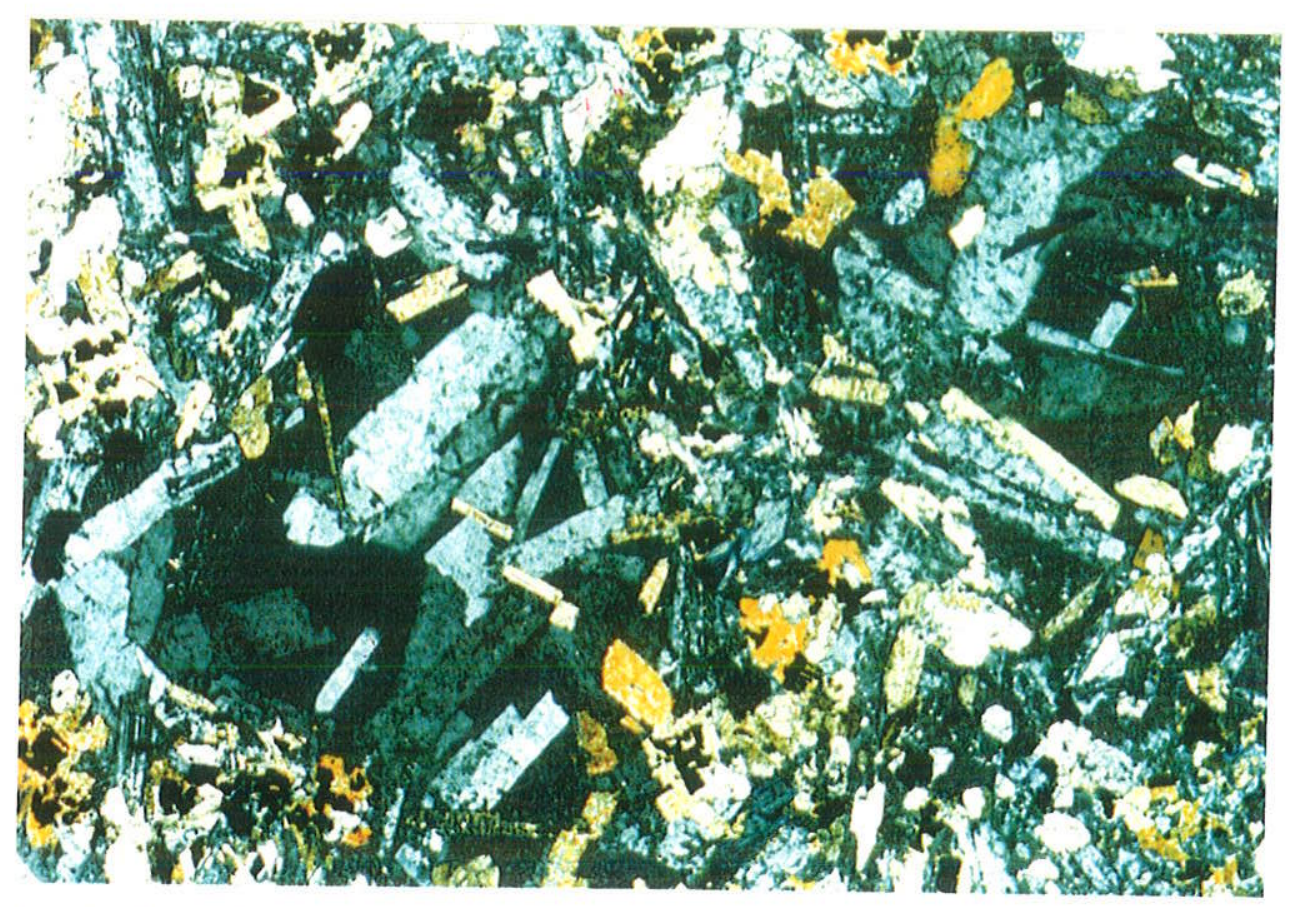

Fotomicrografia 42 - Sannaíto, com clinopiroxênio, kaersutita e biotita, de coloridos variados, e opacos. Ocelos, lado esquerdo, é à direita, parte superior. Ocelos com feldspato potássico, analcita (isótropa), alguma biotita e kaersutita. Também aparece plagioclásio alterado, minoritário. Dimensão maior, 2,80 $\mathrm{mm}$, filtros azul e fosco, polarizadores semicruzados.

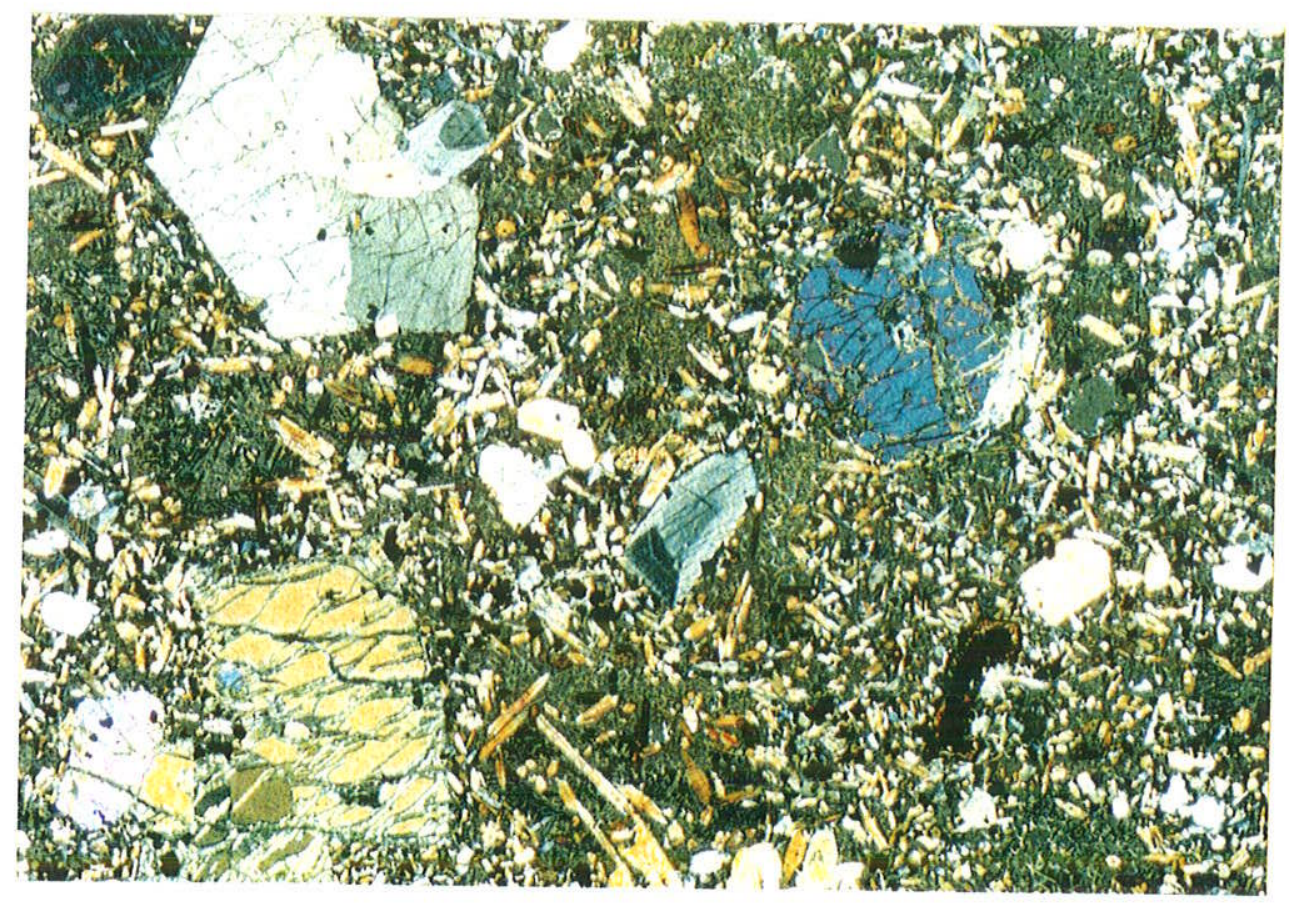

Fotomicrografia 43 - Monchiquito. Coloridos: microfenocristais de olivina (coloridos fortes) e clinopiroxênio com zoneamento setorial. Matriz granular com os mesmos mais opacos. Matriz quase isótropa: fêmicos finos, analcita, vidro, vidro pouco cristalizado. Sem feldspato. Dimensão maior, 5,50 mm, filtros azul e fosco, polarizadores semicruzados. 


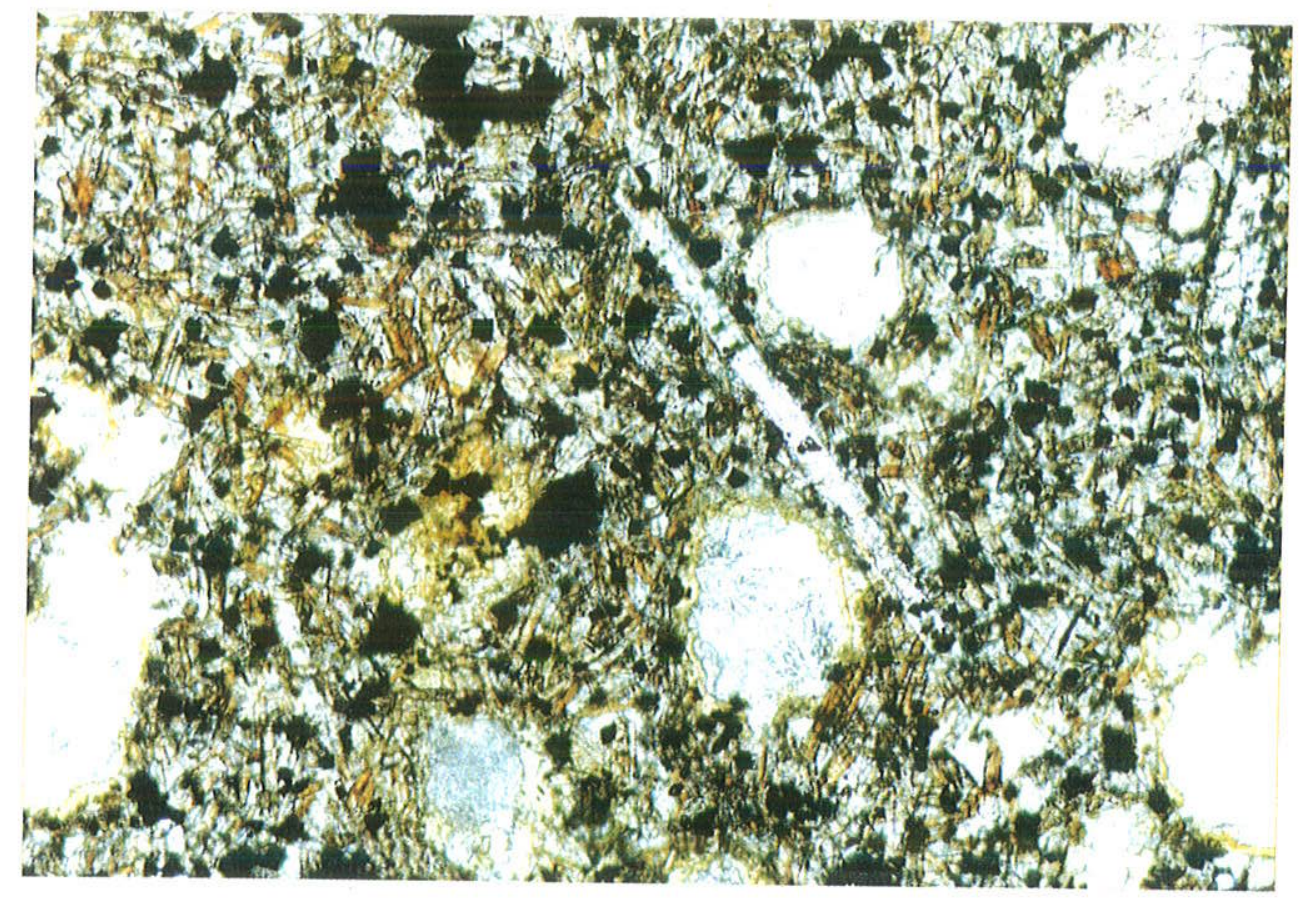

Fotomicrografia 44 - Provável monchiquito. Destaques maiores: ocelos com carbonato, zeólita, serpentina; apatita (centro) e clinopiroxênio (canto superior direito). Matriz granular: opacos (notar a quantidade), kaersutita e clinopiroxênio prismático. A textura não é tipicamente lamprofírica. Dimensão maior, 1,39 $\mathrm{mm}$, filtros azul e fosco, polarizadores descruzados.

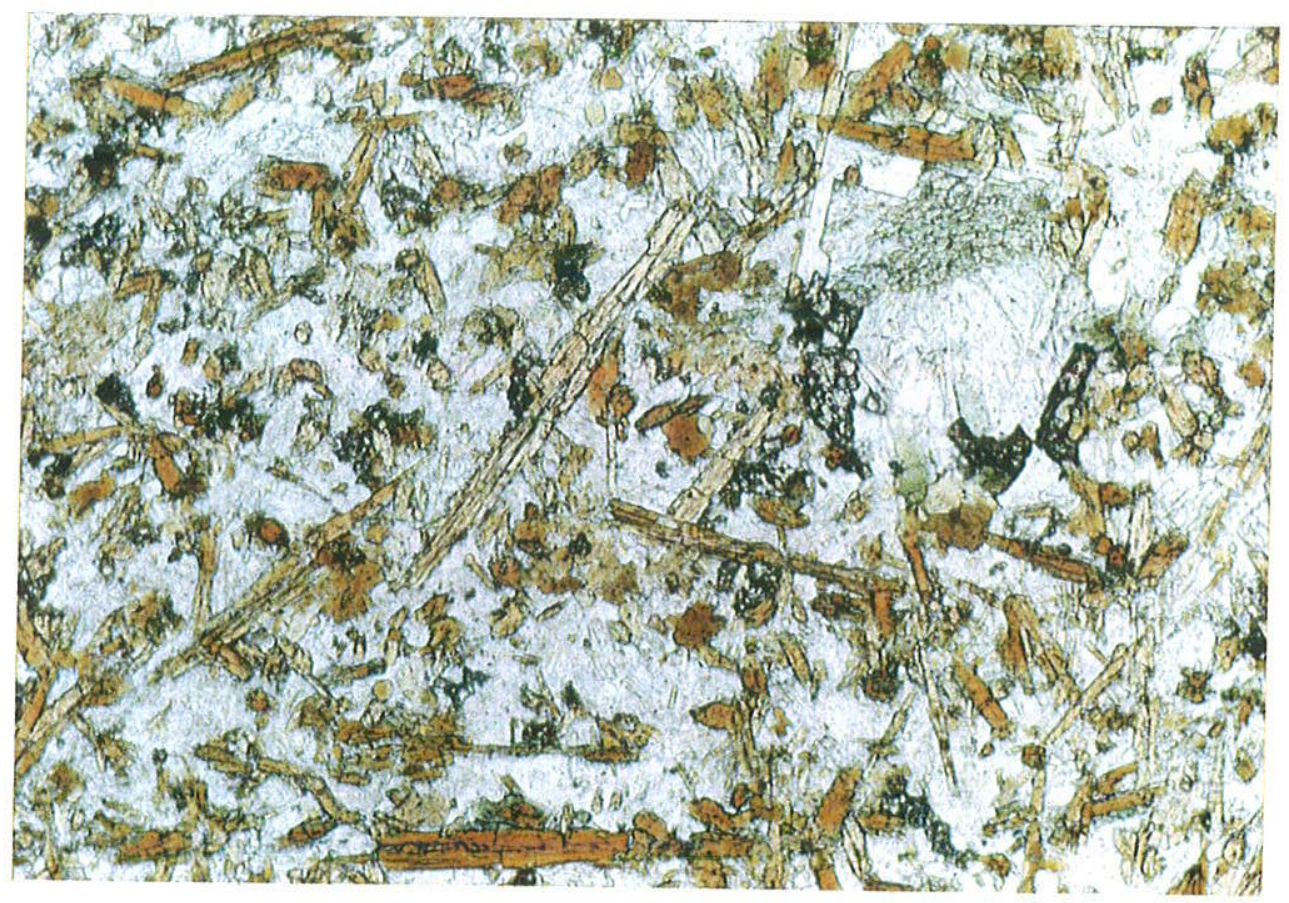

Fotomicrografia 45 - Lamprófiro não classificado (camptonito? sannaíto?). Matriz clara com feldspato (?), material isótropo (?) e apatita. Coloridos: kaersutita prismática, longa, e titanita (?). Dimensão maior, 1,39 $\mathrm{mm}$, filtros azul e fosco, descruzados. 
padrões de deformação inexistente nos diques intrusivos nos sienitos e, na maior parte, daqueles que também cortam os charnoquitos.

A análise petrográfica dessas rochas, contudo, não resolveu o problema que esses tipos representam.

Todos os quatro diques amostrados, dois na Pontinha e outros dois, a leste do Saco do Coruja, são petrograficamente semelhantes.

Essas rochas mostram agregado matricial muito fino, granular/granoblástico, de plagioclásio, clinopiroxênio, opacos, biotita vermelha e, por vezes, anfibólio verde, sem qualquer vestígio de orientação mineral. As proporçōes entre as fases félsicas e fêmicas variam, ora predominando a biotita vermelha, o clinopiroxênio ou ainda o plagioclásio.

Em uma das amostras, à semelhança das rochas diabásicas/dioríticas hornfélsicas, ocorrem poiquiloblastos bem destacados, somente que, neste caso, de biotita.

Nas outras amostras destacam-se os fenocristais (megacristais, talvez) de clinopiroxênio pardo, com formas bem definidas, no geral geométricas, mas quase sempre sem cantos e angulosidades, muito embora com retilinidade dos contornos e relações angulares entre "faces" bem definidas. Alguns individuos chegam arredondar-se bastante. Com freqüência, mostram embainhamentos cheios com a matriz, ou esta aparece inclusa, chegando a substituir quase integralmente o piroxênio. São comuns formas com a aparência de fragmentos quebrados. Todos os individuos apresentam fina lamelação opaca interna, perpendicular às bordas, e restritas às bordas.

A textura é, em quase tudo, igual aos arranjos porfiriticos, mesmo com o arredondamento dos cantos (Fotomicrografia 46). Contudo, a matriz é tipicamente granoblástica, e muito fina $(<0,1 \mathrm{~mm})$.

\subsection{Feições petrográficas especiais}

Algumas características das rochas, em geral, não configuram exatamente litotipos. Apesar disso, têm importância bastante na história do alojamento e cristalização dos corpos igneos e na sua história ulterior. Para não sobrecarregar demasiadamente as descrições petrográficas com detalhes minuciosos, ainda que importantes, procurou-se destacá-los da descrição das rochas onde ocorrem, e tratá-los à parte.

\subsubsection{Variações mineralógicas e texturais internas dos diques máficos}

Alguns diques máficos alcalinos foram amostrados transversalmente, em geral borda 
ou contato e centro.

Alguns em três pontos, com o dique máfico do ponto 326 , com $6 \mathrm{~m}$ de largura, sendo coletado em oito pontos: cinco amostras nos primeiros $40 \mathrm{~cm}$, a partir do contato, sendo duas delas no contato (contato e borda interna); uma amostra do centro, e outras duas espaçadas entre o centro e os primeiros $40 \mathrm{~cm}$ a partir da borda.

Em todas as amostras examinadas em secções delgadas, que apanharam a encaixante charnoquítica e o dique, não se notaram quaisquer efeitos mineralógicos e texturais na encaixante. Esse comportamento foi observado tanto no dique com $6 \mathrm{~m}$ de espessura, como naqueles com $0,50 \mathrm{~m}$.

A textura e a mineralogia das amostras dos diques, contudo, demonstram acentuada e regular variação na mineralogia e na textura.

Nas amostras cuja secção delgada apanhou dique e encaixante, nota-se a presença de vidro imediatamente no contato. Dentro do universo de uma secção delgada, em distância linear de não mais que alguns milimetros, verifica-se variação muito rápida. Vidro marromavermelhado ou cinzento escuro, denso, com fraturamento perlitico passa a vidro mais claro, havendo recorrência de tipos, em bandas milimétricas e intervalo total de não mais que 2 a 3 $\mathrm{mm}$ (Fotomicrografia 47). Nesse intervalo não se nota cristalização - cristalitos e micrólitos, que só aparecem depois dos 2 a $3 \mathrm{~mm}$ de distância. Esses microcristais, nas rochas estudadas de clinopiroxênio e plagioclásio, aumentam rapidamente em quantidade, tal que a $10 \mathrm{~mm}$ ou pouco mais do contato predominam amplamente, tornando-se dificil constatar-se ainda a existência ou não de vidro.

Na região holohialina, notam-se inclusões, parte carregadas pelo vidro e de dimensões totalmente desproporcionais ao estágio de cristalização, e parte de origem discutivel. Neste último caso, esquadram-se glóbulos carbonáticos, em grande quantidade, coalescidos e de difícil percepção, que já começam a aparecer encostados à encaixante. No primeiro caso, estão os fenocristais, perfeitamente idiomórficos, principalmente de clinopiroxênio inalterado, olivina com até 2 a $3 \mathrm{~mm}$ (mesma ordem de grandeza da faixa vítrea) totalmente alterada em serpentina (e carbonato) e opacos (Fotomicrografia 48), às vezes embainhada com vidro como preenchimento, e de plagioclásio idiomórfico ripiforme, tabular ou com forma de "castelo", também parcialmente alterado.

Na medida em que aumenta a distância do contato, os glóbulos carbonáticos, inicialmente com frações de milímetro de diâmetro, dispersammse na matriz já parcialmente microcristalina, e aumentam de tamanho (Fotomicrografia 47). Também o clinopiroxênio e o plagioclásio se dispersam e alcançam maiores dimensōes, e a olivina os acompanha de forma mais moderada. Opacos inicialmente como poeira fina, principalmente nos vidros cinzentos, concentram-se em grânulos pequenos e inteiros, não se observando formas esqueléticas, e têm comportamento semelhante ao dos outros minerais. Em algumas amostras, na outra extremidade da secção delgada (> 15-20 mm de distância do contato), já são reconheciveis 


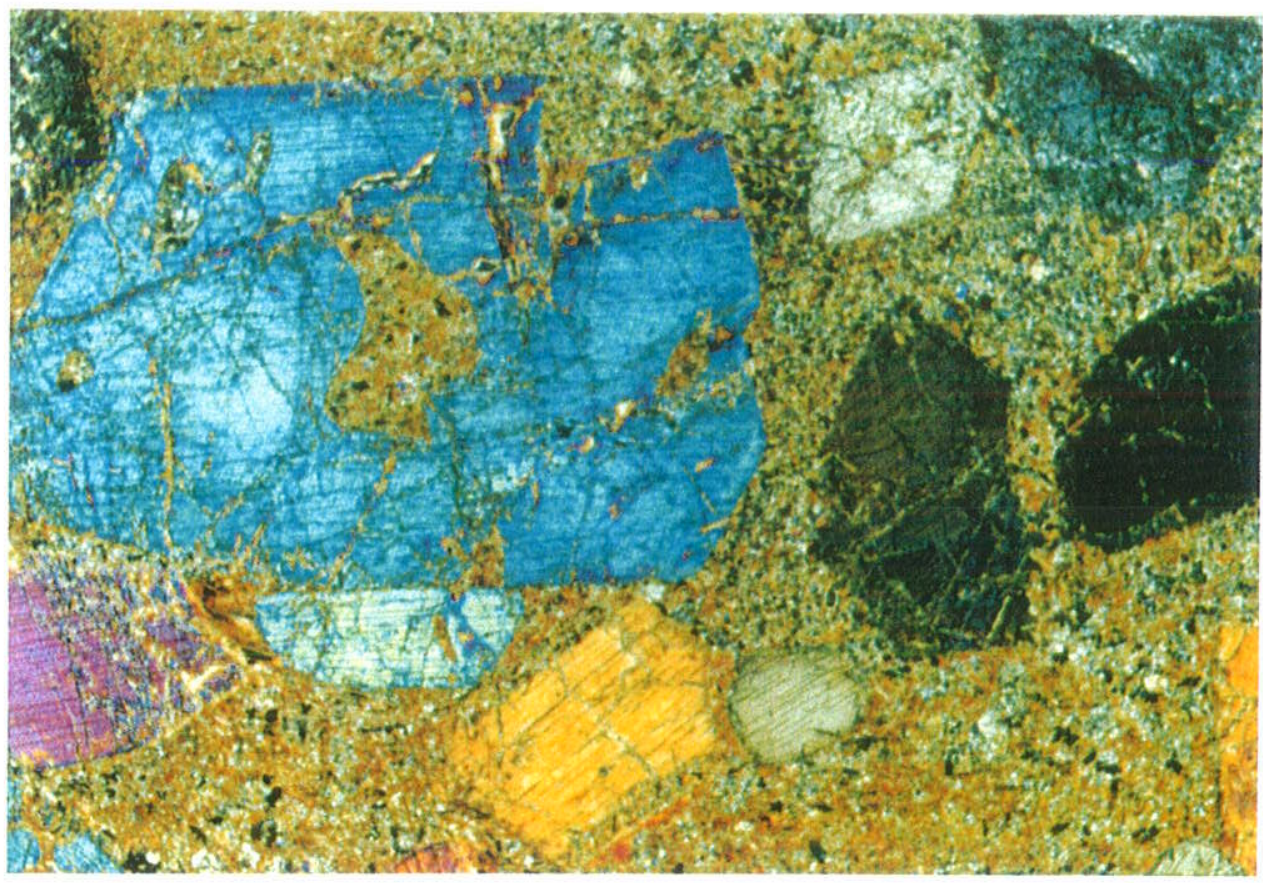

Fotomicrografia 46 - Rocha máfica-ultramáfica (deformada). "Fenocristais" de clinopiroxênio, idiomórficos, cantos arredondados e embainhados, com matriz de preenchimento. Matriz granular, aspecto granoblástico, muito fino, com biotita, clinopiroxênio, opacos e plagioclásio. Dimensão maior, 5,50 mm, filtros azul e fosco, polarizadores semicruzados.

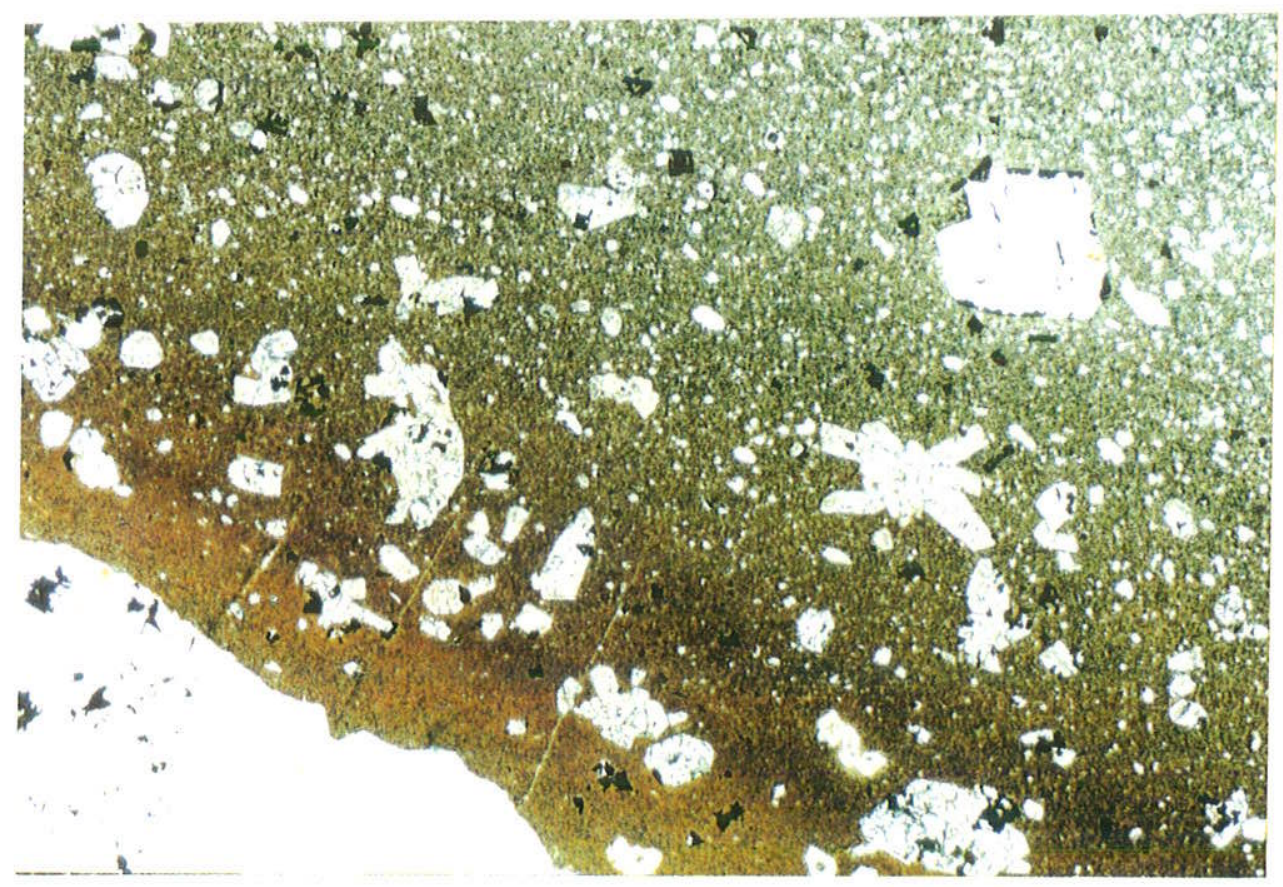

Fotomicrografia 47 - Dique lamprofírico, contato com charnoquito (canto inferior). Vidro marrom alaranjado, com glóbulos de carbonato. Fenocristais de olivina, clinopiroxênio e opacos. Até 1,5 mm do contato, o vidro é homogêneo. As esferas de carbonato aumentam de tamanho. Canto direito superior, rocha já quase holocristalina. Dimensão maior, $5,50 \mathrm{~mm}$, filtros azul e fosco, polarizadores descruzados. 
precariamente a biotita e o anfibólio.

Nos primeiros milímetros e, ocasionalmente, em uma secção delgada, a estruturação em bandas de fluxo está sempre presente. Junto a ela, nota-se orientação do plagioclásio e de parte do piroxênio. Também chama a atenção o fato desses microfenocristais, menores, tenderem a grupar-se no contato.

Esses vidros foram observados somente nos diques máficos, por falta de amostras adequadas dos diques félsicos, bem como, em muitos casos, pela ausência de feiçōes marcantes de resfriamento.

$E$ interessante registrar as variações vistas nas amostras BZ-326/A1 a BZ-326/A7, do dique do Saco do Coruja, semelhantes àquelas reconhecidas em diques menores. De uma ou de outra forma, essas variaçōes são há muito conhecidas e referidas na literatura petrológica clássica (cf. McBirney, 1984, etc.).

A amostra do centro do dique é mesocrática, porfiritica e com granulação média. Ao microscópio, contém 15 a $25 \%$ de megacristais e poucos ocelos $(<10 \%)$, de forma variada. Os megacristais são centimétricos a subcentimétricos e de difícil qualificação: como aparecem em aglomerados de olivina, clinopiroxênio e plagioclásio (Fotomicrografia 36) com inclusões, poderiam ser xenocristais ou até microxenólitos. Algum plagioclásio, isolado, centimétrico/subcentimétrico, mostra borda limpa e contínua, e pelo menos $90 \%$ de sua área interna é cheia de inclusões dos outros minerais. Fenocristais menores de clinopiroxênio zonado e de biotita marrom-avermelhada, esquelética, alongada, são comuns (Fotomicrografias 38 e 42). Pelo menos $60 \%$ a $70 \%$ da rocha é representada por fração mais fina, matricial com traves e ripas de plagioclásio semelhante aos fenocristais, biotita também vermelha, opacos em grãos de tamanho variado e apatita prismática a acicular. Além dessas assembléias, aparecem poucos ocelos (5-10\%), ovalados ou de formato irregular, com material isótropo sujo, pardo a avermelhado (vidro) e incolor, limpo (analcita), e feldspato potássico. Nota-se ainda a presença de biotita vermelha alongada e de titanita, ausentes opacos e clinopiroxênio. Material isótropo, principalmente incolor, ocorre intersticialmente. A kaersutita é ausente.

A amostra seguinte, $1,5 \mathrm{~m}$ distante da primeira no sentido do contato, exibe pouca variação. No geral, o tamanho diminui, bem como a quantidade de megacristais. Embora menores $(<5 \mathrm{~mm})$, os ocelos aumentam em quantidade.

A amostra seguinte, a $50 \mathrm{~cm}$ do contato, mostra sensivel redução na granulometria, aumentando a participação de material isótropo e dos ocelos, ainda menores. Começam a aparecer opacos esqueléticos, mas näo na forma de grades aciculares, e kaersutita. Entre os $40 \mathrm{~cm}$ de distância do contato e o contato, foram retiradas quatro amostras, e as modificaçōes continuaram a aparecer. A mineralogia manteve-se qualitativamente uniforme, exceçāo feita à kaersutita, que aumenta e iguala-se à biotita vermelha. Eleva-se também a fração isótropa intersticial e não mais ocorrem megacristais. Prosseguindo, cresce a quantidade de ocelos, agora representando mais do que $20 \%$ da rocha. A kaersutita é mais abundante e a biotita 
vermelha somente está presente nos ocelos. Os opacos aparecem ainda como grânulos pequenos e aumenta a quantidade de grades ortogonais. A modificação notável seguinte é o quase desaparecimento da kaersutita e o alongamento das ripas de plagioclásio e dos prismas de clinopiroxênio, com relação entre dimensões de 10:1 ou mais. A última amostra, junto ao contato, mas sem tê-lo apanhado, apresenta matriz muito fina e com estrutura de fluxo. Mineralogicamente, contém clinopiroxênio e kaersutita, em pequena quantidade, ambos aciculares, carbonato e material microgranular indistinto, além de opacos granulares e em grades ortogonais muito finas. Algum plagioclásio tem dimensões maiores e forma retangular.

É possivel que diques de dimensões diversas sejam classificados como tipos de rochas diferentes, quando, na verdade, as rochas examinadas refletem principalmente variações na taxa de resfriamento e na nucleação e crescimento dos cristais. Se realmente representarem liquidos magmáticos diferentes, a composição química deverá refletir o fato.

\subsubsection{Intercrescimentos granofíricos e micrográficos}

Entre as rochas quartzo sieníticas e quartzo microssieniticas, com teores mais altos de quartzo, e entre porçôes de charnoquitos, das proximidades ou das zonas de contato, é comum que esse mineral assuma características peculiares. Algumas vezes, essas feições são observadas em contatos apanhados em secção delgada, entre microssienitos e sienitos, e microssienitos e charnoquitos, principalmente. Tratamse dos intercrescimentos granofíricos, micrográficos e as feições rotuladas de "finger print" (cf. Smith e Brown, 1988), às vezes atípicos.

Esses intercrescimentos podem aparecer em pequena quantidade, em um ou dois cristais de feldspato alcalino, mais homogêneo ou mais micromesopertítico, ou então, estar presentes em praticamente todos os grãos de feldspato alcalino da secção delgada.

Em alguns casos, pode ocorrer simultaneamente quartzo finamente intersticial, preenchendo espaços intergranulares de contornos geométricos e irregulares, em continuidade cristalina em grande distância. Noutros, em que o contato foi apanhado, tem-se quartzo cuneiforme formando alinhamento continuo e paralelo ao contato, no lado da rocha supostamente aquecida (sienito), e ausente além dessa linha. A mesma secção pode mostrar, ainda, quartzo de forma arredondada, tamanho e distribuição regulares.

$\mathrm{Na}$ maior parte das secções examinadas, onde esses intercrescimentos de quartzo cuneiforme, ou intersticial anguloso, foram reconhecidos, e que representam a maioria das amostras dos quartzo (micro) sienitos e charnoquitos, a secção delgada foi feita para apanhar o contato ou é das suas proximidades (Fotomicrografias 49 e 50).

Pelo menos em dois contatos envolvendo charnoquito cisalhado, mas não em milonito, os planos e faixas de cisalhamento parecem não ter atingido alguns grãos de 


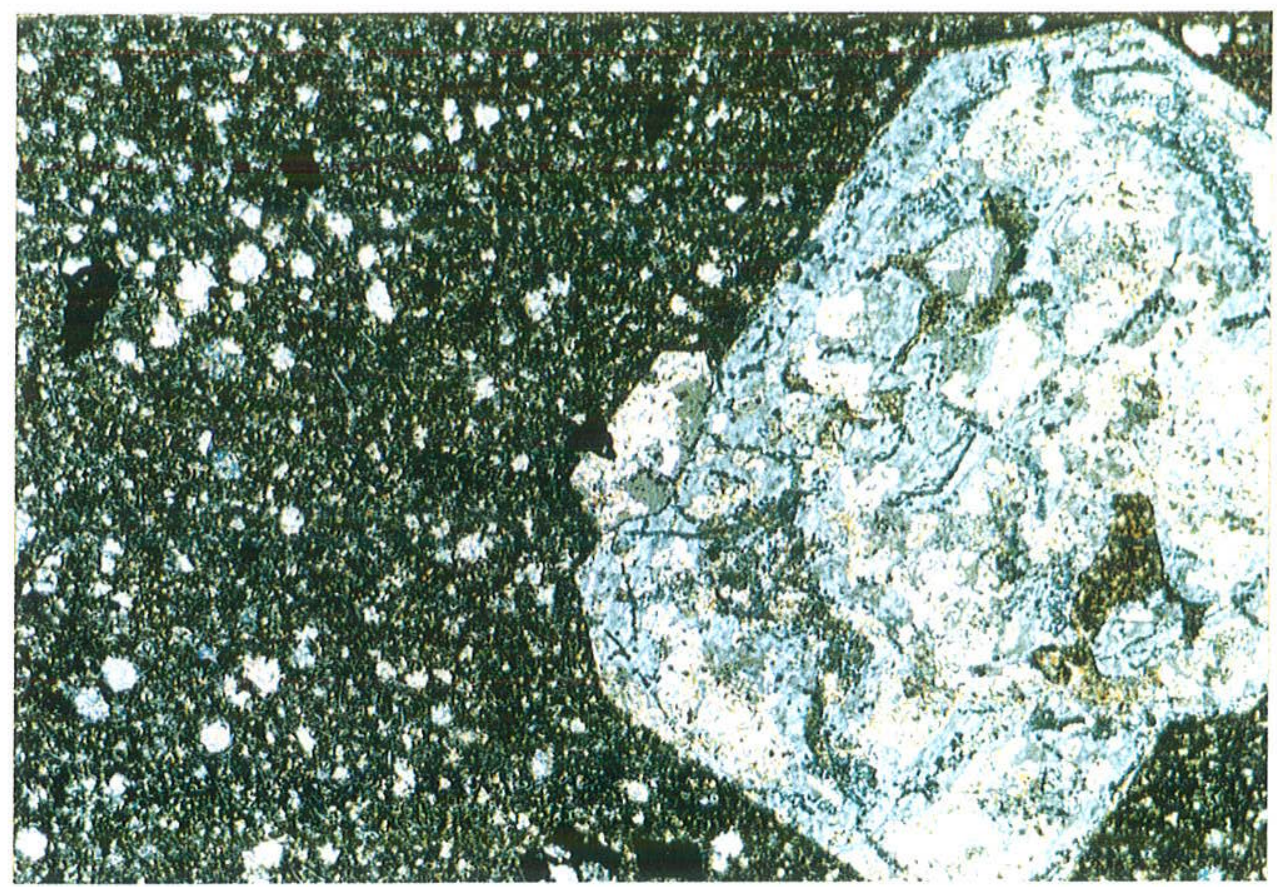

Fotomicrografia 48 - Fenocristal de olivina junto ao contato anterior. Região bastante cristalizada e grande quantidade de carbonato em glóbulos e opacos. Minerais ainda criptocristalinos, não reconheciveis. A olivina está alterada em serpentina + carbonato e algum opaco. Dimensão maior, 1,39 mm, filtros azul e fosco, polarizadores semicruzados.

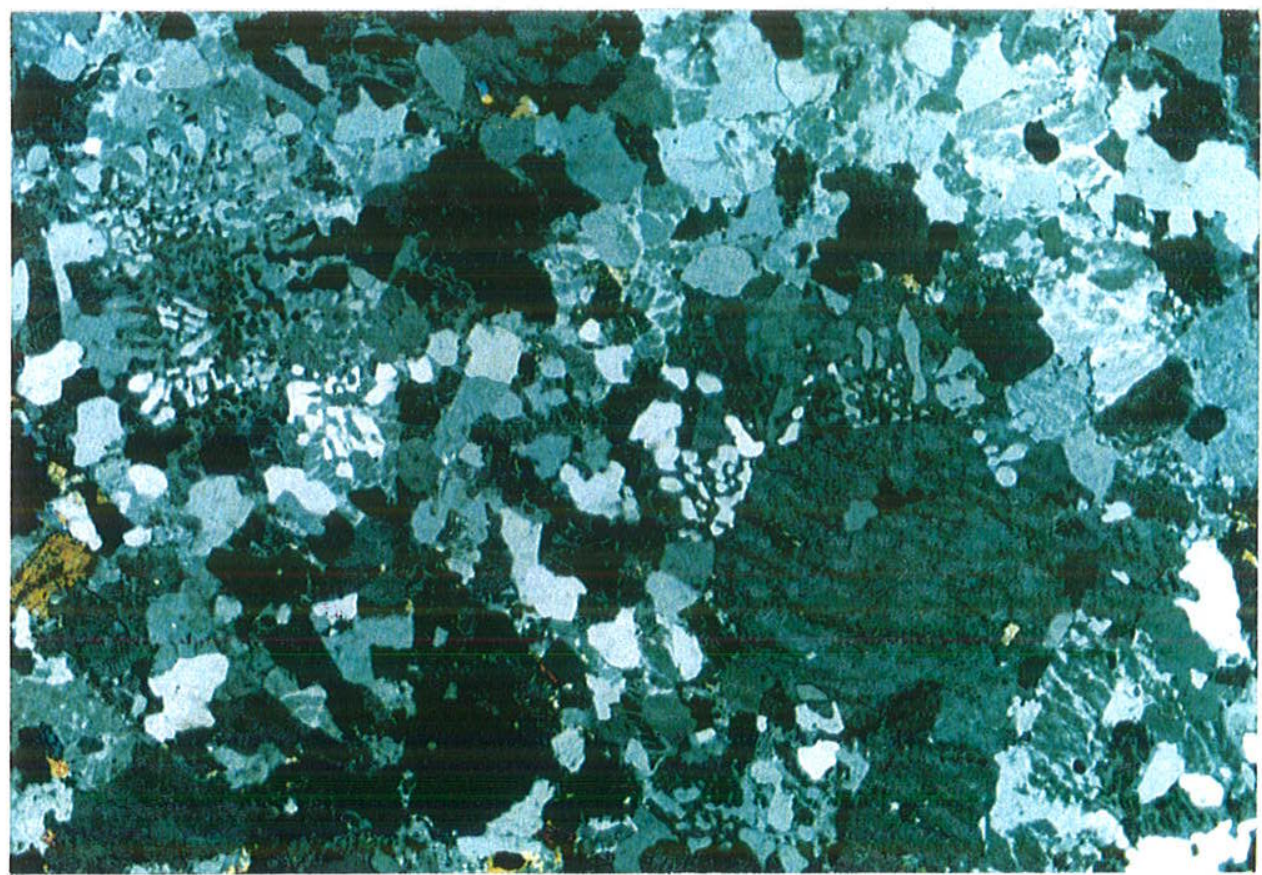

Fotomicrografia 49 - Quartzo microssienito, com intercrescimento granofírico. Notar no centro, à direita, um feldspato homogêneo, aparentemente não pertítico, orlado por quartzo granofírico. Dimensão maior, $5,50 \mathrm{~mm}$, filtros azul e fosco, polarizadores semicruzados. 
feldspato com o quartzo cuneiforme. Ao contrário, este desenvolve-se sobre gräos do feldspato alcalino afetados pelo cisahamento. $\mathrm{Na}$ mesma amostra, outros individuos aparecem segmentados (Fotomicrografia 50).

É importante observar que rochas granofiricas e/ou micrográficas não foram observadas desvinculadas ou distantes dos contatos.

\subsubsection{Ocelos}

Essas estruturas estão presentes em quase todos os diques máficos. Têm dimensões desde centimétricas/subcentimétricas a submilimétricas, e formas predominantemente esferoidais. Existem aquelas, contudo, com formas irregulares, mas quase sempre arredondadas. Aparecem em faixas nos diques, em posição intermediária com relação às bordas e o centro, e suas dimensões diminuem no sentido dos contatos, embora sua presença possa aumentar. No campo, ou nas amostras de mão, podem ser notadas pelas cores brancas ou mais claras (Foto 43), ou ainda por formarem cavidade de dissolução intempérica ou ressaltos arredondados, pelo mesmo motivo.

Em secção delgada exibem contornos perfeitamente definidos, às vezes orlados por biotita e/ou anfibólio suborientado, ou mais difusos com a matriz. Às vezes, acham-se delimitados pela ausência de fases minerais presentes no resto da rocha, como, por exemplo, clinopiroxênio e opacos. Outras vezes, têm mineralogia própria, além de distinta do restante da rocha. As rochas podem conter um ou mais tipos de ocelos (Foto 43). De qualquer forma, os ocelos observados obedecem a apenas alguns poucos padrōes de forma e de assembléias minerais internas e de borda.

Em um tipo, predominam as formas esferoidais, sendo interessante notar que, embora varie em quantidade transversalmente ao dique, seu tamanho é quase constante (Fotomicrografia 51). Pode aparecer sob forma totalmente irregular (Fotomicrografia 52), o que é raro. É normalmente límpido e incolor, contendo material isótropo, com ou sem carbonato minoritário, que pode ocupar qualquer posição (Fotomicrografia 53). É freqüente que esse tipo mantenha uma estreita envoltória interna de serpentina ou zeólita. O material isótropo desses tipo de ocelos aparece intersticialmente no restante da rocha. Acredita-se que deva ser analcita.

Esse tipo pode passar na mesma rocha a esferas de carbonato (Fotomicrografia 48), às quais poder-se-ia denominar simplesmente de esferas ou glóbulos carbonáticos. É comum a coexistência de ambos os materiais.

Talvez o tipo mais abundante nas rochas com granulação um pouco mais grossa (médias) seja aquele com vidro sujo, pardo-avermelhado nas porçöes mais centrais, segmentado e orlado por porções incolores, limpidas (Fotomicrografia 54). Esse tipo mostra 


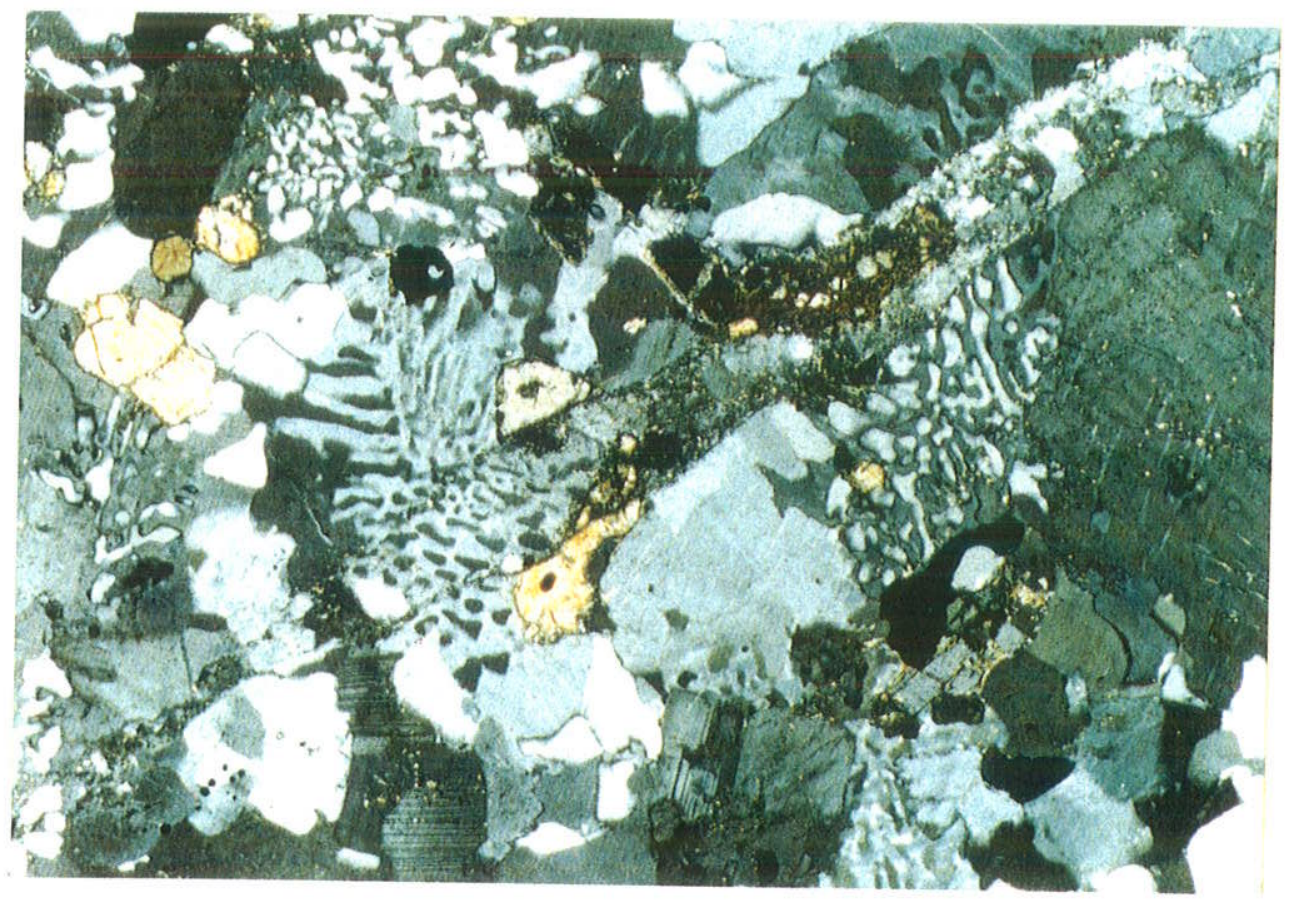

Fotomicrografia 50 - Charnoquito, junto a contato com dique máfico do tipo diabásico hornfélsico. Faixa de cisalhamento em diagonal NE-SW corta uma porção granofírica, e não afeta a seguinte. Presentes opacos e ortopiroxênio. Dimensão maior, $2,80 \mathrm{~mm}$, filtros azul e fosco, polarizadores semicruzados.

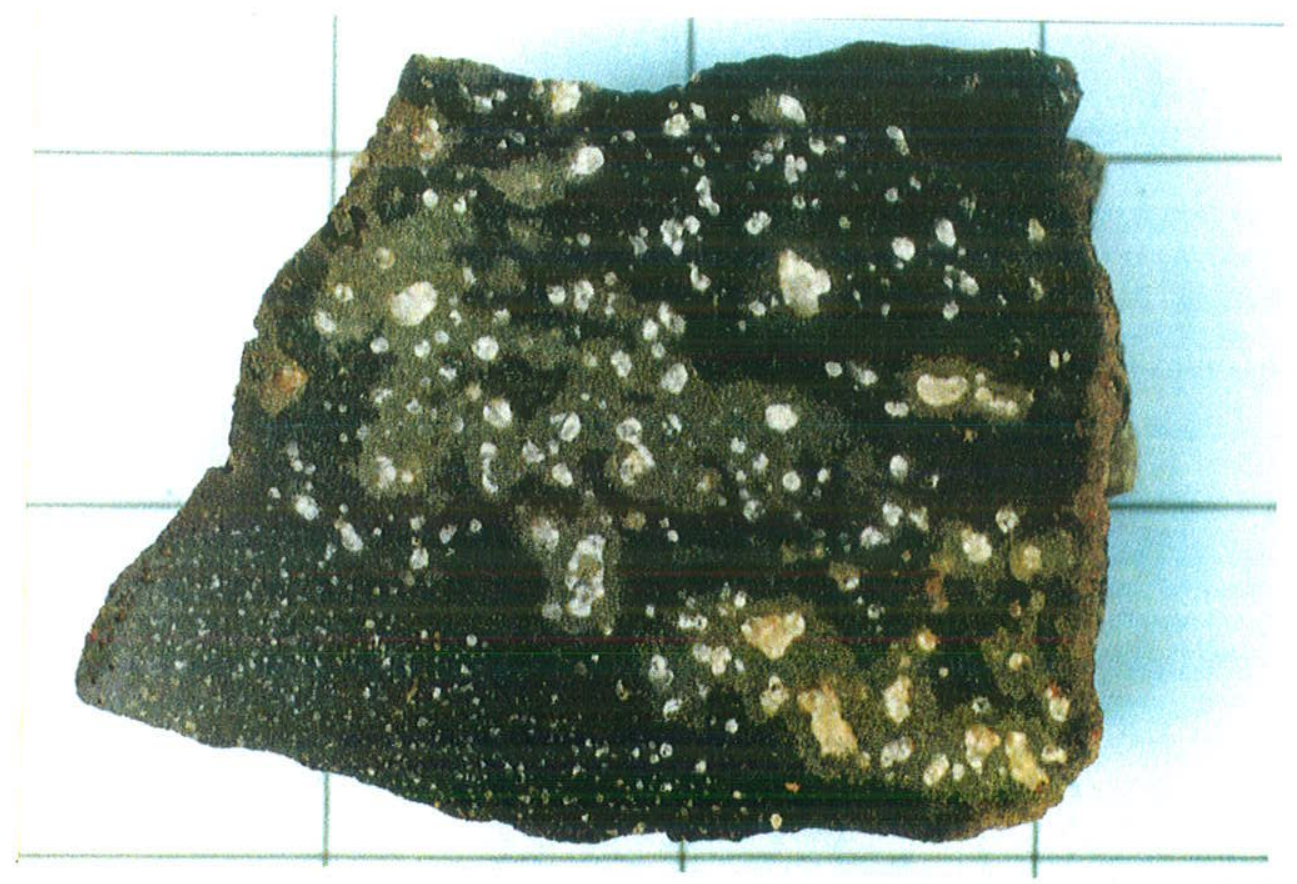

Foto 43 - Lamprófiro. Observam-se dois tipos de ocelos. Junto aos de forma irregular, maiores, a rocha adquire cor mais clara, por diminuição ou ausência dos fêmicos. Reticulado: $5 \times 5 \mathrm{~cm}$.. 


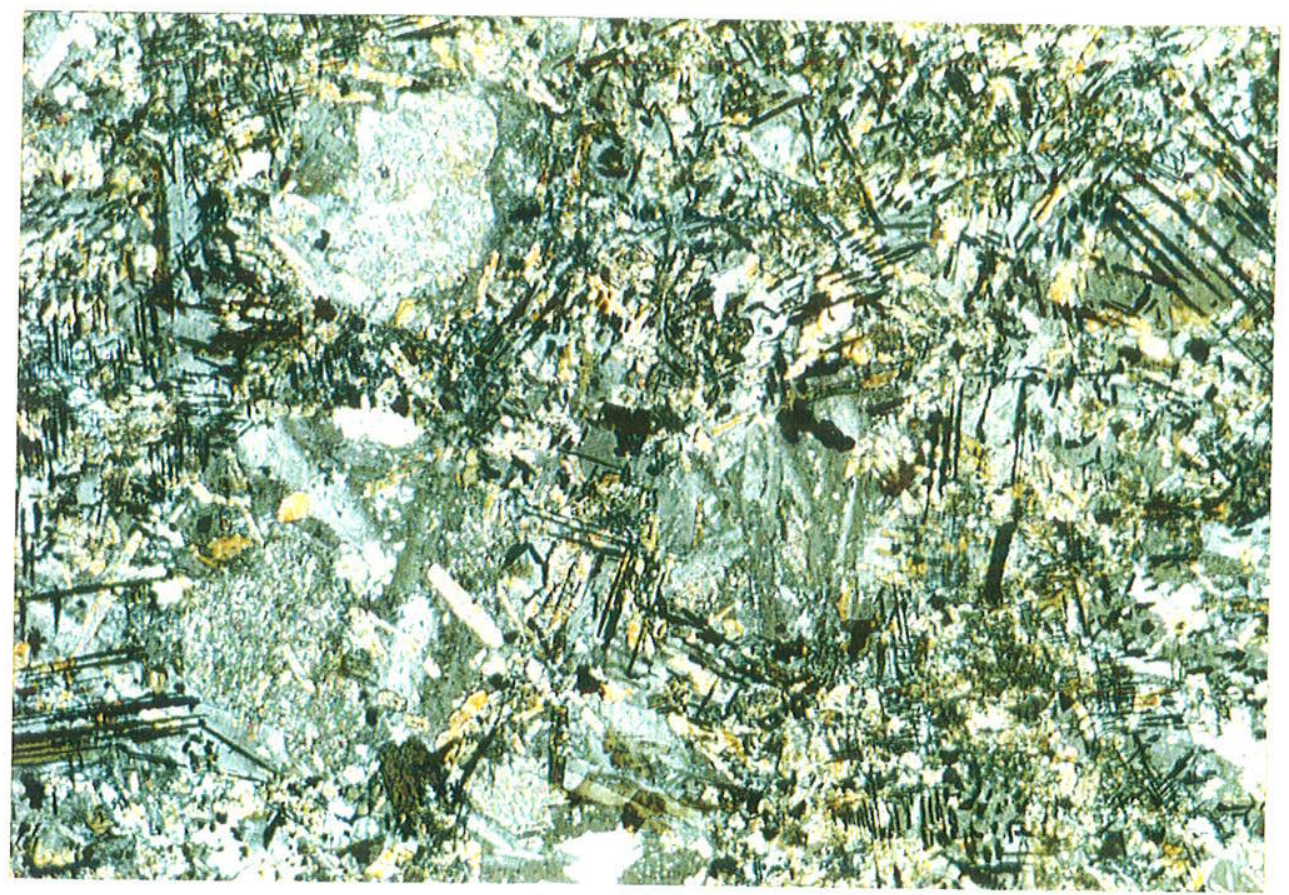

Fotomicrografia 51 - Lamprófiro (camptonito/sannaíto) com ocelos esféricos (4), portadores de feldspato potássico, analcita, carbonato, biotita e kaersutita. Plagioclásio (?) presente fora dos ocelos. Notar redes de opacos e sua ausência nos ocelos. Dimensão maior, $1,39 \mathrm{~mm}$, filtros azul e fosco, polarizadores semicruzados.

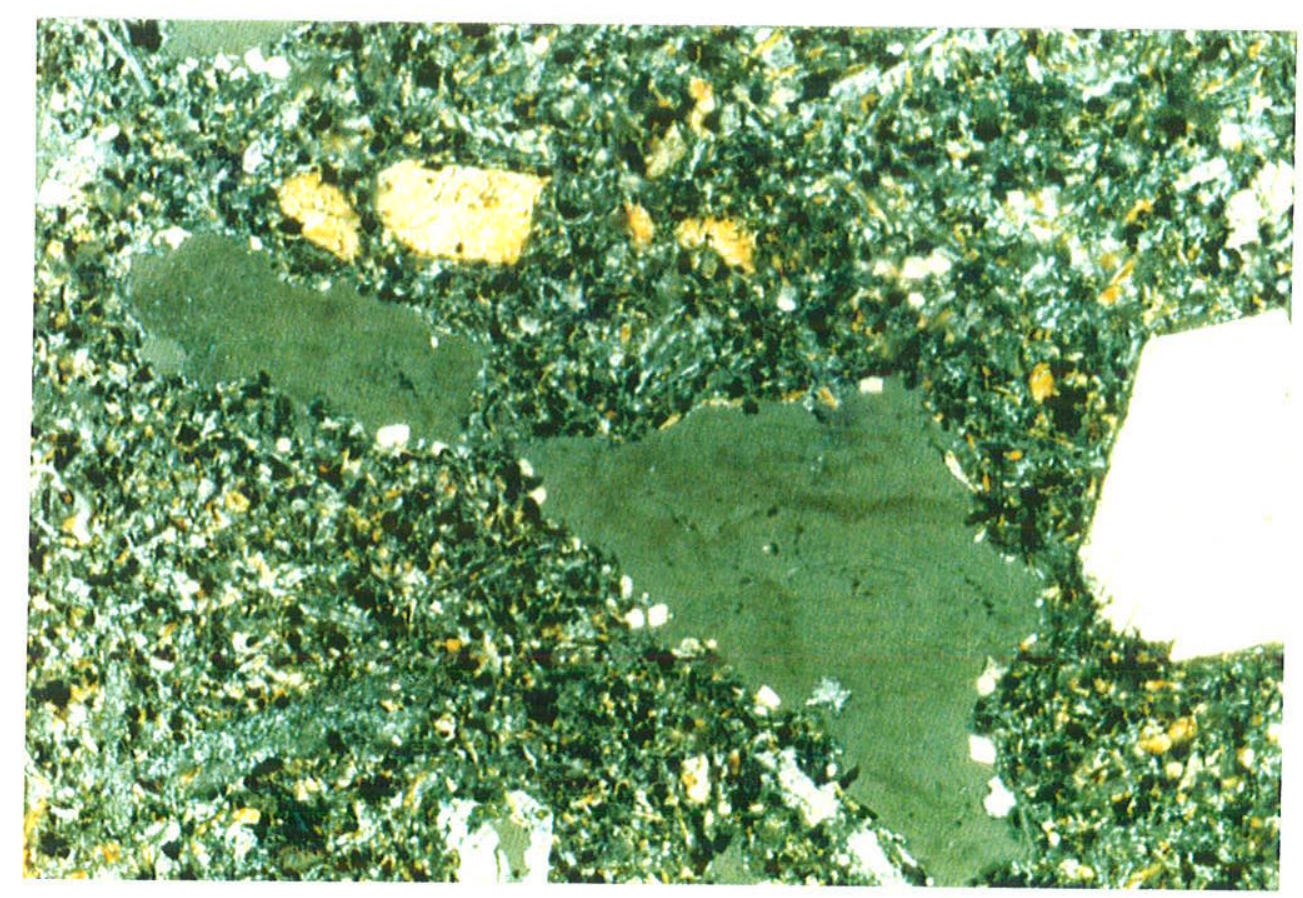

Fotomicrografia 52 - Ocelos de formas irregulares, em lamprófiro. Ocelo com analcita e zeólita, esta apenas orlando. Matriz: opacos, clinopiroxênio, biotita, kaersutita, feldspato, analcita, vidro (?). Dimensão maior, 2,80 $\mathrm{mm}$, filtros azul e fosco, polarizadores semicruzados. 


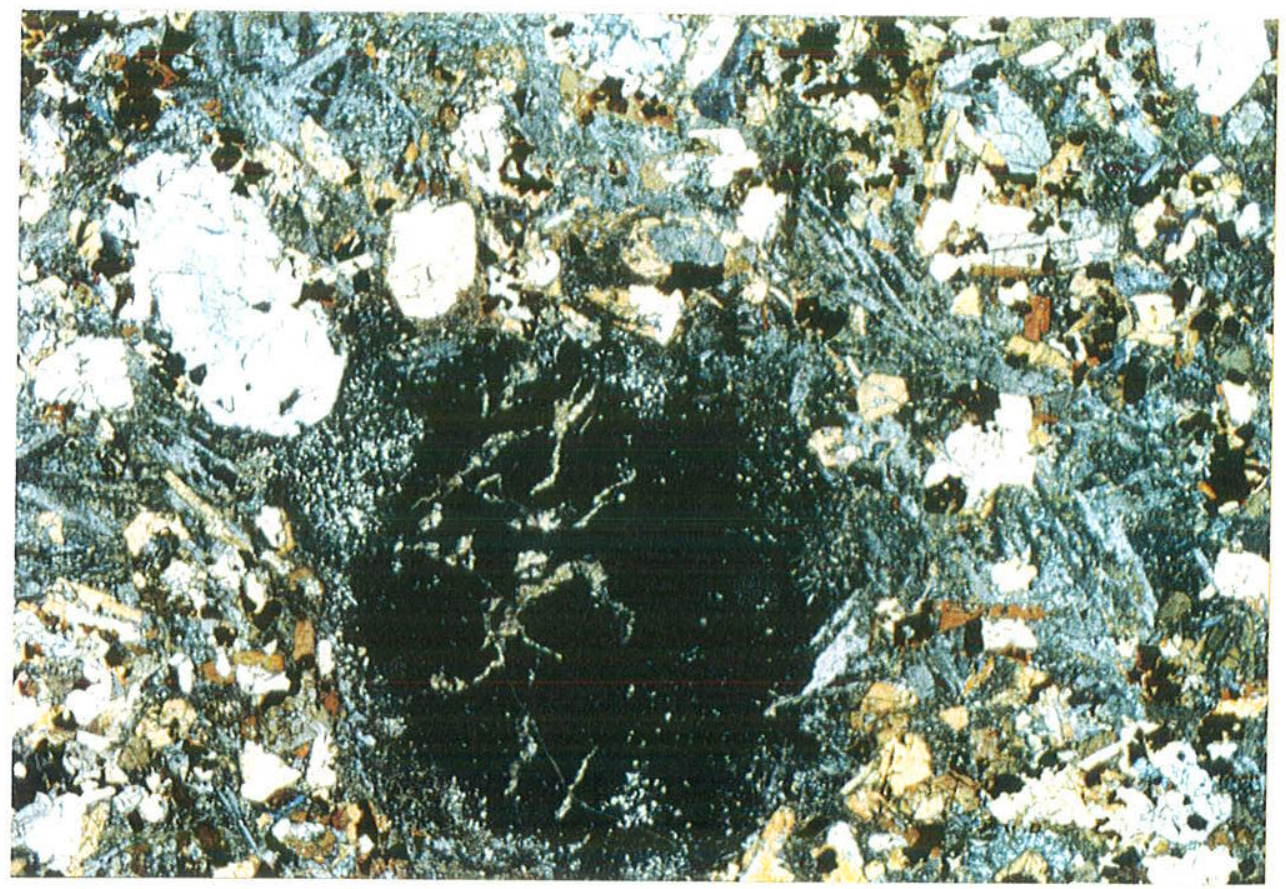

Fotomicrografia 53 - Ocelo esférico de analcita com carbonato e serpentina. Rocha: camptonito, com clinopiroxênio, biotita, kaersutita, opacos, plagioclásio, vidro (?) e analcita. Dimensão maior, 5,50 mm, filtros azul e fosco, polarizadores cruzados.

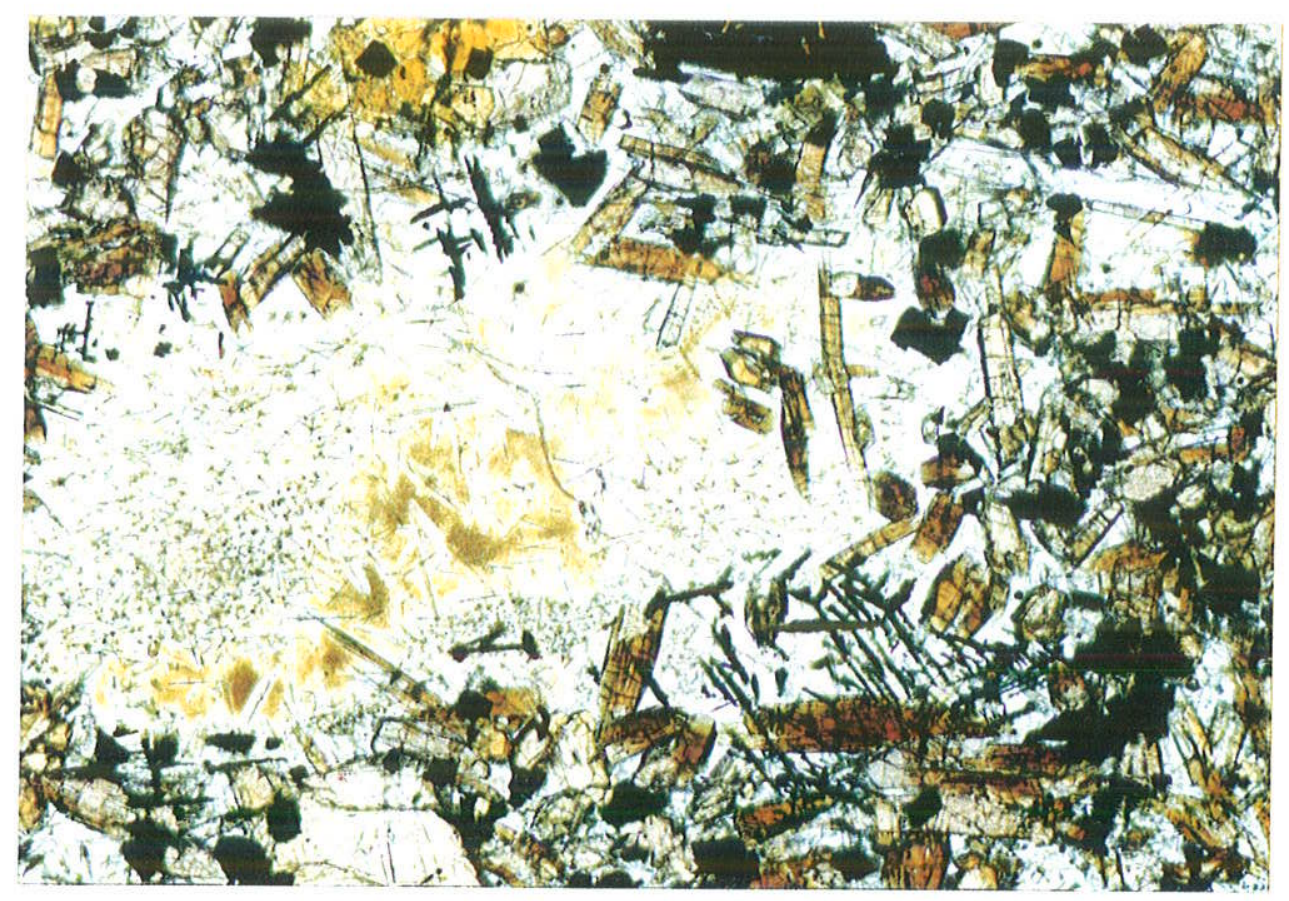

Fotomicrografia 54 - Ocelo de analcita e vidro. Vidro marrom, analcita incolor e fibras (biotita), além de feldspato potássico e kaersutita, mais desenvolvidos. Notar relações clinopiroxênio pardo rosa com a kaersutita. Observar opacos em grãos e grades. Dimensão maior, $1,39 \mathrm{~mm}$, filtros azul e fosco, polarizadores descruzados.. 
fibras escuras, de disposição caótica, de biotita, além de placas alongadas retangulares de feldspato potássico, em geral dispostas ao acaso, das bordas para o centro. Nele ainda é freqüente a presença de alguns prismas longos de kaersutita ou palhetas de biotita. Também é comum orla externa, mal definida de biotita e/ou anfibólio, e contendo alguns gräos de titanita.

Um outro tipo, em geral mais raro, é uma variante do primeiro, assim que, junto àquela mineralogia já referida, pode predominar o feldspato potássico (Fotomicrografia 51),

Existem ainda ocelos de formas irregulares, compostos unicamente por feldspato potássico, precariamente identificado. Apresenta feixes sinuosos e divergentes de lamelas feldspáticas, de bordas irregulares.

Além da duvidosa presença do plagioclásio, quase sempre inexistente, o que mais caracteriza e torna discernivel os ocelos é a ausência de opacos, clinopiroxênio e olivina.

$E$ interessante registrar que nas rochas que exibem grades ortogonais de finas traves de opacos, estas nunca penetram nos ocelos, embora se superponham total ou parcialmente a todos os outros minerais, excluindo-se a olivina (Fotomicrografias 51 e 54).

\subsubsection{Xenocristais (glomerocristais) e xenólitos}

Sem dúvida, são feições importantes e merecem destaque. Pecam, no entanto, pelas interpretações, quase sempre duvidosas.

\subsubsection{Xenocristais}

Alguns minerais, estranhos mesmo às rochas onde ocorrem, parecem constituir-se em xenocristais, às vezes com conotações importantes.

É o caso de cristais de plagioclásio, de feldspato alcalino e de ortopiroxênio em alguns quartzo sienitos e quartzo microssienitos. Nota-se certo relacionamento de características, atípicas dos sienitos, mas que nunca aparecem isoladamente.

Primeiro, essas características são comuns aos álcali feldspato-quartzo sienitos e álcali feldspato-quartzo microssienitos. Segundo, as amostras de interesse são encontradas sempre nas zonas e proximidades dos contatos com charnoquitos. Além disso, essas características, que incluem os possiveis xenocristais, estão presentes nas rochas tidas como híbridas.

Os xenocristais de plagioclásio mostram evidências de alguma reabsorção, além de fragmentação e deformação típica dos charnoquitos (Fotomicrografia 55). Em geral, são envolvidos por granulação mais fina e, não raro, têm perímetro interno mais sódico, aliado ao manchamento irregular, também mais sódico. Tal como nos charnoquitos, exibem fraturamento subparalelo com preenchimento mineral amarelado/alaranjado. Alguns restos de feldspato alcalino chamam a atenção por apresentarem padräo de exsolução semelhante àquele dos charnoquitos ou então pela sua homogeneidade. Também mostram fraturamento, inexistente 


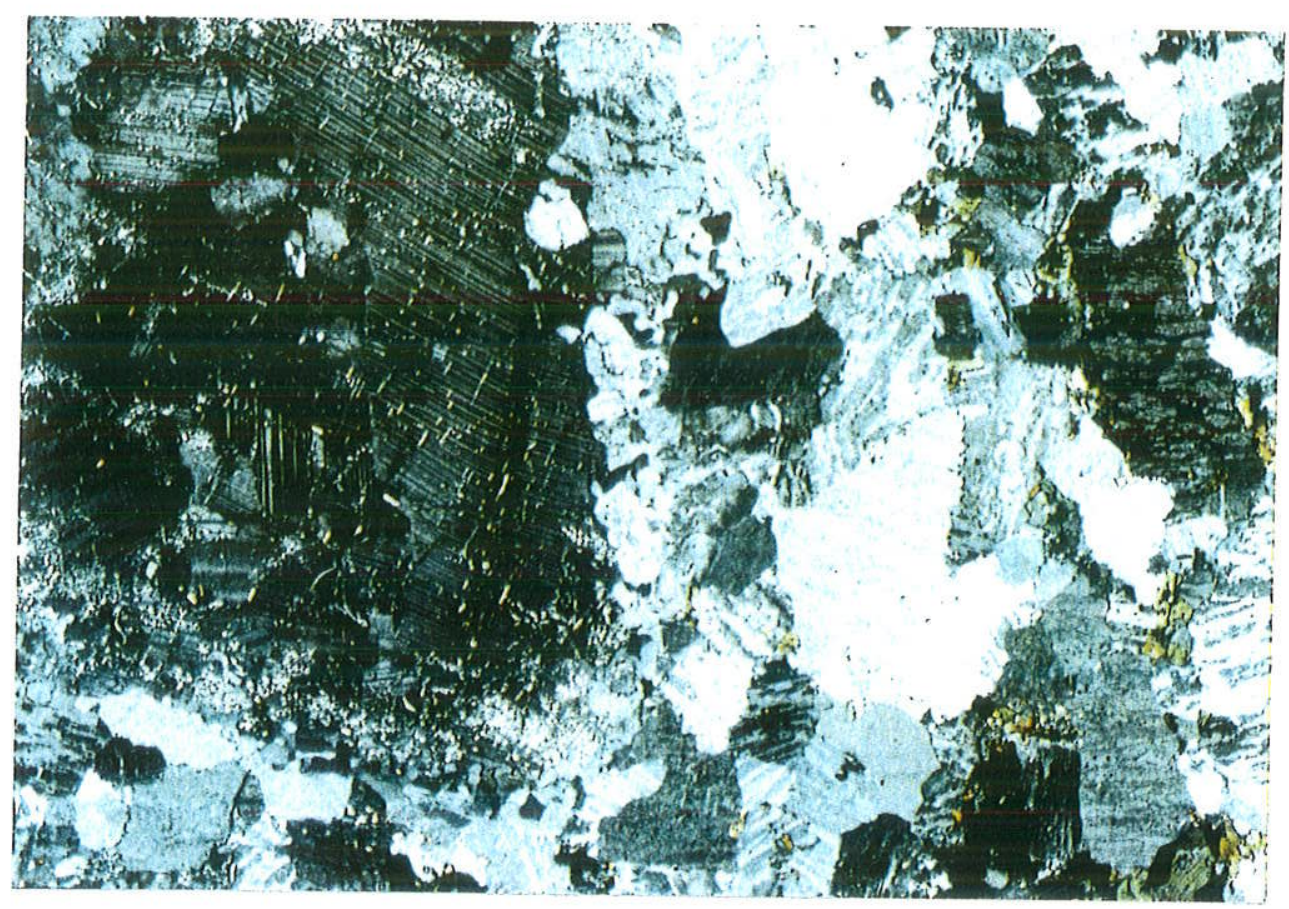

Fotomicrografia 55 - Microssienito mesopertítico, com restos de plagioclásio de charnoquito, típico, deformado (previamente). Notar contato e orla externa, mais fina, do plagioclásio. Dimensão maior, 5,50 $\mathrm{mm}$, filtros azul e fosco, polarizadores semicruzados.

nos sienitos típicos. Por último, restos inequívocos e raros de ortopiroxênio, bastante alterado, aparecem nesses sienitos mais quartzosos, com freqüência associados aos outros dois minerais citados.

Nos diques máficos, são poucas as amostras portadoras de megacristais, aparentes às vezes, e que na verdade correspondem a pequenos agregados parcialmente arredondados e embainhados, com olivina, clinopiroxênio e plagioclásio (Fotomicrografia 36). Não parece haver grande diferença composicional entre os minerais desses microxenólitos e os da rocha encaixante. Dentro do pequeno número de observações, aqueles de maiores dimensões chegam a $10 \mathrm{~mm}$ ou pouco mais. Chama a atenção o padrão de inclusões, que mantém algumas diferenças em relação à rocha hospedeira.

O plagioclásio, tanto dos microxenólitos, como quando isolado e maior, mostra faixa interna irregular crivada de inclusões, em grande parte não identificáveis, que desenham núcleo de formas curvas, também com inclusões, às vezes totalmente substituído. A partir desse núcleo, desenvolve-se zona externa muito limpa, que mantém continuidade cristalina, vista através das lamelas de geminação. Não se percebem diferenças ópticas sistemáticas entre o núcleo e a borda.

Em algumas amostras, ocorrem também xenocristais de anfibólio amarelado/esverdeado, opticamente diferente daquele integrando a rocha (Fotomicrografia 37).

Xenocristais centimétricos, com auréola de reação circular, de feldspato alcalino pertítico, são observados no dique riolítico do ponto 326 (BZ 326B). Esses xenocristais, além da 
auréola de reação, apresentam formas arredondadas a elipticas (Foto 40).

\subsubsection{Xenólitos do tipo I}

Os xenólitos mais importantes, pela sua presença, foram denominadas informalmente de tipo 1. As suas principais zonas de ocorrência acham-se indicadas na Figura 3, junto aos contatos.

Como referido previamente, eles ocorrem imersos nos álcali feldspato-quartzo microssienitos e álcali feldspato microgranitos, e constituem-se de blocos de charnoquito e blocos menores de (meta) máfica (Fotos 13, 14, 25 e 26). Infelizmente, afora amostras do charnoquito, cortado por (meta) máfica, não se conseguiram boas amostras dessa rocha para microscopia.

Nas amostras do charnoquito-(meta) máfica, é possivel distinguir-se algumas características. A primeira delas é que, invariavelmente, o charnoquito mostra-se cisalhado em grau variável, além de recristalizado. Em algumas das amostras, onde ocorrem também veios sieníticos, nota-se novo cisalhamento, que afeta tanto o charnoquito recristalizado, quanto o sienito. Também se observa, no charnoquito, o desenvolvimento de intercrescimento granofírico, aparentemente não tão atingido pelo segundo cisalhamento. Fraturamento, que afeta tanto o charnoquito quanto a (meta) máfica, é acompanhado pelo desenvolvimento de anfibólio. O ortopiroxênio dos charnoquitos é conservado, sem maior alteração.

Talvez número maior de amostras e de seç̧óes delgadas pudesse revelar detalhes sobre os eventuais efeitos da imersão dos blocos xenolíticos no material sienítico.

Número suficiente de amostras dos xenólitos de (meta) máficas foi conseguido. Tanto as amostras de blocos xenolíticos totalmente imersos nos sienitos, quanto aquelas com contatos com charnoquitos, ambos imersos nos sienitos, são semelhantes.

Os xenólitos máficos são, em tudo, semelhantes aos diques diabásicos hornfélsicos, aos quais, às vezes, estão diretamente associados (Fotomicrografias 34 e 35). São rochas cinzentas escuras e pretas, de granulação fina a média, homófanas, às vezes maciças e homogêneas, às vezes venuladas. Possuem dimensöes variadas, a grande maioria decimétrica, e formas externas angulosas, por vezes, fragmentária.

Podem ser, genericamente, classificados como metadiabásicos e meta microdioríticos, hornfélsicos. Mostram textura variável entre blastossubofitica a blastointergranular, a praticamente granoblástica, até quase, localmente, com os minerais na forma de polígonos.

O aspecto textural é dado principalmente pelo plagioclásio ripiforme, mais ou menos alongado, chegando até tabular nas rochas mais dioríticas. Em algumas amostras, a textura ignea é perfeitamente preservada, modificada pelo arredondamento dos fêmicos em geral e pela ondulação e quase embainhamento dos contornos externos do plagioclásio. Em geral, a forma geométrica retangular regular do plagioclásio é vista na sua parte central, demarcada pelo turvamento cinzento, a partir do qual desenvolve-se porção externa limpa, que expande o 
núcleo, de forma mais irregular. Nesse mosaico, representando 50 a $60 \%$ da rocha, eventual e localmente, observam-se estruturas circulares do mesmo plagioclásio, em arranjo mais granoblástico, estando os máficos ausentes. Estruturas semelhantes, porém, com ortopiroxênio poiquiloblástico ocupando boa parte dela, ou com o mesmo mineral formando auréola, são também reconhecidas. São poucos os fenocristais, estes, exclusivamente de plagioclásio, de forma retangular ou tabular.

Com certa freqüência, as ripas do plagioclásio exibem orientação paralela, mais ou menos pronunciada, não sendo acompanhada, nessa característica, pelos outros minerais.

O plagioclásio tem composição variada do centro para a borda, às vezes de forma acentuada, tendo sido verificadas composições entre $A n_{35}$ a $A n_{55}$, predominando aquelas mais sódicas que $A n_{50}$. As bordas limpas são, às vezes, de micromesopertita ou microantipertita em rochas portadoras de algum quartzo e caracterizadas por textura mais granoblástica e plagioclásio mais tabular. O quartzo aparece em duas ou três amostras, não ultrapassando alguns porcento. O plagioclásio, além de turvação cinzenta, mostra micropigmentação opaca e inclusão de outros minerais. A mais importante das inclusões corresponde a pequenos grãos prismáticos curtos ou esferoidais, minúsculos, aparecendo em grande quantidade. De dificil definição, as caraterísticas ópticas observáveis (relevo, cor, birrefringência, ângulo de extinção e elongação) levam à conclusão de que, na grande maioria das vezes, trata-se de ortopiroxênio, acompanhado ou não de clinopiroxênio, em quantidade menor. Na mesma secção delgada, essas inclusões estão presentes em alguns lugares, ausentando-se em outros. Ainda, elas não convivem com outras inclusões. A despeito dessas inclusões, o plagioclásio não adquire aspecto típico poiquilítico ou poiquiloblástico.

A assembléia fêmica inclui \pm biotita \pm anfibólio \pm clinopiroxênio \pm ortopiroxênio, que se fazem acompanhar sempre de opacos. A apatita tem presença e teor variável. Alterações tardias são raras e de pequena monta.

A biotita, sempre avermelhada-alaranjada $\left(Y, Z^{\prime}\right)$ a amarela clara/alaranjada é o mais conspicuo dos fêmicos. Varia em teor de amostra para amostra ou na mesma amostra. Apresenta formas equidimensionais, sendo pouco orientada.

O clinopiroxênio, quase sempre quase incolor ou incolor, pode ocorrer incluso no anfibólio ou capeado por este mineral, ao qual se segue a biotita. Nesse caso, está sempre cheio de inclusões opacas. Parece tratar-se de tipo augítico, não tendo sido verificado, em algumas tentativas, baixos valores de $2 \mathrm{~V}\left(\sim 25^{\circ}\right.$ ) (o que não exclui, de vez, a possibilidade da ocorrência de pigeonita). Também pode aparecer livre, com ou sem ortopiroxênio, tornando-se mais limpo e, com alguma freqüência, portador de microlamelação opaca perpendicular a (001).

O ortopiroxênio, pouco a não pleocróico (esverdeado/rosado), além das formas já referidas, pode se fazer presente como individuos maiores, mais regulares de contornos angulosos e retilineos, e nunca está alterado.

Nas rochas com as estruturas esféricas de agregado granoblástico de plagioclásio, o 
ortopiroxênio aparece preenchendo toda a estrutura, como individuo único, de forma irregular, poiquiloblástico. Nessas mesmas estruturas, ocorre orlando-as como um rosário de grãos.

O anfibólio está sempre presente acompanhado da biotita, podendo ou não incluir o clinopiroxênio. Forma placas sem angulosidade ou agregados de formas lamelares bizeladas, orlados por biotita. $\mathrm{Na}$ grande maioria das amostras, exibe cores esverdeadas a marronpardacento a avermelhado $\left(Z^{\prime}, Y\right)$, e amarelado claro, amarelo-esverdeado claro a pardacento claro $\left(X^{\prime}\right)$.

Os opacos são granulares, distinguindo-se os da trama da rocha (maiores) dos inclusos, prováveis produtos de alteração.

$O$ acessório mais comum, e quase único, é a apatita, que ocorre em quantidade moderada, na forma de prismas curtos ou equidimensionais.

De modo geral, os fêmicos desses xenólitos têm formas típicas das texturas xenoblásticas, granoblásticas, mostrando contornos irregulares e curvos.

\subsubsection{Xenólitos do tipo II}

O xenólito mostrado na Foto 11 pode ser desse tipo. Em todo caso, aqueles amostrados são de pequenas dimensões, centimétricas, e invariavelmente arredondados. Têm cor cinzenta escura, granulação média a fina e caráter homófano e maciço. A sua ocorrência é mais irregular, aparecendo imersos nos sienitos, às vezes do tipo grosso, e sem ligação espacial visivel com os demais xenólitos. Apesar disso, limitam-se também às zonas de contato, mesmo as mais distais.

Nas amostras investigadas, são semelhantes aos xenólitos do tipo 1, com algumas diferenças: sua textura é sempre de caráter mais granoblástico e não se encontrou neles o ortopiroxênio.

\subsubsection{Contatos e feições de cisalhamento}

Boa parte dos contatos se faz acompanhar por feições de cisalhamento, microscópicas.

Os contatos examinados ao microscópio foram aqueles apanhados em secção delgada, tarefa nem sempre fácil. Os mais evidentes, e presentes, são os dos diques máficos com as encaixantes, principalmente os charnoquitos.

Os diques diabásicos, hornfélsicos ou não, apresentam contato brusco com os charnoquitos. Com certa freqüência, esses diques segmentam-se ao longo da direção das lentes e porções charnoquíticas (ao microscópio, exibem notáveis efeitos nas proximidades, de interpretação duvidosa, porém.). Forma-se conjunto de fatias, de espessura centimétrica, alternando-se o charnoquito com a rocha de diques. Macroscopicamente, nota-se faixa milimétrica nas bordas das fatias do dique. Ao microscópio, são observadas variações 
composicionais correspondentes. No charnoquito, ocorre concentração, contínua, formando fileiras paralelas aos contatos de opacos e piroxênio. No sentido da interface, segue-se o aparecimento, dentro do feldspato, de piroxênio semelhante ao do dique, que, gradativamente, aumenta de quantidade. $E$, a partir de um certo ponto, não se vê mais o feldspato do charnoquito, mas a assembléia clinopiroxênio mais plagioclásio do dique (Fotomicrografia 56).

Alguns fragmentos de feldspato do charnoquito podem aparecer isolados dentro dessa assembléia de dique. Essa passagem tem a espessura de milimetros. Gradativamente, a rocha de dique volta à sua mineralogia normal, com o aparecimento da biotita avermelhada, às vezes antecedida por anfibólio verde. Do lado do charnoquito, é comum o surgimento de intercrescimentos granofíricos e assemelhados, em maior ou menor quantidade. Faixas estreitas de cisalhamento, intenso, são interrompidas por zonas de intercrescimentos granofíricos, mas nem sempre. Em alguns lugares, cortam $e$ interrompem esses intercrescimentos (Fotomicrografia 50).

Os contatos entre os diques lamprofíricos e encaixante charnoquitica exibem características completamente diferentes. Estudados com certo detalhe tanto em amostras do dique $B Z 326 \mathrm{~A}$, o mais possante da liha, quanto em amostras de contatos de diques mais estreitos ( $B Z 301 \mathrm{~A}, 303 \mathrm{C}, 312 \mathrm{~B}$ ), de até $0,5 \mathrm{~m}$, evidenciam acentuadas semelhanças. Ao contrário dos diques diabásicos, a encaixante não mostra efeito algum, salvo cisalhamento $e$ microbrechação. Na realidade, foram observadas duas variedades de contatos. Em uma primeira, tem-se contato imediato da encaixante com um vidro de cor vermetha, ou marrom ou cinzento, denso. Não há qualquer interação vidro-encaixante. A faixa vítrea não tem mais que 1 milimetro, quando começam a aparecer microcristais birrefringentes, que, gradativamente, aumentam de tamanho (Fotomicrografia 47). Até a distância de até 4 a $5 \mathrm{~mm}$, o vidro ocorre intersticialmente. A faixa proximal de vidro puro apresenta sempre vidro colorido, fenocristais e estrutura de fluxo. Os fenocristais, de clinopiroxênio e/ou de olivina e/ou de plagioclásio, exibem, por vezes, orientação paralela ao contato. Impregnando a massa vítrea, é comum a presença de opacos finos (vidros cinzentos) ou de carbonatos, em corpos esféricos. As massas carbonáticas tornam-se maiores e se dispersam pela rocha à medida em que aumenta a distância do contato. É também interessante notar que certo acúmulo de fenocristais também se faz presente. Esses possuem dimensöes desproporcionalmente avantajadas para as camadas vítreas. A olivina, quando presente, está sempre alterada em serpentina, com ou sem carbonato, e opacos, apresentando não raro embainhamento de vidro (Fotomicrografia 48).

Numa segunda variedade de contato, ocorre cisalhamento ou aparece uma zona de mistura de porções da encaixante com vidro e parte do dique, sempre com estrutura de fluxo, ou ainda, tem-se faixa milimétrica de microbrecha, com fragmentos minerais microscópicos da encaixante, em matriz vitrea. Essa faixa dá lugar bruscamente, por um lado, ao vidro do dique e, por outro, ao charnoquito.

Contatos das rochas sieníticas e microssieniticas entre si ou com rochas do 
embasamento são muitos variáveis. Em geral, contatos sienito-microssienito podem ser bruscos ou gradativos, sem evidências maiores de processos mecânicos enérgicos. Os contatos, ao microscópio, não são retilíneos, mas irregulares e com reentrâncias, sendo que na maioria das vezes a rocha mais fina (nos contatos bruscos) parece interromper a rocha grossa, às vezes penetrando-a parcialmente (Fotomicrografia 57) ou até isolando fragmentos poliminerálicos dessa última. Algum efeito, talvez termal, é notado, como indicado pelo aparecimento de linha regular de quartzo cuneiforme, paralela ao contato, do lado da rocha intrudida. Essa observação foi verificada em dois pontos, onde a rocha mais fina continha alto teor de quartzo e a mais grossa pouco quartzo.

O contato dos microssienitos de diques ou veios com os charnoquitos não mostra, aparentemente, efeito algum. Nota-se certo alinhamento dos feldspatos dos sienitos, no que eles são acompanhados pelo máfico presente, clinopiroxênio por exemplo. Algumas amostras desse tipo de contato exibem cisalhamento, tanto no sienito intrusivo, quanto na encaixante. Esse tipo de contato é sempre brusco.

Apenas uma amostra de contato entre riólitos e encaixante foi examinada. Ela apresenta estrutura de fluxo pronunciada, com presença de vidro e faixa de microbrechação (Foto 44).

Contatos com rochas nefelínicas, algumas pegmatóides ou muito grossas, demonstram alguma invasão das porções nefelínicas no sienito vizinho (Foto 45).

Como entre os sienitos/microssienitos, os contatos com aplitos mostram acomodação calma entre as partes.

\subsubsection{Veios}

Relegados a um segundo plano, petrologicamente, os veios podem assumir bastante importância em algumas situações.

Aborda-se aqui aquelas feições alongadas, com espessura máxima de alguns centímetros, claramente distintas das rochas que as hospedam.

De modo geral, quase todos os tipos de diques podem assumir as dimensões de veios. Isso ocorre, em especial, com os tipos microssieniticos e aplíticos. Interessa mais se ocupar dos veios naquelas situações em que podem auxiliar a esclarecer a relação entre as rochas e outras feições, muito embora possam eles complicar algumas situações.

A princípio, é de interesse tratar os veios sieníticos que intrudem litologias diversas, os veios portadores de nefelina, as porções diferenciadas venuladas, peralcalinas e agpaiticas, e os veios de possivel remobilização.

Veios microssieníticos e quartzo microssieniticos cortam, por exemplo, xenólitos do tipo 1. Mostram mesopertitas típicas predominantes, variando bastante o teor de quartzo, desde a ausência até 10 a $20 \%$. O fêmico, quando presente, é principalmente clinopiroxênio, que 


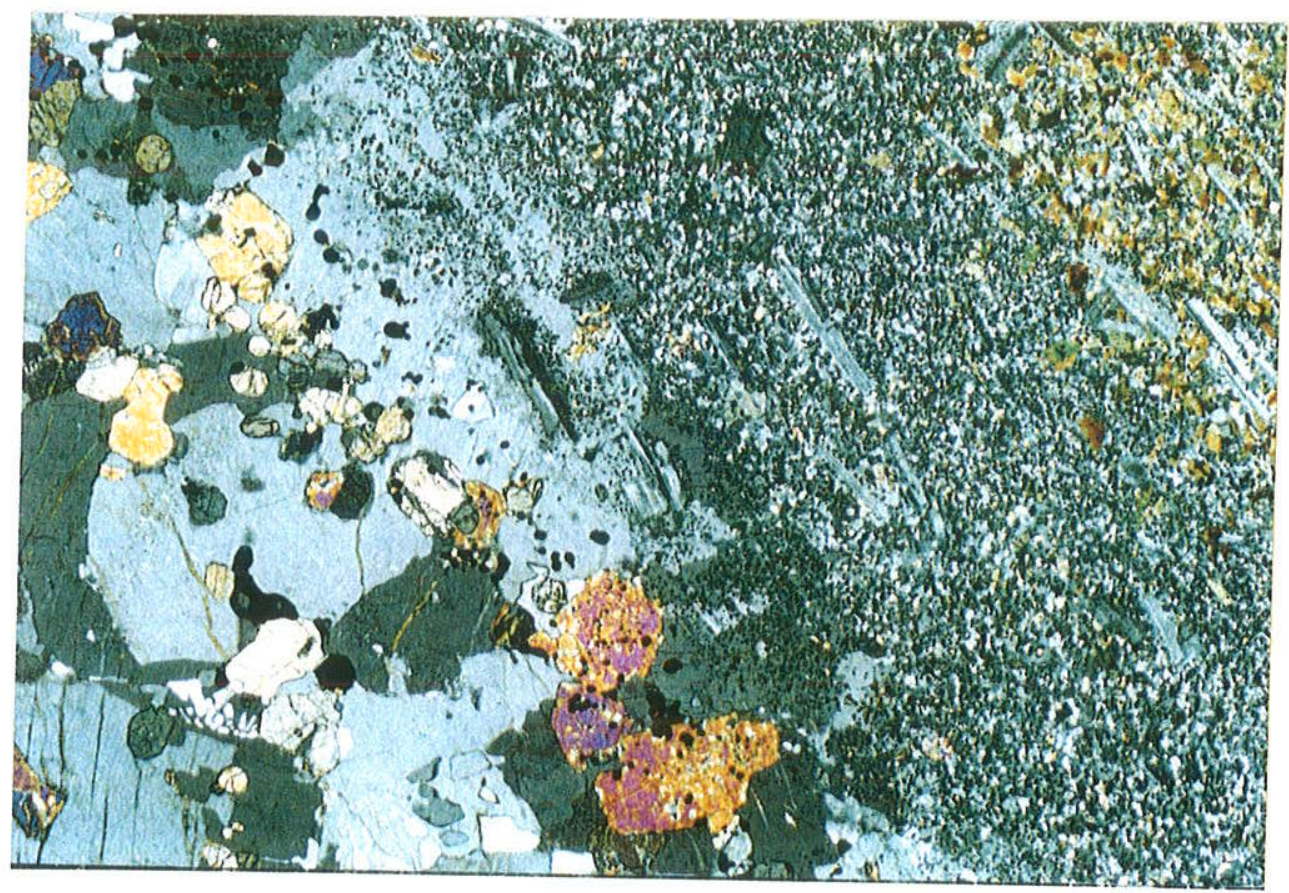

Fotomicrografia 56 - Contato rocha diabásica hornfélsica com charnoquito. No charnoquito, à esquerda, alinhamento do ortopiroxênio e dos opacos, poucos intercrescimentos granofíricos. O dique inicia com faixa de plagioclásio (mais cálcico), piroxênios e opacos $(2 \mathrm{~mm})$ e, só mais distante, passa à mineralogia original, com biotita. Faixa de transição de interpretação polêmica. Plagioclásio paralelo. Dimensão maior, $5,50 \mathrm{~mm}$, filtros azul e fosco, polarizadores semicruzados.

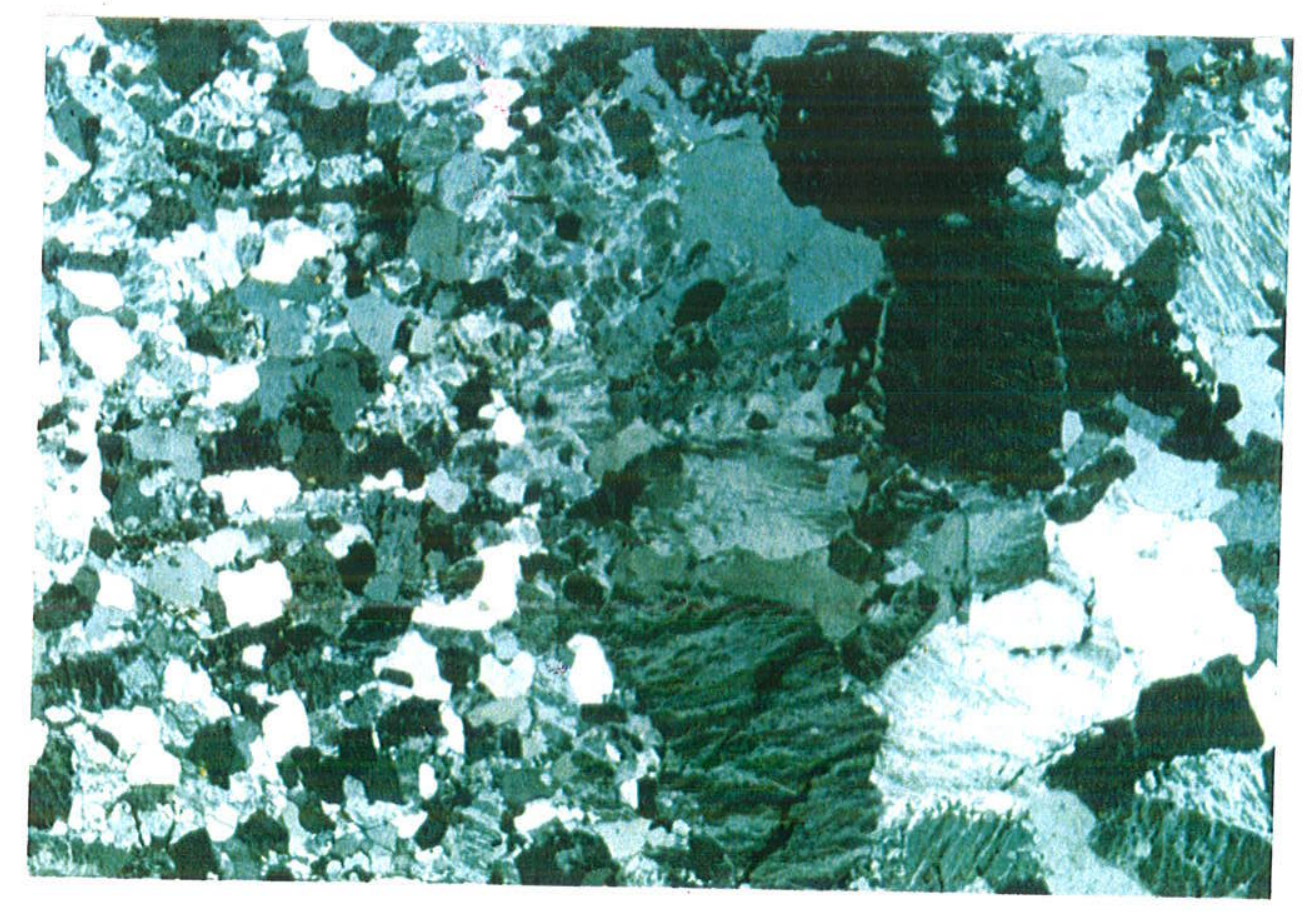

Fotomicrografia 57 - Contato entre microssienitos (quartzo, branco). Notar a interface de acomodação entre as partes, sem evidências de reação e cisalhamento. Dimensão maior, 5,50 mm, filtros azul e fosco, polarizadores semicruzados. 


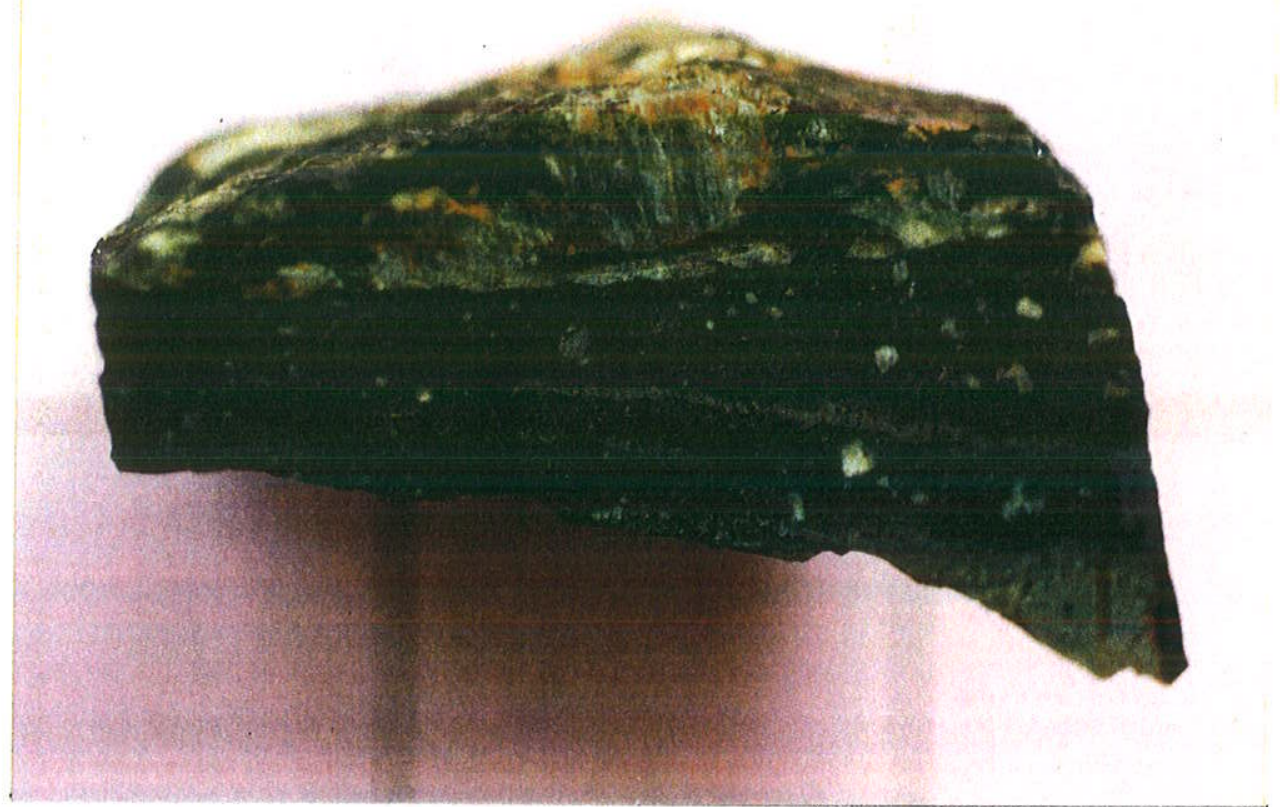

Foto 44 - Contato "riólito" - charnoquito. O contato mostra cisalhamento, com formação de faixa microbrechada e estrutura fluxionar. Na extremidade direita, inferior, já se observa o riólito normal. Reticulado: $5 \times 5 \mathrm{~cm}$.

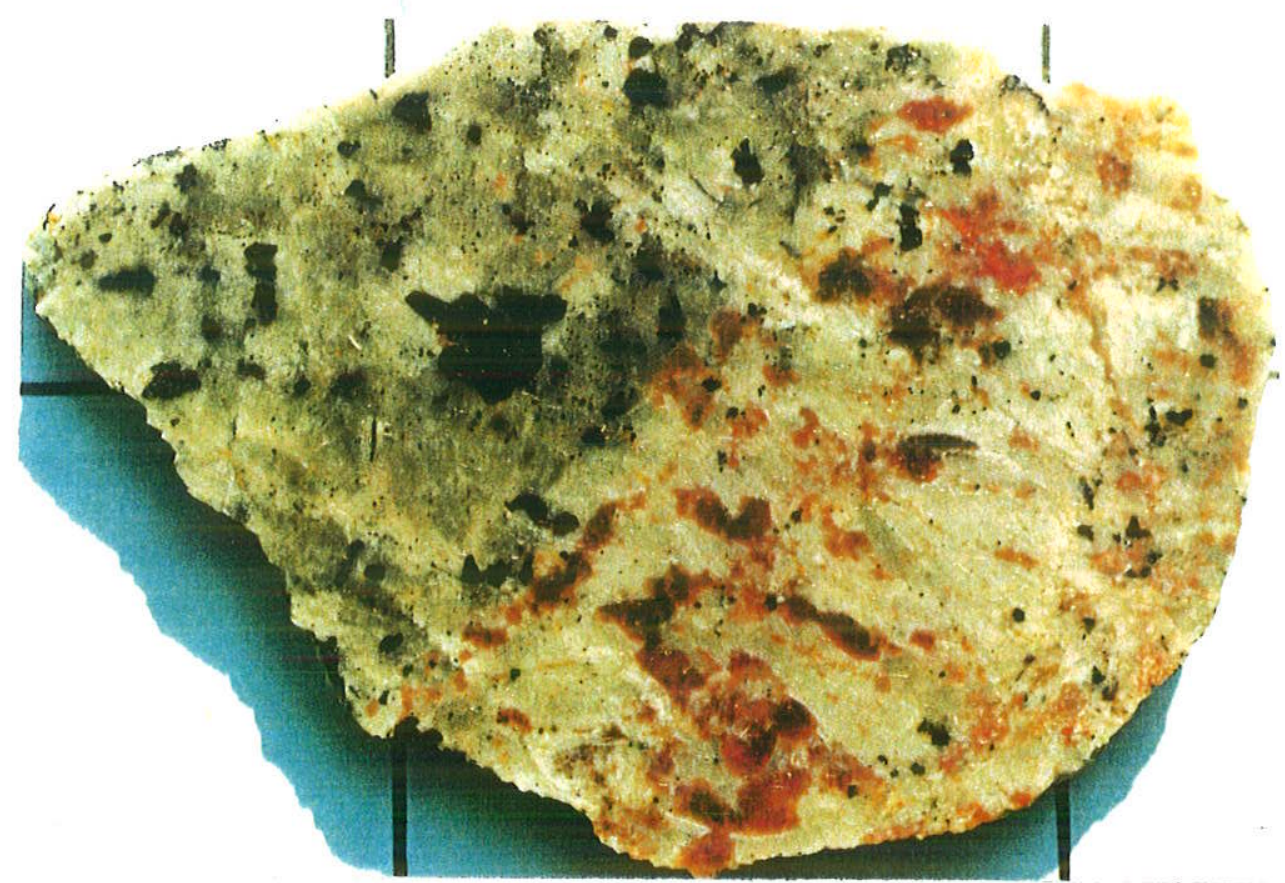

Foto 45 - Sienito em contato com porção nefelínica, também sienítica, pegmatóide. Notar alguma invasão, discreta, do nefelina sienito na encaixante. Reticulado: $5 \times 5 \mathrm{~cm}$. 
forma fileiras nos contatos dos veios. Esses veios sieníticos nos xenólitos cortam feições prévias, como veios de remobilização e fraturas. Não aparece efeito de contato na encaixante (Fotomicrografia 58).

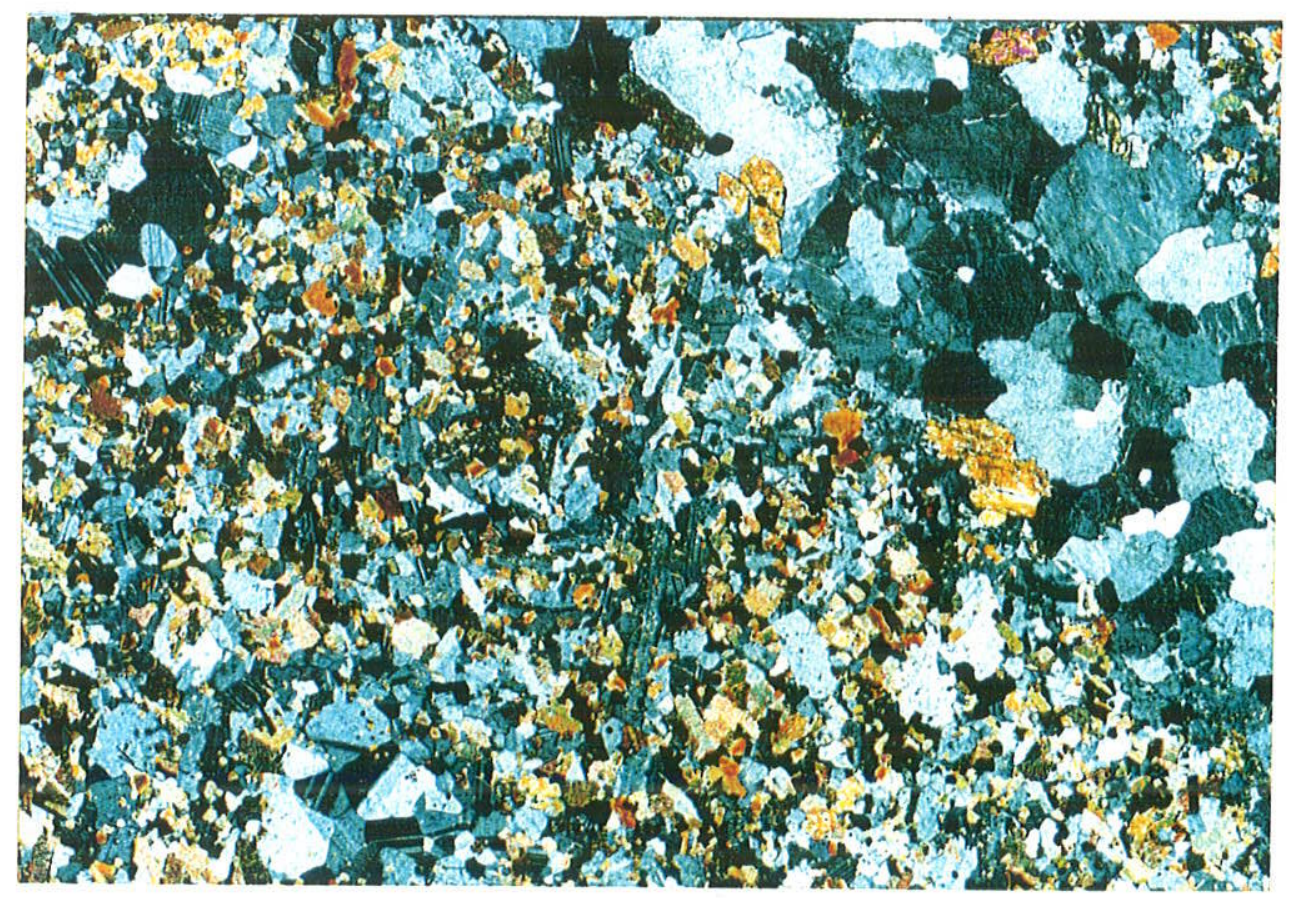

Fotomicrografia 58 - Veio de microssienito (canto superior direito), com mesopertita e raro quartzo, em rocha diabásica hornfélsica. Alinhamento e subparalelismo mineral junto ao contato, pouca interação entre partes. Dimensão maior, $5,50 \mathrm{~mm}$, filtros azul e fosco, polarizadores semicruzados.

Esses mesmos tipos de veios, às vezes, apresentam mesopertitas menos típicas dos sienitos, podendo ainda ter ortopiroxênio. Em alguns casos, são tipicamente sieníticos e mostram estrutura de fluxo, com o feldspato alcalino, mesopertítico, de forma retangular, orientado paralelamente aos contatos.

Nos sienitos ou mesmo nas encaixantes, como os milonitos, os veios microssieníticos evidenciam pouco a nenhum efeito de borda.

Alguns veios, essencialmente feldspáticos e quartzo-feldspáticos, podem conter plagioclásio isolado e ortopiroxênio. Nesses, o feldspato alcalino é mais homogêneo. Tanto essa variedade, como uma outra, veios de plagioclásio e clinopiroxênio, cortando os xenólitos do tipo I, não demonstram efeito de contato e são penetrados pelos veios sieníticos mais típicos. Esses veios são considerados como sendo de remobilização ("back veining").

A nefelina não está presente em qualquer das rochas plutônicas como mineral formador. Amostras dos pontos 159 (Ponta Sudeste), 158 e 163 (Saco Grande) contêm nefelina, mas é certo que se tratam de porções venuladas, sem contatos bruscos e retilíneos (Foto 45), mas, ao microscópio, nitidamente diferentes da rocha hospedeira. Apresentam 
textura diferente, com certo subparalelismo mineral, e limites bem definidos. Nesses veios o mineral associa-se principalmente a feldspato alcalino e fêmicos, poucos. Não há efeito visivel de borda.

Nos fonólitos em geral podem aparecer porções diferenciadas, sob a forma de veios $e$ venulação (Foto 42). Esses veios são sempre portadores de nefelina e de outros minerais pouco comuns, típicos de associações agpaiticas (Ti-Zr silicatos de cálcio e sódio, em geral). Não apresentam limites ou contatos bem definidos e, aparentemente, dispersam-se pela rocha hospedeira. Esta, em geral, é também portadora de mineralogia incomum, dentro daquela citada. Foram reconhecidos, opticamente, eudialita, enigmatita $e$, com insegurança, astrofilita e lamprofilita (Fotomicrografia 31).

Nos diques máfico-ultramáficos deformados (item 6.5.4.) podem ocorrer veios variados, em geral félsicos, e que passam desde tipos quartzosos aos inteiramente constituídos de feldspato alcalino, com ou sem piroxênio ou outro fêmico, até aqueles portadores de plagioclásio. Cortam e deslocam os "fenocristais" e não mostram deformação. Possuem textura com aspecto variável, desde granoblástica (minoria) até ígnea do tipo hipidiomórfica.

\subsection{Discussão, sintese e avaliação}

Neste capitulo, foram abordadas as rochas encaixantes do embasamento Brasiliano e as alcalinas plutônicas e hipoabissais, bem como outros tipos mostrando caracteristicas dúbias e de correlação insegura.

As rochas de interesse, as alcalinas e correlatas, cobrem dois espectros composicionais distintos, além de totalmente diferentes. De um lado, rochas félsicas, plutônicas, todas de caráter feldspático, com e sem quartzo, representadas por álcali feldspato sienitos e álcali feldspato-quartzo sienitos e suas variedades mais finas. Correspondem, em outros trabalhos, aos nordmarquitos e pulasquitos. Não ocorrem rochas com feldspatóides na moda. Procuroumse dar importância às texturas observadas e sua eventual correspondência com o posicionamento geográfico das amostras, assim como sua relação com a mineralogia, em particular, o quartzo. Foi visto que variações texturais observadas permitem distinguir sienitos "foiáticos" e "subfoiaíticos", sem quartzo, até quartzo sienitos com arranjo alotriomórfico. Também foi registrada e descrita a variação para microssienitos, sempre nas zonas de contato, e a aparente relação da maior presença de quartzo e de anfibólio nessas rochas.

Ainda entre as félsicas, descrevem-se as rochas de diques, variáveis desde fonólitos, de características peralcalinas e altamente diferenciados, passando por rochas traquíticas, até rochas de composição "riolítica" ou microgranítica, incluindo as variedades microssieníticas. Não é demais lembrar a predominância das mesopertitas e a ausência do plagioclásio em todas 
as rochas investigadas.

As rochas modalmente félsicas correspondem aos campos 2 (raras), $6^{*}, 6,6^{\prime}$ e 11 do triângulo duplo Q-A-P-F (cf. Le Maitre, 1989).

De outro lado do espectro composicional, aparecem rochas de composiçâo básica, basálticas a dioriticas, em geral, correspondendo aos campos 10, 10' e 14 (cf. Le Maitre, 1989). Todas essas variedades são rochas de dique e, para grande parte, foi atribuida classificação petrográfica (e geológica) de lamprófiros, diabásios e microdioritos.

São insignificantes as rochas com mais do que $20 \%$ de quartzo, sendo que praticamente nenhuma amostra cai nos campos $7,7^{*}, 7^{\prime}, 8,8^{*}, 8^{\prime}, 9,9^{*}$ e $9^{\prime}$, exceção feita aos tipos lamprofiricos, que podem variar entre camptonitos e sannaitos (minoria) e, portanto, ocupar também os campos 7', 8' e 9', ou mesmo 12 e 13.

Björnberg e Ellert (1955) descrevem nordmarquitos, com xenólitos parcialmente digeridos, e sienitos, ambos com ortoclásio pertitico e oligoclásio, e textura hipidiomórfica granular, o que não corresponde exatamente às descrições deste capítulo. Como rochas de diques, eles citam nordmarquitos aplitos, sienitos aplitos hiperstênicos, bostonitos, hedrumitos, tinguaítos (com eudialita, astrofilita e hainita) e teschenitos, sem referência aos lamprófiros. Acredita-se que as rochas mencionadas por esses autores são as mesmas descritas aqui, havendo tão somente diferenças quanto à descrição e ao vocabulário. Por exemplo, ortoclásio e oligoclásio, analisados separadamente, são na verdade as mesopertitas, com a ressalva de que a fase sódica é a albita, e não o oligoclásio. A rocha descrita como teschenito é, provavelmente, algum tipo tomado como lamprófiro. Entre os minerais, não citam a fluorita, mas relacionam a hainita, identificada, e que deve estar entre os $\mathrm{Ti}$ - $\mathrm{Zr}$ silicatos ora não identificados.

Os mesmos autores se referem a dois tipos básicos: um (meta) diabásico (préalcalinas) e um diabásico (pós-alcalinas). As mineralogias têm correspondência com aquelas fornecidas neste capitulo, ainda que as significativas caracteristicas texturais dos (meta) diabásios não sejam apontadas.

Rochas plutônicas das ithas foram abordadas em Freitas (1947), Coutinho (1973) e Motoki (1986), geológica e petrograficamente. Deixa-se de citar Hennies e Hasui (1977), por esse trabalho não incluir qualquer informação petrográfica, afora descriçăo de campo.

Freitas (1947), sem dúvida, é o trabaho mais completo do ponto de vista geológico e, petrograficamente, mais detalhado e extenso. Esse autor lista rochas "eruptivas alcalinas, básicas e quartzo dioríticas". Entre as alcalinas aborda as plutônicas, classificadas como nordmarquitos, (biotita) pulasquitos, nefelina sienitos e foiaitos. Os três primeiros tipos são descritos como "hipidiomórficos granulares", com predominio dos minerais albita e anortoclásio, "concrescidos", o que conduz à conclusão de que säo as mesmas mesopertitas de Búzios, com os feldspatos alcalinos descritos de forma diferente, ou (pouco provável) trata-se realmente de anortoclásio e albita "concrescidos". Mais: o anortoclásio citado foge da caracterização 
encontrada em Deer et al. (1993) e Tröger (1979). Os foiaitos são referidos como tendo textura foiaitica $e$, somente, anortoclásio. Além dessas rochas, são citados essexitos foiaitos, essexitos e teralitos.

Aborda, ainda, as rochas hipoabissais: diabásios, mais antigos, e bostonitos, microfoiaitos, sodalita microfoiaítos, microteralitos, nefelina sienito aplitos, sodalita fonólitos e traquitos.

A grande maioria das rochas da liha de São Sebastião tem sua contrapartida em Búzios, à exceção dos diabásios e das rochas plutônicas portadoras de feldspatóides, respeitadas as diferenças de nomenclatura e descritivas.

Coutinho e Melcher (1973) descrevem teralitos e foiaitos, inexistentes em Búzios. Entre as rochas de diques relacionam microfoiaitos, "rhomb porphyries", lamprófiros, sienobasaltos e microshonkinitos, a maioria com tipos correspondentes em Búzios.

Motoki (1986) relaciona sienitos azuis (com quartzo) e brancos (com fóides) na liha de Vitória. Discute também os xenólitos, chamando a atenção para as granulometrias mais finas no sentido dos contatos. As semelhanças descritivas são grandes, com esse autor caracterizando bem as mesopertitas e assinalando a ausência do plagioclásio.

Todos os cinco corpos alcalinos plutônicos são bastante semelhantes, com apenas duas ocorrências plutônicas diferentes conhecidas nas ithas: aquela da ltha do Monte de Trigo, exclusivamente com foiaítos e teralitos, e o suposto "stock" das Canas, na liha de São Sebastião, que somente mostra amontoados de blocos de rochas variadas, sieníticas, essexíticas até piroxeniticas, estratificadas e cumuláticas. Os cinco corpos são sieniticos, com rochas álcali feldspáticas, desde as variedades com quartzo, nas bordas, até os nefelina sienitos junto às porções centrais.

As diferenças registradas entre as ocorrências se devem às diferentes porções emersas ou a problemas de amostragem, ou mesmo descritivos. Somente nos corpos da llha de São Sebastião pode-se esperar encontrar associação completa de todos os tipos, particularmente nos corpos da Serraria e de São Sebastião, que se mantêm quase inteiros.

Além das abordagens das rochas de diques já mencionadas, dois trabalhos visaram especialmente esse tipo de ocorrência no litoral, o de Damasceno (1966) e o de Garda (1995). Damasceno (1966) descreve diabásios e lamprófiros e um microdiorito, sem detalhar a petrografia. O trabalho de Garda (1995) revisita os mesmos diques, e estende a pesquisa para sul e para algumas ithas, além de descrever com mais detalhamento os diabásios, lamprófiros (que compartimenta) e rochas picriticas. Afora menção às rochas traquiticas, ambos os trabalhos preocupam-se com rochas básicas e ultrabásicas. Nota-se bastante semelhança entre as rochas lamprofíricas do litoral e as de Búzios, a menos de alguns detalhes. Em muitas das rochas do litoral o teor de olivina é alto, aliado à ocorrência de fenocristais de biotita e de anfibólio, este presente em amostra única e o primeiro ausente em Búzios. Além disso, Garda (1995) relata a presença de microxenólitos de carbonatito em lamprófiros, feição também não 
encontrada em Búzios. Registram ainda lamprófiros com melilita, ausentes em Búzios.

Os conhecimentos acumulados, geológicos e petrográficos, das rochas igneas da costa litorânea e das ithas vizinhas a Búzios permitem sintese preliminar geral:

todos os corpos plutônicos alcalinos cretácicos são de rochas sieníticas, álcali feldspáticas, com quartzo ou com nefelina, ou sem esses minerais; todos os tipos sieníticos que ocorrem em mais de um lugar (com e sem quartzo) são semelhantes petrograficamente, obedecendo distribuição concêntrica;

. foiaítos típicos estão presentes tão somente nas lhas do Monte do Trigo e São Sebastião;

. parte da llha do Monte de Trigo (20\%) e suposto stock em Sāo Sebastião são formados de rochas de caráter básico alcalino (essexitos, teralitos, piroxenitos, etc);

- sienitos de granulação média a fina são descritos em Búzios e na liha de Vitória, nas proximidades dos e nos contatos, contendo xenólitos das encaixantes;

- diques de diabásio típico ocorrem no titoral (em grande número) e na liha de São Sebastião, estando ausentes nas ilhas restantes;

- lamprófiros aparecem na costa e nas lihas do Monte de Trigo e Búzios, e mostram bastante similaridade;

quartzo traquitos, traquitos (e bostonitos) e traquitos com nefelina são citados em todos os trabalhos. Isto é, ocorrem em toda a área (e mais) abrangida na Figura 1;

fonólitos, nefelina microssienitos (e microfoiaitos) são rochas encontradas nas llhas do Monte de Trigo, São Sebastião, Búzios e Vitória, mas não há informações sobre a sua ocorrência na região costeira;

outros tipos hipoabissais, variavelmente descritos como andesitos ou microdioritos, são citados por Freitas (1947) e Garda (1995), e encontrados em Búzios.

os diques rioliticos de Búzios não parecem correlacionáveis aos da llha de São Sebastiäo;

Os outros aspectos, de caráter mais específico, merecem algum comentário. É o caso dos feldspatos das rochas plutônicas e de parte das rochas félsicas de diques.

Em Búzios, é universal o caráter mesopertítico do feldspato, havendo rochas com feldspatos opticamente homogêneos, mas certamente criptopertiticos. Notamse algum dominio das fases albiticas. Também chama a atenção os padrões dessas mesopertitas, bastante regulares, entre os quais destaca-se o "tigrado", termo descritivo usado para os feldspatos da Ilha do Monte de Trigo (Coutinho e Melcher, 1973). Também o padrão em manchas ("patch"), em que a fase albítica aparece geminada, é relatado noutros trabalhos. Acredita-se que algumas mudanças do padrão devam-se à posição de corte do feldspato, antes que à variação da pertita. Motoki (1986) descreve mesopertitas semelhantes às de Búzios, assim como Freitas (1947), embora empregando outra terminologia. Chama a atenção em Búzios, o fato de que as mesopertitas são iguais, tanto nos sienitos, quanto nas rochas de diques. Essas características 
poderiam significar que os feldspatos foram semelhantes ao se cristalizarem nas várias ocorrências citadas, e como as rochas que formam são também semelhantes, as massas magmáticas totais e os líquidos deveriam mostrar similaridades, ressalvando-se as diferenças já apontadas. Mais ainda, que dadas as semelhanças dos focos alcalinos próximos, durante e/ou após o seu alojamento, todos os corpos se resfriaram e se cristalizaram, em condições termais e de pressão de água semelhantes, provavelmente experimentando fases tardimagmáticas e hidrotermais também análogas.

É possivel que esses tipos de pertita correspondam, principalmente, à uma segunda fase de exsolução, induzida por aporte de fluidos aquosos (cf. Smith e Brown, 1988). Contudo, se o terreno como um todo, ainda em condição subsuperficial, experimentou aumento da pressão de água, fica difícil entender a sobrevivência dos piroxênios em geral, e em especial do ortopiroxênio.

Não se acredita, aqui (cf. Deer et. al., 1993; Tröger, 1979), na presença de anortoclásio junto às rochas plutônicas, tal como Freitas (1947) descreve, e tampouco se acredita que esse autor tenha errado, à vista precisão das outras informações que fornece. É provável que algum anortoclásio esteja presente nas rochas de diques, em particular nos fonólitos.

Com relação às rochas máficas, correlacionáveis aos episódios do Cretáceo Superior, compõem elas assembléia bastante variada já referida. A existência ou inexistência de um ou outro tipo petrográfico de dique talvez se deva mais à classificação adotada e ao vocabulário descritivo. Ocorrem na costa e em todas as ilhas. Algumas descrições de Coutinho e Melcher (1973) e de Garda (1995), quando comparadas com as de Búzios, apresentam muitas similaridades. Os clinopiroxênios são descritos como Ti-augitas, genericamente, e sempre mostram cores róseas a pardo-amareladas, enquanto que os anfibólios como kaersutitas ou hornblendas basálticas. De qualquer forma, a suposição de Motoki (1986) de que essas rochas, os teralitos da llha do Monte de Trigo e mesmo o "corpo" das Canas, representariam tipos magmáticos parentais, ainda que a nivel de petrografia, é factivel.

$\mathrm{Na}$ Itha dos Búzios, existem rochas que poderiam fazer parte de seqüencia de diferenciação a partir dos diabásios (basaltos, basaltos alcalinos) e lamprófiros (basanitos), como representantes magmáticos parentais, evoluindo para micromonzodioritos (traquibasaltos) e ainda lamprófiros (tefritos). Como visto, não foram registradas composições monzodioríticas, monzoníticas (latíticas) e mesmo sieníticas (traquíticas), quer as variedades com quartzo, quer as saturadas ou as portadoras de fóides que corresponderiam aos tipos magmáticos alcalinos na classificação TAS (cf. Le Maitre, 1989, Fig. B.13) aos fonotefritos e tefrifonólitos. Essas ausências composicionais são polêmicas: "Daly's gap", amostragem, seleção de amostras?

De qualquer forma, as rochas seguintes nessa sequência seriam os sienitos e traquitos (álcali feldspáticos), que representam, seguramente, mais de $95 \%$ das rochas igneas 
cretácicas da liha. $E$, a partir dos traquitos, resíduos altamente diferenciados, quer insaturados, como os fonólitos, quer supersaturados, como os quartzo traquitos, "riólitos" e "microgranitos". Os tipos "riolíticos", de diques, não são riólitos petrograficamente: essas rochas têm todas as características de traquitos com excesso de quartzo.

As feições petrográficas dos minerais são importantes.

Já foram discutidas as mesopertitas, em geral. Mas resta lembrar as características dos outros feldspatos: plagioclásio e feldspato potássico (sanidinio?) dos lamprófiros, e albita e feldspato potássico (sanidínio? anortoclásio?) dos fonólitos. Se a maior parte dos feldspatos das rochas da ltha foi atingido por episódios tardios ou hidrotermais, o que teria ocorrido com essas rochas?

Boa parte do plagioclásio mostra alteração variada, mas não saussuritização, que poderia ser a resposta aos mesmos episódios; crescimentos secundários mais sódicos, de borda, também poderiam registrar os mesmos eventos. Os diques lamprofíricos, em geral, exibem os félsicos e a matriz parcialmente transformados em zeólitas, carbonatos, serpentina e, às vezes, clorita.

Já as rochas fonoliticas com dois feldspatos independentes apresentam muito pouca transformação, quando existente. Como supostamente são as rochas mais tardias, haveria a possibilidade de terem se cristalizado simultânea a posteriormente aos episódios tardimagmáticos, ou mesmo terem feito parte dos mesmos líquidos residuais finais, talvez enriquecidos em sódio. É interessante lembrar que outras rochas, como os aplitos e os quartzo microssienitos, mostram total eliminação dos fêmicos e presença de minerais de alteração variados, mas não identificados, além da maior concentração de zircão e de fluorita, esta aparentemente tardia. Face à universalidade das (pertitas e) mesopertitas, a existência de dois feldspatos nos fonólitos admite apenas soluções hipotéticas. A presença de deformação nos feldspatos dessas rochas é também consistente com o modelo de colocação bem mais tardia em encaixantes sieníticas, já geologicamente sensiveis a deformações.

Os clinopiroxênios apresentam tipos, óptica e quimicamente variados, ao lado de características petrográficas diversas. Nas rochas plutônicas, variam entre tipos augíticos/diopsídicos (saliticos), quase sempre com zoneamento mais ou menos pronunciado, para tipos hedembergiticos ou mais egirinicos. As transições para variedades mais férricas e/ou sódicas, se dão no sentido centro $\rightarrow$ borda ou entre amostras. As rochas mais a oeste sienitos, quartzo sienitos e tipos petrográficos de granulação mais fina - tendem a exibir clinopiroxênios mais magnesianos, evoluindo no sentido sul (Saco Grande) e leste (Ponta Sudeste) para individuos com zoneamento mais pronunciado e características ópticas comuns às variedades hedembergíticas/egirínicas. Feições de corrosão magmática, interpretadas por Motoki (1986) como devidas a reaquecimento geral e desequilibrio com as fases líquidas geradas, são bem discutiveis. É freqüênte que os limites do grão interrompam o zoneamento, mas existem aqueles, aparentemente corroídos, onde o zoneamento desenha as bordas. 
Transformações tardias em anfibólio (e/ou biotita) denominados de uralita também são passiveis de discussão. Parece mesmo que a assembléia desses minerais representa, na maioria das vezes, seqüencia normal de cristalização. O aparecimento do anfibólio e/ou da biotita poderia ser atribuido à entrada ou ao aumento de água no sistema, até então praticamente anidro. As relaçöes texturais entre os fêmicos e os félsicos, com os primeiros inclusos nesses últimos em muitas ocasiōes, indicam que os fêmicos iniciaram sua cristalização antes, seguindo-se então a cristalização simultânea dos feldspatos. Os clinopiroxênios incluem ou moldam parcialmente os opacos e a apatita, de provável cristalização anterior e simultânea, e nunca incluem as mesopertitas, o anfibólio e a biotita.

Não foi observada seqüência textural piroxênio $\rightarrow$ anfibólio $\rightarrow$ biotita. Os dois últimos mantêm relação textural igualitária, ambos interdigitando-se com alguma constância com a mesopertita ou entre si. Incluem igualmente o piroxênio. Tais relações parecem indicar que tanto o anfibólio como a biotita se formaram após o piroxênio e, simultaneamente, aos feldspatos, já em estágio avançado de cristalização. O aparecimento de biotita, com ou sem o anfibólio, poderia estar ligado à disponibilidade de potássio e alumínio, por sua vez relacionados à cristalização do feldspato.

Nos diques félsicos, as relações são mais ou menos iguais àquelas observadas nos microssienitos.

Variedades traquíticas possuem fenocristais de feldspato com núcleo limpo, provavelmente precoces, além de anteriores aos fêmicos. Piroxênio, opacos, biotita e, mais subordinadamente, anfibólio, em indivíduos pequenos, orlam esses núcleos e demarcam por alinhamento as fases posteriores de crescimento desses fenocristais. Já nas matrizes, embora apertados ou intersticiais com relação aos feldspatos, aqueles minerais mostram paralelismo com esses últimos e não aparecem inclusos, o que poderia indicar crescimento simultâneo. Nessas rochas de diques, a forma dos feldspatos poderia estar ligada a fatores diversos: velocidade do fluxo magmático, menor viscosidade do magma (mais fluido no sistema ou temperaturas mais altas) ou diferenciais de pressão mais altos. As matrizes de traves longas de feldspatos podem evidenciar deformação, confundivel com padrōes mesopertíticos. Foram três os tipos de feldspatos verificados: mesopertitas, com bordas albíticas, pertitas com bordas albíticas e, por último, a assembléia dos dois feldspatos em individuos independentes. Este último caso deixa dúvidas sobre a gênese da albita (magmática?).

São diferentes as assembléias dos ferromagnesianos, quando se comparam os diques microssieníticos com as rochas de afinidade mais alcalina, traquitos e fonólitos. Nos primeiros, os fêmicos são semelhantes aos dos sienitos, enquanto que nas últimas eles têm caracteristicas mais sódicas e férrico-ferrosas. De modo geral, as texturas indicam nefelina e sodalita como últimos minerais a se cristalizarem, às vezes simultaneamente aos feldspatos. Invariavelmente, o feldspato albitico, em palhetas, parece ser um dos primeiros minerais a se formar, seguido ou simultâneo às mesopertitas; surgem depois o piroxênio e o anfibólio. 
Feldspato potássico pode ombrear-se aos fóides e fazer parte de mosaico de fundo, sobre o qual aparecem os fêmicos. Estes, por sua vez, parecem ser simultâneos ou posteriores aos feldspatos, sendo que o anfibólio apresenta relações conflitantes: ocupa posição semelhante ao piroxênio, desenvolve-se em individuos maiores, poiquiliticos, que incluem os feldspatos albiticos e silicatos raros, ou ainda, está presente como núcleo do piroxênio (em todas as situações, o anfibólio é opticamente igual). Já os Ti-Zr silicatos demonstram ser anteriores a todos os minerais, exceto aos feldspatos, ou são produtos de substituição tardia, adquirindo hábito pouco compreensivel, uma vez que eles crescem sobre as outras fases.

Os diques máficos representam um outro universo mineralógico e petrográfico. Seus minerais formadores mais comuns são plagioclásio, clinopiroxênio e opacos (magnetita, principalmente), acompanhados ou não por olivina, anfibólio, biotita, feldspato potássico, analcita e vidro, além de apatita, titanita, carbonatos, zeólitas e serpentina. Boa parte dessas rochas é porfiritica ou microporfirítica, com fenocristais de olivina, clinopiroxênio e plagioclásio, às vezes agrupados. Os fenocristais (ou xenocristais?) apresentam-se limpos ou com inclusões e não mostram diferenças sensiveis com relação ao resto da rocha; à exceção de alguns individuos de plagioclásio, não foi observada reação com a matriz. Olivinas, imersas em vidro, junto a contatos, exibem embainhamentos acentuados, preenchidos por vidro, a indicar absorção parcial do mineral e, portanto, desequilibrio com esses vidros marginais. Se o vidro representa o liquido magmático original, então essas olivinas ter-se-iam fracionado de outro líquido qualquer. Nos mesmos vidros, outros fenocristais (plagioclásio, clinopiroxênio) estão variavelmente alterados, a indicar desequilibrio com o liquido. Por outro lado, os mesmos minerais apresentam-se inalterados longe dos contatos, em aparente equilibrio com as matrizes hipocristalinas.

Além dos fenocristais (xenocristais), os diques máficos contêm microfenocristais de olivina, não zonada, e de clinopiroxênio e plagioclásio zonados. O clinopiroxênio apresenta acentuado zoneamento recorrente, aparentemente entre duas composiçōes extremas, às vezes com grande porção central homogênea. Essas feições indicariam sucessivas e rápidas mudanças nas condições físicas e/ou químicas da fração ainda líquida ou aportes de sucessivos líquidos magmáticos. Com relação à biotita e ao anfibólio (kaersutita? hornblenda basáltica?), registrou-se que esses minerais ocorrem juntos ou apenas um deles esta presente. Nāo exibem, texturalmente, qualquer relação entre si. O anfibólio se mostra autônomo ou associado ao piroxênio e tanto poderia ser simultâneo como, pelo menos em parte, posterior àquele mineral. A biotita, por vezes autônoma, freqüentemente orla os opacos ou, juntamente com estes, dispõem-se ao redor da olivina. Todos esses minerais ferromagnesianos, incluindo os hidratados, não têm características de tardios ou secundários, mas de mineralogia primária, livremente desenvolvida.

Algumas secções delgadas mostram três gerações morfológicas de opacos: granulares e maiores, granulares a esqueléticos, menores, e grades muito finas, sugerindo 
fases distintas de crescimento a taxas de resfriamento diferentes, com flutuações bruscas. $\dot{E}$ interessante notar que as grades desenvolvem-se sem respeitar a grande maioria dos minerais, a não ser a olivina e os ocelos.

Embora os ocelos apresentem mineralogia normalmente interpretada como tardia, a menos dos vidros, eles têm sido considerados primários (cf. Rock, 1991). Se as grades de opacos antecedem a quase todos os minerais dessas rochas, respeitando sempre a olivina (e, ocasionalmente, o piroxênio) e os limites dos ocelos, eles seriam realmente primários e anteriores aos próprios opacos. Contudo, a mineralogia que exibem (analcima, zeólitas, serpentina) poderia, pelo menos em parte, ser tardia.

Outros tipos de diques máficos, de caracteristicas mais basálticas, mas que contêm anfibólio e/ou biotita podem representar magmas também com água, sendo os fêmicos, primários, e não o produto da substituição de possivel piroxênio. Essas características permitiriam sugerir que os prováveis representantes parentais das rochas de Búzios sejam magmas portadores de maior ou menor quantidade de fluidos aquosos.

Embora não haja qualquer registro de carbonatitos, nem mesmo como microxenólitos, os glóbulos e ocelos de carbonatos podem também ser primários, e representar imiscibilidade de ponderável fração carbonática nos magmas parentais.

Os diques deformados, máfico-ultramáficos, admitem mais de uma interpretação. Por um lado, são portadores de mineralogia e textura ígnea, não havendo no entanto explicação única para a convivência das formas geométricas com o arredondamento dos cantos. Também a matriz, exibindo caráter granoblástico, foge um pouco das texturas ígneas. Por outro lado, apresentam-se deformados plasticamente, o que levaria a se pensar neles como parte da encaixante. Não obstante, talvez a idéia de diques simplutônicos possa compatibilizar características conflitantes. Para mostrar os padrões de deformação vistos, em geral não tão intensos quanto aos da Foto 33 , seria necessário que o dique e a encaixante sienítica, sempre híbrida, também estivessem em estado plástico, com grau de cristalização avançado, mas inferior a 60 ou $70 \%$ da massa já solidificada. Encaixado em massa sienítica mais fria, mas capaz de permanecer por mais tempo aquecida, poderia desenvolver a textura observada, tipica de contato termalmente contrastante. A possivel matriz inicial, mais fina, mantida a temperaturas ainda elevadas pela encaixante, recristalizar-se-ia no aspecto observado. Assim, é bem possivel que esses diques façam parte das atividades ígneas neocretácicas, embora, petrograficamente, não seja possivel decidir pelo seu caráter alcalino ou não.

Os diques do ponto 191 (Fotos 23 e 24) são lamprofíricos, típicos, e intrudem rochas sieníticas. Estão interrompidos na sua extremidade SW (fotografada). Na laje por onde deveriam passar, o sienito é fino, com alguma foliação/fraturamento, além de portador de grande quantidade de xenólitos de charnoquito e de rocha (meta) máfica (Fotos 25 e 26). Os xenólitos são do tipo 1 , de rocha diabásica hornfélsica, igual aos outros da zona principal de contato. Os xenólitos, conseqüentemente, nada têm a ver com esses diques. Talvez a 
explicação mais aceitável seja a de que o ponto 191 encontra-se situado em zona de contato, onde possiveimente tenha havido alguma movimentação, levando à interrupção dos diques. Também caberia a alternativa de que os diques, embora não relacionados aos xenólitos, sejam intrusivos nos charnoquitos, ainda que microssienitos tenham sido amostrados como encaixante na extremidade dos diques. Também nesse caso os diques estariam interrompidos no contato sienito-charnoquito. De qualquer modo, o ponto 191 não mostra rochas em situação simplutônica.

O exame petrográfico dos xenólitos do tipo I revela rochas diabásicas/microdioríticas, termalmente metamorfisadas, com textura hornfélsica. Algumas das ocorrências mais expostas apontam para a presença de dique máfico intrusivo no charnoquito, sendo o conjunto englobado por microssienito (Fotos 13 e 14), rico em xenólitos do tipo 1 e de charnoquito, este em maior parte. As rochas básicas dos xenólitos contêm ortopiroxênio em paragênese de equilibrio. Embora o charnoquito mostre pelo menos dois episódios de cisalhamento, a rocha do dique não registra cisalhamento algum. Contatos, examinados ao detalhe, indicam estrutura de fluxo no dique, com plagioclásio ripiforme a tabular paralelo ao contato com o charnoquito. $O$ ortopiroxênio aparece normalmente dentro do plagioclásio e, no contato, invade gradativamente o charnoquito, que, por sua vez, exibe alinhamento de ortopiroxênio mais desenvolvido e opacos, acompanhando o contato. As primeiras questōes: a assembléia do dique, posterior ao charnoquito, reagiu com os feldspatos do charnoquito, substituindo-os progressivamente por meio do consumo de anfibólio? Ou o ortopiroxênio é um mineral posterior ao episódio intrusivo do dique, produto de metamorfismo de alto grau, enquanto que os feldspatos estariam crescendo poiquiloblasticamente sobre o dique? As possiveis soluções: o ortopiroxênio é produto de metamorfismo termal, com consumo de anfibólio e quartzo (ou mesmo sillica do plagioclásio, que se tornaria mais cálcico), sendo de geração distinta do ortopiroxênio do charnoquito. A fonte termal teria sido o corpo sienítico. A outra explicação seria remetida a episódios Brasilianos e pré-Brasilianos, e metamorfismo de alto grau. Nesse caso, o sienito teria apanhado o conjunto dique-charnoquito tal como se apresenta. Na primeira hipótese, o sienito teria causado o efeito termal, e o dique poderia ser representante dos diabásios do Eocretáceo, não encontrados na llha. Esta solução é menos provável, uma vez que as condições de formação do ortopiroxênio exigem meio anidro ou quase, aliada à presença de $\mathrm{CO}_{2}$, embora as temperaturas até pudessem ser alcançadas pela massa sienítica $\left(700^{\circ} \mathrm{C}\right.$ ) (cf. Newton et al.,1980; Schumacher et al., 1990). Essas ocorrências de ortopiroxênio, em situações complexas, são relatadas em outros trabalhos (cf. Azevedo Sobrinho, 1995), na faixa do complexo Metamórfico Costeiro.

Outras caracteristicas dos xenólitos do tipo I (a maioria) - como dimensões (decimétricas, métricas, não mensuráveis), angulosidade dos tipos máficos e subangulosidade daqueles charnoquíticos, quantidade maior próxima ao contato, com gradativa diminuição até 200-300 m de distância dessa zona até a ausência, presença de xenólitos do tipo II, venulaçāo 
sienitica generalizada e fragmentação das peças - indicam processo de alojamento da intrusão pelo mecanismo de "stopping" (cf. Hall, 1987; Marsh, 1982). Além dessas características mais geológicas, o exame petrográfico demonstrou que os xenólitos charnoquiticos foram submetidos a fusão parcial, variável em intensidade, e que os do tipo I, básicos, pouco foram afetados pelo processo, embora os do tipo II tenham aparentemente sofrido intensa corrosão magmática, com pequena influência na mineralogia.

As rochas charnoquiticas têm composição próxima à do eutético granítico, a baixas pressões de água. Não é fora da realidade afirmar que, provavelmente, fragmentos de composição charnoquitica, correlacionáveis aos xenólitos do tipo II, foram integralmente assimilados. A coexistência de xenólitos dos tipos l e II nos mesmos locais indica, sem dúvida, momentos e fontes de origem diferentes, com os do tipo II tendo experimentado residência muito mais prolongada no magma sienítico e, obviamente, sendo de origem anterior aos do tipo 1. Não existindo tipos intermediários, em dimensões e formas, podem eles representar dois momentos distintos de ascensão da massa magmática, talvez mais quente em um primeiro pulso.

As variações granulométricas nos microssienitos, contínuas e descontínuas, são também indicativas de distintas massas magmáticas com diferentes contrastes termais, o que significaria que, após primeiro momento de colocação de parte do magma, e que possivelmente não atingiu sua posição final (cf. Marsh, 1982), novas massas móveis e aquecidas posicionaram-se pelo caminho já aberto, misturando-se às primeiras, ainda não consolidadas. O alojamento final, cada vez ocupando mais espaço e mais próximo à superfície, deve ter sido progressivo e contínuo, e não repentino, a julgar pelas rochas e outras feições petrográficas avaliadas. Com gradientes termais cada vez menores, pelo aquecimento das porções externas, seria mesmo de se esperar granulaçōes mais grossas.

A passagem para os sienitos "hibridos", de granulação grossa e com restos de minerais dos charnoquitos, sugerem condições diferentes daquelas experimentadas pelos microssienitos com xenólitos. Em qualquer das duas situações, houve sem dúvida assimilação parcial das encaixantes, alterando a composição da rocha assimilante, principalmente no que toca à sílica, e sendo responsável, pelo menos em parte, pela presença do quartzo. A fusão parcial dos charnoquitos pode ter sido acompanhada pelo aumento da pressão de água, parte da qual da própria massa em fusão. Talvez o aumento da pressão de água possa ter alterado a seqüência de formação dos minerais, passando a cristalizar anfibólio (ou biotita) no lugar do piroxênio e, conseqüentemente, o aparecimento de mais quartzo.

A petrografia ainda registra rochas com poucas evidências de cisalhamento ou de deformação plástica, mesmo nos vários contatos. Não ocorrem sienitos cataclásticos ou miloníticos, de monta, indicando ausência de campo de tensões de cisalhamento locais intensos e, se os houve ou há, regionalmente, não há registro de zonas importantes de alívio. Essa condição parece também ter prevalecido na Itha de Vitória, muito embora Freitas (1947) 
atribua a falhamentos gravitacionais os cumes da liha de São Sebastião.

Petrograficamente, as rochas de natureza mais insaturada e alcalina são os fonólitos que, por sua vez, estão presentes como variedades com características mais ou menos agpaíticas. A partir dos contatos, a tendência manifesta nos sienitos é mais ou menos contínua, variando entre aquelas supersaturadas a saturadas, com os piroxênios adquirindo características mais ferrosas/férricas e mais sódicas, no sentido geográfico do Saco Grande e da borda oriental da llha, principalmente da Ponta Sudeste. A biotita também muda no mesmo sentido, indo de composições mais magnesianas a mais ferrosas e titaniferas. Os diques máficos também variam petrograficamente, entre aqueles plenamente insaturados até rochas saturadas, e entre rochas de maior tendência alcalina para mais fracamente alcalinas. Tanto petrográfica quanto geologicamente, os fonólitos parecem ter sido as últimas rochas a se formar, a partir de líquidos bastante enriquecidos em elementos químicos incompativeis (TR, $\mathrm{Zr}$ ), evidentemente em sódio e potássio, além de outros.

Nenhuma evidência foi encontrada de que os sienitos estariam cortando ou interrompendo outras rochas, a não ser aquelas das encaixantes Brasilianas. Como tanto os lamprófiros, como os diabásios e traquitos intrudem os sienitos, são eles todos posteriores às rochas plutônicas. Mas, petrográfica e geologicamente, não foram observadas relações satisfatoriamente elucidativas entre essas rochas de diques.

Já foi objeto de avaliação o tamanho e a forma do corpo intrusivo da llha dos Búzios. As variações petrográficas relatadas quanto ao teor de quartzo, às texturas, às variaçóes dos piroxênios e das biotitas e à localização restrita dos fonólitos altamente diferenciados são coerentes com a proposta contida na Fig. 5. Por analogias já feitas, estende-se o modelo para todos os corpos intrusivos das ilhas. No caso de Búzios, a porção sienítica da llha corresponderia ao quadrante NW, da possivel forma elíptica achatada. Essa forma pode evidentemente estar modificada (em qualquer dos corpos litorâneos) por falhamentos, submersos. 


\section{CAPÍTULO 7 \\ QUIMICA MINERAL}

O programa elaborado para a análise química dos minerais formadores das rochas da Iha dos Búzios objetivou sua caracterização e classificação. Esse programa preocupou-se, principalmente, com os elementos químicos maiores e importantes na composição química dos minerais. Outros elementos, porventura presentes em teores detectáveis, e igualmente relevantes na ocupação de sítios estruturais, foram também determinados.

Dessa forma, os feldspatos foram analisados para $\mathrm{Si}, \mathrm{Al}, \mathrm{Ca}, \mathrm{Na}, \mathrm{K}$ e $\mathrm{Fe}, \mathrm{Sr}$ e $\mathrm{Ba}$. Nefelinas, sodalitas e analcitas, igualmente analisados, mais os ânions $\mathrm{Cl}$ e $\mathrm{SO}_{3}$. Todos os ferromagnesianos (olivinas, piroxênios, anfibólios, biotitas, magnetitas e ilmenitas) foram analisados para $\mathrm{Si}, \mathrm{Ti}, \mathrm{Al}, \mathrm{Fe}, \mathrm{Mg}, \mathrm{Ca}, \mathrm{Na}, \mathrm{K}$ e Mn e Ba.

A tentativa de analisar melilitas frustou-se, uma vez que os resultados obtidos se mostraram inconsistentes, não servindo sequer para a sua identificação segura.

Durante o trabalho analítico, os objetivos ampliaram-se um pouco, passando a haver preocupação com zoneamentos quimicos, características das relações texturais, presença de exsoluções, existência de xenocristais, microxenólitos etc. Os resultados, expressos em porcentagens em peso dos óxidos, estão reunidos nas Tabelas 1 a 17, que também contêm as fórmulas estruturais, bem como, quando usual, os componentes moleculares extremos. Os valores numéricos são apresentados graficamente nas Figuras 6 a 16. Todo o tratamento matemático e gráfico; a partir dos valores porcentuais dos óxidos, foi executado no programa "Minpet for Windows - version 2,02" (Richard, 1995).

É importante observar que cada coluna de valores representa um ponto analisado, tendo havido preocupação com a qualificação dos pontos, separando-se, sempre que possivel, núcleo de borda, grãos comuns, matrizes, xeno, feno e microfenocristais etc. Tão importante quanto essas separação, as amostras e os grãos foram escolhidos dentro de universo mais variado possivel, porém restrito na quantidade de análises, tendo em vista os objetivos e os problemas logísticos.

Considerando-se a limitação na quantidade de análises, valores isolados ou grandes agrupamentos de valores analíticos não têm significância estatística rigorosa e quantitativa.

\subsection{Os feldspatos}

Algumas análises difratométricas, pelo método do pó, foram feitas em dez separados praticamente puros de feldspatos de sienitos. Os resultados identificam e caracterizam estruturalmente albita, microclinio e ortoclásio da "série microclinio, ortoclásio, albita de baixa temperatura" (cf. Deer, 1978). A albita aparece em todas as amostras investigadas, com ligeira 
indicação de predominio sobre as outras fases. Em seis das amostras, as reflexões de Bragg características do microclinio são mais intensas, em grau variável, sugerindo presença maior dos domínios ordenados (Al, Si), até o valor 1,0 de ocupação das posições $t_{1}(\mathrm{O})$, isto é, ordenamento total nas posições do Al. Em quatro das amostras, há predomínio de reflexão única para alguns planos escolhidos $(130,131,132$ e 241), apontando para a existência de plano de simetria e, conseqüentemente, desordem total nas posições do Al tetraédrico, o que caracteriza o ortoclásio. Nas amostras em que microclínio é mais abundante, pode aparecer ou não ortoclásio e, naquelas em que este último predomina, o microclinio sempre ocorre. Existe quase que uma seqüência contínua entre os estados perfeitamente ordenados ("microclínios máximos") até os totalmente desordenados ("ortoclásio"), ora com predominância de um ou outro.

Esses resultados são coerentes com a microscopia óptica e com os resultados das análises químicas.

\subsubsection{Características químicas}

Os resultados analíticos acham-se tabelados, juntamente com as formulas estruturais, e os componentes moleculares albita (Ab), ortoclásio (Or) e anortita (An) (Tabelas 1 a 3). Os dados são também apresentados em gráficos Ab-Or-An (Figs. 6 e 7).

\subsubsection{Os feldspatos dos sienitos}

Nestas rochas aparecem somente feldspatos alcalinos sob a forma de mesopertitas e micromesopertitas, com algum predomínio das fases albiticas, que representam não menos que $55 \%$ e não mais que $60 \%$ em avaliação microscópica. São poucas as amostras com alguns individuos opticamente "homogêneos", e bastante raras aquelas com todo o feldspato "homogêneo". A utilização de grandes aumentos ao microscópio (400x), as informações difratométricas e mesmo as químicas confirmam a dominância das fases albíticas, homogêneas, e permitem estabelecer a natureza micro/submicro/criptopertitica das fases potássicas $(\sim 0,001<0,005 \mathrm{~mm})$. Os indivíduos homogêneos, apresentando em geral composições muito variadas, devem ser criptomesopertiticos, uma vez que se tratam de variedades de baixa temperatura, principalmente nos casos das composições intermediárias $\left(\mathrm{Ab}_{30-60} \mathrm{Or}_{40-70}\right)$. Os valores analíticos, correspondentes aos termos mais puros, quer $\mathrm{Ab}$, quer Or, parecem indicativos de fases levemente criptoantipertíticas e criptopertíticas, e de alguma solução sólida ( $\mathrm{Na}, \mathrm{K}$ ) remanescente (cf. Smith, 1988).

De forma geral, as análises (Tabela 1, Fig. 6a) mostram a existência de algumas amostras com feldspato quase perfeitamente exsolvido, sem valores intermediários, e outras

semelhantes, mas com valores AbOr-OrAb intermediários, e ainda outras com espectro contínuó AbOr-OrAb. Os valores intermediários e, possivelmente alguns relacionados às fases 
(a)

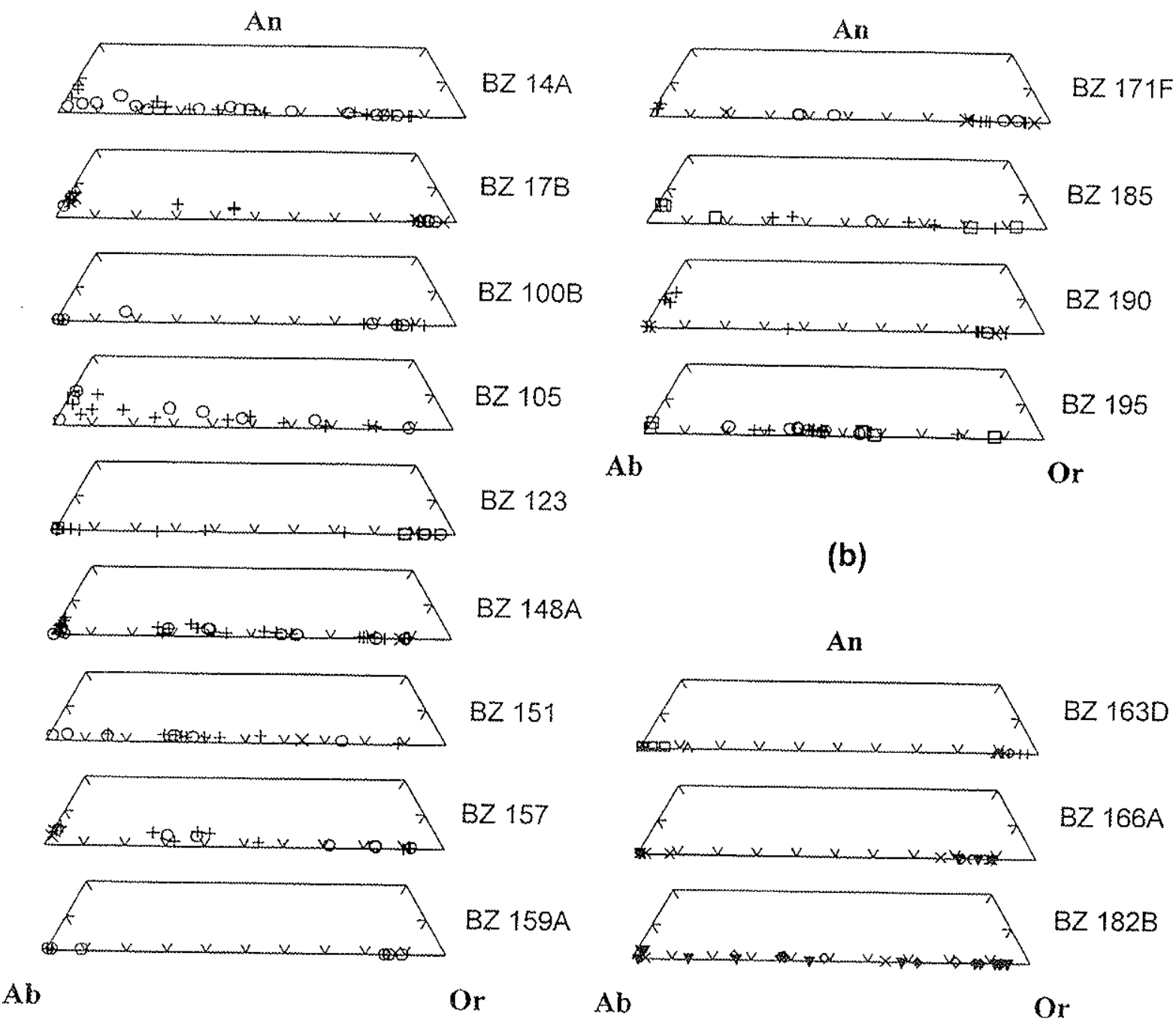

Figura 6 - Composições pontuais de feldspatos, por amostra, para (a) sienitos e microssienitos (amostras BZ 123) e (b) diques félsicos da Ilha dos Búzios, no triângulo An-Ab-Or (\% em peso). Grão comum: núcleo + , borda $\bigcirc$; microfenocristal: núcleo borda $\diamond$; intergranular $\times$; incluso $\square$; grão da matriz: núcleo $\nabla$, borda $\nabla$. 


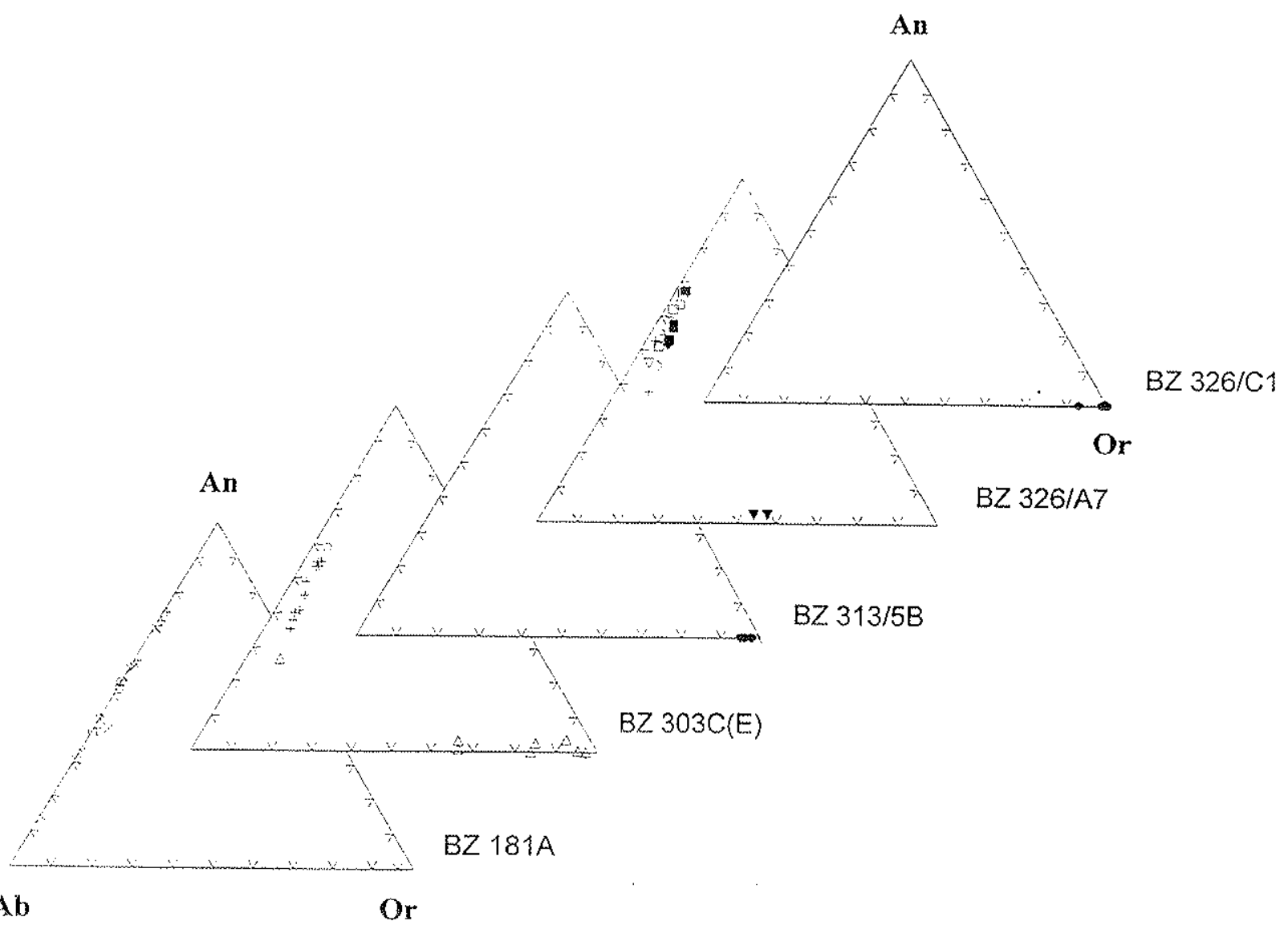

Figura 7 - Composições pontuais de feldspatos, por amostra, para os diques máficos da Itha dos Búzios, no triângulo An-Ab-Or (\% em peso). Xenocristal: núcleo borda $\square$; ocelo . Demais símbolos como na Figura 6. 
potássicas intermediárias, podem ter diferentes significados: presença de submicro a criptomesopertitas e submicro a criptopertitas $(\leqslant 0,005 \mathrm{~mm})$, análise efetuada em lamelas muito estreitas $(0,015-0,020 \mathrm{~mm})$ ou ocorrência de alguma solução sólida.

Todas as amostras apresentam valores $A n=0$ para as fases potássicas, ocorrendo o mesmo em cinco delas para as fases albíticas. Pequeno número, não mais que cinco ou seis, com AbOr intermediários contêm An abaixo de 1\%. Nenhuma das análises chega a Or $_{100}$, embora algumas situem-se proximas $\left(\mathrm{Or}_{95-98}\right)$ e todas as composiçöes albíticas, para An aproximadamente igual a 0 , atingem valores $A b_{99-100}$.

Ainda no casos em que $A n \cong 0$, as fases albíticas demostram pequena variação, em torno de $A b_{97-100} \mathrm{Or}_{0-3}$. Já as potássicas podem variar entre os extremos $\mathrm{Or}_{68-98} A b_{2-32}$. Para uma mesma amostra, esse intervalo máximo se reduz a algo em torno de ${ } r_{68-89} A b_{32-11}$, alcançando variação mínima na amostra $\mathrm{BZ} 159 \mathrm{~A}$, com $\mathrm{Or}_{85-89}$. Excluidas algumas poucas amostras, o intervalo Or $_{82-89} A b_{18-11}$ está sempre presente. Ainda para $A n \cong 0$, ocorrem dois intervalos com ausências composicionais, um entre $\mathrm{Or}_{70 / 90-60} \mathrm{Ab}_{30 / 10-40}$ e $\mathrm{Or}_{60-50} A b_{40-50}$ e o outro entre $A b_{95-75} \mathrm{Or}_{5}$. 25, e que separam as composições mais sódicas e as mais potássicas das composições intermediárias.

Os valores de An aumentam mais visivelmente para valores de Or menores que 70 , e o fazem continuamente na medida em que cresce $\mathrm{Ab}$. An chega no máximo a $10 \%$, para as fases com $O r \cong 0$, em uma ou duas amostras. Na maioria das amostras, com $O r \cong 0$, cinco incluem valores muito próximos ou iguais a $A b_{100} A n_{0} \mathrm{Or}_{0}$, e em três delas essa composição varia pouco (BZ 100B, 159A e 190). Nas outras dez amostras, os valores AbAn oscilam, de forma pouco regular, entre $A b_{100} A n_{0}$ e $A b_{90} A n_{10}$. Para as composições com Or $r_{70-0}$, An varia regular $e$ continuamente entre 10 e $\sim 0 \%$. De qualquer forma, o teor de An é na maioria das análises inferior a $5 \%$.

Algumas informações adicionais são talvez importantes. Nas amostras BZ $100 \mathrm{~B} e$ 159A, a fase potássica é o microclínio, e elas não apresentam composições intermediárias, indicando desmisturaçäo bastante acentuada. A amostra BZ 185 contém ortoclásio, exibindo espectro composicional contínuo. A amostra BZ 151 tem o feldspato opticamente homogêneo, e o mesmo acontece, parcialmente, com as amostras BZ 105 e 185. Essas três amostras são as que demonstram maior continuidade nas variações composicionais.

Entre os elementos analisados nos sienitos, Fe é o que mais aparece. A maioria dos teores é menor que $1 \%$ e grande parte inferior a $0,5 \%$. Alguns valores, contudo, são bem maiores, atingindo $3,36 \%$, portanto, uma diferença média em torno de 5 a $10 x$. As variações observadas são, principalmente, entre as distintas amostras. Categorias de indivíduos ou localização do ponto analisado apresentam pequenas variações. Há bastante semelhança nos teores de $\mathrm{Sr}$ e $\mathrm{Ba}$, em geral inferiores a $0,1 \%$. Embora pouco expressivo em termos absolutos, o teor de Ba é sempre superior ao do $\mathrm{Sr}$ e, com freqüência, chega a valores entre 0,10 até $0,50 \%$. No caso de Ba parece haver certa correlação com Or, sendo suas maiores 
concentrações observadas nos feldspatos com Or $_{80}$, ou superior. Também esses elementos variam pouco, mais entre as amostras do que entre grãos ou pontos diferentes.

\subsubsection{Os feldspatos dos diques félsicos}

Foram analisados feldspatos de dois fonólitos (BZ 163D e 166A) e de um traquito (BZ 182B), com os resultados aparecendo na Tabela 2 e Figura $6 \mathrm{~b}$. Como visto nos fonólitos, os feldspatos ocorrem como fases isoladas, albita e sanidinio (?), ou como fases exsolvidas no mesmo indivíduo cristalino (micropertitas e micromesopertitas).

Os fonólitos apresentam composiçōes sódicas, $A b_{90-100} \mathrm{Or}_{0-10}$, ou potássicas, ${ } r_{75-95} A b_{5}$. 25 , e teores de An menores que 1 a $2 \%$. As composições para o traquito estão espalhadas no intervalo $\mathrm{Ab}_{99,5} \mathrm{Or}_{0,5}-\mathrm{Or}_{95} \mathrm{~A} \mathrm{~b}_{5}$, não havendo destaque quer para os microfenocristais, quer para os indivíduos matriciais.

Nos diques félsicos, há que se separar os fonólitos do traquito (BZ 182B), exibindo diferenças grandes nos teores do elemento $\mathrm{Fe}$. O Fe, com concentrações maiores nos indivíduos da matriz e bordas de fenocristais, oscila entre 0,30 e $0,80 \%$ nos fonólitos e entre 0,50 a $2,50 \%$ no quartzo traquito. Poucas vezes $\mathrm{Sr}$ ou Ba ultrapassam $0,05 \%$, limitando-se a valores genéricos de $0,0 x \%$, com variações paralelas dos dois elementos. Não há correlação com os teores de Ab, An ou Or, verificada.

\subsubsection{Os feldspatos dos diques máficos}

Os resultados analíticos constam da Tabela 3 e os gráficos Ab-An-Or da Figura 7. As rochas analisadas cobrem todo o espectro composicional químico e representam os "tipos" magmáticos da Ilha: $\mathrm{BZ} 181 \mathrm{~A}$, basalto alcalino; 315/5B, basanito; $303 \mathrm{C}$ e $326 \mathrm{~A}$, tefrito e 326 C1, traquibasalto.

O feldspato alcalino está presente em todas as amostras, sendo de natureza fortemente potássica, exceção feita à amostra BZ 326/A7, de composição intermediária. Não ocorrem fases albiticas, ou mesmo mais sódicas que $A b_{\sim 53} \mathrm{Or}_{\sim 44} A n_{3}$. Os plagioclásios, embora predominantes nos diques máficos, foram determinados somente no basalto alcalino e nos tefritos, estando ausente nas demais amostras escolhidas.

O feldspato alcalino restringe-se principalmente ao intervalo or $_{>90-100} A b_{<10-0}$, com teores de $A n$ próximos de zero. $A$ amostra $B Z 303 C$ mostra variaçäo maior, até $\operatorname{Or}_{>65} A b_{<35}$ e $A n_{<5}$, enquanto que na amostra $B Z 326 A 7$ a sua composição é $O r_{>50<60} A b_{>50<60}$, com $A n_{>5}$.

Os plagioclásios apresentam ampla variação composicional, desde $A n_{\sim 75} A b_{\sim 25}$ até $A n_{-30} A b_{\sim 70}$; análise única forneceu valor aproximado de $A b_{85} A n_{15}$ no basalto alcalino. Nas análises da amostra 181A, Or é praticamente zero, à exceção de um ponto. Nas outras duas amostras em que o mineral foi analisado, Or aumenta sensivelmente com $\mathrm{Ab}$, chegando até os $10 \%$.

Os plagioclásios analisados representam grãos comuns, "xenocristais", 
microfenocristais e matriz, embora os resultados não evidenciem relações distintiva claras entre as diferentes categorias, de certa forma arbitradas. A mesma observação é válida para o feldspato alcalino.

Na amostra BZ 181A, um diabásio, foram analisados indivíduos comuns, maiores (GC) e menores (intergranulares), que, ao final, não exibem grandes diferenças químicas. Com relação a $\mathrm{Fe}, \mathrm{Sr}$ e $\mathrm{Ba}$, parece importante a relação $\mathrm{Ab}$ :An para esses elementos. Às menores proporções, em torno de 0,3-0,4 ( $\left.\mathrm{Ab}_{25-30} \mathrm{An} \mathrm{n}_{70-78}\right)$, correspondem os maiores valores de $\mathrm{Fe}(1,30$ $1,60 \%)$, os menores de $\mathrm{Sr}(0,24-0,26 \%)$ e valores de Ba quase nulos $(<0,02 \%)$, com altas razões Sr/Ba (»-10). Nos plagioclásios com proporções $\mathrm{Ab}$ :An mais altas, 2 e $6\left(\mathrm{Ab}_{66} \mathrm{~A} n_{33}\right.$ e $\left.A b_{85} A n_{14}\right)$, são registrados os menores valores de $\mathrm{Fe}(0,13-0,82 \%)$, valores baixos (relativamente) de $\mathrm{Sr}(0,22-0,30 \%)$ e variados de $\mathrm{Ba}$, este aparentemente não correlacionável aos altos teores de $\mathrm{Ab}$. Os valores extremos de $\mathrm{Sr}$, entre 0,35 e 0,40\%, correspondem aos plagioclásios intermediários, com razões $A b$ :An entre 0,8 e 1,4 $\left(A b_{44} A n_{54}-A b_{56} A n_{42}\right)$. Nesses feldspatos, o $\mathrm{Fe}$ apresenta teores intermediários e o Ba variados, com moderada tendência de acompanhar o $\mathrm{Sr}$.

Nessa amostra foi analisado um único grão de feldspato alcalino $\left(\mathrm{Or}_{96}\right)$, com $\mathrm{Fe}=0,18$, $\mathrm{Sr}=0,06$ e $\mathrm{Ba}=0,58$.

Em sintese, a amostra $B Z 181 \mathrm{~A}$ tem valores relativamente modestos para $\mathrm{Fe}(0,13-$ $1,60 \%), \mathrm{Sr}(0,22-0,40 \%)$ e $\mathrm{Ba}(0,00-0,16 \%)$, com razões $\mathrm{Sr} / \mathrm{Ba}$ variadas $(0,3-15)$.

Nas outras amostras analisadas, todas lamprofíricas, aparecem diferenças entre as categorias de individuos. Embora um tanto fastidioso, näo há como se fazer uma síntese global inteligivel, e daí, a compartimentação.

Nas amostras $313 / 5 \mathrm{~B}$ e $326 / \mathrm{C} 1$, foram analisados os feldspatos dos ocelos, todos muito potássicos e composicionalmente variáveis entre $\operatorname{Or}_{93} A b_{7}$ e $\operatorname{Or}_{99,6} A b_{0,4}$, com $A n=0$. Os teores de $\mathrm{Fe}$ são excepcionalmente baixos, entre 0,04 e $0,18 \%$, moderados os de $\mathrm{Sr}$, em torno de $0,40-0,50 \%$, mas com mínimos de $0,03-0,12 \%$, e altos a moderados os de $\mathrm{Ba}$, desde 0,23 até $1,75 \%$. As razões $\mathrm{Sr} / \mathrm{Ba}$ variam entre 0,27 e 2,3. Duas das nove análises exibem comportamento diferente, sendo uma delas considerada matricial; nelas, o Fe se eleva a $0,32 \%$, o Sr baixa a 0,02-0,03\% e o Ba a 0,08-0,07\%.

$\mathrm{Na}$ amostra BZ 303C, foram analisados "grãos comuns" de plagioclásio e matriz de feldspato alcalino, sendo uma única análise feita em plagioclásio matricial. Este, com composições entre $\mathrm{Ab}_{58} \mathrm{An}_{35} \mathrm{Or}_{7}$ e $\mathrm{Ab}_{40} \mathrm{An}_{55} \mathrm{Or}_{5}$, possui teores de Fe entre 0,47 e 1,12\%, de $\mathrm{Sr}$ entre 0,92 e 1,78\% e de Ba entre 0,21 e $0,56 \%$, além de razões $\mathrm{Sr} / \mathrm{Ba}$ entre 3,0 e 6,1 . Os maiores teores de $\mathrm{Sr}$ e de $\mathrm{Ba}$ são encontrados nos plagioclásios com baixas razões $\mathrm{Ab}: \mathrm{An}$, de $0,72\left(A b_{40} A n_{55}\right)$ a $0,96\left(A b_{47} A n_{49}\right)$, sendo verdadeira a reciproca: os menores teores de $\mathrm{Sr}$ e de Ba estão presentes nos plagioclásios com razões $A b$ :An de 1,10 $\left(A b_{49} A n_{45}\right)$ a 1,65 $\left(A b_{58} A n_{35}\right)$. $\mathrm{Na}$ matriz, o feldspato alcalino varia entre $\mathrm{Or}_{97} A b_{3} A n_{0}$ e $\mathrm{Or}_{65} A b_{32} A n_{3}$, com Fe entre 0,10 e $1,21 \%$, Sr entre 0,01 e $0,32 \%$ e Ba entre 0 a $0,28 \%$. Há alguma correlação dos teores de Or e 
de $\mathrm{Sr}$ e $\mathrm{Ba}$, cujas razões variam entre 0,25 e 2,5. O plagioclásio matricial, $A b_{65} A n_{27} \mathrm{Or}_{8}$, apresenta Fe igual a $0,57 \%$, Sr igual a $0,78 \%$ e Ba igual a $0,31 \%$.

$\mathrm{Na}$ amostra BZ 326A7, não se verificaram diferenças acentuadas nesses elementos entre algumas categorias de indivíduos de plagioclásio. Assim, grãos matriciais, microfenocristais e grãos comuns podem ser reunidos e separados daquilo que se julgou que fossem xenocristais. No primeiro grupo, o $\mathrm{Fe}$ varia pouco $(0,70-1,24 \%)$, Sr mostra teores elevados, entre 1,02 e 1,69\%, e Ba de 0,18 a 1,23\%, sendo a razão entre eles variável entre 1,2 e 6,8 . Os maiores teores de $\mathrm{Sr}$ e Ba são concomitantes e correspondem às razões $\mathrm{Sr} / \mathrm{Ba}$ menores $(1,2$ a 2,2$)$, e às maiores razões $A b: A n, 1,06$ a 1,42 $\left(A_{48} b_{48-54} A n_{38-45}\right)$. O plagiociásio mostra razões $A b$ :An entre 0,60 a 1,42, com Or entre 4 e $8 \%$. Feldspato alcalino da matriz possui baixos teores de $\mathrm{Sr}$ e $\mathrm{Ba}(<0,2 \%)$, com razões Sr:Ba compreendidas no intervalo 1-3.

Entre os "xenocristais", altera-se a composição média do plagioclásio, variando de $A b_{30} A_{67} \mathrm{Or}_{3}$ até $A b_{45} A n_{51} \mathrm{Or}_{4}$, com razões $\mathrm{Ab}$ :An entre 0,44 e 0,88 , mais baixas que as do plagioclásio já discutido. O Fe mostra valores, em média, mais altos, entre 1,03 e 1,45\%, enquanto que $\mathrm{Sr}$ e Ba mais baixos, respectivamente, 0,98 a $1,39 \%$ e 0,14 a $0,45 \%$, com razões $\mathrm{Sr}: B a$ mais altas, 3,1 a 7,1. Valores mais elevados são concordantes para $\mathrm{Sr}$ e $\mathrm{Ba}$, mas não são acompanhados pelo $\mathrm{Fe}$. Não ocorre relação com a razão $\mathrm{Sr}: \mathrm{Ba}$, uma vez que essa se mantém situada entre 3 e 7 , embora seja mantida a relação com os teores de $A b$ mais elevados (razões Ab:An entre 0,65-0,88).

\subsection{Os feldspatóides}

$\dot{E}$ oportuno lembrar que nas rochas examinadas petrograficamente ocorre nefelina nos fonólitos e alguns microssienitos, acompanhada ou não por sodalita, quase sempre subordinada. A analcita aparece na maioria dos diques máficos, lamprofíricos, quer como mineral matricial e intersticial, com contornos indistintos, quer nos ocelos, quase sempre ao lado de vidro. Os resultados das análises desses minerais estão nas Tabelas 4 e 5 , onde também se encontram os dados referentes à fórmula quimica mineral e os componentes moleculares usuais para a nefelina ( $\mathrm{Ne}$, nefelina; $\mathrm{Ks}$, kalsilita; $\mathrm{Qz}$, quartzo).

Embora seja grande o número de amostras com nefelina e com sodalita, esses minerais foram analisados somente na amostra BZ 163D.

As nefelinas apresentam grande homogeneidade composicional (Tabela 4a), com pequenas variações. $\mathrm{O} \mathrm{Na}_{2} \mathrm{O}$ situa-se entre 16,21 e $16,27 \%$ e o $\mathrm{K}_{2} \mathrm{O}$ entre 5,57 e $5,70 \%$, praticamente inexistente o $\mathrm{CaO}$. Em termos de componentes moleculares, Ne passa de 73,66 a $74,54 \%$, Ks de 18,61 a 19,68\% e Qz de 6,49 a 7,48\%. Essas composições situam-se pouco acima do "campo de convergência Morozewics-Buerger" (cujos limites são as composiçōes $\mathrm{Ne}_{75} \mathrm{Ks}_{31} \mathrm{Qz}_{24}$ e $\mathrm{Ne}_{73} \mathrm{Ks}_{27} \mathrm{Qz}_{0}$ ), indicando temperaturas de cristalização da ordem de $700^{\circ} \mathrm{C}$. 
As análises das sodalitas (Tabela 4b) confirmam o grupo mineral e a variedade como sendo sodalita (cf. Deer, 1978). Os teores de $\mathrm{Na}_{2} \mathrm{O}$ variam entre 24,45 e 24,93\% e os de $\mathrm{Cl}$ entre 6,86 e $7,33 \%$, mostrando homogeneidade composicional, embora em número restrito de amostras e de indivíduos.

As analcitas foram analisadas, em maior número de amostras e em numerosos individuos, em duas situações texturais: matriciais/intersticiais e ocelares. Os resultados (Tabela 5) evidenciam dois agrupamentos composicionais, que correspondem, em geral, às duas situações citadas. As analcitas matriciais têm valores de $\mathrm{Na}_{2} \mathrm{O}>10,0 \%, \mathrm{~K}_{2} \mathrm{O}<1,0 \%$, $\mathrm{CaO}<1,0 \%$ e $\mathrm{FeO}<1,0 \%$; as dos ocelos apresentam freqüência maior dos valores de $\mathrm{Na}_{2} \mathrm{O}<5,0 \%, \mathrm{CaO}>2,0 \%$ e $\mathrm{FeO} 1,0-3,0 \%$, com teores de $\mathrm{K}_{2} \mathrm{O}$ anormalmente elevados, entre 2,0 e $5,00 \%$.

Em uma única amostra, foram analisados grãos de nefelina e de sodalita. A nefelina apresenta valores muito baixos para $\mathrm{Sr}$ e $\mathrm{Ba}$, sendo o Fe mais significativo, em especial nas rochas fonolíticas: 1,21 a 1,54\%. A sodalita possui teores de Fe entre 0,61 e 0,75, além de Sre Ba praticamente nulos.

Já as analcitas pesquisadas em quatro amostras de diques máficos, principalmente como matriz e constituinte dos ocelos, contêm valores mais significativos. Para as variedades matriciais, o Fe varia de 0,05 a $1,69 \%$, o Ca de 0,04 a $2,65 \%$, o Sr 0,00 a $0,96 \%$ e o Ba de 0,00 a $0,11 \%$, com as razões $\mathrm{Sr} / \mathrm{Ba}$ oscilando entre 1 e 8,7 . As razões $\mathrm{Na}_{2} \mathrm{O} / \mathrm{K}_{2} \mathrm{O}$ variam entre 0,38 e 433. Aparentemente, $\mathrm{Fe}, \mathrm{Ca}, \mathrm{Sr}$ e $\mathrm{Ba}$ aumentam com a elevação de $\mathrm{K}$, no que são normalmente acompanhados por $\mathrm{Na}$; com a elevação de $\mathrm{K}$ e diminuição de $\mathrm{Na}$, pode ocorrer aumento de $\mathrm{Fe}$, mas queda nos teores de $\mathrm{Ca}$, $\mathrm{Sr}$ e $\mathrm{Ba}$. A razão $\mathrm{Sr} / \mathrm{Ba}$ não acompanha diretamente as variações de $\mathrm{Sr}$ e $\mathrm{Ba}$, mas há certa tendência para a diminuição com o crescimento da concentração desses elementos.

Entre as analcitas ocelares observam-se as seguintes variações: Fe de 0,29 a 2,88\%; Ca de 0,02 a $5,81 \%$; Sr de 0,00 a $1,13 \%$; Ba de 0,00 a $0,19 \% ; \mathrm{K}$ de 0,05 a $4,52 \%$; e razões $\mathrm{Sr} / \mathrm{Ba}$ entre 1,5 e 6,0 e $\mathrm{Na} / \mathrm{K}$ entre 1,11 e 254 . A tendência geral é de que para valores menores de $\mathrm{Na}$ e maiores de $\mathrm{K}$, tem-se aumento nos teores de $\mathrm{Fe}, \mathrm{Ca}, \mathrm{Sr}, \mathrm{Ba}$ e na razão $\mathrm{Sr} / \mathrm{Ba}$. As amostras BZ 303C, 313/5B e $326 \mathrm{~A} 7$ possuem baixos conteúdos de $\mathrm{K}(<0,1 \%)$, enquanto que a amostra $326 \mathrm{C} 1$ mais elevados, com o elemento apresentando certa preferência para o material dos ocelos $\left(\mathrm{K}_{2} \mathrm{O}\right.$ variando de $\sim 3,80$ a $\left.4,50 \%\right)$.

\subsection{As olivinas}

As olivinas analisadas são de rochas lamprofíricas e aparecem como fenocristais/microfenocristais e xenocristais (?), ou parte de "microxenólitos", nunca matricialmente. Não há diferenças significativas entre os valores analiticos registrados na Tabela 6 , que 
também reúne a fórmula estrutural do mineral.

Todos os resultados obtidos são de olivinas magnesianas, com valores de 76,3 a $84,5 \%$ para Fo, que correspondem à variedade crisolita. Os teores de alguns outros elementos são moderados, com $\mathrm{CaO}$ variando de 0,18 a $0,38 \%$; $\mathrm{MnO}$ de 0,17 a 0,53\%; e NiO de 0,12 a $0,24 \%$. Observerse que NiO está ausente em parte das análises.

Os valores de $\mathrm{MgO}$ e $\mathrm{FeO}$ não exibem variação continua. A olivina da amostra $\mathrm{BZ} 326$ A7 possui composição média $\mathrm{FO}_{76,6}$, com máximo de $76,9 \%$ e minimo de $76,3 \%$. Na amostra $\mathrm{BZ}$ $326 \mathrm{C} 1$, a média é de $\mathrm{Fo}_{83}$, com valores extremos de $84,5 \%$ e $80,6 \%$. A variação reconhecida é, claramente, de amostra para amostra, sendo pouco significativas as diferenças entre individuos ou centro/borda do mesmo indivíduo.

\subsection{Os piroxênios}

Petrologicamente, são estes os minerais ferromagnesianos mais importantes, estando presentes em todos os tipos de rochas da llha, não obstante aparecerem como "restos" ou ausentarem-se parcialmente em alguns deles (quartzo microssienitos e amostras de diques traquiticos).

$\mathrm{Na}$ condução das análises, os pontos analisados foram agrupados em grãos comuns (a grande maioria), intergranulares e inclusos nos sienitos. Nos diques máficos, as categorias texturais são mais variadas e adotou-se, até certo ponto arbitrariamente, as classes denominadas de xenocristais, microfenocristais e grãos matriciais. Nos diques félsicos, foram analisados somente grãos comuns, aceitos tão-só como núcleos face às suas dimensões reduzidas. Em todos os agrupamentos, e sempre que possivel, foram analisados núcleo (N) e bordas $(B)$ dos cristais. Núcleos e bordas não significam, obrigatoriamente, ponto único no centro do indivíduo e outro no seu limite periférico, mas em geral dois a cinco pontos distribuidos entre essas posições. Dessa forma, é de se esperar resultados mais constantes nos núcleos e mais variáveis nas bordas, o que não invalida a prática.

Tendo em vista a visão conjunta e comparativa dos resultados e dos tratamentos gráficos, a exposição é feita em blocos, sem a subdivisão adotada para os feldspatos.

Os resultados analíticos, expressos em porcentagem em peso dos óxidos, as fórmulas estruturais calculadas com base em 6 átomos de oxigênio e 4 cátions, e os componentes moleculares extremos, Wo-En-Fs e Jd-WEF-Ae, bem como os valores $Q$ e $J$ estão nas Tabelas 7 a 9 . Ferro total foi calculado como $\mathrm{FeO}$ e a relação $\mathrm{Fe}^{2+} / \mathrm{Fe}^{3+}$ foi determinada na fórmula estrutural através do balanço de cargas. O tratamento gráfico é apresentado nas Figuras 8 a 14.

A classificação e a nomenclatura adotadas seguem a proposta do IMA (Morimoto, 1988), com os dados projetados nos gráficos $Q \times J(Q=C a+M g+F e ; ~ J=2 ~ N a)$, En - Fs - Wo 
$\left(\mathrm{En}=\mathrm{Mg}_{2} \mathrm{Si}_{2} \mathrm{O}_{6} ; \mathrm{Fs}=\mathrm{Fe}_{2} \mathrm{Si}_{2} \mathrm{O}_{6} ; \mathrm{Wo}=\mathrm{Ca}_{2} \mathrm{Si}_{2} \mathrm{O}_{6}\right)$ e Jd $-\mathrm{WEF}-\mathrm{Ae}\left(\mathrm{Jd}=\mathrm{NaAlSi}_{2} \mathrm{O}_{6} ; \mathrm{WEF}=\mathrm{Wo}+\mathrm{En}+\right.$ $\mathrm{Fs} ; \mathrm{Ae}=\mathrm{NaFe}^{3+} \mathrm{Si}_{2} \mathrm{O}_{6}$ ). São ainda apresentados graficamente os valores auf (átomos por unidade de fórmula) dos elementos em diagramas com os números $\mathrm{mg \#} \mathrm{(mg \#} \mathrm{=} \mathrm{MgO} / \mathrm{MgO}$ * $\mathrm{FeO}$ ), além do tradicional triângulo de variação $\mathrm{Mg}-\left[\mathrm{Fe}^{2+4}+\mathrm{Mn}+\left(\mathrm{Fe}^{3+}-\mathrm{Na}\right)\right]-\mathrm{Na}$.

\subsubsection{Classificação e caracterização molecular}

Os clinopiroxênios dos sienitos apresentam acentuada variação composicional, mostrando inclusive separação gráfica visivel entre núcleos e bordas (126 pontos). No diagrama $Q \times J$ (Fig. 8), alinham-se nos limites superiores do campo Quad, desde composições fortemente ferromagnesianas, estendendo-se para o campo cálcio-sódico, com acentuada tendência sódica. Nesse campo, algumas composições aproximam-se dos valores limites, máximos de $Q$ e mínimos de $\mathrm{J}$, grupando a maioria das análises dos núcleos. Alguns núcleos posicionam-se no limite Quad/Ca-Na, e poucos o ultrapassam. Aparentemente, as bordas estendem-se muito mais no campo Ca-Na. O gráfico En-Fs-Wo aparece na mesma ilustração, com os resultados analíticos formando dois grupamentos separados de pontos: o maior deles cai nos campos das augitas e dos diopsídios, adentrando o das hedembergitas, e o outro, com composições mais ricas em ferro e mais pobres em cálcio, mostrando termos ainda augíticos e (poucos) hedembergíticos. Segundo a classificação de Poldervaart e Hess (1951; cf. Deer et al., 1978), os minerais corresponderiam a augitas e salitas, até ferrossalitas, ferroaugitas, hedembergitas e ferrohedembergitas. Ainda na mesma figura, os valores analíticos estão projetados no triângulo composicional, também molecular, Jd-WEF-Ae. A distribuição dos pontos é análoga àquela descrita para o gráfico $Q \times \mathrm{J}$, com os núcleos ocupando o campo Quad e as bordas avançando mais no sentido das egirina-augitas. Toda a distribuição é quase linear e próxima ao lado Ae-WEF, com valores de Jd $\leq 5 \%$.

Os clinopiroxênios dos diques félsicos, sempre com grande participação do componente sódico, exibem distribuição linear, tanto no gráfico $Q \times \mathrm{J}$, quanto no Jd-WEF $A e$ (Fig. 9). No primeiro deles, alinham-se paralelamente e muito próximo ao limite superior dos campos Ca-Na e $\mathrm{Na}$, desde valores em torno de $Q$ e J 1,0 até composiçöes sódicas, com $\mathrm{Q} \sim 0,3$ e J 1,7. A distribuição de pontos indica vazio intermediário, que deve ser atribuído ao fato de terem sido analisadas somente duas amostras, uma com piroxênio mais cálcico e a outra de natureza mais sódica. No diagrama Jd-WEF-Ae, mostram distribuição semelhante, estando alinhados paralelamente e próximos ao lado WEF-Ae $(\mathrm{Jd} \leq 5 \%)$, com valores de Ae $\sim 45 \%$, campo das egirinamaugitas, até Ae $75 \%$ e WEF $<20 \%$, campo das egirinas. Vazio composicional similar ao anterior está também presente (WEF 30-45\%).

Os clinopiroxênios dos diques máficos, não obstante suas variações ópticas, principalmente quanto à cor, pleocroísmo e zoneamento, quando lançados no gráfico $Q \times J$ (Fig. 10) agrupam-se densamente no campo Quad, com valores restritos de $Q(1,60-1,80)$ e J 

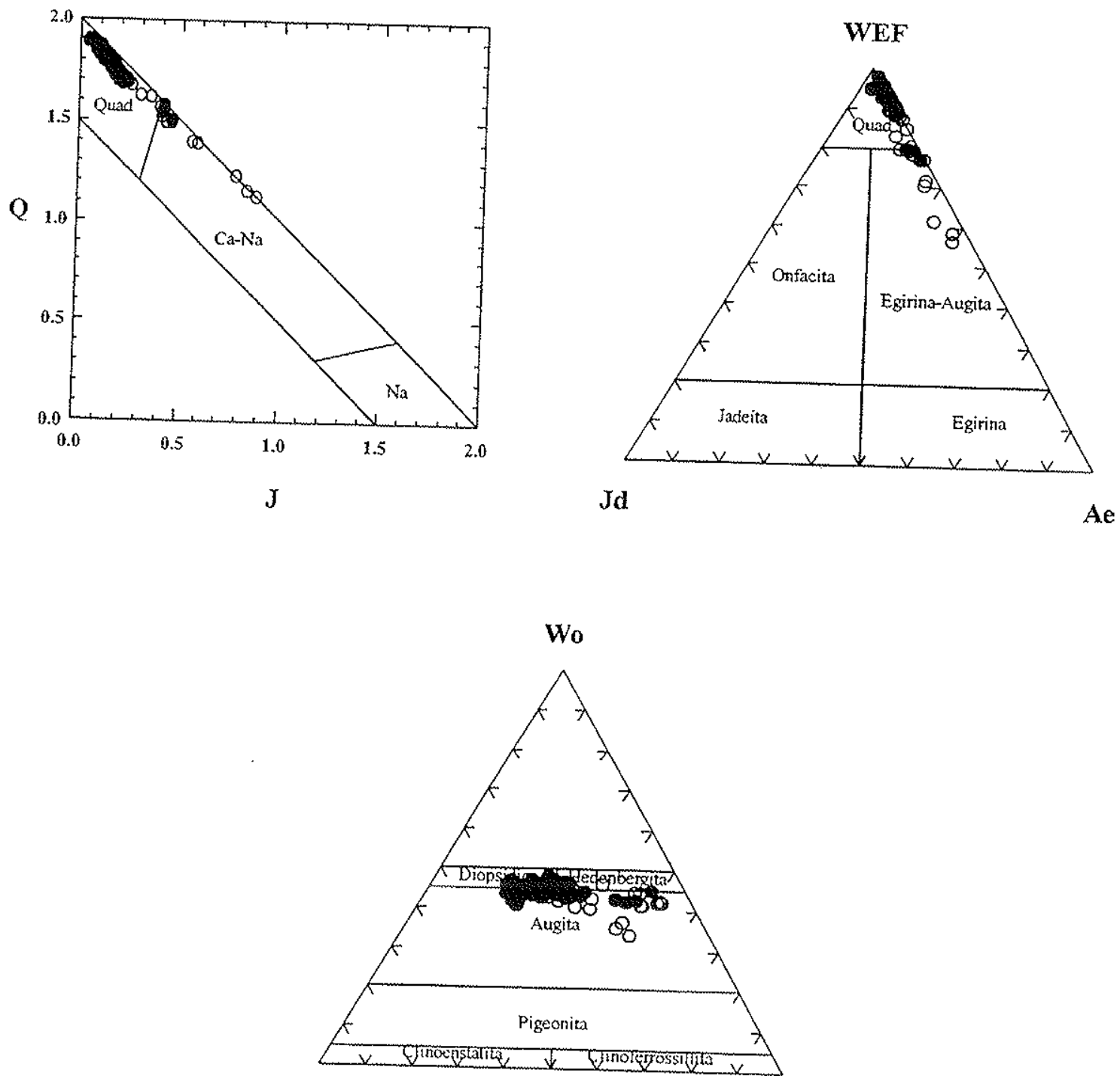

En

Fs

Figura 8 - Diagramas Quad $\left(\mathrm{Ca}+\mathrm{Mg}+\mathrm{Fe}^{2+}\right)-J(2 \mathrm{Na})$, En (enstatita) - Fs (ferrossilita) - Wo (wollastonita) e Jd (jadeíta) - Ae (egirina) - WEF (Quad) de Morimoto (1988) para piroxênios de sienitos da tha dos Búzios. Grão comum: núcleo borda $\bigcirc$; 

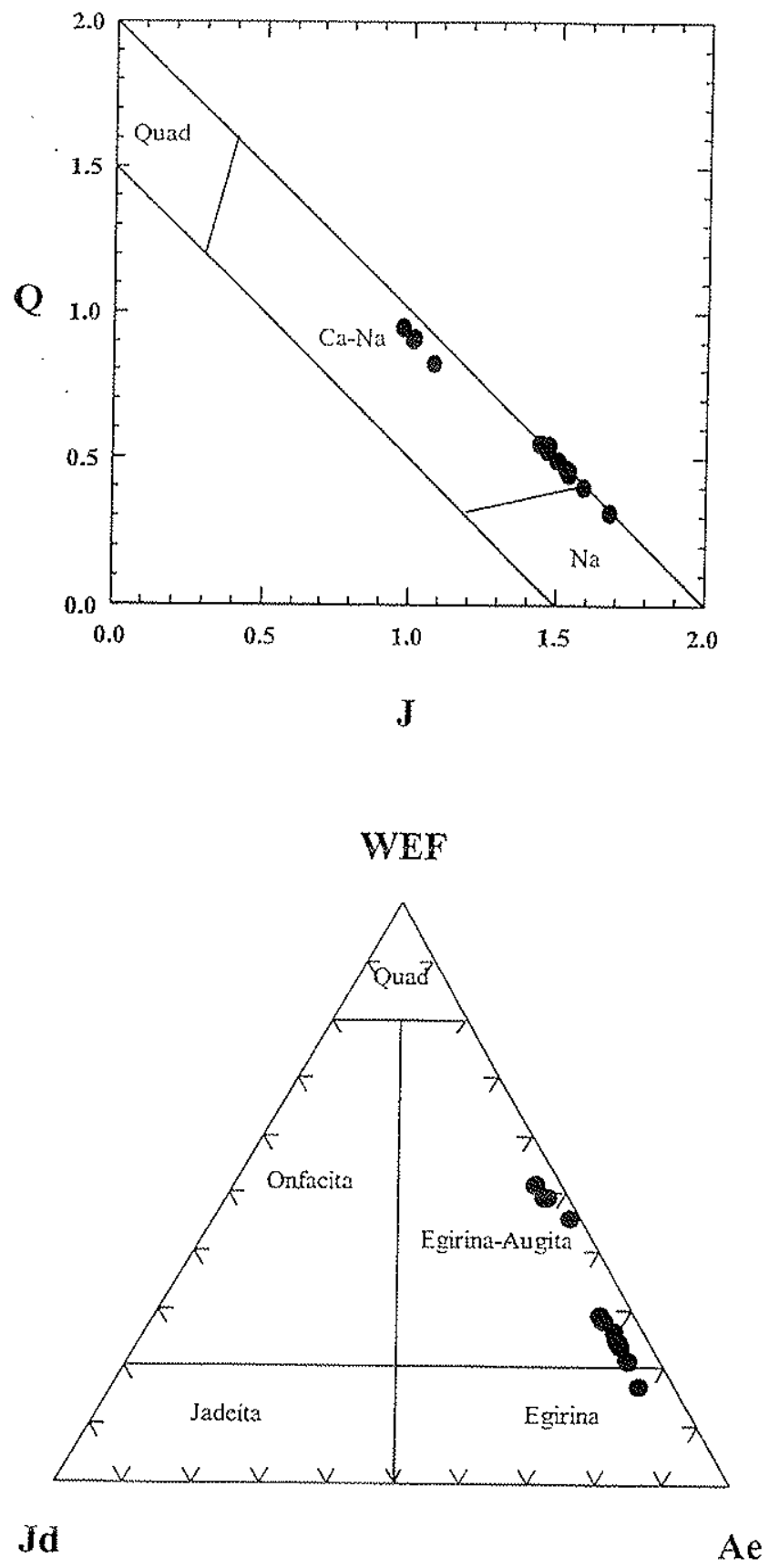

Figura 9 - Diagramas Quad $\left(\mathrm{Ca}+\mathrm{Mg}+\mathrm{Fe}^{2+}\right)$ - J (2Na) e Jd (jadeíta) - Ae (egirina) - WEF (Quad) de Morimoto (1988) para piroxênios de diques félsicos da Ilha dos Búzios. Símbolos como na Figura 8. 

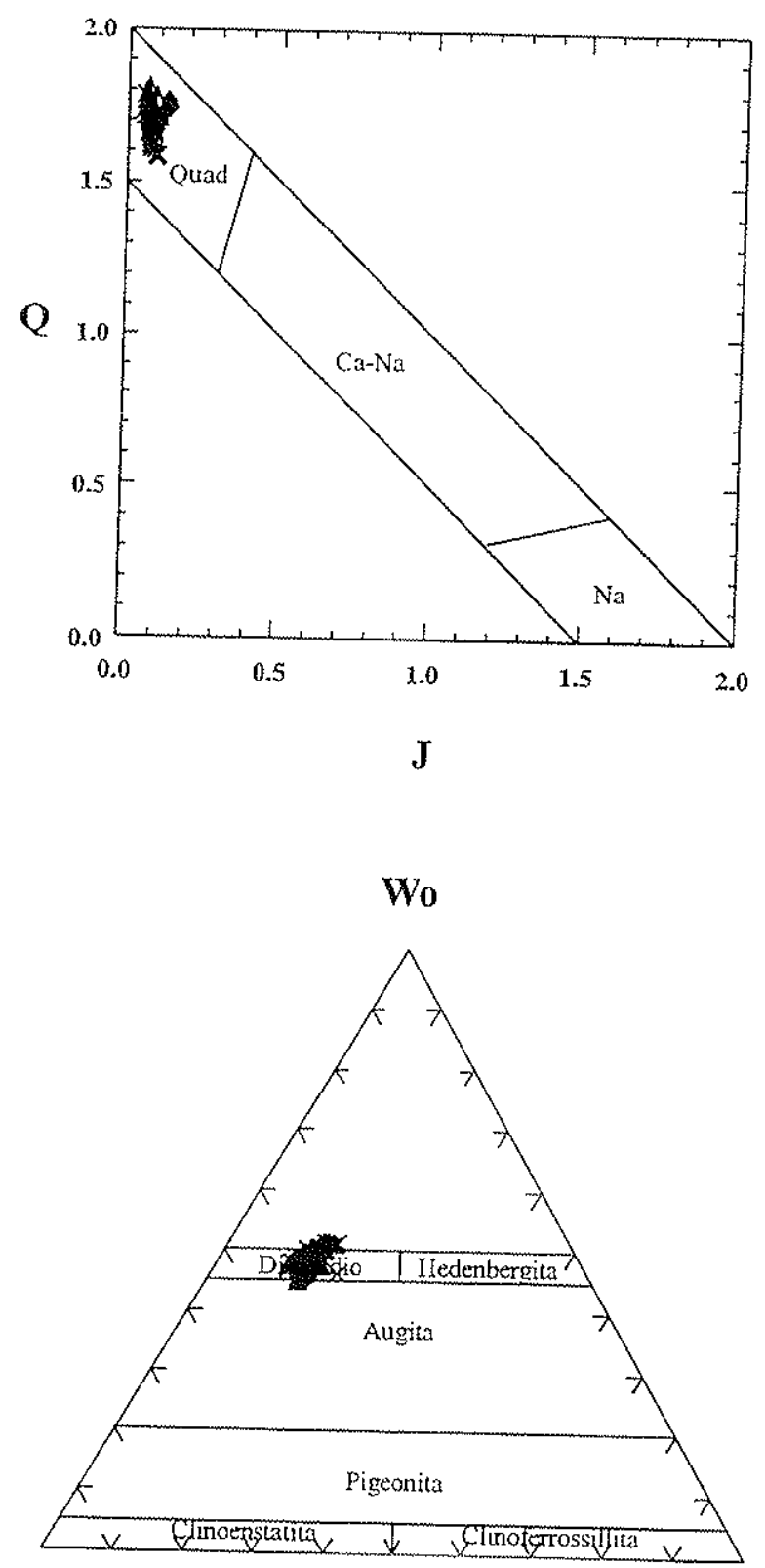

En

Fs

Figura 10 - Diagramas Quad $\left(\mathrm{Ca}+\mathrm{Mg}+\mathrm{Fe}^{2+}\right)-\mathrm{J}(2 \mathrm{Na})$ e En (enstatita) - Fs (ferrossilita) - Wo (wollastonita) de Morimoto (1988) para piroxênios de diques máficos da Ilha dos Búzios. Matriz $\times$; microfenocristal: núcleo $\mathbf{A}$, borda $\triangle$; xenocristal: núcleo borda $\diamond ;$ demais símbolos como na Figura 8. 

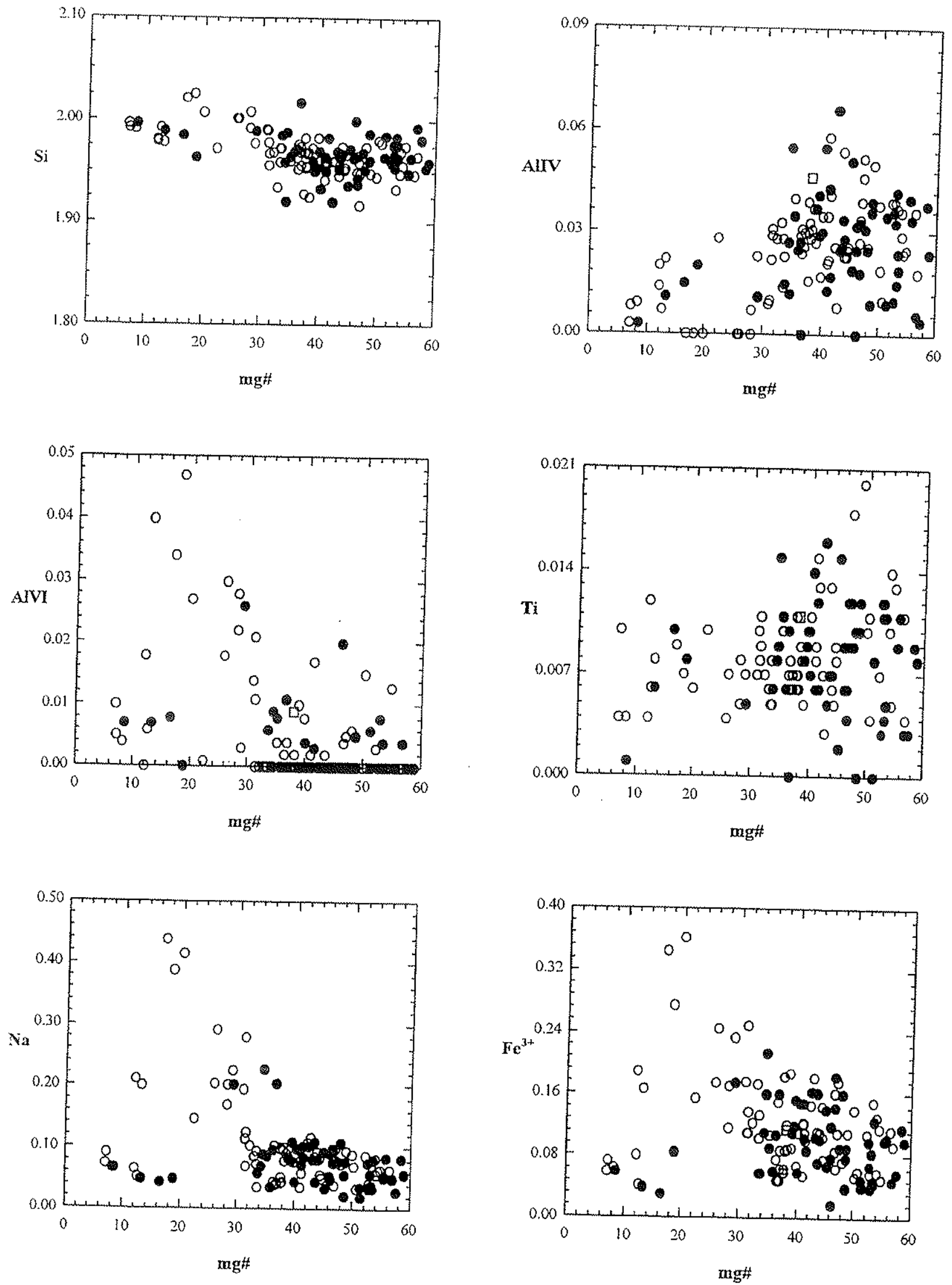

Figura 11a - Diagramas de variação mg\# vs. $\mathrm{Si}, \mathrm{Al}^{\mathrm{IV}}, \mathrm{Al}^{\mathrm{VI}}$, $\mathrm{Ti}, \mathrm{Na}$ e $\mathrm{Fe}^{3+}$ (auf) para piroxênios de sienitos da Ilha dos Búzios. Símbolos como na Figura 8. 

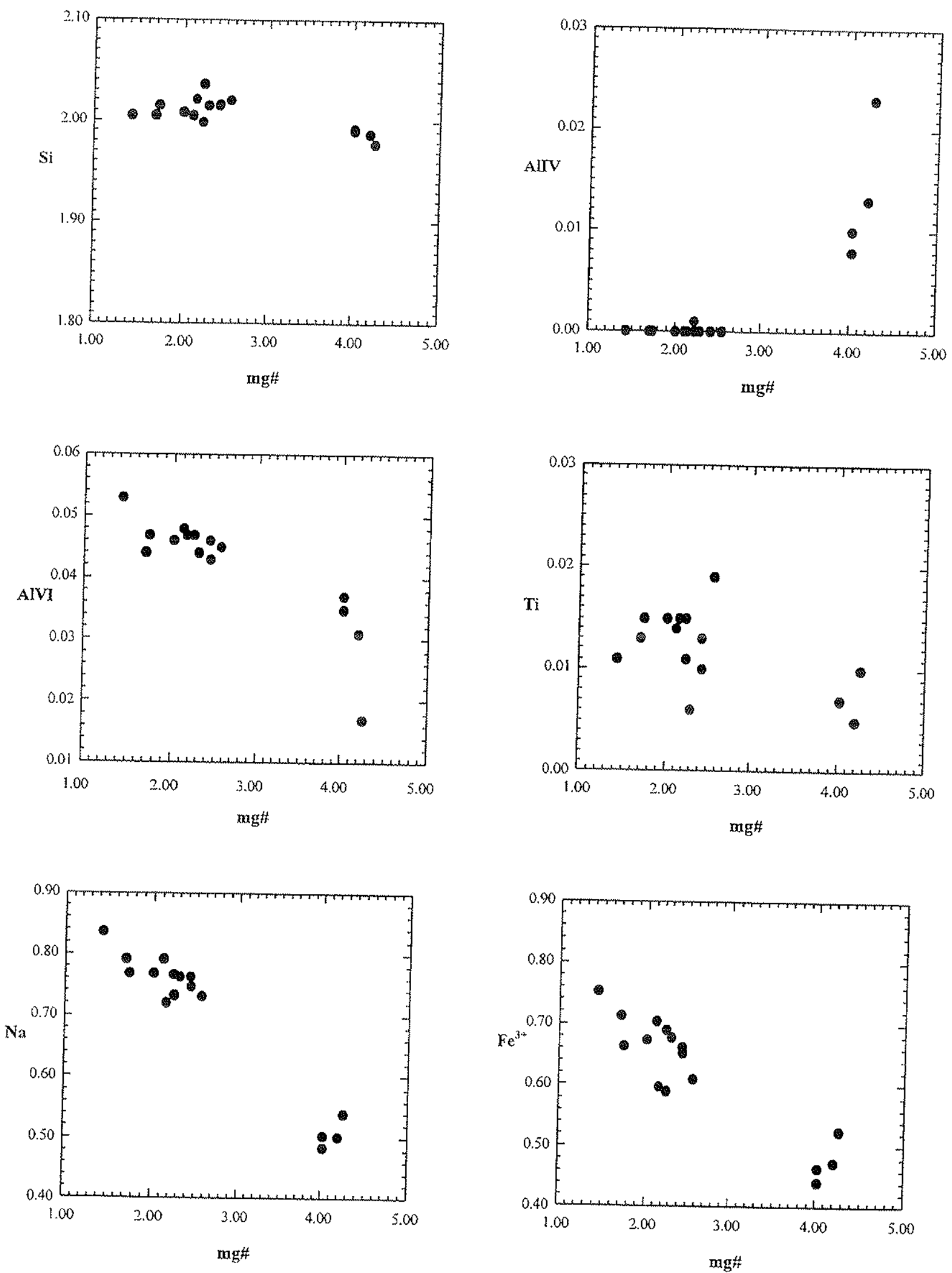

Figura 1 1 b - Diagramas de variação mg\# vs. Si, $\mathrm{Al}^{\mathrm{IV}}, \mathrm{Al}^{\mathrm{VI}}$, Ti, Na e Fe $\mathrm{Fe}^{3+}$ (auf) para piroxênios de diques félsicos da Ilha dos Búzios. Símbolos como na Figura 8. 

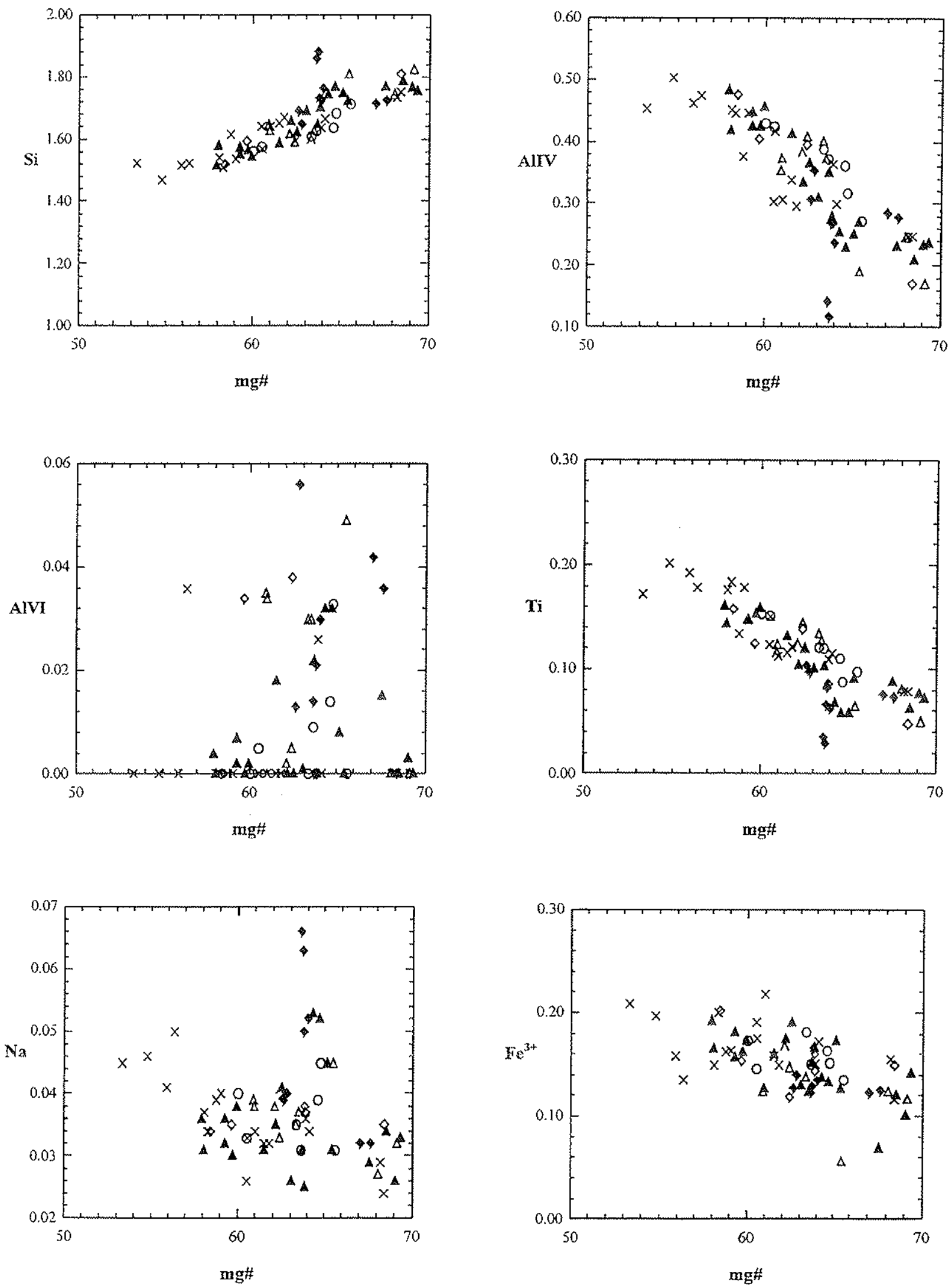

Figura 11c - Diagramas de variação mg\# vs. Si, $\mathrm{Al}^{\mathrm{IV}}, \mathrm{Al}^{\mathrm{VI}}, \mathrm{Ti}, \mathrm{Na}$ e $\mathrm{Fe}^{3+}$ (auf) para piroxênios de diques máficos da Tlha dos Búzios. Símbolos como nas Figuras 8 e 10. 


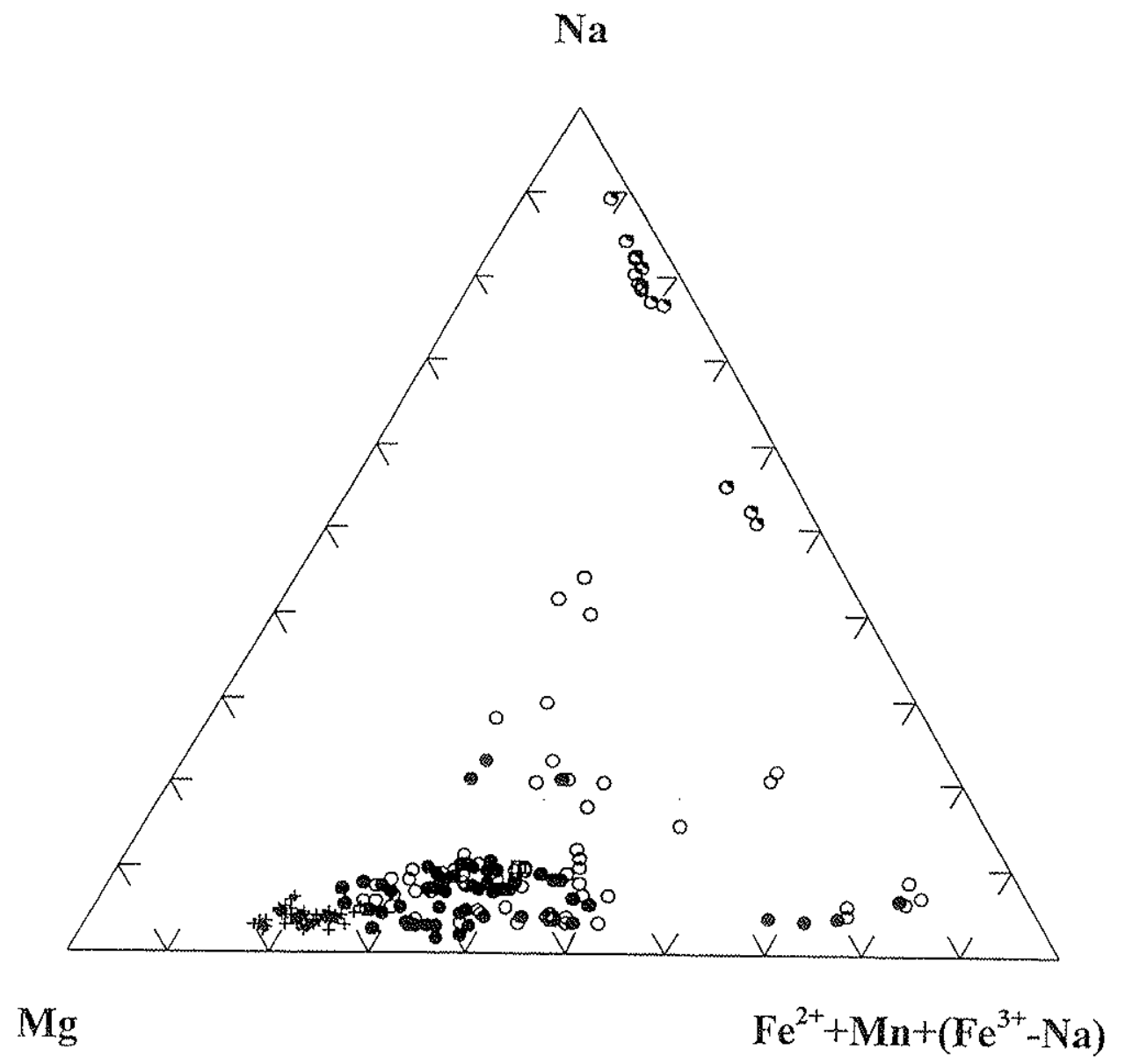

Figura 12 - Diagrama $\mathrm{Mg}-\mathrm{Na}-\left[\mathrm{Fe}^{2+}+\mathrm{Mn}+\left(\mathrm{Fe}^{3+}-\mathrm{Na}\right)\right]$ para piroxênios de sienitos (grão comum: núcleo , borda $O$; inclusão $\square)$, diques félisicos $(\circlearrowleft)$ e diques máficos $(+)$ da Ilha dos Búzios. 


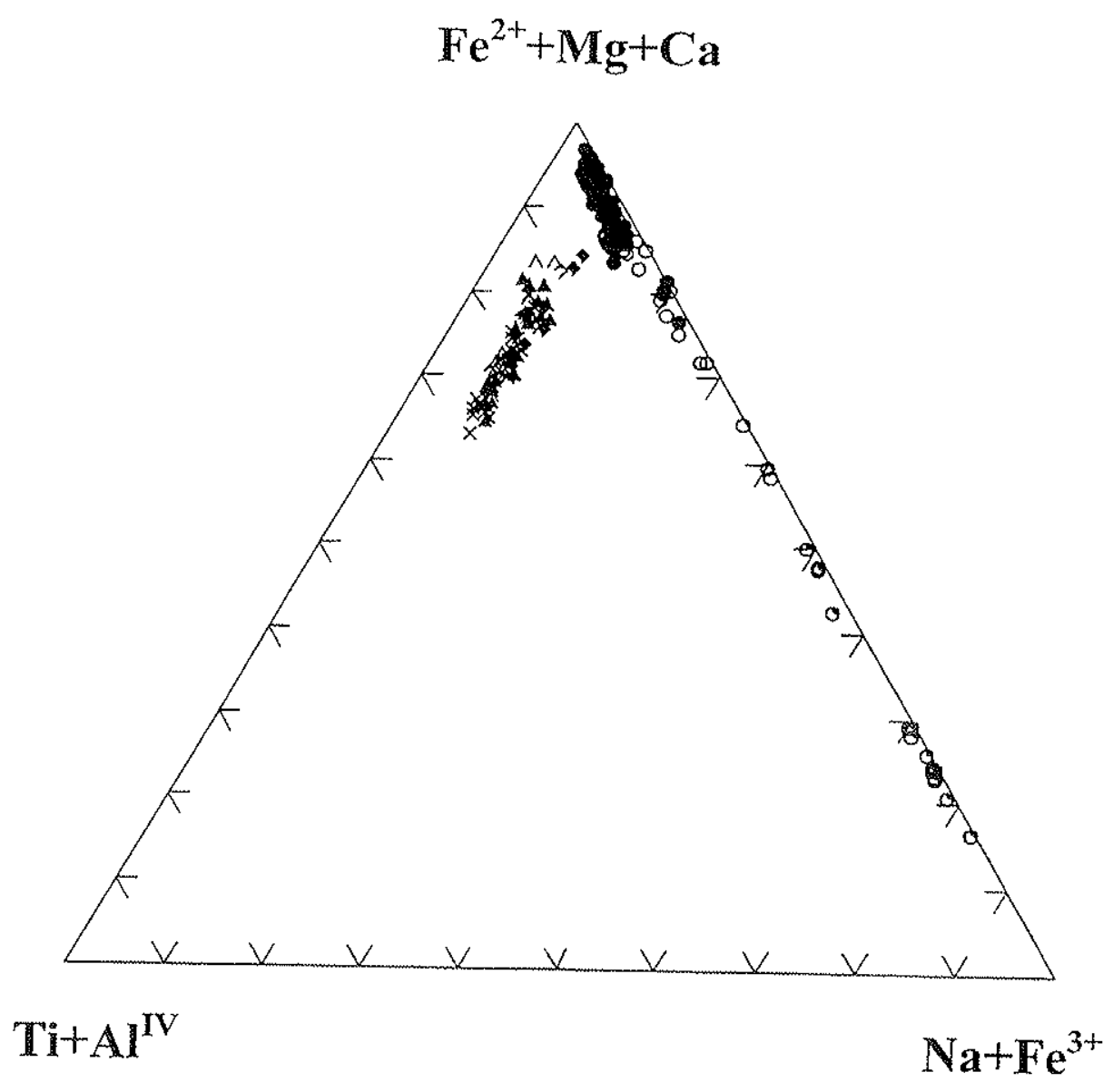

Figura 13 - Diagrama $\left(\mathrm{Ti}+\mathrm{Al}^{\mathrm{IV}}\right)-\left(\mathrm{Fe}^{2+}+\mathrm{Mg}+\mathrm{Ca}\right)-\left(\mathrm{Na}+\mathrm{Fe}^{3+}\right)$ para piroxênios de sienitos (grão comum: núcleo , borda $\bigcirc$; inclusão $\square$ ), diques félsicos $(\varangle$ ) e diques máficos (xenocristal: núcleo , borda $\diamond$; microfenocristal: núcleo , borda $\triangle$; cristal da matriz: $X$ ) da Itha dos Búzios. 


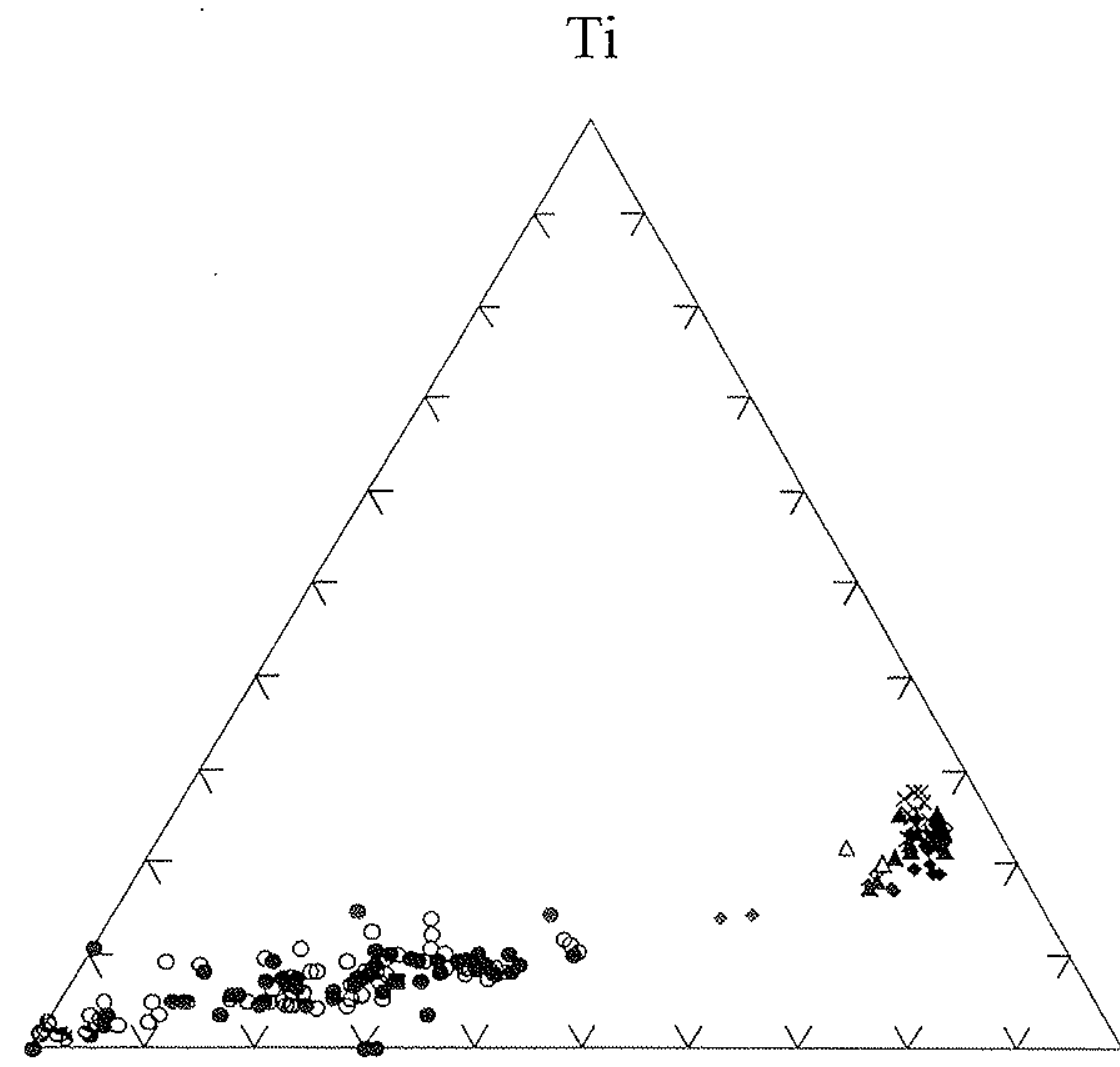

$\mathrm{Na}$

$\mathrm{Al}^{\mathrm{IV}}$

Figura 14 - Diagrama Na Ti-Al ${ }^{\mathrm{IV}}$ para piroxênios de sienitos (grão comum: núcleo , borda $O$; inclusão $\square$ ), diques félsicos ( $\diamond$ ) e diques máficos (xenocristal: núcleo , borda $\diamond$;

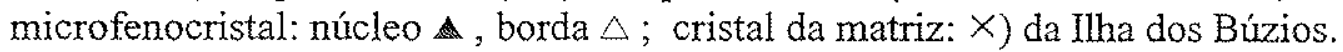


$(0,05-0,15)$ e natureza fortemente cálcio-ferromagnesiana. Da mesma figura consta o triângulo En-WEF-Fs, onde as composições estão também densamente agrupadas no centro do campo dos diopsidios, com número restrito de composiçōes augíticas. Conforme a classificação de Poldervaart e Hess (1951; cf. Deer et. al., 1978), corresponderiam a salitas e augitas (e fassaitas ?).

\subsubsection{Valores mg\# e ocupações cationnicas}

Nos diagramas mg\# $x$ auf, mostra-se a variação desse parâmetro em relação a alguns cátions (Figs. 11a-c), importantes estruturalmente e nas substituições acopladas. Em T: Si, $\mathrm{Al}^{\mathrm{N}}$ e $\mathrm{Fe}^{3+}$; em $\mathrm{M} 1: \mathrm{Al}^{\mathrm{V}}$, $\mathrm{Ti}$ e $\mathrm{Fe}^{3+}$; em $\mathrm{M} 2$ : $\mathrm{Na}$. Os valores de $\mathrm{Mg}$ e $\mathrm{K}$ em M2 são quase sempre nulos, enquanto que as flutuaçöes de $\mathrm{Ca}$ em $\mathrm{M} 2$ e de $\mathrm{Mg}$ em M1 refletem-se nos diagramas classificatórios já abordados. Com bastante freqüência, os valores tanto de $\mathrm{Fe}^{3+} \mathrm{em} \mathrm{T}$, como de $\mathrm{Al}^{\mathrm{VI}}$, são nulos, com alguns valores diferentes erráticos.

Os clinopiroxênios dos sienitos exibem em geral ampla variação no valor de mg\#, entre 7,0 e 59,0, e correlação nem sempre muito evidente com os cátions escolhidos (Fig. 11a). 0 número de análises (pontos plotados) é de 126, sendo 53 de núcleos e 73 de bordas de grãos. A distribuição dos valores de mg\# não é regular, inexistindo agrupamentos ou tendências muito acentuadas, ainda que essas características estejam presentes. Entre mg\# 7,0 e 33,5, aparecem 24 pontos ( $19 \%$ do total) de bordas e 5 de núcleos ( $4 \%$ do total), sendo que os 97 pontos restantes, 49 de bordas e 48 de núcleos ( $77 \%$ do total), concentram-se entre 33,5 e 59,0 . Isto é, o valor 33,5 separa predomínio de bordas (valores inferiores) da igualdade de freqüencia de composições de bordas e núcleos. A variação de mg\# nas bordas é de certa forma duas vezes superior à dos núcleos. Estes mantêm caracteristicas mais ferromagnesianas e variam menos.

Quando se examinam isoladamente as amostras, verifica-se que $1 / 3$ a $1 / 2$ delas têm bordas com mg\# menores e que parte apresenta valores bem distintos para bordas e núcleos. A maioria das amostras se espalha por pequeno intervalo, sendo que apenas duas (BZ $159 \mathrm{~A} e$ BZ 171; Ponta Sudeste e Saco Grande, respectivamente) cobrem toda área composicional; a amostra BZ 100B, que é destoante das outras sob qualquer aspecto, possui valores de mg\# $<19,0$ e inferiores a 13,0 para as bordas. Ainda com valores inferiores 33,5 , aparece parte das composições pontuais das amostras BZ 159A (até 17,0) e 171F (até 12,0).

Quando as amostras são tratadas em conjunto, as tendências acham-se em grande parte obliteradas, ainda que visiveis. Quando isoladas, é bem marcada a tendência de valores menores de $\mathrm{mg}$ \# para as bordas e maiores para os núcleos.

A Figura 11a reúne a correlação Si x mg\#. Gráficos amostra por amostra foram feitos e analisados, mas não são apresentados para não sobrecarregar ainda mais as figuras. Sem ter que recorrer ao exame detido das tabelas, é possivel verificar que Si ocupa quase toda posição 
$T$, desde $1,915(96 \%)$ a 2,000, com alguns valores anômalos acima de 2,000, estes referentes às amostras BZ 159A ou 171F. A análise individual revela correlação negativa entre Si e mg\# nas amostras $\mathrm{BZ} 100 \mathrm{~B}$ e 159A; o conjunto, no entanto, exibe correlaçäo pouco convincente. Também não ocorre tendência nitida de agrupamento ou tendências marcantes entre núcleos e bordas, embora algumas amostras contenham bordas com $\mathrm{Si}$ superiores aos dos núcleos (BZ 151 e 159A).

Em termos numéricos, para $70 \%$ dos valores de mg\# superiores a 31,0 , bordas e núcleos comprimem-se igualitariamente entre $\mathrm{Si}=1,940-1,990$.

A deficiência estrutural aumenta levemente com mg\#, chegando à ocupação minima de $95,7 \%(1,915)$, sendo compensada por $\mathrm{Al}^{\mathrm{N}}$ (até 0,070). O Al, por sua vez, distribui-se pelas posições tetraédricas (até 0,070 ) e octaédricas (até 0,050 ), em proporções inversas. Nestas últimas, $98 \%$ dos valores não ultrapassam 0,030 , havendo, contudo, leve tendência de decréscimo com o aumento de $\mathrm{mg \# .} \mathrm{A} \mathrm{grande} \mathrm{maioria} \mathrm{dos} \mathrm{núcleos} \mathrm{tem} \mathrm{Al}^{\mathrm{V} 1}$ inferior a 0,010, enquanto que nas bordas predominam valores variáveis entre 0,010 e 0,050 , sendo a freqüência dos mais altos correspondente a mg\# 14-18. Grande número de valores nulos $(60 \%$ do total) acumula-se a partir de mg\# 31.

A deficiência estrutural nas posições $T$ cresce ligeiramente com mg\#, portanto, maior nos núcleos que nas bordas. Comparados os resultados ponto a ponto, é muito maior a participação de $\mathrm{Fe}^{3+}$ em $\mathrm{T}$ com $\mathrm{Al}^{\mathrm{VI}}$ igual a zero, do que o $\mathrm{Al}$ em excesso ocupando, além das posições vacantes de $\mathrm{Si}$, posições $\mathrm{M} 1$, com $\mathrm{Fe}^{3+}$ em $\mathrm{T}$ igual a zero.

$\mathrm{O}$ aumento de $\mathrm{Al}^{\mathrm{N}}$ com mg\# chega aos valores mais altos, 0,056-0,066, para mg\# = $40-43$, após o que a proporção do elemento decresce até 0,037 para mg\# máximo. Do agrupamento maior de valores $\mathrm{Al}^{\mathrm{N}}$, com $\mathrm{mg \#}>28$, destaca-se seqüência de composições com $\mathrm{mg \#} \leq 22\left(12 \%\right.$ total), com $\mathrm{Al}^{\mathrm{N}} \leq 0,028$. Esse agrupamento corresponde à amostra $\mathrm{BZ} 100 \mathrm{~B}$, alguns pontos da amostra $171 \mathrm{~F}$ e pontos nulos da amostra 159A. São poucos os valores nulos de $\mathrm{Al}^{\mathrm{N}}$, ao contrário de $\mathrm{Al}^{\mathrm{V} !}$.

Ti mostra valores de, no máximo, 0,020, no geral sem correlação aparente com mg\#, espalhando-se em boa parte do campo de variação $(m g \#>26)$. $O$ exame isolado das amostras revela alguma tendência, ainda que variável: linear positiva ou negativa, separação de bordas e núcleos ou ainda mistura de valores. Tanto a amostra BZ 159A como a 171F apresentam correlação negativa com valores maiores de Ti para as bordas e para valores menores de mg\#. O mesmo agrupamento de valores isolados, com correlação positiva com mg\#, é observado para os pontos aquém de mg\# 22.

$\mathrm{Na}$ varia entre 0,025 e 0,430 . Agrupa-se densamente $(78 \%$ dos pontos) para os valores máximos de mg\# $(\geq 32)$ e mínimos de $\mathrm{Na}(0,025-0,110)$, em correlação não muito regular, mas nitidamente inversa e algo assintótica. Os valores restantes (22\%) distribuem-se entre $\mathrm{mg \#}=7-19$ e $\mathrm{Na}=0,035-0,090$ (amostra BZ 100B e pontos das amostras BZ $159 \mathrm{~A}$ e $171 \mathrm{~F}$ ) e no campo $\mathrm{mg \#}=12-37$ e $\mathrm{Na}=0,150-0,440$. Com o agrupamento de $78 \%$ dos pontos $\mathrm{e}$ 
a distribuição dos restantes $22 \%$, o arranjo geral não é muito homogêneo, mas a forma descrita é visivel. Também existe tendência mais ou menos clara para valores de Na superiores para as bordas, acima de 0,100, com os dos núcleos situando-se abaixo de 0,230. Examinados isoladamente, as amostras apresentam algumas características constantes. Primeiro, tendem a ter seus pontos analisados alinhados; segundo, esse alinhamento mostra correlação negativa com mg\#, tão menos acentuada quanto maior o mg\#; terceiro, as bordas exibem valores de $\mathrm{Na}$ sempre superiores aos dos núcleos.

$\mathrm{Fe}^{3+}(\mathrm{T}+\mathrm{M} 1)$ contém valores de até 0,360 , a partir de 0,015 . Tal como o $\mathrm{Na}$, o elemento mostra correlação negativa com mg\#, com distribuição pobre acima de 0,180 e mg\# $<31$. O agrupamento se adensa para o intervalo além de $m g \#=31$ e abaixo de $F e=0,180$. Vistas de forma isolada, as amostras raramente se alinham, mas exibem em geral correlação negativa, muito menos nítida que a do $\mathrm{Na}$.

Os piroxênios foram analisados somente como núcleos em duas amostras de diques félsicos insaturados. Ambas possuem valores baixos de $\mathrm{mg}$, com reduzido intervalo de variação (Fig. 11b): 1,43 a 2,55 e 4,01 a 4,25. Na BZ 163D (mg\# menor), Si é anormalmente elevado, com a maioria dos valores entre 1,999 e 2,025; já a amostra 166A tem Si menor, entre 1,977 e 1,992. Mesmo para os valores mínimos, praticamente não ocorre deficiência de ocupação $(98,8 \%)$. A primeira amostra tem valores nulos para $\mathrm{Al}{ }^{\mathrm{N}}$, compativel com $\mathrm{Si} \quad(z$ 2,000). $\mathrm{Na} 166 \mathrm{~A}$, os pontos distribuem-se entre 0,008 e 0,023 . Ainda que com base em pequeno número de análises, é possível distinguir-se dois aspectos: primeiro, queda nos valores de uma para outra amostra, com correlação negativa com mg\# e, segundo, dentro da mesma amostra, a configuração é semelhante. Ti mostra leve correlação negativa com mg\# e valores sempre baixos: 0,006 a 0,019 (BZ 163D) e 0,017 a 0,035 (BZ 166A). Na e Fe exibem distribuição gráfica semelhante: correlação negativa entre as amostras, valores mais ou menos grupados, decrescentes na amostra BZ 163D. Os valores absolutos são de 0,721-0,838 para $\mathrm{Na}$ e de 0,484 a 0,540 para $\mathrm{Fe}^{3+}$ na amostra BZ 163D; na BZ 166A, Na varia de 0,541 a 0,753 e $\mathrm{Fe}^{3+1}$ de 0,441 a 0,526 .

Nos diques máficos, foram feitas 67 análises em piroxênios de quatro amostras, todas com características lamprofíricas. Os valores de mg\# variam entre 53,3 e 69,4 (Fig. 11c). Entre mg\# 53,3-56,4, somente ocorrem grãos matriciais, em número de quatro ( $6 \%$ do total). Entre mg\# 57,9 e 65,7 , acham-se distribuídos $78 \%$ dos pontos, mais ou menos agrupados. Acima de mg\# 65,7 até 67,6 , há ausência de valores, e os $16 \%$ restantes estão compreendidos entre mg\# 67,6 e 69,4. O intervalo total de variação é de somente 16,1, com freqüência máxima de valores entre mg\# 62 e 65 (25 pontos, 37\% do total); entre mg\# 58 e 66, a distribuição dos resultados se dá mais regularmente $(50, \sim 75 \%)$. Os valores mínimos de mg\#, em ordem crescente, são: grãos matriciais (MTZ; 53,3), núcleo de microfenocristais (MFN, 57,9), bordas ce xenocristais (XFB, 58,4), grãos comuns (GC, 60,0), bordas de microfenocristais (MFB, 60,8) e núcleo de xenocristais (XFN, 62,6). Os valores máximos para mgł são, em ordem 
decrescente, MFN (69,4), MFB (69,2), MTZ e XFB $(68,4)$, XFN $(67,6)$ e GC $(65,6)$, e os intervalos são em, ordem decrescente, de 15,1 (MTZ), 11,5 (MFN), 10,0 (XFB), 8,4 (MFB), 5,6 (GC) e 5,0 (XFN).

Os valores de Si variam entre 1,880 e 1,465 , havendo concentração em intervalo pouco menor com $92 \%$ dos pontos dispostos entre 1,810 e 1,515. Há nítida correlação positiva de Si com mg\#, definindo-se faixa de pontos mais ou menos alinhados, com o vazio de valores (mg\# 65,7-67,6), destacando-se dela alguns gräos matriciais e par de núcleos de xenocristais. Entre as análises, 55 (82\%) possuem valores de $\mathrm{Si}<1,750$ e, portanto, qualquer que seja o piroxênio ele deve ser classificado como sub-silícico (cf. Morimoto, 1988). Mais que isso, todos os resultados indicam deficiências nas posições tetraédricas, desde moderadas (11\%) a bastante acentuadas (28\%). Valores de Si entre 1,644 e 1,712 (ocupação T de 82,2 e 85,6\%) são comuns a todas as seis categorias texturais.

Os resultados obtidos nos chamados xenocristais, quando observados em conjunto, levam à confirmação da suposição. Já pontos isolados em amostras isoladas descartam essa suposição para a grande maioria delas, restando somente um único par de pontos com comportamento químico destoante e, portanto, sugestivo de uma natureza estranha à amostra.

Os menores valores para Si são de grãos matriciais, em torno de 1,465-1,510, e os maiores correspondem aos supostos xenocristais, 1,860-1,880, seguidos por microfenocristais, com freqüência maior dos núcleos. Os intervalos de variação de Si em auf, em ordem decrescente, são de 0,290 (MFB), 0,285 (MTZ), 0,276 (MFN), aparentemente sem correlação com os valores máximos (XFN, 1,880; MFB, 1,822; MFN, 1,789; MTZ, 1,750), nem com os mínimos (MFB, 1,517; MFN, 1,513; MTZ, 1,465).

Examinado o campo de variação, amostra por amostra, todas elas exibem correlação positiva Si $x$ mg\# e distribuem-se subparalelamente pela faixa de variação inteira, sem que se note distribuição particular das categorias texturais. Aquelas amostras com mais pontos matriciais analisados (três delas) parecem estender-se, igualmente, por maior intervalo de pares de valores Si x mg\#: BZ 313/5B, 1,465-1,769 e 53,3-69,2, BZ 326C1, 1,520-1,769 e 56,4$69,4, \mathrm{Bz} 303 \mathrm{C}, 1,515-1,822$ e 57,9-69,2, respectivamente. A amostra $B Z 326 \mathrm{~A} 7$ distribui-se por intervalo menor, havendo somente análises de microfenocristais: 1,644-1810 e 62,1-68,5.

As deficiências em Si são compensadas sobretudo por $\mathrm{Al}^{N}$, mas não completamente. $\mathrm{Em}$ boa parte das amostras, $\mathrm{Fe}^{3+}$ ocupa posições $\mathrm{T}$. $\mathrm{Al}^{\mathrm{V}^{\mathrm{i}}}$ é nulo, em $\mathrm{M} 1$, em metade das análises, e o mesmo ocorre com $\mathrm{Fe}^{3+}$. $\mathrm{O} \mathrm{Al} \mathrm{N}^{\mathrm{V}}$ tem distribuição simétrica e inversa à do $\mathrm{Si}$, em correlação negativa com mg\#. Os intervalos de valores apresentam distribuição semelhante à do $\mathrm{Si}$, quando examinados amostra por amostra. As amostras BZ 313/5B, $326 \mathrm{C} 1$ e $303 \mathrm{C}$ distribuem-se por todo o campo de variação, entre os valores extremos aproximados de $\mathrm{Al}^{N}=$ 0,504-0,169 (os de mg\# já foram apontados), e a amostra BZ 326 A7 destaca-se em intervalo menor, de 0,352-0,169. O par de valores únicos da amostra $B Z 303 \mathrm{C}$, de possível xenocristal, possui $\mathrm{mg \#}=63,5-64,0$, em posição invertida com relação ao Si. Al ${ }^{\mathrm{Vl}}$ mostra metade dos 
valores, nulos, acima de mg\# 58, e a outra metade, näo nula, com freqüência maior de valores até 0,035 , para $\mathrm{mg \#}>58$. Os nulos de $\mathrm{Al}^{\mathrm{VI}}$ correspondem a pontos onde $\mathrm{Fe}^{3 \cdot+}$ participa em $\mathrm{T}$. O valor máximo de $A l^{v /}$ é de 0,056 , para $m g \#=62,8$. Não há qualquer tendência manifesta na distribuição dos pontos, quer no seu conjunto, quer vistos amostra por amostra.

A distribuição de Ti é feita supondo-se posicionamento exclusivamente em $\mathrm{M} 1$, com o elemento exibindo distribuição muito semelhante à do $\mathrm{Al}^{\mathrm{N}}$, em correlação negativa com mg\#. Os valores máximos de $\mathrm{Ti}$, de grãos matriciais, situam-se no intervalo $0,202-0,170$, e correspondem a números minimos de $\mathrm{mg} \#, 53,3-56,4$. As outras categorias texturais começam a comparecer a partir dos valores de $\mathrm{Ti}=0,161$, e menores, e mg\# $=57,9$, e maiores, atingindo mínimos em torno de 0,050-0,045, para $\mathrm{mg \#}=69,2$, em bordas de feno/microfenocristais. 0 par de possiveis xenocristais, já destacado para outros elementos, aparece com valores de Ti inferiores, 0,030-0,035. As amostras mantêm a tendência do conjunto, tal como comentado para o Si, mas não há grupamentos ou tendências manifestas entre as diferentes categorias texturais, a não ser os grãos matriciais referidos. O intervalo 0,100-0,150 é compartilhado por todas as categorias e mais que $50 \%$ dos valores para Ti estão acima de 0,100 , devendo-se assim adotar o adjetivo "titanifero" ("titanian"), e a modificação "com titânio" ("titanoan") para os restantes $(\mathrm{Ti}>0,010)$.

Os valores para $\mathrm{Na}$ situam-se entre 0,025 a 0,066, semelhantes aos dos piroxênios Quad dos sienitos. Esses valores, distribuídos no campo mg\#, exibem correlaçăo negativa, com distribuição aleatória das categorias texturais, em faixa larga mais ou menos definida, caracterizada por campos com maior concentração de valores e zonas com ausência de valores. Os grãos matriciais aparecem com os valores mais altos, em faixa com ausência de outras categorias: $\mathrm{Na}=0,041-0,050$, para $\mathrm{mg \#}=53,3-56,4$. Após a ausência de valores, entre mg\# 56,4-57,9, define-se área com o maior número de resultados, entre mg 57,9-64,0, e $\mathrm{Na}=$ 0,041 a 0,025, com maior concentração acima de 0,031. Entre mg\# 64,0 e 76,5, apenas quatro análises se fazem presentes, com o $\mathrm{Na}$ dentro do comentado. Nova concentração de pontos analíticos ocorre, agora, para os valores máximos de mg\# e mínimos de $\mathrm{Na}$, respectivamente, 67,5-69,3 e 0,025-0,035. Destacam-se dessa distribuição de pontos o possivel xenocristal da amostra $\mathrm{BZ} 303 \mathrm{C}$, com $\mathrm{mg \#} \sim 63,7$ e $\mathrm{Na} \sim 0,062-0,066$, seis valores da amostra $\mathrm{BZ} 326 \mathrm{A7}$ (microfenocristais), além de um da amostra BZ $326 \mathrm{C1}$ : um grupo com mg\# 64,7-65,4 e $\mathrm{Na}=$ 0,045 e outro com $\mathrm{mg \#} \sim 63,7-64,7$ e $\mathrm{Na} \sim 0,050-0,053$. Assim, na faixa principal de distribuição dos valores de $\mathrm{Na}$, acham-se $80 \%$ dos dados analíticos, com $59 \%$ no agrupamento central maior, $15 \%$ no menor, e $6 \%$ matriciais, com os menores valores de mg\# e maiores de $\mathrm{Na}$. Afora o isolamento de quatro análises de grãos matriciais, não se observa qualquer arranjo ou tendência especial entre as categorias texturais. Novamente, o par de valores, tido como xenocristal, mostra teor cationico fora da tendência geral e, no caso, mais alta. Visto o conjunto, de outra forma, percebe-se que todas as categorias de grãos incluem valores de $\mathrm{Na}$ entre 0,027 e 0;045. Mais uma vez, quando examinados os números amostra por amostra, nota-se 
que todos acompanham a distribuição de um extremo a outro, excluida a $B Z 326 \mathrm{~A} 7$, que, como visto, limita se a intervalo com mg\# menores $e$, no caso, $\mathrm{Na}$ com valores maiores (para os mesmos mg\# do conjunto de amostras).

$\mathrm{O} \mathrm{Fe} \mathrm{F}^{3+}(\mathrm{T}+\mathrm{M} 1)$ apresenta distribuição semelhante à do $\mathrm{Na}$, com melhor agrupamento dos pontos analiticos. Exibe, igualmente, compartimentação em três conjuntos de pontos, separados por ausência de valores nos mesmos intervalos mg\#. Assim, o pequeno conjunto de valores correspondentes aos grãos matriciais $(6 \%$ do total) reúne os números mais altos de $\mathrm{Fe}^{3+}$, entre 0,135 e 0,208 . O maior agrupamento, com $75 \%$ dos valores, varia entre $0,116 \mathrm{e}$ 0,201 , seguindo-se conjunto menor para os valores extremos de mg\#, e mínimos de $\mathrm{Fe}^{+3}$, com $15 \%, 0,100$ a 0,149 . Ponto de grão matricial isolado mostra valores $\mathrm{mg} \# / \mathrm{Fe}^{3+}$ de $61 / 0,216$, e borda de microfenocristal $65,6 / 0,053$. Entre os valores de $\mathrm{Fe}^{+3}=0,114$ e 0,191 estão $88 \%$ dos números encontrados. A exemplo dos outros cátions, afora o isolamento de grãos matriciais com os menores valores de mg\# e o agrupamento dos pontos, não há arranjo ou tendência particular observada quanto às categorias texturais e par de valores $\mathrm{mg} \# / \mathrm{Fe}^{3+}$. Por outro lado, todas as categorias possuem parte dos dados analiticos entre 0,114 e 0,170. As amostras, isoladamente, acompanham a tendência geral, embora de forma mais irregular e, aparentemente, com variação mais acentuada da proporção de $\mathrm{Fe}^{3+}$. É preciso observar que nos valores usados, o $\mathrm{Fe}^{3+}$ em M1 é muito mais representativo que em $\mathrm{T}$. Esse, a propósito, mostra valores muito variados e freqüentemente iguais a zero.

\subsubsection{Variações químicas totais}

O exame das tabelas de dados analíticos, dos diagramas classificatórios e dos diagramas mg\#, evidencia as caracteristicas quimicas dos piroxênios das rochas alcalinas da Ilha dos Búzios, em grande parte compartimentados em tipologias petrográficas: sienitos, diques félsicos e diques máficos. A apreciação das variações globais do conjunto de rochas há também que ser examinada, com tratamento gráfico apropriado. É certo que neste caso se perde um pouco a resolução dos detalhes e variações internas por tipos, amostras ou classes texturais, já examinados, porém. Mas torna-se possivel a visão conjunta, importante quanto aos aspectos petrológicos evolutivos.

Considerou-se, aqui, outro aspecto. As caracteristicas petrográficas dos piroxênios dos diques máficos e seus altos teores de $\mathrm{Al}_{2} \mathrm{O}_{3}$ e $\mathrm{TiO}_{2}$ que, somados, chegam a $18 \%$, não aparecem nos diagramas classificatórios. Tais piroxênios, costumeiramente chamados de titanoaugitas ou titano-salitas, acabam inscrevendo-se nos diopsídios e mesmo fassaítas no polígono classificatório de Poldervaart e Hess (1951; cf. Deer, 1978). Garda (1995) considerou as características petrográficas, especialmente o pleocroísmo típico, como devidos a elementos sem importância estrutural, e apenas como de alto poder cromóforo. Mas subsiste um aspecto: descontada a sílica, variável entre 40 e $50 \%$, nos 50 a $60 \%$ em peso de óxidos restantes, $\mathrm{Al}_{2} \mathrm{O}_{3}$ 
$+\mathrm{TiO}_{2}$ chega a $18,36 \%$ (para $38,80 \%$ de $\mathrm{SiO}_{2}$ ), ou seja, $30 \%$ dos óxidos. Há nítida correlação inversa $\mathrm{SiO}_{2}: \mathrm{Al}_{2} \mathrm{O}_{3}+\mathrm{TiO}_{2}$, e os valores para a soma estão entre 5 e $18 \%$, com média de $12,4 \%$, para $\mathrm{SiO}_{2}=40-50 \%$. A maior parte das amostras tem soma acima de $10 \%$, poucas abaixo de $8 \%$ e raras são as que chegam a $5 \%$.

Tentativamente lançaram-se todos os resultados analiticos em combinações variadas, buscando-se a ligação das composições WEF com os elementos $\mathrm{Al}, \mathrm{Ti}, \mathrm{Na}$ e $\mathrm{Fe}^{3+}$, e levando em conta as considerações da freqüência de substituições acopladas (cf. Cameron e Papike, 1981).

No gráfico triangular $\mathrm{Mg}-\mathrm{Na} \sim\left[\left(\mathrm{Fe}^{2+}+\mathrm{Mn}+\left(\mathrm{Fe}^{3+}-\mathrm{Na}\right)\right]\right.$ (Fig. 12) verifica-se o acúmulo das composições dos piroxênios dos diques máficos, bastante magnesianos (entre 70 e $80 \%$ de $\mathrm{Mg}$ ), e que evoluem para composições mais ricas em $\mathrm{Fe}$, com baixos teores e variação para Na. A maior parte das composições dos piroxênios das rochas sieniticas aparece em continuidade, na forma de agrupamento sem solução de continuidade, até atingir-se relação $\mathrm{Mg}: \mathrm{Fe}^{2+}+\mathrm{Mn}+\left(\mathrm{Fe}^{3+}-\mathrm{Na}\right)$ aproximadamente igual a 1:1, com pequena elevação do $\mathrm{Na}$ até proporções próximas de $10 \%$ (recalculadas para o gráfico triangular). Esse conjunto de composições reúne aproximadamente $80 \%$ ou mais dos pontos analisados $(>200)$. Com posicionamento bem destacado, estão presentes as composições dos piroxênios dos diques félsicos, próximas ao lado $\mathrm{Na}-\mathrm{Fe}^{2+}+\mathrm{Mn}+\left(\mathrm{Fe}^{3+}-\mathrm{Na}\right)$ do triângulo, com menos que $10 \%$ de $\mathrm{Mg}$, e alinhadas no sentido de maior teor de $\mathrm{Na}(\sim 90 \%)$, embora descontinuamente. Composições agrupadas, de forma também evidente e com certo alinhamento, aparecem bastante enriquecidas em $\mathrm{Fe}(\sim 70 \%$ - 80\%, recalculado), com valores baixos para $\mathrm{Na}(\leq 10 \%)$, mas já com leve tendência de enriquecimento nesse elemento. Esse conjunto de pontos corresponde a uma única amostra, BZ 100B, já destacada anteriormente em outros tratamentos gráficos. Quase duas dezenas de pontos apresentam composições intermediárias, em conjuntos subalinhados, com tendência de enriquecimento em $\mathrm{Fe}$ e $\mathrm{Na}$, ou mais em $\mathrm{Na}$ que $\mathrm{Fe}$, e correspondendo às amostras BZ 171 F (mais $\mathrm{Fe}$ ) e BZ 159A (mais Na). Embora ligados ao grupamento maior de composições, esses alinhamentos indicam enriquecimento em $\mathrm{Fe}-\mathrm{Na}$ e $\mathrm{Na}(-\mathrm{Fe})$, mas no conjunto há grandes espaços vazios. Além dessas feições gráficas, nota-se em geral que as bordas dos cristais são mais ricas em Fe ou Na. Como um todo, não é possivel traçar configuração evolutiva única para os piroxênios das rochas alcalinas de Búzios. Pelo menos três seqüências são sugeridas, a partir de conjunto mais ferromagnesiano continuo dos diques máficos e dos sienitos, em direção aos diques félsicos de caráter mais alcalino. A primeira representada pela amostra $B Z 100 \mathrm{~B}$, com nítido enriquecimento em $\mathrm{Fe}$; a segunda; com enriquecimento em Fe-Na, e correspondente à amostra BZ 171F; e uma terceira, amostra $B Z$ 159A, com tendência nitidamente mais sódica. Ainda entre essas duas últimas, aparece pequeno conjunto de composições, parte da amostra BZ 171F e parte da amostra BZ $159 \mathrm{~A}$. Pode-se sugerir várias explicações alternativas paras as tendências químicas evolutivas sugeridas e para os vazios composicionais. Essas possiveis seqüencias mostram similaridades 
com várias outras descritas na literatura (p.e. Yagi, 1966; Tyler e King, 1967; Stephenson, 1972; Larsen, 1976; além das relativas às ocorrências brasileiras reunidas em Gomes et al., 1987).

As substituições catiônicas nos piroxênios são razoavelmente conhecidas, e as soluções sólidas mais importantes aparecem incorporadas nos tratamentos gráficos em geral, envolvendo CaMg, CaFe e também o par $\mathrm{NaFe}^{3+}$. Algumas são balanceadas e outras envolvem compensaçöes de carga. As deficiências em $\mathrm{Si}$, compensadas por $\mathrm{Al}^{\mathrm{IV}}$ e $\mathrm{Fe}^{3+}$, implicam em deficiência de carga, a ser compensada em M1 ou M2. Examinados os dados disponiveis, os piroxênios de rochas mais evoluídas de Búzios caracterizam-se por grande enriquecimento em $\mathrm{Na}$ e $\mathrm{Fe}^{3+}$; aqueles referentes às menos evoluidas, ou seja, os diques máficos, evidenciam aumento excepcional de Ti e Al. O tratamento para os "Outros", como sugerido por Morimoto (1988) para as substituições relacionadas no mesmo trabalho, pareceram inadequadas para uma visão conjunta das variações químicas de todas as amostras e que viessem a incluir Ti e Al. Além disso, seguindo as sugestões do IMA para a classificação dos piroxênios (Figs. 8-10), não aparecem piroxênios "Outros", tal como definidos naquele trabalho. Os piroxênios dos diques máficos enquadrar-se-iam nos de "Composição Incomum", ou ricos em $\mathrm{Na}$ (substituição 2, componente S2) ou ricos em Ca (substituições 3 e 4, e componentes S3 e S4), seguindo o mesmo autor. O mais provável é que o material de Búzios possa ser visto como a substituição 4, com presença do componente $\mathrm{S} 4$ (sem nome especial: Ti-tschermakita?).

No extenso trabalho de Cameron e Papike (1981) são investigadas as substituições acopladas e, entre as várias sugeridas, novamente aparece 0 par Ti-Al como bastante importante nas rochas basálticas.

Levando em conta as limitações, selecionaram-se alguns gráficos que incorporam os componentes possivelmente presentes, e em quantidade importante, nos piroxênios de composições extremas. São tratamentos tentativos, construídos em bases catiônicas (Figs. 13 e 14) e de valor qualitativo.

A Figura 13, Quad (catiônico) - M1Ti+ TAl - M2Na + M1Fe ${ }^{3+}$, é uma tentativa de ligação das composições Quad, agora relacionando, em bases catiônicas, $\mathrm{Na}$ e $\mathrm{Fe}^{3+}$ e $\mathrm{Ti}$ e $\mathrm{Al}$ (que estaria no vértice da jadeíta). O lado Quad - $\mathrm{Na}+\mathrm{Fe}^{3+}$ praticamente não se altera e é onde se arranjam os piroxênios dos sienitos e dos diques félsicos. Os piroxênios dos diques máficos, contudo, saem completamente fora do campo Quad, evoluindo para as composições mais titânio-aluminosas, incluindo ainda componente egirínico não desprezivel.

A Figura 14 reúne os elementos participantes importantes nos piroxênios representativos dos extremos composicionais. Dada a incerteza envolvendo o $\mathrm{Fe}^{3+}$, optou-se pelo gráfico M2Na-TAl-M1T1. Este mostra distribuição regular de pontos composicionais, desde denso aglomerado no vértice $\mathrm{Na}$ - os diques félsicos - que evoluem para termos mais aluminosos, com aumento menos evidente de $\mathrm{Ti}$, nos piroxênios dos sienitos, com leve diferença entre núcleos (Al maior) e bordas (Na maior). Após certa descontinuidade, aparecem 
os piroxênios dos diques máficos, francamente mais aluminosos e que apresentam pequeno e brusco enriquecimento em Ti. Chama a atenção a separação de par de xenocristais, denso conjunto de microfenocristais e, no sentido de enriquecimento em Ti, o agrupamento de grãos matriciais. Na realidade, o sentido evolutivo deve ser, em parte, o inverso do descrito: a partir de microfenocristais mais aluminosos dos diques máficos, haveria enriquecimento em $\mathrm{Ti}$ nos grãos matriciais mais tardios. A despeito de ausências composicionais, em estágios mais adiantados e já em rochas totalmente diversas, ou sienitos, os piroxênios evoluiriam de termos mais aluminosos e com algum titânio, para os termos sódicos puros, sem Al e sem Ti. A posição dos xenocristais não é facilmente compreensivel.

\subsection{Os anfibólios}

Estes minerais fazem-se presentes em todos os tipos de rochas, igualando-se aos piroxênios em várias amostras, ausentando-se em parte delas, e aparecendo em algumas sem piroxênio, alguns sienitos (com quartzo) e diques traquíticos.

Foram analisados 66 pontos em oito amostras de sienitos, 24 pontos em duas amostras de diques félsicos e 23 pontos em três amostras de diques máficos, totalizando 113 análises. Os resultados, em óxidos e cátions, são apresentados nas Tabelas 10 a 12 , tendo-se calculado as fórmulas estruturais com base em 23 átomos de oxigênio. Além disso, as fórmulas estruturais obedeceram as recomendações do. IMA (Leake, 1978), sendo o Fe calculado como FeO.

\subsubsection{Classificação}

As classificações foram feitas segundo o fluxograma recomendado pelo IMA (cf. Leake, 1978). Não foram registrados anfibólios de Fe-Mg-Mn em Búzios. Os anfibólios cálcicos e sódico-cálcicos foram lançados em gráficos compartimentados ("quadros") Si $\times \mathrm{Mg} / \mathrm{Mg}+\mathrm{Fe}^{2+}$. Os cálcicos limitados aos valores $(\mathrm{Ca}+\mathrm{Na})_{B} \geq 1,34$ e $\mathrm{Na} \mathrm{B}_{\mathrm{B}}<0,67$, e subdivididos em quatro planos maiores, cf. figura 3 de Leake (1978): A. $(\mathrm{Na}+\mathrm{K})_{A}<0,50 ; \mathrm{B}$. $(\mathrm{Na}+\mathrm{K})_{A} \geq 0,50$ e $\mathrm{Fe}^{3+}<$ $\mathrm{Al}^{\mathrm{V}} ; \mathrm{C} .(\mathrm{Na}+\mathrm{K})_{\mathrm{A}} \geq 0,50$ e $\mathrm{Fe}^{3+}>\mathrm{Al}^{\mathrm{VI}}$.

Todas as opções são para $\mathrm{Ti}<0,50$, à exceção da $\mathrm{D}$ com $\mathrm{Ti}>0,50$. Os sódicocálcicos reúnem aqueles minerais apresentando $(\mathrm{Ca}+\mathrm{Na})_{B} \geq 1,34$, e com $\mathrm{Na}_{\mathrm{B}}$ compreendido entre 0,67 e 1,34. Aqui, são duas as alternativas: A. $\operatorname{com}(\mathrm{Na}+\mathrm{K})_{A}<0,50$, e B. $\operatorname{com}(\mathrm{Na}+\mathrm{K})_{A}>$ 0,50 . Os alcalinos, finalmente, distribuem-se em planos com valores $\mathrm{Na}_{B} \geq 1,34$, com dois quadros classificatórios: A. com $(\mathrm{Na}+\mathrm{K}) \geq 0,50$ e B. com $(\mathrm{Na}+\mathrm{K})<0,50$, sendo a abcissa, neste caso, $\mathrm{Fe}^{3+} / \mathrm{Fe}^{3+}+\mathrm{Al}^{\mathrm{Vl}}$.

Os anfibólios das rochas sieniticas da llha são mostrados na Figura 15a e suas 

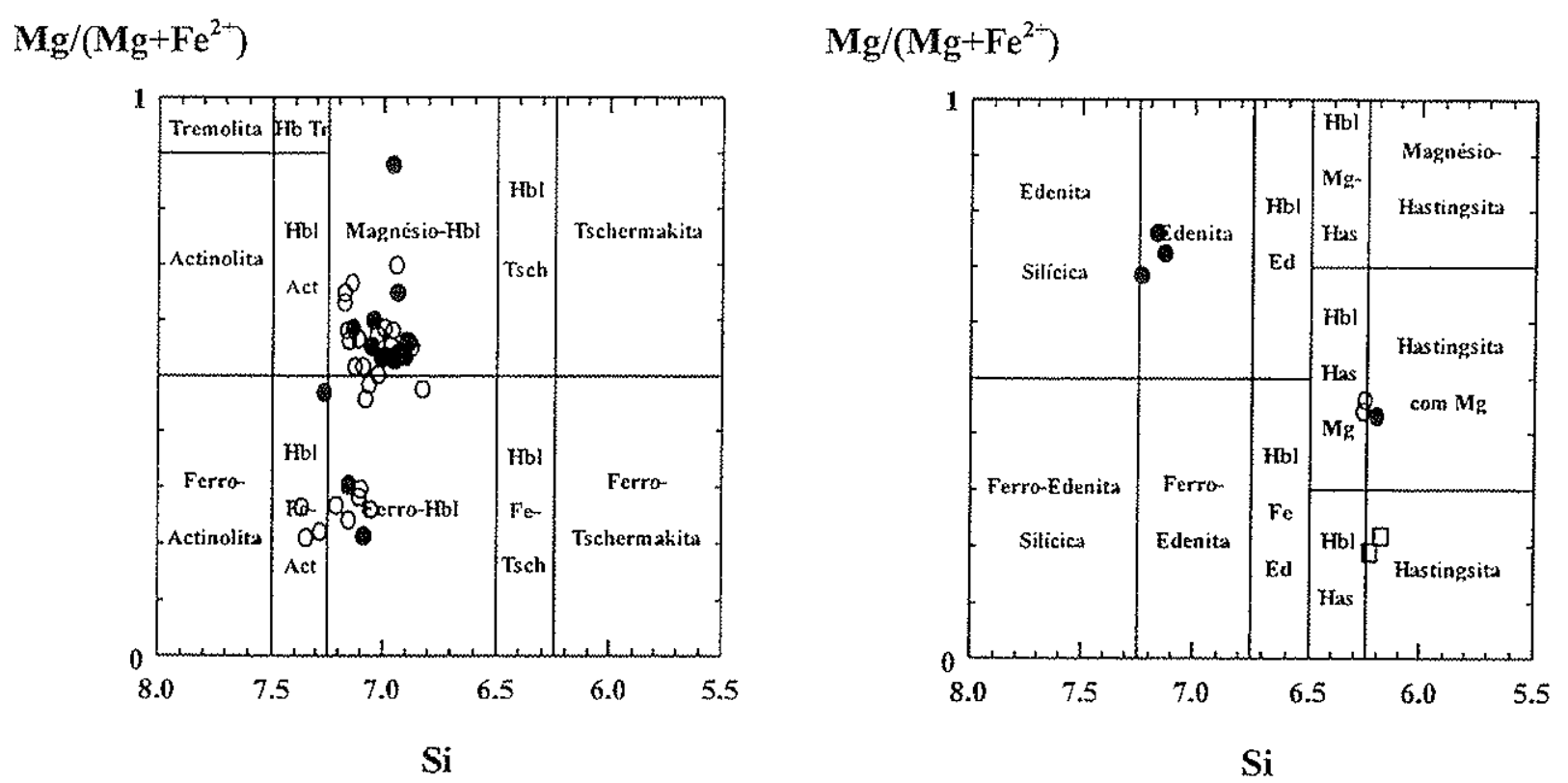

Si

$\mathrm{Si}$
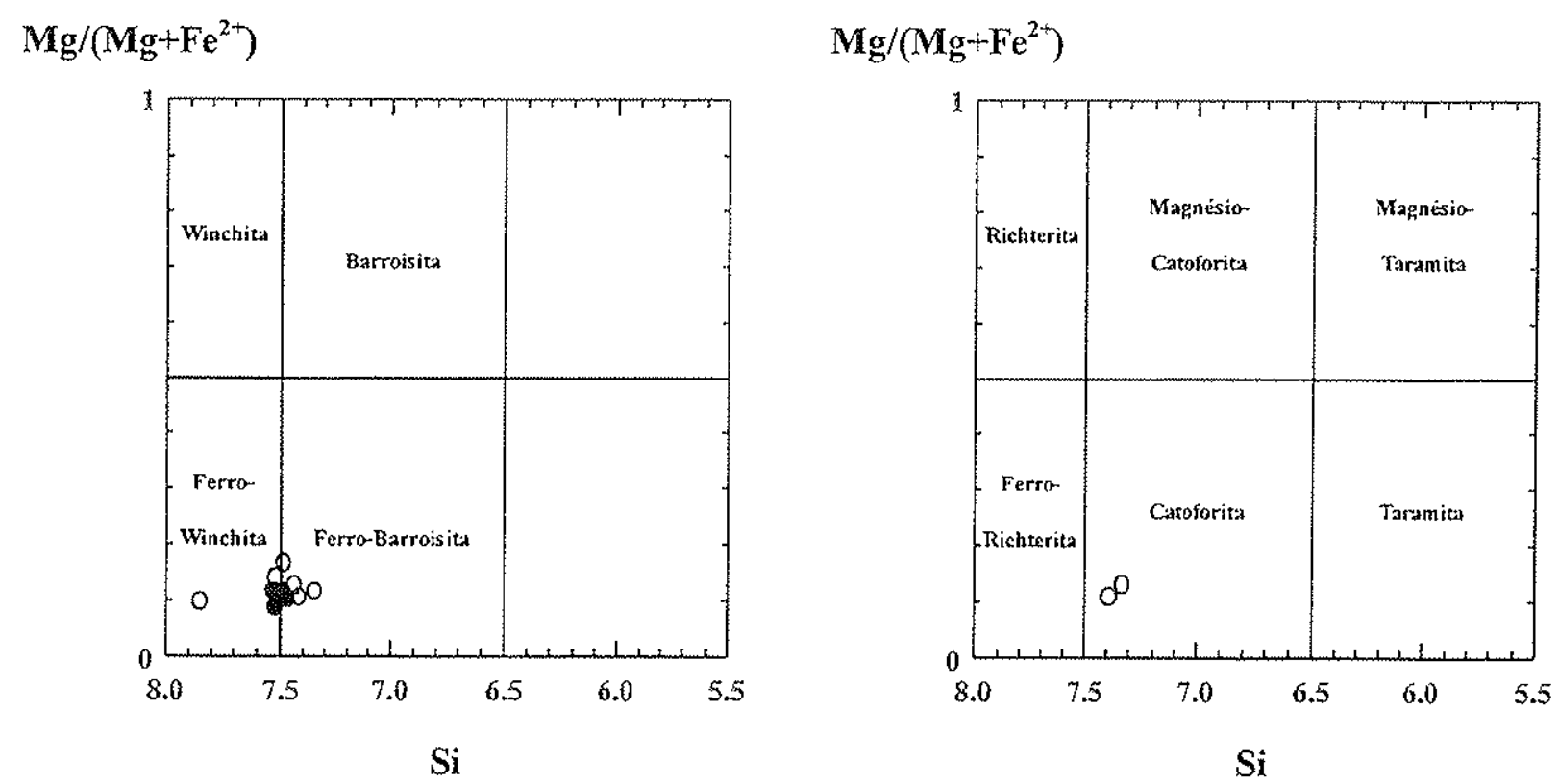

Figura 15a - Diagramas Si vs. $\mathrm{Mg} /\left(\mathrm{Mg}+\mathrm{Fe}^{2+}\right)$ de Leake (1978) para anfibólios cálcicos $\left[(\mathrm{Ca}+\mathrm{Na})_{\mathrm{B}}\right.$ $\geq 1,34 ; \mathrm{Na} \mathrm{B}_{\mathrm{B}}<0,67$ auf], acima, e sódico-cálcicos $\left[(\mathrm{Ca}+\mathrm{Na})_{\mathrm{B}} \geq 1,34 ; \mathrm{Na}\right.$ entre $0,67 \mathrm{e}$ 1,34 auf], abaixo, de sienitos da llha dos Búzios. Grão comum: núcleo • borda $\bigcirc$, inclusão $\square$. 
composições na Tabela 10, incluindo os tipos cálcicos e sódico-cálcicos. Exibem grande variaçäo composicional, aparentemente descontinua, e consistente com as características ópticas desses minerais. A razão $\mathrm{Mg} / \mathrm{Mg}+\mathrm{Fe}^{2+}$ varia entre 0,1 e 0,9, com $\mathrm{Ca}>1,63$ e $\mathrm{Na}<$ 0,63 , e são todos cálcicos à exceção da amostra $B Z 123$, contendo representantes sódicocálcicos com valores de $\mathrm{Ca}_{\mathrm{B}}=1,140-0,880$ e $\mathrm{Na}_{\mathrm{B}}=0,860-1,112$. As amostras $\mathrm{BZ} 17 \mathrm{~B}, 105$ e 157 (NE, borda oeste e centro-oriental do corpo sienítico) apresentam o maior agrupamento composicional, sendo classificáveis como magnésio-hornblenda (a maior parte), ferrohornblenda e hornblenda ferro-actinolita. No mesmo quadro, aparece ponto composicional isolado referente à amostra BZ 190 (Saco Grande, próximo a Ponta Sul), correspondendo a uma magnésio-hornblenda com alta razão $\mathrm{Mg} / \mathrm{Mg}+\mathrm{Fe}^{2 \cdot+}$. Ainda no mesmo quadro, encontrame a amostra $\mathrm{BZ} 100 \mathrm{~B}$, mais rica em $\mathrm{Fe}$, com composições projetadas nos campos da ferroactinolita hornblenda e ferro-hornblenda. No outro quadro classificatório (fig. 3C, cf. Leake, 1978), situa-se a amostra BZ 171F (Saco Grande, centro), edenita para os núcleos e hastingsita para as bordas, com enriquecimento em Fe. Também outro ponto da amostra $\mathrm{BZ}$ 190 é de uma edenita, mostrando enriquecimento em $(\mathrm{Na}+\mathrm{K})_{\mathrm{A}}$ relativamente ao ponto isolado, cálcico, referido. Ainda no mesmo quadro e, de forma isolada, tem-se a amostra BZ 185 (centro norte da Ilha), classificável como magnésio-hastingsita hornblenda e magnésio-hastingsita. Os anfibólios sódico-cálcicos, limitados à amostra BZ 123 (Costa Oeste), possuem maior número de composições correspondentes a uma ferro-winchita/ferro-barroisita, núcleos e algumas bordas, e outras bordas de natureza mais ferro-winchita $(\mathrm{Si} \sim 8,0)$ ou mais ferro-barroisita até catoforita, indicando novamente aumento em $(\mathrm{Na}+\mathrm{K})_{\mathrm{A}}$.

As figuras classificatórias usadas de Leake (1978) para os anfibólios dos sienitos são as de número $3 \mathrm{~A}$ e $\mathrm{C}$ (cálcicos) e $4 \mathrm{~A}$ e $\mathrm{B}$ (sódico-cálcicos).

Os anfibólios dos diques félsicos constam da Tabela 11 e Figura 15b. Esta inclui as figuras $4 \mathrm{~B}$ (anfibólios sódico-cálcicos) e $5 \mathrm{~A}$ e $\mathrm{B}$ (anfibólios alcalinos), os primeiros com ( $\mathrm{Na}+\mathrm{K}$ ) $\geq 0,50$, e os últimos com $(\mathrm{Na}+K) \geq 0,50$ e $(\mathrm{Na}+\mathrm{K})<0,50$. A amostra $\mathrm{BZ} 166 \mathrm{~A}$, dique félsico do Saco Grande central, agrupa-se muito mais entre as catoforitas, mas inclui taramitas. $A$ amostra BZ 182B, traquitica, da extremidade nordeste da liha, contém arfvedsonita e riebeckita.

Os diques máficos (Tabela 12 e Fig. 15c), correspondentes às figuras $3 A, B, C$ e D dos anfibólios cálcicos de Leake (1978), representam as amostras BZ 181A (rocha máfica diabásica - basalto alcalino - da Ponta Leste) e as amostras BZ 303C e 326C1 (rochas lamprofíricas do Saco do Coruja e Costa Sul Oriental). Os anfibólios da primeira têm $\mathrm{Ti}<0,50$, e agrupam-se maiormente como magnésio-hornblendas, com ponto composicional isolado de edenita e outro de magnésio-hastingsita hornblenda. As demais amostras são de kaersutita.

\subsubsection{Variações composicionais}

Tendo em vista a quantidade de variáveis no espaço classificatório dos antibólios e 


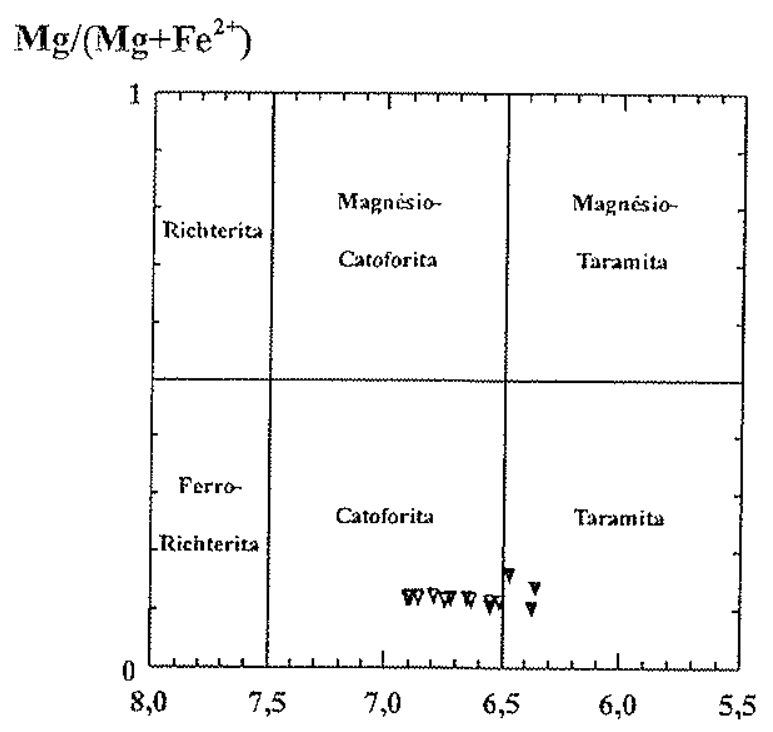

$\mathrm{Si}$

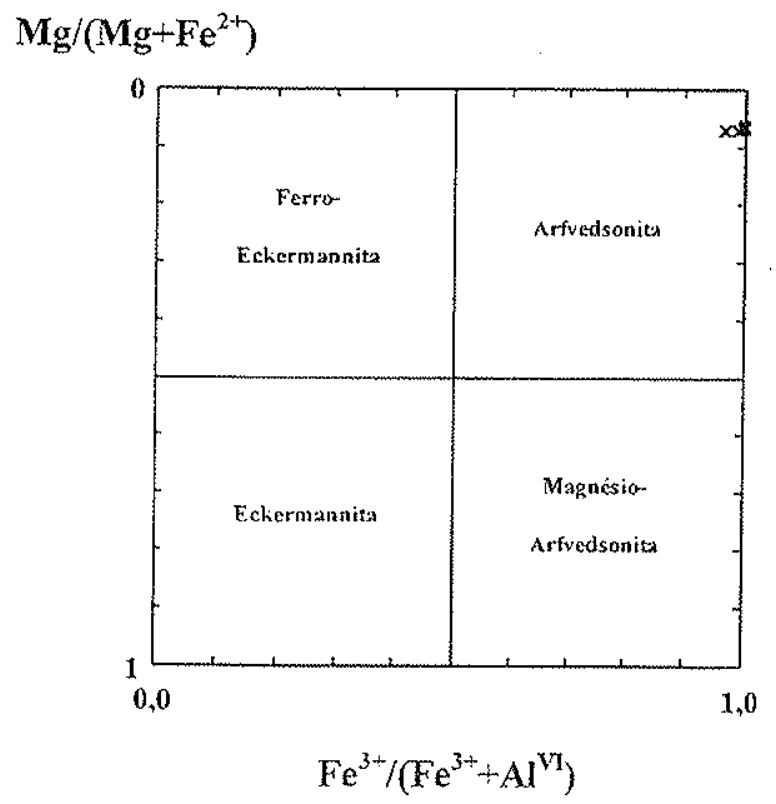

\section{$\mathrm{Mg} /\left(\mathrm{Mg}+\mathrm{Fe}^{2-1}\right)$}

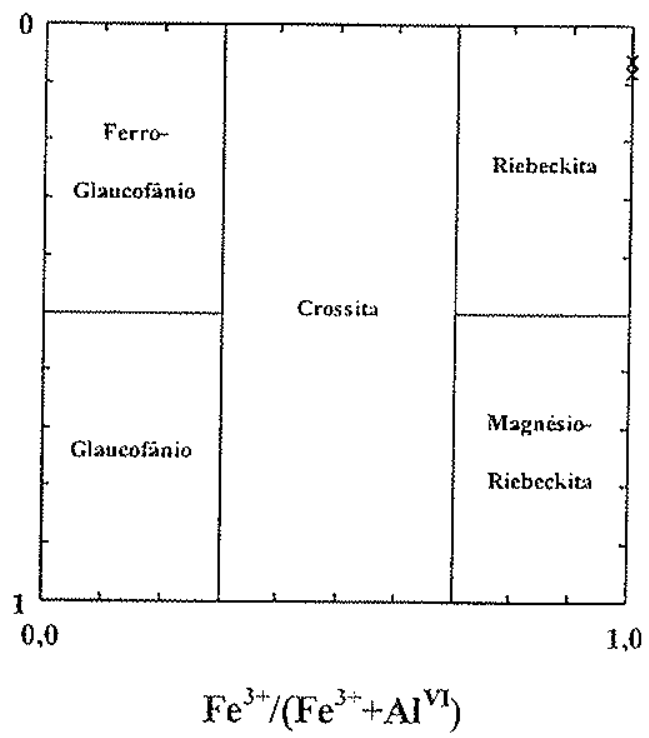

Figura 15b - Diagramas Si vs. $\mathrm{Mg} /\left(\mathrm{Mg}+\mathrm{Fe}^{2+}\right)$ para anfibólios sódico-cálcicos $\left[(\mathrm{Ca}+\mathrm{Na})_{\mathrm{B}} \geq 1,34\right.$; $\mathrm{Na}_{B}$ entre 0,67 e 1,34 auf], acima, e $\mathrm{Fe}^{3+} /\left(\mathrm{Fe}^{3+}+\mathrm{Al}^{\mathrm{VI}}\right)$ vs. $\mathrm{Mg} /\left(\mathrm{Mg}+\mathrm{Fe}^{2+}\right)$ para anfibólios alcalinos ( $\left.\mathrm{Na}_{\mathrm{B}} \geq 1,34\right)$, abaixo, de Leake (1978) de diques félsicos da llha dos Búzios. Grão comum: núcleo $\nabla$, borda $\nabla$; grão da matriz $\times$. 
$\mathrm{Mg} /\left(\mathrm{Mg}+\mathrm{Fe}^{2+}\right)$

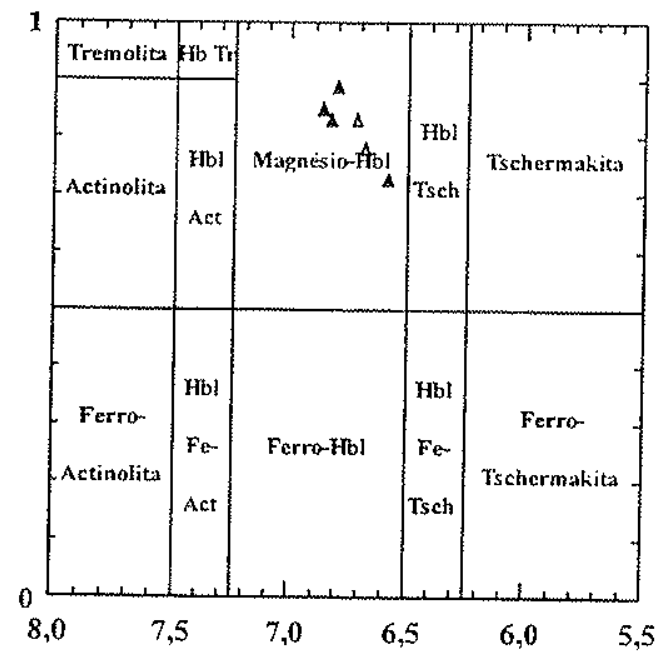

Si

\section{$\mathrm{Mg} /\left(\mathbf{M g}+\mathrm{Fe}^{2+}\right)$}

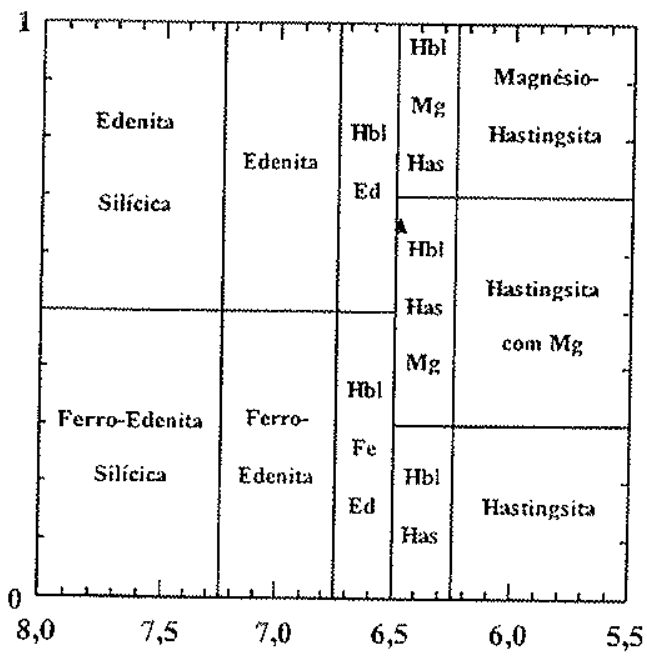

$\mathrm{Si}$

\section{$\mathrm{Mg} /\left(\mathrm{Mg}+\mathrm{Fe}^{2+}\right)$}

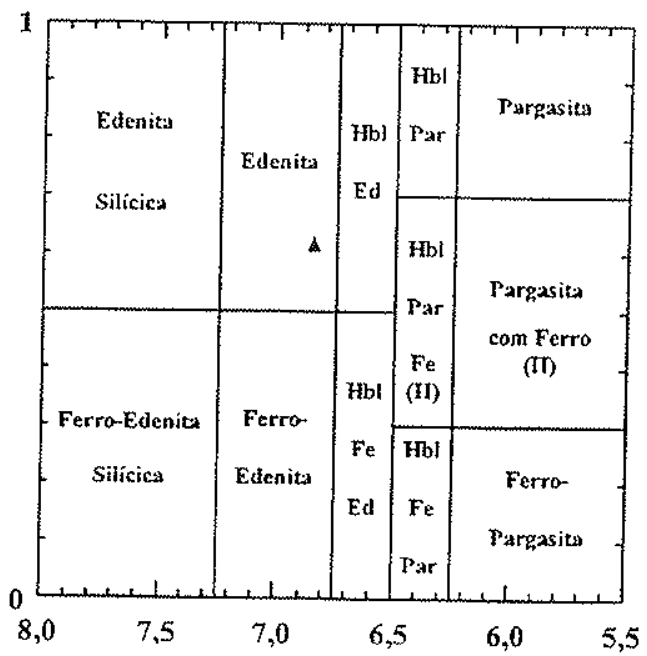

Si

$\mathrm{Mg} /\left(\mathrm{Mg}+\mathrm{Fe}^{2+}\right)$

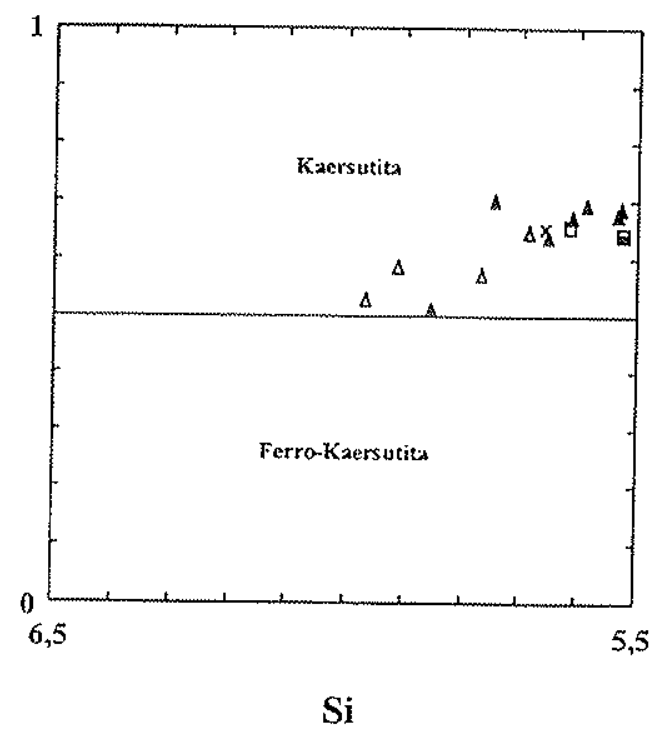

Figura $15 \mathrm{c}$ - Diagramas Si vs. $\mathrm{Mg} /\left(\mathrm{Mg}+\mathrm{Fe}^{2+}\right)$ de Leake (1978) para anfibólios cálcicos $\left[(\mathrm{Ca}+\mathrm{Na})_{\mathrm{B}}\right.$ $\geq 1,34 ; \mathrm{Na}_{\mathrm{B}}<0,67$ auf] de diques máficos da ltha dos Búzios. Grão comum: núcleo $\triangle$, borda $\triangle$; ocelo ; Inclusão $\square$. 
sua compartimentação em inúmeros planos, dificultando sobremaneira a apreensão do comportamento do conjunto de composições, resolveu-se recorrer a alguns tratamentos gráficos adicionais (Figs. 16 a 18). A primeira, mg\# [mg\# $=\mathrm{MgO} \times 100 /(\mathrm{MgO}+\mathrm{FeO})] \times$ cátions em auf, permite algumas considerações sobre a distribuição e as variações catiônicas nas várias amostras e no conjunto das rochas e, eventualmente, comparações com outros minerais fêmicos, analogamente tratados. Adotando-se igual indice de diferenciação para as rochas, foi possivel fazer-se comparações entre rochas e minerais. A Figura 17, aparentemente "óbvia", na verdade é bastante ilustrativa e fornece, graficamente, condições para análise da distribuição das composiçōes em termos de Si e Al, assim como das suas ocupações e deficiências tetraédricas e eventual existência de $\mathrm{Al}^{\mathrm{V} l}$ e de $\mathrm{TFe}^{3+}$. A Figura 18 inspirou-se em alguns trabalhos publicados (Ferguson, 1978; Brooks e Gill, 1982 etc.), onde se postula a recorrência da cristalização de piroxênios e anfibólios. O triângulo $\mathrm{Mg}-\left[\mathrm{Fe}^{2+}+\mathrm{Mn}+\left(\mathrm{Fe}^{3+}-\mathrm{Na}\right)\right]-\mathrm{Na}$, em geral utilizado para os piroxênios, praticamente não tem sido adotado para os anfibólios, mas parece bastante ilustrativo.

O valor mg\# (óxidos) varia entre 2,0 e 56,0 correspondente a $\mathrm{Mg} /\left(\mathrm{Mg}+\mathrm{Fe}^{2+}\right)$ entre 0,1 e 0,9 . Os anfibólios dos sienitos variam descontinuamente, com as amostras agrupando-se entre 3,0 e 15,0, 23,0 e 38,0 e 50,0 e 55,0; os diques félsicos, entre 2,0 e 7,0 em um dos extremos, e os máficos, entre 36,0 e 56,0 , no outro.

O Si em auf varia, quase continuamente, entre 7,860 e 5,430, e o plano Si x mg\# mostra agrupamentos descontínuos de composições, correspondentes a cada amostra ou conjunto. No geral, mostra leve tendência inversa. Os sienitos estendem-se da amostra BZ 123 e 100B, com valores de 7,340-7,540 e 7,060-7,370, respectivamente, para valores de mg\# entre 3,0-7,0 e 9,0-15,0; seguem-se as amostras BZ 17B, 105 e 157, que se ajuntam entre os valores de 7,260 e 6,830, no intervalo $\mathrm{mg \#}=23,0-38,0$. Para os mais altos valores de mg\# $(50,0-55,0)$ correspondem os de Si $(6,970-7,250)$, para núcleos de anfibólios das amostras $\mathrm{BZ}$ $171 \mathrm{~F}$ e 190. A amostra BZ 185 e bordas de grãos da já citada $171 \mathrm{~F}$ apresentam-se isoladas, com valores, respectivamente, de 6,180-6,240 e 6,210-6,270, para mg\# de 10,0-12,0 e 24,0 26,0. Em resumo, os sienitos variam, principalmente, entre Si e mg\# de 6,830-7,540 e 3,0-55,0. Destacam-se desses intervalos, as amostras BZ 185 e $171 \mathrm{~F}$, mais o ponto isolado da amostra BZ $123(7,860$ e 4,0, respectivamente).

Os diques félsicos restringem-se ao intervalo de mg\# de 2,0-7,0, com Si de 6,3506,900 (BZ 166A) e 7,650-7,770 (BZ 182B), e dispõem-se em seqüência aos sienitos.

O diagrama discrimina bem as amostras dos diques máficos, separando as kaersutitas daqueles de caráter lamprofírico, dos anfibólios cáicicos "normais" da amostra BZ 181A. Todas as análises acham-se limitadas ao intervalo de $\mathrm{mg} \#=36,0-56,0$, com valores de Si entre 5,4405,960 para as primeiras e 6,470-6,860 para as últimas.

O Al, em gráfico semelhante, é uma figura especular do Si, com relação a um plano paralelo à abcissa. Varia entre praticamente zero (o mesmo ponto isolado da amostra $\mathrm{BZ} 123$ ) 

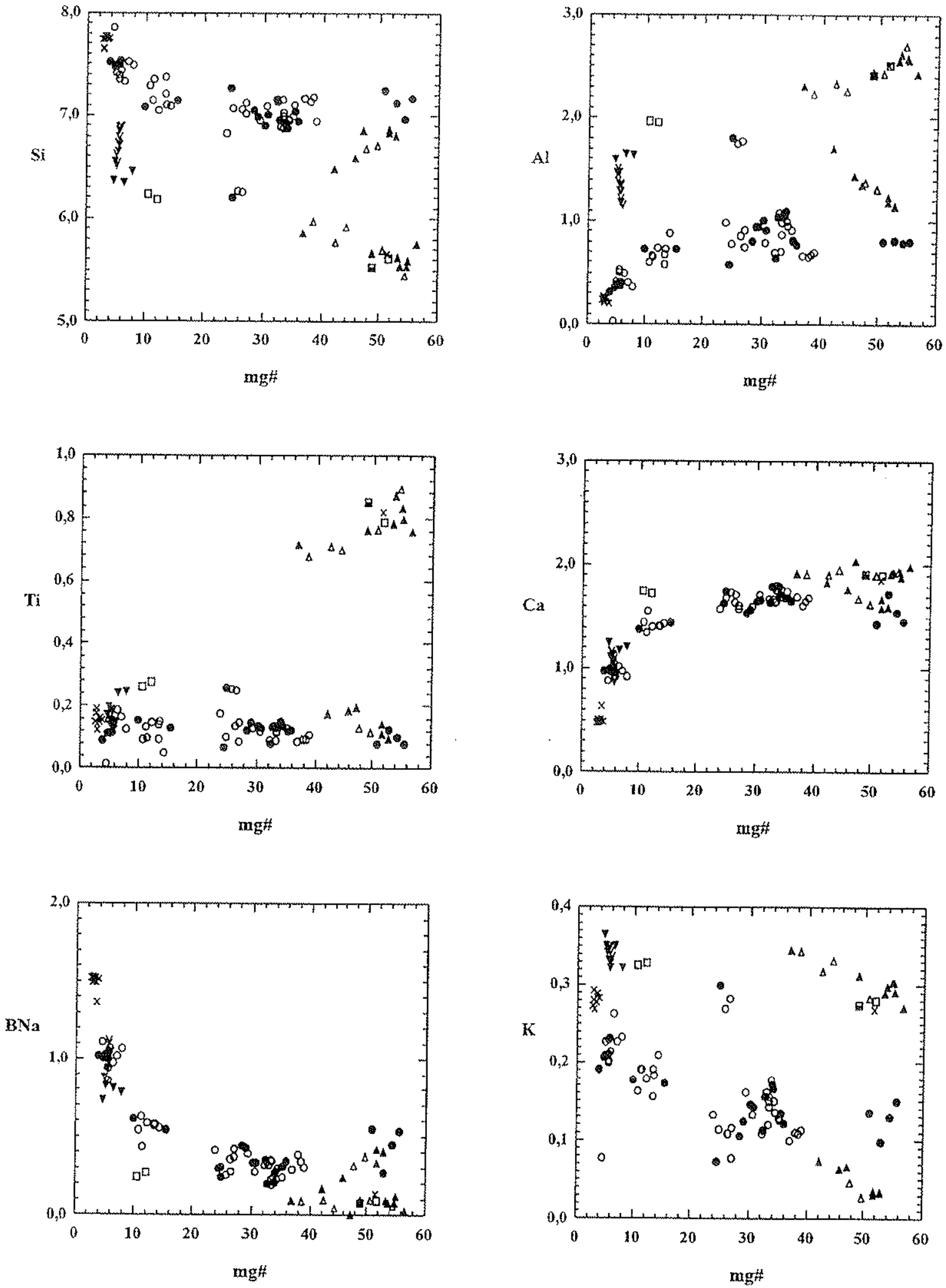

Figura 16 - Diagramas de variação mg\# vs. $\mathrm{Si}, \mathrm{Al}, \mathrm{Ti}, \mathrm{Ca}, \mathrm{BNa}$ e $\mathrm{K}$ (auf) para anfibólios de sienitos, diques félsicos e diques máficos da tllha dos Búzios. Símbolos como na Figura 15. 


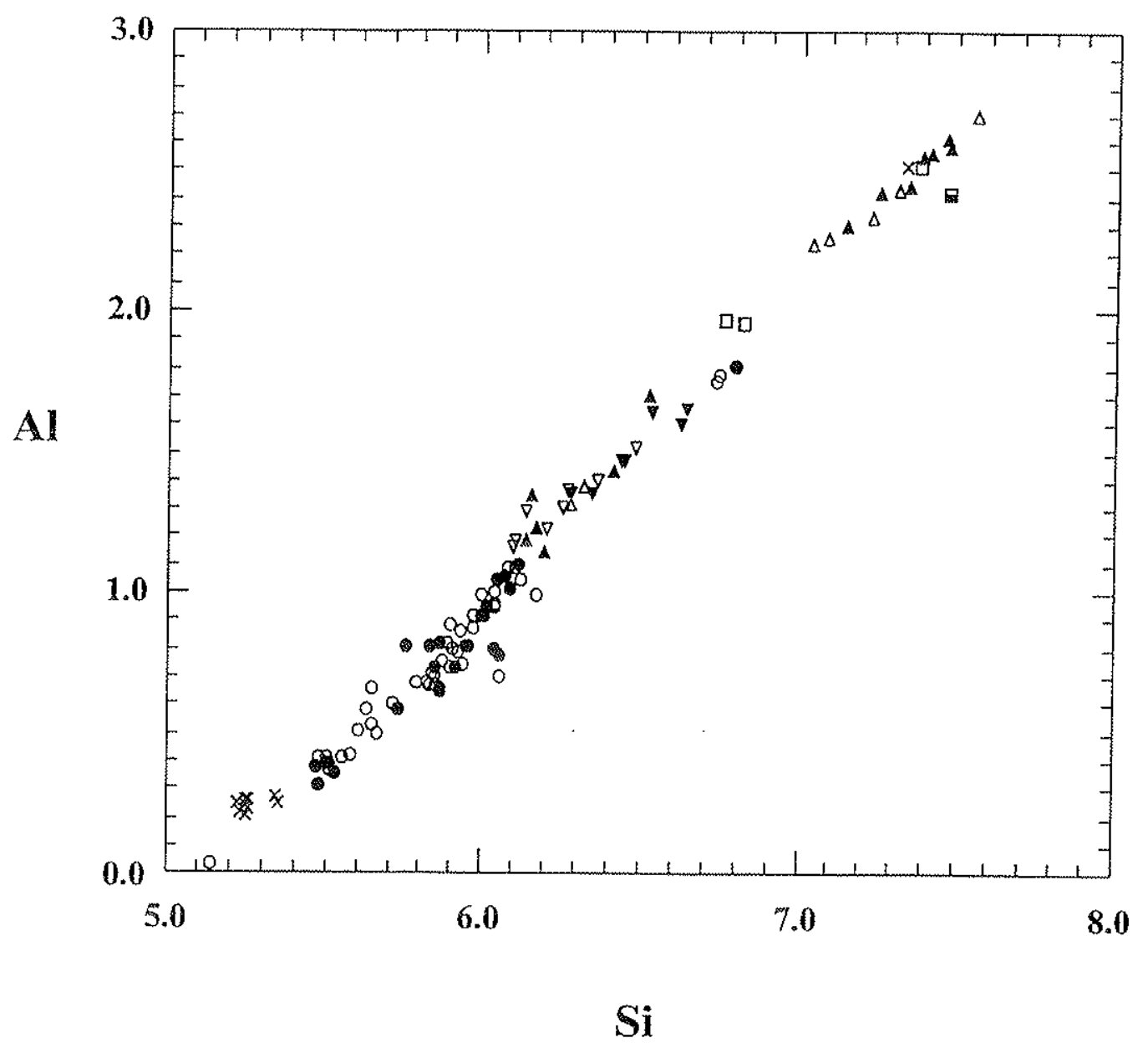

Figura 17 - Diagrama Si vs. Al (auf) para anfibólios de sienitos, diques félsicos e diques máficos da Ilha dos Búzios. Símbolos como na Figura 15. 

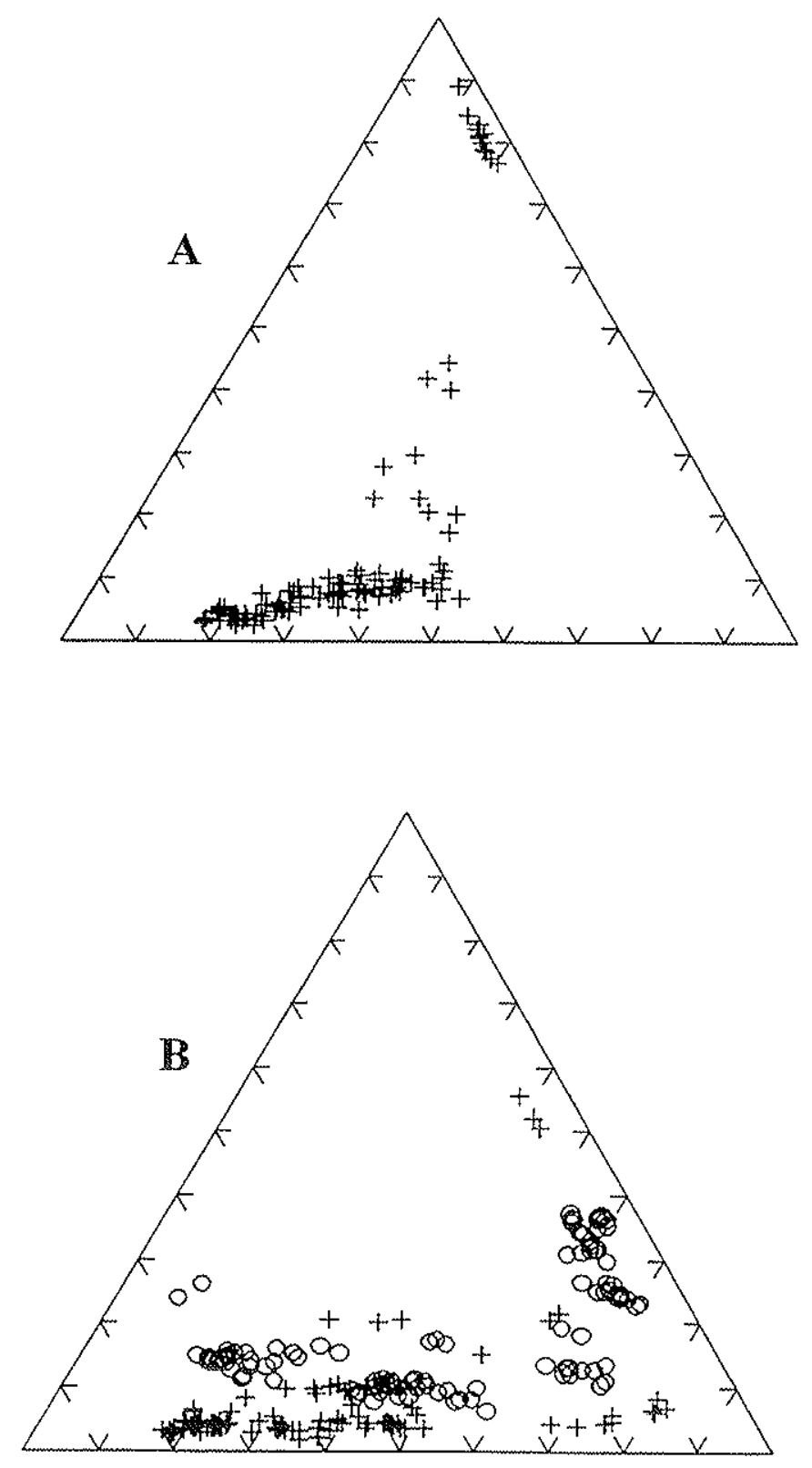

Figura 18 - Diagrama $\mathrm{Mg}-\mathrm{Na}-\left[\mathrm{Fe}^{2+}+\mathrm{Mn}+\left(\mathrm{Fe}^{3+}-\mathrm{Na}\right)\right]$ para $(\mathrm{A})$ : composição de piroxênios $(+)$ das rochas sem anfibólios e $(\mathrm{B})$ : rochas com coexistência de piroxênios $(+)$ e anfibólios (O). 
até 2,690 (mesmo ponto com Si mínimo, para anfibólio de dique lamprofírico). Os sienitos têm proporções compreendidas entre $A l=0,320-1,100, \mathrm{com}$ as mesmas amostras isoladas $(\mathrm{BZ} 185$ e 171F) com valores, agora, mais altos: 1,740-1,960. Os diques félsicos, para esses minerais, apresentam proporçōes de $A l$ entre $0,210-0,290$ (BZ 182) e 1,170-1,660 (BZ 166A); já os diques máficos possuem valores de $A$ de 1,140-1,700 (BZ 181A) e de 2,240-2,690 (rochas lamprofíricas).

O Ti, diversamente dos cátions comentados, agrupa um pouco mais, e com mais continuidade, os anfibólios analisados, exceção feita aos das rochas lamprofíricas. Os valores distribuem-se entre 0,070 e 0,280 (com dois valores de 0,018 e 0,050, amostra BZ 123), envolvendo todo o conjunto analítico. Não ocorrem valores para Ti entre 0,280 e 0,675. Entre este último e 0,890 , distribuem-se os dados analíticos para os anfibólios dos diques lamprofíricos (BZ 303C1 e 326C).

O Ca mostra distribuição mais ou menos contínua de valores, em curva assintótica positiva. Assim, destacam-se os valores relativos à amostra $B Z 182 B$, dique félsico, agrupamse os das amostras BZ 166A (dique félsico) e 123 (sienito). A não ser pelos valores mg\#, já comentados, os grupos de rochas e amostras não são melhor discriminados. Ca varia entre 0,470 e 2,040 .

O Na, na posição $\mathrm{B}$, varia entre nulo e 1,520, em distribuição aproximadamente assintótica, negativa. A maioria dos valores é menor que 0,630. Acima, aparecem os referentes aos diques félsicos e à amostra $\mathrm{BZ} 123$, sendo que os máximos correspondem à amostra $\mathrm{BZ}$ 182B. Entre 0,630 e zero estão todos os dados de BNa para todas as outras rochas. Abaixo do valor de 0,170 , somente existem anfibólios dos diques máficos, a grande maioria correspondendo a kaersutitas. Estas, por sua vez, têm BNa de até 0,420 . Nos anfibólios dos sienitos, BNa oscila entre 0,170 e 0,630 .

$\mathrm{O} \mathrm{K}$ acha-se distribuído de forma algo diferente. Seus números relativos aos sienitos arranjam-se em agrupamentos com disposição descontínua, em curvatura negativa, com seqüência de valores semelhantes aos do $\mathrm{Si}$, e compreendidos, principalmente, entre 0,100 e 0,230 , além de raros pontos isolados fora desse intervalo $(0,074$ e 0,255). As amostras $B Z 185$ e $171 \mathrm{~F}$ (bordas de grãos), como com relação a outros cátions, apresentam variação fora desses intervalos, e entre 0,257 e 0,328 , mais altos, portanto. Nos diques félsicos, os teores situam-se entre 0,257 e 0,366 (este valor é máximo para $\mathrm{K}$ ), invertendo-se, porém, o posicionamento das amostras $B Z 182 \mathrm{~B}$ e BZ 166A, com esta última exibindo proporções mais altas. Nos diques máficos, os valores de K grupam-se abaixo (BZ 181A, entre 0,026 e 0,073) ou acima (BZ 303C e 326C1, entre 0,256 e 0,344) daqueles relativos aos sienitos.

Para os sienitos, os números de TTi, CAl, CCa, BMg, BFe ${ }^{2+}, \mathrm{BMn}$ e $\mathrm{ACa}$ são nulos. Quando $\mathrm{TFe}^{3+}$ é igual a zero, CAl torna-se diferente de zero. $\mathrm{TFe}^{3+}$ é sempre nulo nos anfibólios das amostras $B Z 171 \mathrm{~F}$ e 185 , e varia entre 0,023 e 0,245 nas restantes. $\mathrm{CFe}^{3+}=0,328-1,102$, com valores inferiores nas amostras $\mathrm{BZ} 171 \mathrm{~F}(0,260-0,464)$ e $185(0,017-0,035)$. Os demais 
cátions variam como se segue: $\mathrm{CMg}, 0,322-3,393 ; \mathrm{CFe}^{2+}, 0,476-3,483 ; \mathrm{CMn}, 0,106-0,333$ e ANa 0,041 a 0,000-0,707.

Nos diques félsicos, são praticamente nulas as proporções para TFe ${ }^{3+}$ e CAl, este com raros valores de até 0,149 na amostra $B Z 166 \mathrm{~A}$, e aquele presente até 0,100 na BZ 182B. Os demais cátions e respectivos valores são: $\mathrm{CFe}^{3+}, 0,624-1,069 ; \mathrm{CMg}^{3}, 0,214-0,569 ; \mathrm{CFe}^{2+}, 2,902-$ 3,611; CMn, 0,334-0,478 e ANa, 0,187-0,703.

Nos diques máficos, não se fazem presentes $\mathrm{TFe}^{3+}$, TTi, CCa, $\mathrm{BMg} \mathrm{Fe}^{2+}$ e $\mathrm{Mn}$ e $\mathrm{ACa}$ sendo $\mathrm{CFe}^{3+}$ geralmente nulo nos diques lamprofíricos. Os outros cátions, seguidos dos valores máximos e mínimos, são: CAl, (0) 0,097-0,200; $\mathrm{CFe}^{3+}, 0,597-1,165$ (BZ 181A); CMg, Fe ${ }^{2+}$ e $\mathrm{Mn}$, respectivamente, 2,087-3,280, 1,226-2,009 e 0,015-0,041. ANa varia entre 0,132 e 0,612.

$\dot{E}$ interessante destacar o Mn, nãó mostrado graficamente. Suas proporçōes, unicamente nas posiçōes $B$, variam entre 0,500 e zero, praticamente, mostrando valores contínuos e decrescentes com mg\#. Os diques félsicos são os portadores dos maiores valores, acima de 0,330, seguindo-se, com regularidade, os sienitos, sempre abaixo de 0,300 até 0,100, tal que os anfibólios desses dois tipos de rochas apresentam disposição regular e assintótica, negativa, sequenciada: amostras BZ 166A, 182B (diques), 123, 100B, 185, 17B, 105 e 157, e 190 e $171 \mathrm{~F}$ (sienitos), estas últimas com teores mínimos. Os diques máficos agrupam-se, isolados das outras rochas, com valores em torno de 0,010-0,040. A seqüencia de números é semelhante àquela mostrada por BNa.

As ocupações e distribuições de $\mathrm{Si}, \mathrm{Al}_{\text {e }} \mathrm{Fe}^{3+}$ podem ser parcialmente compreendidas a partir da Figura 17. Nesta, a diagonal, positiva, representa o valor de $\mathrm{Si}+\mathrm{Al}=8,000$. Abaixo dela, os valores podem chegar principalmente a 7,805 e até 7,645; acima, 8,155 e 8,195. Com valores máximos de $\mathrm{Si}$ e minimos de $\mathrm{Al}$ aparece a amostra $\mathrm{BZ} 182 \mathrm{~B}$, do dique traquitico, seguindo se as amostras BZ 123 e $100 \mathrm{~B}$ de sienitos e o restante dos sienitos. Sem descontinuidades, misturam-se os dados relativos às amostras $\mathrm{BZ} 166 \mathrm{~A}$ (dique félsico) e $181 \mathrm{~A}$ (dique máfico). Os valores isolados, já vistos em outros cátions, das amostras BZ 185 e $171 \mathrm{~F}$ (bordas) aparecem a seguir. Pequeno intervalo vazio está presente entre os pares $\mathrm{Si} \times \mathrm{Al}$ de $6,185 \times 1,970$ e $5,960 \times 2,200$. Os diques máficos restantes (lamprofiricos) são os que exibem os valores extremos na seqüência. Grande parte dos sienitos e dos diques félsicos mostra $\mathrm{Si}+$ $\mathrm{Al}=8,000$, inexistindo, portanto, $\mathrm{Al}^{\mathrm{Vl}}$ e TFe ${ }^{3+}$ nessas amostras. A maior parte dos sienitos tem a soma $<8,000$, a indicar que as proporções de Si e Al não são suficientes para o preenchimento das posições tetraédricas, passando a haver a ocupação $\mathrm{TFe}^{3+}$. Os diques félsicos e máficos e as amostras $B Z 185$ e $171 \mathrm{~F}$ já contêm valores superiores a soma de 8,000 , indicando nelas a presença de $\mathrm{Al}^{\mathrm{V}} \mathrm{e}$ a ausência de $\mathrm{TFe}^{3+}$. Todos os diques máficos lamprofíricos são os que possuem os maiores valores e, portanto, com $\mathrm{Al}^{\mathrm{Vl}}$ e sem $\mathrm{TFe}^{3+}$. De modo geral, as posições $\mathrm{T} e$ $C$ estão sempre completamente preenchidas, mesmo porque o próprio artifício de cálculo leva a isso, e em poucas análises, as posiçōes $B$ não estão ocupadas, com valores pouco deficientes (até 1,930, amostras $\mathrm{BZ} 100 \mathrm{~B}$ e 105, de sienitos). As posições $\mathrm{A}$ ( $\mathrm{Na}$ e $\mathrm{K}$ ), que nas amostras 
de Búzios representam a soma $\mathrm{A}(\mathrm{Na}+\mathrm{K})$, uma vez que $\mathrm{ACa}=0$, variam entre 0,073 e 0,924 nos sienitos (valor máximo na amostra $B Z 171 \mathrm{~F}$ ).

Com relação às mudanças químicas e tendências de variações composicionais observáveis no triângulo $\mathrm{Mg}+\left[\mathrm{Fe}+\mathrm{Mn}+\left(\mathrm{Fe}^{3+}-\mathrm{Na}\right)\right]-\mathrm{Na}$, tradicionalmente empregada para piroxênios, e já comentadas previamente, é interessante notar que as rochas contendo esses minerais, mas sem anfibólios (Fig. 18a), mostram um delineamento composicional mais definido, com menor enriquecimento $\mathrm{em} \mathrm{Fe}^{3+}$, este indicativo de tendência sódica mais direta. $\dot{\mathrm{E}}$ - caso das amostras também portadoras de biotita (BZ 14A, 148A, 151, 159A e 195) de sienitos, dique félsico (BZ 163D) e máfico (BZ 326A7), ou somente de piroxênios (dique máfico $B Z 313 / 5 B$ ). Todas as demais (Fig. 18b) contêm piroxênios juntamente com anfibólios ou com biotitas, ou mesmo ambos, e sugerindo a ocupação de espaços composicionais por anfibólios, onde não aparecem os piroxênios. Alguns desses espaços, e as tendências múltiplas vistas na Figura 12 (piroxênios), poderiam ser o resultado de número insuficiente de análises, mas é sugestivo que com esse desmembramento, uma tendência mais diretamente sódica acha-se melhor definida entre os piroxênios das rochas sem anfibólios. De forma um tanto grosseira, as análises dos piroxênios e dos anfibólios em conjunto apontam primeiramente uma tendência para o aumento de $\mathrm{Fe}$, seguida de enriquecimento em $\mathrm{Na}$. A mesma disposição é observada se isolados os anfibólios.

Como observações finais, existe correlação positiva $\mathrm{Fe} / \mathrm{Fe}+\mathrm{Mg} \times \mathrm{Na}$ (total). A distribuição de valores inicia-se com tendência negativa entre os diques máficos (baixos valores) e os sienitos com os mesmos valores, passando então para ascensional positiva até a amostra BZ 166A (fonólito) e BZ 123B (anfibólios sódico-cálcicos de sienitos).

Comparados aos piroxênios, os anfibólios de uma mesma amostra exibem composições pouco variadas, qualquer que seja o parâmetro levado em conta, à exceção dos núcleos e bordas dos minerais da amostra $B Z 171 \mathrm{~F}$, do dique fonolítico e dos diques lamprofíricos. As variações são muito maiores entre tipos de rochas e amostras, antes que entre grãos de mesmas amostras ou partes distintas do mesmo cristal. Parte dessa caracteristica composicional deve-se, sem dúvida, ao número restrito de análises em algumas amostras ou ainda ao pequeno número de amostras da mesma litologia.

\subsection{As biotitas}

Estes minerais ocorrem também em todos os tipos de rochas da liha. Em parte dos sienitos, têm presença mais importante que os anfibólios, e até mesmo que os piroxênios. Sua concentração diminui nos diques félsicos, de caráter mais insaturado e mais alcalino. Eles exibem como características variáveis, mas prontamente reconhecidas, a cor e o pleocroísmo, possivelmente ligadas à presença maior ou menor de alguns dos cátions $\left(\mathrm{Fe}^{2+}, \mathrm{Fe}^{3+}, \mathrm{Mn}\right.$, Ti e 
$\mathrm{Fe} / \mathrm{Mg})$.

Foram feitas 115 análises, parte envolvendo núcleos e bordas das diferentes categorias texturais arbitradas para os indivíduos. Entre os sienitos, foram analisadas biotitas de onze amostras, totalizando 91 pontos analíticos. Entre os diques félsicos, uma amostra e 5 análises, e entre os máficos, três amostras e 19 análises.

As análises visaram aos elementos principais tradicionais, além de $\mathrm{Ba}$, tendo em vista os altos teores presentes nas biotitas dos diques máficos. Os resultados, em porcentagem em peso dos óxidos, e a fórmula estrutural, calculada na base de 22 átomos de oxigênio e 16 cátions, são fornecidas nas Tabelas 13 a 15 . O único tratamento gráfico apresentado é o de uso classificatório e rotineiro $\left(\mathrm{Al}^{\mathrm{N}} \times \mathrm{Fe} / \mathrm{Fe}+\mathrm{Mg}\right)$, onde foram lançados todos os valores obtidos (Fig. 19).

No conjunto, as biotitas mostram ampla variação em $\mathrm{Mg}$ e $\mathrm{Fe}$, com valores entre 0,429 e 4,706 e 1,491 e 4,883, respectivamente. Considerando separadamente os grupos de rochas, os valores para Mg e Fe variam, respectivamente, nos sienitos, entre 1,120 e 2,559 e 2,876 e 4,192; diques félsicos, entre 0,429 e 0,464 e 4,636 e 4,883 e, nos diques máficos, entre 2,216 e 4,706 e 1,491 e 2,485. Individuo incluso em piroxênio, possivelmente um microxenólito de dique máfico, destaca-se dos demais, com valores entre 3,494-4,706 para Mg e 1,495-1,794 para Fe. No geral, as razōes $\mathrm{Mg} / \mathrm{Fe}$ são moderadas a baixas, sempre inferiores a 2,0, exceção feita ao indivíduo citado e a outras duas análises de grãos comuns, também de diques. Assim, as biotitas dos diques félsicos poderiam ser chamadas de ferro-biotitas e as dos diques máficos de magnésio-biotitas; nos sienitos, esses mesmos minerais também poderiam ser referidos como ferro-biotitas, conquanto talvez seja preferivel utilizar-se o termo biotita, simplesmente. As quatro análises citadas previamente já são bastante magnesianas, o suficiente para corresponderem à flogopitas (cf. Deer et al., 1978, 1993; Ulbrich, 1983). Segundo Rock (1982), as biotitas de Búzios poderiam ser classificadas como titânio-biotitas $(T i>0,50)$ e biotitas titaníferas (Ti entre 0,10 e 0,50). Ainda em termos de nomenclatura e classificação, tomando o parâmetro $(\mathrm{Fe}+\mathrm{Mn}) /(\mathrm{Fe}+\mathrm{Mn}+\mathrm{Mg})$ como indicador aproximado do teor de annita, esses minerais variariam entre annita $90 \%$ e $30 \%$ nos diques félsicos e máficos, respectivamente. Além da possibilidade de relacionar esse índice às variações de cor nas micas, o seu aumento acentuado é indicativo de valores altos de $\mathrm{Fe}^{3+}$, embora o teor desse elemento não seja calculado. Os nomes das variedades constantes na Figura 19, relativos às composições extremas, são os de emprego rotineiro, exceção feita ao da "eastonita", presente em Tröger (1979) e Deer et al. (1978), mas em desuso (cf. Deer et al., 1993).

A Figura 19 evidencia certo espalhamento nos dados plotados, não obstante mostre tendência continua de variação entre os valores maiores e menores de $\mathrm{Al}^{N}$ e $\mathrm{Mg}$ ("eastonita", diques máficos e sienitos, respectivamente), com as biotitas dos diques félsicos se mostrando mais enriquecidas no termo annita. Apesar da continuidade composicional, as composições das biotitas ficam bem delimitadas relativamente aos diques máficos e aos sienitos. 


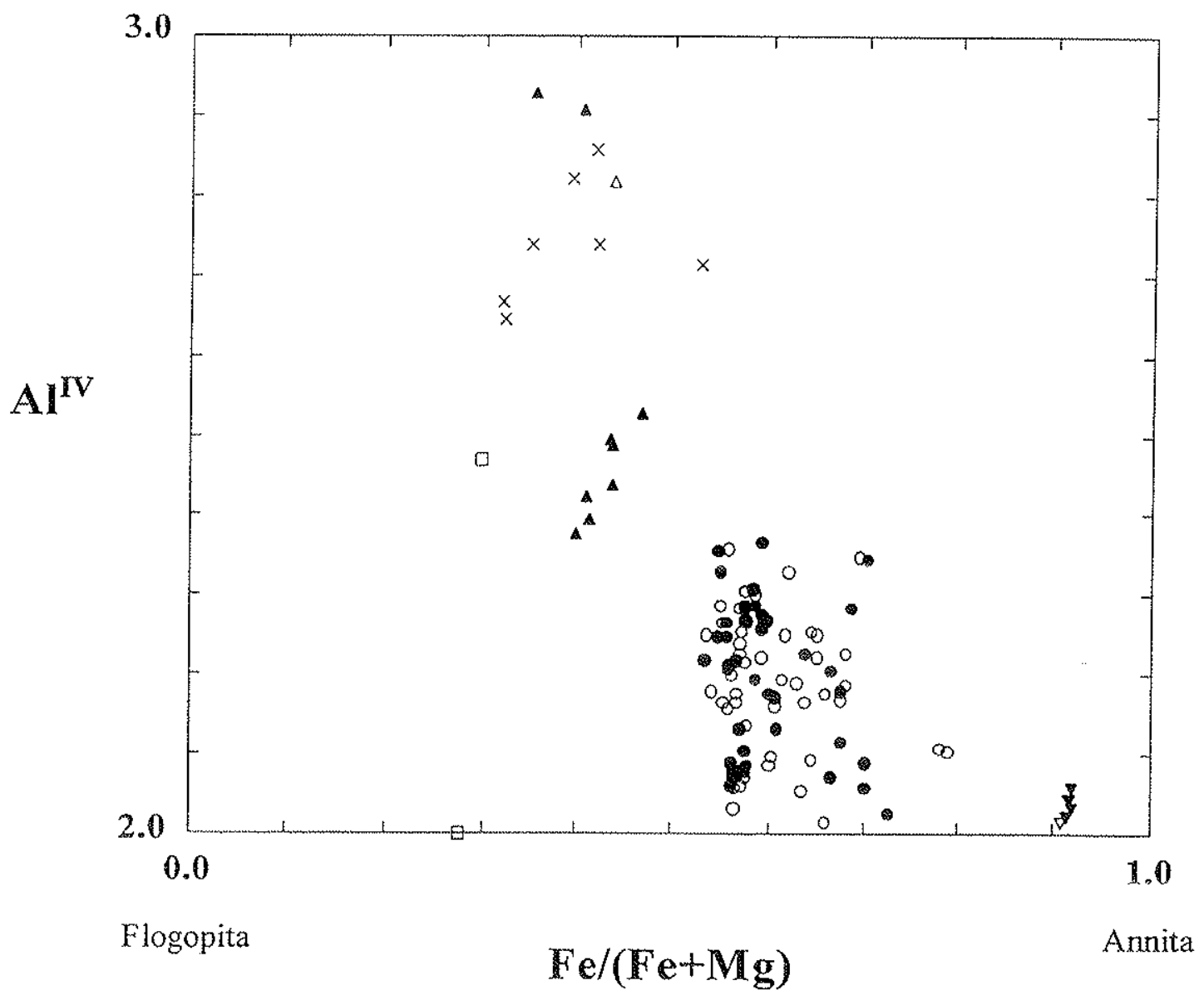

Figura 19 - Diagrama $\mathrm{Al}^{\mathrm{rV}}$ vs. $\mathrm{Fe} /(\mathrm{Fe}+\mathrm{Mg})$ para biotitas de sienitos, diques félsicos e diques máficos da Ilha dos Búzios. Símbolos como na Figura 15. 
Os indivíduos analisados apresentam em geral $\mathrm{Si} \otimes \mathrm{Al}^{\mathrm{N}}$ insuficientes para as ocupações tetraédricas, não havendo sobra de $\mathrm{Al}^{\mathrm{VI}}$ para as posições octaédricas. Si varia entre 5,437-5,985 nas biotitas dos sienitos, 5,669-5,828 e 4,911-5,772, respectivamente, nas dos diques félsicos e máficos. $\mathrm{Al}^{\mathrm{N}}$, mantida a mesma ordem das rochas, varia entre $2,015-2,365$, 2,015-2,059 e 1,991-2,928. $\mathrm{Al}^{\mathrm{VI}}$ atinge 0,050 e tem poucos valores não nulos, variados, para $\mathrm{Si}+\mathrm{Al}^{\mathrm{Vl}}=8,000$, sendo que $90-95 \%$ deles são iguais a zero. Ti é sempre elevado, e na mesma seqüência dos grupos de rochas, é variável entre 0,290-0,600, 0,429-0,465 e 0,044-1,120. Ba apresenta teores nulos nas biotitas dos sienitos e dos diques félsicos, chegando a 0,398 nos diques máficos lamprofíricos e a valores nulos ou a moderados no dique máfico diabásico ( $B Z$ 181A).

É interessante notar a correlação positiva entre $\mathrm{Ba}, \mathrm{Ti}$ e $\mathrm{Al}\left(\mathrm{Al}^{\mathrm{N}}\right)$ e negativa desses elementos com Si e K.

Com relação aos parâmetros indicadores de "diferenciação", suposta, a razão $(\mathrm{Fe}+\mathrm{Mn}) /(\mathrm{Fe}+\mathrm{Mn}+\mathrm{Mg})$ varia como já descrito. Relativamente a $\mathrm{Fe} /(\mathrm{Fe}+\mathrm{Mg})$, com comportamento em geral pouco diferente da anterior (baixos valores de $\mathrm{Mn}$ ), somente quatro análises possuem números inferiores a $0,33(\mathrm{Mg} / \mathrm{Fe}=2,0)$, correspondendo às duas análises das inclusões já referidas e mais duas de grãos matriciais; todas as quatro exibem valores semelhantes e $\mathrm{Al}^{\mathrm{V}}$ variado $(2,000-2,665)$. As outras análises de biotitas dos diques máficos apresentam valores entre 0,34 e 0,44 (um valor $0,53, \mathrm{Mg} / \mathrm{Fe}<1,0$ ), agrupando-se aqueles da amostra BZ 181A (máfica diabásica) entre 0,40 e 0,44 e $\mathrm{Al}^{\mathrm{IV}} \mathrm{em}$ torno de 2,370-2,530. Quanto aos sienitos, a maior parte das análises ocupa pequeno intervalo, $A l^{N} 2,010-2,360$ e $\mathrm{Fe} /(\mathrm{Fe}+\mathrm{Mg})=0,55-0,70$, enquanto que os diques félsicos estão restritos aos pares de valores $A l^{\mathrm{V}}=2,010-2,060$ e $\mathrm{Fe} /(\mathrm{Fe}+\mathrm{Mg})=0,91-0,92$.

\subsection{Os óxidos}

Foram feitas análises em minerais opacos, identificados, microscópica e preliminarmente, como magnetitas e ilmenitas. Estas últimas contam com 42 análises nos sienitos e 3 nos diques máficos, e as primeiras com 27 e 20 , respectivamente, totalizando assim 92 pontos analíticos. Näo houve maiores preocupações com as categorias texturais, embora bastante variadas nas rochas de diques e, tampouco, na distinção de indivíduos isolados ou de fases exsolvidas. Os opacos estão praticamente ausentes nos diques félsicos traquíticos e fonoliticos.

Os resultados, reunindo a porcentagem em peso dos óxidos, a fórmula estrutural e as proporções moleculares encontram-se nas Tabelas $16 a, b$ e $17 a, b$. Para as magnetitas, a base de cálculo foi de 32 oxigênios e 24 cátions, e para as ilmenitas 6 oxigênios e 4 cátions. A razão $\mathrm{Fe}^{2+} / \mathrm{Fe}^{3+}\left(\mathrm{FeO}\right.$ e $\left.\mathrm{Fe}_{2} \mathrm{O}_{3}\right)$ foi calculada a partir de $\mathrm{FeOl}$ ( $\mathrm{FeO}$ inicial, fornecido diretamente pelo 
programa de cálculos da microssonda), conforme Carmichael (1967) e com o auxílio do programa "Minpet for Windows" já referido.

Os resultados confirmam os minerais esperados, e foram lançados no triângulo classificatório $\mathrm{FeO}-\mathrm{Fe}_{2} \mathrm{O}_{3}-\mathrm{TiO}_{2}$, em proporçöes moleculares, recalculadas para $100 \%$ (cf. Buddington e Lindsley, 1964).

As magnetitas apresentam ampla variação em $\mathrm{TiO}_{2}$, permitindo definir magnetitas titaniferas nos sienitos $\left(\mathrm{TiO}_{2}=0,40-7,78 \%\right)$ e titano-magnetitas nos diques máficos $\left(\mathrm{TiO}_{2}=\right.$ $17,05-24,25 \%)$. As ilmenitas são mais freqüentes nos sienitos, e daí o pequeno número de análises nos diques máficos, onde elas rareiam, e exibem teores de $\mathrm{TiO}_{2}$ entre 44,05\% e $52,23 \%$ nos sienitos e $47,37 \%$ e $50,13 \%$ nos diques.

As magnetitas, na verdade, são soluções sólidas da série ulvöspinélio-magnetita (UspMt) e as ilmenitas da série ilmenita-hematita (IImHem). Os resultados analíticos tabelados foram tratados conforme essa terminologia. Dada a presença de outros cátions, a apresentação gráfica depende em muito de recálculo (cf. Buddington e Lindsley, 1964), que pode embutir bastante imprecisão. Não obstante, os componentes foram calculados, para várias composições extremas e para fins de comparação entre tipos de rochas e amostras.

As magnetitas dos sienitos variam entre Usp $_{1,2-22,8} \mathrm{Mt}_{98,8-77,2}$, estando a maioria das composições acima de $\mathrm{Mt}_{90}$. Além disso, parece haver algum enriquecimento em $\mathrm{Fe}_{2} \mathrm{O}_{3}$, em desequilibrio. Entre as amostras, as com os maiores proporções de Mt são a BZ 159A e a 17B, com valores em torno ou acima de $\mathrm{Mt}_{95}$. Em termos de óxidos, as maiores participações são de $\mathrm{TiO}_{2}(0,40-7,78 \%)$, $\mathrm{FeO}(29,20-35,80 \%)$ e $\mathrm{Fe}_{2} \mathrm{O}_{3}(58,8-67,50 \%)$, como seria de se esperar. Os outros apresentam-se em baixos teores: $\mathrm{SiO}_{2}$ até $0,19 \%, \mathrm{Al}_{2} \mathrm{O}_{3}, 0,72 \%$ e $\mathrm{MnO}$ até $1,86 \%$, sendo praticamente nulos os valores para $\mathrm{Cr}_{2} \mathrm{O}_{3}, \mathrm{MgO}$ e $\mathrm{NiO}$.

Nos diques máficos, esses minerais apresentam maior variação composicional $e$, por vezes, elevada participação de outros elementos. As composições variam entre $\mathrm{Usp}_{40,0} \mathrm{Mt}_{60,0} \mathrm{e}$ Usp $_{93,7} \mathrm{Mt}_{6,7}$, havendo uma Usp ${ }_{100}$ e quatro valores $\mathrm{Mt}_{100}$. $\mathrm{A}$ amostra $\mathrm{BZ} 303 \mathrm{C}$ contém Usp $\mathrm{s}_{100}$, um valor $\mathrm{Mt}_{100}$ e outros em torno de $\mathrm{Mt}_{20.30}$; a amostra 313/5B tem $\mathrm{Mt}_{100}$ e os outros entre $\mathrm{Mt}_{6,7} \mathrm{e}$ $\mathrm{Mt}_{40,0}$; as amostras $326 \mathrm{~A} 7$ e $326 / \mathrm{C} 1$ possuem $\mathrm{Mt}_{100}$, com a maior parte das composições entre $\mathrm{Mt}_{35,3}$ e $\mathrm{Mt}_{60,0}$.

Não se notam tendências entre as categorias de gräos e bordas e núcleos, provavelmente, devido ao número restrito de análises.

Em termos de óxidos, as variações composicionais extremas são: $\mathrm{TiO}_{2}(0,0) 17,0-24,20 \%$, FeO 21,5-56,7\% e $\mathrm{Fe}_{2} \mathrm{O}_{3}(0,05)(7,20)$ 22,00-60,00\% como majoritários, evidentemente, sendo os valores nulos correspondentes a $\mathrm{Mt}_{100} \mathrm{e} \mathrm{Usp}_{100}$. Os restantes variam entre zero e máximos de 
$\mathrm{SiO}_{2} 5,40 \%, \mathrm{Al}_{2} \mathrm{O}_{3} 6,50 \%, \mathrm{Cr}_{2} \mathrm{O}_{3} 2,20 \%$, MnO 1,60\%, MgO 6,24\% e NiO 0,58\%. A não ser o $\mathrm{MnO}$, é modesta a nula a presença de $\mathrm{NiO}$ e mesmo de $\mathrm{Cr}_{2} \mathrm{O}_{3}$ em todas as rochas. Já os teores de $\mathrm{SiO}_{2}, \mathrm{Al}_{2} \mathrm{O}_{3}$ e $\mathrm{MgO}$ são consideravelmente altos nos minerais dos diques máficos, e baixos a nulos nos sienitos.

As ilmenitas dos sienitos têm composições $\| \mathrm{Im}_{87,8-99,6} \mathrm{Hem}_{12,2-0,41}$ havendo uma composição $\mathrm{Im}_{35} \mathrm{Hem}_{65}$. A variação composicional para cada amostra é menor que o intervalo total e não ultrapassa os $5 \%$, com a maioria dos resultados apresentando $\|_{\rightarrow 99}$, e grande número acima de $1 \mathrm{Im}_{95}$. O menor valor representativo para $I \mathrm{Im}, 87,8$, é da amostra $\mathrm{BZ} 148 \mathrm{~A}$, e o maior, 99,6, da amostra BZ 159A, que inclui também o valor anômalo de $\| \mathrm{Im}_{34,9}$. Os óxidos maiores são $\mathrm{TiO}_{2} 44,00-52,20 \%$, $\mathrm{FeO} 30,70-42,00 \%$ e $\mathrm{Fe}_{2} \mathrm{O}_{3}$ 0,30-11,00\%. Somente $\mathrm{MnO}$, com 2,85-12,82\%, é bastante representativo. Os demais variam entre zero e 0,50\%.

As três únicas análises da solução $\mathrm{Im}-\mathrm{Hem}$ nos diques máficos mostram valores $\operatorname{llm}_{96,2-90,7} \mathrm{Hem}_{3,8-9,3}$. Em termos de óxidos, a participação é de $\mathrm{TiO}_{2} 47,30-50,10 \%$, FeO 35,60$42,60 \%$ e $\mathrm{Fe}_{2} \mathrm{O}_{3} 3,70-9,20 \%$. Entre os outros, tem presença o $\mathrm{MnO}, 0,98-2,25 \%$, e o $\mathrm{MgO}$, $0,10-4,60 \%$. Os demais são, praticamente, nulos.

\subsection{Síntese e observações preliminares}

Pelos resultados apresentados, o programa analitico de química mineral pode parecer incompleto para uma apreciação mais rigorosa. É satisfatório, contudo, tendo em vista as finalidades pretendidas. Fica claro que o número de amostras envolvidas é insuficiente, principalmente para os diques félsicos, e o número de análises em muitos casos pequeno. Os dados cobrem de forma aceitável o espectro composicional de alguns dos minerais, caso dos feldspatos alcalinos, biotitas, óxidos, e mesmo piroxênios e anfibólios em parte das rochas. Todavia, o maior número de amostras, ou de análises, dificilmente alteraria de forma substancial os resultados. Em outros casos e para alguns outros minerais (nefelinas, sodalitas, olivinas), um contingente maior de amostras e análises poderia delinear melhor as caracteristicas químicas desses minerais, vindo a preencher vazios composicionais e, eventualmente, estender intervalos de variação.

\subsubsection{Os feidspatos}

Os feldspatos alcalinos mostram-se razoavelmente definidos em suas características gerais, sugestivas de cristalização e evolução tardia complexa para os sienitos e diques 
félsicos. Os estados estruturais, como eles se apresentam, com predomínio de albita de baixa temperatura e microclínios, com domínios desordenados de ortoclásio, raramente mais representativos que os microclínios, na forma de micro (cripto) mesopertitas e pertitas, são compativeis com rearranjos cristaloquímicos tardios, possivelmente (auto) metassomáticos/hidrotermais, e não exclusivamente devidos à sua história termal (Larsen, 1976; Ulbrich, 1983 etc.).

As rochas em que esse mineral associa-se ao estágio magmático inicial são aquelas onde os processos tardios e as interações com as encaixantes foram menores. Correspondem aos tipos presentes mais internamente no corpo, no sentido sul e sudeste da llha (Ponta Sul e Ponta Sudeste), que não contêm quartzo ou o têm em quantidade pequena $(\sim 1 \%)$, e que exibem arranjos em "sineusis". Destacam-se aí as amostras BZ 159A e 190 (analisadas), com desmisturação mais completa e presença de termos extremos AbOr e OrAb. A amostra 100B é semelhante a elas, mas é da costa oeste, proximidades do contato e exigiria outra explicação (dique ?). Nas partes mais a norte, no sentido dos contatos ou do interior da llha, as composições variam continuamente ou, ao lado dos componentes extremos, mostram parcela de composições intermediárias isoladas. Esse padrão poderia ser tomado como revelador de criptopertitas e processos menos completos de exsolução.

O padrão das mesopertitas é universal na llha, com poucas variações. Qualquer que tenha sido o processo (s) atuante (s), toda a massa rochosa foi atingida, com eventuais diferenças devidas principalmente à pressão de água.

As condições de cristalização devem ter sido do tipo "hipersolvus", com os feldspatos participando da cristalização magmática inicial como fase única, como ortoclásio bastante sódico ou então como sanidínio. Com as temperaturas atingindo o "solvus", teve início o processo de exsolução, provavelmente incompleta. A cristalização e resfriamento nessas condições pressupõem baixas pressões, não inferiores a $1 \mathrm{~kb}$, nem muito superiores.

Durante essa evolução, a partir de algum momento, o fator $\mathrm{H}_{2} \mathrm{O}$ adquiriu grande importância. Tanto o abaixamento da temperatura como o da pressão de água apresentam variações, sendo esta última maior nas proximidades dos contatos. A presença da água, variável com a cristalização, deve ter perdurado por longo intervalo.

Não há relação aparente entre os feldspatos mais homogêneos, a maior ou menor presença do ortoclásio e o posicionamento geográfico. Como visto, os mais homogêneos são os que exibem maior continuidade composicional e, entre eles, somente na amostra BZ 185 (costa norte-central), que se distingue por sua granulação média, predomina o ortoclásio (mais as amostras 119, da Pontinha, e 193, do Saco Grande, não analisadas). 
Não se dispõe de elementos seguros, mas a exemplo do sucedido rotineiramente em corpos ígneos de resfriamento lento e natureza alcalina, soluções enriquecidas em $\mathrm{Na}$ e elementos incompativeis (até essas condições) devem ter aumentado de forma gradativa sua participação, principalmente nas porções mais internas da massa total, mais preservada do exterior. Dois fatores diferentes, e em parte interdependentes, complicam o quadro: a presença de soluções externas e a fusão parcial e mobilização da rocha encaixante, em volumes não conhecidos com segurança.

A mobilização do $\mathrm{Na}$ e do $\mathrm{K}$ poderia ter sido simplesmente efeito do resfriamento e de algum fluido presente. Não parece factível a mobilização de $\mathrm{Na}$, tão somente porque uma vez mobilizado ele haveria que se fixar novamente no lugar de outro elemento, que, obrigatoriamente, teria que se deslocar. As composições, levemente mais albíticas, parecem ser resultantes daquela inicial, e não decorrentes de aporte externo. E, no caso de autometassomatismo, teria havido em algum ponto empobrecimento em $\mathrm{Na}$. Considerando domínios restritos, da ordem de milimetros a centímetros, esse mecanismo pode ter atuado: de modo geral, os centros dos individuos e as fímbrias periféricas, bem como grãos de matriz fina intersticial, são mais albiticos.

Entre os elementos menores/traços, destaca-se o Fe, a niveis um pouco anormais, ainda que de distribuição homogênea. Os outros analisados, $\mathrm{Ba}$ e $\mathrm{Sr}$, mostram teores e distribuição semelhante, com pequenas variações correlacionáveis às relações $A b / O r$. Aparentemente, as fases com $\mathrm{Or}_{>80}$ possuem $\mathrm{Ba}$ com teores um pouco mais elevados.

Nos diques félsicos, os feldspatos exibem exsolução mais acentuada entre os fonólitos e espectro contínuo no traquito (BZ 182B). Resfriamento mais tardio, líquidos magmáticos mais enriquecidos em álcalis e atuação maior e mais prolongada de soluções residuais teriam sido responsáveis por essa diferença. Os teores dos elementos menores são semelhantes aos dos sienitos, mas o Fe tende a apresentar concentrações mais altas junto às bordas e grãos matriciais. Tal variação poderia estar ligada a soluções residuais, atuantes também nos sienitos, não obstante menos aparentes nos últimos.

Nenhum desses tipos de rocha contém plagioclásio significativo, e as albitas são portadoras de teores de no máximo e, mais raramente, $A n_{10}$. É constante o leve incremento em An com o teor de Ab.

Os plagioclásios aparecem somente nos diques máficos. Mesmo aqui são visíveis e individualizáveis somente em três das cinco amostras: BZ 181A (basalto alcalino), 303C e 326 A7 (tefritos). Eles se fazem presentes em outras amostras e mesmo entre as analisadas, em que aparentemente estão ausentes, eles devem ocorrer como material micro-criptocristalino. A maior variação em An é encontrada na amostra 181A, caracterizando não só diferentes 
indivíduos, como núcleos e bordas de grãos $\left(A n_{85-15}\right)$. Nessa amostra, o teor de Or no plagioclásio é praticamente zero. Nas outras duas citadas (tefritos), há significativo aumento de Or, entre as composições extremas de $A n_{60.70}$ e $A n_{30-40}$. Essa diferença na presença de $\mathrm{K}$ é importante e significativa entre os minerais félsicos, podendo indicar rochas de diferentes origens, ou ainda, que o basalto alcalino seria o produto menos evoluído, a partir de fonte única.

Nos mesmos diques aparecem também feldspatos alcalinos, 'todos potássicos $\left(\mathrm{Or}_{50-100}\right)$, sendo esses minerais nas amostras $\mathrm{BZ} 313 / 5 \mathrm{~B}$ e $326 \mathrm{C} 1$ os únicos analisados, com Or $r_{90-100}$. Nestas últimas litologias, eles são homogêneos, sugerindo a presença de sanidínio, compativel com temperaturas mais altas de cristalização, incluindo os individuos ocelares analisados. Estas rochas e os feldspatos, descartados outros tipos de alteração ou de mineralogia tardia presente (zeólitas, argilominerais, serpentina), tipicos, parecem ter sido refratários às mesmas soluções que atuaram em todo o maciço e que afetaram tanto os sienitos como os diques félsicos, ou poderiam ter sido ligeiramente mais tardios (a geologia não é conclusiva).

Os plagioclásios dos diques máficos não apresentam grandes variações em $\mathrm{Fe}$, sendo os menores teores aqueles de grãos matriciais. Sr tem valores baixos nos plagioclásios do basalto e elevados nas outras rochas, mas mais baixos nos individuos matriciais. Ba é muito variado e iguala-se aos outros na amostra BZ 326A7, acompanhando-os nas matrizes. $O$ comportamento desses elementos nos plagioclásios varia de rocha para rocha, tal que ora aumentam, ora diminuem com a razão $A b / A n$, não sendo realista pensar-se simplesmente em termos de substituição de $\mathrm{Ca}$ e K. Quanto aos feldspatos alcalinos, sempre potássicos, das rochas com plagioclásio, parece haver relação mais visível do teor de Or com Ba, e mesmo com Sr; já as razões Sr/Ba são bastante variadas, sem padrão único. Esses minerais, na rocha basáltica, possuem $\mathrm{Ba}$ com teor moderado a baixo, porém, superior ao do $\mathrm{Fe}$ e Sr. Nos indivíduos ocelares, Fe é baixo $(0,18 \%)$, $\mathrm{Sr}$ moderado a baixo $(0,50 \%)$ e $\mathrm{Ba}$ alto $(1,75 \%)$. Nos grãos matriciais, o $\mathrm{Fe}$ pode manter-se ou cair, enquanto que $\mathrm{Sr}$ e $\mathrm{Ba}$ sempre diminuem $(0,0 \mathrm{x}$ $0,30 \%)$. É interessante notar que o Fe das matrizes é mais alto que aquele dos ocelos.

Como preliminares, as variações de $\mathrm{Fe}, \mathrm{Sr}$ e $\mathrm{Ba}$ são sugestivas de diferenças entre o basalto e as rochas lamprofíricas, estas parecendo mais primitivas. Quando se comparam os resultados obtidos nos ocelos e nas matrizes, também surgem diferenças, sugestivas de processos evolutivos já avançados, com "líquidos" magmáticos residuais, já empobrecidos em $\mathrm{Sr}$ e $\mathrm{Ba}$ e até enriquecidos em $\mathrm{Fe}$, com evolução rápida, e dentro ainda das rochas máficas. Quer dizer, o intervalo composicional dos diques máficos já poderia incluir evolução marcante de tipos mais primitivos para tipos bem mais evoluidos. São significativas as diferenças em Sre 
Ba entre os indivíduos ocelares, os comuns e as matrizes, estas sempre empobrecidas por fatores desde $2 x$ (plagioclásios) até mais que $100 x$.

Os feldspatos dos sienitos incluem parte minoritária dos minerais ferromagnesianos, especialmente o clinopiroxênio, além de acessórios ocasionais, apatita e opacos. Os mesmos minerais participam da trama textural, havendo relacionamento igualitário entre eles e os feldspatos. Em algumas amostras, com textura tipicamente magmática ("foiaítica", ver Capítulo 6), parte dos fêmicos torna-se mais intersticial. Essas feições sugerem seqüência complexa, iniciando-se com os fêmicos e acessórios. Na verdade, estes últimos poderiam estar participando como sólidos de massa magmática muito mais volumosa, de caráter essencialmente feldspático, que iniciou sua cristalização já completamente separada do(s) magma(s) siálico(s) mais primitivo, parental. Isto é, embora sem características cumuláticas, é possivel que os sienitos tenham evoluido à semelhança de rochas cumuláticas (especialmente as rochas foiaiticas). Durante a cristalização lenta, liquidos minoritários, aprisionados, de natureza ferromagnesiana e de composição mais próxima à dos líquidos parentais, cristalizaram as fases fêmicas e os acessórios restantes. Os processos tardios submagmáticos e subsolvus, até temperaturas relativamente baixas, teriam sido responsáveis pela obliteração de eventuais feições cumuláticas mais típicas. Evidentemente, as massas sieniticas atualmente expostas não sofreram afundamento, tendo permanecido em equilibrio estático ou apenas pequena flutuação.

Nos diques félsicos, insaturados, tanto as paragêneses como as relações texturais são outras. Nessas rochas, os feldspatos alcalinos micro-mesopertiticos, ou somente potássicos, aparecem comumente em duas geraçōes, uma delas mais relacionada com as nefelinas e sodalitas. Nesta, os indivíduos maiores igualam-se aos fóides, vindo a formar um mosaico de fundo sobre o qual, e/ou envolvendo-o, aparecem os indivíduos ripiformes, finos, ou como pequenas "lascas" alongadas da outra geração. Duas explicações são possiveis: os indivíduos maiores são poiquiliticos e, portanto, mais tardios, ou então as inclusões são produtos de substituições tardias. Tendo em vista o subparalelismo e as ondulações de provável fluxo envolvente observado no agregado "matricial", é mais provável que parte deste tenha iniciado a cristalização mais cedo, talvez parcialmente interrompida (ausência de fluxo? diminuição da velocidade de fluxo?), momento em que os feldspatos e os fóides do mosaico de fundo, idiomórficos e equidimensionais, iniciaram sua cristalização envolvendo, ou mesmo reabsorvendo os primeiros. Reiniciando o fluxo, voltariam os feixes subparalelos. A nefelina e a sodalita pouco aparecem como fases intersticiais nesses feixes. A mineralogia restante, fêmicos e minerais raros, é posterior, e embora em individuos pequenos, bem desenvolvida. 
Nos diques máficos em geral, o plagioclásio é fase primária e inicial, em parte somente antecedido pela olivina, clinopiroxênio e acessórios. As feições texturais não são muito conclusivas para as relações daquele mineral com os restantes, mas sugerem contemporaneidade. As variações composicionais, núcleo-bordas-matriz, manifestas em zoneamento óptico, indicam intervalo de cristalização mais ou menos prolongado, simultâneo a mudanças no líquido reagente e/ou nas condições de cristalização em geral, ou então, a mudanças das posições relativas do líquido e dos cristais. As composições finais, bem mais sódicas $\left(A b_{85-70}\right)$, bem como o nítido enriquecimento em Or apontam para liquidos residuais capazes de cristalizar os feldspatos alcalinos analisados, sempre matriciais/intersticiais.

Embora não analisados quimicamente, cumpre lembrar a presença de microfenocristais de plagioclásio (mais olivina e clinopiroxênio) nos vidros, junto aos contatos.

Não é também demais mencionar que, em Búzios, os sienitos (e variedades microgranulares) representam mais que $95 \%$ das rochas expostas, sendo que neles as micromesopertitas constituem em média $90 \%$. Nos diques félsicos, fonólitos e traquitos no caso, os minerais fêmicos podem aumentar um pouco a sua quantidade, dando-se ainda o aparecimento dos feldspatóides, mas dificilmente os feldspatos correspondem a menos que $50 \%$. E mesmo entre os diques máficos em geral, os feldspatos são também bastante representativos, ainda que mais variavelmente.

\subsubsection{Os feldspatóides}

Nefelinas e sodalitas foram analisadas em apenas um fonólito (BZ 182B, da Ponta Leste), embora presentes em outras ocorrências de rochas semelhantes.

A composição das nefelinas analisadas, todas com $Q_{\sim 6-7 \%}$ e $\mathrm{Ne}_{73.74}$, indicam temperaturas acima de $775^{\circ} \mathrm{C}$ (cf. Hamilton, 1961). O mesmo geotermômetro, utilizado em outros lugares (Ulbrich, 1983; Motoki, 1986), apresentou temperaturas conflitantes com aquelas obtidas por outra metodologia, a de Powell e Powell (1977). O fundamento do primeiro são as reações de equilibrio (troca) Ne-líquido para ajustar as razões "subsolidus" com feldspatos alcalinos coexistentes, com trocas de $\mathrm{Na}$ e $\mathrm{K}$ e sem mudanças na razão Si/Al. As reações de troca seriam no sentido de atingir-se a composição teórica $\mathrm{Na}_{3} \mathrm{KAl}_{4} \mathrm{Si}_{4} \mathrm{O}_{16}\left(\mathrm{Ne}_{75} \mathrm{Ks}_{25}\right)$, considerada a mais estável (cf. Edgar, 1974; Smith e Tuttle, 1957). Observe-se que, para $Q=0$, o solvus $\mathrm{Ne}-\mathrm{Ks}$ situa-se entre $\mathrm{Ne}_{73}$ e $\mathrm{Ne}_{100}$. O geotermômetro de Powell e Powell (1977) emprega a razão entre a fração molar de Ab no feldspato alcalino com a fração molar de Ks ou Q na nefelina. Na amostra analisada de Búzios, o feldspato alcalino tem composições 
regularmente distribuidas entre $A b_{100} O r_{0}$ e $A b_{0} O r_{100}$, o que inviabiliza a utilização desse último método.

Todas as nefelinas das várias amostras de fonólitos e álcali feldspato-nefelina microssienitos apresentam caracteristicas texturais semelhantes, sendo o mineral bem desenvolvido até um certo "status" de fenocristal, além de freqüentemente idiomórfico. Adicionalmente suas relações com os feldspatos e os demais constituintes dessas rochas indicam cristalização inicial, talvez um mineral "liquidus", em igualdade com parte do feldspato, mas incluindo outra parcela deste mineral. No último caso, não há evidência de substituição. Essa situação sugeriria também intervalo de cristalização prolongado.

Nas rochas com nefelina, é freqüente a presença em teores variados, mas sempre baixos, de minerais "agpaíticos" (cf. Ulbrich, 1983), raros $\mathrm{Ti}, \mathrm{Zr}$ silicatos de $\mathrm{Ca}, \mathrm{Na}, \mathrm{TR}$, que se formaram posteriormente a todas as outras fases, inclusive a nefelina. Os minerais fêmicos, entre os quais o clinopiroxênio é o mais importante, também são posteriores às nefelinas e aos feldspatos. Essas relações texturais obedeceriam à ordem agpaítica de cristalização (cf. Bard, 1986), da qual resultam "texturas agpaíticas".

As alterações, de pequena monta, restringem-se à cancrinita e à alguma "poeira" não identificada, indicando que as nefelinas sobreviveram quase íntegras após os rearranjos cristaloquímicos "subsolvus", durante o restante da evolução submagmática, marcante nos feldspatos e noutros minerais.

As sodalitas, embora comumente tomadas como secundárias, substituindo a nefelina e feldspatos, podem ser magmáticas (cf. Edgar, 1974). Nas amostras examinadas, esse parece ser o caso. Embora tenham hábito semelhante ao das nefelinas, não evidenciam qualquer indicio de substituição, como também não incluem outros minerais.

As analcitas, analisadas em todas as amostras lamprofíricas, estão presentes nas matrizes e em ocelos. Nestes últimos, coexistem com feldspato alcalino (sanidinio?), vidros, porções micro a criptocristalinas, carbonatos, às vezes alguma alteração (zeólitas, serpentina), além de minerais fêmicos ocasionais (kaersutita, biotita). Afora os minerais de alteração dessas rochas, aparentemente não especialmente ligados à analcita, os ocelos e essas analcitas parecem primários, havendo, como salientado previamente, indicações de precocidade. Nas matrizes, acompanham o feldspato alcalino, vidros e materiais criptocristalinos, nos interstícios entre os indivíduos de plagioclásio. Neste caso, poderiam ser mais tardias, embora participantes de associações minerais iguais às dos ocelos.

A literatura tem indicado natureza primária e secundária para as analcitas (Peters, 1966; Edgar, 1974), com a ressalva que parte das informações experimentais refere-se a 
sinteses com materiais anidros, e com composições ideais $\mathrm{Ab}_{50} \mathrm{Ne}_{50}$. Nessas condições, há fusão incongruente acima de ponto invariante, a $665^{\circ} \mathrm{C}$ e $4,75 \mathrm{~kb}$.

A entrada de $\mathrm{K}_{2} \mathrm{O}$ no sistema reduz as condições de PT para $630^{\circ} \mathrm{C}$ e $2,3 \mathrm{~kb}$ (Morse, 1969; Edgar, 1974, respectivamente). O campo de estabilidade das soluções sólidas é bastante reduzido com o aumento das temperaturas, donde se conclui que, quando magmático, o mineral tem composição pouco variada.

Há considerável variação nos teores de $\mathrm{Ca}, \mathrm{Fe}$ e $\mathrm{K}$, em média, quando confrontadas as analcitas de Búzios, ocelares e matriciais: as primeiras possuem teores mais elevados em todos esses cátions, particularmente o K. Já comparadas as amostras, não se notam grandes variações composicionais.

É possivel que, embora mais pobres em $\mathrm{K}$, as analcitas matriciais sejam de condições mais brandas e tardias, pelo menos submagmáticas, tomando parte em fração líquida residual, variável em quantidade e composição conforme a rocha se mostre mais ou menos evoluída. É possivel mesmo que as analcitas matriciais sejam de substituição.

\subsubsection{As olivinas}

Foram analisadas em duas amostras lamprofíricas (tefrito e traquibasalto). Têm composição restrita ao campo das crisolitas, com $\mathrm{FO}_{76}$ a $\mathrm{Fo}_{84,5}$, correspondentes a mg\# $64,4 \mathrm{e}$ 75,2 , sendo a mais magnesiana a dos traquibasaltos. Estas, contudo, foram tomadas texturalmente como microxenólitos (megacristais?), em agregado com clinopiroxênio e plagioclásio, com inclusão de flogopita. Esse material mostra pouca reação de borda com a rocha hospedeira. Mesmo não sendo anteriores à rocha, mas "hóspedes", seriam de cristalização magmática primária e precoce. Não são antecedidas por qualquer outro mineral, nem mesmo opacos, e não mantêm qualquer relação com os ocelos. Exemplares não analisados, e que aparecem imersos em vidros nos contatos dos diques, fazem-se acompanhar de plagioclásio e clinopiroxênio, todos idiomórficos. Nesta condição, a olivina é embainhada, evidenciando corrosão magmática, com preenchimento matricial. Como comentado, MnO não ultrapassa $0,50 \%$, NiO pode chegar até $0,24 \%$ e $\mathrm{CaO}$ a $0,38 \%$, sendo o $\mathrm{Cr}$ praticamente não detectado.

As características texturais e químicas desses minerais indicam equilibrio com as rochas portadoras, salvo para aquelas corroidas pelos vidros (alteradas e não analisadas) e as dos conjuntos tomados como microxenolíticos, que poderiam ser autólitos. Tanto as rochas hospedeiras como as olivinas não correspondem a materiais mais primitivos, mas tampouco podem ser tomados como muito evoluidos. 


\subsubsection{Os piroxênios}

Os gráficos da Figura 8 (cf. Morimoto, 1978) delimitam composicionalmente e permitem classificar os piroxênios dos sienitos de Búzios. Revelam que as bordas têm mais forte tendência no sentido cálcio-sódico, sódico ou férrico-ferroso que os núcleos. Destacam-se no quadrilátero tradicional, as amostras $B Z 159 \mathrm{~A}$ e $171 \mathrm{~F}$, com bordas mais ricas em $\mathrm{Fe}$, e a amostra BZ 100, com bordas e núcleos ainda mais ricos em Fe. Esse enriquecimento em Fe, ou Fe e $\mathrm{Na}$, é acompanhado por discreta variação de $\mathrm{Ca}$.

Gráficos reunindo valores de mg\# (óxidos \%) e cátions caracterizam com mais detalhe o quimismo desses minerais, além das diferenças entre amostras, núcleos e bordas.

Os valores de mg\# ( 7-60) cobrem amplo intervalo e sugerem a tendência das bordas para números menores, principalmente a partir de $\mathrm{mg \#}<35$, voltando a destacar-se aquelas amostras já referidas. Estas mesmas dispõem-se por quase todo o intervalo composicional dos piroxênios, mostrando a mesma tendência, com bordas menos magnesianas.

Para valores menores de mg\#, há discreto aumento em Si. O $\mathrm{Na}$ e $\mathrm{Fe}^{3+}$ apresentam comportamento semelhante, com correlação negativa, moderadamente definida, no que diz.

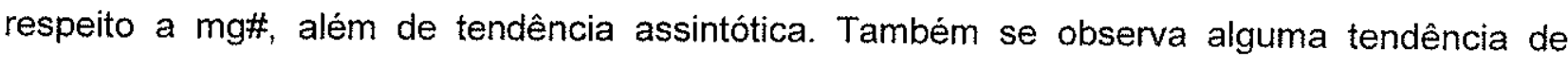
elevação dos teores nas bordas. Como de resto em todos os tratamentos gráficos, sobressaem-se a amostra BZ $100 \mathrm{~B}$ e as bordas das amostras 159A e 171F. O Ti não possui tendência definida; já o $\mathrm{Al}^{\mathrm{V} l}$ exibe distribuição semelhante à do $\mathrm{Fe}^{3+}$, embora contenha muitos valores nulos, o que indica $\mathrm{Al}^{\mathrm{IV}}$ esgotado em $\mathrm{T}$. Este último mostra correlação positiva, pobremente definida, com mg\#. Todas as demais amostras têm maiores variações entre si, entre núcleos e bordas dos cristais, com valores para mg\# e os cátions comentados distribuindo-se em intervalos moderados, mas não insignificantes (mg\# 33-60).

O conjunto geral apresenta núcleos mais magnesianos, correspondentes à cristalizaçăo magmática inicial, e portadores de teores menores de $\mathrm{Si}, \mathrm{Al}^{\mathrm{V}}$, $\mathrm{Na}$ e $\mathrm{Fe}^{3+}$. Esses núcleos evoluem para valores mais baixos de mg\#, e mais altos de $\mathrm{Si}$, $\mathrm{Al}^{\mathrm{v}}$, $\mathrm{Na}$ e $\mathrm{Fe}^{3+}$, além de pequenos de $\mathrm{Al}^{\mathrm{l}}$. Há leve queda no $\mathrm{Ca}$ com o incremento em $\mathrm{Fe}^{3+}$ e $\mathrm{Na}$. Mesmo levando em conta somente os núcleos, as variações são consideráveis, ampliadas pelas bordas. As maiores variações globais são registradas para $\mathrm{Na}$ e $\mathrm{Fe}^{3+}$ (respectivamente, 0,020-0,440 e 0,020-0,360), que não mantêm a relação $1: 1$, mas no geral com aparente sobra de $\mathrm{Fe}^{3+}$, provavelmente em T. Seguem-se o Si, Alv e All , todos em torno ou abaixo de 0,100 e, por último, o $\mathrm{Ti}(0,020)$. Em termos de WEF, os núcleos mais magnesianos apresentam grande diversidade composicional, com evolução desde salitas, ferrossalitas a hedembergitas (com Ca 
máximo) e, paralelamente, desde augitas a ferrohedembergitas. Um primeiro grupo é o das amostras já discutidas, e um segundo formado pelas restantes. As amostras BZ 159A e 171F mostram para Ca:Mg:Fe + Mn valores moleculares em torno de 47:35:16, enquanto que a amostra $B Z 100 B, 43: 16: 41$, para os núcleos. No restante das amostras, as relações se alteram para 42:38:19. Nota-se maior variação simultânea $\mathrm{Mg}$ - $(\mathrm{Fe}+\mathrm{Mn})$, com o Ca chegando a 48 com $\mathrm{Mg}: \mathrm{Fe}=1: 1$. Esses valores extremos alteram-se para 34:17:49 e 44:10:45 (BZ 159A e 171F) e 42:6:51 (BZ 100B), e nas demais amostras para 44:33:33 (BZ 148A), com Ca igual a 34 ( $B Z$ 159A) e 42 (BZ 190), para as bordas. A partir dos extremos hedembergíticos, passa a haver maior enriquecimento em $\mathrm{Na}$, e formação de egirina-augitas.

Esse conjunto de composições repete, parcialmente, aquelas descritas e discutidas há muito na literatura internacional por vários autores (Aoki, 1964; Yagi, 1966; Gomes et al., 1970; Larsen, 1976; Parsons, 1980) e, mais recentemente, em trabalhos focalizando ocorrências nacionais, algumas das quais exibindo menor variação composicional, ausência de termos egirinicos ou mesmo egirina-augíticos (Lages, Morro Redondo, Passa Quatro, Tunas etc.). De forma geral, Jd mantém-se a baixos niveis, com leve incremento com Al. Nos sienitos, não ultrapassa a $5,5 \%$, valor único.

Os piroxênios dos sienitos são minerais magmáticos, mostrando alguma evolução de provável natureza submagmática, ou talvez mesmo subsólida, com o aparecimento de manchas internas ou porções periféricas de anfibólio e/ou de biotita, além de outros minerais esporádicos. Indicam precedência sobre os outros, com exceção dos opacos, aos quais incluem, mais junto às bordas. Não são idiomórficos, mantendo apenas parte com bordas retilineas e comumente se agregam ou formam conjunto com outros máficos. Além disso, grãos menores aparecem inclusos no feldspato alcalino.

Essas feições e as características composicionais, assim como a acentuada diferença núcleo-borda sugere fracionamento inicial a partir de magma sienitico mais primitivo. É possivel que os núcleos atuais tenham sido conservados parcialmente, prosseguindo sua evolução quando da cristalização dos feldspatos. Aqueles encapsulados tiveram desenvolvimento interrompido. De forma similar aos processos cumuláticos, o magma restante, mais alcalino, deu seqüência à cristalização essencialmente feldspática, em condições anidras desde o início, pelo menos até um certo momento, talvez já em condições abaixo do "tiquidus". A homogeneidade do corpo e da composição dos feldspatos leva a crer que não houve grandes variações nos cátions disponiveis por longo período, permanecendo em parte as condições de $\mathrm{pH}_{2} \mathrm{O}$ e $\mathrm{fO}_{2}$. As relações texturais e a maior riqueza em $\mathrm{Na}\left(\mathrm{e} \mathrm{Fe}^{3+}\right)$, mantendo-se $\mathrm{Si}^{4+}$ e $\mathrm{Al}^{3+}$, são indicativas de que a massa feldspática, formada já em condições submagmáticas, seguiu seu desenvolvimento por largo intervalo. Líquidos aprisionados devem ter permitido o final da 
cristalização dos piroxênios, quase que totalmente originados em condições de "liquidus", que, ao mesmo tempo em que esgotavam $\mathrm{Mg}$, $\mathrm{Fe}$ e $\mathrm{Ca}$, enriqueciam-se nas bordas em $\mathrm{Na} \mathrm{e} \mathrm{Fe}^{3+}$, a $\mathrm{fO}_{2}$ maiores, talvez por abertura do sistema. Mesmo com a queda em $\mathrm{pH}_{2} \mathrm{O}$, sendo aumentadas as atividades de $\mathrm{Na}$, Al e $\mathrm{K}$, a diminuição da temperatura deu ênsejo à criștalização da biotita e/ou do anfibólio, talvez logo abaixo das condições magmáticas. Essas mesmas mudanças da composição magmática e das condições de PT em geral também geraram alguma substituição do piroxênio. Os líquidos residuais finais, com o aumento de $\mathrm{Na}$, experimentou incremento na atividade em sílica.

Entre os diques félsicos, os piroxênios analisados são cálcio-sódicos (egirinaaugíticos), na amostra BZ 166A (Saco Grande, centro), a sódicos (egirínicos), na 163D (Saco Grande, leste). A participação de Jd é pequena e constante. Essas composições apresentam continuidade no sentido sódico, com as bordas cálcio-sódicas encontradas nos sienitos. Mesmo considerando as limitações decorrentes do pequeno número de amostras e de análises, é possivel tecer ainda algumas considerações com relação aos piroxênios dos sienitos, que mostram continuidade de valores para mg\# $(\sim 4,5-1,3)$, e conteúdos mais altos em todos os cátions, à exceção de $\mathrm{Al}^{\mathrm{iV}}$ e Ti. Além de excesso de Si na amostra BZ 163D, são notáveis os valores de $\mathrm{Na}$ e $\mathrm{Fe}$, que chegam a mais do que o dobro dos equivalentes para os sienitos. Destaque-se o já comentado comportamento de $\mathrm{Ti}, \mathrm{Na}$ e $\mathrm{Fe}$, todos com correlação inversa relativamente a mg\#, não ocorrendo queda no primeiro deles, que tenderia a fixar-se nos minerais raros dessas paragêneses mais alcalinas (Ulbrich, 1983). O gráfico Mg-Fe-Na mostra as egirina-augitas e egirinas, linear e paralelamente dispostas próximas ao lado $\mathrm{Fe}-\mathrm{Na}$, a partir de Na:Fe 1:1. Neste caso, as composições extremas dos piroxênios dos sienitos evoluem no sentido dessas composições egirínicas, ainda que um largo intervalo composicional se faça presente entre elas.

O excesso de Si em uma amostra, e a pequena deficiência em outra, correspondem a $A^{\prime v}$ nulo ou com valores baixos $(0,010-0,030)$, respectivamente, e a nenhum valor de $A l^{\mathrm{V}}{ }^{\mathrm{I}}$ menor que 0,018. Talvez, daí, o aparecimento da molécula jadeítica, muito embora em pequenos teores $(\mathrm{Jd} \sim 5 \%)$. O Na e o $\mathrm{Fe}$ são mais ou menos equivalentes, inexistindo $\mathrm{TFe}^{3+*}$, mantendose o Ti em níveis baixos $(<0,020)$. Assim, não cabe para esses minerais moléculas adicionais envolvendo $\mathrm{Ti}$, à semelhança de piroxênios semelhantes da liha de Vitória (Motoki, 1986), e diversamente daqueles de Poços de Caldas (Ulbrich, 1983).

É interessante salientar um aspecto dos piroxênios de Búzios já comentado : quando integrando-se sienitos e diques félsicos, tem-se alguma similaridade com os da ocorrência de "sienitos híbridos" de Poços de Caldas (Ulbrich, 1983), cujos piroxênios mostram grande 
variação composicional. O conjunto de composições obtidas (sienitos e diques félsicos) inserese na média de grande número de ocorrências, ver, por exemplo, Morbidelli et al. (1995).

Esse conjunto, além das continuidades apontadas, exibe suas características quimicas evolutivas na Figura 14. Ainda que com descontinuidades, as curvas iniciam-se em composições magnesianas $\left(\mathrm{Mg}_{-70}\right)$, evoluindo então para as férrico-ferrosas. A partir das composições intermediárias para Fe:Mg (sempre com $\mathrm{Na}>0$ ), define-se uma tendência para $\mathrm{Fe}^{2+}+\mathrm{Fe}^{3+}$, com Na constante (amostra $\mathrm{BZ} 100 \mathrm{~B}$, algumas outras bordas), e outra quase que diretamente para as egirinas da amostra BZ 163D (amostra BZ 159A). Entre essas duas linhas evolutivas extremas, delineiam-se, de forma pobre, tendências ferro-sódicas. Esse quadro foge um pouco de vários outros, a maioria talvez, incluindo a llha de Vitória, em que os piroxênios mostram tendências lineares únicas. Contudo, no lacólito de Shonkin Sag, foram estabelecidos padröes semelhantes aos de Búzios (Nash e Wilkinson, 1970); mesmo em Poços de Caldas, embora para corpos diferentes dentro da província, são definidas inumeráveis linhagens (Ulbrich, 1983).

Os piroxênios dos diques máficos de Búzios apresentam continuidade no sentido mais magnesiano, e até mesmo superposição composicional, com aqueles mais primitivos dos sienitos.

Na Figura 10 (cf. Morimoto, 1988), eles ocupam campo composicional muito restrito, e já comentado. Com relação às variações dos cátions e de mg\#, é importante ressaltar alguns aspectos. O valor mg\# inicia-se a 53 (grãos matriciais), e aumenta substancialmente a freqüência de composições a mg\# 58, com continuidade com as dos sienitos. O Si exibe pequena descontinuidade com relação aos sienitos e, adicionalmente, correlação positiva com mg\#, invertendo assim a tendência até então observada. Todos os outros cátions mostram correlação negativa, à exceção de $\mathrm{Al}^{\mathrm{V}}$, não definivel. Dessa forma, o $\mathrm{Al}^{\mathrm{IV}}$ inverte o padrão (pobre) dos sienitos, e $\mathrm{Al}^{\mathrm{V}}$ e $\mathrm{Ti}$ não podem ser correlacionados. Confrontados, porém, os valores absolutos dos cátions, não há tendência de continuidade entre eles. Ocorre alguma, $\mathrm{e}$ pobre, com $\mathrm{Al}^{\mathrm{lv}}$, superposição parcial com $\mathrm{Al}^{\mathrm{V}}$ e com $\mathrm{Na}$, nenhuma com Ti e alguma com $\mathrm{Fe}$.

Tendo em conta as variações ópticas nos piroxênios dos diques máficos, consistentes com mudanças nos teores de $\mathrm{Al}_{2} \mathrm{O}_{3}$ e $\mathrm{TiO}_{2}$ (cuja soma chega a mais que $18 \%$ ), foram feitos tratamentos gráficos empregando-se moléculas hipotéticas adicionais, como proposto por Cameron e Papike (1981) e outros. As Figuras 13 e 14 constituem partes desses tratamentos, em valores catiônicos, em que se procurou conservar o ápice correspondente a WEF. A sequência para os diques félsicos e sienitos pouco se altera, mas aquela das rochas máficas amplia consideravelmente o seu campo, saindo do quadrilátero WEF e evoluindo para a hipotética molécula "Ti-tschermakítica", com alguma descontinuidade em relação aos sienitos. 
A covariação M2Na-TAl-M1Ti apresenta contínuo desenvolvimento entre sienitos e diques félsicos, desde $\mathrm{Na}: \mathrm{Al}=1: 1$ até o ápice sódico. No sentido do $\mathrm{Al}$, mas com larga descontinuidade, situam-se os diques máficos. Em detalhe, estes mostram inflexão para o Ti, com uma particularidade: as composições mais ricas em Ti são as das bordas de cristais e de gräos matriciais. As razões $2 \mathrm{M} 1 \mathrm{Ti} \times \mathrm{TAl}$ são próximas a 1 , levemente maiores para as matrizes. Observados os diques félsicos e máficos, nota-se a exclusão mútua entre $\mathrm{Na}$ e $\mathrm{Al}$ (WEF-M2NaTAl), embora as composições com TAl admitam algum M2Na ( 1\%). Os piroxênios dos diques máficos são visivelmente magmáticos, como tradicionalmente na literatura, podendo incluir xenocristais, com algum desenvolvimento tardio, talvez submagmático para kaersutitas, e alterações tardias, já subsólidas.

As variações em $\mathrm{Ca}, \mathrm{Mg}$ e Fe (total) mostram certo "continuum" entre os piroxênios, ignoradas algumas ausências composicionais. As variações nos outros cátions exibem valores absolutos e correlação com mg\# variadas, e com visivel quebra entre rochas félsicas e máficas.

\subsubsection{Os anfibólios e as biotitas}

Os anfibólios dos sienitos de Búzios podem ser vistos como tendo evoluidos a partir de magnésio-hornblendas, levando-se em conta as amostras, o ponto analisado e os parâmetros classificatórios, Si e Mg/(Mg+Fe) ou outros quaisquer $\left[\mathrm{Al}^{\mathrm{IV}}+\mathrm{Ca} \times(\mathrm{Si}+\mathrm{Na}+\mathrm{K})\right.$, conforme Giret et al., 1980]. A partir dessa composições mais primitivas, passariam a ferromornblendas, com $\mathrm{Mg} / \mathrm{Fe}$ menores, e a hornblenda ferro-actinolitas, com Si e $(\mathrm{Si}+\mathrm{K}+\mathrm{Na})$ maiores e $\left(\mathrm{Al}^{\mathrm{IV}}+\mathrm{Ca}\right)$ menores que os dos outros tipos. Nos mesmos sienitos, com aumento de $(\mathrm{Na}+\mathrm{K})$ e $\mathrm{Fe}^{3+}>\mathrm{Al}^{\mathrm{lV}}$, evoluiriam para edenitas, magnésio-hastingsitas e hastingsitas, com diminuição relativa em $(\mathrm{Si}+\mathrm{Na}+\mathrm{K})$ e aumento em ( $\mathrm{Al} \mathrm{I}^{\mathrm{V}}+\mathrm{Ca}$ ) e Fe. A amostra BZ 123, de microssienito, quebra essas transformações, mostrando anfibólios já sódico-cálcicos: ferro-winchitas, ferro-barroisitas e catoforitas, com leve indicação paralela de variação núcleo-bordas. Neste caso, Si pouco muda, mas $(\mathrm{Si}+\mathrm{Na}+\mathrm{K})$ varia para mais, com queda paralela de $\left(\mathrm{Al}^{\mathrm{lV}}+\mathrm{Ca}\right)$, mantendo-se constante a razão $\mathrm{Mg} / \mathrm{Fe}$.

Os anfibólios sódico-cálcicos dos diques félsicos parecem tornar-se menos silícicos no sentido núcleo-bordas, e entre as taramitas e catoforitas. Paralelamente, aumenta ( $\mathrm{Si}+\mathrm{Na}+\mathrm{K})$ e $\operatorname{diminui}\left(\mathrm{Al}^{\mathrm{IV}}+\mathrm{Ca}\right)$.

Os anfibólios dos diques máficos são semelhantes aos dos sienitos (amostra $\mathrm{BZ}$ $181 \mathrm{~A})$, com magnésio-hornblendas passando a edenitas [mais $(\mathrm{Si}+\mathrm{Na}+\mathrm{K})$ e menos $\left(\mathrm{Al} l^{\mathrm{V}}+\mathrm{Ca}\right)$ ] e a magnésio-hastingsita hornblendas [mais $\left.\left(\mathrm{Al}^{\mathrm{I}}+\mathrm{Ca}\right)\right]$. Os outros, dos lamprófiros, são todos kaersutitas, que poderiam ser vistos como variantes titaniferas de hornblendas (sensu lato) ou mesmo de pargasitas. 
Os anfibólios constituem um grupo complicado. Têm, praticamente, sitios estruturais para qualquer cátion, admitem ampla variação em $\mathrm{Fe}^{2+} / \mathrm{Fe}^{3+}$ e, além disso, incorporam $\mathrm{OH}, \mathrm{F}$ etc. Como qualquer outro grupo de minerais dependem das atividades catiônicas nos magmas e, portanto, da composição da rocha. Mas, aparentemente, são mais sensiveis às relações e mesmo a teores bruscos de alguns cátions, à atividade em sílica e às condiçöes de pressão $\left(\mathrm{H}_{2} \mathrm{O}\right.$ e total). Além disso, não só a $\mathrm{P}_{\mathrm{H} 2 \mathrm{O}}$ é importante, como também a saturação de vapor, assim que a relação $P x T^{\circ} \mathrm{C}$ mostra-se crítica. Se não bastasse, $\mathrm{fO}_{2}$ é também decisivo. Na dependência de todos esses parâmetros, podem vir a ser os minerais "liquidus" em um sistema ígneo, além dos primeiros a se cristalizarem. $\mathrm{Na}$ ausência de outras fases hidratadas, o modelo teórico experimental proposto por Wones e Gilbert (1982), para $\mathrm{P}_{\mathrm{H} 2 \mathrm{O}}=\mathrm{P}_{\text {tot }}, \mathrm{fO}_{2}$ média $\left(\mathrm{Fe}_{3} \mathrm{O}_{4}\right.$ presente), a $P$ constante no campo entre as curvas $L$ (líquido) e $S$ (sólido), pode levar a várias seqüências. Nele, L (curva "liquidus"), em parte, representa equilíbrio com piroxênio e a pressões mais altas, com anfibólio. O ponto de inflexão em L (que separa L-Px de L-anfibólio) muda bastante, com os menores valores de pressão sendo encontrados em sistemas andesíticos; em sistemas com $\mathrm{SiO}_{2}$ maior, o ponto desloca-se para $\mathrm{T}^{\circ} \mathrm{C}$ menor e $\mathrm{P}$ maior, reduzindo o campo dos anfibólios em equilíbrio com o líquido. Para $\mathrm{SiO}_{2}$ menor (que o andesito), a inflexão desloca-se para $\mathrm{T}^{\circ} \mathrm{C}$ maior e $\mathrm{P}$ maior, aumentando o campo dos anfibólios (nota: a curva PX-L é negativa e a Anf-L positiva). Se $\mathrm{F}_{\mathrm{O} 2}$ cair, $\mathrm{Fe}_{3} \mathrm{O}_{4}$ desaparece e dá lugar à olivina, existindo também indicações de que para $\mathrm{H}_{2} \mathrm{O}$ entre $1,5-6 \%$ Sat (Wones e Gilbert, 1982) tem-se a reação hornblenda $\rightarrow$ olivina + liquido.

Nesse sistema, a partir de pressões maiores e altas temperaturas, bem como mantido - gradiente de queda em P e T, na medida em que se atenuam as condições iniciais podem ocorrer várias seqüências de cristalização: anfibólio-piroxênio-magnetita, piroxênio-anfibóliomagnetita e piroxênio-magnetita-anfibólio. Abaixo de certas condições iniciais, não mais o anfibólio se mostra em equilíbrio com o líquido, que passa a ser uma fase subsólida.

As paragêneses ferromagnesianas dos sienitos de Búzios são representadas por clinopiroxênios, anfibólios e biotita, com os opacos sempre presentes. Após estes últimos, os máficos de presença mais constante são os clinopiroxênios. Ambos são anidros, e acima de certos valores de $\mathrm{pH}_{2} \mathrm{O}$ de saturação para determinadas temperaturas, os clinopiroxênios se desestabilizam. A existência de amostras com clinopiroxênio íntegro, ou pouco transformado, é indicadora de condições de baixas pressões de água, em lugares diferentes e momentos diversos durante o resfriamento da massa magmática sienítica. A coexistência com anfibólios, biotita ou ambos indica o mesmo sentido de condições, mas agora em mínimos de estabilidade em termos de $\mathrm{pH}_{2} \mathrm{O}$ de saturação, além de outros condicionantes. 
A existência de cavidades miaroliticas nas regiões próximas a contatos e em áreas com xenólitos, em especial nas rochas com quartzo, é sugestiva de que houve saturação em fluidos $\left(\mathrm{H}_{2} \mathrm{O}, \mathrm{CO}_{2}\right.$ etc.) em estágios abaixo do "liquidus", submagmático, e que podem ter persistido até condições "subsolidus"(como parece, a julgar pelos feldspatos). A raridade, e mesmo a ausência dessas cavidades no sentido do interior do corpo e, ao mesmo tempo, a presença generalizada de zonas pegmatóides (além da presença universal das micromesopertitas) pode ser compativel com variações nas condições de $\mathrm{pH}_{2} \mathrm{O}$ ou de saturação. Este fator depende não só da $\mathrm{pH}_{2} \mathrm{O}$, mas também da temperatura, e se esta apresentar variações das bordas para o centro do corpo ( $T^{\circ} \mathrm{C}$ maiores), no mesmo momento é de se esperar que a massa magmática, mesmo já com ponderável fração sólida (abaixo do "liquidus"), venha a experimentar simultaneamente condições de supersaturação nas bordas e insaturação nas porções mais centrais. Variações tanto na pressão de $\mathrm{H}_{2} \mathrm{O}$, como na temperatura e saturação em $\mathrm{H}_{2} \mathrm{O}$ (e outros fluidos), podem estar também vinculadas a fatores geológicos e tectônicos.

Os anfibólios e as biotitas apresentam campos de estabilidade térmica em grande parte superpostos. Havendo subsaturação em $\mathrm{H}_{2} \mathrm{O}$, é possivel que persista a cristalização dos piroxênios até minimos termais. Com a saturação, passa a haver verdadeira competição entre os anfibólios e as biotitas, cujo resultado irá depender da atividade em sílica e em potássio, principalmente.

Com algumas exceções, ferro-biotitas são fases mais estáveis que os ferro-anfibólios, para $\mathrm{fO}_{2}$ do tampão $\mathrm{FMQ}$. Com as mudanças em $\mathrm{fO}_{2}$, os $\mathrm{Mg} / \mathrm{Ca} / \mathrm{Na}$ anfibólios tornam-se mais estáveis (cf. Wones e Gilbert, 1982). Biotitas mais magnesianas são estáveis a valores de $\mathrm{fO}_{2}$ mais altos, enquanto que magnésio-richteritas são mais estáveis que as micas em condições mais baixas. Tanto a estabilidade térmica dos anfibólios como das biotitas depende das suas composições e evolui em função de $\mathrm{fH}_{2} \mathrm{O}, \mathrm{fO}_{2}, \mathrm{~T}^{\circ} \mathrm{C}$ e da presença, no magma ou no líquido em equilíbrio, de $\mathrm{FeO}, \mathrm{MgO}, \mathrm{CaO}, \mathrm{SiO}_{2}, \mathrm{Al}_{2} \mathrm{O}_{3}$ etc., ou seja, da composiçăo global do líquido, que definirá qual dos minerais (após os piroxênios) irá cristalizar primeiro ou qual será o único a cristalizar.

Nesse sentido, além da saturação em $\mathrm{H}_{2} \mathrm{O}$ e fO $\mathrm{f}_{2}$, é de especial importância a atividade em sílica. Os anfibólios são extremamente sensiveis às variações desse parâmetro, refletindo as mudanças ocorridas durante o resfriamento do magma. De forma bem geral, parece que as biotitas são mais estáveis a baixos valores de atividade em silica; da mesma forma, pressões de $\mathrm{H}_{2} \mathrm{O}$ mais baixas e teores moderados de $\mathrm{K}_{2} \mathrm{O}$ tendem a favorecer a presença desses minerais. Em condições de $\mathrm{fO}_{2}$ mais alta e $\mathrm{K}_{2} \mathrm{O}$ menor, os anfibólios são privilegiados (Wones e Gilbert, 1982). 
Pelas paragêneses dos sienitos de Búzios e complexidade das relações anfibólio biotita, com todas as variáveis importantes, químicas e termoquímicas, torna-se extremamente difícil o tratamento comparado entre esses minerais quanto às condições de cristalização. $O$ que se pode dizer é que as associações observadas e as composições químicas correspondentes são o produto da interação da composição química global do magma, dos líquidos e das condições de $\mathrm{T}^{\circ} \mathrm{C}, \mathrm{P}_{\text {tot }}, \mathrm{pH}_{2} \mathrm{O}$ (mais fluidos com $\mathrm{CO}_{2}, \mathrm{~F}, \mathrm{Cl}$ etc.) e saturação em $\mathrm{H}_{2} \mathrm{O}$

A despeito de toda complexidade do assunto, voltando-se um pouco mais para os anfibólios, dados experimentais apontam as magnésio-hastingsitas como sendo os anfibólios de mais alta estabilidade térmica (Gilbert et al., 1982), bem como que a substituição $\mathrm{Fe}^{3+} \rightarrow \mathrm{Al}$ aumenta essa estabilidade, enquanto que $\mathrm{Mg} \rightarrow \mathrm{Fe}^{2+}$ a abaixa. De modo geral, os anfibólios com composições entre hornblendas-pargasitas-hastingsitas mostram curvas de estabilidade termal crescente, para pressões de fluidos até $2,5 \mathrm{~kb}$ e $1100^{\circ} \mathrm{C}$, passando desde ferropargasitas até magnésio-hastingsitas. Todos os membros extremos do quadrilátero composicional ( $\mathrm{FePa}-\mathrm{MgHa}$ ) são Ne normativos e, experimentalmente, instáveis com $\mathrm{SiO}_{2}$ em excesso. Composições hornblêndicas, não muito diferentes das referidas, são estáveis com excesso de $\mathrm{SiO}_{2}$, indicando forte elevação da atividade em sílica entre esses anfibólios (Gilbert et al., 1982).

Entre os anfibólios sódico-cálcicos, as magnésio-richteritas possuem estabilidade termal superior àquelas ricas em $\mathrm{Fe}$. O mesmo mineral, potássico, apresenta limites de estabilidade consideravelmente ampliados $\left(>1200^{\circ} \mathrm{C}, 25 \mathrm{~kb}\right)$.

Entre os anfibólios alcalinos, as riebeckitas são estáveis até $\pm 450-550^{\circ} \mathrm{C} e \sim 3 \mathrm{~kb}$, para o tampão $\mathrm{HM}$, mas admitindo grande variação em $\mathrm{fO}_{2}$; arfvedsonitas, na presença de quartzo, têm curva de estabilidade semelhante, a temperaturas superiores pouco variadas: 650 $730^{\circ} \mathrm{C}$ e pressäo de fluido até $3 \mathrm{~kb}$ (Gilbert et al., 1982).

As variedades presentes nos sienitos e diques félsicos parecem razoavelmente coerentes com as informações teóricas e experimentais, mostrando evolução composicional de acordo com as variações, primeiramente em $\mathrm{T}^{\circ} \mathrm{C}$ e depois em $\mathrm{PH}_{2} \mathrm{O}$. É evidente, pelo exposto, que os limites mais definidos são aqueles da composição das rochas onde se encontram.

Aparentemente, as biotitas seguem em paralelo, pela evolução do teor de annita, ou teor de Mg. As biotitas magnesianas até flogopitas contendo os maiores valores de $\mathrm{Al}^{\mathrm{lV}}$ correspondem, nos diques máficos, às kaersutitas.

Os números mg\# para as biotitas apresentam correspondência com aqueles dos anfibólios, e mesmo dos piroxênios, com valores em torno de 4,0 (dique félsico BZ 182B), pequeno intervalo entre 4 a 12 , seguindo-se os sienitos que alcançam até $\mathrm{mg \#} 30$ e os diques 
máficos lamprofíricos com até mg\# 59 - o mesmo valor encontrado para as kaersutitas. Como nem todas amostras contêm as mesmas associações, algumas daquelas destacadas não aparecem. Todas as biotitas possuem $\mathrm{Ti}$ alto, sendo os maiores valores os das rochas lamprofíricas $\left(\mathrm{TiO}_{2}=9,79 \%\right.$, Ti 1,2) refletindo as kaersutitas $\mathrm{e}$ as rochas hospedeiras. Tratamentos gráficos variados $\left[\mathrm{Fe}(\mathrm{Fe}+\mathrm{Mg}) \times \mathrm{Al}^{\mathrm{IV}}, \mathrm{mg \#} \times \mathrm{Si}, \mathrm{Ti}\right.$, $\mathrm{Fe}$ etc.] mostram continuidade composicional, interrompida, no caso das biotitas, por intervalos. Embora os valores extremos de mg\# coincidam razoavelmente, não há estrita concordância diretamente observável para esses intervalos, em boa parte, provavelmente, em razão de ausência de análises, e não por representarem parâmetros aleatórios.

Os padrões de continuidade composicional, levando-se em conta diversos cátions ou combinações, são diferentes entre esses três minerais. Em geral, apresentam correlações positivas ou negativas, às vezes certo espalhamento, ou então constância de valores para os mesmos pares. As maiores ausências de correlação, ou mesmo inversão de tendências, estão presentes entre os piroxênios para Si $\times$ mg\# e Al $x$ mg\#. Nestes minerais, são também observadas descontinuidades composicionais marcantes entre os diques máficos e as rochas félsicas em geral ( $\mathrm{Si}, \mathrm{Al}, \mathrm{Ti}, \mathrm{Na}$ e $\mathrm{Fe}^{3+}$ ).

\subsubsection{Os óxidos}

Como visto, os sienitos contêm Ti-magnetitas e ilmenitas coexistentes, quer em indivíduos independentes, quer intercrescidos, sendo que as ilmenitas formam lamelas, "gotas" ou ocupam as bordas dos grãos. Essas feições podem ser, em parte, magmáticas, e em parte efeitos de "oxidação-exsolução" das ilmenitas durante o resfriamento lento, já em estágio subsólido.

Composicionalmente, tanto as magnetitas apresentam-se bastante ricas em $\mathrm{Mt}$, como as ilmenitas em IIm. As composições das soluções Mt-Usp seriam indicativas de temperaturas finais abaixo de $700^{\circ} \mathrm{C}$, para $\mathrm{fO}_{2}$ do tampão $F M Q$, a $1-2 \mathrm{~kb}$. As ilmenitas, ainda com composição mais restritas na série $11 \mathrm{~m}-\mathrm{H}-\mathrm{m}$, estariam quase que superpostas às curvas dos tampões NNO, FMQ, CCO e WM, quase verticais no campo $\mathrm{T}^{\circ} \mathrm{C} \times \| \mathrm{Im}-\mathrm{Hm}$, não sendo possivel qualquer estimativa (cf. Lindsley, 1991).

A coexistência das séries Mt-Usp e llm-Hm com biotitas e/ou anfibólios (hornblendas) pode admitir as seguintes reações de equilíbrio:

$$
\begin{gathered}
2 \mathrm{Bi}+\mathrm{O}_{2}=2 \mathrm{Or}+2 \mathrm{Mt}+\mathrm{H}_{2} \mathrm{O}(1) \\
2 \mathrm{Hb}+\mathrm{O}_{2}=4 \mathrm{CPX}+2 \mathrm{Mt}+8 \mathrm{Q}+2 \mathrm{H}_{2 \mathrm{f}}(2) \mathrm{e}
\end{gathered}
$$




$$
\begin{gathered}
\mathrm{Bi}+31 \mathrm{~m}=\mathrm{Or}+3 \mathrm{Usp}+\mathrm{H}_{2} \mathrm{O}(3) \\
\mathrm{Hb}+3 \mathrm{IIm}=4 \mathrm{CPx}+2 \mathrm{Usp}+8 \mathrm{Q}+2 \mathrm{H}_{2} \mathrm{O}(4)
\end{gathered}
$$

As reações (1) e (2) envolvem componentes extremos (por exemplo, Or do feldspato presente) e magnetita, e são anotados como tampões para $\mathrm{fO}_{2}$, respectivamente $\mathrm{KMB}$ e HMAQ; as reações (3) e (4) incluem ilmenita e ulvöespinélio da magnetita, e são indicadas como KUIIB e QUAHII.

Em todas elas, o aumento de $\mathrm{H}_{2} \mathrm{O}$ no magma desloca o equilíbrio para a esquerda, com a formação de biotita ou de "hornblenda", e aumenta os valores da $\mathrm{fO}_{2}$. Em (1), feldspato e magnetita são consumidos; já em (2), piroxênio, magnetita e quartzo. Para estas reações, se houvesse aumento de $\mathrm{fO}_{2}$ por outros motivos, a reação se deslocaria para a direita, consumindo biotita ou anfibólio, e dando lugar à magnetita e a outros silicatos. Em (3), são consumidos feldspato e Usp, formando ilmenita e biotita, e em (4) originam-se hornblenda e ilmenita às expensas de clinopiroxênio, Usp e $Q$.

As composições $\mathrm{Mt-Usp_{ss }}$ dos diques máficos é muito variada e corresponde a intervalo muito amplo de temperatura e $\mathrm{fO}_{2}$. As composições das ilmenitas, com base em apenas 3 análises, são muito próximas ao extremo puro $\mathrm{Im}$.

A aplicação do geotermômetro de Buddington e Lindsley (1964) mostra, para os sienitos, temperaturas entre $580^{\circ} \mathrm{C}$ e $680^{\circ} \mathrm{C}$ e $-\log \mathrm{fO}_{2} \sim 18-21$. Para os diques máficos, os resultados são de $870-960^{\circ} \mathrm{C}$ e $-\log \mathrm{fO}_{2} \sim 11-13$, mas para uma única análise de ilmenita.

Os diques félsicos não apresentam minerais de óxidos de $\mathrm{Fe}$ e $\mathrm{Ti}$, muito mais em razão de $\mathrm{pH}_{2} \mathrm{O}$ e $\mathrm{fO}_{2}$, mas também em parte dos baixos valores de $\mathrm{TiO}_{2}$ total. 


\section{CAPÍTULO 8 \\ A COMPOSIÇÃO QUIMICA DAS ROCHAS}

Todo o acervo analítico encontramse nas Tabelas 22,23 e 24, respectivamente, para os sienitos (e dois charnoquitos), diques félsicos e diques máficos.

\subsection{As classificações químicas das rochas}

Não tem sido habitual tratar-se um pouco melhor a classificação das rochas, afora em raros trabalhos de caráter geral, ou em trabalhos especificos sobre o tema.

Existe uma proposta de cunho internacional desde 1989 (Le Maitre, 1989), que não tem sido seguida irrestritamente. Além disso, ela não é "perfeita", e vários autores encontram vantagens em outros sistemas, como, por exemplo, aquele de De La Roche (De La Roche et al., 1980; De La Roche, 1986), que utiliza os parâmetros R1 e R2.

Após duas décadas de consultas a especialistas do mundo inteiro, conduzidas por subcomissão da IUGS, editaram-se as recomendações sobre a classificação das rochas ígneas (Le Maitre, 1989). Embora questionadas, parece importante o reconhecimento e a adoção dessas recomendações, ainda que parcialmente, pois permitem linguagem comum. Além disso, a proposta não é só consistente, como coerente, e estabelece parâmetros classificatórios claros e bem definidos, e em boa parte de fácil aplicação. A edição de Le Maitre incorpora um glossário com 1586 nomes de rochas ígneas, muitos em desuso, além de vasta quantidade de uso esparso, o que dificulta parte do trabalho petrológico e a uniformização dos conhecimentos. Cunhados a partir de 1880-1890, até 1930-1940, segundo os critérios mais variados, esses nomes "presenteiam" as rochas alcalinas com $38 \%$ do total (600).

As recomendações da IUGS serão usadas, adiante. Contudo, para manter uniformidade com o grande número de pesquisas publicadas pelo grupo brasileiro-italiano, e que vem empregando a classificação de De La Roche, adicional e comparativamente, as composições das rochas foram lançadas no plano R1R2, com a rede classificatória desse autor.

Vale lembrar que a recomendação primeira da IUGS é que as rochas igneas sejam arranjadas modalmente. Não sendo isso possível, dada a presença de minerais micro/criptocristalinos e/ou vidro, passar-se-ia à classificação química, no campo TAS com a rede classificatória de Le Bas (Le Bas, 1986, em Le Maitre, 1989). Tanto nesse diagrama, como 
no R1R2, é rotina utilizar-se nomenclatura para "tipos magmáticos", sendo indiferente termos empregados para rochas vulcânicas (mais comum) ou para as plutônicas.

\subsubsection{As rochas alcalinas de Búzios: a classificação da IUGS}

A Figura 20, diagrama TAS com a rede de Le Bas, (1986), mostra a distribuição e a classificação das rochas.

Tal como em várias outras ocorrências brasileiras, em que coexistem rochas plutônicas sieniticas e diques variados (Lages, SC; São Sebastião, SP etc.), de pronto chama a atenção a bimodalidade acentuada. As 12 amostras correspondentes aos diques máficos são básicas e ultrabásicas, e concentram-se nos campos U1 dos tefritos (OK $10 \%)$ e basanitos $(\mathrm{Ol}>10 \%)$, com oito delas, $\mathrm{B}$ dos basaltos, com duas amostras, e $\mathrm{S} 1$ dos traquibasaltos, também com duas amostras. Não há amostras nos campos U2, U3, S2 e S3, dos fonotefritos, tefrifonólitos, traquiandesitos basálticos e traquiandesitos, respectivamente. Essa ausência composicional corresponde ao intervalo $50-60 \%$ de $\mathrm{SiO}_{2}$.

Petrograficamente, os basaltos correspondem aos diques diabásicos (ver item 6.5.1.1.) e as rochas restantes aos lamprófiros (ver item 6.5.3.). Embora, do ponto de vista petrográfico, estas últimas tenham sido classificadas como camptonitos e, subsidiariamente, como sannaítos e monchiquitos, não existem equivalentes químicos aos sannaítos. A aparente contradição deve-se à presença de plagioclásio normativo não observado ao microscópio, provavelmente porque ocorre como material micro-criptocristalino e, potencialmente, no vidro.

Entre as rochas félsicas, a maioria das análises é de sienitos (tipo magmático=traquito), caindo no campo homônimo. Os diques félsicos supersaturados derivam para os riólitos, enquanto que os insaturados para fonólitos (campos $T, R$ e Ph, respectivamente).

A IUGS recomenda a subdivisão das rochas dos campos $S 1, \mathrm{~S} 2$ e $\mathrm{S} 3$. É de interesse, aqui, o campo $\mathrm{S} 1$, dos traquibasaltos. Conforme $\mathrm{K}_{2} \mathrm{O}$ seja maior ou menor que $\left(\mathrm{Na}_{2} \mathrm{O}-2\right)$, esses tipos podem ser subdivididos em traquibasalto potássico e hawaiito, respectivamente. As rochas do campo $T$ (traquito=sienito) admitiriam modificadores adequados: se próximas aos fonólitos, traquifonólitos, e se próximas aos riólitos, traquidacitos.

É necessário observar que não há proporcionalidade entre o número de amostras e a correspondente área de exposição. Com certeza, os diques representam qualquer coisa em torno de $1 \%$. Entre as amostras de diques, contudo, há alguma proporcionalidade, talvez com alguma subavaliação de tipos traquiticos, "stricto sensu". 


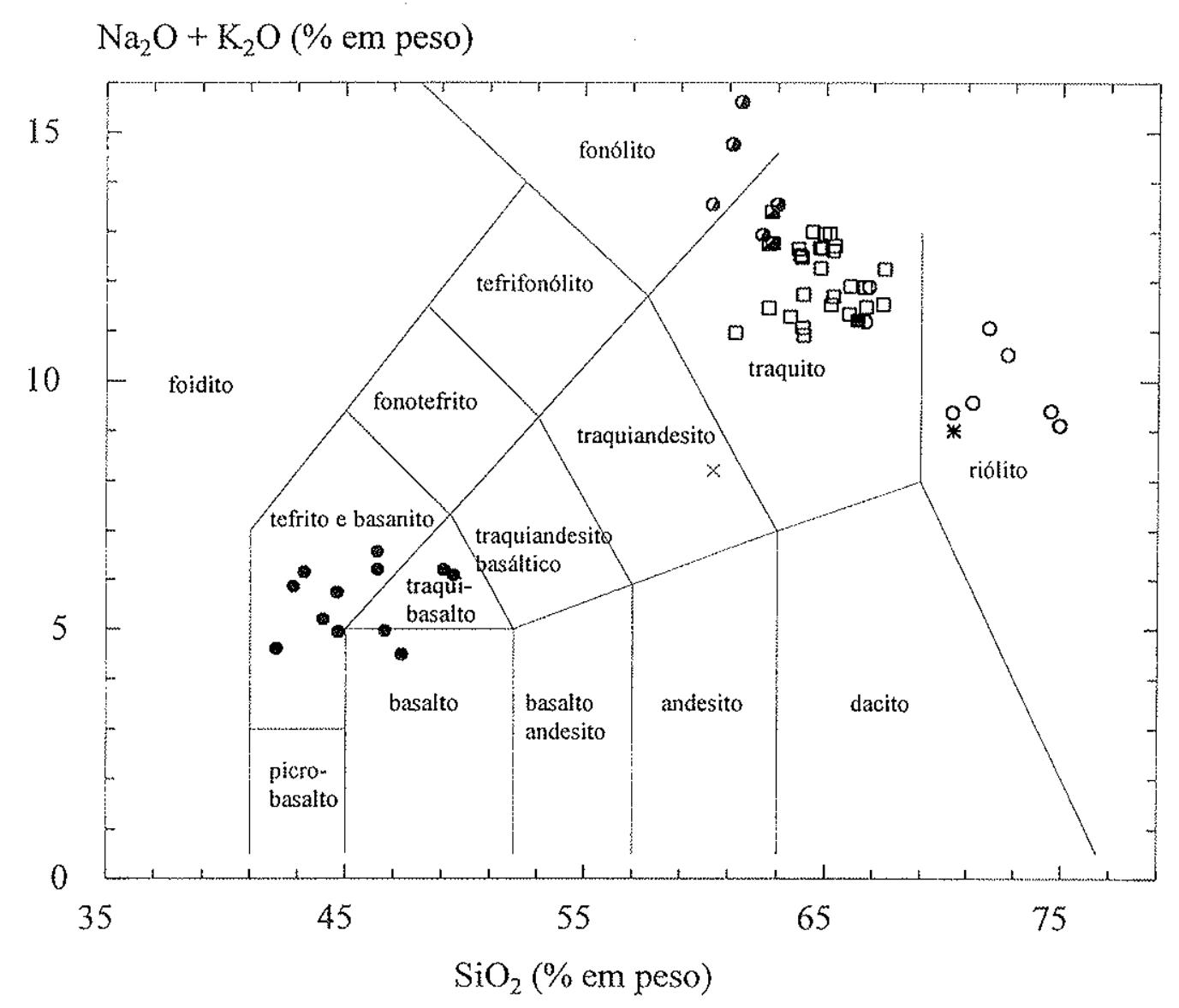

Figura 20 - Diagrama Total Álcalis Sílica "TAS" (Le Maitre, 1989). Sienitos $\square$; Ne-sienitos $\square$; Q-sienitos mangerito de Búzios $X$; charnoquito de Ubatuba (média para 23 análises, Neumann, 1993) *. 


\subsubsection{As rochas alcalinas de Búzios: a classificação no campo R1R2}

A Figura 21 mostra as composições das rochas de Búzios no campo R1R2. Não constitui surpresa a mesma bimodalidade já vista no diagrama TAS.

Os diques máficos grupam-se nos campos dos basaltos alcalinos (2), basanitos (2), tefritos (5) e traquibasaltos (3). Não aparecem rochas fonotefriticas e traquiandesíticas, que caracterizam o "gap" composicional. Os sienitos agrupam-se no campo correspondente, mostrando leve tendência, por um lado, para as composições traquifonolíticas (sienitos nefelínicos ou "com nefelina") e, por outro, para os quartzo sienitos (3 e 2 amostras, respectivamente). Os diques félsicos insaturados ocupam o campo dos traquifonólitos e dos fonólitos, enquanto que os supersaturados, o dos quartzo traquitos, riólitos e riólitos alcalinos. Há, portanto, ampla variação em R1 (<-1000 ou > 2000), mantendo-se R2 quase constante.

\subsubsection{Comparação das classificações}

A mais séria discrepância, aliada também à certa polêmica, reside nos lamprófiros. Estas rochas podem ser assim classificadas pelas características de campo e petrográficas (a importante participação dos ocelos, das kaersutitas, dos Al-Ti piroxênios e a textura porfirítica e panidiomórfica), além daquelas de ordem química (alto Ba, por exemplo), mas não existe um único campo químico lamprofírico (cf. Rock, 1982; Le Maitre, 1989). Talvez, circunstancialmente, as amostras selecionadas para a química mineral, em razão de suas caracteristicas químicas e petrográficas, tenham contribuido no sentido de utilizar-se apenas as variedades com feldspato alcalino. Assim, esses tipos enquadrar-se-iam entre os sannaitos. Normativamente, contudo, as mesmas rochas mostram altos teores de An e, conseqüentemente, não são sannaítos, tratando-se mesmo de camptonitos ou de monchiquitos.

As diferenças observadas entre as classificações examinadas não são das mais relevantes. As duas amostras de basaltos, no diagrama TAS, caem no campo das rochas alcalinas (cf. MacDonald e Katsura, 1964); já no R1R2, situam-se diretamente entre os basaltos alcalinos. Basanitos e tefritos têm campos delimitados em R1R2, enquanto que no diagrama TAS há que se verificar a porcentagem de OI (normativa), se maior ou menor que $10 \%$. Os traquibasaltos, indiferenciados em R1R2, seriam classificados como hawailtos e traquibasaltos potássicos no TAS (Le Bas, 1986; Le Maitre, 1989). Os riólitos, no diagrama TAS, passariam a riólitos e riólitos alcalinos no R1R2. 


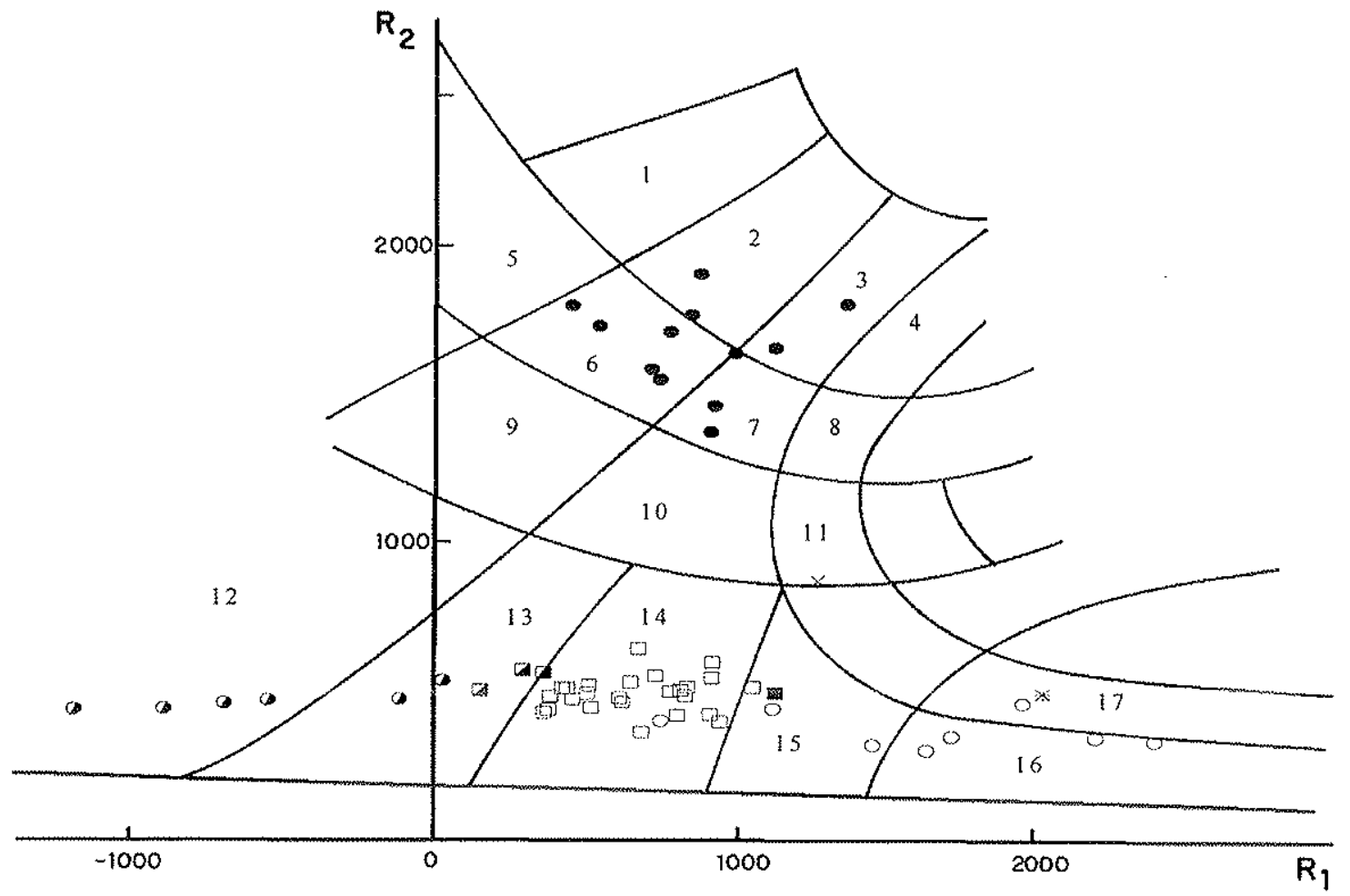

Figura 21 - Diagrama de classificação R1R2 de De La Roche et al. (1986). Símbolos como na Figura 20. Em parênteses, equivalente intrusivo. 1, ankaratrito (melteigito); 2, basanito (teralito); 3 , basalto alcalino (gabro alcalino); 4 , olivina basalto (olivina gabro); 5, nefelinito (ijolito); 6, tefrito (essexito); 7, traquibasalto (sienogabro); 8, latibasalto (monzogabro); 9 , fonotefrito (essexito); 10, traquiandesito (sienodiorito); 11, latito (monzonito); 12, fonólito (sienito nefelínico); 13, traquifonólito (nefelina sienito); 14, traquito (sienito); 15, quartzo traquito (quartzo sienito); 16, riólito alcalino (granito alcalino); 17, riólito (granito). 


\subsubsection{Os valores normativos}

As Tabelas 22, 23 e 24 incluem as normas (CIPW), com valores calculados através do programa New Pet.

Todos os cálculos através desse programa são feitos sempre segundo um critério e valor para a razão $\mathrm{Fe}^{2+} / \mathrm{Fe}^{3+}$. Boa parte, senão todo o tratamento gráfico, depende também desse parâmetro. O critério empregado, como sugerido por Rollinson (1994), foi o de repartir o Fe total em $\mathrm{FeO}$ e $\mathrm{Fe}_{2} \mathrm{O}_{3}$, adotando-se o valor de 0,85 para a razão $\mathrm{FeO} /\left(\mathrm{FeO}+\mathrm{Fe}_{2} \mathrm{O}_{3}\right)$. Razões mais altas ou mais baixas resultaram em valores normativos menos realistas, ocorrendo o aparecimento de hematita ou acmita excessiva, ou ainda quartzo ou nefelina a niveis muito artificiais.

Levando-se em conta a mineralogia presente nas rochas, é bastante grande a aproximação dos resultados, particularmente no que diz respeito à presença ou ausência de nefelina ou de quartzo.

As variadas opções que o programa oferece, contudo, possuem algumas inconsistências internas.

Assim, as rochas classificadas como tefritos e basanitos no diagrama TAS dependeriam dos valores normativos de Ol; já na malha classificatória R1R2, as mesmas rochas aparecem como tefritos ou como basanitos. Esses diagramas dependem exclusivamente das porcentagens absolutas dos óxidos utilizados, não havendo qualquer artifício de cálculo. O valor Ol, contudo, embute premissas do cálculo das normas CIPW, e toda uma seqüência de recálculos, no mínimo, discutível.

O resultado real neste caso é que, se Ol for levado em conta, somente as amostras BZ $313 / 5$ e $303 \mathrm{C}$ estariam no limite de $\mathrm{OI}=10 \%$. Todos os outros diques máficos teriam OI superior e, portanto, seriam classificáveis no diagrama TAS como basanitos.

Com relação à classificação QAPF (Le Maitre, 1989), embora tenha finalidade modal, ela pode ser empregada com valores normativos. O excesso do plagioclásio normativo é de tal ordem que os álcali feldspato sienitos, modais, passariam a monzonitos, quartzo monzonitos e até mesmo monzodioritos.

Apesar desses desvios, naquilo que se refere à saturação em sílica, os resultados modais e normativos mostram consistência e variam de forma semelhante. As três amostras de sienitos nefelina-normativos não apresentam nefelina modal, mas os valores calculados para Ne estão longe de extravagantes $(0,86$ a $2,14 \%)$. 
Pelos motivos apontados, os resultados normativos foram pouco utilizados, uma vez que conduziriam a resultados, às vezes contraditórios, e freqüentemente de difícil interpretação. Em todo caso, vale a avaliação de caráter geral.

Entre as 30 amostras de sienitos, três são portadoras de nefelina normativa (todas do Saco Grande), como dito, e as outras três saturadas $(\mathrm{Q}=\mathrm{Ne}=\mathrm{O})$. Entre as restantes, seis possuem $Q<2,0 \%$ e dezesseis entre 2 e $10 \%$. Uma amostra tem valor igual a 10,03 e a outra, 28,50 (BZ 191B, Ponta Sul). Somente cinco contêm Ol na norma, ainda que com baixos teores. Os feldspatos representam 78 a $93 \%$ da mineralogia, e são em geral alcalinos, sistematicamente com $A b>O r$, a menos de duas amostras. A relação $A b$ :Or varia entre 1:1 a 1,5:1, com $70 \%$ dos valores entre 1,1:1 a 1,3:1 (52 a 57\% de Ab). Os valores de An passam de O a $5,41 \%$ (na rocha). Algumas amostras contêm $A c$, e menor número Ns, ambas fases pouco abundantes. Quase todas as amostras exibem $\mathrm{Mt}$, II, e Ap, com conteúdos abaixo de $2,0 \%$ e $\|>M t$. De modo geral, a distribuição e os valores para $Q$ e Ne são concordantes com os resultados petrográficos e consubstanciam as tendências gerais geográficas apontadas. Às rochas modalmente sem quartzo, correspondem aquelas com nefelina, saturadas ou com baixos valores de Q. Este aumenta no sentido dos contatos, a oeste, na Pontinha ou na encosta entre os cumes centrais da Iha, a Ponta Sul e o Saco do Coruja, região que separa a cunha charnoquitica dos charnoquitos da encosta oeste. A amostra BZ 191B deve refletir a proximidade de charnoquitos e xenólitos ou, concomitantemente, a proximidade a faixas de cisalhamento (Ponta Sul).

Os diques félsicos reúnem cinco amostras de nefelina e olivina normativas e sete de quartzo e hiperstênio normativos, correspondendo às rochas fonolíticas e "riolíticas", respectivamente.

As fonolíticas têm $\mathrm{Ne} \sim 7,36-14,96 \%$, com Ac e Ns de até 3,08 e 4,90, respectivamente. Mt praticamente inexiste, enquanto que $\|$ e Ap estão reduzidos a valores inferiores a $0,70 \mathrm{e}$ $0,20 \%$, respectivamente. Nestes tipos, é maior a consistência entre petrografia e norma. Os valores para os feldspatos, todos alcalinos, são de 70-80\%, com An quase igual a zero. As razões $A b$ e Or se mostram mais altas que nos sienitos, variando entre 1,1 e 1,8.

As sete amostras quartzo normativas possuem $Q=6,56-31,60$ e $\mathrm{Hy}=2,27-6,39$, em proporções inversas às do valor de $Q$. A soma $A b+O r+A n$ situa-se entre 64 e $82 \%$, com razões Ab:Or entre 0,8 e 1,7, e An no máximo de 4,5\%.

Os diques máficos são todos portadores de $\mathrm{Ne}(2,27-13,37 \%)$ e Ol $(10,46-18,60 \%)$ normativos. A soma Ab+Or+An varia entre 34 e $61 \%$, com relação distinta entre os membros. 
Tabela 18 - Valores analíticos máximos (M) e mínimos (m) para os elementos maiores (\% em peso) e numeros mg\# das rochas de Búzios.

\begin{tabular}{|c|c|c|c|c|c|c|c|c|c|c|}
\hline & \multicolumn{2}{|c|}{ Sienitos } & \multicolumn{2}{|c|}{$\begin{array}{c}\text { Diques } \\
\text { fonoliticos }\end{array}$} & \multicolumn{2}{|c|}{ Diques rioliticos } & \multicolumn{2}{|c|}{ Diques máficos } & \multicolumn{2}{|c|}{ Conjunto } \\
\hline & $m$ & $\mathrm{M}$ & $\mathrm{m}$ & $\mathrm{M}$ & $m$ & $\mathrm{M}$ & $\mathrm{m}$ & $M$ & $\mathrm{~m}$ & $\mathrm{M}$ \\
\hline $\mathrm{SiO}_{2}$ & 61,25 & 64,45 & 60,13 & 62,98 & 66,63 & 74,88 & 42,11 & 49,50 & 42,11 & 74,88 \\
\hline $\mathrm{TiO}_{2}$ & 0,23 & 1,23 & 0,09 & 0,38 & 0,11 & 0,54 & 2,03 & 5,27 & 0,09 & 5,27 \\
\hline $\mathrm{Al}_{2} \mathrm{O}_{3}$ & 15,78 & 17,49 & 17,91 & 19,73 & 14,02 & 16,33 & 3,22 & 16,82 & 13,22 & 19,73 \\
\hline $\mathrm{Fe}_{2} \mathrm{O}_{3}$ & 0,39 & 0,96 & $0, \overline{41}$ & 1,06 & 0,22 & 0,65 & 1,68 & 2,22 & 0,39 & 2,22 \\
\hline $\mathrm{FeO}$ & 2,01 & 4,88 & 2,07 & 5,43 & 1,13 & 3,30 & 8,55 & 11,33 & 2,01 & 11,33 \\
\hline $\mathrm{MnO}$ & 0,01 & 0,43 & 0,15 & 0,47 & 0,03 & 0,31 & 0,15 & 0,24 & 0,01 & 0,47 \\
\hline$\overline{\mathrm{MgO}}$ & 0,15 & 1,52 & 0,00 & 0,42 & 0,08 & 0,78 & 4,93 & 8,59 & 0,00 & 8,59 \\
\hline $\mathrm{CaO}$ & 0,08 & 2,33 & 0,49 & 1,49 & 0,06 & 1,10 & 7,14 & 11,50 & 0,06 & 11,50 \\
\hline $\mathrm{Na}_{2} \mathrm{O}$ & 4,42 & 6,85 & 7,57 & 11,04 & 3,33 & 6,28 & 2,45 & 4,24 & 2,45 & 11,04 \\
\hline $\mathrm{K}_{2} \mathrm{O}$ & 5,39 & 7,33 & 2,50 & 6,32 & 4,17 & 6,57 & 1,63 & 2,91 & 1,63 & 7,33 \\
\hline $\mathrm{P}_{2} \mathrm{O}_{5}$ & 0,03 & 0,50 & 0,01 & 0,07 & 0,01 & 0,20 & 0,42 & 1,96 & 0,01 & 1,96 \\
\hline $\mathrm{mg} \#$ & 9,25 & 38,07 & 0,00 & 17,42 & 4,21 & 33,33 & 42,23 & 58,52 & 0,00 & 58,52 \\
\hline
\end{tabular}

Tabela 19 - Composições médias (\% em peso) para algumas rochas extraídas de Cox et al., (1990; valores selecionados de Le Maitre, 1976, de Banco de Dados com 26373 análises).

\begin{tabular}{|l|c|c|c|c|c|}
\hline Amostra & Sienitos & Fonólitos & Rílitos & Tefritos & Basanitos \\
\hline $\mathrm{SiO}_{2}$ & 58,58 & 56,19 & 72,82 & 47,80 & 44,30 \\
\hline $\mathrm{TiO}_{2}$ & 0,84 & 0,62 & 0,28 & 4,76 & 2,51 \\
\hline $\mathrm{Al}_{2} \mathrm{O}_{3}$ & 16,64 & 19,04 & 13,27 & 17,00 & 14,90 \\
\hline $\mathrm{Fe}_{2} \mathrm{O}_{3}$ & 3,04 & 2,74 & 1,48 & 4,12 & 3,94 \\
\hline $\mathrm{FeO}$ & 3,13 & 2,03 & 1,11 & 5,22 & 7,50 \\
\hline $\mathrm{MnO}$ & 0,13 & 0,17 & 0,06 & 0,15 & 0,16 \\
\hline $\mathrm{MgO}$ & 1,87 & 1,07 & 0,39 & 4,70 & 8,54 \\
\hline $\mathrm{CaO}$ & 3,53 & 2,72 & 1,14 & 9,18 & 10,19 \\
\hline $\mathrm{Na}_{2} \mathrm{O}$ & 5,24 & 7,79 & 3,55 & 3,69 & 3,55 \\
\hline $\mathrm{K}_{2} \mathrm{O}$ & 4,95 & 5,24 & 4,30 & 4,49 & 1,96 \\
\hline $\mathrm{P}_{2} \mathrm{O}_{5}$ & 0,29 & 0,18 & 0,07 & 0,63 & 0,74 \\
\hline
\end{tabular}


Tabela 20 - Elementos traços (em ppm) das rochas de Búzios. A média é aritmética, não incluindo valores julgados anômalos.

\begin{tabular}{|c|c|c|c|c|c|c|c|c|c|c|c|c|}
\hline & \multicolumn{3}{|c|}{ Sienitos } & \multicolumn{3}{|c|}{ Diques fonolíticos } & \multicolumn{3}{|c|}{ Diques riolíticos } & \multicolumn{3}{|c|}{ Diques máficos } \\
\hline & $\mathrm{M}$. & $m$ & Média & $\mathrm{M}^{-1}$ & $\mathrm{~m}$ & Média & $\mathrm{M}$ & $\mathrm{m}$ & Média & $M$ & $m$ & Média \\
\hline $\mathrm{Cr}$ & 11 & 0 & 2 & 4 & 0 & 2 & 7 & 0 & 4 & 178 & 25 & 74 \\
\hline $\mathrm{Ni}$ & 18 & 2 & 8 & 21 & 6 & 10 & 15 & 7 & 10 & 89 & 33 & 59 \\
\hline $\mathrm{Rb}$ & 227 & 66 & 126 & 297 & 196 & 237 & 260 & 118 & 178 & 93 & 47 & 57 \\
\hline $\mathrm{Ba}$ & 1459 & 75 & 620 & 89 & 12 & 40 & 778 & 22 & 225 & 3019 & 461 & 1449 \\
\hline $\mathrm{Sr}$ & 315 & 14 & 108 & 1157 & 7 & 25 & 100 & 9 & 32 & 2236 & 724 & 1426 \\
\hline $\mathrm{Nb}$ & 682 & 40 & 95 & 1211 & 221 & 505 & 656 & 33 & 216 & 92 & 39 & 62 \\
\hline $\mathrm{Zr}$ & 1999 & 105 & 332 & 5045 & 1085 & 1527 & 2914 & 187 & 1096 & 244 & 49 & 150 \\
\hline $\bar{Y}$ & 266 & 2 & 48 & 229 & 44 & 68 & 177 & 26 & 83 & 46 & 33 & 38 \\
\hline $\mathrm{La}$ & 527 & 46 & 99 & 627 & 33 & 167 & 292 & 60 & 147 & 84 & 30 & 60 \\
\hline $\mathrm{Ce}$ & 557 & 90 & 193 & 881 & 64 & 285 & 560 & 115 & 286 & 165 & 55 & 120 \\
\hline $\mathrm{Nd}$ & 467 & 45 & 95 & 201 & 23 & 87 & 228 & 53 & 48 & 94 & 33 & 66 \\
\hline
\end{tabular}

Tabela 21 - Valores médios (ppm) para elementos traços de rochas alcalinas, calculadas a partir das médias de províncias alcalinas brasileiras (cf. Morbidelli et al., 1995b).

\begin{tabular}{|c|c|c|c|c|c|c|}
\hline & Sienitos & $\begin{array}{l}\text { Álcali } \\
\text { sienitos }\end{array}$ & $\begin{array}{c}\text { Fonólito } \\
\text { peralcalinos }\end{array}$ & Fonólitos & Tefritos & Basanitos \\
\hline $\mathrm{Cr}$ & 10 & 0 & 9 & 6 & 85 & 522 \\
\hline $\mathrm{Ni}$ & 10 & 0 & 3 & 12 & 91 & 277 \\
\hline $\mathrm{Rb}$ & 123 & 121 & 201 & 155 & 50 & 59 \\
\hline $\mathrm{Sr}$ & 622 & 2126 & 1062 & 1049 & 887 & 1054 \\
\hline $\mathrm{Ba}$ & 2138 & 971 & 376 & 859 & 864 & 950 \\
\hline $\mathrm{Zr}$ & 312 & 413 & 959 & 727 & 264 & 269 \\
\hline $\mathrm{Nb}$ & 67 & 126 & 211 & 181 & 78 & 54 \\
\hline Y & 21 & 23 & 27 & 32 & 25 & 30 \\
\hline $\mathrm{La}$ & 64 & 99 & 128 & 114 & 42 & 63 \\
\hline $\mathrm{Ce}$ & 126 & 202 & 210 & 212 & 90 & 125 \\
\hline $\mathrm{Nd}$ & 26 & 85 & 54 & 82 & 43 & 53 \\
\hline $\mathrm{La} / \mathrm{Nb}$ & 0,95 & 0,78 & 0,61 & 0,63 & 0,54 & 1,17 \\
\hline $\mathrm{Zr} / \mathrm{Nb}$ & 4,65 & 3,27 & 4,54 & 4,01 & 3,38 & 4,98 \\
\hline
\end{tabular}


Entre os basanitos e os tefritos, as proporções säo, para Or $=1,0$, de $A b=0,2-2,0$ e $A n=1,0$ 1,6; para os basaltos alcalinos e traquibasaltos, de $A b=A n=1,5-2,5$. Todas as amostras exibem valores elevados para $\|>M t$ e Ap.

\subsection{Características químicas gerais}

Nem todas as rochas de Búzios podem ser chamadas de alcalinas, no sentido mais restrito (cf. Sorensen, 1974).

Entre os sienitos, faltam as características típicas, quer quimicas, quer mineralógicas, para grande parte das amostras. Tanto os clinopiroxênios como os anfibólios exibem caráter mais cálcico (e ferromagnesiano), com poucas amostras de caráter mais alcalino (cálcicosódicos). Os índices agpaíticos (I.A.) variam entre 0,880 e $<1,000$, havendo apenas sete amostras com valores pouco acima disso, até 1,075. Modalmente, não há sienitos com nefelina e apenas três amostras são nefelina normativas. Contudo, até onde exposto, o corpo apresenta afinidades e tendências alcalinas, que se acentuam mais no sentido sudeste-leste, o mesmo das presumiveis porções centrais, submersas. Essas características são semelhantes às de outras ocorrências brasileiras (Vitória, São Sebastião) e tem caráter mais ou menos geral. A literatura sobre corpos sieníticos mostrando variações entre augita sienitos, com quartzo, e nefelina sienitos, com piroxênios sódicos, é abundante, parecendo mais representar uma regra geral antes que exceção. Essas rochas correspondem aos tipos chamados "miasquiticos" (I.A. $<1,1$, que não raro convivem, geograficamente, com agpaítos tipicos.

Os diques félsicos supersaturados (também quartzo normativos) mostram características semelhantes, alguns deles com Ac e Ns.

Os diques félsicos insaturados não só obedecem aos critérios mais estritos para serem chamados de alcalinos, como a maior parte apresenta caracteristicas agpaiticas, com $I . A .>1,1$ e mineralogia acessória típica (eudialita, $\mathrm{Ti}$ - $\mathrm{Zr}$ silicatos de $\mathrm{Na}, \mathrm{Ca}$ ).

$\mathrm{O}$ conjunto de rochas félsicas varia desde as peralcalinas $\left(\mathrm{Al}_{2} \mathrm{O}_{3} / \mathrm{Na}_{2} \mathrm{O}+\mathrm{K}_{2} \mathrm{O}<1\right)$, o que inclui a quase totalidade dos fonólitos, alguns sienitos e diques "riolíticos", até sienitos e riólitos metaluminosos e mesmo peraluminosos.

Quanto à silica, as rochas plutônicas são todas intermediárias $\left(\mathrm{SiO}_{2}=52-66 \%\right)$, raramente ultrapassando os $66 \%$ de $\mathrm{SiO}_{2}$, e passam de saturadas a supersaturadas, modalmente, incluindo tipos com nefelina normativa. Os diques félsicos analisados dividem-se em ácidos e supersaturados e intermediários e insaturados, os primeiros com quartzo e os outros com nefelina, modal e normativa. 
Os diques máficos são básicos e ultrabásicos, todos insaturados e feldspatoidais (analcima), além de metaluminosos $\left(\mathrm{Al}_{2} \mathrm{O}_{3} /\left(\mathrm{Na}_{2} \mathrm{O}+\mathrm{K}_{2} \mathrm{O}\right)>1,4\right)$, com l.A. máximo de 0,62 .

A Figura 22 mostra nítido agrupamento dos diferentes tipos, aparecendo no campo subalcalino somente os diques félsicos ácidos. Todas as outras rochas ocupam o campo das rochas alcalinas, com diferenças visiveis na combinação de valores $\left(\mathrm{Na}_{2} \mathrm{O}+\mathrm{K}_{2} \mathrm{O}\right) \times \mathrm{SiO}_{2}$. Aos diques máficos cabem os menores valores em álcalis e aos fonólitos os maiores.

As rochas de Búzios participam do "trend" alcalino de MacDonald e Katsura (1964) (Fig. 23), não obstante o largo intervalo composicional entre o grupo das máficas e o das félsicas.

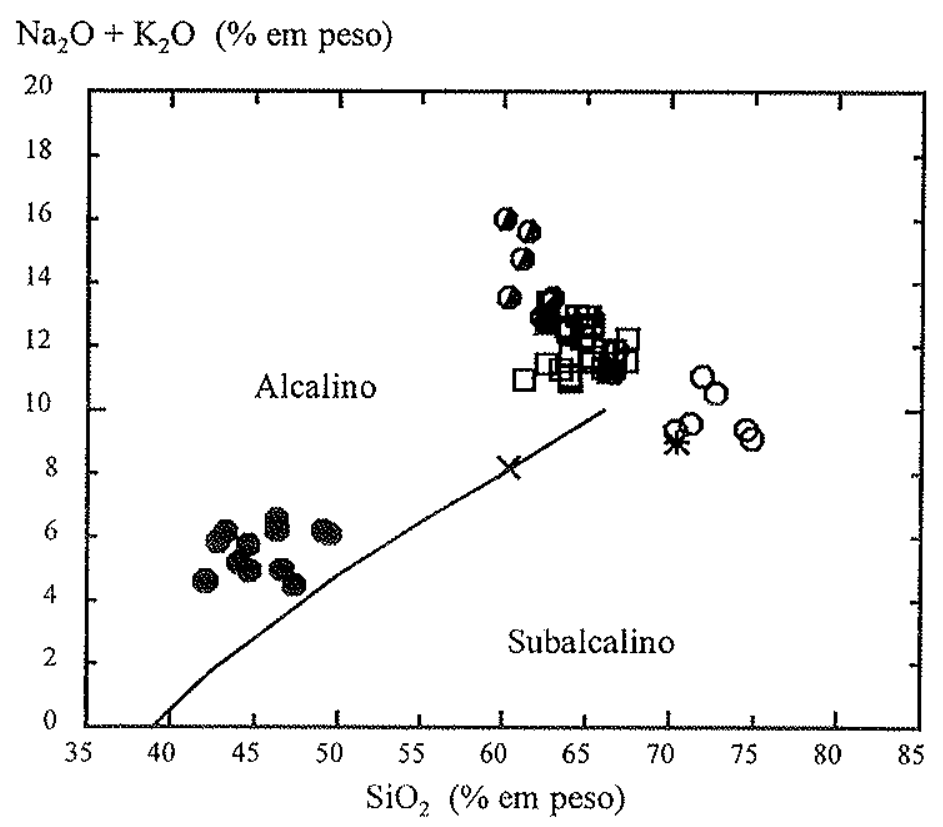

Figura 22 - Diagrama TAS com campos alcalino e subalcalino (MacDonald e Katsura, 1964). Símbolos como na Figura 20.

A grande maioria dos resultados analíticos aponta para rochas com maior afinidade potássica, incluindo as máficas, até o limite com as séries de alto potássio (Fig. 24). Duas amostras de rochas máficas são sódicas, assim como a maioria dos fonólitos.

\subsection{Os elementos maiores}

A Tabela 18 reúne os valores máximos e mínimos para todos os elementos analisados, de forma a facilitar a visibilidade das informações e a análise das variações presentes. 


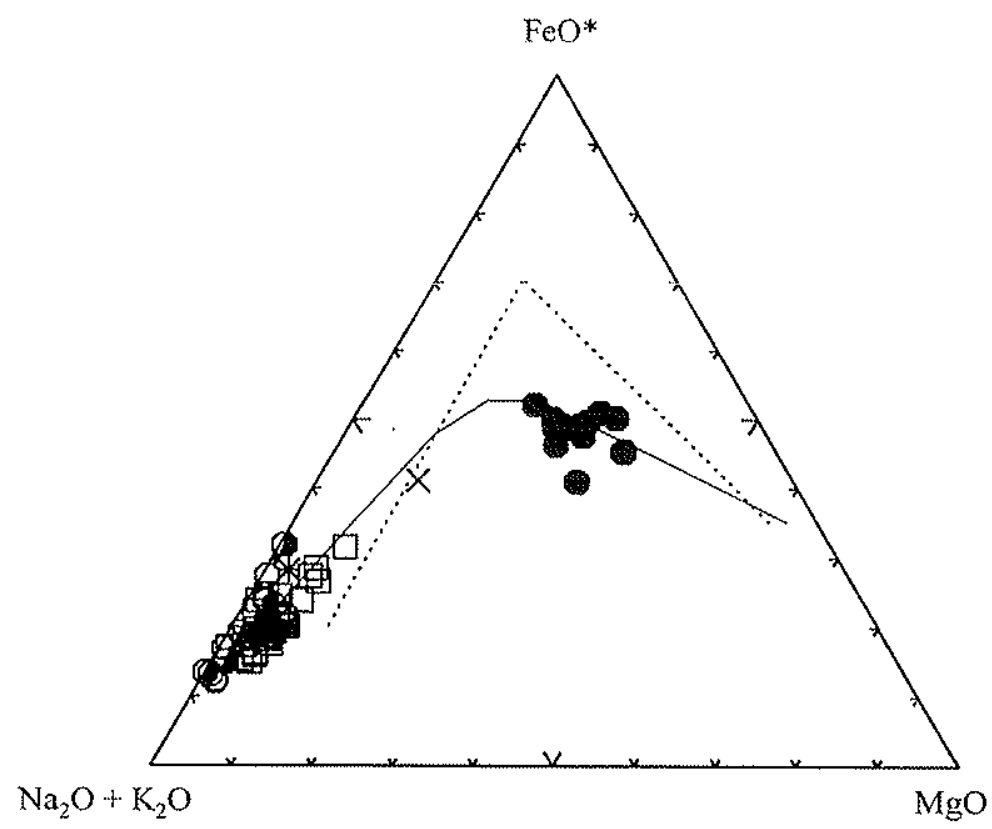

Figura 23 - Diagrama AFM mostrando "trend" médio de toleítos havaianos (linha tracejada) e suíte alcalina (linha cheia) de MacDonald e Katsura (1964). Símbolos como na Figura 20.

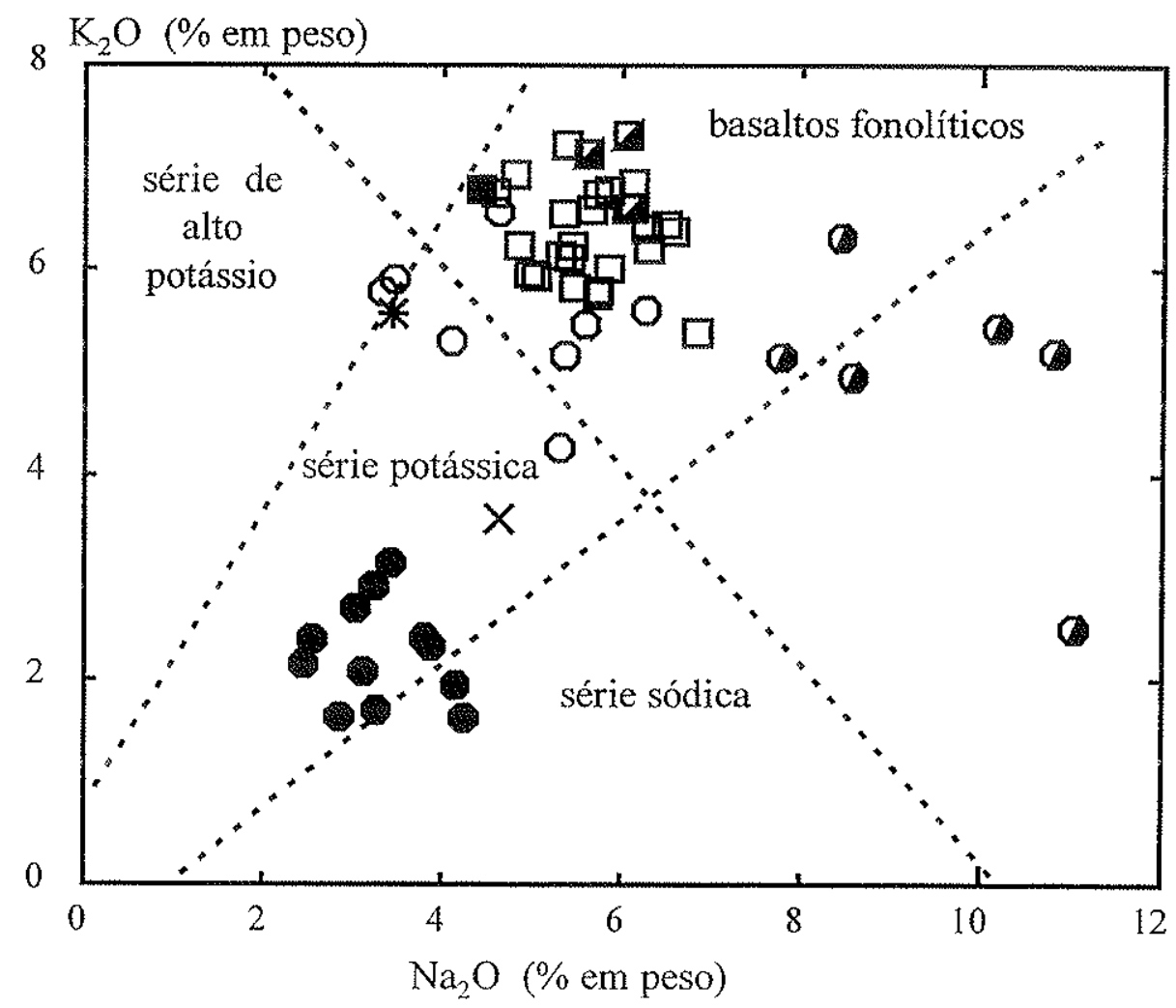

Figura 24 - Diagrama $\mathrm{K}_{2} \mathrm{O}$ vs. $\mathrm{Na}_{2} \mathrm{O}$ (Middlemost, 1975). Símbolos como na Figura 20. 
Comparando-se os dados obtidos para elementos maiores com os da Tabela 19 (cf. Cox et al., 1980), que representam valores médios selecionados, pode-se fazer as seguintes observações.

Os diques máficos de Búzios colocam-se dentro do intervalo dos basanitos e tefritos da Tabela 19 quanto a $\mathrm{SiO}_{2}, \mathrm{Al}_{2} \mathrm{O}_{3}, \mathrm{MgO}, \mathrm{CaO}$ e $\mathrm{Na}_{2} \mathrm{O}$. Têm teores mais elevados de $\mathrm{TiO}_{2}$, $\mathrm{MnO}, \mathrm{P}_{2} \mathrm{O}_{5}$ e muito maiores para $\mathrm{FeO}$, possivelmente em decorrência do critério e do valor para a razão $\mathrm{Fe}^{2+} / \mathrm{Fe}^{3+}$ aqui adotados. Teores menores são apresentados por $\mathrm{Fe}_{2} \mathrm{O}_{3}$ e $\mathrm{K}_{2} \mathrm{O}$. Afora a diferença para $\mathrm{FeO}$, acentuada, as composições são razoavelmente semelhantes.

Os diques fonolíticos mostram maiores valores para $\mathrm{SiO}_{2}$ e $\mathrm{FeO}$, e bem maiores para $\mathrm{MnO}$ e $\mathrm{Na}_{2} \mathrm{O}$. São menores os teores de $\mathrm{TiO}_{2}, \mathrm{Al}_{2} \mathrm{O}_{3}, \mathrm{Fe}_{2} \mathrm{O}_{3}, \mathrm{~K}_{2} \mathrm{O}$ e $\mathrm{P}_{2} \mathrm{O}_{5}$ e, acentuadamente menores, os de $\mathrm{MgO}$ e $\mathrm{CaO}$. Mais uma vez cabe observar que, às vezes, existem diferenças ponderáveis, mas não a ponto de implicarem em caracteristicas incomuns e extremadas das rochas da ltha.

As rochas "riolíticas" analisadas possuem valores médios menores para $\mathrm{SiO}_{2}, \mathrm{Fe}_{2} \mathrm{O}_{3} \mathrm{e}$ $\mathrm{CaO}$, e maiores para os óxidos restantes. Novamente, as diferenças não são de grande monta.

Os sienitos têm composição semelhante ao "sienito-tipo" da Tabela 19, no que toca a $\mathrm{TiO}_{2}, \quad \mathrm{Al}_{2} \mathrm{O}_{3}, \quad \mathrm{Na}_{2} \mathrm{O}$ e $\mathrm{P}_{2} \mathrm{O}_{5}$. Conteúdos maiores são exibidos por $\mathrm{SiO}_{2}$ e $\mathrm{K}_{2} \mathrm{O}$, sendo acentuadamente maiores os de $\mathrm{FeO}$ (ver observação para os diques máficos) e $\mathrm{MnO}$, e bem menores os de $\mathrm{Fe}_{2} \mathrm{O}_{3}$ (idem observação para $\mathrm{FeO}$ ), $\mathrm{MgO}$ e CaO.

As maiores diferenças ocorrem nos tipos félsicos, e relacionadas principalmente a $\mathrm{FeO}, \mathrm{Fe}_{2} \mathrm{O}_{3}, \mathrm{MnO}, \mathrm{MgO}$ e $\mathrm{CaO}$.

Diagramas bivariantes, com o número $\mathrm{mg \#}[\mathrm{MgO} \times 100 /(\mathrm{MgO}+\mathrm{FeO})]$ como índice de diferenciação, são fornecidos na Figura 25a. O número mg\# varia entre 0 e 58,52 e guarda razoável correspondência com o tipo de rocha, repartindo-se nos intervalos de 0-17,42 para os fonólitos, 4,21-33,33 para os "riólitos", 9,25-38,07 para os sienitos e 42,23-58,52 para os diques máficos. É um largo intervalo, mas não chega a alcançar os valores de rochas bastante primitivas, a indicar que, em Búzios, mesmos os tipos litológicos mais primitivos (diques máficos) se derivaram a partir de magmas já evoluidos $(6,11<\mathrm{MgO}<8,59)$. Os números mg\# permitem supor que as amostras BZ 326A6 (tefrito), 181A (basalto alcalino) e 301C (basanito) são as rochas menos evoluidas da liha. A elas seguem-se os outros basanitos, tefritos $e$ basaltos alcalinos, culminando nas mais evoluídas, tefritos e traquibasaltos.

O valor mg\# apresenta pequena solução de continuidade entre 38,07 e 42,23, que se faz visivel em quase todos os diagramas. 
Mostram correlação negativa $\mathrm{SiO}_{2}, \mathrm{Al}_{2} \mathrm{O}_{3}, \mathrm{Na}_{2} \mathrm{O}$ e $\mathrm{K}_{2} \mathrm{O}$ e positiva, $\mathrm{TiO}_{2}, \mathrm{FeO}_{\mathrm{t}}, \mathrm{MgO}$, $\mathrm{CaO}$ e $\mathrm{P}_{2} \mathrm{O}_{5}$. O MnO, a partir da passagem rochas máficas-félsicas, espalha-se igualmente para valores menores e maiores.

Para todos os óxidos, as análises arranjam-se em grupos de forma ou mais ou menos alinhada, nitidamente delimitadas as rochas máficas das félsicas. As delimitações mais alinhadas são aquelas correspondentes a $\mathrm{TiO}_{2}, \mathrm{MgO}, \mathrm{Na}_{2} \mathrm{O}$ e $\mathrm{P}_{2} \mathrm{O}_{5}$. Há uma certa descontinuidade e nítida quebra de inflexão em alguns dos óxidos, caso do $\mathrm{MgO}$, e noutros, a tendência mais ou menos linear só é observada na porção félsica (mg\# < 38,07), com maior dispersão nos diques máficos: caso do $\mathrm{FeO}_{4}, \mathrm{CaO}$ e $\mathrm{K}_{2} \mathrm{O}$. Este último mostra, para as rochas félsicas, correlação levemente negativa.

Os óxidos das rochas félsicas também aparecem de maneira variada: ora sienitos, fonólitos e "riólitos" estão separados $\left(\mathrm{SiO}_{2}, \mathrm{Al}_{2} \mathrm{O}_{3}\right.$ e $\left.\mathrm{Na}_{2} \mathrm{O}\right)$, ora assumem valores semelhantes, - que acarreta superposição gráfica. A razão $\mathrm{Al}_{2} \mathrm{O}_{3} / \mathrm{SiO}_{2}$, não incluída, mostra boa discriminação de todos os grupos de rochas, separando, inclusive, os sienitos dos fonólitos e dos "riólitos".

\subsection{Os elementos traços}

Os elementos traços constam das Tabelas 22, 23 e 24. Seus valores extremos e médios estão na Tabela 20; na 21, são fornecidas os resultados das médias calculadas a partir de dados de várias províncias alcalinas brasileiras, tratadas em Morbidelli et al. (1995b). Faz-se necessária advertência com relação aos valores médios de alguns traços ( $\mathrm{Sr}, \mathrm{Ba}, \mathrm{Zr}$ etc.), dado aos elevados desvios padrões, quase acima de $50 \%$, freqüentemente de 100 até $200 \%$.

Com relação a valores absolutos, destacam-se, entre os sienitos de Búzios, os valores para TR e $\mathrm{Y}$ da amostra $\mathrm{BZ} 107$ (cumes centrais da llha), muito superiores à média, e os de Rb, $\mathrm{Sr}, \mathrm{Ba}$ e $\mathrm{Nb}$ abaixo. Estes mesmos elementos possuem teores menores que a média na amostra BZ 305B (Laje da Escola). Muito discrepantes são os valores de $\mathrm{Zr}$ nas amostras BZ $100,198 \mathrm{~A}$ e 302 , todas de sienitos com quartzo.

Comparando-se os dados das Tabelas 20 e 21 para rochas sieníticas, as de Búzios mostram valores semelhantes a maiores para $\mathrm{Ni}, \mathrm{Rb}, \mathrm{Zr}, \mathrm{Nb}, \mathrm{Y}, \mathrm{La}, \mathrm{Ce}$ e $\mathrm{Nd}$, e menores para $\mathrm{Cr}, \mathrm{Ba} e \mathrm{Sr}$.

Nos diques fonolíticos (Tabela 23), destacam-se as amostras BZ 165B (Saco Grande Central), com valores variavelmente superiores para $\mathrm{Ni}, \mathrm{Ba}, \mathrm{Sr}, \mathrm{Nb}, \mathrm{Zr}, \mathrm{Y}, \mathrm{La}, \mathrm{Ce}$ e $\mathrm{Nd}$, aparentemente a mais diferenciada entre os fonólitos. Já a amostra BZ 166B, das mesmas proximidades, sobressaj-se pelo inverso: menores valores para $\mathrm{Zr}, \mathrm{Y}, \mathrm{La}, \mathrm{Ce}$ e $\mathrm{Nd}$. Os valores 
$\mathrm{SiO}_{2}$

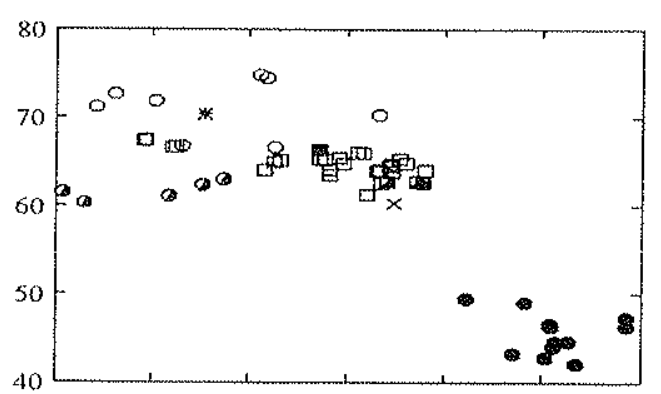

$\mathrm{Al}_{2} \mathrm{O}_{3}$

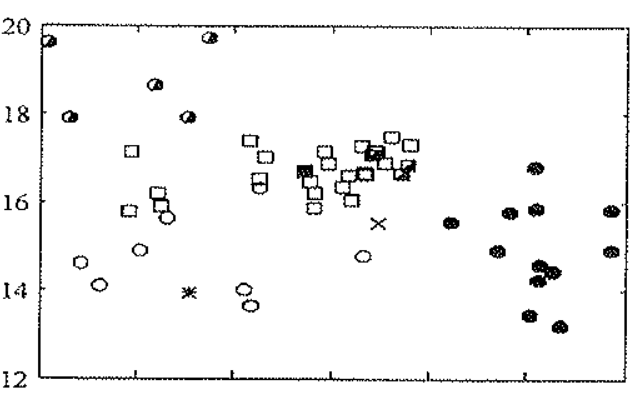

$\mathrm{MnO}$

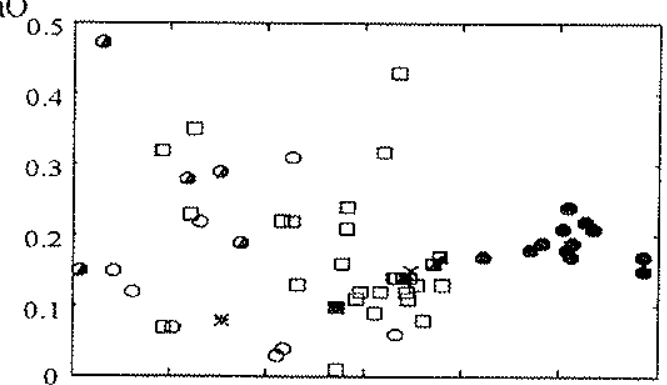

$\mathrm{CaO}$

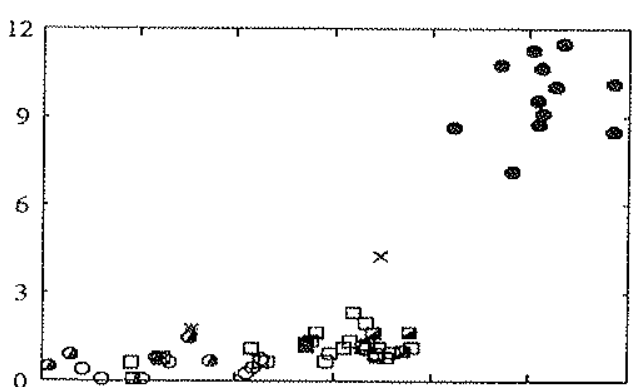

$\mathrm{K}_{2} \mathrm{O}$

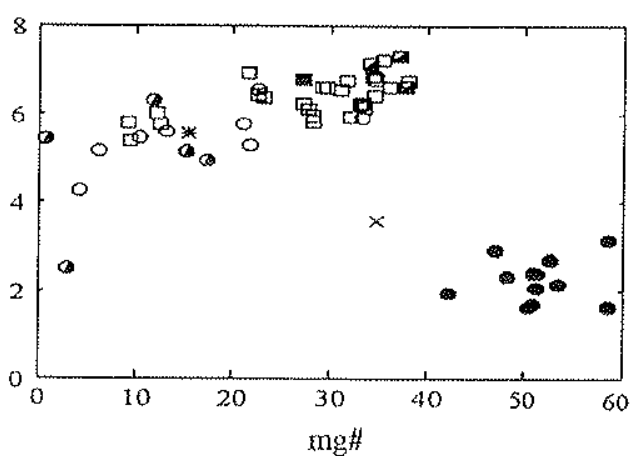

$\mathrm{THO}_{2}$

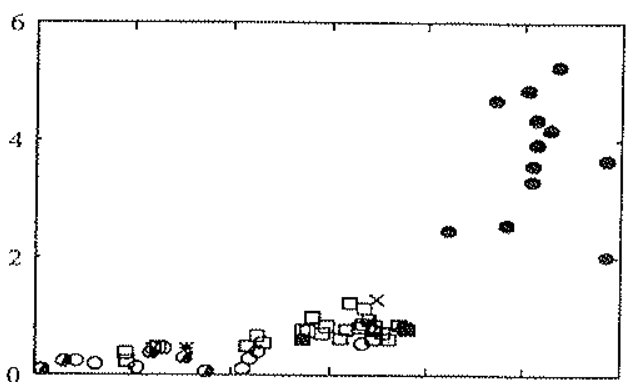

$\mathrm{FeO}$,

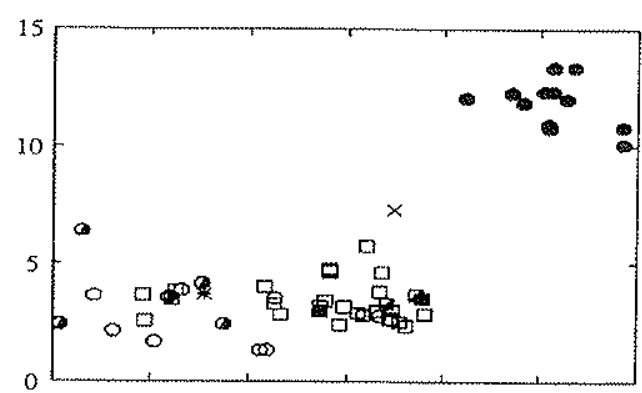

$\mathrm{MgO}$

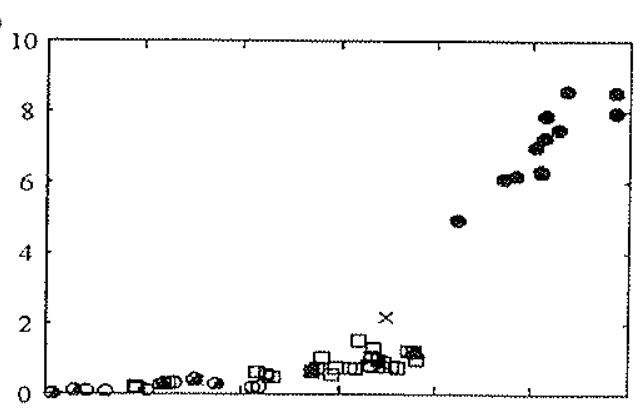

$\mathrm{Na}_{2} \mathrm{O}$

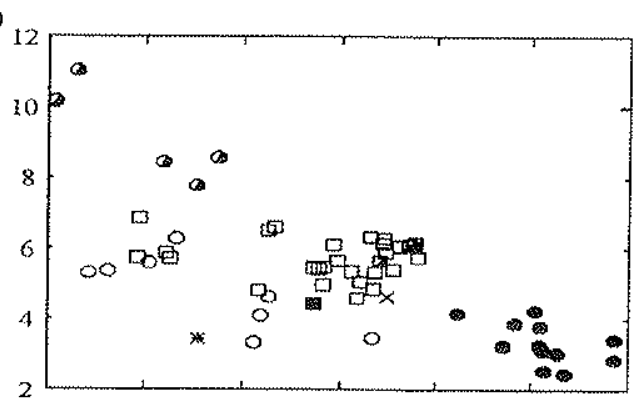

$\mathrm{P}_{2} \mathrm{O}$

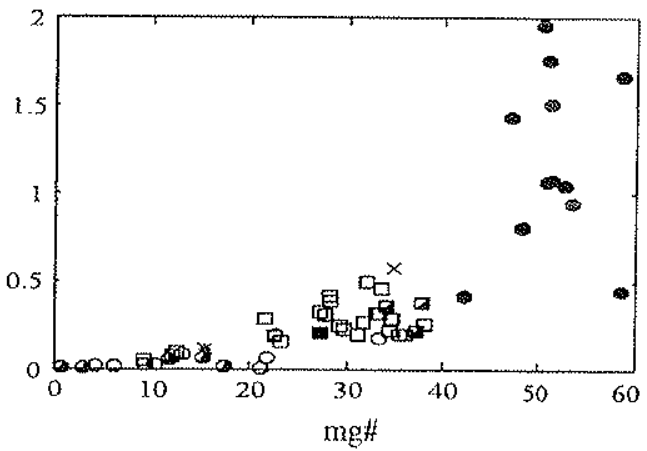

Figura 25a - Diagramas bivariantes: $\mathrm{mg} \#\left[\mathrm{MgO} \times 100 /\left(\mathrm{MgO}+\mathrm{FeO}_{\mathrm{t}}\right)\right]$ vs. elementos maiores. Símbolos como na Figura 20. 
$\mathrm{Cr}$

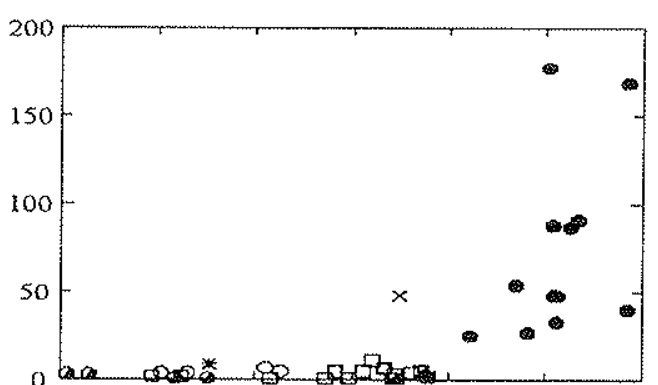

$\mathrm{Rb}$

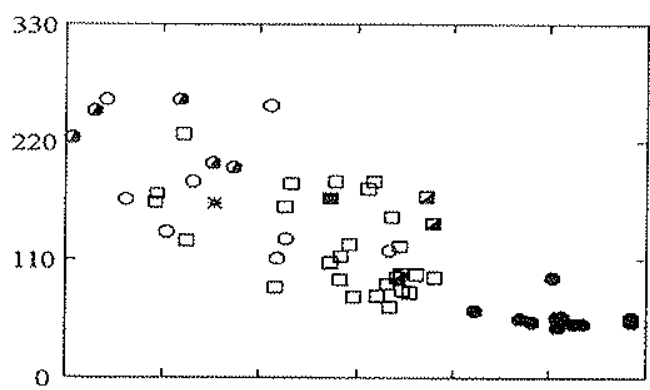

$\mathrm{Sr}$

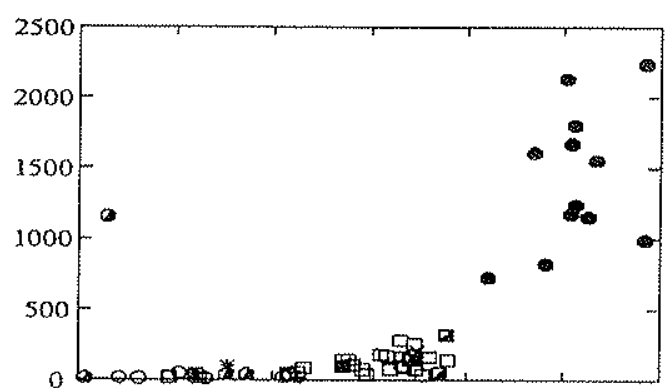

$\mathrm{Zr}$

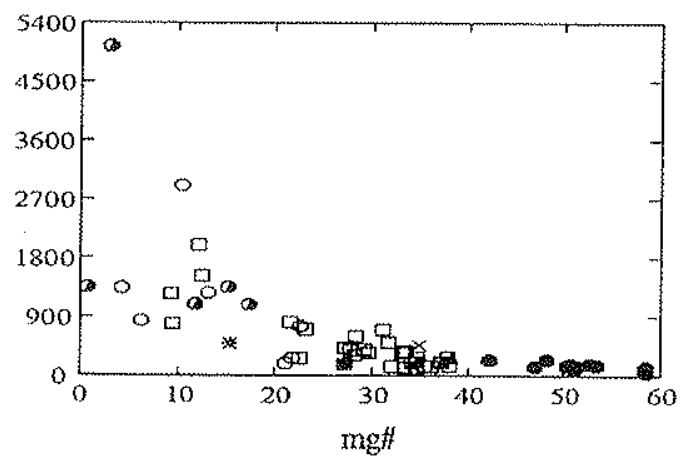

Ni

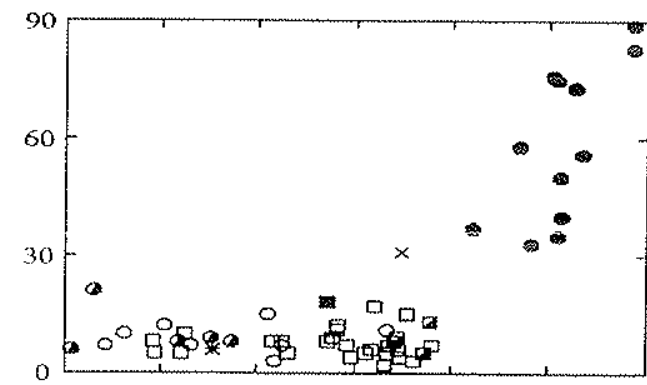

$\mathrm{Ba}$

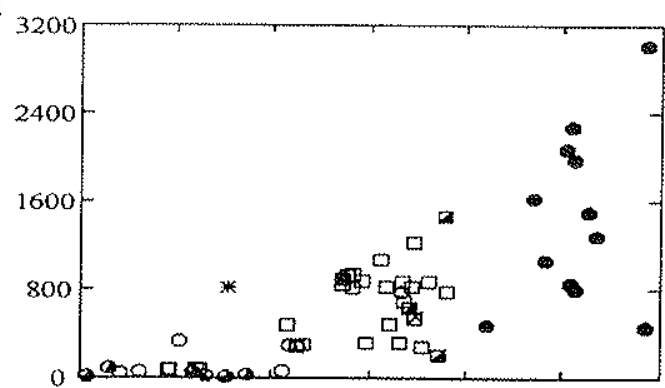

$\mathrm{Nb}$

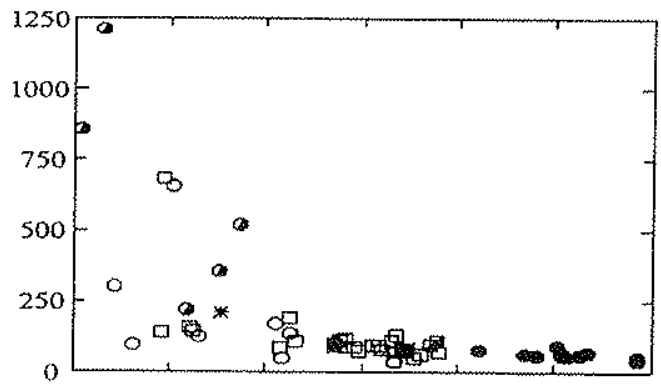

Y

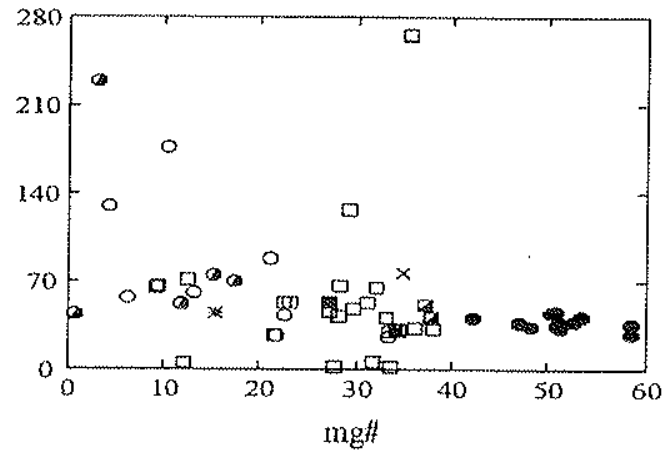

Figura 25b - Diagramas bivariantes: mg\# $\left[\mathrm{MgOx} 100 /\left(\mathrm{MgO}+\mathrm{FeO}_{t}\right)\right]$ vs. elementos traços. Símbolos como na Figura 20. 
La

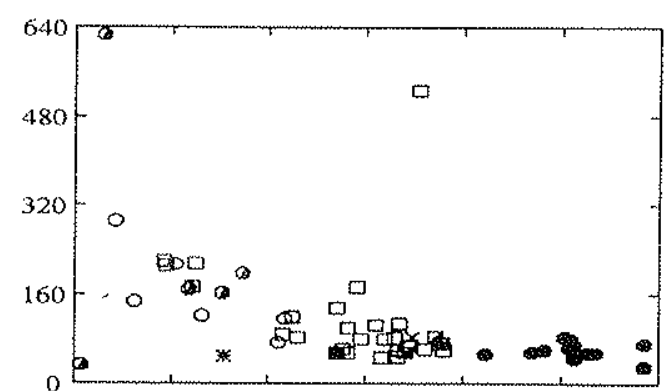

$\mathrm{Nd}$

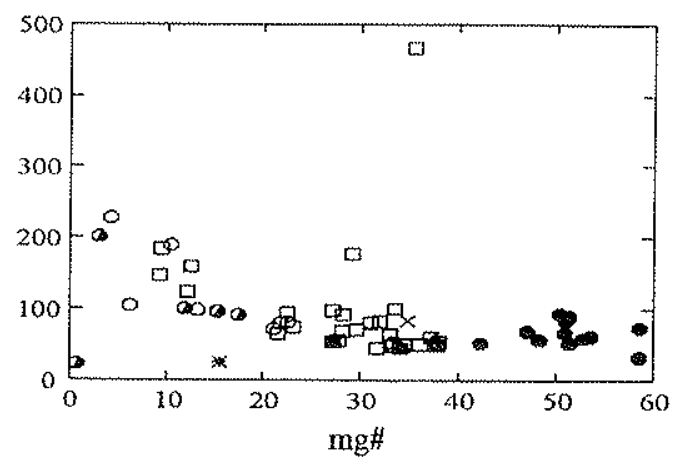

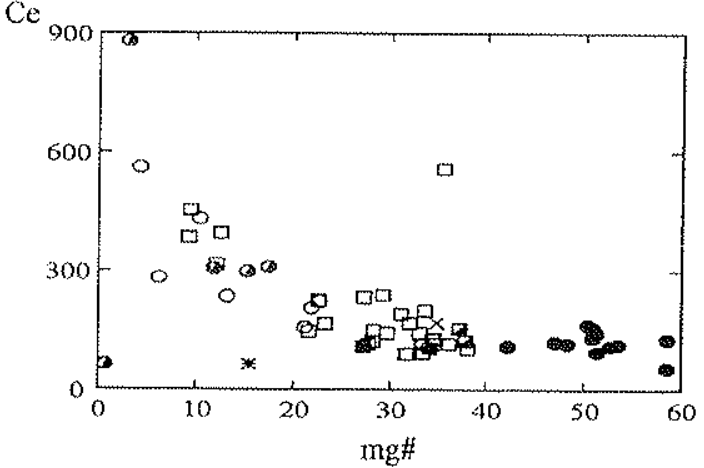

Figura 25c - Diagramas bivariantes mg\# [MgOx100/(MgO+FeO)] vs. elementos Terras Raras. Símbolos como na Figura 20. 
médios de Búzios (Tabela 20) são bem superiores para $\mathrm{Nb}, \mathrm{Zr} \in \mathrm{Y}$, diferença atenuada com relação a $\mathrm{La}, \mathrm{Ce}, \mathrm{Nd}, \mathrm{Rb}$ e Ni. Os teores de $\mathrm{Cr}$ são menores, e bastante inferiores os de $\mathrm{Ba} e$ Sr.

Os riólitos não aparecem no trabalho de Morbidelli et al. (1995b), mas comparados aos fonólitos de Búzios mesmo, exibem diferenças pouco significativas. São similares os teores de $\mathrm{Cr}, \mathrm{Ni}, \mathrm{Sr}, \mathrm{Y}, \mathrm{La}, \mathrm{Ce}$ e Nd, maiores os de Ba e menores os de Rb, $\mathrm{Nb}$ e $\mathrm{Zr}$.

Os diques máficos de Búzios apresentam diferenças nos traços entre basanitos/tefritos e basaltos alcalinos/traquibasaltos. Nesses, as médias de $\mathrm{Cr}, \mathrm{Ba}, \mathrm{Sr}, \mathrm{La}$, Ce e Nd são menores, e maiores as de Zr. Comparativamente aos basanitos e aos tefritos da Tabela 21, o conjunto indiferenciado máfico de Búzios possui teores de $\mathrm{Sr}$ e Ba consideravelmente superiores, e $\mathrm{Y}$, $\mathrm{La}, \mathrm{Nd}$ e Ce similares ou pouco maiores. Os valores para Rb assemelham-se, como também os de $\mathrm{Cr}$, no tocante aos tefritos. Ni é menor com relação aos tefritos e bem inferior quando comparado aos basanitos.

Todo o conjunto de valores foi lançado em diagramas bivariantes, tendo mg\# como discriminante (Figs. 25b e c). Neles, observam-se correlações positivas e melhor definidas para $\mathrm{Sr}$ e $\mathrm{Ni}$, pouco menos para $\mathrm{Cr}$ e com maior dispersão para $\mathrm{Ba}$. São negativas e bem definidas as correlações com $\mathrm{Zr}, \mathrm{Nb}, \mathrm{Y}, \mathrm{La}, \mathrm{Nd}$ e Ce. Para Rb, embora a distribuição se mostre peculiar, a correlação também é negativa. A partir dos pontos analíticos dos sienitos (mg\#=20-40), $\mathrm{Cr}$ e $\mathrm{Sr}$ apresentam teores baixos e constantes no sentido dos valores menores de $\mathrm{mg} \#$, onde fonólitos e riólitos misturam-se; no sentido oposto (dos diques máficos), o mesmo ocorre com $\mathrm{Zr}, \mathrm{Nb}, \mathrm{Y}, \mathrm{La}, \mathrm{Nd}$ e $\mathrm{Ce}$. As distribuições apresentam certa concavidade e maior dispersão para valores maiores de mg\# para os elementos $\mathrm{Sr}$, $\mathrm{Ni}$ e $\mathrm{Ba}$ ou, no sentido contrário, para $\mathrm{Zr}, \mathrm{Nb}, \mathrm{Y}$, La, Nd e Ce.

A quebra à altura de mg\# 40 é bem menos aparente entre os elementos traços. Normalmente, um dos conjuntos (rochas félsicas, rochas máficas) tem comportamento linear, com a mudança entre os dois se dando exatamente a mg\# $\sim 40$. As porções félsicas são mais lineares para os elementos $\mathrm{Cr}$, $\mathrm{Sr}$ e $\mathrm{Ba}$, já as máficas para $\mathrm{Zr}, \mathrm{Nb}, \mathrm{Y}, \mathrm{La}$, Nd e Ce. Em outros casos, ou ocorre tendência visivel, mas com dispersão variável, ou um dos conjuntos apresenta dispersão: para os diques máficos, $\mathrm{Cr}, \mathrm{Sr}$ e $\mathrm{Ba}$, e para as restantes, $\mathrm{Rb}$ e $\mathrm{Ba}$ (sienitos), $\mathrm{Zr}, \mathrm{Nb}$, Y, La, $\mathrm{Nd}$ e Ce (diques félsicos).

É notável, entre as máficas, por um lado a grande variação dos valores e a dispersão das composições ( $\mathrm{Cr}, \mathrm{Sr}, \mathrm{Ni}$ e $\mathrm{Ba}$ ) e, por outro, a pequena variação e a linearidade da disposição de alguns elementos ( $\mathrm{Zr}, \mathrm{Nb}, \mathrm{Y}, \mathrm{La}, \mathrm{Nd}$ e Ce).

Cumpre ainda observar que o mangerito e o "charnoquito de Ubatuba" só encontram destaque junto aos elementos $\mathrm{Cr}$, $\mathrm{Ni}$ e $\mathrm{Ba}$. 
As amostras sugeridas como possivelmente de composição mais primitiva apresentam-se mais grupadas para alguns elementos, com valores mais altos para $\mathrm{Cr}$ e $\mathrm{Ni}$, além de mais baixos para $\mathrm{Rb}, \mathrm{Zr}, \mathrm{Nb}, \mathrm{Y}, \mathrm{La}, \mathrm{Nd}$ e Ce.

\subsubsection{Diagramas multi-elementos ("spidergrams")}

As variações dos elementos traços incompativeis, incluindo $\mathrm{K}$ e Ti, e normalizados para o manto primitivo, são mostradas nas Figuras 26 e 27. Para visualização mais fácil e análise comparativa, cinco dos seis gráficos apresentados representam combinações de perfis ("sombras") como fundo ao lado de perfis individuais de amostras. Como fundo, foram utilizados os diques máficos e os sienitos.

Todas as rochas mostram-se bastante enriquecidas nos incompativeis, cabendo aos diques máficos as menores taxas. Mesmo assim, eles exibem valores mais elevados (Fig. 26A) que as rochas menos evoluídas dos distritos alcalinos brasileiros sem carbonatitos (cf. Morbidelli et al., 1995b).

Considerando as razões $\mathrm{Rb}_{N} / Y_{N}, \quad \mathrm{Rb}_{N} / Z r_{N}$ e $Z r_{N} / Y_{N}$ como indicativas do grau de fracionamento médio, e as mais adequadas, ficam bastante destacadas (Fig. 26A) as fortes anomalias positivas para $\mathrm{Ba}, \mathrm{Nb}, \mathrm{La}, \mathrm{Ce}, \mathrm{Sr}$ e $\mathrm{Nd}$ e menos pronunciadas para $\mathrm{K}$ e $\mathrm{Ti}$. Se for tomada como referencial somente a primeira das razões, tem-se o aparecimento de anomalia negativa para $\mathrm{Zr}$, o que não seria facilmente explicável. As razões citadas são de $8,50,4,86 \mathrm{e}$ 1,75 , respectivamente, indicando fracionamento mais forte entre $\mathrm{Rb}$ e $\mathrm{Zr}$, e menos pronunciado a partir deste, como seria de se esperar. Outras razões normalizadas também indicam atenuação gradativa do fracionamento $\left(\mathrm{Ce}_{N} / Y_{N}=8,09, \mathrm{Nd}_{N} / Y_{N}=6,55\right)$.

Comparando-se graficamente os sienitos aos diques máficos (Fig. 26B), observa-se enriquecimento variável em $\mathrm{K}, \mathrm{Nb}, \mathrm{La}, \mathrm{Ce}, \mathrm{Nd}$ e $\mathrm{Zr}$, e empobrecimento em $\mathrm{Ba}, \mathrm{Sr}$ e $\mathrm{Ti}$, este bastante pronunciado nos dois últimos elementos. Rb passa a uma figura 1,3 a $2,5 x$ maior, e $Y$ mantém-se igual, a não ser por duas amostras enriquecidas $(6,5 x)$ e três empobrecidas (14x). As mesmas razões anteriores passam a 14,87, 4,85 e 3,06, respectivamente.

Com relação aos diques fonolíticos (Fig. 26C), o pequeno número de amostras empresta pouca segurança ao valor médio de alguns dos elementos ( $\mathrm{Nd}$, particularmente), mas no geral acentua-se o enriquecimento em $\mathrm{Nb}, \mathrm{La}, \mathrm{Ce}$ e $\mathrm{Zr}$, e o empobrecimento em $\mathrm{Ba}, \mathrm{Sr}$ e Ti. Os niveis de $\mathrm{K}$ se mantêm, Nd espalha-se para mais e para menos, e tanto $\mathrm{Rb}$ como $\mathrm{Y}$ aparecem enriquecidos. Essas tendências relacionam-se tanto às máficas como aos sienitos (Figs. 26A-C). As razões $\mathrm{Rb}_{N} / Y_{N}, \mathrm{Rb}_{N} / \mathrm{Zr}_{\mathrm{N}}$ e $\mathrm{Zr}_{\mathrm{N}} / \mathrm{Y}_{\mathrm{N}}$ passam, respectivamente, a 19,74, 1,98 e 9,94. Pelo valor da primeira e da última razão e a julgar pelos enriquecimentos $e$ 

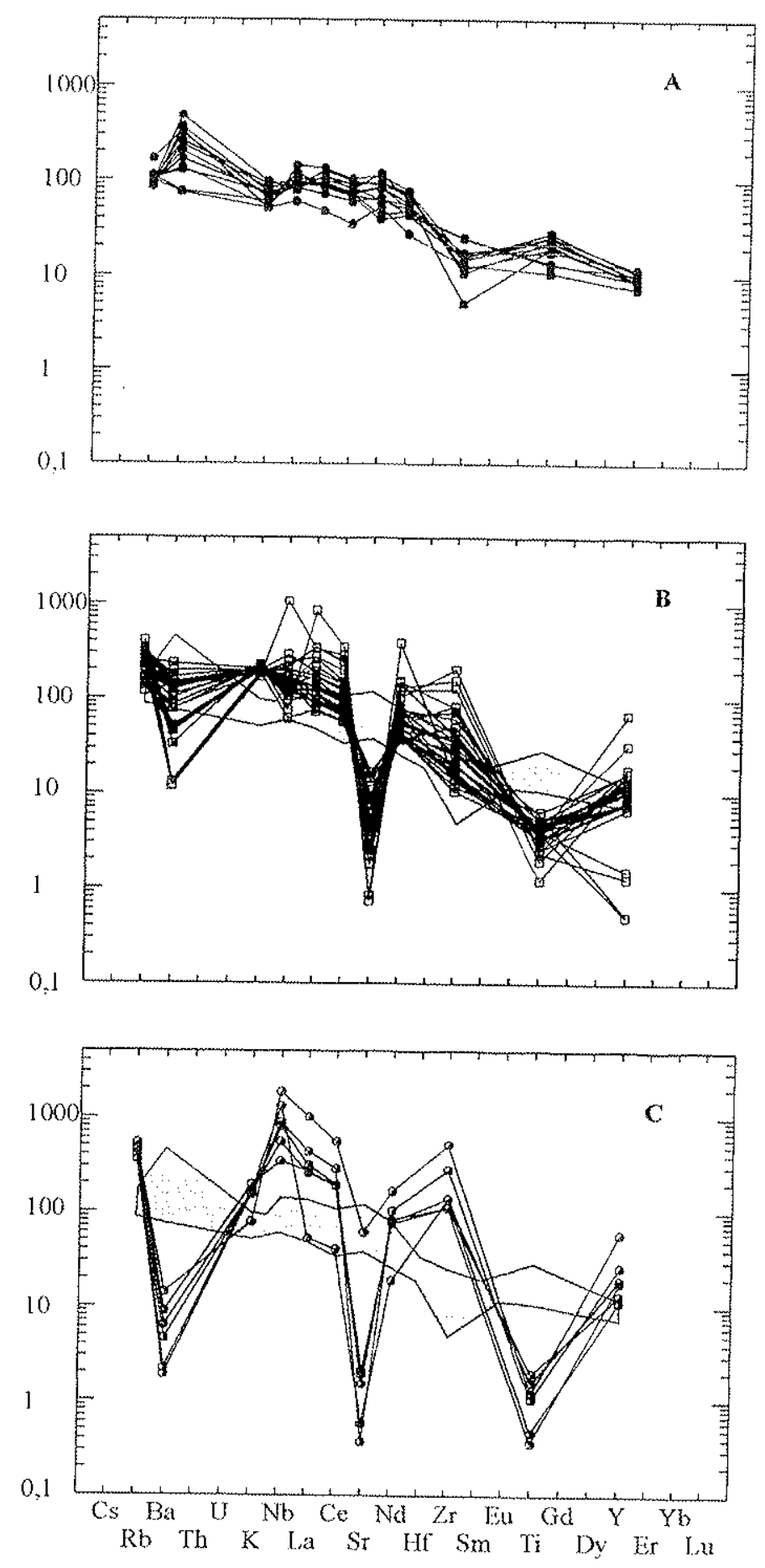

Figura 26 - Diagramas multi-elementos (spidergram) normalizados a partir do manto primitivo (Wood et al., 1979). A, diques máficos; B, sienitos, Q-sienitos e Ne-sienitos, sobre sombra de diques máficos; $\mathrm{C}$, diques insaturados sobre sombra de diques máficos. Símbolos como na Figura 20. 

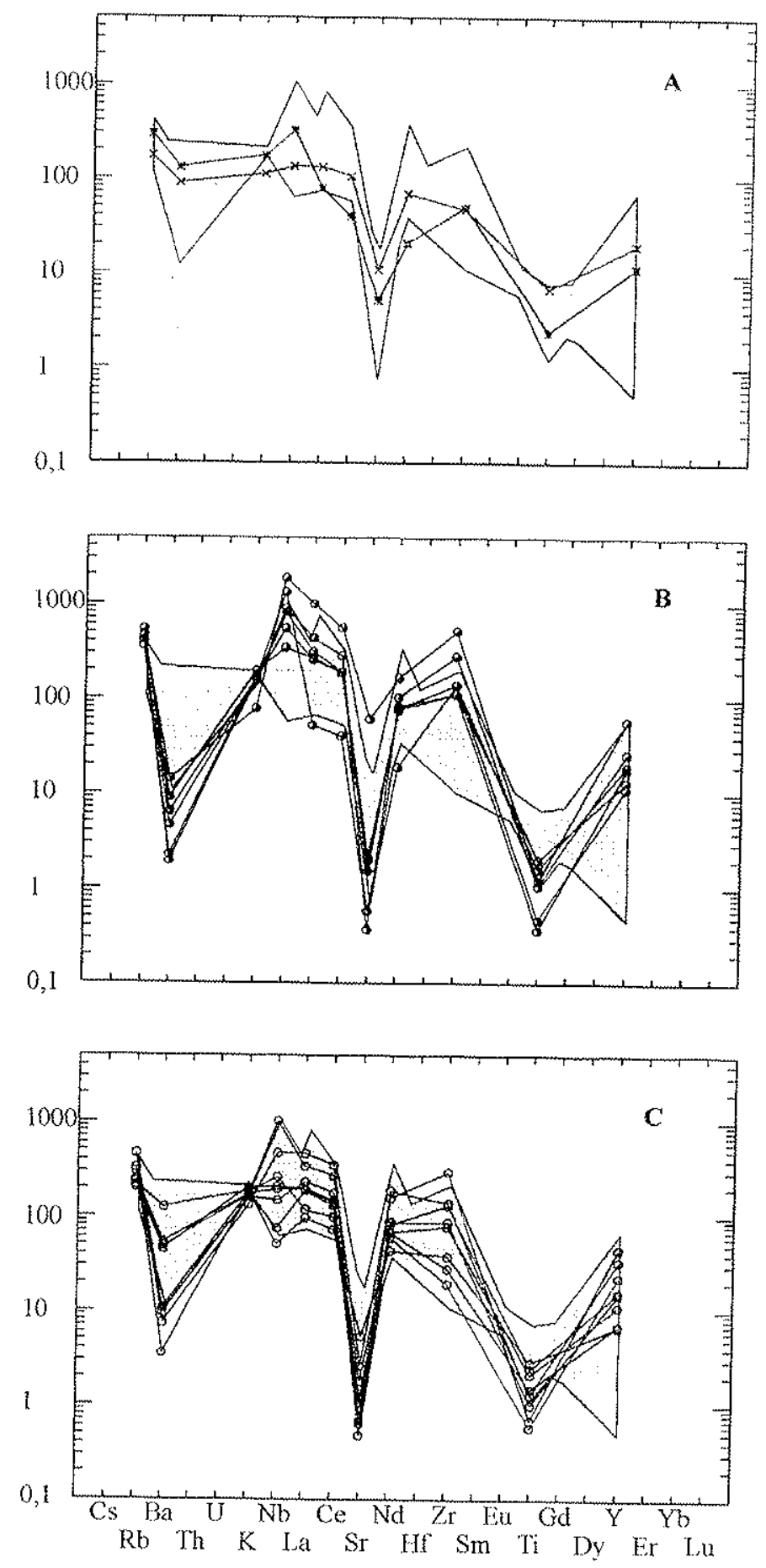

Figura 27 - Diagramas multi-elementos (spidergram) normalizados a partir do manto primitivo (Wood et al., 1979). A, Charnoquito de Ubatuba (média para 23 análises, Neumann, 1993) e mangerito sobre sombra de sienitos; $B$, diques insaturados sobre sombra de sienitos; $\mathrm{C}$, diques supersaturados sobre sombra de sienitos. Símbolos como na Figura 20. 
empobrecimentos relativos, parece que essas rochas (os fonólitos) se constituem nas mais evoluidas da liha.

A amostra de mangerito e os valores do "charnoquito de Ubatuba" (Fig. 27A) evoluem dentro dos limites dos sienitos, de forma mais ou menos concordante com estes, e completamente sem contrastes. Assim, qualquer dos elementos químicos envolvidos não poderia oferecer indicação de mistura ou contaminação por fusão das rochas encaixantes.

O gráfico reunindo fonólitos e sienitos (Fig. 27B) demostra que se acentuam os enriquecimentos e os empobrecimentos dos mesmos elementos dos sienitos, à exceção do $\mathrm{Ke}$ do Nd. A comparação das rochas "rioliticas" com os sienitos (Fig. 27C) mostra atenuação e um certo espalhamento de valores em relação aos enriquecimentos e empobrecimentos observados nos fonólitos, e bastante aproximação com o padrão exibido pelos sienitos. As razões $\mathrm{Rb}_{N} / Y_{N}, \mathrm{Rb}_{N} / \mathrm{Zr}_{\mathrm{N}}$ e $\mathrm{Zr}_{N} / Y_{N}$ passam, respectivamente, a 12,17, 2,09 e 5,82.

A razäo $\mathrm{Rb} / \mathrm{Y}$ indica que o fracionamento é mais intenso nos fonólitos, diminuindo nos sienitos e sendo menor nos diques máficos, ainda que estes, como referido, também representem tipos evoluidos. Os riólitos apresentam razão abaixo dos sienitos talvez devido ao maior enriquecimento de $\mathrm{Y}$ em relação a $\mathrm{Rb}$. A porção média das distribuições relativa aos mais incompativeis evidencia que, a despeito do enriquecimento nos sienitos, $\mathrm{Rb}$ e $\mathrm{Zr}$ mantiveram as proporções e aumentaram igualmente. Para os fonólitos, houve enriquecimento muito maior em $\mathrm{Zr}$, e pouco menos para os riólitos. As razões $\mathrm{Zr} / Y$, que podem servir como indicativo do fracionamento na porção dos elementos menos incompativeis, é bastante atenuada com relação ao perfil inteiro ou à sua parte inicial. Assim, as razões Rb/Zr são maiores para os diques máficos e sienitos, mas menores para fonólitos e "riólitos", provavelmente devido ao enriquecimento em Zr nessas últimas rochas.

Nas figuras examinadas, parece claro que as litologias mais evoluídas são os fonólitos, seguidos pelos "riólitos" e sienitos, estes sem dúvida as rochas félsicas menos diferenciadas. Contudo, quando comparados aos diques máficos, os sienitos mostram-se bastante mais evoluidos. Mesmo os tipos máficos já apresentam fracionamento, ainda que não exagerado, mas certamente mais proeminente que as rochas menos evoluidas de províncias magmáticas alcalinas brasileiras desprovidas de carbonatitos (cf. Morbidelli et al., 1995b).

\subsection{Considerações preliminares}

Nas Figuras 3 e 5, ilustra-se a geologia e a distribuição geográfica das rochas da llha dos Búzios, assim como a distribuição dos outros corpos alcalinos vizinhos. As relações de proximidade entre os corpos, muito mais íntima entre as litologias presentes em cada corpo, 
conduzem à tendência natural de associação entre corpos e litologias. Não estivessem os diques félsicos e máficos próximos uns aos outros, além de cortando o corpo sienítico da llha, seria muito dificil pensar-se na possivel evolução das rochas umas das outras, e com o processo se iniciando pelas mais primitivas presentes, as máficas.

Outras semelhanças e diferenças podem reforçar a hipótese de que as rochas sejam "cogenéticas" ou mesmo tornar inviável ou improvável tal hipótese.

A análise química das rochas e o tratamento dos resultados analíticos buscam caracterizámlas e classificá-las quimicamente, em uma primeira instância. Não menos importante é a análise dessas informações, que jamais irão provar a verdade hipotética, e nem o contrário. Padrões de evolução química semelhante, características químicas coerentes entre si, servirão para remover obstáculos a modelos formulados com base nas metodologias previamente empregadas. Não provarão nada, mas definirão diferenças e identidades evolutivas semelhantes, servindo para fortalecer, enfraquecer ou inviabilizar os modelos propostos.

A geologia, a petrografia e a química mineral não deixam muita dúvida sobre a associação de caráter cogenético das rochas félsicas da llha dos Búzios. A química das rochas demonstra que os sienitos são os tipos menos evoluidos, e que os fonólitos são os mais, a partir dos sienitos, em paralelo com os "riólitos", quimicamente pouco menos evoluidos que os fonólitos.

Admite-se, para a llha de São Sebastião, que o "stock" homônimo pode ter evoluido a partir de magma sienítico menos evoluído, semethante ao que deu origem às rochas do "stock" da Serraria (cf. Bellieni et al., 1990). Ora, os processos evolutivos em petrologia têm características de continuidade, sendo assim poder-se-ia admitir que o tipo magmático do "stock" da Serraria teria, por sua vez, se derivado de magma menos evoluido, e dos tipos sieniticos passar-se aos monzonitos etc., seguindo-se raciocinio inverso. Seria o bastante fracionar o plagioclásio e reduzir a atividade de alguns elementos químicos maiores ( $\mathrm{Ca}, \mathrm{Mg}$ ), processo teoricamente possivel e sem grandes obstáculos químicos e termodinâmicos. $O$ processo operante para São Sebastião teria sido a cristalização fracionada, com as rochas mais evoluidas apresentando $\mathrm{Eu}_{\mathrm{E}} \mathrm{Eu}^{*}>1$, compatível o com desenvolvimento cumulático de feldspatos.

A hipótese de evolução via acumulação de fases, talvez não só de feldspatos, decorrente da cristalização fracionada, foi sugerida para Búzios no Capitulo 7. É difícil imaginar outro processo para formar massas feldspáticas tão proeminentes e de composição tão monótona. O mesmo mecanismo poderia operar continuamente, somente aparecendo resultados mais volumosos a partir de massas críticas feldspáticas minimas. O processo pode 
ter operado, também, em outros distritos contendo corpos sieniticos semelhantes. Texíuras mais tipicas teriam sido obliteradas pelos processos "subsolidus", comumente ativos.

O modelo associativo dos sienitos, fonólitos e riólitos começa em Búzios nas relações de campo. Tanto a petrografia geral como as caracteristicas minerais mais minuciosas assinalam a grande identidade entre os tipos. A química mineral demonstrou a continuidade das composições das fases mais importantes, assim como as suas caracteristicas também semelhantes. Os elementos, maiores e traços, apresentam distribuição compativel com o mesmo modelo, e as razões entre alguns elementos, os incompatíveis de grupos variados (LFS, HFS e TR), mostram padrões evolutivos também consistentes com a idéia de sienitos menos evoluídos, pelo menos na porção emersa exposta. É possivel que, mais centralmente, o corpo alcalino de Búzios, bem como os outros vizinhos, contenham litologias mais evoluidas, possivelmente no sentido da insaturação em sílica e aumento dos álcalis e enriquecimento em parte desses elementos. As informações de campo, batimétricas, regionais, petrográficas e de química mineral são consistentes com a modelagem aproximada proposta para Búzios (Fig. 5), corroboradas na química das rochas, e pela mineralogia normativa decorrente, e que permite situar as amostras com nefelina normativa ou $\operatorname{com} Q=0$, ou muito baixo, nas porções a sul (Saco Grande) e a leste da Ilha.

A predominância dos feldspatos alcalinos é tão grande, e os processos "subsolidus", parcialmente ligados à presença de fluidos ativos, aquosos, talvez alcalinos, que os números da química de rocha total ressentem-se dessa característica. Invariavelmente, $\mathrm{SiO}_{2}+\mathrm{Al}_{2} \mathrm{O}_{3}$ somam, sozinhos, 76 a $85 \%$ em peso das rochas, restando 24 a $15 \%$ para os outros óxidos. Daí, talvez, as linearidades pobres, os espalhamentos relativos e até a falta de correlação mais definida para alguns dos elementos. Embora não mostrado graficamente, a correlação negativa moderada e discriminação dos grupos de rochas para $\left(\mathrm{Al}_{2} \mathrm{O}_{3} / \mathrm{SiO}_{2}\right) \times \mathrm{mg \#}$ é bastante evidente.

Aos processos tipicamente acumulativos, faltariam algumas feições típicas nos sienitos, ainda que observadas em rochas máficas vizinhas, e, provavelmente, resultantes do mesmo episódio magmático: as estratificações e as variações rítmicas, cripticas ou não. Quimicamente, só trabalhos metodologicamente orientados para essa feição especifica poderiam trazer informações.

Visto as rochas félsicas, resta um problema. $E$ os diques máficos? Por que a suposição de que representariam magmas parentais? Seriam "cogenéticos"/"comagmáticos"?

$\mathrm{Na}$ verdade, não estivessem cortando os sienitos e abundassem nas proximidades (muito embora, também pelo litoral todo e outras regiões), eles apenas conformar-se-iam a tipos magmáticos potencialmente parentais. Mas, estão lá, em intima associação com os sienitos. A afinidade alcalina, a composição quimica total compatível, os detalhes da sua 
mineralogia etc. aumentam de muito a probabilidade de que sejam realmente parentais, e não só potencialmente parentais.

Mas existem problemas. Primeiro, um "gap" composicional a $50-60 \%$ de $\mathrm{SiO}_{2}$ que se

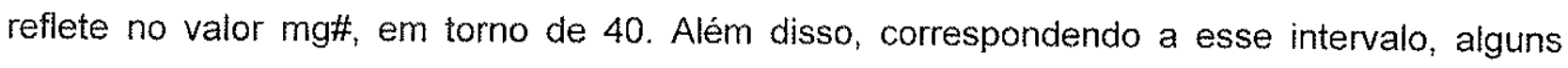
minerais exibem também quebra repentina composicional, não acomodável muito facilmente (ver, para os piroxênios, o comportamento dos elementos). Mesmo nos diagramas bivariantes químicos, a mg\# 40, raramente deixa de aparecer uma quebra, interrompendo a continuidade composicional. Para valores maiores e menores que esse índice, pode corresponder brusca alteração nas concentrações absolutas, bem como nas tendências. Tal característica é mais visivel entre os elementos maiores, especialmente $\mathrm{SiO}_{2}, \mathrm{FeO}_{\mathrm{t}}, \mathrm{MgO}, \mathrm{CaO}$ e $\mathrm{K}_{2} \mathrm{O}$, tornando-se mais atenuada entre os traços. Sem dúvida, um número maior de análises modificaria os padrões das curvas, podendo, contudo, até piorá-las.

Mudanças nas condições físico-químicas do magma em evolução, talvez decorrentes de causas externas? Tectônicas, de larga escala, por alterações mais ou menos rápidas, nas condições de equilíbrio-desequilíbrio termomecânico regional? Como conseqüência dessas situações hipotéticas, poderia haver mudança acentuada na atividade em sílica, $\mathrm{fO}_{2}, \mathrm{fH}_{2} \mathrm{O}$, ocasionando salto composicional. Fase cumulática nova, quimicamente diferente, poderia alterar modal e quimicamente os produtos. São especulações, que esbarram em contraargumento: e os elementos que apresentam evolução normal? Nesse caso, pode-se dizer que somente $\mathrm{Ni}$ e $\mathrm{Cr}$, entre os compatíveis, exibem padrão regular, além do $\mathrm{Na}_{2} \mathrm{O}$.

Qualquer que seja a alternativa, os diques máficos mostram afinidades com as rochas félsicas, e poderiam representar magmas parentais, já evoluídos, porém.

A ligação da evolução dos magmas félsicos, por fusão parcial das encaixantes, a partir dos sienitos ou dos fonólitos, não encontra muito respaldo na quimica das rochas. As encaixantes destacam-se pouco e ocupam posições tais que, geometricamente, não explicariam as composições félsicas a partir da mistura máficas-encaixantes. Talvez o charnoquito de Ubatuba, que assume composições intermediárias entre os sienitos e parte dos riólitos, ou entre parte dos fonólitos (os mais evoluídos) e os sienitos, pudesse explicar parcela da evolução e dos tipos presentes, nas interações sienitos-charnoquito-quartzo sienitos + riólitos e fonólitos - charnoquitos - sienitos. 


\section{CAPITULO 9}

\section{ISOTOPIA KJAr E Rb/Sr E GEOCRONOLOGIA}

É bastante grande o número de idades disponiveis sobre as rochas alcalinas do sudeste brasileiro, desde os idos de 1966 (Amaral et al., 1967; Sonoki e Garda, 1988; Ulbrich et al., 1991). A grande maioria utiliza informações KJAr. Outras metodologias, e outras finalidades que não a obtenção de idades, contam com menor número. É o caso das idades Rb/Sr e das razões iniciais ${ }^{87} \mathrm{Sr} /{ }^{86} \mathrm{Sr}$.

Neste trabalho foram obtidas 9 análises $\mathrm{K} / \mathrm{Ar}$ e $5 \mathrm{Rb} / \mathrm{Sr}$, sendo os dados reunidos nas Tabelas 25,26 e 27.

\subsection{Idades $\mathrm{K} / \mathrm{Ar}$}

Quatro das idades são de sienitos. Os resultados, brutos, indicam idade média de $82,3 \pm 4,4 \mathrm{Ma}$. A idade média selecionada, ou mesmo preferencial, é de $81,4 \pm 2,6 \mathrm{Ma}$. Entre os cinco diques datados, foram selecionados apenas dois, e separadas três idades muito

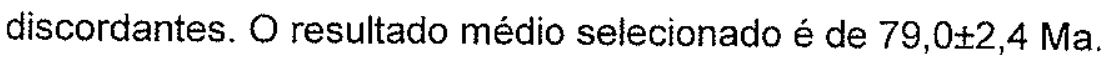

As idades discordantes dos diques referem-se às amostras $\mathrm{BZ} 327 \mathrm{C}(97,2 \pm 2,6 \mathrm{Ma})$, BZ 181A $(117,0 \pm 6,9 \mathrm{Ma})$ e BZ 326C $(148,3+5,8 \mathrm{Ma})$. O valor da primeira, um quartzo microssienito/microgranito encaixado em zona de contato sienito-charnoquito, é boa do ponto de vista laboratorial (ver Tabela 25), mas inconsistente geologicamente, pelo menos ao nível do que se conhece. Se a rocha é mais antiga, afetada por longo tempo pelo sienitos, tenderia a dar idade bem próxima a estes. A amostra BZ 181A, um basalto alcalino cortando os sienitos da Ponta Leste, já não é tão boa, laboratorialmente. A única explicação para esse valor é o excesso de ${ }^{40} \mathrm{Ar}$, derivado das encaixantes Brasilianas. A terceira amostra apresenta idade aceitável laboratorialmente e geologicamente possivel. Ela corresponde a um dique máfico de

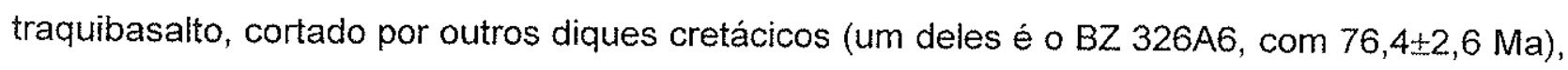
encaixados nos charnoquitos, mas à distância considerável dos sienitos. A única ressalva é que foi usada rocha total, com possivel presença de carbonatos e vidro. Esses materiais poderiam rebaixar os valores, mas não aumentá-los. Essa idade pode ser real e indicar atividade alcalina, no local, mais precoce.

\subsection{As informações $\mathrm{Rb} / \mathrm{Sr}$}

Os resultados analíticos e aqueles obtidos através do programa ISOJOB (Vlach, 1990) constam das Tabelas 26 e 27. 
Tabela 25 - Valores analíticos para K e Ar e idades para as rochas da llha do Búzios.

\begin{tabular}{|c|c|c|c|c|c|c|c|c|c|}
\hline SPK & Amostra & Rocha & Material & $\% \mathrm{~K}$ & $\begin{array}{l}75 \% \\
\text { Erro }\end{array}$ & $\begin{array}{c}\operatorname{Ar} 40 \\
\operatorname{Rad}\end{array}$ & $\begin{array}{l}\text { Ar.Atm. } \\
(\%)\end{array}$ & $\begin{array}{l}\text { Idade } \\
\text { (Ma) }\end{array}$ & $\begin{array}{c}\text { Erro } \mathrm{Ma} \\
(\%)\end{array}$ \\
\hline 4916 & $\mathrm{BZ} 148 \mathrm{~A}$ & Sienito & Biotita & 7,0891 & 0,5000 & 24,39 & 16,55 & 86,5 & $2,8 \quad(3,3)$ \\
\hline 4946 & $\mathrm{BZ} 100 \mathrm{Bl}$ & Q-Sienito & Anfibólio & 0,7628 & 4,4638 & 2,43 & 55,47 & 80,7 & $9,7(12,1)$ \\
\hline 7398 & BZ, $327 \mathrm{C}$ & Microgranito & Biotita & 6,9133 & 0,5851 & 26,82 & 11,94 & 97,2 & $2,6 \quad(2,6)$ \\
\hline 7401 & $\mathrm{BZ} 158^{A} \mathrm{E}$ & Sienito & Biotita & 7,3936 & 0,5000 & 23,77 & 15,21 & 80,9 & $2,0 \quad(2,4)$ \\
\hline 7402 & $\mathrm{BZ} 163 \mathrm{~B}$ & Ne-microssienito & Biotita & 5,8298 & 0,5000 & 18,93 & 12,30 & 81,7 & $2,3 \quad(2,8)$ \\
\hline 7403 & $\mathrm{BZ} 181 \mathrm{~A}$ & Basalto alcalino & Anfibólio & 0,6044 & 0,5000 & 2,84 & 38,66 & 117,0 & $(5,9)$ \\
\hline 7404 & $\mathrm{BZ} 326 \mathrm{C}$ & Traquibasalto & Rocha total & 1,5464 & 2,3535 & 9,28 & 4,67 & 148,3 & $5,8 \quad(3,9)$ \\
\hline 7405 & $\mathrm{BZ} 171 \mathrm{~F}$ & Sienito & Biotita & 7,3493 & 0,6020 & 23,68 & 11,76 & 81,1 & $3,2 \quad(4,0)$ \\
\hline 7413 & $\mathrm{BZ} 326 \mathrm{~A} 6$ & Tefrito & Biotita & 5,8733 & 1,2371 & 17,79 & 16,50 & 76,4 & $2,6 \quad(3,4)$ \\
\hline
\end{tabular}

Tabela 26 - Valores analíticos para $\mathrm{Rb}$ e $\mathrm{Sr}$ e razões ${ }^{87} \mathrm{Sr} /{ }^{86} \mathrm{Sr}$ e ${ }^{87} \mathrm{Rb} /{ }^{86} \mathrm{Sr}$ para rochas da llia dos Búzios.

\begin{tabular}{|c|c|c|c|c|c|c|c|c|}
\hline SPK & Amostra & Rocha & Rb ppm & Sr ppm & $\begin{array}{c}\text { Razão } \\
\text { medida } \\
{ }^{87} \mathrm{Sr}{ }^{86} \mathrm{Sr}\end{array}$ & Erro \pm ) & ${ }^{87} \mathrm{Rb} /{ }^{86} \mathrm{Sr}$ & Erro ( $t)$ \\
\hline 12947 & $\mathrm{BZ} 3136 \mathrm{~A}$ & Basanito & 55 & 1208 & 0,70510 & 0,00010 & 0,132 & 0,004 \\
\hline 12948 & $\mathrm{BZ} \mathrm{177}$ & Sienito & 112 & 130 & 0,70798 & 0,00007 & 2,494 & 0,071 \\
\hline 12949 & $\mathrm{BZ} 178 \mathrm{C}$ & Fonólito & 306 & $\sim 4$ & 0,89205 & 0,00094 & 243,706 & 6,768 \\
\hline 12950 & $\mathrm{BZ} 165 \mathrm{~B}$ & Fonólito & 236 & 35 & 0,72569 & 0,00007 & 19,550 & 0,552 \\
\hline 12951 & $\mathrm{BZ} 326 \mathrm{~A} 7$ & Tefrito & 49 & 2304 & 0,70481 & 0,00015 & 0,062 & 0,002 \\
\hline
\end{tabular}


Tabela 27 - Razões iniciais calculadas com o programa ISOJOB (Vlach, 1990) a partir das xazões medidas (atuais), para várias idades hipotéticas de rochas da Ilha dos Búzios.

\begin{tabular}{|c|c|c|c|c|c|c|}
\hline Amostra & Rocha & Razão medida ${ }^{87} \mathrm{Sr}{ }^{86} \mathrm{Sr}$ & \multicolumn{4}{|c|}{ Razões Inicias calculadas } \\
\hline & & & $85 \mathrm{Ma}$ & $80 \mathrm{Ma}$ & $75 \mathrm{Ma}$ & $70 \mathrm{Ma}$ \\
\hline $\mathrm{BZ} \mathrm{3136}{ }^{\mathrm{A}}$ & Basanito & 0,70510 & 0,70494 & 0,70495 & 0,70496 & 0,70496 \\
\hline BZ 177 & Sienito & 0,70798 & 0,70497 & 0,70514 & 0,70532 & 0,70550 \\
\hline $\mathrm{BZ} 178 \mathrm{C}$ & Fonólito & 0,89205 & 0,59772 & 0,61504 & 0,63236 & 0,64968 \\
\hline $\mathrm{BZZ} 165 \mathrm{~B}$ & Fonólito & 0,72569 & 0,70208 & 0,70347 & 0,70486 & 0,70625 \\
\hline $\mathrm{BZ} 326 \mathrm{A7}$ & Tefrito & 0,70481 & 0,70473 & 0,70474 & 0,70474 & 0,70475 \\
\hline Médias & & & 0,70418 & 0,70457 & 0,70497 & 0,70536 \\
\hline Desvios & & & $0,199 \%$ & $0,110 \%$ & $0,035 \%$ & $0,094 \%$ \\
\hline
\end{tabular}

Tendo em mãos as idades KAr, mesmo que não representem idades absolutamente seguras, pode-se chegar às razões ${ }^{87} \mathrm{Sr} r^{86} \mathrm{Sr}$ iniciais, conhecidas as concentrações de $\mathrm{Rb}$ e $\mathrm{Sr}$ atuais, totais. Dessa forma, obter-se razões diferentes, via tentativas com diferentes valores para KJAr. É bastante interessante que a razão $\mathrm{Rb} / \mathrm{Sr}$ total seja a menor possivel, mas razões atuais mais altas não invalidam o método. A validade do método baseia-se no fato de que, conhecido o decaimento do $\mathrm{Rb}$ e a idade da rocha, é possivel calcular-se o ${ }^{87} \mathrm{Sr}$ proveniente do decaimento no intervalo pós-cristalização. Em geral, para rochas relativamente jovens, $0{ }^{87} \mathrm{Sr}$ radiogênico é de pequena monta face ao já existente no magma em cristalização.

Foram empregadas várias amostras, com teores e razões $\mathrm{Rb} / \mathrm{Sr}$ diferentes. Essa situação permite também viabilizar "isócrona" ("errócrona") de referência. A fim de avaliar os resultados da aplicação do $1 S O J O B$, foram utilizadas idades variáveis entre 65 e $85 \mathrm{Ma}$, para as cinco amostras. Uma delas, BZ 178C, com dados conflitantes para os teores de $\mathrm{Rb}$ e $\mathrm{Sr}$, acabou sendo desprezada à vista dos resultados dispersos e muito diferentes encontrados nas demais amostras. Razões iniciais calculadas para essa amostra, com diferentes dados iniciais, apontam para valores inferiores a 0,70000 , obviamente impossiveis. Fracionamento isotópico natural é discutivel, mas parece que há indicações de que possa ocorrer em circunstâncias especiais, pela atuação de soluções/fluidos enriquecidos, ou pelo $\mathrm{Ca}^{+}$, ou por trocas catiônicas em feldspatos e micas (cf. Faure e Powell, 1972). A amostra BZ 178C é de um fonólito, altamente evoluído, agpaítico e com mineralogia acessória rara.

Com a finalidade de obter-se razão inicial mais veridica possivel, e que deveria corresponder à melhor idade, procurou-se ajustar os valores das várias razões obtidas para as diversas amostras, a diferentes idades. Os desvios padrões para as amostras minimizam-se 
em torno de $0,025 \%$, ponto de inflexão (mínimo) para a curva parabólica resultante dos desvios obtidos entre $65 \mathrm{Ma}$ e $85 \mathrm{Ma}$, com desvios máximos em torno de 0,18-0,20\%. Combinando-se esse parâmetro, com a reta negativa idade-razão inicial, chegou-se a $R_{0}=0,705000$, correspondente a 74,5 Ma. Este valor considerado como média mínima. As razões iniciais para cada tipo de rocha podem ser aquelas correspondentes a $75 \mathrm{Ma}$ : amostra BZ 313A, basanito,

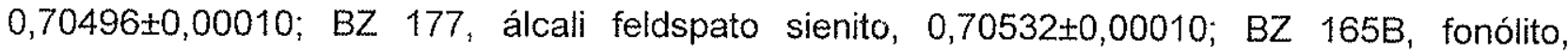

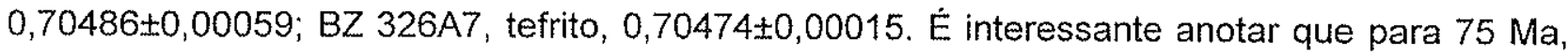
a razão inicial média entre as amostras é pouco diferente, 0,70497, com desvio padrão absoluto de $0,00025(0,035 \%)$. As representantes máficas, por apresentarem razões $\mathrm{Rb} / \mathrm{Sr}$ muito baixas, têm seus valores de razões iniciais pouco variáveis no intervalo 65-85 Ma: 0,70498-0,70495 e 0,70475-0,70474, para o basanito e o tefrito, respectivamente.

Pode-se, finalmente, tomar como valores finais, para a utilização do ISOJOB, 0,70500 como razão inicial média para sienitos, fonólitos e diques máficos. Como razões extremas, para a mesma idade de $75 \mathrm{Ma}$, os valores de 0,70474 para o tefrito, e 0,70532 para o sienito. Se assumir-se idade mais próxima aos valores $\mathrm{K} / \mathrm{Ar}$, diga-se $80 \mathrm{Ma}$, esses valores passariam a 0,70347, do fonólito, e 0,70514, para o mesmo sienito.

O programa ISOJOB, seus resultados e tratamentos matemáticos posteriores, assumem algumas premissas. Primeiro, tal como aplicado para Búzios, as rochas devem ser comagmáticas, isto é, derivadas de fonte única ou de fontes com leves diferenças quimicas e isotópicas, e com evolução sequencial. Corretos os pressupostos, dever-se-iam obter razões iniciais iguais ou muito próximas para as mesmas idades, em diferentes amostras (o que ocorre). Se, a partir dos mesmos dados analiticos, fosse construido um diagrama isocrônico (ou ${ }^{87} \mathrm{Sr} /{ }^{86} \mathrm{Sr} \times{ }^{87} \mathrm{Rb} /{ }^{86} \mathrm{Sr}$ ), as idades e as razões iniciais deveriam resultar iguais ou muito próximas.

A "errócrona" da Figura 28 foi construida com base nos mesmos valores analíticos, descartada a amostra BZ 178C. Na medida em que os pontos estão dispersos, e dois deles (basanito e tefrito) quase fornecem diretamente as razões iniciais, por se acharem muito próximos ao eixo ${ }^{87} \mathrm{Sr} /{ }^{86} \mathrm{Sr}$, a reta definida não é destituida de valor, muito embora o valor de MSWD $(4,952)$ seja considerado elevado.

As razões atuais das amostras máficas são de 0,705100 e 0,704810, com média de 0,704955 , muito próxima ao valor encontrado. Seus valores para $\mathrm{Rb}$ e $\mathrm{Sr}$ de 55 e $49 \mathrm{ppm}$ e 1208 e 2304 ppm, respectivamente, são convenientes, mas estão nos limites, ou os ultrapassam para a utilização de determinações feitas por fluorescência de raios $X$; o certo seria nova dosagem por diluição isotópica, o que não ocorreu. Nesses casos, o CPGeo do IGUSP desautoriza o uso do termo "isócrona". Não obstante, a Figura 28 mostra resultados 


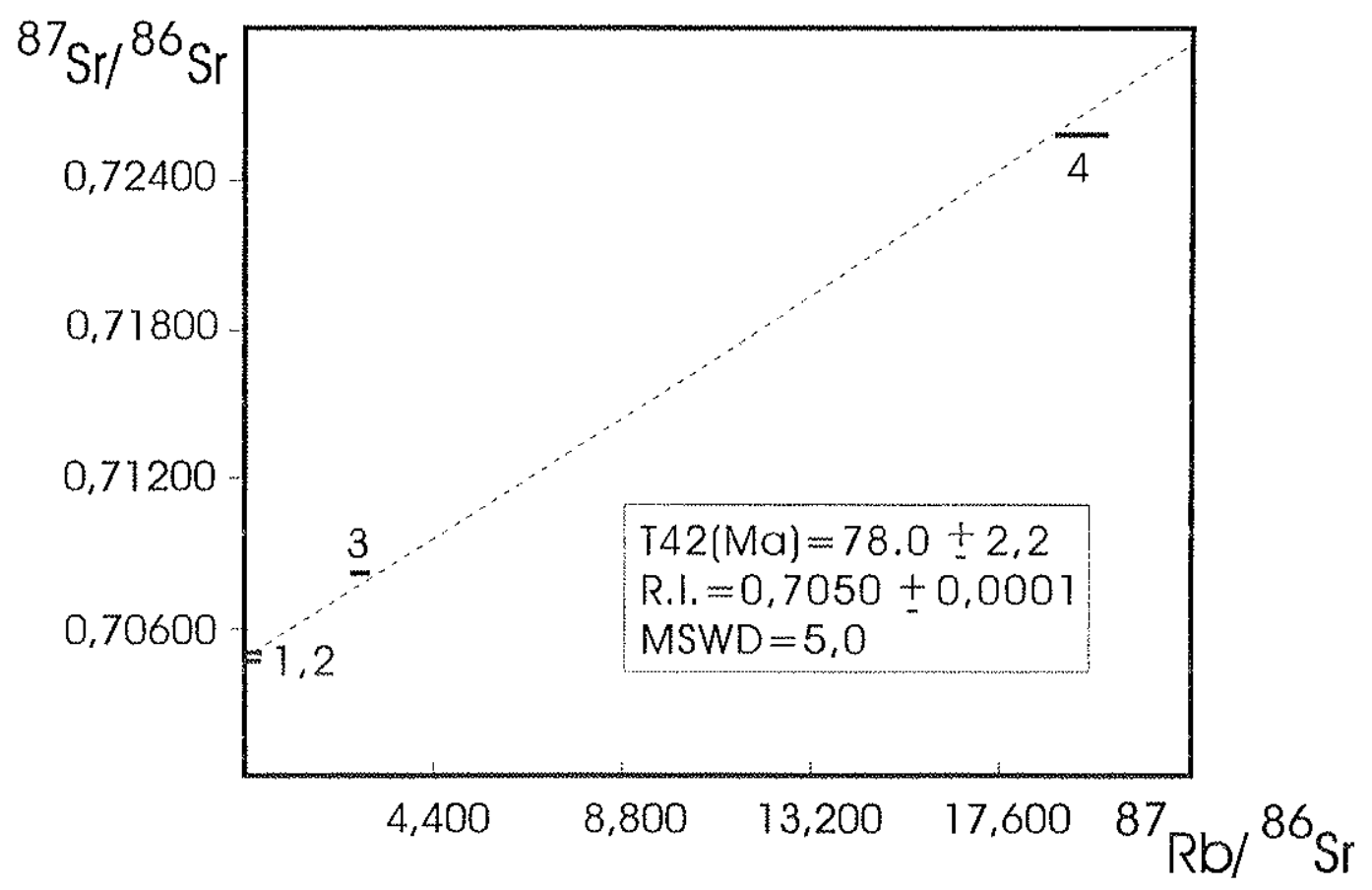

Figura 28 - Gráfico ${ }^{87} \mathrm{Sr} /{ }^{86} \mathrm{Sr} \times{ }^{87} \mathrm{Rb} /{ }^{86} \mathrm{Sr}$ para rochas alcalinas da llha dos Búzios. Valores analíticos obtidos de rochas totais. As barras indicam desvio padrão dos valores médios. Amostras: 1, BZ 313/6A e 2, BZ 326A7, diques máficos; 3, BZ 177 , sienito; 4, BZ 165B, fonólito. 
bastante aceitáveis: idade de 78,0 $\pm 2,2 \mathrm{Ma}$, com $R_{0}=0,70500 \pm 0,00008$, com valor elevado de MSWD, porém. Valores convergentes, em certa medida, com a utilização do ISOJOB.

\subsubsection{Avaliação e discussão dos resultados}

As idades das rochas da liha dos Búzios estão balizadas pelos valores $\mathrm{K} / \mathrm{Ar}$ de 81,4 Ma e 79,0 Ma, respectivamente, para sienitos e diques (em geral), e pelos resultados de $75 \mathrm{Ma}$, para o desvio padrão mínimo das razões iniciais, com a utilização do programa ISOJOB (cf. Vlach, 1990), e 78,0 2 2,2 Ma, resultante de "errócrona". As idades K/Ar discriminam sienitos e diques, e a metodologia $\mathrm{Rb} / \mathrm{Sr}$ fornece resultado médio, admitindo contemporaneidade e caráter comagmático e cogenético para todos os tipos. As razões iniciais ${ }^{87} \mathrm{Sr} /{ }^{86} \mathrm{Sr}$ balizam-se pelos valores de 0,70500 0,0001 , pela "errócrona", concordante com o valor 0,70500 , com a utilização do ISOJOB e curvas de ajustes de desvios padrões e da reta idade $x$ RI. Pouco diferentes disso, embora muito próximas aos valores reais, são as razões atuais para o tefrito e o basanito, mas cuja média, praticamente, é coincidente: 0,70495.

Para a llha de Vitória, as idades existentes são de $80,32 \pm 1,97 \mathrm{Ma}$ a $89,58 \pm 3,18 \mathrm{Ma}$

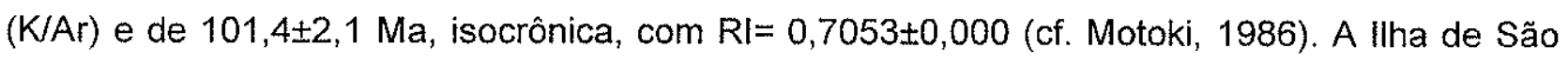
Sebastião mostra valor médio, recalculado (cf. Sonoki e Garda, 1988), de $84 \pm 3 \mathrm{Ma}$, para os sienitos, e valor mínimo de $78 \pm 8$ Ma para os diques (valores iniciais de K/Ar cf. Amaral et al., 1967). Informaçöes $\mathrm{Rb} / \mathrm{Sr}$, para $84 \mathrm{Ma}$, fornecem valores de 0,70533 e 0,70507, respectivamente, para os "stocks" da Serraria e do Mirante, e de 0,70462 e 0,70433, para os basanitos e tefritos, respectivamente (cf. Bellieni et al., 1990). Nefelina sienito (feldspato alcalino) e "rhomb porphyry" (biotita) da llha do Monte de Trigo indicam idades K/Ar de 79,9 e 79,8 Ma (cf. Coutinho e Melcher, 1973). Razões iniciais ${ }^{87} \mathrm{Sr} /{ }^{86} \mathrm{Sr}$, compiladas para várias províncias alcalinas brasileiras, indicam frequência máxima acentuada para o valor 0,7050 0,7055 (cf. Morbidelli et al., 1995); em outra compilação mais recente, em que se comparam alcalinas brasileiras e paraguaias, o mesmo intervalo mostra a mesma frequência máxima (cf. Gomes et al., 1996). Interessante nesta última comparação é o fato de que a essa freqüência máxima corresponde ausência de valores no Paraguai, que ou se mostram menores ou maiores.

Finalmente, Faure e Powell (1972) apresentam compilação de $R_{0}$ para rochas alcalinas variadas do mundo todo, sendo o menor valor, 0,7034, relacionado com os carbonatitos do "rift" africano.

Finalizando este capítulo, pode-se concluir que há carência de dados mais confiáveis $\mathrm{K} / \mathrm{Ar}$, e que a confiabilidade das determinações existentes é muito variada. 
Faltam também idades Rb/Sr para quase todas as ocorrências. É possivel que rochas plutônicas e diques sejam discrimináveis geocronologicamente, principalmente a partir do momento em que se passe a contar com datações ${ }^{40} \mathrm{Ar} /{ }^{39} \mathrm{Ar}$. 


\section{CAPÍTULO 10 CONSIDERAÇÕES FINAIS}

A região sudeste da Plataforma Brasileira (Almeida, 1967) mostra evolução peculiar, com relação às margens continentais atlânticas sul-americanas. Embora mantenha semelhança com as porções mais meridionais e mais setentrionais, a diversidade, as dimensões e a intensidade dos registros tectônicos e magmáticos não têm similar. Parece haver consenso quanto à interrelação do rifteamento atlântico e a separação do Brasil e África, e as manifestações sincrônicas magmáticas e formação das bacias marginais.

Os eventos que antecederam e acompanharam o desmembramento do supercontinente gondwânico são, ao que tudo indica, mais antigos e de amplitude muito maior que os registros da região sudeste (cf. Almeida, 1967; Gomes et al., 1996). Já Freitas (1947) chamava a atenção para as similaridades estruturais, tectônicas e magmáticas entre os dois continentes, e remetia os eventos ao Permiano.

Possiveis origens mantélicas para as várias manifestações magmáticas, com inicio já no Permo-Triássico, esparsamente registradas, associam as idades a anomalias termomecânicas (termotectônicas e termomagmáticas) mantélicas iniciadas há mais de 1500 Ma.

É bastante provável que, concluido o ciclo Brasiliano ( $\pm 600 \mathrm{Ma}$ ou menos), os efeitos das anomalias termais mantélicas se fizessem sentir na Bacia do Paraná, já em formação, com depósitos silurianos e ordovicianos. $O$ abatimento da depressão intracratônica prosseguiu pelo menos até o Permo-Carbonífero, sem registros magmáticos.

A já notória reativação Wealdeniana (Almeida, 1967) tem sido, de certa forma, dividida em dois eventos sul-atlânticos, o mais antigo batizado como "Evento Sul-Atlantiano Precoce" (Conceição et al., 1988).

São muitas as evidências de que, realmente, o tectonismo de rifteamento do Atlântico Sul começou bem mais cedo, por volta de $225 \mathrm{Ma}$, em tempos triássicos ou pós-permianos. Essa primeira fase, precoce, teria durado até $160 \mathrm{Ma}$, já no Jurássico Superior. São evidências dessa fase (cf. Conceicão et al., 1988), as pulsações magmáticas, os riftes, a alteração na estratigrafia das bacias existentes etc. Ao que tudo leva a crer, os registros seriam reflexos de rearranjos das placas.

É interessante assinalar o modelo evolutivo do Arco de Ponta Grossa, estrutura persistente e importante nas relações com o magmatismo mesozóico. De acordo com os trabalhos da Petrobrás (p.e. Conceição et al., 1988), as formações juro-triássicas indicam uma região elevada, pois que se afinam contra o Arco, gradativamente. Formações permianas e 
cretácicas (os basaltos) mostram claras transgressões sobre a região do Arco, não demonstrando estar ele elevado na ocasião.

Entre os indicios crustais, com origem mantélica muito mais antiga, e espalhados por toda a Plataforma Brasileira, também merece destaque a rehomogeneização isotópica do $\mathrm{Sr}$ para várias formações da Bacia do Paraná (Formação Ponta Grossa - Formação Rio do Rastro), certamente ligada a evento térmico de aquecimento anormal, e datado de $180 \mathrm{Ma}$.

De modo geral, os registros tidos como precoces apontam para movimentações crustais, em ambiente distensional generalizado. Como resultado, o rifteamento ter-se-ia iniciado no Platô das Malvinas, atingindo até a Bacia de Pelotas.

O segundo evento, tardio, cujos registros são mais fartos, teve seu início há $160 \mathrm{Ma}$, dando prosseguimento ao processo de abertura a partir do Platô de São Paulo.

\subsection{Esboço da evolução geológica da Região Sudeste}

É a partir do final do Jurássico, e durante o Cretáceo e o Cenozóico, que se deu a fase mais intensa de magmatismo e tectonismo em toda região sudeste.

O episódio mais formidável, sem dúvida, foram os derrames basálticos da Bacia do Paraná, com idade aproximada de 120-130 Ma, e duração provável de $10 \mathrm{Ma}$, ou mais (Mantovani et al., 1994).

Logo após o extravasamento das lavas basálticas, que compartimentadas ou não, são correlacionáveis às da Namíbia, deve termse iniciado a fase de falhamentos axiais. Como visto, Conceição et al. (1988) separa os ciclos de rifteamento em dois: o primeiro, entre 160-225 Ma, indiviso, e o segundo, com $45 \mathrm{Ma}$ de duração, entre 115-160 Ma, dividido, em bases sedimentológicas e bioestratigráficas, em uma fase de depressão (135-160 Ma) e outra de falhamentos (115-135 Ma). Supostamente, sedimentos pré-basaltos devem estar presentes na Bacia de Santos, e em outras, que então se formaram.

Além dos derrames basálticos, diques de litologia e idade similares estão presentes por toda a parte, às bordas erosivas da atual Bacia do Paraná. Assim é no litoral norte de São Paulo, até o Rio de Janeiro, incluindo a llha de São Sebastião.

Algumas datações de rochas alcalinas demonstram que elas antecedem e são simultâneas aos basaltos (Ulbrich et al., 1991; Garda et al., 1994), já indicando condições de formação de magmas alcalinos a partir do manto, a taxas de fusão parcial menores. Há uma certa correlação entre grau de afinamento crustal, alteração no equilibrio térmico e posicionamento das isotermas (Chang et al., 1990) e, simultaneamente, despressurização e eventual fusão mantélica. Quanto maior o afinamento crustal, mais favoráveis as condições para fusões parciais de maior monta e, como conseqüência, a geração de magmas de caráter 
mais básico. A menores taxas de afinamento, menor é a fusão, e maiores as chances de formação de magmas alcalinos. De modo geral, essas taxas devem situar-se em torno dos 5 m $10 \%$.

Esse panorama, resumido, procura juntar causas (mantélicas) e efeitos, tectônicos e magmáticos.

De certa forma, boa parte da tectônica antecedeu os fenômenos magmáticos, mas, a rigor, há alguma simultaneidade dos eventos.

São importantes no sudeste, tectonicamente a evolução da Serra do Mar e das depressões marginais. É dificil entender a elevação da Serra do Mar como proposta por vários autores (Almeida, 1976, 1983; Almeida e Carneiro, 1989) sob regime distensional. O topo da Serra da Mantiqueira, possível continuação da Serra do Mar para oeste, eleva-se a $2.000 \mathrm{~m}$, e a Bacia de Santos, em frente, tem seus depósitos centrais a $8.000 \mathrm{~m}$, e até a $13.000 \mathrm{~m}$, com desnivelamentos de 10.000 a $15.000 \mathrm{~m}$.

É provável que as elevações continentais tenham se iniciado no Cretáceo Inferior, servindo como fonte para sedimentos terrigenos, parcialmente associados à Formação Serra Geral, quase simultâneos aos basaltos. A grande espessura de sedimentos do Cretáceo, na Bacia de Santos, deve ser proporcional ao levantamento das áreas vizinhas a leste. O próprio Falhamento de Santos, mais ou menos coincidente com a Charneira da Bacia, pode ter sido o primeiro limite do fronte da Serra do Mar, atualmente recuada a $70 \mathrm{~km}$.

No Eoceno (Paleoceno?), rifteamento de menor escala originou o rifte do Vale do Paraiba, que teria passado, em seguida, a uma bacia do tipo "pull-a-part". O pacote sedimentar cretácico, mais espesso em Santos, tornou-se mais espesso no Cenozóico, na Bacia de Campos, talvez por influência do rio Paraíba, enclausurado. Com certeza no início, essa nova Bacia foi pouco deprimida, a julgar pelos sedimentos finos das camadas de base (Formação Tremembé). À mesma época, e mesmo posteriormente, devem ter-se formado outras bacias e depressões relacionadas à tectônica iniciada no Juro-Cretáceo ("graben" da Guanabara, Bacia de Itaboraí etc.).

Parte do cenário de hoje, iniciado há mais ou menos $140 \mathrm{Ma}$, conserva problemas não resolvidos. A Bacia de Taubaté (=Paraiba) é pouco conhecida e tem sua maior espessura próximo à Pindamonhangaba, com $800 \mathrm{~m}$, portanto, com a sua base abaixo do nivel do mar. Trabalho sísmico da Petrobrás (Marques, 1990) mostra refletor na base, não identificado, mas possivelmente representando rochas igneas, talvez básicas (sapata? derrames?).

A taxa de erosão é uma incógnita. Seria importante ter-se pelo menos uma idéia, já que parte da diferença entre os corpos alcalinos, quase certamente, é devida ao nivel de exposição atual. 
Não há um único trabalho finat sobre a evolução da margem continental, que sintetise e dê resposta satisfatória a todos os problemas. O acúmulo e a velocidade das informações provenientes das perfurações e dos perfis geofísicos da Petrobrás é muito grande. Sem dúvida, somente o conhecimento pleno das seqüências deposicionais das bacias marginais, em particular a de Santos, poderá levar ao conhecimento da evolução tectônica e estrutural das áreas vizinhas (ver Almeida, 1976, 1983; Almeida e Carneiro, 1989; Asmus, 1981; Chang et al., 1990a, b; Dias et al., 1990; Macedo, 1990, etc.).

\subsection{O magmatismo Mesozóico-Cenozóico da Região Sudeste}

São várias as propostas de compartimentação das rochas magmáticas do CretáceoTerciário da Região Sudeste, tanto no que tange às litologias (Ulbrich e Gomes, 1981), quanto às idades ou pela intensidade e volume das manifestações, como na tentativa de relacionar idade-condicionante ("direções") tectônico.

A compartimentação de Gomes et al. (1996), parcialmente baseada em Almeida (1983) e Trompette (1994), é bastante razoável. As províncias alcalinas maiores, grupando número variável de ocorrências, estariam condicionadas às grandes feições tectônicas. Existem contudo aqui alguns senões. Conforme dados da Petrobrás (Zalán et al., 1990), o Arco de Ponta Grossa não teria sido tão ativo à época dos derrames basálticos.

Ao que parece, a antiga Província Serra do Mar, que passaria a vincular-se ao Cinturão Ribeira, está mais ligada ao desenvolvimento da Bacia de Santos. Os campos de força distensional, dos quais resultaram falhamentos normais - normais lístricos, e que aproveitaram grandes lineamentos mais antigos, deram origem às escarpas continentais e ao abatimento do assoalho das Bacias de Santos e Campos.

A constatação de que as manifestações igneas sempre precederam as tectônicas (Almeida, 1976, 1983) não parece ser rigorosamente obedecida. Parece mais ter havido alternância entre magmatismo e tectonismo, com épocas de maior intensidade tectônica ou magmática. O arranjo e seleção de idades K/Ar (Ulbrich et al., 1991), delimitando cronogrupos de 133, 108, 84 e $65 \mathrm{Ma}$, aparentemente sem relação direcional ou de vizinhança, leva à conclusão de que as rochas alcalinas teriam distribuição aleatória: uma amostragem de magmas, sempre disponiveis, determinada casualmente pela tectônica.

O intervalo total de idades para todo o magmatismo ainda não é seguramente conhecido. As porções norte da Bacia de Santos, e sul da Bacia de Campos, forneceram amostras de lavas básicas (Macedo, 1990) e básicas alcalinas (Chang, et al., 1990b), freqüentemente precedidas por turbiditos, com idades entre 105 e $\sim 50 \mathrm{Ma}$. Na Bacia de 
Campos, lavas básicas alcançam área de pelo menos $10.000 \mathrm{~km}^{2}$, incluindo vulcanoclásticas, com idades de 53-83 Ma (Dias et al., 1990).

O intervalo 83-93 Ma é de grande importância estratigráfica na Bacia de Santos e, praticamente, reconhecido em quase todas as bacias marginais (Pereira, 1992). Nesse intervalo, registranse a máxima transgressão do período, a discordância NTC (NeoturonianoEoconiaciano), de idade 88-89,5 Ma, além de magmatismo básico (80-90 Ma). A discordância NTC, admitida em quase todas as bacias, possui caráter erosivo subaéreo-submarino, e achase ligada a causas tectônicas. Ao mesmo tempo, e talvez com causa comum, tem se vulcanismo não registrado (ou sem vestígios) no continente. $\mathrm{Na}$ Bacia de Campos, ocorre reativação de falhamentos e a formação de diabásios, com idade de $81,5 \mathrm{Ma}$, associados a turbiditos. É possivel, também, registrar novo soerguimento da Serra do Mar e na parte norte da Bacia de Santos, acompanhados por magmatismo de $88 \mathrm{Ma}$ (Pereira, 1992).

Como causa geral dos fenômenos, são destacadas mudanças gerais na geometria das placas e/ou na velocidade de deslocamento da Placa Sul-Americana (ver Sadowski, 1987). A discordância é pouco mais antiga que a anomalia magnética $34(84 \mathrm{Ma})$, que retrataria grandes mudanças dos fundos oceânicos, envolvendo alteração nos pólos de abertura e nas taxas de espalhamento. Vários pesquisadores da Petrobrás consideram que o marco NTC seria o evento estatigráfico mais importante do Aptiano (113-119 Ma) ao Paleoceno (66 Ma).

Aos acontecimentos registrados na Bacia de Santos, e em outros locais, corresponderiam eventos tectônicos, deposicionais e magmáticos na área continental, a oeste da charneira da bacia. Dentre eles, merecem citação: as elevações diferenciais na Bacia do Paraná, as possiveis reativações de falhamentos normais, os novos soerguimentos da Serra do Mar e a ocorrência de atividade magmática de natureza intrusiva (ausência de extrusões?).

\subsection{A llha dos Búzios}

É aproximadamente dentro do intervalo 90-80-70 Ma que se colocam vários corpos alcalinos continentais. As ocorrências do litoral norte de São Paulo estão situadas dentro desse intervalo, com idades em torno dos $80 \mathrm{Ma}$ (ver Capítulo 9). Esse valor ( $84 \mathrm{Ma}$ ) coincide com um dos cronogrupos de Ulbrich et al. (1991), e com o magmatismo interno das Bacias de Santos e Campos. Não é só a idade: a proximidade do Falhamento de Santos e da charneira da Bacia $(\sim 30-60 \mathrm{~km})$ ao grupo de corpos alcalinos do litoral norte estabelece ligação cronológica e geográfica entre os eventos.

Parece não haver maiores dúvidas quanto às ligações entre os processos tectônicos e magmáticos do Cretáceo e Terciário, aquelas permanecendo apenas a nivel de detalhes. É nas 
anomalias, equilíbrios e desequilibrios termais e termomecânicos que repousam as causas da evolução tectono-magmática das margens continentais, e de parte do interior continental.

O estudo de grande número de províncias alcalinas, resumido em Morbidelli et al. (1995) e Gomes et al. (1996), entre outros, mostra por outros caminhos a derivaçăo mantélica dos focos alcalinos do sudeste brasileiro, quer com alguma contribuição crustal, quer esta ausente.

As sinteses citadas apontam para várias caracteristicas semelhantes entre as rochas alcalinas da Província Serra do Mar de Almeida (1983) ou do Cinturão Ribeira de Gomes et al. (1996). As semelhanças começam com as formas de ocorrência, predominantemente plutônicas, como "stocks", ou na forma de diques variados. Mais ao detalhe, ressalta-se a predominância das litologias sieníticas, com quimismo variado, mas quase sempre de características gerais similares, bem como a mineralogia e a quimica mineral. Ainda insuficientemente estudados permanecem os diques, tantos os de caráter mais primitivo, como aqueles mais evoluídos, associados aos corpos centrais ou dispersos.

Os resultados do presente trabalho são concordantes com a maior parte das informações até então conhecidas sobre as alcalinas do Cinturão Ribeira/Serra do Mar, em particular com as informações a respeito das alcalinas das Ilhas de São Sebastião e Vitória.

O Capítulo 5 e as Figuras 3 e 5 merecem comentários adicionais. São várias as dúvidas que permanecem em aberto com relação aos aspectos geológicos. As mais importantes são a verdadeira forma e dimensões do corpo, modelado na Figura 5 , e os tipos de contatos com as "encaixantes". A parte emersa do "stock" de Búzios não deve representar mais do que $25-30 \%$ das suas reais dimensöes. A modelagem dos outros corpos, tratada no Capítulo 5 , obedece aos mesmos critérios e assim são propostos limites possiveis e bastante viáveis, incluindo a llha de Vitória. Em Búzios, não se observaram contatos verticalizados, embora o traçado, em parte, sugira relações verticalizadas sienito-encaixante. Ao contrário, são vários os locais sugestivos de contatos mergulhantes. Se isso realmente ocorre, as encaixantes da face oeste poderiam ser uma cunha quilométrica do embasamento, parcialmente deslocada. À exceção da llha do Monte de Trigo e do suposto "corpo das Canas", todos os outros cinco "stocks" conhecidos têm grandes semelhanças. Desigualmente expostos e amostrados, apresentam alguns resultados divergentes, de pequena monta. É bem possivel que todos eles, a exemplo de inúmeras ocorrências de outros locais, reúnam rochas insaturadas e supersaturadas no mesmo corpo.

A petrografia confirma, aprofunda e esclarece parte da geologia. Assim, ficam definidos quartzo-álcali feldspato microssienitos e quartzo-álcali feldspato sienitos, microssienitos e álcali feldspato sienitos das bordas para o centro do corpo, colocado nas proximidades do Saco Grande. Não só a moda, como as variações ópticas dos minerais 
apontam para o mesmo sentido: rochas com mais quartzo e mais anfibólio nas bordas, rochas com menos quartzo, até sua ausência, e mais piroxênio para o centro. A presença dos diques insaturados confirma a mesma suposição, apontando para rochas mais diferenciadas, de caráter mais alcalino e mais insaturado no Saco Grande central e para leste.

A presença de cavidades miaroliticas associadas aos sienitos com quartzo, e nas proximidades dos contatos, sugere supersaturação em $\mathrm{H}_{2} \mathrm{O}$ e $\mathrm{fH}_{2} \mathrm{O}$ mais altas, dado compatível com informações experimentais e com a mineralogia. $\mathrm{O}$ aumento da pressão de $\mathrm{H}_{2} \mathrm{O}$ desestabilizaria o piroxênio, dando lugar ao anfibólio como fase primária $e$, concomitantemente, causando o aparecimento do quartzo ou a supersaturação em $\mathrm{SiO}_{2}$ da rocha. $\mathrm{O}$ mesmo poderia ocorrer se a biotita tomasse o lugar do anfibólio ou então coexistisse com ele.

Não parece haver dúvidas de que houve assimilação da rocha encaixante, e isso alterou pouco o magma em colocação. É pouco provável que a massa sienítica possa ter fundido grandes volumes de charnoquito, havendo fundamentos para essa afirmativa: primeiro, os xenólitos são subangulosos e, segundo, não há como extrair-se calor suficiente do corpo sienítico para fundir tratos consideráveis de rocha semelhante. Embora o charnoquito e o mangerito tenham composição próximas ao eutético, o sienito também a tem. O mais factível é que a fusão de pequenas porções (10\%? 30\%?) da encaixante tenha auxiliado na supersaturação em $\mathrm{SiO}_{2}$ do magma sienítico.

A química mineral mostra continuidade composicional entre todos os tipos de rochas, para os anfibólios e biotitas. Essa continuidade é particularmente visivel em diagramas FeOxMgO. Para os piroxênios, a distribuição dos tipos titaníferos das rochas máficas apresenta disposição um pouco à parte dos restantes, como se obedecessem a "trend" próprio e autônomo e que, repentinamente, alterou-se para sentido diverso, com pequena descontinuidade composicional. Tal comportamento não seria explicável por "insuficiência" de análises. Talvez por variação concomitante em $\mathrm{SiO}_{2}, \mathrm{TiO}_{2}$ e $\mathrm{Al}_{2} \mathrm{O}_{3}$. Os mesmos piroxênios, se levados em conta outros cátions ( $\mathrm{Mg}, \mathrm{Ca}, \mathrm{Fe}$ ), mostram continuidade e muito mais afinidades composicionais. Outras explicações também seriam cabiveis como, por exemplo, as mudanças nos parâmetros físico-quimicos, bastante limitados para a coexistência dos diopsídios subsilícicos titaníferos e as kaersutitas.

As composições químicas das rochas identificam dois grupamentos: de um lado, as rochas félsicas, que se interrelacionam, confirmando geologia, petrografia e química mineral, e de outro, as máficas.

Um "gap" composicional ocorre para $\mathrm{SiO}_{2}, \mathrm{MgO}, \mathrm{CaO}, \mathrm{FeO}_{\mathrm{T}}$ e $\mathrm{K}_{2} \mathrm{O}$, mas não está presente para os outros elementos. Essa descontinuidade tem lugar entre 50 e $60 \%$ de $\mathrm{SiO}_{2}$, correspondente a mg\#= 40 . 
As variações químicas separam os sienitos dos diques. Alguns dos elementos, ou razões, discriminam diques fonolíticos de diques rioliticos. Enriquecimentos e empobrecimentos em elementos incompatíveis (LFS, HFS e TR) indicam os sienitos como as rochas félsicas mais primitivas, que evoluem, por aumento de álcalis e queda na silica e enriquecimentos e empobrecimentos mais acentuados nos incompativeis, para os fonólitos. Por via semelhante, mas com enriquecimento em silica, são derivadas as rochas supersaturadadas. A Figura 29 ilustra a disposição das rochas no sistema residual Q-Ne-Ks, com os sienitos distribuídos no alto termal, a partir do qual evoluem os fonólitos para o eutético insaturado, e os "riólitos" para o eutético supersaturado a temperaturas menores.

Entre as rochas máficas e os sienitos faltam os termos intermediários alcalinos. Passase de rochas quase que somente com plagioclásio e fêmicos diretamente para rochas com $90 \%$ de feldspato alcalino.

Existem duas alternativas. Em uma primeira, os diques máficos não teriam qualquer relação com as outras rochas. Mas é problemático deixar de considerar tantas interrelações: a ocorrência no campo, com relações de proximidade, posicionamento estrutural etc., o caráter alcalino das máficas, as continuidades composicionais para a maior parte dos elementos e para as composições minerais. Restaria uma segunda: as rochas máficas, que não são tipo único, mas que têm largo espectro composicional e evolutivo, desde as variedades mais primitivas (basaltos alcalinos, basanitos, tefritos) até as mais evoluidas (traquibasaltos), representariam os magmas parentais.

O padrão de enriquecimento e os teores elementares das rochas máficas mais primitivas já indicam fracionamento adiantado, a partir de fusões mantélicas, segundo os modelos já propostos (Morbidelli et al., 1995; Bellieni et al., 1990, etc.).

Os fracionamentos propostos na literatura recente não são muito compativeis com a situação de Búzios. Em geral, os modelos mostram evolução a partir de basanitos para fonólitos, com fracionamento variável de olivina, clinopiroxênio, plagioclásio e óxidos opacos. Para as rochas de Búzios, é preciso acrescentar a essas fases a participação da kaersutita e da biotita magnesiana.

A continuidade do processo levaria a rochas com modas empobrecidas nos ferromagnesianos, menos empobrecidas em plagioclásio, talvez menos cálcicos (como sugerem bordas de grãos e matrizes das rochas máficas), e aumento do feldspato alcalino. Talvez nesse ponto intermediário passasse a ocorrer processo de acumulação do plagioclásio, originando rochas de composição semelhante a monzogabros, monzodioritos, monzonitos e sienitos. Esse processo teria se dado em condição estática ou durante a ascenção da massa magmática progressivamente mais rica em feldspato alcalino. 


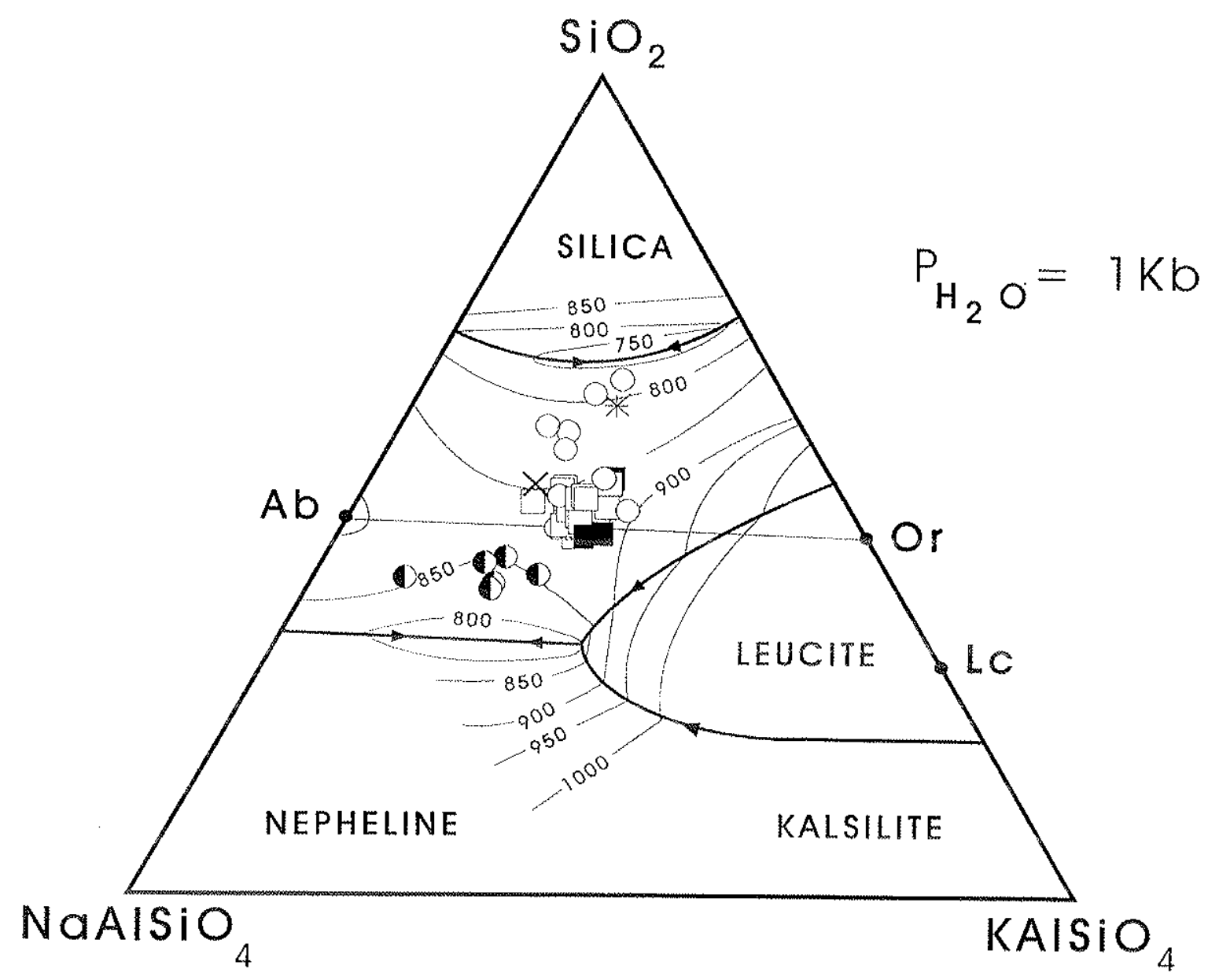

Figura 29 - Superfície do "liquidus", no sistema Q - Ne - $\mathrm{Ks} \mathrm{a} \mathrm{pH}_{2} \mathrm{O}=1 \mathrm{~kb}$, com isotermas e linhas cotéticas (Hall, 1987). Plotadas composições normativas das rochas da Ilha dos Búzios. Símbolos como na Figura 20. 
A posição atual da intrusão seria o resultado da ascenção contínua, e em pulsos, da massa magmática parcialmente cristalizada, ocupando espaços cada vez maiores e mais superficiais. A combinação de "stoping" e expansão lateral dinâmica, somados à ação de campo de forças distensionais, de atuação prolongada, constantes e de caráter regional, seria responsável pela abertura dos espaços. Eventuais zonas de fraqueza crustal podem ter tido alguma influência em profundidade, mas a julgar pelas formas dos outros corpos alcalinos do litoral, todos elípticos e de dimensões da mesma ordem de grandeza, as anisotropias de qualquer natureza, devem ter sido minimas nos sítios de alojamento final. Evolução subsólida, com ação de fluidos (externos?), está registrada nos feldspatos. 


\section{CAPÍTULO 11}

\section{BIBLIOGRAFIA}

AOKI, K. (1964) Clinopyroxenes from alkaline rocks of Japan. Amer. Miner., 49:1199-223.

ALMEIDA, F.F.M. (1964) Fundamentos geológicos do relevo paulista. Bol. Inst. Geog. Geol., 41:167-263.

ALMEIDA, F.F.M. (1967) Origem e evolução da Plataforma Brasileira. Bol. D.N.P.M., 241, 36 p.

ALMEIDA, F.F.M. (1976) The system of continental rifts bordering the Santos Basin, Brazil. An. Acad. bras. Ciênc., 48 (suplemento):15-26.

ALMEIDA, F.F.M. (1983) Relações tectônicas das rochas alcalinas mesozóicas da região meridional da plataforma Sul-americana. Rev. Bras. Geoc., 13:139-158.

ALMEIDA, F.F.M. e CARNEIRO, C.D.R. (1989) Magmatic occurrences of post-permian age of the South American Platform. Bol. IG-USP, Ser. Cient., 20:71-85.

AZEVEDO SOBRINHO, J.M. (1995) Petrologia dos charnoquitos da região de Itariri (SP). Dissertação de Mestrado, IG-USP, 112p.

AMARAL, G.; CORDANI, U.G.; KAWASHITA, K.; REYNOLDS, J.H. (1996) Potassium-argon dates of basaltic rocks from Southern Brazil. Geochim. Cosmochim. Acta, 30:159-189.

AMARAL, G.; BUSHEE, J.; CORDANI, V.G.; KAWASHITA, K.; REYNOLDS, J.H. (1967) Potassium-argon ages of alkaline rocks from Southern Brazil. Geochim. Cosmochim. Acta, 31:117-142.

BARD, J.P. (1980) Microtextures des roches magmatiques et métamorphiques. Masson, 192p. BECCALUVA, L.; BORN, H.; BROTZU, P.; COLTORTI, M.; CONTE, A.; GARBARINO, C.; GOMES, C.B.; MACCIOTTA, G.; MORBIDELLI, L.; RUBERTI, E.; SIENA, F.; TRAVERSA, G. (1992) Fractional crystallization and liquid immiscibility processes in the alkaline-carbonatite complex of Juquiá, São Paulo, Brazil. J. Petrol., 33:1371-1404.

BELLIENI, G.; BROTZU, P.; COMIN-CHIARAMONTI, P.; ERNESTO, M.; MELFI, A.J.; PACCA, I.G.; PICCIRILLO, E.M.; STOLFA, D. (1983) Petrological and paleomagnetic data on the plateau basalts to rhyolite sequences of the southern Paraná basin (Brazil). An. Acad. brasil. Ciênc., 55:355-383.

BELLIENI, G.; COMIN-CHIARAMONTI, P.; MARQUES, L.S.; MELFI, A.J.; NARDY, A.J.R.; PAPATRECHAS, C.; PICCIRILLO, E.M.; ROISENBERG, A.; STOLFA, D. (1986) Petrogenetic aspects of acid and basaltic lavas from Paraná plateau (Brazil): geological, mineralogical and petrological relationships. J. Petrol., 27:915-944. 
BELLIENI, G.; MONTES-LAUAR, C.R.; DE MIN, A.; PICCIRILLO, E.M.; CAVAZZINI, G.; MELFI, A.J.; PACCA, I.G. (1990) Early and Late Cretaceous magmatism from São Sebastião Island (SE-Brazil): geochemistry and petrology. Geochim. Brasil., 4:59-83.

BJÖRNBERG, A.J.S. e ELLERT, R. (1955) Observações geológicas e petrográficas sobre a litha dos Búzios. An. Acad. brasil. Ciênc., 27:169-182.

BROOKS, C.K e GILL, R.C.O (1982) Compositional variation in the pyroxenes and amphiboles of the Kangerdlugssuag intrusion, East Greenland: further evidence for the crustal contamination of syenite magma. Mineral. Mag., 45:1-9.

BUDDINGTON, A.F. e LINDSLEY, D.H. (1964) Iron-titanium oxide minerals and synthetic equivalents. J. Petrol., 5:310-357.

CAMERON, M. e PAPIKE, J.J. (1981) Structural and chemical variations in pyroxenes. Amer. Mineral., 66:1-50.

CARMICHAEL, I.S.E. (1967) The iron-titanium oxides of salic volcanic rocks and their ferromagnesian silicates. Contr. Mineral. Petrol., 14:36-64.

CHANG, H.K.; KOWSMANN, R.O.; BENDER, A.A.; MELLO, U.T. (1990a) Origem e evolução termomecânica de bacias sedimentares. In: De Raja Gabaglia, G.P. e Milani, E.J. (coords.) Origem e evolução de bacias sedimentares. Petrobrás, p.49-71.

CHANG, H.K.; KOWSMANN, R.O.; BENDER, A.A.; MELLL, U.T. (1990b) Novos conceitos sobre o desenvolvimento das bacias marginais do leste brasileiro. In: De Raja Gabaglia, G.P. e Milani, E.J. (coords.) Origem e evolução de bacias sedimentares. Petrobrás, p.269-289.

CLARKE, D. (1994) New Pet. Software, New Foundland University.

COMIN-CHIARAMONTI, P.; CUNDARI, A.; GOMES, C.B.; PICCIRILLO, E.M.; CENSI, P.; DE MIN, A.; BELLIENI, G.; VELAZQUEZ, V.F.; ORUÉ, D. (1992) Potassic dyke swarm in the Sapucai-Graben eastern Paraguay: petrological mineralogical and geochemical outlines. Lithos, 28:283-301.

CONCEIÇÃO, J.C.J.; ZALÁN, P.V.; WOLFF, S. (1988) Mecanismo, evolução e cronologia do Rift Sul-Atlântico. Bol. Geoc. Petrobrás, 2/4:255-265.

COUTINHO, J.M.V. e MELCHER, G.C. (1973) Levantamento geológico e petrográfico na tha do Monte de Trigo (Litoral Norte de São Paulo, Brasil). Rev. Bras. Geoc., 3:243-256.

DALRYMPLE, G.B. e LAMPHERE, M.A. (1969) Potassium-argon dating. W.H. Freeman and Co., 258p.

DAMASCENO, E.C. (1966) Estudo preliminar dos diques de rochas básicas e ultrabásicas da região de Ubatuba, Estado de São Paulo. An. Acad. brasil. Ciênc., 38:293-303.

DE LA ROCHE, H.C. (1986) Classification et nomenclature des roches ignées: un essai restauration de la convergence entre systématique quantitative, typologie de usage et modélisation genétique. Bull. Soc. Géol. France, 2:313-337. 
DE LA ROCHE, H.C.; LETERRIER, J.; GRAND-CLAUDE, P.; MARCHAL, M. (1980) A classification of volcanic and plutonic rocks using R1-R2 diagram and major element analyses: its relationship with current nomenclature. Chem. Geol., 29:183-210.

DEER, W.A.; HOWIE, R.A.; ZUSSMAN, J. (1978) An introduction to the rock-forming minerals. Longman, $578 p$.

DEER, W.A.; HOWIE, R.A.; ZUSSMAN, J. (1993) An introduction to the rock-forming minerals.. Longman Scientific \& Technical, 696p.

DELANEY, P.T. e POLLARD, D.D. (1981) Deformation of host rocks and flow of magma during growth of minette dykes and breccia-bearing inclusions near Ship Rock, New Mexico. U.S. Geol. Surv. Prof. Pap., 1202:1-61.

DELANEY, P.T.e POLLARD, D.D. (1982) Solidification of basaltoc magma during flow in a dyke. Amer. J. Sci., 282:856-885.

DIAS, J.F.; SCARTON, J.C.; ESTEVES, F.R.; CARMINATTI, M.; GUARDADO, L.R. (1190) Aspectos da evolução tectono-sedimentar e a ocorrência de hidrocarbonetos na Bacia de Campos. In: De Raja Gabaglia, G.P. e Milani, E.J. (coords.) Origem e evolução de bacias sedimentares. Petrobrás, p.333-360.

EDGAR, A.D. (1974) Experimental studies. In: Sorensen, H. (ed.) The alkaline rocks. John Wiley \& Sons, 622p.

FAURE, G. e POWELL, J.L. (1972) Strontium isotope geology. Springer-Verlag, 188p.

FERGUSON, A.K. (1978) The crystallization of pyroxenes and amphiboles in some alkaline rocks and the presence of a pyroxene compositional gap. Contr. Mineral. Petrol., 67:11-15.

FREITAS, R.O. (1947) Geologia e petrologia da llha de São Sebastião. Bol. Fac. Fil. Ciênc. Let. USP, 85:1-244.

FREITAS, R.O. (1976) Definição petrológica, estrutural e geotectônica das cintas orogênicas antigas do litoral norte do Estado de São Paulo. Bol. Inst. Geol., 1:1-176.

GARDA, G.M. (1995) Os diques básicos e ultrabásicos da região costeira entre as cidades de São Sebastião e Ubatuba, Estado de São Paulo. Tese de Doutoramento, 1G-USP, 156p.

GARDA, G.M.; ESPERANÇA, S.; CARLSON, R.W. (1994a) The petrology and geochemistry of coastal dykes from São Paulo State, Brazil: implications for variable lithosferic contributions to alkaline magmas from the western margin of the South Atlantic. International Symposium on the Physics and Chemistry of the Upper Mantle, São Paulo, Extended Abstracts, p. 62-64.

GARDA, G.M.; JULIANI, C.; SCHORSCHER, J.H.D.; NEUMANN, R.; BOHLAND NETO, F. (1992) Vulcanismo recorrente e feições geológicas afins em diques básicos ultrabásicos da Praia Vermelha do Sul, Município de Ubatuba, SP. Bol. IG-USP, Publ. Esp., II Jornadas Cientificas, $12: 45-46$. 
GARDA, G.M.; SCHORSCHER, J.H.D.; ESPERANÇA, S.; CARLSON, R.W. (1995) The petrology and geochemistry of coastal dykes from Säo Paulo State, Brazil: implications for variable lithosferic contributions to alkaline magmas from the western margin of the South Atlantic. An. Acad. brasil. Ciênc., 67:191-216.

GARDA, G.M.; SCHORSCHER, J.H.D.; WALDRAN, H.; EGGINS, S. (1994b) Trace element characteristics of the lamprophyric dykes from the north coast of São Paulo State, Brazil. International Symposium on the Physics and Chemistry of the Upper Mantle, São Paulo, Extended Abstracts, p. 106-107.

GILBERT, M.C.; HELZ, R.T.; POPP, R.K.; SPEAR, F.S. (1982) Experimental studies of anphibole stability. In: Veblen, D.R. e Ribbe, P.H. (eds.) Amphiboles: petrology and experimental phase relations. Reviews in mineralogy, Mineral. Soc. Amer., 9B:229-353.

GIRET, A.; BONIN, B.; LEGER, J.M. (1980) Amphibole compositional trends in oversaturated and undersaturated alkaline plutonic ring-complexes. Can. Miner., 18: 481-495.

GOMES, C.B. (1974) Mineralogia do dique de Toninhas, Ubatuba, litoral norte do Estado de São Paulo: Feldspatos. Rev. Bras. Geoc., 4:80-87.

GOMES, C.B. e BERENHOLC, M. (1973) Some geochemical features of the Toninhas dyke, Ubatuba, State of São Paulo, Brazil. $2^{\text {a }}$ Cong. Lat. Am. Geol, Memoria II, Caracas.

GOMES, C.B. e RUBERTI, E. (1979) Mineralogia do dique de Toninhas, Ubatuba, litoral norte do Estado de São Paulo: Piroxênios. Bol. Miner., 6:55-66.

GOMES, C.B.; BARBIERI, M.; BECCALUVA, L.; BROTZU, P.; CONTE, A.; GARBARINO, C.; MACCIOTTA, G.; MELLUSO, L.; MORBIDELLLI, L.; RUBERTI, E.; SCHEIBE, L.F.; TAMURA, R.M.; TRAVERSA, G., (1987) Petrological and geochemical studies of alkaline rocks from continental Brazil. 2. The Tunas massif, State of Paraná. Geochim. Brasil., 1:201-234.

GOMES, C.B.; DAMASCENO, E.C.; MELCHER, G.C.; BORN, H. (1967) Observações geológicas preliminares sobre a liha de Vitória, SP. Bol. Paran. Geoc., 26:334-346.

GOMES, C.B.; MORO, S.L.; DUTRA, C.V. (1970) Pyroxenes from the alkaline rocks of Itapirapuã, São Paulo, Brazil. Amer. Miner., 55:224-30.

GOMES, C.B.; MORBIDELLI, L.; RUBERTI, E.; COMIN-CHIARAMONTI, P. (1996) Comparative aspects between post-palaeozoic alkaline rocks from the western and eastern margins of the Paraná Basin. In: Comin-Chiaramonti, P. e Gomes, C.B. (eds.) Alkaline magmatism in Central-Eastern Paraguay-Relationships with coeval magmatism in Brazil. EDUSP/FAPESP, São Paulo, p.249-274.

HALL, A. (1987) Igneous petrology. Longman Scientific Technical, 573p.

HAMIL.TON, D.L. (1961) Nephelines as crystallization temperature indicators. J. Geol., 69:321 . 329. 
HARKER. A. (1909) The natural history of igneous rocks. Macmillan, 384p.

HENNIES, W.T. (1964) Rochas alcalinas de São Sebastião. $18^{\circ}$ Cong. Bras. Geol., Poços de Caldas.

HENNIES, W.T. e HASUI, Y. (1968) Geocronologia das rochas eruptivas da liha de São Sebastião, SP. $22^{\circ}$ Congr. Bras. Geol., Belo Horizonte, Anais, p.145-148.

HENNIES, W.T. e HASUI, Y. (1977) Contribuição ao reconhecimento da geologia da liha de São Sebastião. I Simpósio de Geologia Regional, São Paulo, Atas, p.199-209.

HIGGINS, W.M. (1971) Cataclastic rocks. U.S. Geol. Survey. Prof. Paper 687, 110p.

KAWASHITA, K. (1972) O método Rb/Sr em rochas sedimentares. Aplicação para as Bacias do Paraná e Amazonas. Tese de Doutoramento, IG USP, 111p.

KUNO, H. (1968) Differentiation of basalt magmas. In: Hess, H.H. e Poldervaart, A. (eds.) Basalts. Interscience, 2:623-688.

LARSEN, L.M. e STEENFELT, A. (1974) Alkali loss and retention in an iron-rich peralkaline phonolite dyke from the Gardar province, South Greenland. Lithos, 7:81-90.

LEAKE, B.E. (1978) Nomenclature of amphiboles. Mineral. Petrogr. Acta, 22:195-224.

LE MAITRE, R.W. (ed.) (1989) A classification of igneous rocks and glossary of terms. Blackwell Scientific Publications, Oxford, 193p.

LINDSLEY, D.H. (1991) Experimental studies of oxide minerals. In: Lindstey, D.H. (ed.) Oxide minerals: petrologic and magnetic significance. Reviews in Mineralogy, Mineral. Soc. Amer., 25:69-106.

MACEDO, J.M. (1990) Evolução tectônica da Bacia de Santos e áreas continentais adjacentes. In: De Raja Gabaglia, G.P. e Milani, E.J. (coords.) Origem e evolução de bacias sedimentares. Petrobrás, p.361-376.

MACDONALD, G.A. e KATSURA, T. (1964) Chemical composition of Hawaiian lavas. J. Petrol., 5:82-133.

MACKENZIE, W.S.; DONALDSON, C.H.; GUILFORD, C. (1993) Atlas of igneous rocks and their textures. Longman Scientific \& Technical, 148p.

MANTOVANI, M.S.M.; STEWART, K.; TURNER, S.; HAWKESWORTH, C.J. (1994) Duration of Paraná magmatism and implications for the evolution and source regions of continental flood basalts. International Symppsium on the Physics and Chemistry of the Upper Mantle. Extended Abstracts, São Paulo, p.47-48.

MARQUES, A. (1990) Evolução tectono-sedimentar e perspectivas exploratórias da Bacia de Taubaté, São Paulo, Brasil. Bol. Geoc. Petrobrás, 4/3:253-262.

MARSCH, d.b. (1982). On the mechanics of igneous diapirism, stopping, and zone melting. Amer. J. Sci., 282:808-855. 
McBIRNEY, A.R. (1984) Igneous petrology. Freeman, Cooper \& Company, $504 p$.

McDOUGALL, I. e RÜEGG, N.R. (1966) Potassium-argon dates on the Serra Geral Formation.

Geochim. Cosmochim. Acta, 30:191-195.

MIDDLEMOST, E.A.K. (1975) The basalt clan. Earth Sci. Rev., 11:337-364.

MIDDLEMOST, E.A.K. (1989) Iron oxidation ratios, norms and classification of volcanic rocks.

Chem. Geol., 77:19-26.

MINIOLI, B.; PONÇANO, W.L.; OLIVEIRA, S.M.B. (1974) Extensão geográfica do vulcanismo basáltico do Brasil meridional. An. Acad. brasil. Ciênc., 43:433-437.

MORBIDELLI, L.; GOMES, C.B.; BECCALUVA, L.; BROTZU, P.; CONTE, A.M.; MACCIOTTA, G.; RUBERTI, E.; TRAVERSA, G. (1993) Petrologia e geoquímica de distritos alcalinos brasileiros: uma síntese. $4^{\circ}$ Congr. Bras. Geoq., Brasilia, DF, Resumos Expandidos, p.33-37. MORBIDELLI, L.; GOMES, C.B.; BECCALUVA, L.; BROTZU, P.; CONTE, A.M.; RUBERTI, E.; TRAVERSA, G. (1995) Mineralogical, petrological and geochemical aspects of alkaline and alkaline-carbonatite associations from Brazil. Earth Sci. Rev., 39:135-168.

MORIMOTO, N. (1988) Nomenclature or pyroxenes. Mineral. Mag., 52:535-550.

MORSE, S.A. (1969) Syenites. Carn. Inst. Washington Yearbook, 67:112-120.

MOTOKI, A. (1986) Geologia e petrologia do maciço alcalino da Ilha de Vitória, SP. Tese de Doutoramento, IG-USP, 245p.

MOTOKI, A. e GOMES, C.B. (1984) Caracterização geológica e petrográfica do maciço alcalino da liha de Vitória, SP. XXXIII Congr. Brasil. Geol., Rio de Janeiro, Anais, IX:4392-4399.

MOTOKI, A.; GOMES, C.B.; DUTRA, C.V. (1987) Assimilação de rochas encaixantes pelo magma nefelina sienítico do maciço alcalino da tha de Vitória, SP. $1^{\circ}$ Congr. Bras. Geoq., 1:375-397.

NASH, W.P. e WILKINSON, J.F.G. (1970) Shonkin Sag Laccolith Montana. I. Mafic minerals and estimates of temperature, pressure, oxygen fugacity and silica activity. Contr. Mineral. Petrol., 25:241-269.

NEUMANN, R. (1993) Contribuição à petrologia das rochas charnockíticas de Ubatuba, leste do Estado de São Paulo. Dissertação de Mestrado, IG-USP, 86p.

NEWTON, R.C.; SMITH, J.V.; WINDLEY, B.F. (1980) Carbonic metamorphism, granulites and crustal growth. Nature, 288:45-49.

PEREIRA, M.J. (1992) Considerações sobre a estratigrafia do Cenomaniano-Santoniano em algumas bacias marginais brasileiras e sua implicação na história tectônica e sedimentar da margem continental. Bol. Geoc. Petrobrás, 6/3/4:171-176.

PETERS, Tj.; LUTH, W.C.; TUTTLE, O.F. (1966) The melting of analcite solid solutions in the system $\mathrm{NaAlSiO}_{4}-\mathrm{NaAlSi} \mathrm{O}_{3}-\mathrm{H}_{2} \mathrm{O}$. Amer. Miner., 51: 736-753. 
PICCIRILLO, EM.; COMIN-CHIARAMONTI, P.; MELFI, A.J.; STOLFA, D.; BELLIENI, G.; MARQUES, L.S.; GIARETTA, A.; NARDY, A.J.R.; PINESE, J.P.P.; RAPOSO, M.I.B.; ROISENBERG, A. (1988) Petrochemistry of continental flood basalt-rhyolite suites and related intrusives from the Paraná basin (Brazil). In: Piccirillo, E.M. e Melfi, A.J. (eds.) The Mesozoic flood volcanism of the Paraná Basin: petrogenetic and geophysical aspects. IAGUSP, p.107-156.

PITCHER, W.S. (1995) The nature and origin of granite. Blackie Academic \& Professional, $321 \mathrm{p}$.

POWELL, M. e POWELL, R. (1977) A nepheline-alkali feldspar geothermometer. Contr. Mineral. Petrol., 62:193-204.

RENNE, P.R.; ERNESTO, M.; PACCA, I.G.; COE, R.S.; GLEN, J.M.; PREVOT, M.; PERRIN, M. (1992) The age of Paraná flood volcanism, rifting of Gonwanaland, and the JurassicCretaceous boundary. Science, 258:75-979.

RICKWOOD, P.C. (1990) The anatomy of a dyke and the determination of propagation and magma flow directions. The Second International Dyke Conference, Adelaide, Proceedings Mafic dykes and emplacemen mechanisms, p. 81-100.

ROCK, N.M.S. (1982) Chemical mineralogy of the Monchique alkaline complex, Southern Portugal. Contr. Mineral. Petrol., 81:64-78.

ROCK, N.M.S. (1991) Lamprophyres. Blackie \& Son Ltd., 285p.

ROLYNSON, H.R. (1994) Using geochemical data. Longman Scientific \& Technical, 351p.

SADOWSKI, G.R. (1987) A possible relation between pulses of platform activation and plate kinematics. Tectonophysics, 143:43-57.

SCHUMACHER, R.; SCHENK, V.; RAASE, P.; VITANAGE, P.W. (1990) Granulite facies metamorphism of metabasic and intermediate rocks in the Hiphland series of Sri Lanka. In: Ashworth, J.R. e Brown, M. (eds.) High-temperature metamorphism and crustal anatexis. Unwin Hyman, p. 235-271.

SIBSON, R.H. (1977) Fault rocks and fault mechanisms. J. Geol. Soc. London, 133:191-213.

SMITH, J.V. e TUTTLE, O.F. (1957) The nepheline-kalsilite system: I, X-ray data for the crystalline phases. Amer. J. Sci., 255:285-305.

SONOKI, I.K. e GARDA, G.M. (1988) Idades K/Ar de rochas alcalinas do Brasil meridional e

Paraguai oriental: compilação e adaptação às novas constantes de decaimento. Bol. IGUSP, Série Científica, 19:63-85.

SMITH, J.V. (1974) Feldspar minerals. Springer-Verlag, 690p.

SMITH, J.V. e BROWN, W.L. (1988) Feldspar minerals. 1. Springer-Verlag, 828p. 
STEIGER, R.H. e JAEGER, E. (1978) Subcomission on geochronology: convention on the use of decay constance in geochronology. Contribution to the geologic time scale. Studies in Geology, 6:67-72.

STEPHENSON, D. (1972) Alkali clinopyroxenes from nepheline syenites of the South Qôroq Centre, South Greenland. Lithos, 5:187-201.

TRÖGER, W.E. (1979) Optical determination of rock-forming minerals. E. Schweizerbart'scheverlagsbuchhandlung, 188p.

THORNTON, C.P. e TUTTLE, O.F. (1960) Chemistry of igneous rocks I. Differentiation index. Amer. J. Sci., 258:664-684.

TYLER, R.C. e KING, B.C. (1967) The pyroxenes of the alkaline igneous complexes of Eastern Uganda. Mineral. Mag., 280:5-22.

ULBRICH, H.H.G.J. e GOMES, C.B. (1981) Alkaline rocks from continental Brazil. Earth Sci. Rev., 17:135-154.

ULBRICH, H.H.G.J.; GARDA, G.M.; ULBRICH, M.N.C. (1991) Avaliação das idades KJAr dos maciços alcalinos do Brasil sul oriental e Paraguai oriental. Bol. IG-USP, Publ. Esp., I Jornadas Cientificas, 9:87-91.

ULBRICH, M.N.C., (1983). Aspectos mineralógicos e petrológicos de nefelina sienitos do macico alcalino de Poços de Caldas, MG-SP. Tese de Doutoramento, IG-USP, 369p.

VLACH, S.R.F. (1990) ISOJOB: um programa par manipulação e cálculos isotópicos $\mathrm{Rb} / \mathrm{Sr}$, $\mathrm{Sm} / \mathrm{Nd}$ e Lu/Hf em microcomputadores. $36^{\circ}$ Congr. Bras. Geol., Natal, RN. Resumos p.7475.

WAGER, L.R. (1968) Rhythmic and cryptic layering in mafic and ultrarnafic plutons. In: Hess, H.H. e Poldervaart, A. (eds.) Basalts. The Poldervaart treatise on rocks of basaltic composition, vol. 2., Interscience, New York, p.573-622.

WILLIAMS, H.; TURNER,F.J.; GILBERT, C.M. (1970) Petrografia. EDUSP-Polígono, 445p.

WONES, D.R. e GILBERT, M.C. (1982) Amphiboles in the igneous environment. In Amphiboles: petrology and experimental phase relations. Reviews in Mineralogy, Mineral. Soc. Amer., 9B:355-390.

WOOD, D.A.; TARNEY, J.; VARET, J.; SAUNDERS, A.D.; BOUGAULT, H.; JORON, J.L.; TREVIL, M.; CANN, J.R. (1979) Geochemistry of basalts drilled in the North Atlantic by IPOD Leg 49: implications for mantle heterogeneity. Earth Planet. Sci. Lett., 42:77-97.

YAGI, K. (1953) Petrochemical studies of the alkalic rocks of the Morotu District, Sakhalin. Bull. Geol. Soc. Amer., 64:769-810.

ZALÁN, P.V.; WOLFF, S.; CONCEIÇÃO, J.C.J.; MARQUES, A.; ASTOLFI, M.A.M.; VIEIRA, I.S.; APPI, V.T.; ZANOTTO, O.A. (1990) Bacia do Paraná. In: De Raja Gabaglia, G.P. e Milani, E.J. (coords.) Origem e evolução de bacias sedimentares. Petrobrás, p.135-168. 


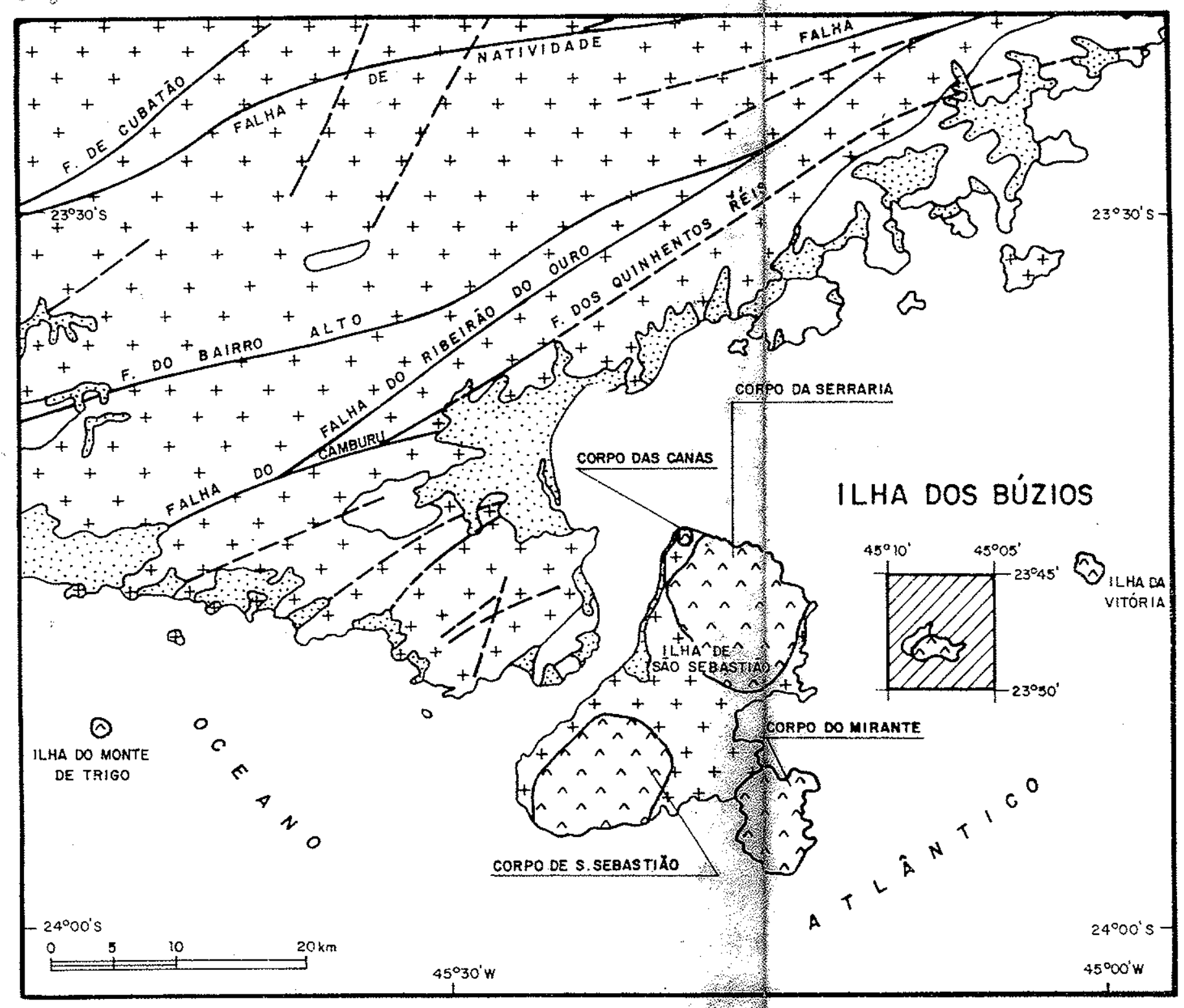

\section{LEGENDA}

$\because$ QUATERNÁRIO

$\hat{n}$ ROCHAS ALCALINAS

++ embasamento

PRÉ-CAMBRIANO

- falhas

- - FOtOlineamentos

- CONTATOS GEOLÓgICOS

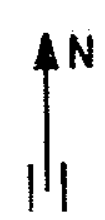

LOCALIZAÇÄO DA

ÁREA NO ESTADO

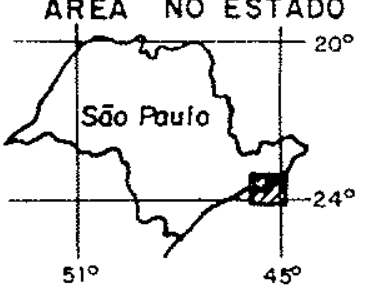

\section{$M A P A$}

DE LOCALIZAÇĀO

FONTE: MAPA GEOLÓGICO DO ESTADO DE SĀO PAULO - ESCALA : :500 ODO PROMIN ÉRIO-1981 (MOdificodo)

Figura 1 - Mapa de Localização da Ilha dos Búzios, SP 
$+x^{4}+$

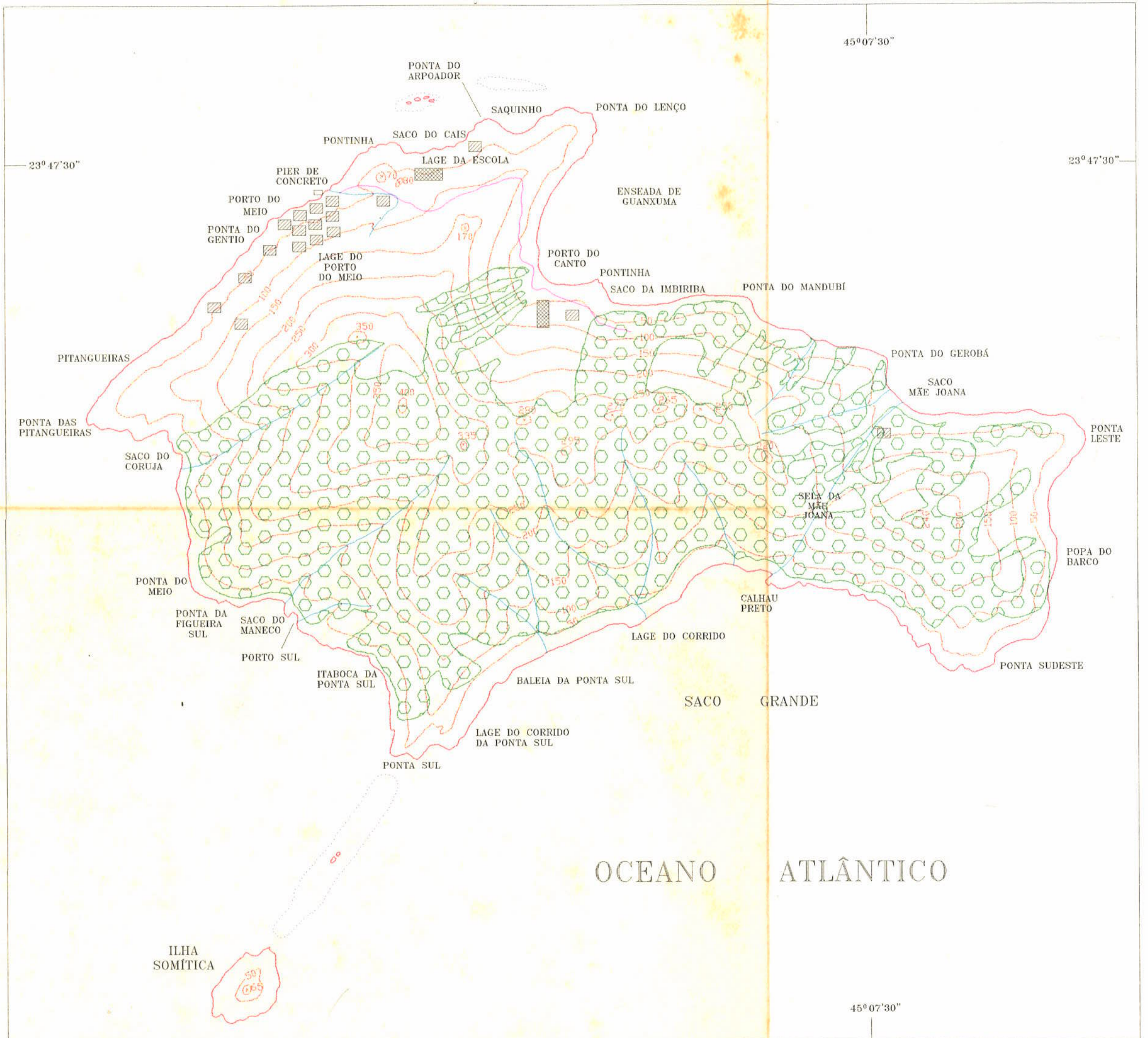

Figura 2: Mapa geográfico e toponímico da Ilha de Búzios, SP.
LEGENDA

$R \cdot C$

$v=1$

PARCÉls

CURVAS DE NVELL COM EQUIISTANGIAS

DE 50m

GURVAS DE NIVEL COM COTA IGUAL A Om-

DRENAGEM, RAVINA.

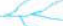

CUME E CURVA DE NVEL ANTERIOR

VEGetTaçẵo DENSA (6)

MORADIAS, ESCOLAS 四 핌

ESCALA

$\begin{array}{llllll}0 & 200 & 400 & 600 & 800 & 1000 m\end{array}$

ARTICULACÃO DAS FOLHAS

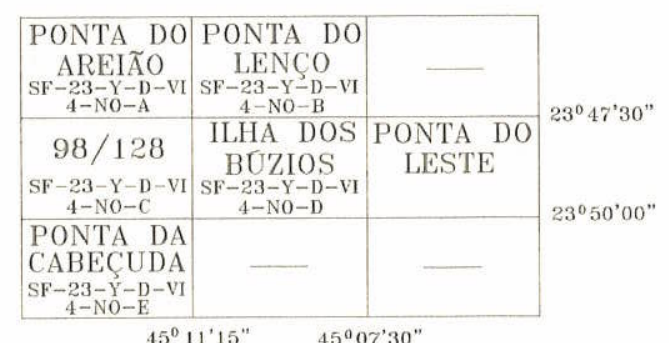

ILHA DOS BÜZIOS(SP)

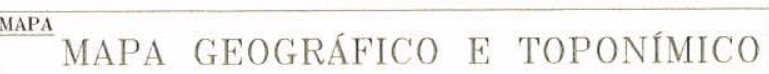
AUTOR FRANCISCO RUBENS ALVES BASR CARTOGRRFICA PROJETO MACRO EIXO/1977-1978 DESENHISTA ALEXANDRE TOMIO S.P. 19/07/1996 


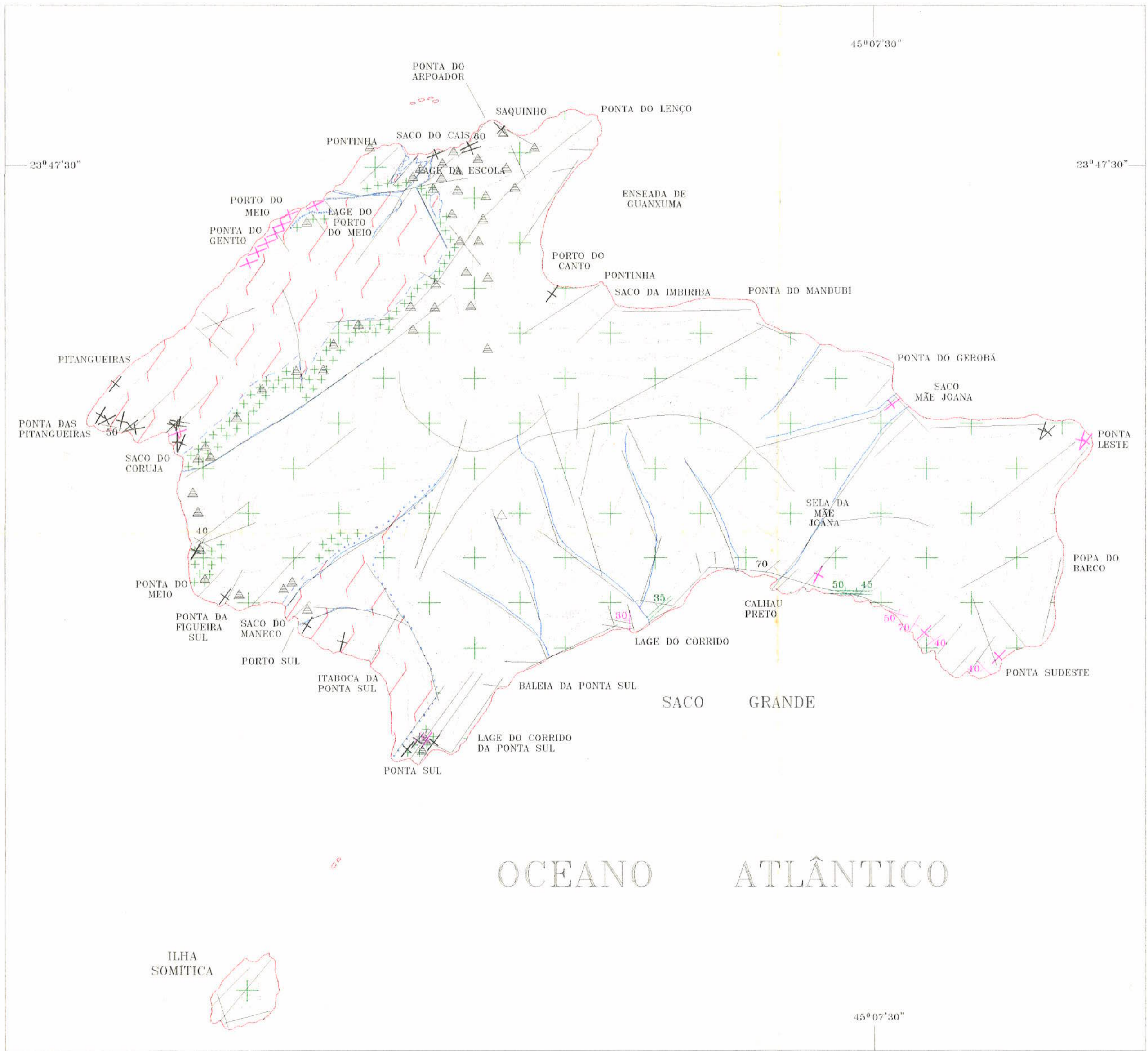

LEGENDA

MGES EMERS

PARCÉS

CURVAS DE NIVELL EQUUDISTANCIA DE 50m

CURYAS DE NIVEL CON COTS IGULA

CUME E CURVA DE NIVEL ANTERTOI
NUITIPLA DE 5 .

CONTATOS OBSERVAD
PROVNAFI

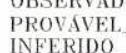

LINEAMENTO FOTOGEOLOGICO
IOPOCPSFICO E FRATTRAS

CHARNoquTros

ICRO SIENTrO

SIENITOS

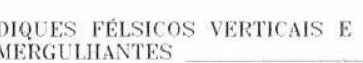

$\begin{aligned} & \text { DIOUES MAFICOS VERTCAIS E } \\ & \text { WERGLLHANTES }\end{aligned}+t_{45}$

BANDAMENTO PEGMATODE

ESCALA

0 $\quad 200 \quad 400 \quad 600 \quad 800 \quad 1000 m$

ARTICULACAO DAS FOLHAS

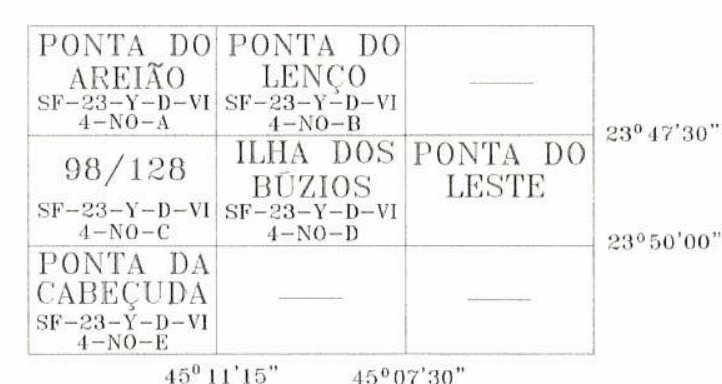

ILHA DOS BUZIOS (SP) MAPA GA GEOLŌGICO DA ILHA DOS BÚZIO, SP AUTOR FRANCISCO RUBENS ALVES BASE CARTOGRAFICA PROJETO MACRO EIXO/1977-1978 EXECUTADA POR TERRAFOTO/SEP DISPONIBLIDADE SEP-IGC \begin{tabular}{|l|l|} 
DESENHISTA ALEXANDRE TOMIO & S.P. $19 / 07 / 1996$ \\
\hline
\end{tabular} 
NSTHtht O OE GEOCIENCIAS - US

T. 2390

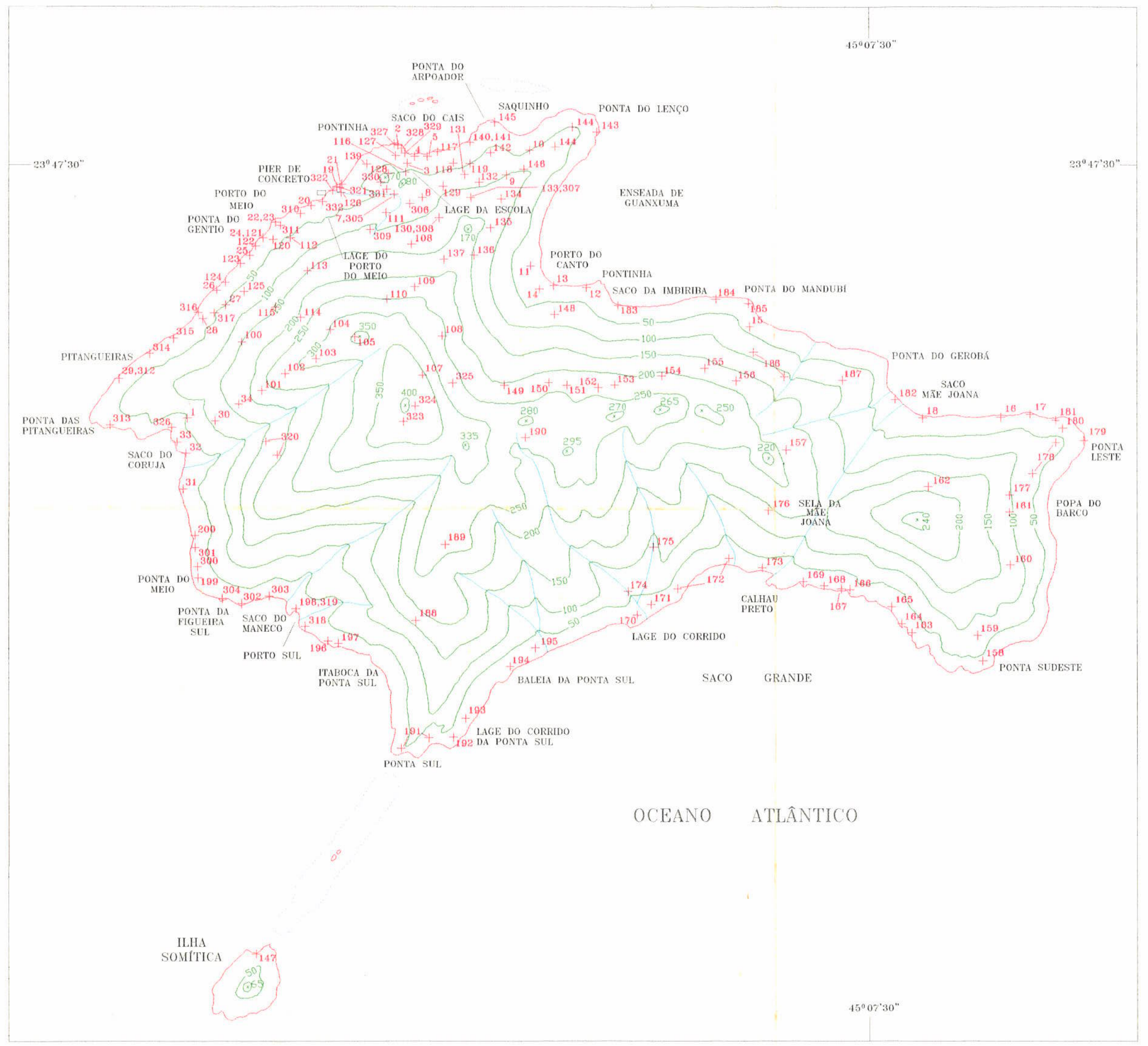

\section{LEGENDA}

Lagers EMmersas

parcéts

CURVAS DE NIVEL, COM EQUIISTANCA DE

CURVAS DE NIVEL COM COTA IGTAL. A Om-

DRENAGEM, RAVINA

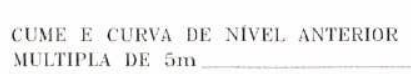

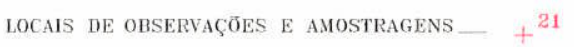

ESCALA

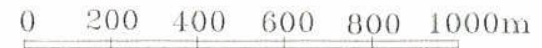

\section{aRTiculaÇ̃̃o das FOLHAS}

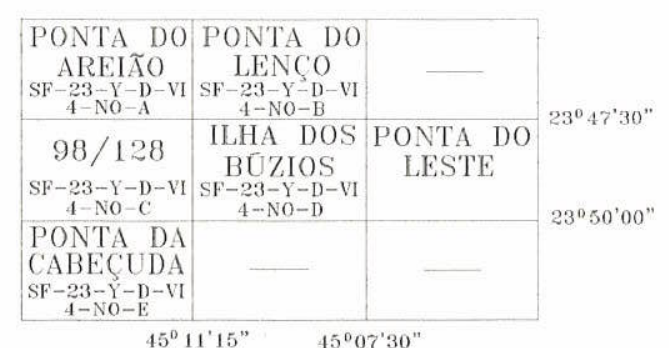

ILHA DOS BUZZIOS (SP) MAPA MAPA DE LOCALIZACT̃O DOS PONTOS

AUTOR DE OBSERVAÇOES E AMOSTRAGENS

BASE CARTOGRRAFICA PROJETO MACRO EIXO/1977-1978 BASE CARTOGRAFCA PROJETO MACRO EIXO/1977-1978
EXECUTADA POR TERRAFOTO/SEP DISPONBLLDADE SEP-IGC \begin{tabular}{|l|l|}
\hline DESENHISTA ALEXANDRE TOMIO & S.P. 19/07/1996
\end{tabular}

Figura 4: Mapa de localização dos pontos de observações e amostragem 
NCTITITO DE GEOCIENCIAS = USPINSTITUTO DE GEOCIENCIAS - USF - IBLIOTEOA -

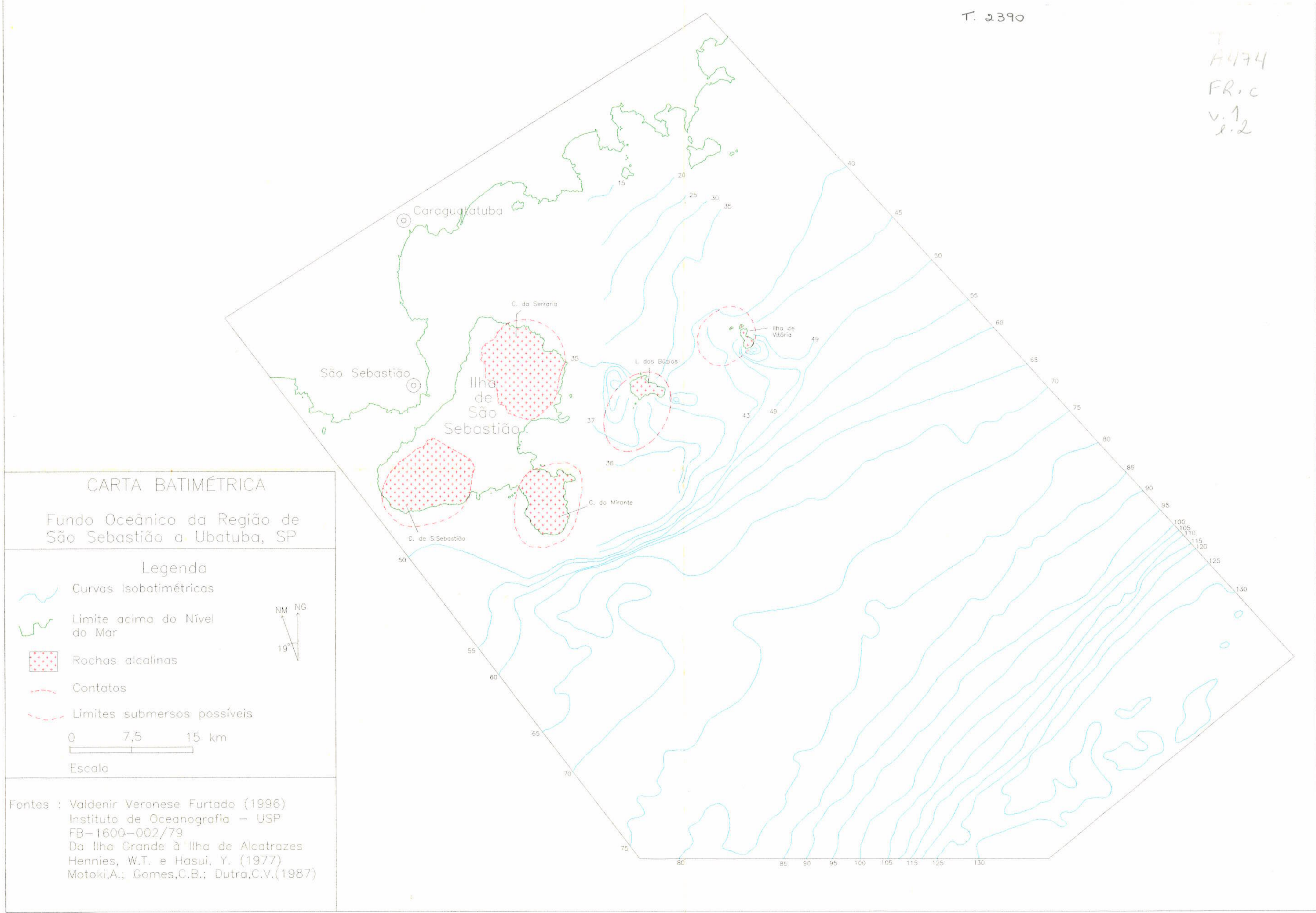

